\title{
Ecuador and international investment law and policy
}

Citation for published version (APA):

Espinosa Velasco, S. X. (2019). Ecuador and international investment law and policy: between constitutional sovereignty and state responsibility. [Doctoral Thesis, Maastricht University]. Boekenplan Maastricht. https://doi.org/10.26481/dis.20190329se

Document status and date:

Published: 01/01/2019

DOI:

10.26481/dis.20190329se

Document Version:

Publisher's PDF, also known as Version of record

\section{Please check the document version of this publication:}

- A submitted manuscript is the version of the article upon submission and before peer-review. There can be important differences between the submitted version and the official published version of record.

People interested in the research are advised to contact the author for the final version of the publication, or visit the DOI to the publisher's website.

- The final author version and the galley proof are versions of the publication after peer review.

- The final published version features the final layout of the paper including the volume, issue and page numbers.

Link to publication

\footnotetext{
General rights rights.

- You may freely distribute the URL identifying the publication in the public portal. please follow below link for the End User Agreement:

www.umlib.nl/taverne-license

Take down policy

If you believe that this document breaches copyright please contact us at:

repository@maastrichtuniversity.nl

providing details and we will investigate your claim.
}

Copyright and moral rights for the publications made accessible in the public portal are retained by the authors and/or other copyright owners and it is a condition of accessing publications that users recognise and abide by the legal requirements associated with these

- Users may download and print one copy of any publication from the public portal for the purpose of private study or research.

- You may not further distribute the material or use it for any profit-making activity or commercial gain

If the publication is distributed under the terms of Article $25 \mathrm{fa}$ of the Dutch Copyright Act, indicated by the "Taverne" license above, 
Ecuador and International Investment Law and Policy: Between Constitutional Sovereignty and State Responsibility

Sebastián Xavier Espinosa Velasco 
Ecuador and International Investment Law and Policy: Between Constitutional Sovereignty and State Responsibility

\author{
Dissertation
}

to obtain the degree of Doctor at Maastricht University, on the authority of the Rector Magnificus Prof.dr. Rianne M. Letschert in accordance with the decision of the Board of Deans, to be defended in public on 29 March 2019 at $10.00 \mathrm{hrs}$.

by

Sebastián Xavier Espinosa Velasco 


\section{Supervisors}

Prof.dr. P. Van den Bossche

Prof.dr. Leïla Choukroune

\section{Assessment Committee}

Prof. dr. M.G. Faure (chair)

Prof. dr. A.W. Heringa

Dr. Katia Fach Gómez, University of Zaragoza (Spain)

Dr. Rodrigo Polanco Lazo, University of Bern (Switzerland) 


\section{ECUADOR AND INTERNATIONAL INVESTMENT LAW AND POLICY: BETWEEN CONSTITUTIONAL SOVEREIGNTY AND STATE RESPONSIBILITY}

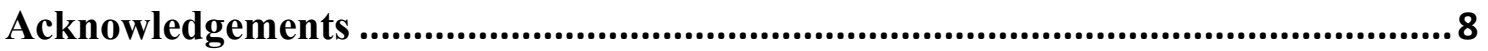

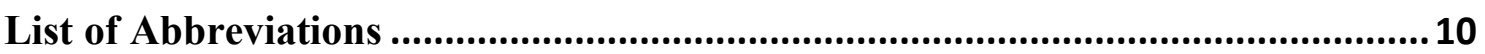

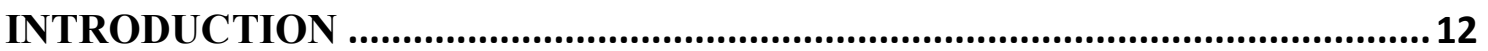

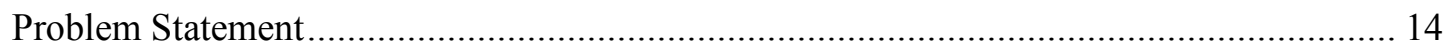

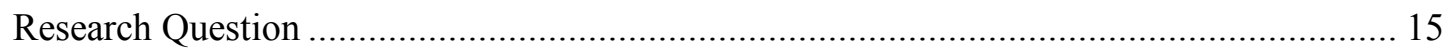

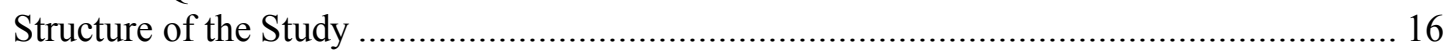

CHAPTER I: INTERNATIONAL INVESTMENT PROTECTION IN THE LIGHT OF ECUADORIAN CONSTITUTIONAL EVOLUTION ........................ 17

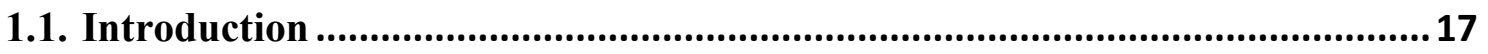

1.2. The Foundation of the Republic and the Constitutional History's Milestones 18

1.2.1. Evolution of the Constitutional Provisions that Set the Public and Private Boundaries 23

1.2.2. First period: The Birth of the National State and the Incipient Definition of a Basic

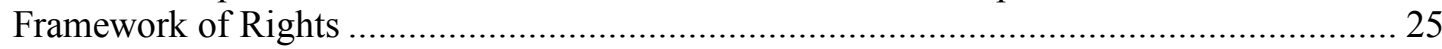

1.2.3. Second Period: Institutionalization of the Public Sector and Expansion of Regulatory Powers 29

1.2.4. Third Period: Oil Boom and Insertion of Ecuador in the Global Economic Context 33

1.2.5. Constitutional Reform, Deregulatory Trends and the Expansion of Neoliberal

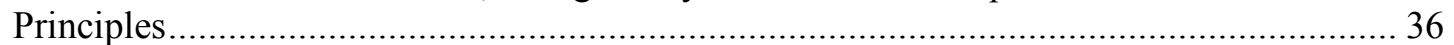

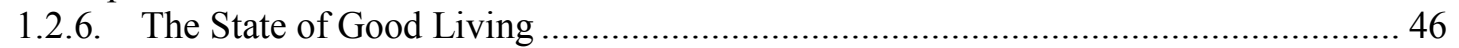

1.3. Constitutional Approach to the Right to Property ........................................65

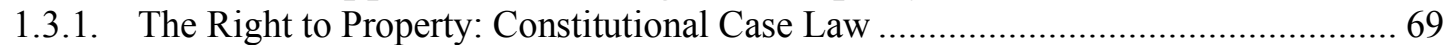

1.3.2. The Right to Property: Supreme Court's Case Law ................................................. 74

1.4. The Evolution of the Regulatory Space in the Ecuadorian Constitutional

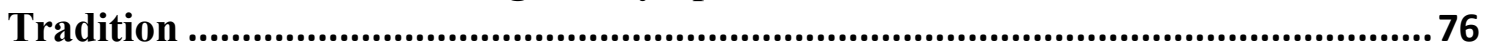

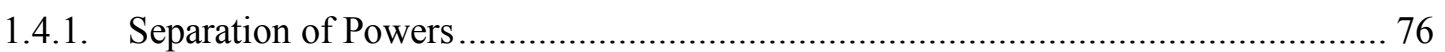

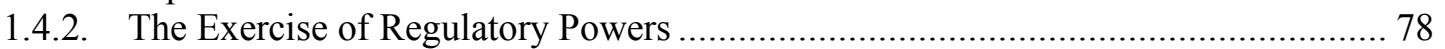

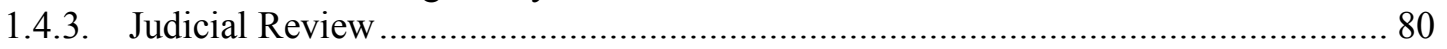

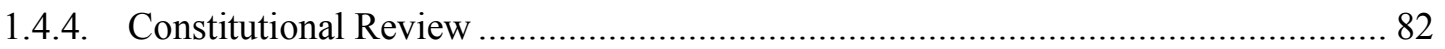

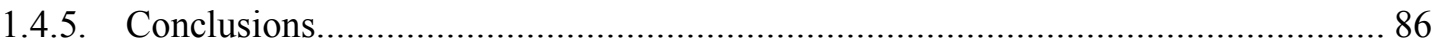

1.5. Status of International Obligations in the Ecuadorian Constitutionalism ......87

1.5.1. Constitutional Supremacy and International Obligations .................................... 87

1.5.2. Negotiation, Signature, Ratification and Denunciation of International Treaties ..... 89

1.5.3. Limitations to the Delegation of Sovereign Powers ............................................... 92

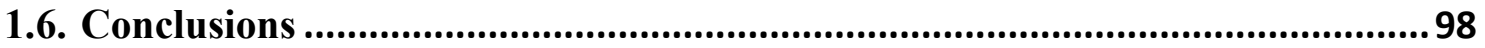

CHAPTER II: THE ARTICULATION OF THE SYSTEM OF

INTERNATIONAL INVESTMENT PROTECTION IN ECUADOR ................. 102

2.1. Introduction 
2.2. Constitutional evolution, incorporation of International Law and protection of foreign investment

2.2.1. The Configuration of National Institutionalism and First International Instruments for the Protection of Foreign Capital.

2.2.2. The Construction of the Pan-American Order and the Hemispherical Protection of

Cross-Border Interests.

2.2.3. Multilateral Attempts for Unifying Private International Law and the Growing influence of Arbitration as an International Mechanism of Dispute Settlement.

\subsection{The Construction of the Global Order After World War II and the}

Transnational Protection of international Capital

2.3.1. Articulation of the UN System and Institutional Design for the Protection of

Transnational Capital

2.3.2. The Bretton Woods Institutional System

2.3.3. The Organization of American States ....

2.3.4. Development of International Rules for the Settlement of Disputes Involving Public

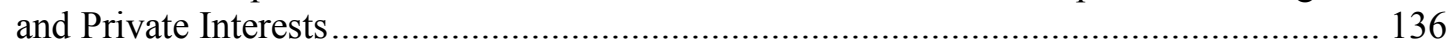

2.3.5. Multilateral Measures for Unifying International Trade Rules............................. 140

2.3.6. Consolidation of International Rules Regarding State Responsibility .................. 144

2.3.7. Early Adoption of Bilateral Investment Treaties (BITs) by Ecuador ..................... 146

2.3.8. The Emerging Conflict Between Constitutional Provisions and International

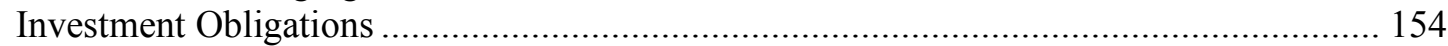

2.3.8.1. The Principle of Equality Before the Law................................................ 154

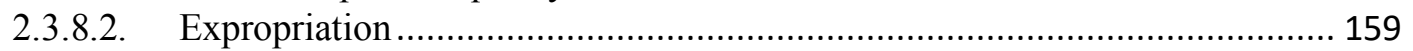

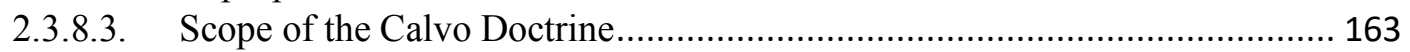

2.3.8.4. The Void Effect of International Norms in Contradiction to the Constitution 168

2.3.9. The Andean Pact and the Establishment of a Regional Investment Regime .......... 170

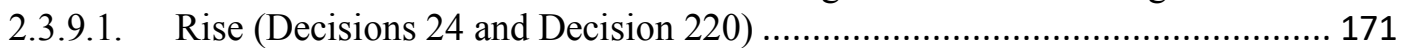

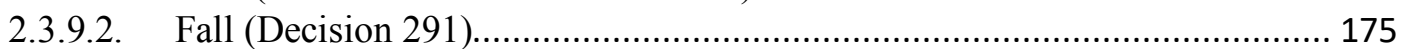

2.3.9.3. Contradiction Between Andean Supranational obligations and BITs provisions 177

2.4. The Liberalization Trend and the Privatization of Justice 184

2.4.1. Public Measures Adopted for Attracting Foreign Direct Investment and Liberalizing

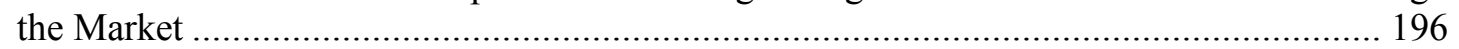

2.4.2. The Irregular Contractual Submission to ICSID Jurisdiction .............................. 208

2.4.3. Boom of Bilateral Investment Treaties........................................................... 217

2.4.4. The Internal Procedure of Approval of the ICSID Convention ............................. 224

2.4.5. The Avalanche of Investment Disputes at the Outset of the XXI Century ............. 232

\subsection{Towards the Re-Definition of the Coexistence Between the State and the}

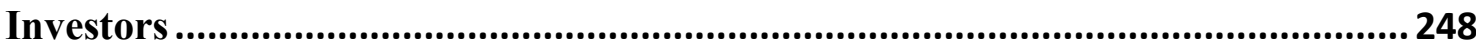

2.5.1. The Process of Disengagement from International investment Obligations........... 248

2.5.2. Relevant Official Actions for Redefining the Relationship Between the State and the

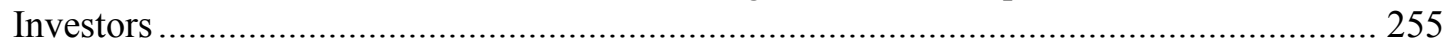

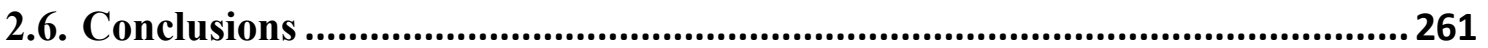

CHAPTER III: THE REFORM OF INTERNATIONAL INVESTMENT PROTECTION IN A CONTEXT OF INSTABILITY ........................................2 263

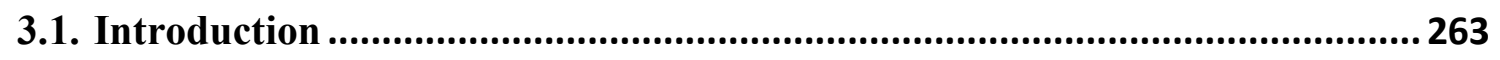

3.2. The Attempt to Reshape Investment Protection Rules in the Battlefield ...... 264

3.2.1. Confronting Ecuador's reformistic impetus with the logic of Investor-State Dispute

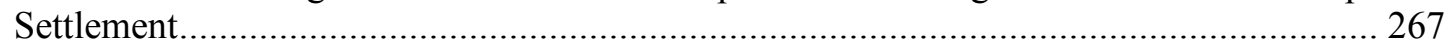


3.2.2. Appraising the Ecuadorian Litigation Experience Against Comparative Standards 278

3.3. Learning by Doing: The Evolution of Regulatory Mechanisms to Avoid the State's exposure to International Investment Disputes

3.3.1. Arbitral Experimentalism and Development of Substantive Standards in the

Ecuadorian Disputes 288

3.3.2. The Discursive Battle Surrounding the Reform of International Investment Protection 294

3.3.3. Reformist Pragmatism and the Omnipresence of International Legal Concepts..... 298

3.4. Drawing the New Boundaries of Investor- State Conflict Management........ 310

3.4.1. Influencing Investment Commitments through Domestic Measures ...................... 310

3.4.2. The System of Investment Protection as Neutralizer of Core Legal Values........... 320

3.4.3. The Necessity to Bury the Calvo doctrine in Order to Achieve Realistic and Balanced

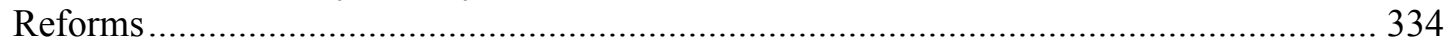

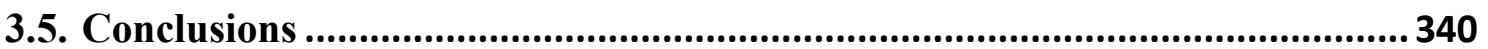

CHAPTER IV: THE IMPLEMENTATION OF INTERNATIONAL INVESTMENT OBLIGATIONS IN A NEW CONSTITUTIONAL CONTEXT 342

\subsection{New Constitutional Context and Pre-existing International Investment}

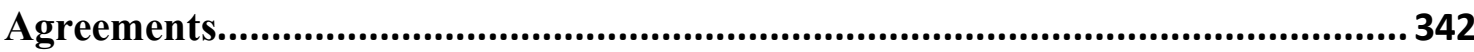

4.2. Constitutional Control in a Context of Instability .......................................343

4.2.1. The Principle of Constitutional Supremacy into Motion....................................... 343

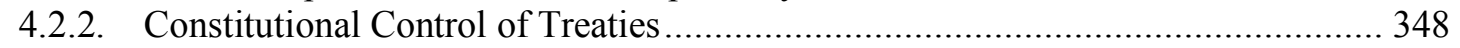

4.3. Constitutional Control of International Investment Agreements .................. 354

4.3.1. The Review Process of Bilateral Investment Treaties ........................................... 354

4.3.2. Constitutional Control of Treaties in Changed Circumstances ............................... 357

4.3.3. Domestic Effects of BITs Provisions Declared Incompatible with the Consittution 360

4.4. The Coexistence of Two Constitutional Like Regimes ................................... 362

4.4.1. National Perceptions Defining the International Investment Law Regime ............ 367

4.4.2. First Measures Challenging the Effects of International Investment Agreements .. 372

4.4.3. Revisiting the Notions of Sovereignty in the light of Public International Law ..... 375

4.4.4. Developing National Legislation to Resist the Effects of International Investment Law 377

4.5. Constitutional Boundaries Allowing the State's Submission to International

Arbitration Involving Private Parties

4.5.1. Scope of the Constitutional Exception Allowing for Treaty Based Arbitration

Involving the State and Individuals

4.6. Drawing the Boundaries between the Constitutional Space and the International Legal Framework

4.6.1. The Termination of Treaties under Changed Circumstances

4.6.2. Mechanisms for Termination of Treaties as Interpreted by the Constitutional Court 394

4.6.3. Termination of Treaties and Severance of the Relevant Provisions.

4.6.4. The Doctrine Rebus Sic Stantibus as Ground for Terminating Treaties

4.6.5. Application of Survival Clauses.

4.6.6. The Interplay of State and Investors Interests in the Dispute Settlement Arena..... 411

4.6.7. The Interpretation of International Treaties by the Constitutional Court ............... 414

4.6.8. Judicial Interpretation and Resistance to International Law ................................. 418 


\subsection{Reconciling Further Investment Obligations with the New Constitutional}

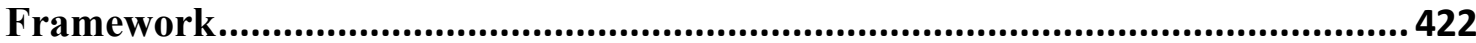

4.7.1. The Interplay between Domestic Regulations and International Investors' rights.. 424

4.7.2. Regulatory Change and Investors' Interests ..................................................... 426

4.7.3. Controlling Regulatory Change Through Iinternational Investment Agreements

(IIAs) 427

4.7.4. Boundaries of Regulatory Deference Provided for BITs: Expectation vs. Reality. 434

4.8. Contractual Repercussions of the BITs' Constitutional Review.................... 439

4.8.1. Constitutional Review of Contracts.................................................................. 445

4.8.2. Constitutional Control and Investors' Contractual Rights..................................... 451

4.8.3. Consent To Arbitration Under Changed Circumstances ....................................... 457

4.9. Reaction to Changed Circumstances .................................................................460

4.9.1. Constitutional Control of Legislative Measures Changing the Economic Terms of Oil

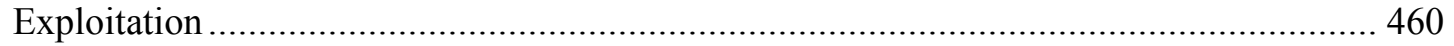

4.9.2. Assessing the Possibility of Reacting to Changed Circumstances Within the oil Investment Disputes Faced by Ecuador ........................................................................... 466

4.9.3. The Effectiveness of Contractual Remedies to Adapt Changed Circumstances ..... 475

4.9.4. Appraising the Futility of Contractual Stipulations of Renegotiation .................... 478

4.9.5. The Application of Domestic Law within International Investment Contracts ...... 482

4.9.6. The Introduction of Legal and Contractual Waivers to Resort to the Protection of

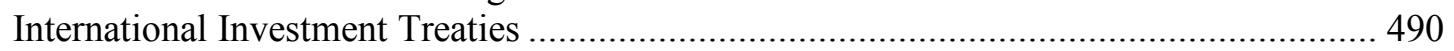

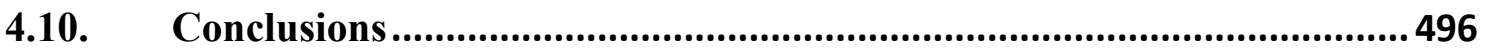

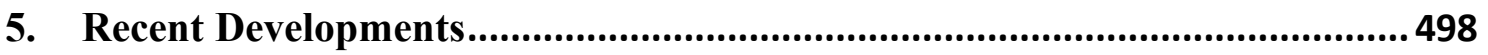

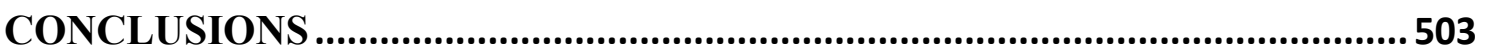

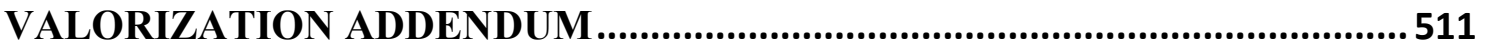

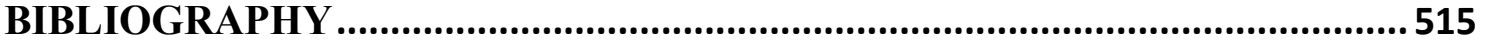

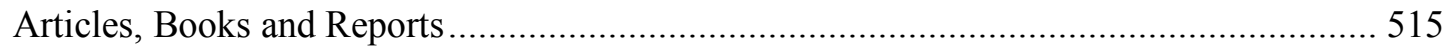

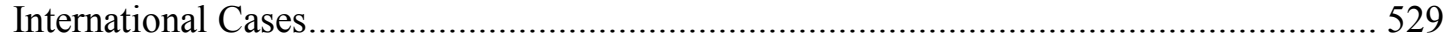

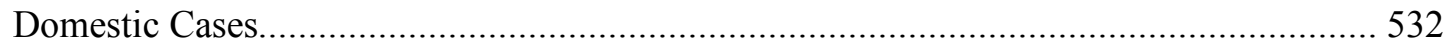

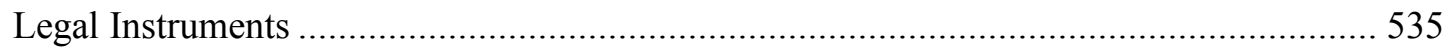

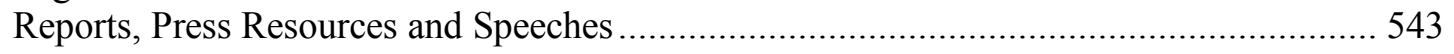




\section{Acknowledgements}

Engaging with Maastricht University was a long sought personal goal that came to fruition thanks to the confidence and generous support of the Faculty of Law when I was accepted in the Advanced Master in International and European Economic Law on 2010, with a full tuition waiver.

As a Master's student, I never dreamt that this life-changing experience would be followed by the possibility to take on a $\mathrm{PhD}$ under the supervision of two of my most respected professors, Leïla Choukroune and Peter van den Bossche. The lessons, places and people I met under their mentoring enriched my academic, and especially, my personal experience in unforeseen ways.

I cannot sufficiently thank Leïla's and Peter's encouragement and companionship in pushing me to go further and achieving my goals. Their guidance opened doors to many forums, where I was the first Ecuadorian with the privilege to attend. Going that far would not have been possible without the scholarship granted by the Ecuadorian Government to pursue my doctoral studies. Much of this effort is dedicated to my fellow citizens who funded this endeavor, especially to those who did not have the opportunity to go to the University.

The development of my ideas was furthered by the semester I spent as a visiting scholar at Columbia University thanks to the sponsorship of the Center on Sustainable Investment and the support of Lisa Sachs and Lise Johnson. I was also very fortunate to carry out my research within the Commission for the Integral Citizens' Audit of the Treaties of Reciprocal Protection of Investments and of the International Arbitral System on the Subject of Investments in Ecuador.

I would also like to express sincere gratitude to the members of the Assessment Committee for my PhD dissertation; Prof. M.G. Faure, Prof. A.W. Heringa, Dr. Katia Fach Gómez and Dr. Rodrigo Polanco Lazo for their interest in my research and for finding time to read my manuscript, of which the final version was enriched by their feedback. 
I am also indebted to the people that helped me embark on this journey as a student of the Faculty of Law at Maastricht University and afterwards, as a $\mathrm{PhD}$ candidate associated to the Institute of Globalisation and International Regulation. My special thanks go to Prof. Aalt Willem Hering and Prof. Hildegard Schneider, former deans of the Faculty, and to Sophie Janssen and Diane Crook.

I gratefully acknowledge the unconditional support of Licette Poll and Diana Schabregs throughout this entire journey. Their skillful, committed and generous management made possible to fulfill this research and accomplish ambitious goals, both from the academic and personal perspectives either in Maastricht or anywhere in the world.

From the bottom of my heart, I want to thank my family, specially my parents, Patricio and Nancy and my siblings, Giovanni and Juan Carlos, for their endless support, patience and love throughout these years of $\mathrm{PhD}$ research, which was sweetened by the presence of my nephews, Juanse and Emilio. Their confidence in me was the engine to follow my own voice and getting the best of myself during difficult times; most of this thesis is their achievement. I also want to wholeheartedly thank the people who were part of this voyage in different periods and who helped me undergo and move forward even though it meant goodbyes and losses. Finally, I want to thank Sofía for renewing my enthusiasm to walk through the last steps for finishing this thesis with her optimism and care.

I am very lucky and proud to have achieved this milestone in my beloved Maastricht University. 


\section{List of Abbreviations}

AEC-Alberta Energy Company

ATJ-Andean Tribunal of Justice

ASR-Articles on the Responsibility of States for Internationally Wrongful Acts of the International Law Commission

BIT-Bilateral Investment Treatment

CAITISA- Commission for the Integral Citizens' Audit of the Treaties of Reciprocal Protection of Investments and of the International Arbitral System on the Subject of Investments

CEL- Special Bidding Commission

CETA- Comprehensive Economic and Trade Agreement

CRE-Constitution of the Republic of Ecuador

ECJ-European Court of Justice

ECLAC-United Nations Economic Commission for Latin America and the Caribbean

ECOSOC- General Assembly and in the Economic Social Council

EU-European Union

EU Singapore FTA- European Union Singapore Free Trade Agreement

FDI- Foreign Direct Investment

FET-Fair and Equitable Treatment

GATT-General Agreement on Tariffs and Trade

IACAC- Inter-American Commercial Arbitration Commission

IBRD-International Bank for Reconstruction and Development

ICC-International Chamber of Commerce

IIA-International Investment Agreement

ICC- International Chamber of Commerce

ICSID Convention-Convention on the Settlement of Investment Disputes Between States and Nationals of Other States

IDA-International Development Association

IDB- Inter-American Development Bank

ICJ- International Court of Justice

IIT- International Investment Treaties 
IFC-International Financial Corporation

ILA-International Law Association of Legal Science

ILC- International Law Commission

IMF- International Monetary Fund

ISDS- Investor State Dispute Settlement

ITLOS- International Tribunal for the Law of the Sea

LCIA- London Court of International Arbitration

MFN- Most Favoured Nation

MOSTA- Modernization of the State Technical Assistance Project

MIGA- Multilateral Investment Guarantee Agency

NCA- National Constituent Assembly

New York Convention-Convention on the Recognition and Enforcement of Foreign Arbitral Awards

OLEPPA: Organic Law on Encouragement of Public Private Associations and Foreign Investment

Oxy- Occidental Exploration and Production Company

PCA-Permanent Court of Arbitration

PERTAL- Public Enterprise Reform Technical Assistance Loan

TTIP- Transnational Trade and Investment Partnerships

TRIPS- Agreement on Trade- Related Aspects of Intellectual Property Rights

UNASUR- Unión de Naciones Sudamericanas

UNCITRAL- United Nations Commission on International Trade Law

UNCTAD- United Nations Conference on Trade and Development

UNIDROIT-International Institute for the Unification of Private Law

USA-United States od America

VCLT-Vienna Convention on the Law of Treaties

WB-World Bank

WTO-World Trade Organization 


\section{INTRODUCTION}

The multifaceted connotations of the concept of sovereignty express their omnipresence along the lines of the social contract. In times of political unrest, this concept has been linked to resistance and used as a catalyst for reforms impacting in the State's legal framework, both inwards and outwards. From a legal perspective, sovereignty is the essential tenet of statehood. Both the creation of Domestic Law and the engagement in International Law constitute forms of State sovereignty. The overarching latitude of International Investment Law and the decisions derived from its dispute settlement system have challenged such basic understanding, fueling a sentiment of sovereignty dispossession.

The legitimacy concerns regarding the regime of international investment protection have oriented the policy and academic discussion mainly towards matters related to International Law and, predominantly, to the dispute settlement system as the tip of the iceberg. Understandably, such approach has been replicated by policy-makers by targeting investment arbitration inwards and outwards. Despite the constitutional-like principles embedding International Investment Law and its inextricable link to Domestic Law in the demarcation of rights, obligations and disputes, the influence of Domestic Law on the development and evolution of the system has been overlooked.

This research analyzes the deployment of International Investment Law from the prism of Domestic Law and policy and the interaction between Domestic and International Law within this field. This analysis addresses the multiple ways that Domestic Law shapes the articulation, deployment, enforcement and interpretation of International Investment Law. It also examines the multiple ways in which International Investment Law engages and influences key policies, regulations and rulings. Additionally, it approaches the influence of such interaction defined by the interests of internal and external stakeholders and, ultimately, on the State's exposure to international responsibility.

In this context, Ecuador's experience concerning the deployment of international investment protection rules is illustrative because: 1) like many developing countries, it has followed a policy script advocating for the adoption of international investment agreements and further enabling instruments (regulatory and contractual) as key features of responsible State behavior; 2) its legal framework has been historically embedded by a predominant normative reference to sovereignty-especially concerning natural 
resources - that collides with further constitutional provisions that put on equal footing public policy prerogatives with foreign private interests; 3 ) it has become one of the main State respondents in investment disputes and one of the most active countries advocating for the illegitimacy and necessity to reform the system.

The small relevance of a developing country such as Ecuador in the geopolitical arena contrasts with its high exposure to investment disputes and its unprecedented proposals to react to such regime. Using sovereignty as a tool to challenge the system, the Ecuadorian Government adopted a set of unilateral measures aimed at: 1) terminating and withdrawing from international treaties that enshrine investment protection rules; 2) reforming the constitutional and statutory framework in order to purportedly reassert regulatory powers and to restrict investment arbitration; 3) refining constitutional control over existing and future international obligations; 4) advocating for a regional forum for the promotion and protection of investments and settlement of disputes; and 5) developing a domestic legal framework for the governance, regulation, promotion and protection of investments.

Looking at the evolution of the constitutional, statutory, contractual and adjudicative outcomes occurring on fields related to foreign investment allows to ascertain the evolution of good governance concepts used at international and domestic levels. As well as the divorce between Domestic and International Law to conciliate such conflict.

From the treaty making process perspective, an insulation of international investment agreements from the essential limits of Domestic Law and contract based commitments may be noticed. This isolation has proven problematic, considering that the effects derived from the system's deployment at an adjudicatory level have been perceived as illegitimate, which has fueled chauvinist sentiments covered by a mantra to retrieve sovereignty.

This uncertainty, in addition to aggravating the legitimacy crisis of International Investment Law, upsets a peaceful co-existence between International and Domestic Law, as well as between international and national adjudicators. The latter being tempted by the task of assuring the inflexible predominance of Constitutional Law over International Law based on the allegation of incompatibility of international investment agreements with a revisited constitutional framework.

As recent developments in Ecuador show, the unexpected shifts in policies ranging from nationalist driven strategies to the aggressive return of neoliberal 
conceptions, reveal — on one hand — the frailty of measures implemented to set up a new logic of coexistence between the State and foreign investors; and - on the other handthe adaptability of pro-market principles to return and recover apparently lost ground. Since "the devil is in the detail", the notable reappearance of unlimited investment protection attempts has adopted the shape of domestic reforms, leaving clearance from existing obstacles for signing international investment agreements for a later stage.

In light of the aforementioned, a comprehensive legal analysis of the Ecuadorian experience-from articulation, enforcement, resistance, abolishment and reconstruction of various tools for investment protection - contributes to a general understanding of the singularities and challenges that International Investment Law undergoes in Latin America. Lastly, such analysis depicts the relationship between Domestic and International Law in each one of these stages linked to State responsibility.

\section{Problem Statement}

The futility of declaring the supremacy of International Law within the national legal order in the same way as claiming the predominance of the Constitution related to International Law is well established ${ }^{1}$. Following such understanding that highlights the intricate influence of Domestic Law in the establishment, enforcement and reform of the foreign investment protection system, it is necessary to pay comprehensive attention to the various interactions that regulatory acts and contract based obligations develop due to their connection with international investment agreements.

If investment tribunals have exercised a form of regulatory scrutiny over domestic law and regulatory measures under the framework of international investment agreements, national adjudicators - empowered by revisited constitutional provisions and powers - have begun to challenge the legitimacy and lawfulness of such instruments under the prism of a national legal order. In view of the reluctance towards the system, the extent to which the adoption of unilateral measures - along with the constitutional review of existing treaties - rather than limiting the country's exposure to State liability may increase it.

In the case at hand, the assorted constitutional and statutory provisions, as well as the political statements and decisions of public policy registered alongside the evolution

\footnotetext{
${ }^{1}$ See, Nollkaemper (André), "The effects of treaties in domestic law" in Research Handbook on the Law of Treaties, Edited by Tams (Christian J.), Tzanakopoulos (Antonio) and Zimmermann (Andreas), EdwarElgar, $138 \mathrm{p}$.
} 
of the framework for protection of foreign investors, may prove a misinterpretation of the scope and nature of the protection provided for in International Investment Law.

Moreover, the long-standing deference given to the Executive to adopt international treaties limited to lax filters of constitutional conformity-together with an apparent monist approach - may provoke odd situations due to the emergence of a new constitutional framework and revisited mechanisms of constitutional control. According to Ecuadorian constitutional case law, international treaties are considered part of the domestic legal framework, meaning that if they are found incompatible with the Constitution due to the application of the mechanism of ex post facto control, they have to be removed of the national legal framework. Given that such a control involves the interpretation of legal concepts and principles developed by International Law contrasted to the wording of revisited constitutional provisions, it deserves an analysis as to whether such domestic interpretations constrain the category, scope and contents of the Executive's foreign policy and treaty-making powers.

In addition, the stormy relationship between Domestic law and International law in all the layers of the system of foreign investment protection unfolds the relevant role of the former on enabling and substantiating the latter. Overall it is contended that any measure aimed to redraw the boundaries of the system has to consider the multidimensional interactions between Domestic Law and International Law. Meaning that any attempt for reform shall not be monolithic and, consequently, must be preceded by an integral assessment that gives due consideration to treaties, regulations and contracts. This endeavor should be accompanied by an assessment of the internal governance structure- built from technical capacities and the identification of regulatory actions that have often triggered investment disputes.

\section{Research Question}

The main research question to be answered in the present study is as follows:

What is the relationship between International Investment Law and Domestic Law in the articulation, enforcement and reform of the foreign investment protection system?

What are the implications for the State's responsibility arising from the adoption of measures to react to claimed adverse effects of International Investment Law by means of 1) ex post facto constitutional control of Bilateral Investment Treaties; 2) the consequential termination of these treaties; and 3) the concurrent 
review of foreign investment's protection framework through treaty, statutory, regulatory and contractual reforms?

\section{Structure of the Study}

Based on the main research question, this study is organized into four chapters. Chapter I addresses the evolution of international investment protection throughout the Ecuadorian constitutional history. Chapter II covers how the international investment protection system articulates by analyzing the assimilation of International law in the Ecuadorian constitutional evolution, emphasizing the protection of foreign investment. It embraces a comprehensive study of this regime's configuration at the international and domestic law-making levels, the regulatory decisions that enabled this mechanism to be set in motion and the emerging defense mechanisms through the intervention of adjudicative bodies.

Chapter III explores the Ecuadorian State's attempts to redefine the boundaries of international investment protection in a context of instability. Furthermore, it analyzesfrom a legal perspective - the perceptions, responses and proposals attempted within the context of reform and relationship rebuilding with foreign investors, and contrasts it with the transformations recently developed at an international level. Lastly, Chapter IV assesses the implementation of international investment obligations in a new constitutional context, stemming from the doctrine of fundamental change of circumstances applied by the Ecuadorian Constitutional Court to declare Bilateral Investment Treaties incompatible with the Ecuadorian Constitution. 


\section{CHAPTER I: INTERNATIONAL INVESTMENT PROTECTION IN THE LIGHT OF ECUADORIAN CONSTITUTIONAL EVOLUTION}

\subsection{Introduction}

The unforeseen effects caused by International Investment Law on fundamental people's rights and by the exercise of a State's sovereign powers has increased global pressure for reforming this regime. Assuming that international obligations are not static and that the protection of investments cannot be considered as an absolute value that overrides essential principles recognized by the international community, this research aims to portray the Ecuadorian constitutional evolution regarding investment protection, as well as its struggles for re-affirming its right to self-determination in view of internal and foreign influences.

In this context, the borders of public and private activities have evolved over time, as well as the interactions between foreign investors and public entities, to whichrecently - the emergence of social groups and recognition of collective rights have been added.

As a consequence, it seems that the pillars over which international obligations have relied on an absolute notion concerning the principle of State sovereignty, especially regarding governance over natural resources. In Ecuador, a State-centered conception of sovereignty has been a trait in the adoption of international obligations. Along this line, the most recent constitutional framework (2008) incorporates obligations and values that transcend the State's sphere and exclusive influence of State actors.

This new landscape imposes substantive and procedural requirements - both for current application and future adoption - of international obligations. At the same time, this research intends to portray the progressive reshaping of borders within which public and private activities work together. According to this analysis, the radical transformation created by the Constitution of 2008; as well as the challenges for adapting its values, prescriptions and proscriptions in the field of international law, are indisputable.

As evidenced, the infamous standpoint of the Ecuadorian State as a respondent in international investment disputes is the result of a complex network of economic forces, legal reforms and social struggles, which historically have modeled the current local scenario in which the international responsibility of this State has been assessed.

It is therefore essential to describe the evolution of the economic, political and legal context, which has shaped the foundations of investment protection since the birth 
of the Ecuadorian State. This detailed approach attempts to delineate the regulatory space and the private autonomy's contours in view of the rules that govern international obligations according to Ecuadorian constitutional tradition. This research assumes that the demarcation is crucial for assessing the State's liability pursuant to current and future international obligations.

To this end, this chapter describes the historical events that surrounded the foundation of the Republic, the evolution of the constitutional regime, as well as its historic milestones. Furthermore, it gives special attention to the analysis of the right to property in the Ecuadorian constitutional tradition. It continues with the analysis of the evolution of regulatory space and the status of international obligations according to the internal legal order. The chapter concludes with the new constitutional framework that drastically transforms the systems of Government and social co-existence, demanding to restructure the entire legal order, including international obligations that differ from human rights conventions.

\subsection{The Foundation of the Republic and the Constitutional History's Milestones}

The establishment of any legal regime and especially of a new constitutional order cannot be assessed in isolation from the driving forces that fueled changes of such magnitude. Scholars such as Trubek and Santos have contributed to the understanding of the well-established and turbulent relationship between law and economic development. ${ }^{2}$ As it is evidenced throughout this chapter, foreign and national rule-makers have used the noun "development" as though it gave them "carte blanche" with functional, and in some way, contradictory meanings along the Ecuadorian constitutional history.

From its foundation, the surge of the concept of rule of law in Ecuador inherited several authoritarian features consolidated during the Spanish colonial period, which privileged the allocation of political powers in the hands of a few influential groups.

The State of Ecuador was officially created by the enactment of the Constitution of 1830; however, it is worth underlining the precedents, which underpinned the realization of the First Constitutional Assembly. In 1809, with the growing instability of the Spaniard Monarchy due to the invasion of Spain by Napoleon and the nomination of his brother Joseph Bonaparte as new ruler of the Americas, a group of "criollos"

\footnotetext{
2 Trubek (David M) and Santos (Alvaro ), The New Law and Economic Development, Edited by David M. Trubek and Alvaro Santos, Cambridge University Press, New York, 2006, 19 P.
} 
attempted to take advantage of this apparent vacuum power and consequentially, claimed to rule on behalf of Ferdinand VII. This failed endeavour, weakened by the lack of popular support, was re-edited in 1811, prompting the proclamation of the Constitution of Quito of $1812^{3}$, with an attempt to crush the spirit of independence and reaffirm loyalty to Ferdinand VII. ${ }^{4}$

These events were the prelude to the definitive loss of control of the Monarchy over the "Audiencia de Quito", which crystalized in 1822, with the approval of the Constitution of Gran Colombia, as the result of the liberation of the colony and the inauguration of a new republic formed by modern Ecuador, Colombia and Venezuela, during a short period of eight years. ${ }^{5}$ The inherent features of a centralized executive authority, as heritage of the absolute monarchical model, would not have been expelled from Ecuadorian constitutional history, which is full of Constituent Assemblies and extensive normative texts.

From the Constitution of 1830 to the current Constitution of 2008, Ecuador has been governed by twenty constitutions. Concerning the Constitution of 1830, Pareja Diezcanseco illustrates:

“(...) It was, as many others inherited by our history, only a piece of paper, not

${ }^{3}$ Gerlach (Allen), Indians, Oil and Politics: A recent History of Ecuador, Scholarly Resources Inc., Wilmington, 2003, 23 p.

${ }^{4}$ Allen Gerlach illustrates about the various events pushing from the independence from the Spaniard Crown:

"On August 2, 1811, another uprising took place, the net result of which was a temporary blending of various political interests in a new governing body. Criollos joined a junta headed by the peninsular president of the Audiencia. A few months later a constitution was issued that vowed allegiance to Ferdinand VII, if and when he should resume the throne with the proviso that the king must respect the institutions and liberties established in the constitution. The junta was soon quashed, however, by royalist forces from Lima."

Gerlach (Allen), Indians, Oil and Politics: A recent History of Ecuador, Scholarly Resources Inc., Wilmington, 2003, 23 p.

${ }^{5}$ Gerlach summarizes the main factors that precipitated the collapse of Gran Colombia:

"Discontent with the tripartite union of Gran Colombia surfaced from the outset. Ecuador's growing opposition to Gran Colombia was fueled by a 30 per cent tax levied on cacao exports to finance Bolivar's final campaign against the Spaniards in Peru and Bolivia and by a disproportionate 21.5 per cent share of independence war debt being thrust upon it. Furthermore, the locals resented outsiders holding most of the top government positions. As the northerners have liberated the region, they determined to dominate it as long as they could.

(...) After Venezuela bolted in January 1830 and the three party entity of Gran Colombia disintegrated, the independent republic of Ecuador was proclaimed on May 13, 1830. A constitutional convention that named Ecuador`s first head of state, General Juan José Flores, wrote a constitution that assured power to a small group of landowners."

Gerlach (Allen), Indians, Oil and Politics: A recent History of Ecuador, Scholarly Resources Inc., Wilmington, 2003, 23 p. 
backed by any social experience capable of ensuring or compelling its enforcement. With it, or against it, President Flores governed as he wished during the term that we would denominate "leap forward": from the colonial rest period to the turbulent waters of the incipient democracy. Little will be said about our first Constitution. Our country has had many of them!"6

The causes for the undervalued significance of the Constitution as an evolving and enduring set of principles, which organize the allocation of powers, ensure the fundamental rights and determine the scope of public provisions, may be summarized within Ecuadorian history, as follows:

(...) Ecuador has a record in the adoption of new constitutions. But this is not caused fundamentally because of the need of changes, but due to political instability, which has brought frequent dictatorships. Amid the political clash, "de facto" governments have been established and the Constitution in force has been broken or derogated. After a certain dictatorial period, the juridical order has been restored through the approval of a new Constitution, which normally, has come into force with a new elected Government. ${ }^{7}$

As Enrique Ayala Mora points out, during our republican history (1830-2012), twenty constitutions have been enacted, their average life expectancy being nine years, without considering the dictatorship periods, which amount to 32 years. ${ }^{8}$ This scholar further explains that this calculation could be misleading, if one considers that during the dictatorship regimes, the application of the rule of law was suspended. Hence, it could be said, that since 1830 Ecuador has been subject, at least formally, to a constitution for a period of 144 years, the average life expectancy of a Constitution being seven years. Equally astonishing is the calculation concerning the number of governments ruling the

\footnotetext{
${ }^{6}$ Pareja Diezcanseco (Alfredo), Historia de la República, Tomo I, Colección Bicentenaria, Campaña de lectura Eugenio Espejo, Quito, 2009, 73 p.

Free translation.
}

7 Ayala Mora (Enrique), Ecuador patria de todos, 2.ed., Quito, Universidad Andina Simón BolívarCorporación Editora Nacional, 2004, p.190 on Avila Santamaría (Ramiro), "El Constitucionalismo Ecuatoriano. Breve Caracterización de la Constitución de 2008”, 954 p.

http://biblio.juridicas.unam.mx/libros/6/2701/34.pdf

Web page visited on February 2015. Free translation.

${ }^{8}$ Ayala Mora clarifies this calculation:

"(...) In the midst of our hectic history, there have been summoned at least, twenty-three assemblies. Some of them did not get to meet, or if they did, they did not finish. Out of these assemblies, nineteen of them enacted a Constitution. We count twenty constitutions because one was enacted without a Constituent Assembly having been convened".

Ayala Mora (Enrique), Historia Constitucional: Estudios comparativos, Biblioteca de Historia. Vol. 36, Universidad Andina Simón Bolívar, Quito, 2014, 15 p.

Free translation. 
country since its creation: one hundred and fourteen, thirty-two of which have been dictatorial. ${ }^{9}$

Bearing in mind the irregular pattern of the Ecuadorian constitutional evolution, it could be affirmed that a chronological analysis of the relevant provisions linked to investment law, could be somewhat fruitless. However, and given the broad space of sovereign scope factually yielded for the implementation of the system of international investment protection, it is essential to identify the most salient constitutional provisions more closely related to the delimitation of sovereign powers and private rights. This analysis may clarify the way the contours of the tempestuous relationship between the State and foreign investors have been shaped. In this context, it must be emphasized that the country has been organized as a Republic since 1835 and has adopted the presidential system since its first Constitution. Both characteristics still remain today. ${ }^{10}$

From the perspective of its political orientation, Avila Santa María, divides Ecuadorian constitutional history into two periods, which represent two models: "liberal and egalitarian":

"Within the first period, there could be identified 4 stages of liberalism: 1) conservative; 2) secular; 3 ) social, and 4) neo-liberal. Concerning the second one, there emerges the Constitution of 2008, which is 5) egalitarian, and it is yet to be seen whether this forms the beginning of a significant and long-lasting period."11

As Avila Santa María underlines, the liberal model is based on the exercise of individual liberties. In broad terms, classical liberalism stands for the "the idea of limited government, the maintenance of the rule of law, the avoidance of arbitrary and discretionary power, the sanctity of private property and freely made contracts, as well as the responsibility of individuals for their own". ${ }^{12}$ In this line, liberalism would aim to

\footnotetext{
${ }^{9}$ Ayala Mora (Enrique), Historia Constitucional: Estudios comparativos, Biblioteca de Historia. Vol. 36, Universidad Andina Simón Bolívar, Quito, 2014, 5 p.

Free translation.

10 Oyarte (Rafael), Derecho Constitutional: Ecuatoriano y comparado, Corporación de Estudios y Piublicaciones, Quito, 2014, 2 p.

Free translation.

11 Ávila Santamaría (Ramiro), "El Constitucionalismo Ecuatoriano. Breve Caracterización de la Constitución de 2008", Biblioteca Jurídica Virtual de Investigaciones Jurídicas de la UNAM, Instituto 954 p; https://archivos.juridicas.unam.mx/www/bjv/libros/6/2701/34.pdf Free translation.

12 Ryan (Alana), "Liberalism”, on Godin (Robert E), Pettit (Philip) and Poge (Thomas) Editors, $A$ Companion to Contemporary Political Philosophy, Chapter 14, 2nd Edition, Volume 1, Blackweel Publishing, 2007, p.362
} 
reduce the action of the government to its minimum expression, in benefit of individual actions supported by the inviolability of property rights and freedom of contract. The same scholar highlights that in the liberal model, it is notable that the economic and political predominance of specific and well identified groups is empowered by stronger capabilities to exercise their liberties, by prevailing over individualism as a way of life and pillar of the ruling economic models. ${ }^{13}$

With such divisions, Avila Santa María warns that the "liberal conservative constitutionalism", linked wealth with political power, disregarding the intervention of the State in economic transactions. This concept arises categorically in the first constitutions, which assigned constitutional rights only to adult male landowners. Therefore, until 1861 the formal exercise of sovereign powers was the privilege of this small elite. ${ }^{14}$ With regard to the "liberal secular constitutionalism", Avila Santa María indicates that the Constitution of 1906 determined the separation between the State and the Catholic Church and incorporated several liberties of the citizens. According to his view, the Constitution of 1929 founded the "liberal social constitutionalism", delineating a minimum space for State action and discretely enlarging the scope of citizen liberties. Avila Santamaría indicates that during this period, universities and scholars promoted the domestic development of legal theory and concepts, applied by the judicial branch, with a strong emphasis on the protection of property rights under the authority of the Civil Code. ${ }^{15}$ The Constitution of 1945 incorporated social, economic and cultural rights; it also strengthened the State's regulatory influence by creating the Central Bank and the General Comptrollership of the State. Later on, the Constitution of 1967 encompassed the notion of public interest to the exercise of property rights. ${ }^{16}$ Following the division

13 Ávila Santamaría (Ramiro), "El Constitucionalismo Ecuatoriano. Breve Caracterización de la Constitución de 2008”, Biblioteca Jurídica Virtual de Investigaciones Jurídicas de la UNAM, Instituto 956 p; https://archivos.juridicas.unam.mx/www/bjv/libros/6/2701/34.pdf

Free translation.

14 Ávila Santamaría (Ramiro), "El Constitucionalismo Ecuatoriano. Breve Caracterización de la Constitución de 2008”, Biblioteca Jurídica Virtual de Investigaciones Jurídicas de la UNAM, Instituto 956 p; https://archivos.juridicas.unam.mx/www/bjv/libros/6/2701/34.pdf

Free translation.

15 Ávila Santamaría (Ramiro), "El Constitucionalismo Ecuatoriano. Breve Caracterización de la Constitución de 2008", Biblioteca Jurídica Virtual de Investigaciones Jurídicas de la UNAM, Instituto 956 p; https://archivos.juridicas.unam.mx/www/bjv/libros/6/2701/34.pdf

Free translation.

16 Ávila Santamaría (Ramiro), "El Constitucionalismo Ecuatoriano. Breve Caracterización de la Constitución de 2008", Biblioteca Jurídica Virtual de Investigaciones Jurídicas de la UNAM, Instituto 956957 pp; https://archivos.juridicas.unam.mx/www/bjv/libros/6/2701/34.pdf 
proposed by Avila Santa María, the last period of liberalism was governed by an open neo-liberal trend, incipiently embraced by the Constitution of 1979, which inaugurated the return to democracy after 7 years of military dictatorship, by establishing a planned market economy. However, the nineteenth Constitution of 1998 prompted the incorporation of vigorous neo-liberal concepts, sweetened by the expansion of rights to vulnerable groups and minorities, as well as strengthening several actions of constitutional control and constitutional remedies. This constitutional framework not only sanctified the most notable principles of Washington Consensus, but also did broaden its scope. Since the return to democracy, the protection of particular economic privileges would have never been more explicit:

The minimal presence of the State, along with the growing social demands, aggravated by the banking crisis of 1999, provoked both, that the promises of rights of this Constitution could not be fulfilled, as well as it affected the effectiveness of the novel constitutional guarantees. The Constitutional Tribunal, at the end, was not the expected arbitrator of constitutionality and conversely, and as it has been the tradition in Ecuador, several coups d' etat grounded the intervention of the Army for re-establishing the social and legal order. ${ }^{17}$

The Constitution of 1998 was paradigmatic for accelerating the most traumatic economic, political and social crisis suffered by the country with the cost of abandoning its own currency and the exodus of millions of Ecuadorians. However, many previous legal reforms implemented from the beginning of the 1990s, were also key to detonate a period of instability, which gave birth to a new Constituent Assembly for the promulgation of the current Constitution in force since 2008, whose main antecedents will be addressed below.

\subsubsection{Evolution of the Constitutional Provisions that Set the Public and Private Boundaries}

It is clear that a mere legal assessment confined to the identification of normative transformations would overlook several factors that have shaped both the domestic legal framework and the regulatory practice. Without diminishing the value of a Constitution as a formal set of rules and values that would control the whole legal order, the turbulent

\footnotetext{
Free translation.
}

17 Ávila Santamaría (Ramiro), "El Constitucionalismo Ecuatoriano. Breve Caracterización de la Constitución de 2008”, Biblioteca Jurídica Virtual de Investigaciones Jurídicas de la UNAM, Instituto 958 p; https://archivos.juridicas.unam.mx/www/bjv/libros/6/2701/34.pdf

Free translation. 
constitutional evolution of Ecuador obliges us to confront the legal analysis with political and economic events that have significantly shocked social and institutional structures. As previously observed, the maturing of the constitutional frameworks in Ecuador has been constantly interrupted, as evidenced by their average life-expectancy:

(...) Considering these realities, it would be thought that the Ecuadorians have become constitutionalism experts; that we have developed a solid constitutional doctrine, and that in the succeeding assemblies there have been accumulated a significant doctrinaire legacy. But this is not the case. Generally, it has been preferred to think that with every Constitution, the country was newly founded, that we started from zero. In fact, neither was this possible, nor were significant changes achieved from one constitution to another. We have come back to the first page every time. Many constitutions have been drafted, but in them, the circumstantial interests have predominated over the institutional continuity. Moreover, most of them were in force during short periods. As we have seen, the average duration of a constitution ranges from seven to eight years. For this reason, constitutional thought and a practice of amendments to the constitution have barely evolved, these being the mechanisms by which the constitutionalism expands and consolidates among the whole ambits of the world. ${ }^{18}$

Along with the binary division of the Ecuadorian constitutional history suggested by Avila Santa María (liberal and egalitarian), it is also worth resorting to other relevant propositions, which suggest complementary distinctions of the constitutional periods, beyond narrowing the analysis to the normative evolution. Hence, Ayala Mora suggests that constitutional development cannot be detached from the evolution of the national State. This approach is particularly convenient, taking into account the unsuccessful development of constitutionalism in Ecuadorian history, as proven by its brief duration:

"During the life of the nation-States, there is a line of continuity along the time, but also discontinuities. Therefore, we can establish the moments in which there are changes to the social identity or perception of the Nation. In the historical trajectory of the national States there are several "national projects". Each of them is propelled by the elites, who control political power, and accepted by social sectors that conserving a subaltern position feel themselves as members of the national community." 19

In this line, Ayala Mora proposes that after the colonial and independence antecedents, three national projects have been succeeded, determining three corresponding historical periods:

\footnotetext{
18 Ayala Mora (Enrique) Historia Constitucional: Estudios comparativos, Biblioteca de Historia. Vol. 36, Universidad Andina Simón Bolívar, Quito, 2014, 15 p.

Free translation.

${ }^{19}$ Ayala Mora (Enrique), Historia Constitucional: Estudios comparativos, Biblioteca de Historia. Vol. 36, Universidad Andina Simón Bolívar, Quito, 2014, 21 p. Free translation.
} 
(...) The first period in force from 1830 to 1895 , was characterized by a traditional society expressed in a "landowning and oligarchical State", with scarce international view, under the framework of a "Criollo National Project". In the second period, between 1895 and 1960, the capitalist relationships in the society gained influence, with a strong insertion in the international system, under the predominance of the secular State and the "Mestizo National Project". The third period is unfinished and we are still living it. From the 60's of the past century, in a world strongly globalized, capitalism has modified significantly the Ecuadorian society, which has suffered deep changes and has committed itself for the construction of the "National Project of Diversity". ${ }^{20}$

Taking these historical periods in their context, this section identifies the most relevant constitutional provisions that have drawn the landscape of the system of protection of investment in Ecuador, focusing on the one hand, on the rights and obligations linked thereto and on the other, to the allocation of powers to the relevant authorities.

\subsubsection{First period: The Birth of the National State and the Incipient Definition of a Basic Framework of Rights}

As previously asserted, the subordination of political rights to a minimum standard of proprietorship was formally abolished by the Constitution of 1861 . Yet, such a requisite was preserved in the case of the right for being elected, until the Constitution of 1884. During the period of construction of the "criollo" national project, the rule was that "the people do not exercise by itself any other function of sovereignty, rather that voting in primary elections under the procedure and rules determined by Constitution and law"21. This period divided by Ayala Mora from 1830 to 1895, was notable for "its economic disarticulation and dispersion of political power"22. Concerning the recognition of rights, Ayala Mora points out that the constitutional frameworks of the nineteenth century, accepted several republican characteristics but, preserved strong features of the monarchic regime:

"There was founded a Republic based on the regionalization, the strengthening of property, the reconstitution of the legal power and the exclusion of the majority

\footnotetext{
${ }^{20}$ Ayala Mora (Enrique), Historia Constitucional: Estudios comparativos, Biblioteca de Historia. Vol. 36, Universidad Andina Simón Bolívar, Quito, 2014, 21-22 pp. Free translation.

${ }^{21}$ Ayala Mora (Enrique), Historia Constitucional: Estudios comparativos, Biblioteca de Historia. Vol. 36, Universidad Andina Simón Bolívar, Quito, 2014, 28 p.

Free translation.

${ }^{22}$ Ayala Mora (Enrique), Historia Constitucional: Estudios comparativos, Biblioteca de Historia. Vol. 36, Universidad Andina Simón Bolívar, Quito, 2014, 27 p.

Free translation.
} 
of the population, namely, women, indigenous and black people and nonowners". ${ }^{23}$

Ayala Mora remarks that the "lords of the land" constructed their national project, as a continuation of the Spanish monarchic regime. The ten Constitutions enacted during the nineteenth century were confined principally to the "organization of the State, the citizenship and the attribution of powers" ${ }^{24}$. As Ayala Mora observes, the fundamental concern of the lawmakers dealt with the re-establishment of the internal order and this had an impact on the constitutional design:

(...) It was not distinguished, therefore, what after several years would been known as "dogmatic part", which established the principles, guarantees and rights, from the "organic part" that regulated the state's structure. The first nine Constitutions devoted a title, almost at the end of the text, to the guarantees, which progressively grew and clarified from one constitutional text to another, but in some cases several regressions were produced. Only in 1878 it was resolved to include, after the rules of citizenship and of the rights and political duties, the provisions about guarantees. Also in this Constitution, based on the proposal of Pedro Carbo, it was established by article 16: "The Ecuadorian Nation recognizes the rights of the man as the basis and object of the social institutions". This was a really important step forward". 25

To ease the analysis, the current section uses the division of historical periods delineated by Ayala Mora. In this context, it provides a brief explanation of each of these periods and identifies the main constitutional provisions, which outline the contours of regulatory space, constitutional guarantees and individual rights. In the context of Investment Law, the provisions recited are relevant to the definition of the scope of the protection for investor's right under the national constitutional framework. Since specific sections are devoted to the constitutional treatment of the right to property, separation of powers and the procedure of adoption of international obligations, the proposed approach disregards the corresponding constitutional provisions.

\footnotetext{
${ }^{23}$ Ayala Mora (Enrique), Historia Constitucional: Estudios comparativos, Biblioteca de Historia. Vol. 36, Universidad Andina Simón Bolívar, Quito, 2014, 28 p.

Free translation.

${ }^{24}$ Ayala Mora (Enrique), Historia Constitucional: Estudios comparativos, Biblioteca de Historia. Vol. 36, Universidad Andina Simón Bolívar, Quito, 2014, 28 p.

Free translation.

${ }^{25}$ Ayala Mora (Enrique), Historia Constitucional: Estudios comparativos, Biblioteca de Historia. Vol. 36, Universidad Andina Simón Bolívar, Quito, 2014, 29 p.
} 
Remarkably, the first Constitution conditioned certain principles and guarantees to citizenship's recognition. This reality as well as the presence of the Catholic Church in the constitutional context did not change during the nineteenth century. ${ }^{26}$ Following Schneiderman, the considerable similarity between investment rules and constitutional provisions placing both constraints in the ability of the state to intervene ${ }^{27}$. The main provisions that initially drafted the intricate contours that defined the complex relationship between domestic and international law are highlighted as follows:

\section{Figure 1:}

\begin{tabular}{|l|l|}
\hline $\mathbf{1 8 3 0}$ & $\begin{array}{l}\text { Formal equality before the law. } \\
\text { Right to petition. } \\
\text { Ministers' duty to refrain from abusing their powers. } \\
\text { Taxation through Legislative Branch. } \\
\text { Recognition of treaties of friendship and trade. }\end{array}$ \\
\hline $\begin{array}{l}\text { 1835 } \\
\text { Ronstitution }\end{array}$ & $\begin{array}{l}\text { Sovereignty rests within the Nation and it is exercised through public power } \\
\text { organs. } \\
\text { The power of the Executive Branch to manage diplomatic relations and } \\
\text { ratify treaties prior to the approval from Congress. } \\
\text { Right to undertake any industrial and commercial activity in accordance with } \\
\text { law and good customs. } \\
\text { Exclusive right of property over inventions or discoveries, including the } \\
\text { obligation to compensate the right holder in case of compulsory disclosure of } \\
\text { data. }\end{array}$ \\
\hline $\begin{array}{l}\text { Constitution } \\
\mathbf{1 8 4 3}\end{array}$ & $\begin{array}{l}\text { Equal treatment for the protection of the rights and properties of } \\
\text { foreigners provided they comply with national law. }\end{array}$ \\
\hline
\end{tabular}

${ }^{26}$ Ayala Mora explains the futility of the incorporation of several constitutional rights:

"As it can be noted, the fundamental issue was not if a right was or not stipulated, but rather its scope of application. The conservative constitutions were more restrictive, whereas the liberal constitutions established greater guarantees. On the other hand, it has to be considered that in certain cases, the guarantees were recognized only to the citizens; hence, women and poor people could not invoke them. The constitutions of the end of century tended to expand all the rights to Ecuadorians, with the exception of those of a political nature. Also the Constitutions established the free entrance of foreigners, who might be covered by the same rights and general guarantees recognized in favour of Ecuadorians".

Free translation.

Ayala Mora (Enrique), Historia Constitucional: Estudios comparativos, Biblioteca de Historia. Vol. 36, Universidad Andina Simón Bolívar, Quito, 2014, 32 p.

27 See, Schneiderman (David), "Investment Rules and the Rule of Law", Constellations Volume 8, No 4, 2001. 


\begin{tabular}{|l|l|}
\hline $\begin{array}{l}\text { Constitution } \\
\mathbf{1 8 4 5}\end{array}$ & $\begin{array}{l}\text { Presumption of innocence and right to reputation. } \\
\text { Principle of supremacy of the Constitution. }\end{array}$ \\
\hline $\begin{array}{l}\text { Constitution } \\
\mathbf{1 8 5 1}\end{array}$ & Principle of natural judge. \\
\hline $\begin{array}{l}\text { Constitution } \\
\mathbf{1 8 5 2}\end{array}$ & $\begin{array}{l}\text { Prohibition of deprivation of property in absence of judicial ruling or in the } \\
\text { cases of public utility provided for by law given a compensation agreed upon } \\
\text { with the owner or valued by good men. }\end{array}$ \\
\hline $\begin{array}{l}\text { Constitution } \\
\mathbf{1 8 6 1}\end{array}$ & $\begin{array}{l}\text { Subordination of the period of protection of the rights of inventor to the } \\
\text { provisions of law. }\end{array}$ \\
\hline $\begin{array}{l}\text { Constitution } \\
\mathbf{1 8 7 8}\end{array}$ & $\begin{array}{l}\text { Congress' power to grant exclusive privileges, benefits and compensation for } \\
\text { promoting and boosting the progress of sciences and arts, as well as initiatives, } \\
\text { inventions and discoveries of the Republic's interest } \\
\text { President's power to issue patents for the exercise of exclusive rights. }\end{array}$ \\
\hline $\begin{array}{l}\text { Constitution } \\
\mathbf{1 8 8 4}\end{array}$ & $\begin{array}{l}\text { Proclamation of the Republic as indivisible, free and independent from any } \\
\text { alien power. }\end{array}$ \\
\hline
\end{tabular}

As it has been indicated, ten constitutions were enacted during the nineteenth century. The heritage of the colonial period is evident in the recognition of citizenship rights, the design of the State and the attribution of powers. The adoption of a republican model heavily influenced by the Church's power and the proclamation of sovereignty from alien powers are distinctive in these constitutional texts. However, the reproduction of centralized structures of power concentrated on dominant groups, namely landowners, left little space for the equal exercise of rights. The condition of property, along with other limitations like non-recognition of the autonomous exercise of rights by women, black and indigenous population, left aside the majority of the population in the construction of the State and the national project. From the first constitutions one can note the protection of the right to private property and the prompt incorporation of prohibitions to its unlawful deprivation, like confiscation, as well as public servants' liabilities in cases, where their exercise of powers could affect liberty, property and security of the citizens.

Notwithstanding that guarantees of equality before the law and constitutional supremacy were enshrined by these Constitutions, they were emptied of any democratic value, considering the limited recognition of citizenship as prescribed by these constitutions.

Finally, the incorporation of the "Calvo Doctrine" by the Constitution of 1897 as shown below depicts the open approach to the numerous Ecuadorian constitutional frameworks 
to adopt state- of the art doctrines, although its corresponding implementation remained largely a dead letter.

\subsubsection{Second Period: Institutionalization of the Public Sector and Expansion of Regulatory Powers}

Following the historic division proposed by Ayala Mora, the second relevant period ("Mestizo National Project"28) was in force from 1895 to 1960. After a national crisis, the strong political leadership of Eloy Alfaro emerged and the "Liberal Revolution" took force. This Revolution established the secular State and the right to freedom of thought. According to Ayala Mora, the export boom of cacao provoked the consolidation of the commercial and banking bourgeoisie of the Coast and specifically of Guayaquil, with the corresponding weakening of the "lords of the land" located in the mountain region. The same scholar highlights as features of this period, the modernization of the State and the society, the political and economic centralization and the economic insertion of the country within the international economic system, in a context of consolidation of an imperialist phase. Hence this historian underlines, that the "dependence concerning international capitalism was defined and deepened". 29

Between 1895 and 1960, six constitutions were enacted, yet the Constitution of 1938 never came into force. At the onset of this period, the Constitution of 1897, served a transitional purpose, after the crisis of 1895. The expansion of provisions within the relentless process of constitutional production is notable, as well as the development of international oriented rules that show both the growing presence of foreign transactions and a regional mainstream advocating for a greater degree of autonomy before foreign relations, as the incorporation of Calvo Doctrine ${ }^{30}$ shows (Constitution, 1897).

\footnotetext{
${ }^{28}$ Ayala Mora (Enrique), Historia Constitucional: Estudios comparativos, Biblioteca de Historia. Vol. 36, Universidad Andina Simón Bolívar, Quito, 2014, 39 p.

Free translation.

${ }^{29}$ Ayala Mora (Enrique), Historia Constitucional: Estudios comparativos, Biblioteca de Historia. Vol. 36, Universidad Andina Simón Bolívar, Quito, 2014, 39 p.

Free translation.

${ }^{30}$ Patrick Julliard defines the "Calvo Doctrine" as follows:
}

The Calvo Doctrine rests upon one core proposition: aliens should not be entitled to any rights or privileges not accorded to nationals. The consequence inevitably follows that, since nationals are entitled to seek redress for their grievance only before local authorities, aliens should not be entitled to seek redress for their grievances before authorities other than local authorities. Thus, for example, aliens should not be entitled to turn to the State of which they are nationals in order to seek diplomatic protection. 
This normative inflation does not only show the recognition of the demands for new social and political actors, but specially the hallmark of the Ecuadorian constitutional design: the abundant incorporation of provisions more closely related to a regulatory framework rather than to a constitutional order. Beginning with 1929 Constitution, a regulatory pattern in subsequent constitutions can be noted, which progressively enlarged the list of constitutional provisions. For instance, the Constitution in force since 2008 has 444 provisions. As shown below - and regardless of certain paradigmatic progresses enshrined in several constitutions-the Ecuadorian constitutional design has been prodigal to delineate narrative features that are far from being applicable:

\section{Figure 2:}

\begin{tabular}{|l|l|}
\hline $\begin{array}{l}\text { Constitution } \\
\text { Constitution }\end{array}$ & $\begin{array}{l}\text { Non-retroactive application of the law. } \\
\text { Incorporation of Calvo Doctrine: "Any contract celebrated between a foreigner } \\
\text { and the Government, or an individual, contains implicitly the condition of } \\
\text { resignation to seek diplomatic protection."31 }\end{array}$ \\
\hline $\begin{array}{l}\text { Secular State, free, independent and indivisible. } \\
\text { Prohibition to adopt treaties opposed to State's independence or detrimental } \\
\text { to its sovereignty. } \\
\text { Obligation to provide "equal treatment" for foreigners to exercise civil rights } \\
\text { and constitutional guarantees. } \\
\text { Principle of "no taxation without representation," forbidding the imposition of } \\
\text { any taxes or contributions not created by law. } \\
\text { Right to a public trial. } \\
\text { Obligation to motivate judicial decisions. }\end{array}$ \\
\hline
\end{tabular}

Julliard (Patrick), "Calvo Doctrine/ Calvo Clause", Max Planck Encyclopedia of Public International Law (MPEPIL), January 2007, http://opil.ouplaw.com/view/10.1093/law:epil/9780199231690/law9780199231690-e689

${ }^{31}$ Patrick Julliard defines "Calvo Doctrine" as follows:

The Calvo Doctrine rests upon one core proposition: aliens should not be entitled to any rights or privileges not accorded to nationals The consequence inevitably follows that, since nationals are entitled to seek redress for their grievance only before local authorities, aliens should not be entitled to seek redress for their grievances before authorities other than local authorities. Thus, for example, aliens should not be entitled to turn to the State of which they are nationals in order to seek diplomatic protection.

Julliard (Patrick), "Calvo Doctrine/ Calvo Clause", Max Planck Encyclopedia of Public International Law (MPEPIL), January 2007, http://opil.ouplaw.com/view/10.1093/law:epil/9780199231690/law9780199231690-e689 


\begin{tabular}{|c|c|}
\hline & $\begin{array}{l}\text { Prohibition to transfer funds for amortization of public debt for purposes different } \\
\text { from their original one, namely the payment of debt. } \\
\text { Prohibition to finance public expenditure with loans. }\end{array}$ \\
\hline $\begin{array}{l}\text { Constitution } \\
1929\end{array}$ & $\begin{array}{l}\text { Encroachment of the State's scope of action by recognizing private autonomy } \\
\text { as well as the rights and guarantees, which-although not expressly enlisted in the } \\
\text { Constitution-are inherent to human personality or derived from the principle of } \\
\text { sovereignty and the republican form of government. } \\
\text { Declarative enlargement of State's duties to make effective principles of economic } \\
\text { justice with the assurance of a minimum standard of wealth compatible with } \\
\text { human dignity. } \\
\text { Massive incorporation of constitutional guarantees within a single title (almost } \\
\text { thirty). } \\
\text { Introduction of the notion of "fundamental guarantees": } \\
\quad \text { Prohibition to confer privileges or impose obligations which improve or } \\
\quad \text { worsen the condition of individuals before others. } \\
\quad \text { Personal freedom and safety, which involves the prohibition of } \\
\quad \text { contract or convention which implies the loss of liberty or resignation to } \\
\quad \text { inalienable rights. } \\
\text { Freedom of trade and industry, according to law. } \\
\text { Prohibition of monopolies, unless authorized by a special or general law. } \\
\text { Free exportation of national goods without restrictions, except for the payment of } \\
\text { customs duties and the conditions set out by law for the protection of their quality } \\
\text { and reputation. } \\
\text { Freedom of contract and freedom of profession. } \\
\text { Freedom of association and right to strike. } \\
\text { Determining minimum wage. } \\
\text { technical and consular positions according to law, with the prohibition to exercise } \\
\text { any jurisdictional power. } \\
\text { of jurisdiction in any contract signed between the State, public entities and } \\
\text { individuals with foreigners in Ecuador. }\end{array}$ \\
\hline $\begin{array}{l}\text { Constitution } \\
1945\end{array}$ & $\begin{array}{l}\text { Simplification of procedural laws with the objective of adopting an oral system. } \\
\text { Incorporation of the principle that states that the omission of legal formalities shall } \\
\text { not sacrifice justice. }\end{array}$ \\
\hline $\begin{array}{l}\text { Constitution of } \\
1946\end{array}$ & $\begin{array}{l}\text { Suppression of the explicit prohibition to waive jurisdiction within } \\
\text { controversies in which the State is party. }\end{array}$ \\
\hline
\end{tabular}




\begin{tabular}{|l|l|}
\hline $\begin{array}{l}\text { Prohibition for foreigners to acquire, maintain or administer property rights in } \\
\text { territories forbidden by law. } \\
\text { Obligation of the State to satisfy payment of public debt in accordance with the } \\
\text { Law of Public Credit and the applicable contracts. } \\
\text { Incorporation of the right to freedom of movement. } \\
\begin{array}{l}\text { Recognition of public monopolies, with a prohibition on transferring them to any } \\
\text { national or foreign company. }\end{array}\end{array}$ \\
\hline
\end{tabular}

Evidently, the six constitutions promulgated during this period portray the growing effort for consolidating a national project, with the progressive incorporation of social groups' demands like those underpinned by peasants and workers. There are also notable struggles for separating the influence of the Catholic Church from the State. The attempts for institutionalizing the State can also be seen through the promotion of public works and the creation of new institutions like the Office of the General Comptrollership of the State and the Central Bank. The acknowledgment of public monopolies, free international trade and expansion of rules concerning public debt may evidence the State's influence in expansion of the economy both internally and externally. In this line the introduction of the principle of private autonomy, as well as the obligation of the State to promote and protect private property, delineated the borderlines within which the subsequent political tensions would be focused: the definition of the role of the State in the economy.

In this context it is noteworthy that nonetheless these constitutional frameworks did not include a specific chapter for determining the principles of the economy, they reaffirmed the well-settled principle that subordinates the exercise of the right to property to social function, which was also regulated in detail by the Civil Code. However, it is clear that the principle of social function only could be applied in harmony with the condensed powers exercised by the State. The Constitution of 1946 declared explicitly the domain of the State over minerals and substances which differ from the soil; in any case it is worth to note that the Civil Code already contained similar rules included in the provisions that regulated the right to property.

The pioneering character of our constitutional frameworks can be clearly observed with certain examples like the obligations imposed on the Judicial Branch in accordance 
to the supposed establishment of an oral trial system, the same that after more than sixty years has still not been fully implemented.

Finally, it is noteworthy that the recognition of the Calvo Doctrine was complemented with the explicit prohibition of stipulating a waiver of jurisdiction in any contract signed between the State, public entities and individuals with foreigners in Ecuador. However, the reference to the contract's signature placed as a pre-requisite for the application of the mentioned prohibition entailed its progressive deterioration.

\subsubsection{Third Period: Oil Boom and Insertion of Ecuador in the Global Economic Context}

The constitutional features in the constitutional frameworks of this period provide evidence of the shift in the political debate towards the definition of the State's role within the economy at the outset of the extractive boom. Also, the influence of the proposals for the establishment of a new international economic order ${ }^{32}$ and specially the consolidation of the right to self-determination and the redefinition of sovereignty over natural resources is noteworthy. ${ }^{33}$

Figure 3:

\begin{tabular}{|l|l|}
\hline $\begin{array}{l}\text { Constitution } \\
1967\end{array}$ & $\begin{array}{l}\text { Strengthening of the social function of the State and its duty to promote } \\
\text { human rights and protect individuals against abuses of public power (human } \\
\text { dignity). } \\
\text { Development of a specific section to the principles of the economy. } \\
\text { Refinement of the right to personal freedom and security by including the } \\
\text { prohibition of punishment for conducts not previously proscribed by law. } \\
\text { Incorporation of the principle "in dubio pro reo". } \\
\text { Subordination of the right to "freedom of enterprise" to the public interest. } \\
\text { Equality before the law between nationals and foreigners, under the } \\
\text { terms prescribed by law, with exception to those constitutional guarantees } \\
\text { and political rights recognized explicitly to Ecuadorians. } \\
\text { State's extra-contractual liability and its correlative right to recovery of } \\
\text { the compensation derived therefrom against the public servants involved. }\end{array}$ \\
\hline
\end{tabular}

\footnotetext{
${ }^{32}$ United Nations, General Assembly, Declaration on the Establishment of a New International Economic Order 3201 (S-VI), Sixth Special session, 1 May 1974.

${ }^{33}$ United Nations, General Assembly, Resolution 1803 (XVII) "Permanent Sovereignty over Natural Resources", 14 December 1962.
} 


\begin{tabular}{|c|c|}
\hline & $\begin{array}{l}\text { Liability of judicial authorities for any unjustified delay in the } \\
\text { administration of justice and the obligation to compensate damages derived } \\
\text { therefrom. } \\
\text { State's obligation to grant incentives in favor of private initiatives aimed at } \\
\text { the creation of new enterprises, as well as their expansion and reinvestment } \\
\text { of benefits into lucrative activities. } \\
\text { Special protection for private investments devoted to infrastructure works. } \\
\text { Equal treatment to national and foreign capital, with the exception of those } \\
\text { areas of investment reserved to the former capital. } \\
\text { Tax legislation aimed at stimulating investment as well as reinvestment of } \\
\text { capital. } \\
\text { Constitutional recognition of "international commercial relations." } \\
\text { Praise for Latin American economic integration for the pursuit of common } \\
\text { progress and the improvement of the conditions of exchange within global } \\
\text { trade. }\end{array}$ \\
\hline & $\begin{array}{l}\text { Proclamation of market economy under the principles of efficiency and } \\
\text { social justice. } \\
\text { State's intervention in the economy to guarantee fair distribution of income } \\
\text { and wealth. } \\
\text { Promotion and protection of human rights as an essential State function. } \\
\text { Strengthening of extra-contractual liability of the State, stating its } \\
\text { obligation to compensate individuals convicted by a court ruling, which is } \\
\text { subsequently reformed or overturned. } \\
\text { Para-fiscal objectives of taxation such as encouragement of investment, } \\
\text { reinvestment, savings and employment for national development. } \\
\text { Prohibition of jurisdiction waiver in contracts signed in Ecuador between } \\
\text { public entities and foreign natural or legal persons. }\end{array}$ \\
\hline
\end{tabular}

The constitutional features from the constitutional frameworks of this period provide evidence of the shift in political debate towards the definition of the State's role within the economy at the outset of the extractive boom. The expectations of the redistributive responsibility of the State - suddenly injected with economic resources to spread the benefits of the extractive activities - fueled the demands of the various social layers. Consequently, State patronage became an important issue of governance, which can be clearly seen in the rules for distribution of the State's wealth and the composition of entities vested with regulatory and control powers, such as the Tribunal of 
Constitutional Guarantees and regulatory agencies formed, for instance, by representatives of unions and industrial enterprises.

The roots of State corporatism and the conception of Public Administration as "asset stripping" gained strength during this period. This notion was reinforced by the strong reliance on the right to private property, a concept that translated into the exercise of sovereignty over natural resources, meaning that the State acted as owner and not as representative in the use of this wealth. This assumption-along with the relaxation of regulatory powers during this period-explains the "patrimonial-based approach" regarding both natural resources and regulatory powers, for which control was progressively yielded as the years went by.

In any case, the core and exclusive duties of the State were sharpened; such is the case in the administration of justice. For instance, the declaration of the principle of "jurisdictional unity" attempted to tackle the dispersion of adjudicative powers exercised by entities that did not belong to the Judicial Branch. A Judicial servant's personal liabilities derived from wrong-doings causing delay or denial of justice, were also caused by said effort.

The Constitution of 1967, resembling the failed Constitution of 1945, inserted the principles of the economy linking "the essential objective of wealth" to human dignity. These principles were projected in the use of natural resources "in accordance to the needs of the national economy," reinforcing the role of the State to set out the main guidelines for economic development. In light of this, the Constitution of 1979 took a step forward and established the State's economic model: "a market economy."

As noted, the high status gained by the right to private property meant that, traditionally, the economy had been assumed as an area confined to the private sphere, obliquely regulated by the State. In this regard, the Constitution of 1979 established the role of the State as actor and not solely as regulator. Ever since then, the fear of a "communist State," predatory of individual liberties, has impregnated the speech of commercial and industrial groups. Due to their influence on the media and, subsequently, on public opinion, these apprehensions have permeated deeply into the middle class, which has been the catalyst of institutional transformations since the end of the twentieth century.

Concerning the evolution of the Calvo Doctrine, until 1945 the prohibition of jurisdictional waivers in contracts in which the State was a party was absolute. From the Constitution of 1946 onwards, the limitation was confined to contracts signed within 
Ecuadorian territory. Although it is debatable whether the limitation of territory served the purpose of circumscribing the effects of the contract to its signature's place, it is clear that this doctrine has been limited to contractual obligations.

Evidently, the scope of application of International Investment Law overrides these boundaries. Whereas the prohibition to seek diplomatic remedies in the case of disputes with foreign persons was never under discussion, the extent of the limitation concerning the waiver of sovereignty remains blurred. Pursuant to the evidence of a strong private-based tradition in the national legal framework, it is not inaccurate to assume that rule makers perceive that the main source of international conflicts involving foreign persons would derive from contractual stipulations. Unfortunately, the current Constitution (2008) has preserved the wording of the provision concerning the Calvo Doctrine. Notwithstanding that it has incorporated further prohibitions related to a waiver of jurisdiction as regarding "contractual or commercial obligations" through the signature of treaties, it is a pity to affirm that the State's sovereign powers still remain at risk.

Noteworthy, between 1979 and 1998, four constitutional codifications were carried out. Without setting aside the circumstantial motivations of the reforms, there is a remarkable recourse that constitutional mechanism adapt to the respective provisions to specific political demands. Although these transformations may be evidence of the prevalence of ruling political parties' interests, it might be stated that the application of a constitutional reform tool was a step forward, compared to the enactment of a brand new constitution. The constitutional codifications in force from 1984, 1993, 1996 and 1997 were adopted under the power of the Congress to approve constitutional reforms, subsequently put into effect with the favorable ruling of the President. It is also worth noting that three codifications were proclaimed during the presidential term of Sixto Durán Ballén, ${ }^{34}$ widely remembered as the main promoter of the failed neo-liberal policies applied in the country.

\subsubsection{Constitutional Reform, Deregulatory Trends and the Expansion of Neoliberal Principles}

Preceding the constitutional reforms of 1996 and 1997, as the main normative tools to implement a neoliberal constitutional framework, the most significant changes from the constitutional reforms of 1984 and 1993 dealt with rearrangements regarding control

Free translation.

${ }^{34}$ Duran Ballén's term lasted from August $10^{\text {th }} 1992$ to August $10^{\text {th }} 1996$. 
of the Judiciary Branch and the development of the institutional design for the incipient constitutional control.

Figure 4:

\begin{tabular}{|c|c|c|}
\hline $\begin{array}{l}\text { Constitutional } \\
1984^{35}\end{array}$ & Codification & $\begin{array}{l}\text { Reinforcement of the principle of legality as well as of the } \\
\text { principle of State's extra-contractual liability. }{ }^{36} \\
\text { Creation of the Tribunal of Constitutional Guarantees }{ }^{37} \text {. } \\
\text { Right to live in a pollution free environment }{ }^{38} \text {. }\end{array}$ \\
\hline $\begin{array}{l}\text { Constitutional } \\
1993\end{array}$ & Codification & $\begin{array}{l}\text { Creation of the Judiciary Branch' administrative council and } \\
\text { reform of the the Supreme Court of Justice's role } \\
\text { (transformation to Court of Cassation) } \text { ) }^{39} \text {. }\end{array}$ \\
\hline
\end{tabular}

${ }^{35}$ Concerning the reforms to the Constitution of 1979 incorporated by the Constitutional Codification of 1984, President Oswaldo Hurtado when he issued his binding ruling concerning the mentioned reforms, stated:

"There have been submitted for my ruling the constitutional reforms approved by the National House of Representatives.

Just in few occasions, in the constitutional history of Ecuador, there have been inserted reforms to a Constitution in force; in turn there have been enacted many constitutions after the rupture of the rule of law. With these antecedents, the extensive constitutional reform approved by the National House of Representatives constitutes an event of historical importance, because it entails the possibility of improving the republican institutions in a democratic system and adapting the provisions of the Constitution, based on the experiences that leave its application, as well as of the variations experienced by the dynamic contemporary Ecuadorian society". (Official Gazette, September 1st, 1983).

Allegedly, the extensive constitutional reform celebrated by the former President Hurtado did not involve substantial changes. For instance, many formal modifications may be identified like the variation of the verb tenses of the provisions, from simple present to future.

${ }^{36}$ This constitutional codification inserted a sub-paragraph concerning the criminal liability of public servants to be ruled by judicial authorities. It also reinforced the responsibility of the justices of the Supreme, Fiscal and Contentious Administrative Courts concerning the damages derived from delay and denial of justice, as well as from breach of law.

${ }^{37}$ This Constitution regulated in detail the procedure of integration and attributions of the tribunal, which was entitled to suspend partially or totally the effects derived from laws, decrees, regulations or any other administrative act in contradiction with the Constitution, provided that the consent of the Congress was obtained

${ }^{38}$ Concerning the constitutional guarantees, it incorporated the right to live in a pollution free environment (Art. 18, 2). It also clarified the right of petition, as an independent constitutional guarantee (Art. 18, 10). Additionally, it refined the scope of the right to liberty and security (Art. 18, 17). The first guarantee mentioned above is noteworthy since it embraces a comprehensive State's obligation, which touches upon certain areas and public activities. The magnitude of this obligation was apparently not foreseen until the end of the 90s, when specialized environmental organizations consolidated their actions for the enforcement of this right. In any case, the insertion of this guarantee influenced other provisions, like the power of the municipalities to expropriate areas for environmental conservation purposes (Art. 50); this basis was not recognized in the Constitution of 1979.

${ }^{39}$ First, it created the National Judicial Council as an entity of the Judiciary Branch. Second, it transformed the role of the Supreme Court to Court of Cassation, which formerly served as a Court of Third Instance. Third, it modified the duration and process of selection of the justices of the Supreme Court, without removing the National Congress's power to appoint such authorities. As it may be noticed from the constitutional reforms of this period, the core of the political disputes was focused in the control of the Judiciary $\mathrm{Br}$ 
From the Constitutional Codification of 1996, one can identify the growing struggle of bringing the relevant constitutional provisions into conformity with the privatization trend of this time, by relaxing the restrictions over investment on strategic sectors, as well as to the recognition of foreign jurisdictions for the settlement of disputes.

In this context the Constitutional Codification of 1996 modified the constitutional provision, which barred the surrender of jurisdiction in contracts signed between the State and foreign public or private persons. Consequently, it introduced as an exception to this prohibition, the submission of jurisdiction derived from international treaties ${ }^{40}$. This reform coincided with the most prolific period of signature of Bilateral Investment Treaties:

Figure 5:

\begin{tabular}{|l|l|}
\hline Codification 1996 & $\begin{array}{l}\text { Declaration of the protection of human rights as the States highest } \\
\text { duty. }{ }^{41} \\
\text { Direct application of constitutional rights and guarantees by any } \\
\text { judicial or administrative authority. }\end{array}$ \\
$\begin{array}{l}\text { Enlargement of the provision concerning "jurisdictional unity" } \\
\text { through the recognition of international treaties as a source of } \\
\text { jurisdiction of judges, courts and tribunals. This provision expressly } \\
\text { acknowledged the arbitration system, negotiation and further }\end{array}$ \\
\hline \begin{tabular}{l} 
alternative mechanisms of dispute settlement (Art. 118)..$^{42}$ \\
\hline
\end{tabular}
\end{tabular}

${ }^{40}$ Constitutional Codification of 1996:

"Art. 16. The contracts signed by the Government or public entities with foreign natural or legal persons imply the waiver of any diplomatic claim. If such contracts were signed in the territory of Ecuador, there shall be no agreement on the submission to a foreign jurisdiction, except in the case of international agreements."

Free translation.

${ }^{41}$ Constitutional Codification of 1996:

"Art. 19. The highest duty of the State consists on respecting and ensuring the respect for human rights guaranteed by this Constitution. All inhabitants of the Republic have the duty to promote the common welfare, strengthen national unity, work for the progress of Ecuador, preserve the Free translation. natural and cultural heritage of the nation and respect the rights of others.

${ }^{42}$ Constitutional Codification of 1996 :

"Art. 118. Under the principle of jurisdictional unity, the exercise of judicial power belongs exclusively to the magistrates, judges and courts specified in the Constitution, laws and international treaties.

Without prejudice to principle of jurisdictional unity, the Judiciary Branch shall act in a decentralized manner

It is recognized the arbitral system, negotiation and other mechanisms of dispute settlement." 


\begin{tabular}{|l|l|}
\hline & $\begin{array}{l}\text { Incorporation of a specific section for environmental protection which } \\
\text { regulated the scope of obligations, as well as public and private } \\
\text { liabilities derived from the right to live in a healthy and ecologically } \\
\text { balanced environment. }\end{array}$ \\
$\begin{array}{l}\text { Strengthening of the constitutional control with the creation of the } \\
\text { Constitutional Tribunal. }\end{array}$ \\
$\begin{array}{l}\text { Refinement of the provision that regulates the State's civil liability } \\
\text { derived from judicial wrongdoing, innocent imprisonment or arbitrary } \\
\text { detention may be noted, as well as from the violation of human rights } \\
\text { and constitutional guarantees }\end{array}$
\end{tabular}

From the abundant Ecuadorian constitutional frameworks' overview, the inexorable expansion of constitutional guarantees and rights is remarkable. In order to ease the acceptance of institutional reforms resetting the allocation of powers in key institutional and economic matters, rulemakers have bound to the same diverse social demands and ocassionally pioneering rights and guarantees never enshrined in compared constitutional frameworks. ${ }^{45}$

The Constitutional Codification of 1997 and the succeeding Constitutions of 1998 and 2008 did not depart from this tendency, although the core interest of the constitutional design during these years was focused on redefining the role of the State in the economy

43 Compared to the Constitutional Codification of 1993 embodying the Tribunal of Constitutional Guarantees, this Constitution reinforced the jurisdictional powers of this Tribunal by suppressing the requirement of the Congress's binding decision for the suspension of the effects of normative and administrative acts deemed as unconstitutional (Art. 175).

${ }^{44}$ Although the State's responsibility concerning the damages derived from judicial and administrative wrongdoing was firmly established in Ecuadorian constitutional history, the linkage of civil liability to the application of a large catalogue of rights and guarantees, involves, at least on paper, a heavy burden to the State and its branches. It suffices to say that this large catalogue of rights includes matters ranging from due process' guarantees to economic, social and cultural rights.

${ }^{45}$ As Ayala Mora explains:

"From 1967 all the constitutions placed the "dogmatic" part at the beginning of the text and this had a great expansion, because numerous rights and guarantees were incorporated, occasionally with detail. Although, the principle of "progressivity" was accepted, which means that once the rights are adopted they should not be suppressed, there were several regressions, but, in general, even in the times of "neoliberal" and "privatization trend" predominance, the constitutions have a clear "guarantee- based" tendency. This trend was deepened with the Constitution of 2008, which devoted an important part of its large text to guarantees and rights, inspired by the socalled Latin American "neo-constitutionalism". Its promoters and apologists affirm that this is part of change of paradigm, with new institutions, a new culture and others source of knowledge."

Ayala Mora (Enrique), Historia Constitucional: Estudios comparativos, Biblioteca de Historia. Vol. 36, Universidad Andina Simón Bolívar, Quito, 2014, 75. p. 
and the control of the Supreme Court of Justice. This period is characterized by one of the most turbulent political periods experienced by Ecuadorian history, with the succession of seven presidents in ten years (1996-2006). Indeed, the Constitutional Codification of 1997 had as its main purpose regularizing a coup. In this regard, the Constitutional Codification of 1997 amalgamated both reforms directly approved by referendum and others passed by decision of the National Congress. For instance, the suppression of the Legislature's power to appoint Supreme Court of Justice's judges was approved by referendum, whereas the National Congress directly inserted the subparagraph that allowed the transfer of public entities' stock to private persons (Art. 61). In the first case, the apparent intent to depoliticize the justice was a pact of the ruling parties to control the maximum entity of the Judiciary Branch appointing allied judges. ${ }^{46}$ In the second case, the predominant political forces, were clearly interested in favouring privatization processes, took this chance to remove any obstacles to to putting their plans into effect.

In harmony with the substantial transformation of the provision, which regulated the economy and its sectors by allowing the privatization of public entities created for the provision of public services, this Constitution adapted certain provisions in order to facilitate the privatization process. In order to counteract the power of these public entities' unions, the Constitution included within the provision that endorsed the right to strike, the prohibition of paralyzing the services of electricity, processing, transport and distribution of combustibles, water, health, education, public transport and telecommunications.

From the organic perspective the most salient innovations of this constitutional codification were, the modification of the process of selection of Supreme Court' judges and the establishment of unlimited terms of service (lifetime appointment). Nevertheless, although the power of appointment and substitution of judges was transferred from the National Congress to the Supreme Court, the former maintained its power to exert control over the justices through political trials.

\footnotetext{
${ }^{46}$ Constitutional Codification of 1997 :

"Fifteenth Transitory Disposition.- To enable the immediate application of the principles approved in the referendum of May 25, 1997, there are declared finished the periods for which the current Supreme Court's judges were appointed, who, however, remain in service until replaced in the manner determined in the following transitory disposition."
}

Free translation. 
The realization of the National Constituent Assembly that enacted the Constitution of 1998 was the result of the referendum of May 1997, whose questions were approved by a majority of votes. ${ }^{47}$ The proximity between the Constitutional Codification of 1997 and the Constitution of 1998, reinforces the assumption that the former served basically three purposes: 1) legalizing the irregular designation of Fabián Alarcón as interim President; 2) assuring control over the Supreme Court with lifetime appointments entrusted for a "one and unique time" to the predominant political parties that allowed the removal of Bucaram and the irregular election of Alarcón; 3) speeding up the privatization process by enabling the transfer of public entities' stocks.

The Constitution of 1998 did only radicalize the guarantees to private investors, coined by the Constitutional Codification of 1996 with the subordination of the State to international jurisdictions derived from any kind of dispute either contract or treaty based and the lifting of the barriers to privatization established by the Constitutional Codification of 1997.

This Constitution, loyal to the domestic constitutional history, embellished its corporative friendly orientation with a significant enlargement of constitutional rights and guarantees. ${ }^{48}$ Notably, this Constitution reinforced the notion of direct applicability of constitutional rights and the establishment of the writ of amparo as the main mechanism of constitutional redress.

In a similar way the consolidation of constitutional enforcement was not only achieved by the writ of "amparo" and its specialization through the jurisdiction of the Constitutional Tribunal. It installed the "diffuse control" of the Constitution by allowing

${ }^{47}$ Referendum, May $25^{\text {th }}, 1997$ :

"Question 3: Do you agree to convene a National Assembly for the sole purpose of reforming the Constitution of Ecuador?"

${ }^{48}$ Ayala Mora summarizes the main features of this Constitution (1998):

"With a rightist majority, there was drafted a very organized and clear text in the Assembly. But there were regressions concerning fundamental issues. It changed the Constitution of 1978 by establishing a State-economic relationship oriented towards privatization and it limited political representation. In the name of "governability" it increased the Executive's power. On the other hand, it recognized the country's diversity, the rights of indigenous and black people, women, children and other social sectors; it enlarged the citizenship to all Ecuadorians; it reformed the Congress, budget's approval and social insurance. But some issues remained pending. One of them was decentralization. Another issue that the Assembly did not resolve was the reform to the Constitutional and Election tribunals. The parties of the majority did not have the political will to do it, because they would lose control over such entities. The Constitution so approved came into force August $10^{\text {th }} 1998 . "$

Ayala Mora (Enrique), Historia Constitucional: Estudios comparativos, Biblioteca de Historia. Vol. 36, Universidad Andina Simón Bolívar, Quito, 2014, 65 p. 
any tribunal or judge to declare inapplicable either by its own motion or by a party's petition, any legal principle contrary to the Constitution or international treaties. ${ }^{49}$ It is also noteworthy, the recognition of the right to legal certainty as a new civil right.

In line with its strong privatization orientation, it radically changed the chapter concerning the economic system`s guidelines by embracing a "market social economy" regime. As a consequence it declared the action of the State within the economy to be "subsidiary", and it also established equal legal treatment between public and private "business activities" (Art. 244) $)^{50}$. In brief, the constitutional framework established the co-existence and concurrence of public and private sectors within the Ecuadorian economy. Concerning the property and management of "economic enterprises", it recognized private, public, mixed, as well as communitarian and self-managed organization (Art. $245^{51}$ ). In line with such orientation, this Constitution opened private

\footnotetext{
${ }^{49}$ It is worth noting that this declaration was compulsory only in the specific case resolved by the incumbent judicial authority; however, this had the obligation to submit the report of such a decision to the Constitutional Tribunal in order that the same rules about the allegedly unconstitutional provision could have general effect.
}

${ }^{50}$ Constitution of 1998 :

"Art. 244. Within the system of social market economy, the State shall:

1. Ensure the development of economic activities by a legal order and institutions that promote, encourage and build confidence. Public and private business activities shall receive the same legal treatment. Equal conditions shall be granted to national and foreign investment.

2. Develop, in a decentralized and participatory manner, plans and programs, mandatory for the public investment and referential for the private investment.

3. Promote the development of competitive markets and activities. Encourage free competition and punish, according to law, monopolistic practices and other that impede and distort the same.

4. Supervise that economic activities comply with the law and regulate and control them in defense of the common wealth. Interest charges on interest are prohibited in the credit system.

5. Create physical, scientific and technological infrastructure; and provide basic services for development.

6. Undertake economic activities as required by the public interest.

7. Exploit rationally the property of its exclusive domain, directly or with private sector's participation.

8. Protect the rights of consumers; punish fraudulent information, misleading advertising, product adulteration, disruption of weights and measures, and breach of quality standards.

9. Maintain a disciplined fiscal policy; encourage savings and investment; increase and diversify exports and care that public borrowing is compatible with the country's ability to pay.

10. Encourage full employment and improving real wages, taking into account the increase in productivity, and provide targeted subsidies to those in need."

Free translation.

${ }^{51}$ Constitution of 1998 :

"Art. 245. The Ecuadorian economy will be organized and will be developed with the co-existence and concurrence of the public and private sectors. Economic enterprises, in their forms of ownership and management, may be private, public, mixed, communitarian or self managed. The State will recognize, guarantee and regulate the same."

Free translation. 
participation in social security. Additionally, it reaffirmed the provincial a municipal governments' right to participate in the royalties derived from the exploitation of nonrenewable resources within their territories.

The provision of public services was acknowledged as the State's responsibility either directly or through delegation to mixed or private companies under concession, association, capitalization, stock ownership transfer or any contractual modality, in accordance to the law (Art. 24952). Without any doubt, the most controversial paragraph of this provision was the prohibition from unilaterally modifying contractual stipulations by future laws or administrative measures. As expected, it devoted a special chapter to investment. This constitutional framework enshrined the State's obligation to guarantee national and foreign capital invested for productive activities. It enabled the law to grant special treatment to public and private investments devoted to activities in the national interest, as well as in less developed regions. It erected the constitutional rank of the "umbrella clause" concerning contracts signed with investors, by allowing the State to establish special guarantees and securities with the aim of protecting such agreements from any legal provision or other decision of "any class" that may affect their clauses (Art. 271 53 ).

An emblematic institution created by this Constitution for the implementation of the privatization process, was the Solidarity Fund. In fact, this autonomous fund constituted a holding entity for state-owned enterprises, whose capital and revenue derived from the transfer of stock of the said entities, and it was intended to undertake investments for

\footnotetext{
${ }^{52}$ Constitution of 1998 :

"Art. 249. It is the responsibility of the State to ensure the supply of public water and irrigation, sanitation, electricity, telecommunications, roads, port facilities and others of a similar nature. These services can be provided directly or by delegation to mixed or private companies through concessions, partnership, capitalization, transfer of stock or any other contractual means, according to the law. Laws or other regulations shall not change the agreed contractual terms unilaterally.

The State will ensure that public services rendered under his control and regulation, responding to principles of efficiency, accountability, universality, accessibility, continuity and quality; and shall ensure that their prices or rates are fair."
}

Free translation.

${ }^{53}$ Constitution 1998.-

"Art. 271. The State shall guarantee domestic and foreign capital that is invested in production, especially for domestic consumption and export.

The law may grant special treatment to public and private investment in less developed areas or activities of national interest.

In contracts signed with investors, the State may establish special guarantees and securities, with Free translation. the end that legislation or other provisions of any kind do not modify them or affect their clauses." 
financing education and health programs, as well as environmental sanitation and response to the effects of natural disasters. ${ }^{54}$ Little success was achieved by the Solidarity Fund on crystallizing its privatization process. Public and syndical opposition aggravated by the rivalry of politicians clearly identified with interested economic groups sabotaged the success of the comprehensive intent of privatization. There was open governmental advocacy for favouring privatization by the alleged inefficiency and political patronage of state owned enterprises. On 2003, President Noboa attributed the privatization-failed process of electricity and telecommunications state owned enterprises to unions, social movements and political parties'interests ${ }^{55}$. The alleged under-valuation of several enterprises was one of the reasons for the public opposition to the privatization process. For instance, the former President, Rafael Correa, when launched his plan for "rescuing" several state owned enterprises, recalled that the valuation of the State's royalties derived from the failed privatization of postal services were fixed in a monthly payment of USD. $15.000^{56}$.

The relentless process of the "deinstitutionalization" of the Ecuadorian State accelerated after the overthrow of President Abdala Bucaram in 1997 and, intensified in subsequent interrupted governments, it underpinned collective demands for a radical change. The political emergence of Rafael Correa took place on his short period as Minister of Economy during 2005, when he advocated the renegotiation of oil contracts by the adoption of legal measures devoted for the improvement of State's revenues derived from oil windfall profits. These initiatives along with the pressure for the termination of the contract with the oil company Occidental made him a rising political star.

\footnotetext{
${ }^{54}$ Constitution 1998.-

"Art. 250. The Solidarity Fund is an autonomous body to combat poverty and eliminate indigence. Its capital will be used in safe and profitable investments and may not be spent or used to purchase securities issued by the central government or public bodies. Its profits will be used to finance exclusively, education, health and sanitation, and to attend the social effects caused by natural disasters.

The Solidarity Fund capital will come from the financial resources generated by the transfer of the assets of companies and public services, except those arising from the transfer of assets and shares of National Financial Corporation, Development Bank and agencies of the autonomous sectional regime, and will be administered in accordance with the law."
}

Free translation.

${ }^{55}$ Diario Hoy, "Noboa culpa de fracaso de privatización a opositores", February $2^{\text {nd }}, 2003$.

http://www.explored.com.ec/noticias-ecuador/noboa-culpa-de-fracaso-de-privatizacion-a-opositores124947.html

56 El Diario, "Gobierno ofrece rescatar los correos postales, August 23 $3^{\text {rd }}, 2007$. http://www.eldiario.ec/noticias-manabi-ecuador/49966-gobierno-ofrece-rescatar-los-correos-postales/ 
Supported by alternative groups and the middle class, he ran for President in the elections of 2006, for the period 2007-2011. In his winning campaign, Correa's political party did not postulate congressional candidates promising to convene to a National Constituent Assembly. As result of his categorical victory, he began to put into effect his principal campaign promise by the issuance of the Decree 002 of 15 January 2007, whereby he promised a referendum. In this referendum he asked the voters for approval to convene a National Constituent Assembly entrusted with full powers, to transform the institutional framework of the State and draft a new Constitution. The voters approved overwhelmingly the referendum. Once the National Constituent Assembly was established, the term of the elected National Congress was cancelled.

Clearly, this period comprises the most vivid contention concerning the definition of State's role in the economy. The arrival of International Investment Law's influence may be perceived from the provision enshrined by the Constitutional Codification of 1996, which reforms the wording related to the Calvo doctrine that exempted the prohibition of jurisdiction waiver regarding contractual disputes in cases where a treaty provided for such submission. Ever since then, the confusion concerning contract and treaty based disputes could not have been overcome.

The futility of this provision's clarification did not tarnish the "leitmotiv" of the Constitution of 1998: establishing the "social market economy" devoted to paving the way to the privatization of the whole public sphere. Not only the transfer of state owned enterprises' ownership and the assets derived from the provision of public services support this statement, but also the waiver of sovereign powers through contracts vested with supra-legal status. Correspondingly, the suppression of the distinction between public and private's economic activities, as well as the reinforcement of equal treaty both to national and foreign activities is equally remarkable. For this purpose, the canonization of the principle of "legal certainty" would be seminal for shielding the stagnation of the State's agreements with relation to the treatment standards conferred on investors. Additionally, the strong emphasis given to arbitration and further alternative mechanisms of dispute privileged the progressive resort to the same ways of dealing with disputes involving the State.

Finally, the unavoidable recognition of collective rights, as well as the reinforcement of environmental duties and consumer protection rights reveal the "expansionary nature" of the Ecuadorian constitutional frameworks, which traditionally have hidden the real purposes of their enactment behind an alleged intention of enlarging constitutional rights. 
In any case the consolidation of the constitutional jurisdiction and control within the Constitution of 1998 radically changed the application of rights and scrutiny over the exercise of public power in the Ecuadorian legal landscape.

\subsubsection{The State of Good Living}

The National Constituent Assembly first convened on November 29, 2007 and approved a draft Constitution in July 2008. Subsequently, this project of Constitution was approved by a referendum in September 2008. The functioning of this Assembly was not exempted from controversies. The participation of numerous collective groups in its drafting slowed down the process of approval. As a consequence, its president, Alberto Acosta, was forced to resign due to his opposition to speeding up the debate. Fernando Cordero replaced him on June $24^{\text {th }} 2008$ and the final draft of the Constitution was approved on July $17^{\text {th }}, 2008$. The "excess of democracy"57 as described by President Correa gave birth to a Constitution of 444 articles:

"The Assembly convened between 2007 and 2008 in Montecristi. It did not adopt an adequate system of discussion and systematization. The drafting of the Constitution was made in a disorganized and rushed manner, with groundless discussions, disregarding the necessary technical-constitutional organization. The Constituent Assembly had to issue the Constitution draft within the deadline set by the referendum. It did a hurried approval and discussed big blocks of provisions, characterized by a rushed debate, virtually nonexistent. A few days before the deadline for the issuance of the Constitution draft, an external committee undertook the final drafting and codification work.

The Constituent Assembly generated as never before expectations about citizen participation. But they were not met. The Constitution ended up being an enormous, cumbersome and contradictory text, with declarative provisions, inappropriate definitions, errors and ambiguities. Many provisions were introduced due to circumstantial motivations. From the left-wing political perspective, it missed the opportunity to have a clear, short, concise Constitution, which could be the base of a progressive long-term project. The drafters deprived the country of a Constitution that could have been the yardstick for the XXI century institutions, and gave the right wing a load of arguments with its deplorable structure and wording.

A few years after being in force, there was virtual consensus that there is a contradiction between the "dogmatic part" of the Constitution, which is

\footnotetext{
${ }^{57}$ Diario "El Tiempo" "La Constituyente acelera el paso", June 2nd 2008. http://www.eltiempo.com/archivo/documento/MAM-2959018
} 
progressive and guarantee based, and the "organic part", which promotes authoritarianism and limitations to democracy." 58

From the late 1990s, the alleged divorce between the "dogmatic" and the "organic" sections of the Constitution has been an important source of conflicts between social groups and public entities. The strengthening of constitutional remedies, along with the growing resort to international organizations for the enforcement of human rights have made it difficult to implement several public decisions concerning, especially, the exploitation of natural resources. In this regard, the divergent interests and the variety of actors that currently surround the public action, obliges the expansion of the boundaries under which the effects of international investment are assessed. Ayala Mora describes the most salient advances achieved by this Constitution:

"The Constitution of Montecristi has important declarative advances and provisions of a progressive cut. It strengthened the role of the state, especially in the economy and, in general, expanded the public sphere. They were necessary measures against neo-liberal dominance that had dismantled the State in Ecuador, Latin America and the world with the aim of promoting concentration of wealth in few hands. The Constitution further extended guarantees and rights of citizens, creating institutions for their protection. It increased the bureaucratic structure without changing the sectional regime, but increased in some aspects, centralization and Executive's control. An axis of the Constitution was the pursuit of "Good Living". Thus the enforcement of rights was promoted. And, an alternative conception of our way of life was raised, rejecting capitalism and consumerism." 59

Pursuant to the national constitutional tradition, this constitutional framework expanded the scope of rights and guarantees. The diverse background of the representatives, linked to social groups and non-governmental organizations, underpinned the struggle for incorporating specific prefabricated notions in constitutional provisions. As a result, the regulatory design of the constitutional framework was accentuated in this Constitution, characterized by an unstoppable expansion of rights and guarantees. ${ }^{60}$ In the light of this

\footnotetext{
${ }^{58}$ Ayala Mora (Enrique), Historia Constitucional: Estudios comparativos, Biblioteca de Historia. Vol. 36, Universidad Andina Simón Bolívar, Quito, 2014, 67 p.

Free translation.

${ }^{59}$ Ayala Mora (Enrique), Historia Constitucional: Estudios comparativos, Biblioteca de Historia. Vol. 36, Universidad Andina Simón Bolívar, Quito, 2014, 66 p.

Free translation.

${ }^{60}$ In this regard, Ayala Mora postulates:

"There is no doubt about the importance of rights and guarantees' progresses registered by our constitutional evolution. But, their recognition in the constitutional texts has not raised the clashes that could have been foreseen. In general and only in few exceptions, for their incorporation as basic rules, there has been little conflict and even scarcer debate. There has been a kind of general
} 
perspective, it is worth noting that the effectiveness of chilling social unrest by the growing recognition of rights and guarantees has diminished over the time, especially during the last 20 years. At the time that social movements improved their organization mechanisms to compel such declarations, constitutional jurisdiction and supranational human rights enforcement have also gained influence. In this context, the logic of the centralization of power further implemented by the ideologists of the same Constitution has faced obstacles when mechanisms of constitutional redress and citizen participation have been activated. In fact, this Constitution designed for lasting "300 years" a process of amendments after 7 years of being in force ${ }^{62}$.

The innovations brought by this Constitution are notable and manifold. The preamble places sovereignty on the people of Ecuador, acknowledges the importance of nature as source of life and vindicates social liberation struggles against all forms of domination and colonialism. It proclaims the construction of a new form of public coexistence in diversity and in harmony with nature, with the end of achieving "good living". In this pact, society should respect, in all its dimensions, the dignity of individuals and community groups.

It transcends the notion of the subordination of the State to the rule of law, by establishing the "constitutional State of rights and justice" (Art. 1). It is remarkable that the first constitutional provision declares the State's absolute and inalienable rights over nonrenewable natural resources. In this regard, sovereignty over such resources might be

tendency to adopt very advanced formulas, in some cases, established for the first time in Latin America and in the world. Though, on the other side, there have existed glaring contradictions and their effective application has been complex, and sometimes belated. There has been progresses in the rights and guarantees recognized in the constitutions, but the same laws devoted for the regulation of these constitutional novelties have limited them, have been delayed or simply never existed. This paradoxical situation has not been given for free. It has served for "cushioning" the strength of social protest, because when a constitutional declaration was obtained, the social action and protest reduced, even though the provisions' effective application were delayed or annulled."

Ayala Mora (Enrique), Historia Constitucional: Estudios comparativos, Biblioteca de Historia. Vol. 36, Universidad Andina Simón Bolívar, Quito, 2014, 103 p.

Free translation.

61 Acosta (Alberto), “A menos Constitución de Montecristi, más caudillismo”, Revista Plan V, August 14th 2014.

http://www.planv.com.ec/historias/politica/menos-constitucion-montecristi-mas-caudillismo

62 On June $26^{\text {th }} 2014$, the President of the National Assembly handed over to the Constitutional Court the project of 17 constitutional amendments in accordance to Art. 441, paragraph 2 of the Constitution.

El Comercio, “Corte Constitutional recibe proyecto de 17 enmiendas constitucionales”, June $26^{\text {th }} 2014$. http://www.elcomercio.com/actualidad/corte-constitucion-proyecto-enmiendas-ecuador.html 
considered as an essential condition of the State. Among the State's fundamental duties there may be identified, the guarantee to make effective human rights, especially the rights to education, health, food, social security and water (Art. 3, 1); the defence of national sovereignty (Art. 3,2); national development planning, the eradication of poverty and promotion of national development, as well as wealth redistribution (Art. 3, 5), and; the guarantee to assure its inhabitants of the right to a culture of peace, integral security and to live in a democratic society free of corruption (Art. 3, 8).

In line with the Constitution of 1998, it acknowledges the rights of persons, communities, peoples and nations. The same provision incorporates nature's rights, which is one of the most transcendent constitutional innovations (Art. 10).

Concerning the principles that govern the exercise of rights, it reaffirms: the direct application of the guarantees and rights set forth in the Constitution and international treaties before any judicial or administrative authority (Art. 11,3); the prohibition of any law or regulation to restrict the scope of constitutional rights and guarantees (Art. 11, 4); interdependence, equal hierarchy, inalienable and indivisible character of rights and guarantees (Art. 11,6); the obligation to develop progressively rights through provisions, case law and public policies and it does set forth the unconstitutionality of any regressive deed or omission that diminishes, undermines or annuls without justification the exercise of rights (Art. 11,8) and; the State's supreme duty to respect and enforce respect for the rights guaranteed in the Constitution (Art. 11,9).

It incorporates a bulky title that governs rights, by dividing them in subsequent chapters, which in accordance to the Ecuadorian constitutional history, would be included within the "dogmatic" part of the Constitution. Such rights include: the human right to water; the right of persons and community groups to safe and permanent access to food; the right of the population to live in a healthy and ecologically balanced environment; the right of persons to a safe and healthy habitat and adequate and decent housing regardless of their social and economic status; the right to health, whose fulfillment is linked to other rights; the right to work; the right to social security; the rights of elderly persons; the rights of persons with disabilities; consumers'rights; the rights of communities, peoples and nations and the rights of nature.

A specific chapter is assigned to the rights of communities, peoples and nations. There are particular remarkable rights to: 1) be consulted prior to plans and programs for the exploitation of non-renewable resources located in their lands; to participate in the profits derived from these projects and; to be compensated for social, cultural and 
environmental damage that they may undergo (Art. 57,7); 2) to be consulted before the adoption of any regulatory measure that may affect their collective rights; 3 ) to keep and develop their own forms of peaceful coexistence and social organization, as well as of the authority exercised within their territories and ancestrally owned community lands (Art. $57,9)$; 4) to create, develop, apply and practice their own legal system and customary law in conformity to constitutional rights; 5) to maintain and promote their practices for biodiversity and natural environment management, and; 6) to not being displaced from their ancestral lands. Finally, it has to be noted that there is a prohibition to perform extractive activities within the territories of the peoples living in voluntary isolation (Art. $57,21)$. It is worth recalling that many of these rights were originally established by the Constitution of 1998 (Art. 84).

To the large list of "liberty rights" already recognized in the former constitutional frameworks, this Constitution incorporated broadly economic and social rights, as well as political and civil rights. Compared to the former Constitutions, there are remarkably: the right to a "decent life" (Art. 66, 1); the right to formal equality, material equality and non-discrimination (Art. 66, 4); the right to perform economic activities individually or collectively, in line with the principles of solidarity, social and environmental responsibility (Art. 66, 15); the right to access to high quality, efficient and effective private and public goods and services (Art. 66, 25); the right to live in a healthy environment that is ecologically balanced, pollution free and in harmony with nature (Art. $66,26)$ and, the right to property, which will be addressed in the specific section devoted to the same (Art. 66, 25). As noted this title incorporates a chapter named "protection rights", which include the right of persons to free access to justice and the effective, 
impartial and expeditious protection of their rights and interests ${ }^{63}$, the right to legal certainty $^{64}$ and the rights to due process (Art. 76$)^{65}$.

The Constitution links the declaration of these rights and guarantees to the imposition of obligations to public entities within a different title denominated "constitutional guarantees". It imposes the obligation to the National Assembly and all bodies with regulatory authority to adjust, formally and materially, all the relevant provisions to the rights set forth in the Constitution and international treaties, as well as those necessary to assure the dignity of human beings or communities, peoples and nations ${ }^{66}$. Particularly notable is the importance attributed to public policies and services, as well as to citizen participation. In this regard the design and provision of such policies and services are subordinated to the principles of solidarity and common welfare, as well as to citizen participation. ${ }^{67}$

\footnotetext{
${ }^{63}$ Constitution of 2008:

"Article 75. Every person has the right to free access to justice and the effective, impartial and expeditious protection of their rights and interests, subject to the principles of immediate and swift enforcement; in no case shall there be lack of proper defense. Failure to abide by legal rulings shall be punishable by law."
}

Free translation.

${ }^{64}$ Constitution of 2008:

"Article 82. The right to legal certainty is based on respect for the Constitution and the existence of prior legal regulations that are clear, public and applied by the competent authorities."

${ }^{65}$ Concerning the guarantees of due process, there are notably: the responsibility of all judiciary and administrative authorities for guaranteeing the enforcement of the respective provisions and parties' rights (Art. 76, 1); the prohibition to judge or punish for a deed or omission, which at the time of its perpetration is not legally categorized as a criminal or administrative offense (Art. 76, 3); the obligation to apply the less severe punishment in case of conflict of provisions (Art. 76, 5); the principle of proportionality for the establishment of criminal, administrative and other punishments (Art. 76, 6); the guarantee to be judged by an independent, impartial and competent judge (Art. 76, 7, k); the principle of motivation for all decisions undertaken by public authorities, and; the right to appeal decisions derived from any proceeding where a decision that affects rights may be involved (Art. 76, 7, m).

Free translation.

${ }^{66}$ Constitution of 2008 :

"Article 84. The National Assembly and all bodies with legal and regulatory authority shall be obligated to adjust, formally and materially, the laws and other legal standards related to the rights provided for in the Constitution and international treaties and those that are needed to guarantee the dignity of human beings or communities, peoples and nations. In no case shall amending the Constitution, laws, other legal and regulatory frameworks or actions by the government endanger Free translation. the rights recognized by the Constitution."

${ }^{67}$ Constitution of 2008:

"Article 85. The drafting, enforcement, evaluation and monitoring of public policies and public services that guarantee the rights enshrined in the Constitution shall be governed by the following provisions: 
It regulates in detail the scope of constitutional guarantees, which include: the rules for application of constitutional remedies (Art. 86), preventive measures (Art. 87), the writ of protection ${ }^{68}$; habeas corpus writ (Art. 89); habeas data writ (Art. 92); writ for failure to comply ${ }^{69}$, and; extraordinary protection writ $^{70}$. The Constitutional Court exclusively resolves the last two actions.

In comparison to the Constitution of 1998, the writ of protection would be similar to the writ of "amparo". The Constitution of 2008, added the writ of failure to comply, the extraordinary writ of protection and the writ of access to public information as constitutional guarantees.

1. Public policies and the provision of public goods and services shall be aimed at enforcing good living and all rights and shall be formulated on the basis of the principle of solidarity.

2. Without detriment to the prevalence of public welfare over individual well-being, when the impacts of the implementation of public policies or the provision of public goods and services undermine or threaten to undermine constitutional rights, the policy or provision must be reformulated or alternative measures shall be adopted to reconcile the conflicting rights.

3. The State shall guarantee the equitable and mutually supportive allocation of the budget for the implementation of public policies and the provision of public goods and services.

In the drafting, implementation, evaluation and monitoring of public policies and public services, the participation of persons, communities, peoples and nations shall be guaranteed."

Free translation.

${ }^{68}$ Constitution of 2008:

"Article 88. The writ of protection shall be aimed at ensuring the direct and efficient safeguard of the rights enshrined in the Constitution and can be filed whenever there is a breach of constitutional rights as a result of deeds or omissions by any non-judiciary public authority against public policies when they involve the deprivation of the enjoyment or exercise of constitutional rights; and when the violation derives from a particular person, if the violation of the right causes severe damage, if it provides inadequate public services, if it acts by delegation or concession, or if the affected Free translation. person is in a status of subordination, defenselessness or discrimination."

${ }^{69}$ Organic Law on Constitutional Guarantees and Constitutional Control:

"Article 93. Proceedings for failure to comply shall be aimed at guaranteeing the application of rules and regulations comprising the legal system, as well as compliance with the rulings or reports of international human rights organizations, when the regulation or decision whose enforcement is being pursued, contains an clear, express and enforceable obligation to do or not to do. The petition shall be filed before the Constitutional Court."

Free translation.

${ }^{70}$ Organic Law on Constitutional Guarantees and Constitutional Control:

"Art. 94.- The extraordinary writ of protection will proceed against definitive judicial rulings or decisions where there has been a violation, by deed or omission, of the rights enshrined in the Constitution, and it shall be filed before the Constitutional Court. This remedy shall be admissible when regular and extraordinary judicial appeals have been exhausted within the legal deadlines, unless the failure to file these resources was not attributable to the negligence of the person bearing the constitutional right that was infringed."

Free translation. 
Later on the Organic Act on Jurisdictional Guarantees and Constitutional Control $^{71}$ regulated such constitutional remedies, as well as the organization and attributions of the Constitutional Court. This legal framework recognized the legal standing of public entities to file extraordinary protection writs, which in practice has been translated on the review of judicial proceedings as not favourable to the State.

As noted, the substantial enlargement of citizen and participation rights is evident from diverse provisions, which both establish these rights and allocate correlative obligations to public authorities. In the first place, the most salient constitutional provision recognizes the rights of the citizens, to participate, individually or collectively, as leading players in decision-making, planning and the management of public affairs. It also, established the people's control over State's institutions and the society. This right concerns to all matters of public interest and will be exercised through mechanisms of representative, direct and communitarian democracy (Art. 95).

To this end, the Constitution recognizes all forms of social organization, as an expression of people's sovereignty devoted to develop processes of self-determination and to influence public decisions, policy making and social control concerning public activities and public services provided by private entities (Art.96). In fact, the constitutional framework enables social organizations: to develop alternative mechanisms for dispute settlement in accordance to the law; to act under the delegation of the competent authority; to claim for damage reparation caused by private or public entities; to formulate proposals for economic, political, environmental, social and cultural redress, and; other initiatives that may contribute to "good living" achievement (Art. 97). In this context, it introduced the "right of resistance" in favour of individuals and communities ${ }^{72}$. To achieve this, the Constitution inserted the "citizen action" to be exercised individually or by representation of the community, when the violation of a right is threatened or caused (Art. 99)

With relation to citizen participation in the different levels of government, the Constitution acknowledges the intervention of society's representatives in the territorial

\footnotetext{
${ }^{71}$ Official Gazette, September $21^{\text {st }}, 200$

72 Constitution 2008:

"Article 98. Individuals and communities shall be able to exercise the right to resist deeds or omissions by the public sector or natural persons or non-state legal entities that undermine or may undermine their constitutional rights, and claim for recognition of new rights."
}

Free translation. 
sphere of each level of government ${ }^{73}$. Mechanisms of direct democracy were also consolidated by this Constitution ${ }^{74}$.

As previously observed, the predominant importance given to planning is evident from the first constitutional provisions that determine the main State's obligations. In this context, the "organic part" of the Constitution, recognizes the President's role to submit the National Development Plan proposal to the National Planning Council for its approval (Art. 171, 4) ${ }^{75}$. Particularly remarkable is the power of the President to dissolve the National Assembly in the case where it repeatedly obstructs the National Development Plan's execution (Art. 148).

The development regime is inextricably linked to the organization of the planning regime; the Constitution devotes a specific title for its regulation. Such a regime comprises economic, political, socio-cultural and environmental systems subordinated to State planning for the achievement of good living (Art. 275). The development's regime objectives are quite significant since they oversee State, communities and individual actions $^{76}$.

\footnotetext{
${ }^{73}$ Such participation concerns : the elaboration of national, sectorial and local plans and policies; the improvement of public investment; the formulation of "participatory budgets"; the strengthening of democracy through permanent mechanisms of transparency, accountability and social control, among others. For implementing citizen participation, public hearings, assemblies, consultative councils and citizen committes will be set up (Art. 100).

${ }^{74}$ The incorporation of the popular normative initiative for proposing the creation, reform and derogation of legal and regulatory provisions enacted either by the Legislative Branch or by any entity that enjoys regulatory competence, should be noted. This initiative also covers proposals for constitutional reforms (Art. 103). Linked with this, the citizens are enabled to request a referendum on any matter, provided there is the support of a minimum amount of citizens inscribed in the voting registry. A referendum requested by decentralized autonomous governments or citizens may not be referred to issues related to taxes or the political-administrative organization of the country (Art. 104). Another powerful citizens' participation tool consists on their capacity to revoke the mandate of elected authorities (Art. 105).
}

${ }^{75}$ The report on the compliance of this plan, as well as the objectives the government intends to achieve, has to be submitted annually to the National Assembly (Art. 171, 7, Constitution 2008).

${ }^{76}$ In this context, these objectives shall pursue: the improvement of quality and expectancy of life; the construction of a fair, democratic, productive, solidarity and sustainable economic system based on the egalitarian distribution of the benefits of development, of the means of production and of decent stable work; the promotion of social participation and control; the restoration and conservation of nature that ensure persons and communities permanent, equitable and quality access to water, air and land, as well as the enjoyment of benefits of natural and subsoil's resources; national sovereignty, Latin-American integration and strategic insertion in the global context, and; the protection and promotion of cultural diversity (Art. 276). 
Under the comprehensive nature conferred on the development regime, the Constitution distinguishes between the State ${ }^{77}$ and people's obligations ${ }^{78}$. This provision illustrates the strong influence of the State as the main actor of the regulatory and economic activities under a centrally planned regime. Compared to the Constitution of 1998, which embraced a market social economy conferring on the State a subsidiary action, the shift of orientation concerning the organization of the economy is radical. As it has been emphasized the National Plan of Development is the main tool of governance in this constitutional framework ${ }^{79}$.

Concerning the territorial organization of the State and the attributions conferred on the decentralized autonomous governments, one can highlight the status given to the territory of the Amazon provinces ${ }^{80}$.

The strong centralization of power in the Executive Branch is clearly evidenced in the determination of its exclusive attributions over national planning; international relations; the economy, tax and customs policies; protected natural areas and natural resources; electromagnetic spectrum and the general system of communications and telecommunications, ports and airports; energy, mineral, oil, gas, forest, biodiversity and water resources, and; the management and control of national state-owned enterprises (Art. 260). Concerning the economic system and policy, the Constitution drastically

\footnotetext{
${ }^{77}$ It is obligation of the State: to guarantee the rights of people, communities and nature; to manage, planning, and regulate the development process; to make and implement public policies and to control and sanction any breach thereof; to produce goods, to create and maintain infrastructure and to provide public services; to boost the development of economic activities through a legal system and political institutions that promote, foster and defend them in accordance to Constitution and law, and; to promote and bolster science, technology, arts, ancestral wisdom and in general, activities resulting from the creative communitarian, associative cooperative and private activities (Art. 277).

${ }^{78}$ The Constitution mandates the participation of persons and communities in all stages and spaces of public governance and of national and development planning, as well as in the execution and control of the development plans fulfillment at all levels. Not less important, is the obligation of the said persons and communities to produce, exchange and consume goods and services with social and environmental responsibility (Art. 278).
}

${ }^{79}$ Accordingly a decentralized national system of participatory planning is established for the purpose of adopting its guidelines and approving the National Plan of Development (Art. 279). The importance underlined may also be observed when the Constitution declares the subordination of the design and execution of the General State Budget to the National Plan of Development (Articles 292 and 293). The Executive Branch designs both instruments.

${ }^{80}$ The Constitution declares such territory to be a special circumscription under special rules of planning, which should take into consideration social, economic, environmental and cultural aspects, as well as land use development guidelines that ensures conservation and protection of ecosystems and the principle of good living (Art. 250). The possibility of conforming to special territorial circumscriptions is also conferred on indigenous and afro-Ecuadorian populations (Art. 257). Additionally, it recognizes the collective land ownership by these peoples as "an ancestral form of territorial organization" (Art. 60). 
overhauls the principles and guidelines provided by former constitutional frameworks. It declares the economic system as social and solidarity, recognizing the human being as its subject and end. This system aims to achieve a dynamic and balanced relationship between society, State and market, in harmony with nature. Its objective consists of ensuring the production and reproduction of material and immaterial conditions for the good living's realization ${ }^{81}$. The system comprises public, private, mixed economy and solidarity sectors, and others as constitutionally established (Art. 283).

With regard to fiscal policy, its main objectives acknowledge the financing of public services, goods and investment; income redistribution through appropriate transfers, taxes and subsidies, and; the creation of investment incentives in the different sectors of the economy and for the production of goods and services, which are socially and environmentally desirable (Art. 285). What is highly remarkable is the incorporation of public procurement as a tool of fiscal policy, prioritizing the purchase of national products and services, especially those provided by popular and solidarity- based economy and micro, small and medium-sized production units (Art. 288).

With relation to public debt, this Constitution is particularly innovative when it introduces the concept of "legitimacy" to public debt. For instance, this notion has underpinned processes of reviewing international obligations, with the creation of the International Auditing Commission for the Public Debt of Ecuador and the Commission for the Integral Citizens' Audit of the Treaties of Reciprocal Protection of Investments and of the International Arbitral System on the Subject of Investments (Art. 290). The subordination of legal proceedings to legitimacy has produced significant outcomes in terms of the definition of the State's obligations in the light of international law. As a result of the public debt's audit, Ecuador declared its default on foreign commercial bonds, namely Global Bonds, which were part of the restructuring of debts in 2000 after the country's 1999 default. ${ }^{82}$ With the aim of preventing improper practices adopted by governments since the 1980 's and particularly during the bank crisis of 1999, the

\footnotetext{
${ }^{81}$ Within the economic policy's objectives enshrined by the Constitution, one can remark the: assurance of an adequate distribution of the country's income and wealth; the encouragement of national production, the accumulation of scientific and technological knowledge, strategic insertion into world economy and complementary productive activities within regional integration the guarantee of food and energy sovereignty; the foster of full employment and value of all forms of work with due respect to labour rights; the foster of fair and complementary exchange of goods and services on transparent and efficient markets and; the encouragement of socially and environmentally responsible consumption (Art. 284).

${ }^{82}$ Internal Auditing Commission for Public Credit of Ecuador, Final Report of the Integral Auditing of the Ecuadorian Debt, Executive Summary, November 2008.
} 
Constitution forbade bailouts and the "statization" of private debts (Art. 290, 7) ${ }^{83}$ It is also inserted the obligation to conduct prior financial, social and environmental assessments on the projects' impacts that entail public debt, as well as the performance of permanent auditing at all stages of foreign and domestic public debt (Art. 291).

As regards the tax regime, one can note the incorporation of the principles of progressivity, efficiency, administrative simplicity, transparency, sufficiency, as well as the priority conferred on direct and progressive taxes ${ }^{84}$. The shift of orientation of tax regime is significant in comparison to the Constitution of 1998, which mentioned as important objectives of the same, the promotion of investment and re-investment. Such principles were put into practice during the privatizing trend for justifying the imposition of tax exemptions for the attraction of foreign investment.

Another notable transformation enshrined in this Constitution consists of the retrieval of regulatory space over the financial sector. First the Central Bank's independence was abolished, subordinating its management to the Executive Branch's economic council (Art. 303). The constitutional framework allocated to this council the exclusive power to issue monetary, credit, exchange and financial policies, formerly entrusted to the Central Bank. Second, there were inserted as important objectives for the application of such policies: 1) the establishment of overall cash flow levels that guarantee adequate financial margins and; 2) the orientation of surplus financial flows towards investment required for the development of the country (Art. 302). For instance, the centralization of financial and fiscal policies has enabled the Government, to establish a Domestic Liquidity Coefficient and to impose restrictions on cash outflows. ${ }^{85}$

\footnotetext{
${ }^{83}$ The large room of autonomy conferred on provincial and municipal regimes may be also observed in public debt rules, when the Constitution authorizes the Executive Branch to decide whether or not to take up debts of the decentralized autonomous governments (Art. 90, 9).

${ }^{84}$ Correspondingly, tax policy is intended to promote: redistribution and employment stimulus; production of goods and services, and; the encouragement of ecological, social and economically responsible conduct (Art. 300).
}

85 Weisbrot, Johnston and Lefebrve remark on the importance of the fiscal and financial policies for effectively dealing with economic recessions:

\footnotetext{
"In May of 2009 the government established a Domestic Liquidity Coefficient, which required that 45 percent of all banks' liquid assets had to be held domestically. This was increased to 60 percent in August of 2012. The purpose was to require Ecuador's banks to keep more of their assets in the country; some hundreds of millions of dollars were brought back as a result of this regulation during the first year. This proved to be extremely important in the government's response to the 2009 world recession

The government also placed a tax on capital leaving the country. Since its implementation, this has become a key source of transparency and also a significant share of government revenue, increasing from less than 1 percent of revenue in 2008 to over 10 percent in 2012. “
} 
Under the Constitution of 1998, the National Congress appointed the members of the Central Bank Board, in accordance to the list of candidates submitted by the President (Art. 262). Logically this shared attribution demanded strong political bargaining, taking into consideration the importance of the attributions assigned to the Central Bank ${ }^{86}$. The sad institutional remembrance of the Central Bank, held by the National Congress ruling parties, derived from the use of its attribution to grant solvency and stability loans to the financial institutions, curiously inserted in a transitory disposition of the Constitution of $1998^{87}$. Without any doubt this improper conduct was one of the main detonating factors of the financial crisis of 1999, which at the end had to be assumed by the taxpayers.

It is not surprising that the trade policy's objectives are also subordinated to development, consolidation and invigoration of the internal market in accordance with the National Development Plan. At the same time, trade actions are aimed at strengthening national production and market, as well as to foster the development of scale economies and fair trade. It emphasizes the contribution of trade policy to guarantee food and energy sovereignty and the reduction of internal inequalities. Also notable is the application of these policies to prevent monopolies and oligopolies, particularly in the private sector (Art. 304). The exemption of this limitation to public economic activities is in conformity with the strong influence allocated to the State as the main player in the economic system.

It highlights the obligation of the State to promote environmentally responsible exports, with preference to those creating more employment and added value and in particular, the exports of small and medium-size producers. At international trade level, it notes the obligation of the State to support imports necessary for the achievement of development

Weisbrot (Mark), Johnston (Jake) and Lefebvre (Stephan), Ecuador's New Deal: Reforming and Regulating the Financial Sector, February 2013, 3 p.

http://www.cepr.net/documents/publications/ecuador-2013-02.pdf

${ }^{86}$ Undr this scheme, the Minister of Finance was authorized to attend the Board's sessions without voting rights.

${ }^{87}$ Constitution of 1998 :

"Forty-second Transitory Disposition;- Until the State has adequate legal instruments to deal with financial crises and for a term not exceeding two years from the effective date of this Constitution, the Central Bank of Ecuador may grant stability and solvency loans and other credits to financial institutions in order to cover the pre-emptive rights of natural persons entering into liquidation procedures."

Free translation. 
objectives, which includes its duty to discourage those that negatively affect domestic production, population and nature (Art. 306). In this regard, it encourages the progressive use of custom duties by the Government during the last years, to foster national production and to protect the balance of payments. Within the constitutional section devoted to trade policy, it also incorporates the prohibition of recourse to diplomatic protection with relation to contracts signed between the State and foreign individuals and entities, with the exception of contracts related to the foreign service (Art. 307).

The constitutional framework devotes a specific section to fair trade. It grants plenty of attributions to the State for regulating, controlling and intervening in economic transactions. A powerful attribution consists on defining pricing policy for protecting domestic production (Art. 335). This section underlines the State's attributions for encouraging competition on equal conditions and opportunities and for assuring the transparency and efficiency of markets (Art. 336).

The Constitution bestows a specific chapter to strategic sectors, public services and enterprises. In this line, it reserves to the State the right to administer, regulate, monitor and manage strategic sectors, pursuant to the principles of environmental sustainability, precaution, prevention and efficiency. It does not establish an exhaustive list of strategic sectors enabling to the law to define the same, according to criteria of importance and size capable of exerting a decisive economic, social, political and environmental influence. Such sectors must be aimed at ensuring the full exercise of rights and the general welfare of society. In any case, it explicitly determines as strategic sectors: energy in all its forms, telecommunications, non-renewable natural resources, oil transport and refining, biodiversity and genetic heritage, electromagnetic spectrum, water and other established by law. Considering these criteria as well as the possibility to include further strategic sectors by law, it is clear that there is as ample margin to expand the list of sectors indicated by the Constitution.

In this context, are State's responsibilities, the provision of public services of water and irrigation, sanitation, electricity, telecommunications, roads, seaport and airport facilities, and others as prescribed by law. The State has the obligation to ensure that the prices and fees of public services are equitable. It also bears the power of regulation and control of the sector`s activities (Art. 314).

The Constitution changed radically the rules concerning the management of strategic sectors, provision of public services and sustainable use of public resources. It requires the creation of public enterprises for undertaking the mentioned tasks, which the 
Constitution of 1998 intended to abolish for privatization purposes. It has to be recalled that under the Constitution of 1998, the enterprises devoted to the management of strategic sectors where converted to private state owned enterprises, whose stocks were the property of the Solidarity Fund; this body was entrusted to implement the privatization process. In contrast, the Constitution of 2008 established such enterprises as public entities, which act under public delegation for the performance of their tasks. With relation to the State`s equity participation in mixed-economy companies, the Constitution authorizes this scheme, as long as the State holds the majority of the shares. It opens the possibility to delegate the participation in strategic sectors and public services to mixedeconomy companies, in which the State owns the majority of the shares. The constitutional framework also foresees the exceptional delegation of such activities to private entities and the popular and solidarity sector, in accordance to the law. ${ }^{88}$

As regards the forms of organization and management of production, the Constitution recognizes their diversity, including community, cooperative, public and private enterprises, associative, familiar, domestic, self- managed and mixed ${ }^{89}$.

This Constitution also modified the rules concerning labour relations, determining its nature as bilateral and direct. Accordingly, it prohibited widely used schemes of labour relationship tolerated by the Constitution of 1998 and its relevant reforms. The prohibition covers all forms of precarious labour relationships like the labour brokerage and outsourcing, labour-hour contracts or any other that may affect the rights of workers, either individually or collectively (Art. 327) ${ }^{90}$.

In harmony with the recognition of nature's rights, the constitutional provisions related to nature and the environment, are extensive and detailed. In the first place is imposed the State's obligation to guarantee a sustainable model of development, environmentally balanced and respectful of cultural diversity. This model must conserve the biodiversity and ecosystem's capacity to natural regeneration in the light of present and future generations' needs. In conformity with citizen participation rights, the State has the duty

\footnotetext{
${ }^{88}$ It has to be highlighted that delegation to mixed economy companies and private enterprises is confined to the limits and periods, prescribed by the law (Art. 316).

${ }^{89}$ It is declared as the State's obligation to promote forms of production that assure the good living and contrariwise, it has the duty to discourage those that violate population or nature's rights (Art. 319). The Constitution subordinates production activities to principles and standards of quality, sustainability, systemic productivity, valuation of work and social and economic efficiency (Art. 320).

${ }^{90}$ The constitutional framework also incorporates obligations concerning the inclusion of persons with disabilities and equal access and treatment to women in the labour force (Art. 330).
} 
to guarantee permanent intervention of related persons, communities, peoples and nations in the planning, implementation and control of all activities exerting environmental impacts. It notes the introduction of the "precautionary principle" that applies in favour of "nature's rights", in case of doubt. There is the particularly powerful obligation to consult the communities that may be affected by a public decision or authorization related to the environment (Articles 396 and 397). In the event of opposition of the community, the State through a higher administrative body not defined by the Constitution, has the privilege to decide whether to uphold this decision (Art. 398).

The Constitution recognizes the State's sovereignty over biodiversity, whose administration and management should be conducted with inter-generational responsibility (Art. 400). In this context, the country is declared to be free of transgenic crops and seeds, with the exception of cases of national interest, dully motivated by the President and subsequent consented to by the National Assembly (Art. 401). It is also prohibited the transfer of rights, included intellectual property rights, over derived or synthetic products, obtained from collective knowledge linked to biodiversity.

The constitutional framework also inserts a section for the protection of natural heritage. The virtually unlimited scope of this heritage includes physical, biological and geological formations, whose value from the environmental, scientific, cultural or landscape standpoint requires protection, conservation, recovery and promotion (Art. 404 ${ }^{91}$ ). It is very significant that there is a prohibition of non-renewable natural resources extractive activities in protected areas, including forestry exploitation; however this ban is not absolute. Exceptionally, these resources may be exploited under motivated request of the President and subsequent declaration of national interest of the National Assembly, which may if it deems appropriate, convene a referendum (Art. 407). It is also forbidden to foreign natural persons or legal entities to acquire lands or concessions in national security and protected areas in accordance with the law. Additionally, the constitutional framework includes specific sections for soil conservation (Articles 409 and 410), management of water resources (Articles 411 and 412), biosphere and climate change (Articles 413, 414 and 414).

The principle of separation of powers, which traditionally has embraced three branches,

\footnotetext{
${ }^{91}$ It created a national system of protected areas for the conservation of biodiversity and the preservation of ecological functions. With this system, the State has the obligation to allocate the financial resources required to ensure the system's financial sustainability and to foster the participation of the communities, peoples and nations in their administration and management (Art. 405).
} 
was also the innovation of the Constitution of 2008. It added the Electoral Branch and the Transparency and Social Control Branch (Art. 204) to the constitutional organic landscape ${ }^{92}$.

The recognition of the principle of legality as a source of public power exercise also imposes on public entities the obligation to coordinate actions for enforcing the enjoyment and exercise of the rights enshrined in the constitutional framework. ${ }^{93}$ This Constitution also re-edited the provision that aims to prevent conflict of interests in the formation of regulatory and control bodies, originally inserted by the Constitution of 1998 (Art. 232).

Concerning the administration of justice, the Constitution enables the judges to apply justice in accordance to the Constitution, domestic law and international treaties of human rights (Art. 102). It is worth mentioning that the Constitutional Court limited expectations concerning the application of indigenous justice, when it constrained such jurisdiction to minor matters, thereby favouring the jurisdiction of judicial bodies in conflicts of "public interest", like criminal offences. ${ }^{94}$

This constitutional framework recognizes arbitration, mediation and other alternative procedures for dispute settlement in accordance to law. Such procedures are limited to matters that are capable of settlement by transaction and accordingly capable of being submitted to arbitration. Legal arbitration may be agreed in public procurement, provided there is a favourable ruling by the Attorney General (Art. 190).

The change of paradigm from a State governed by the rule of law to a State of "rights and justice" involved the consolidation of the constitutional jurisdiction. As a

\footnotetext{
92 The Transparency and Social Control Branch The latter branch comprises the Council for Public Participation and Social Control (Art. 207), the General Comptroller's Office (Art. 211), the Ombudsman's Office (Art. 214) and the superintendent offices created by law (Art. 213). To the control exercised by the superintendent offices to the conformity of economic, social and environmental activities and of the services provided by public and private entities, it has recently added the control undertaken by regulatory agencies attached to the Executive Branch. The control of such agencies is confined to the areas of exclusive management and control of the Executive Branch.
}

${ }^{93}$ Constitution of 2008:

"Article 226.- State institutions, bodies, agencies, public servants and persons who act by virtue of a state power granted to them, shall perform only those duties and wield those powers that are given to them by the Constitution and the law. They will have to coordinate actions for the fulfillment of their purposes and enforce the enjoyment and exercise of the rights recognized in the Constitution."

Free translation.

94 Jurisdicción Delito contra la Vida es Facultad del Derecho Ordinario, Resolución de la Corte Constitucional No. 113, ver Registro Oficial Suplemento 323 de 1 de Septiembre de 2014, 1 p. 
consequence, it is undeniable that the most powerful jurisdictional powers rest in the Constitutional Court's realm. The Constitution preserved the attribution of judges and administrative authorities to directly applying the constitutional provisions in the case of conflicts of hierarchy between norms (Art. 425). However, it suppressed the competence of judges to not apply legal or regulatory provisions deemed to be contrary to the Constitution (diffuse constitutional control), establishing a concentrated system of constitutional control in the Constitutional Court. With the establishment of jurisdictional guarantees, the Constitution entrusted to the first level judges the settlement in the first instance of writs of protection, habeas corpus, habeas data, public access information and interim measures .It conferred on this Court the exclusive competence for interpreting the Constitution and international treaties, which was formerly an attribute of the National Congress. In general, the Constitutional Court rules about the conformity of public decisions to the Constitution. Additionally, it settles competence conflicts between State's branches and the entities established by the Constitution. Finally, it has the obligation to issue prior binding rulings concerning the constitutionality of: 1) international treaties before the National Assembly's ratification; 2) summons to national referendums or those promoted by decentralized autonomous governments and; 3) objections of unconstitutionality invoked by the President in the law drafting process (Art. 438). The rulings and decisions of the Constitutional Court are definitive and not subject to appeal.

Politically, the Constitution of 2008 was the outcome of a traumatic period of nongovernability, instability and failed attempts to establish a comprehensive privatization scheme through the dismantling of the State. The deregulatory efforts had as main purpose diminishing the intervention of the State in the economy in order to attract foreign investment and foster private activities. However due to the structural flaws of Public Administration and its corporatism, this deregulation trend meant the relaxation of rules for all economic activities. Hence, "privatization" was understood as the absence of regulation and the conversion of public monopolies into private ones. The sanctification of contracts as the main source of obligations and the attempt to enforce national and international arbitration as main forums for the settlement of disputes was aligned with this tendency. In practice, this chaotic set of measures aggravated by unfavourable exogenous conditions prompted the financial crisis of the end of the twentieth century, impacting on the subsequent political crisis that lasted ten years. The benefits of the "invisible hand" never showed up, probably due to the fact that the mere absence of the 
State does not necessarily prompt the conditions for the encouragement of a free market and competition.

In this regard, the Constitution of 2008 demonstrates public disenchantment in relation to this period and exacerbates the role of the State, practically in all areas. The declaration of sovereignty over non- renewable natural resources in the first constitutional provision provides evidence for the impetus of the recovery of public influence concerning the management, administration and enjoyment of the same. The installation of the State of "rights and justice" as further interpreted by the Constitutional Court, shows the attempt for overcoming a period of "positivistic dictatorship" by declaring the predominance of the values of justice and democracy over the formal notion of the law. In harmony with the expansive insertion of constitutional rights as coined by the Ecuadorian tradition, the declaration of their inter-dependence, equal hierarchy and indivisible character imposes high standards of fulfillment on rule makers and rule enforcers. This assumption is supported by the incorporation of constitutional guarantees created for the enforcement of these rights as never established by the former Constitutions; this trend started to develop from the constitutional framework of 1998. In this line the consolidation of the constitutional jurisdiction enhances the scope of performance and control of public and private activities.

The expansion of citizen rights and the creation of nature's rights have also changed the dimension of public activities. In this regard, the clash between the dogmatic and the organic part of the Constitution is evident. Whereas a strong emphasis is given to a centrally planned State, the recognition of rights to the citizens and collective groups overrides the State's ambit of influence. In certain cases, the exertion of powers of the State can be limited and annulled by citizens' actions. As a consequence, the contradictions between the interests of the State that struggles for recovering its institutional influence over the management of natural resources and the interests of citizens expressed through collective's actions will be probably intensified over time.

Moreover, the inauguration of a system of popular and solidarity economy along to the principles of a "good living" regime, poses complex duties on the State as the main regulator and actor of the economy. To the economic guidelines, which confer on the State an ample margin for designing its economic policy, there are inextricably linked principles such as sustainability, social and environmental responsibility, as well as others, even more complex such as the duty to guarantee the ecosystem's capacity to natural regeneration. Under a centrally planned model and the centralization of powers in 
the Executive Branch, further struggles for the enforcement of these principles are likely to accentuate the contradictions between the designed institutional structure and the ample category of rights and principles consecrated in the dogmatic part of the Constitution. While the pompous declarations of former constitutional frameworks could have been ineffective due to the absence of procedural remedies for their enforcement, this is no longer the situation within the current Constitution.

In consequence, the main challenge for a strong central planned model under the influence of the Executive Branch is not linked to the institutional strengthening of the capacities of the formal branches of the State, like the judicial and the transparency and social control. In fact, the inter-dependence and equal hierarchy of rights along with the recognition of an ample category of rights to citizens and collective groups, which include limitations and guidelines for undertaking all sorts of activities, are likely to be translated into a close scrutiny of public activities by non-State actors. Therefore, the boundaries of the State's actions and especially the notion of absolute sovereignty in exerting regulatory powers and managing public resources will be progressively constrained.

\subsection{Constitutional Approach to the Right to Property}

A historical overview of the evolution of constitutional treatment for the right to property shows the multiple dimensions that have shaped its scope-either as a civil or liberty right — as a limit to the exercise of sovereign powers or as a tool to achieve economic development. There is evidence from the first Constitution of the strong protection attributed to private property rights. Until the Constitution of 1897 , it may be observed that the wording of the relevant provision involved a negative obligation, only surmountable by judicial ruling or expropriation. The Constitution of 1906 incorporated the denomination "right to property", preserving the negative character of the obligation and introducing in the case of expropriation, the requisite of "prior compensation". As previously observed, the right to property was enshrined from the first Constitution, practically without any limitation, except to the prohibition of "mayorazgos" or linked relationships of property in force since the Constitution of 1835 .

The Constitution of 1929 expressly subordinated the right to property to the accomplishment of its "inherent" social function. This constraint embraced the lawful exercise of regulatory powers by the State, without affecting the negative nature of the right to property, whose deprivation only could take place by judicial ruling or lawful 
expropriation. This has been the general principle predominant along the whole constitutional texts. In this line, it is crucial to underline that the relevant constitutional provisions in the case of deprivation of property make an explicit reference to the word "goods". Hence, it has to be taken into account that the definition of goods has been historically regulated by the Civil Code and encompasses both tangible and intangible assets. ${ }^{95}$ However in the last case, the scope of such intangible property is much narrower than the breadth conferred by International Investment Law to "investments".

This conception underlies three dimensions in which the right to property can be affected. First the subordination of this right to the condition of serving its inherent social function enables the State to exercise regulatory powers, whose effects in the case of causing any impact on the enjoyment of such right would have to be tolerated. Second, the negative obligation concerning the prohibition of deprivation of property and possession of "goods" can only take effect after a judicial ruling or expropriation. In the case of a judicial ruling consisting of deprivation of property, compensation is not a prerequisite. Third, the notion of expropriation is related to the definitive deprivation of property or "goods" as literally established by the different constitutional cases.

In this regard, the social function of property together with the negative obligation of depriving the rights derived therefrom with specific exceptions as already mentioned, have been the distinctive characters of the right to property throughout Ecuadorian Constitutional history. Likewise, it is notable that this negative obligation has traditionally embraced the exceptions of lawful deprivation of property rights either by judicial ruling or lawful expropriation. In the latter case, this exercise has been always constitutionally confined to causes of public utility and compensation.

Although all the Constitutions have recognized the right to property as a civil right or fundamental guarantee, from the Constitution of 1929, the boundaries of the right to property started its relentless expansion, by incorporating not only exclusive and privileged powers in favour of the State concerning certain areas, but also by acknowledging several collective interests related to the enjoyment of specific property

${ }^{95}$ Civil Code of Ecuador:

"Art. 583- Goods consist of corporeal and incorporeal things. Corporeal are those, which have a real substance and can be perceived by the senses, like a house or a book.

Incorporeal are those, which consist of mere rights such as credit and prescriptive easements."

Código Civil del Ecuador, Registro Oficial Suplemento 46, 24 de junio de 2005 
rights. Starting with the Constitution of 1945, the incorporation of aspirational values to the management of the economy and property became a pattern.

In this scenario was the chapter of the Constitution of 1967, which enlarged the general elements of the right to property by regulating the scope and elements of the said right, the prohibition of confiscation of property, expropriations, free contract, agrarian reform, prohibition of indivisibility and non-transferability of property, inheritance rights, surplus value of property, abandoned and idle lands, natural resources, patent property rights, cultural heritage, economic functions of the State and foreign property and tenure.

By the same fashion, the Constitution of 1979 conserved a specific chapter for regulating the right to property, being remarkable for the incorporation of the obligation of the State to promote the property and administration of the workers through the transfer of stocks and shares of the respective enterprises. At the same time, it recognized the employees' share in profits (Art. 49). It also specified the attribution of the municipalities for expropriating, reserving and controlling areas for the development of urban centers in order to make effective the right to housing (Art. 50). As previously underlined, the State guaranteed land property rights with certain limitations, like those related to the intervention in idle lands and the concentration of land ownership (Art. 51).

The following constitutional codifications of 1984, 1993, 1996, 1997, preserved the same constitutional design, although they extracted from the constitutional title assigned to the right to property, the provision concerning expropriation, placing the same within the title of economy and the section, also dividing the economy by sectors (i.e, private, public and mixed).

The Constitution of 1998 both listed the right of property under the civil rights and assigned a specific chapter for its regulation, in which it inserted the provision related to expropriation. In this regard, it is clear that the contours of the right of property individually considered, have not suffered drastic transformations along the constitutional tradition, since its subordination to the social interest was indisputable. Additionally it is noticeable that the successive constitutional frameworks have progressively inserted obligations and social concessions that have explicitly constrained its absolute enjoyment, like the workers participation in companies' profits, or the State's ownership of idle lands. However, the peaceful preservation of the wording of this right has not prevented the attempts to modify certain terms of property concerning key areas of the economy through other constitutional provisions. This is quite clear from the reforms of the 
Constitutional Codification of 1997 further deepened by the Constitution of 1998 that intended to privatize state owned enterprises created for the provision of public services. Whereas the State's domain over non-renewable resources has never been put under discussion, the private or public ownership of the entities created to provide public services has been a political and normative point of contention. The Constitution of 1998 intended to transfer the ownership not only of the state owned enterprises already existent but also of "further rights" associated with the provision of public services. Hence, it is undisputable that the attempt of this Constitution was not to delegate the provision of public services, but to transfer the ownership of all the rights derived from or associated to them. The constitutional provision that created the Solidarity Fund does not leave doubts to this assertion when it establishes that the capital of the same derives from the resources generated both from the transfer of state enterprises and public services' assets (Art. 250).${ }^{96}$ In terms of collective or community land rights, this Constitution did reserve the State's power to expropriate these lands under causes of public utility (Art. 84). However, this notion was overcome by the Constitution of 2008 that suppresses this reservation.

Furthermore, the Constitution of 2008 reforms the constitutional landscape when it recognizes different types of property. This recognition transcends the predominant criteria confined to the right to private property. Concerning, expropriation it preserves the exercise of such power over "goods", wording unaltered along the Ecuadorian constitutional tradition. Taking as a reference the Civil Code's categorization of goods as corporeal and incorporeal, it may be affirmed that in the latter case, expropriation covers "subjective rights" $" 97$ and obligations. Having said this, the extent of

${ }^{96}$ Bogach and. Zolezzi depict the birth and decease of the Solidarity Fund:

"Also, as originally envisioned, the Solidarity Fund was established to act as a fund manager of the proceeds resulting from the privatization of the public owned companies, to be a social projects financier, and to ensure equitable distribution of the fund's profits among Ecuadorians. In practice, as a result of the failure of privatization, the Solidarity Fund has become the owner and the facto administrator of public companies, functions not foreseen in the constitution. The administration of the electricity companies by the fund has not improved the operations and management of those companies but may instead have added an additional layer of bureaucracy to the sector"

Bogach (Susan V.) and Zolezzi (Eduardo), "Electricity Sector" on Revisiting Ecuador's Economic and Social Agenda in an Evolving Landscape, 202, Editors Vicente Fretes-Cibils, Marcelo Giugale, Eduardo Somensato, Editors, The World Bank, Washington DC, 2008.

${ }^{97}$ In accordance to the Civil Law tradition the subjective rights comprise:

"The law gives subjective rights to legal subjects. These include real rights, personal rights, intellectual rights and personality right 
expropriation does not comprise categories enshrined in Bilateral Investment Treaties, like licenses, concessions or authorizations. In this line, Ecuadorian constitutional tradition only contemplates direct expropriation, disregarding categories of regulatory or indirect expropriation as developed by International Investment Law.

There are also innovative aspects like the introduction of specific prohibitions over specific elements and areas, like those related to the appropriation over people's collective and ancestral knowledge and those imposed to financial and media entities and groups. Especially the latter restriction has had a profound political and social impact that has drastically diminished the financial and media groups' influence over public opinion and as consequence, over public elections.

The State also has extended its domain over biodiversity and genetic assets. Finally, it reformed the terms of the State's profit shares with respect to the exploitation of nonrenewable natural resources, subsoil's elements, biodiversity, genetic assets and electromagnetic spectrum, which radically changed the conditions of profitability of such areas existent until this time ${ }^{98}$. In cases like biodiversity this transformation meant the displacement of an activity deemed as private, to the public law dimension.

Pursuant to International Law' developments in terms of environmental protection and the rights of peoples, the Constitution constrained the State's boundaries to exercising sovereignty over natural resources in certain areas and lands, which in appearance would put in the same level both public powers and people's rights for enabling the performance of extractive activities. Without any doubt, this insertion constitutes a substantial transformation to the presumption that vested the State with absolute powers for the management of natural resources.

\subsubsection{The Right to Property: Constitutional Case Law}

In general, the Ecuadorian legal system recognizes the power of public authorities to declare a property's public utility as the basis for expropriation, including public enterprises. However, such public utility is confined to the specific objectives of the public entity exercising this power. For instance, the same Constitution provides specific purposes for which the municipalities may expropriate, as previously indicated.

\footnotetext{
AJ Haupt, D Paizee, K Paizee, JS Saner, I Wasserfal, Person Education South Africa (Pty) Ltd 2009, 52 p.

${ }^{98}$ Constitution 2008, Art. 408.
} 
Eventual opposition to a decision of this nature operates on two levels. The first level has been normally governed by expropriation proceedings, whose object consists in determining the price to be paid for the expropriated property, provided that its public utility is declared in the administrative decision. In this regard, the main legal complaint that may be lodged against an expropriation decision corresponds to the opposition to the price determined for the property at issue before civil courts. The second level comprises the procedural and merit issues linked to the declaration of public utility that can be contested through administrative, contentious administrative and constitutional jurisdictions. With the presumption of legality of administrative acts, it is understandable that within a civil expropriation proceeding, only the price of the property may be discussed. In consequence no further incident is admitted, except to the criteria for the determination of the price of the property in accordance with the evidences and justifications filed in the claim. Claims like damages for the loss of profits are not accepted either.

Having said this, the constitutional and judicial case laws have been consistent with regard to the elements that must be contained in the administrative decision that declares a property's public utility as well as the valuation of the same. Bearing in mind the category of the right to property as a human right, certain related complaints have been brought against Ecuador before the Inter-American Court of Human Rights. The most paradigmatic is the case of Salvador Chiriboga v. Ecuador ${ }^{99}$. Nevertheless the Court concluded that the declaration of public utility was lawful ${ }^{100}$, it determined the responsibility of the State with regard to the proper valuation and timely compensation derived from the deprivation of property. By stressing out that the payment of fair

\footnotetext{
${ }^{99}$ Inter- American Court of Human Rights, Salvador Chiriboga v. Ecuador, Judgment of May 6, 2008. The rights claimed as violated by the Inter-America Commission of Human Rights are summarized as follows:

"7. Finally, the Commission requested the Court to declare that the State is responsible for the violation of the rights enshrined in Articles 8 (Right to a Fair Trial), 21 (Right to Private Property) and 25 (Right to Judicial Protection) of the American Convention, in relation to articles 2 (Domestic Legal Effects) and 1(1) (Obligation to Respect Rights) therein, to the detriment of Maria Salvador Chiriboga. Furthermore, it requested the Court to order the State to adopt certain measures for reparations, as well as the payment of costs and expenses."

100 Inter- American Court of Human Rights, Judgment of May 6, 2008:

"116. Finally, the Court holds that the State deprived Mrs. María Salvador Chiriboga of the right to property for legal and well-grounded reasons of public utility, which consisted in the protection of the environment through the building of the Metropolitan Park. Notwithstanding, the State did not comply with the requirements necessary to restrict the right to property provided for in the general principles of international law and explicitly established in the American Convention."
} 
compensation is a requirement for carrying out a deprivation of property in accordance to the American Convention of Human Rights ${ }^{101}$, the Court adopted the Hull Formula as the standard that fulfills this obligation ${ }^{102}$. It is curious that the Court used as case law for sustaining this specific standard of compensation, international investment awards like the case Compañia del Desarrollo de Santa Elena S.A and the Republic of Costa Rica (No. ARB/96/1) ${ }^{103}$. Finally, the Court concluded that the market value of the property must be taken into account prior to the declaration of public utility. ${ }^{104}$ Although, case law of the Inter-American Court of Human Rights would not constitute a binding precedent for Ecuador it is a strong source of interpretation for constitutional adjudication ${ }^{105}$.

${ }^{101}$ Inter- American Court of Human Rights, Judgment of May 6, 2008:

"95. Article 21(2) of the American Convention expressly establishes as a requirement to be able to carry out a deprivation of property, the payment of just compensation."

102 Inter- American Court of Human Rights, Judgment of May 6, 2008:

"96. To such regard, the Tribunal deems that in cases of expropriation, the payment of a compensation constitutes a general principle of the international law, which derives from the need to look for a balance between the general interest and the owner's interest. The said principle has been sustained by the American Convention in its Article 21 when referring to the payment of a "just compensation". This Court considers that in order to obtain a just compensation, this must be prompt, adequate and effective."

${ }^{103}$ Inter- American Court of Human Rights, Judgment of May 6, 2008:

"97. In this sense, the European Court of Human Rights has construed the rule contained in Article 1 of the Protocol I, considering that it is an essential right to receive compensation for the deprivation of property. Furthermore, the General Assembly of United Nations Organization, by means of Resolution $N^{0} 1803$, pointed out that in the exercise of the State's sovereignty to expropriate for reasons of public utility, the owner shall be paid the appropriate compensation. Even more, the principle according to which the compensation, in the case of expropriation, is enforceable has been reaffirmed by international case-law."

The international case law referred in the footnote of this conclusion comprises:

"International Centre for Settlement of Investment Disputes, Arbitration between Compañía del Desarrollo de Santa Elena, S.A. and The Republic of Costa Rica Case No. ARB/96; Matter of BP (British Exploration Co. v. Lybian Arab Republic, October 10, 1973 and August 1, 1974; Matter of Liamco; and P.I.CJ. The Factory At Chorzów, Judgement No.7 (May 25 $5^{\text {th }}$ 1926)".

See, Footnote 93.

${ }^{104}$ Inter- American Court of Human Rights, Judgment of May 6, 2008:

"98. The Court considers that, in expropriation cases, in order for the just compensation to be adequate, the trade value of the property prior to the declaration of public utility must be taken into account and also, the fair balance between the general interest and the individual interest as referred to in this Judgment (supra para. 63)."

105 See, Resolution of the Constitutional Court, "Protocolo para la elaboración de Precedentes Constitucionales Obligatorios", August 5th, 2010. 
Additionally, the position of the Ecuadorian Constitutional Court concerning the scope of the right to property, defined as the right of all persons to access to property and to its full enjoyment, can be noted. In the case of the deprivation of this right, the same has to be performed in accordance with the conditions constitutionally and legally prescribed. In this context, the Court has concluded that the deprivation of the right of property is only tolerated, prior to a process of expropriation in accordance with due process and legal certainty. Based on the human rights case, Salvador Chiriboga v. Ecuador, the Constitutional Court stated that public utility and social function are not synonyms. It has affirmed that, whereas the former concerns the general welfare, the latter is related to a specific group of people or collectivity. Additionally it concluded that the absence of motivations for performing a declaration of public utility or social function would leave without constitutional grounds the interference of the State into this right ${ }^{106}$. The exercise of this attribution has also to take into account all the means possible to affect as little as possible the protected right, namely the right of property. ${ }^{107}$

Lately, the Constitutional Court has also upheld that the indigenous population's rights to property should take into consideration the particular values and worldviews of these communities concerning the enjoyment of this right. In these particular cases, the Constitutional Court has relied greatly on the case law developed by the Inter-American Court of Human Rights. In the judgment concerning the extraordinary

${ }^{106}$ Inter- American Court of Human Rights, Judgment of May 6, 2008:

73. The reasons of public utility and social interest to which the Convention refers comprise all those legally protected interests that, for the use assigned to them, allow a better development of the democratic society. To such end, the States must consider all the means possible to affect as little as possible other rights and therefore, undertake the underlying obligations in accordance with the Convention.

74. Similar to the social interest, this Court has interpreted the scope of the reasons of general interest established in Article 30 of the American Convention (scope of the restrictions), by pointing out that " $[\mathrm{T}]$ he requirement that the laws be enacted for reasons of general interest means they must have been adopted for the "general welfare" (Art. 32(2)), a concept that must be interpreted as an integral element of public order (order public) in democratic states, the main purpose of which is "the protection of the essential rights of man and the creation of circumstances that will permit him to achieve spiritual and material progress and attain happiness" (American Declaration of the Rights and Duties of Man, Introductory clause 1.)"

75. Furthermore, this Tribunal has pointed out that "the concepts of 'public order' or 'general welfare', as derived from the general interest, when they are invoked as a ground for limiting human rights, must be subjected to an interpretation that is strictly limited to the "just demands" of "a democratic society," which takes account of the need to balance the competing interests involved and the need to preserve the object and purpose of the Convention [...]."

107 Constitutional Court, Recurso Extraordinario de Protección 146, Supplement of the Official Gazette 362, October 27th, 2014. 
action of protection lodged by the "Shuar" indigenous community, against an administrative act that adjudicated a portion of its land considered by the authority as abandoned, the Constitutional Court found the violation of the right to collective property and of the right to due process, in particular the right to challenge the justification of public decisions ${ }^{108}$. By reference to the judgment Mayagna (Sumo) Awas Tingni Community v. Nicaragua held by the Inter-American Court of Human Rights ${ }^{109}$, the Constitutional Court concluded that the notion of the private right of property enshrined by the ordinary legal order, disregards the material and spiritual element that links the land to the communities. Within this worldview, the land should be considered as a natural resource collectively shared and considering the inalienable, imprescriptible and immune to seizure nature of the rights of the communities over the same, no declaration of public utility with purposes of expropriation might apply.

The same reasoning was employed when applied to the constitutional ruling that declared the non- conformity of several provisions of the Mining Law to the Constitution. Therefore, the Constitutional Court imposed on the authorities the obligation to carry out prior consultation processes with the communities before issuing administrative authorizations for the exploitation of mines. In consequence no expropriation can be undertaken over these lands and the authorities have the duty to guarantee the prior consultation of these communities, as well as performing environmental and technical assessments in order to harmonize the exploitation of natural resources with the collective rights to property, linked to the protection of nature's rights. ${ }^{110}$

\footnotetext{
${ }^{108}$ Constitutional Court, "Recurso Extraordinario de Protección 141", Supplement of the Official Gazette, January 23rd 2015.

${ }^{109}$ The Mayagna (Sumo) Awas Tingni Community v. Nicaragua, Judgment of August 31, 2001, Inter-Am. Ct. H.R., (Ser. C) No. 79 (2001):
}

\begin{abstract}
"149. Given the characteristics of the case, some specifications are required on the concept of property in indigenous communities. Among indigenous peoples there is a communitarian tradition regarding a communal form of collective property of the land, in the sense that ownership of the land is not centered on an individual but rather on the group and its community. Indigenous groups, by the fact of their very existence, have the right to live freely in their own territory; the close ties of indigenous people with the land must be recognized and understood as the fundamental basis of their cultures, their spiritual life, their integrity, and their economic survival. For indigenous communities, relations to the land are not merely a matter of possession and production but a material and spiritual element which they must fully enjoy, even to preserve their cultural legacy and transmit it to future generations.
\end{abstract}

110 Resolución de la Corte Constitucional "Inconstitucionalidad por la Forma de la Ley de Minería", Supplement of the Official Gazette, April 21st, 2010. 


\subsubsection{The Right to Property: Supreme Court's Case Law}

As noticed the Supreme Court's case law by acting as Court of Cassation has been steady concerning the scope of the right to property. However, and considering the novelty of the expansion of the notion of the right to property, the rulings identified are exclusively confined to the right to private property. Additionally, it has to be underlined that this Court undertakes an extraordinary review to proceedings linked to the violation of the law and not to the Constitution.

In this context this case law has been focused on the scope of the valuation of the compensation taking into consideration the main object of expropriation proceedings. Correspondingly it has determined that the fair valuations referred by the Constitution and the law, "oblige the judge to determine a formula for attaining a balance between an equitable compensation for the property owner and the collective benefit and need that involves the execution of public works". ${ }^{111}$ To this end, a just or fair compensation "is one that covers or repairs the loss suffered by the property owner by paying a sum of money, to the extent that such a result can be achieved. The payment amount of such a sum of money has to be fixed, thus, taking into account the economic damage that the property owner suffers at the moment that the process of expropriation begins, and, nothing but this damage; therefore, the compensation cannot serve to enrich the owner". ${ }^{112}$ The courts have permanently upheld this principle inasmuch the prior compensation has been made.

Finally, and bearing in mind that the standards of regulatory or indirect expropriation have not been developed in the Ecuadorian legal tradition, it is worth referring to a ruling of the Contentious Administrative Chamber of the National Court of Justice, whereby the concept of indirect expropriation was vaguely tackled. It is worth to note that, from the legislation, as well as from the constitutional and judicial case law review, this is the sole occasion when the concept of indirect expropriation has been addressed. The dispute concerned the lawfulness of the determination of financial loss imposed by the General Comptroller of the State against the authorities responsible for contracting a service that was effectively provided and in consequence, paid. The Court

\footnotetext{
${ }^{111}$ Corte Nacional de Justicia, Sala de lo Civil, Mercantil y Familia, Gaceta Judicial. Año CXI. Serie XVIII, No. 10. Página 3524.

${ }^{112}$ Corte Nacional de Justicia, Sala de lo Civil, Mercantil y Familia, Gaceta Judicial. Año CXI. Serie XVIII, No. 10. Página 3524.
} 
concluded that the authorities did not observe the administrative procedures of public procurement, and thus, if the service was effectively provided, it was the State's duty to pay for the same. In this regard the Court manifested that "the State cannot benefit from goods or services without paying their value (a form of indirect expropriation) ${ }^{\prime 113}$. It is clear that this notion of "indirect expropriation" does not have any connection to the meaning developed in International Law.

In view of the aforementioned, it can be concluded that the constitutional treatment as well as the case law concerning the right to property has been steady. As noted, the scope of the same has been mainly confined to the boundaries of the private right to property delimited by law and social function. In this regard, the domain or property has been mainly linked to the ability to use, enjoy and transfer tangible property pursuant to the Civil Code. This emphasis does not diminish the right to protection of intangible property like intellectual property rights and assets.

In any case, the concept of expropriation has been limited to deliberate takings of property and does not cover measures tantamount to expropriation or regulatory expropriations. In principle the governmental activity that could limit the right to property, has to be tolerated, as long as its exercise is lawful and legitimate. Corresponding compensation for the limitation to the right to property if this does not constitute a taking, could not be invoked under the internal legal order.

Concerning non-renewable resources and strategic sectors, the different constitutional frameworks may evidence the "private-based" approach of the right to property, by categorizing these resources as "property" of the State. It is clear that the State exerts its domain over the same, but it does not mean that it is entitled to transfer their ownership, taking into consideration the inalienable, imprescriptible and immune to seizure nature of these resources. Therefore any limitation derived from the management of these resources could not be discussed within the boundaries of the deprivation of the right to property but within the realm of the impairment of other rights like legal certainty or the rules that qualify the lawfulness and reasonability of public conduct.

The transformation of the boundaries to the right to property from the Constitution of 1998, especially, with relation to collective and people's rights also change the strong "private based" tradition of the right at issue. In this regard, the limitations to the right to

${ }^{113}$ Corte Nacional de Justicia, Sala de lo Civil, Mercantil y Familia, Gaceta Judicial. Año CXI. Serie XVIII, No. 10. Página 3524. 
property have grown over the numerous constitutional frameworks and include different conditions for its exercise, which undoubtedly demark the extent of private autonomy and sovereign powers.

There are remarkable the explicit limitations imposed by the Constitution of 2008 to the right to property, specially, concerning the imposition of the State's profit shares with respect to the exploitation of non-renewable natural resources, subsoil's elements, biodiversity, genetic assets and the electromagnetic spectrum. For instance, the rule that assures the State's participation over profits derived from such activities in an amount that is not inferior to those earned by the company producing them, underlies the obligation to bring the relevant legal provisions and contracts into conformity with this mandate. Furthermore, the possibility to further categorize other sectors of the economy as strategic will mean the displacement of activities deemed as private to public law dimension, with the consequential application of rules such as the aforementioned.

\subsection{The Evolution of the Regulatory Space in the Ecuadorian Constitutional Tradition}

\subsubsection{Separation of Powers}

Ecuador adopted the presidential system of government after its first Constitution. This feature along with the principle of separation of powers among the Executive, Legislative and Judicial Branches has been firmly rooted in the Ecuadorian constitutional tradition. This tripartite division was modified by the Constitution of 2008, which aggregated two branches: Electoral and Transparency and Social Control. According to the Constitution, each branch enjoys autonomy and independence.

The space of regulatory powers is confined to the highest duty of the State consisting in the protection and promotion of human rights. This obligation is projected both to public and private activities. As noted, the numerous Ecuadorian constitutional frameworks have progressively enlarged the rights and guarantees of persons, which were originally established for the safeguard of the citizens' rights before public activities, have expanded their boundaries to relationships normally assumed as merely private. It has to be recalled that the constitutional action of protection can be also filled against individuals and private entities.

One of the most transcendental reforms brought by the Constitution of 2008, as advocated by the Constitutional Court's case law is the establishment of a State of "rights and 
justice". Accordingly, this notion would transcend the legalist and formalist notion of "rule of law" by inserting the value of "justice", which also consolidates the predominance of the constitutional jurisdiction:

(...) The conversion of legality as fundament and limit of the system implies the reduction of the rule of law to the legality and the subordination of the latter to all the other sources, which means that under this model, the law is not subject to any higher norm.

In the French constitutional model, the Constitution is reduced to a mere political declaration of principles; and therefore it is evident the formation of a juridical culture based on the supremacy of the legality, as the sole appropriate juridical manifestation of the general will, in such a way that the Constitution is reduced in this scheme, to an accessory element, dependent of the legal formulation.

(...) With the new constitutional paradigm, the Constitution is no longer a political program and becomes a juridical norm, bringing closer the continental European model to the north-American Common Law model; it has to be recalled that within the north-American tradition is the constitutional judge, who creates the Law and is the constitutional control, which establishes the procedure of production and unification of the juridical order; therefore the Constitution itself is considered as a juridicial rule directly applicable, while constituting the source of further provisions; this is what Kelsen identified when he indicated that Constitutions do not only "govern the creation of laws but also their material content", namely they also determine "fundamental rights which become principles, guidelines and limits for the content of future laws."

(...) However, Ecuador's constitutional system since its inception in the early nineteenth century, has been influenced only by European Continental's constitutional paradigm and therefore, despite the large number of constitutional changes that the country has undergone, the system of sources that has been in Ecuador is substantially the same since the beginning of the Republic, and it has only changed with the promulgation of the new Constitution". 114

The argumentative effort of the Constitutional Court for proving the former "dictatorship of legality" has been indefatigable and it has influenced its decisions concerning the definition of the scope of well-settled principles, like the principle of the separation of powers:

In this regard, it should be noted that in the contemporary State there no longer exists the absolute separation of the so-called "powers". The public power, namely the power of the state, is one and is manifested through functions which are entrusted by the Constitution to different entities, independent of each other, but integrated into the unity of purpose and reasons of political organization within which they perform their respective roles $(\ldots)^{115}$

\footnotetext{
${ }^{114}$ Resolución del Tribunal Constitucional mediante el cual sus magistrados asumen la calidad de jueces de la Corte Constitucional, Supplement of the Official Gazette, October 22 $2^{\text {nd }}, 2008$.

Free translation.

${ }^{115}$ Resolución de la Corte Constitucional 1, Supplement of the Official Gazette 670, March 27th, 2012. Free translation
} 
It has to be stated that the aforementioned constitutional ruling does not diminish either the system of checks and balances, or the constitutional and judicial review derived from any administrative action. In theory, it does attempt to sharpen the mechanisms of coordination among the relevant branches.

\subsubsection{The Exercise of Regulatory Powers}

The Constitution sets manifold obligations, limitations and guarantees to the exercise of regulatory powers by the Public Administration and public servants. Traditionally, the main principles that have surrounded public administrative activities have been: 1) the principle of legality; 2) the principle of judicial review for all administrative action, and; 3) the incorporation of due process guarantees to administrative proceedings.

The constitutional framework also sets forth the principles of Public Administration declaring it as a service to the collectivity governed by the principles of effectiveness, efficiency, quality, hierarchical structure, decentralization, co-ordination, participation, planning, transparency, and evaluation (Art. 227). It is noteworthy that the Constitutional Court has especially invoked this provision and its respective principles when it has assessed the violation of constitutional rights by public servants, as explained below.

It has to be remarked that nevertheless the relevant constitutional provision refers to the judicial review of "administrative acts", such scrutiny covers all conduct and omissions derived from any entity or public servant entrusted with public duties. This guarantee is in conformity with the right to free access to justice. ${ }^{116}$

Among the due process guarantees applicable both to judicial and administrative procedures, there are two which are particularly remarkable, namely the principle of "motivation" of administrative acts and the principle of legal certainty. The principle of motivation involves the "disclosure of the legal and factual basis (justification) and of the reasons for adopting the administrative act". In comparison to the Constitution of 1998, the constitutional framework of 2008 clarified the scope of the principle of legal

${ }^{116}$ Constitution 2008:

"Article 75. Every person has the right to free access to justice and the effective, impartial and prompt protection of their rights and interests, subject to the principles of immediacy and promptness; in no case shall there be defenselessness. Failure to abide by legal rulings shall be punishable by law."

Free translation. 
certainty by subordinating the same to the existence of prior legal regulations that are clear, public and applied by the competent authorities (Art. 82). Among these principles, it is important to recall the effect attached to the right of citizens to fill petitions to public authorities and to receive adequate and timely responses from them. This effect consists of positive administrative silence, which means that in the case that the authority fails to respond to the correspondent's petition within the deadline set forth by law, the request made by the citizen would be deemed as accepted (Art. 207, Administrative Code ${ }^{117}$ ).

In the light of the State's supreme duty that consists of respecting and enforcing the rights guaranteed in the Constitution, the same imposes liabilities derived from the infringement of the rights of individuals ${ }^{118}$. Thus, the State is entitled to exercise the action of recovery against those persons liable for the damage produced, without detriment to civil, criminal and administrative liabilities.

The enlargement of faculties provided to the superintendence offices created as technical bodies of surveillance, auditing, intervention and monitoring of economic, social and environmental activities and of the services provided by public and private entities should be noted. Their purpose is to ensure that these activities and services comply with the provisions of the legal system and achieve the public interest (Art. 213, Constitution). From the Constitution of 1998, these entities have been assumed as bodies that exercise competences of regulation and control. Correspondingly the Constitution of 2008 has imposed "legal reservation" for conferring to entities of "regulation and control", the attribution for enacting regulations with general effects (Constitution, Art. $132,6)$, The constitutional framework also incorporates conflict of interest prohibitions to the authorities appointed for undertaking such competences (Art. 232). Until 1998, three superintendence offices were created by the succeeding constitutions, namely Banks and Insurance, Companies and Telecommunications. With the constitutional framework of 1998 the possibility to create these entities by law was established. Until 2008, only three superintendence offices had been created, but after the enactment of this Constitution this number has risen. From this period, the superintendence offices of

${ }^{117}$ Código Orgánico Administrativo, Ley 0, Registro Oficial Suplemento 31 de 7 de julio de 2017.

118 The relevant constitutional provision determines that the State, its delegates, concession holders and any person exercising public authority, are obliged to redress the infringements to the rights of individuals due the lack of, or the deficiency in, the provision of public services. The same obligation applies to the deeds or omissions of public servants in the performance of their duties. Additionally, the State is liable for arbitrary detention, miscarriage of justice, unjustified delay or inadequate administration of justice, violation to the right of effective legal protection and any violation to the due process rules and principles (Art. 11,9). 
Communication, Market Control Power, Popular and Solidarity Economy and Territorial Order have been founded. It has to be recalled, that these entities conform to the novel Branch of Transparency and Social Control. Along with the creation of these entities, there have been recently created regulatory agencies, within the Executive Branch, which exercise both regulatory and control powers. The difference between superintendence offices and regulatory agencies is blurred. However, the Legislative Branch has sustained the legal design concerning agencies in areas of the Executive Branch's exclusive competence, such as strategic sectors. This approach has raised concerns with relation to the impartiality of the regulatory and control powers of authorities appointed by the President in areas in which the Government participates with its own public companies. Another criticism is related to the expansion of certain attributions of control entrusted either to the superintendence offices or to the agencies. ${ }^{119}$ In this regard, the protective orientation of the State and the reinforcement of its regulatory powers allow anticipating a possible tension between the scope of jurisdictional and regulatory powers.

\subsubsection{Judicial Review}

Judicial review of administrative activities derives from the principle of legality. As Elliot illustrates: "decision-makers act lawfully only so long as they do not transgress these limits on their powers". ${ }^{120}$ In Ecuador, the judicial review of administrative activity is entrusted as a general principle, to the Contentious Administrative Tribunal and Tax Matters Contentious Tribunals. Along the Ecuadorian Constitutional tradition, the Constitution of 1906 conferred on the State Council decisions about contentious administrative matters. It is worth to note that this body lacked judicial jurisdiction,

\footnotetext{
119 Oyarte provides several examples of superintendence offices which in practice, would exert jurisdictional powers, when they are conferred with the power to settle disputes between individuals. An eloquent example would be the settlement of disputes between insurer and insured, whereby the Companies and Insurance Superintendence office resolves claims of the latter against the former, over-riding the insurance contract's provisions and the civil jurisdiction. Oyarte contends that this sort of attribution would violate constitutional principles like jurisdiction unity and natural judge, as well as corrupting the main objectives of these entities, namely the preservation of the social, and not of the private interest.
}

Oyarte (Rafael), Derecho Constitutional: Ecuatoriano y comparado, Corporación de Estudios y Piublicaciones, Quito, 2014, 832. p.

Free translation.

120 Beatson, Matthews and Elliot's, Administrative Law: Text and Materials, Third Edition, Oxford University Press, 1999, 35. p. 
resembling the French model of the beginning of the XIX century ${ }^{121}$; this design changed in $1968^{122}$.

With relation to the nature of these proceedings, it is clear that they essentially constitute remedies for preserving the legal positivistic order and its main principles: legality and hierarchy. The case law has distinguished the subjective remedy from the objective remedy on the basis of the intention of the claimant. While in the first case, the claim attempts to restore a subjective right which has been breached, the second pursues the protection of the law. In the latter case, the judicial review is circumscribed by the assessment of the administrative decision's legality, disregarding subjective rights, and in consequence it seeks its annulment. ${ }^{123}$

${ }^{121}$ Benalcázar Guerrón illustrates about the transformation of the State Council to the Contentious Administrative Tribunal:

Since 1906, when the Constitution of that year established that the administrative jurisdiction would be exercised by the Council of State, there remained in Ecuador the control of legality which was not entrusted to ordinary courts, with variations of little significance until, in 1959, by Decree Emergency Law, the President Camilo Ponce Enriquez, created the Tax Matter Contentious Court to exercise specialized and independent jurisdiction within the Judicial Branch concerning tax matters.

The good results that the presence of this Court gave the administration of justice in this important matter, allowed in 1967 the incorporation of the Contentious Administrative Tribunal by the Constitution, which was assigned the same jurisdiction in the general area, suppressing from the State Council such powers.

Tinajero Villamar (Francisco), "Incidencia de las reformas constitucionales en el contenciosoadministrativo", p. 81 on Benalcázar Guerrón (Juan Carlos), Derecho Procesal Administrativo Ecuatoriano: Jurisprudencia, dogmática y doctrina, Quito, 2007, 109.p

${ }^{122}$ In 1968, the Law on the Contentious Administrative Jurisdiction defined the competences of the Administrative Contentious Tribunals and in general of the relevant proceedings:

"Article 1: "The contentious-administrative remedy may be filed by physical or juridical persons against the regulations, acts, and resolutions of the Public Administration or of semi-public juridical persons that are definitive, and violate a right or direct interest of the plaintiff."

Article 3: "The contentious-administrative remedy is of two kinds: of full jurisdiction or subjective, and of annulment or objective. The remedy of full jurisdiction, or subjective remedy, protects an individual right of the moving party, presumably denied, repudiated, or not recognized totally or partially by the administrative act in question. The remedy of annulment, or objective remedy, or remedy for abuse of power, protects compliance with the objective legal norm, administrative in nature, and may be brought by one who has a direct interest in bringing the action, requesting of the court that it annul the act challenged due to a legal defect."

The Law on Contentious Administrative Jurisdiction was derogated by the General Organic Code of Processes. This Code was published on May 22, 2015.

${ }^{123}$ Benalcázar points out nevertheless that the intention of the claim differs in both classes of remedies, the invalidity of an administrative decision either general or individual can be discussed within both proceedings:

"In sum, the invalidity of an administrative act can be discussed and declared both within the full jurisdiction remedy or the annulment remedy, only in the latter according to the scheme of 
Finally it has to be noted that the effects derived from the outcome of both proceedings are different. While under the subjective remedy, the effects are particular and operate in the future (ex nunc), under the objective remedy the effects are retroactive and the decision restores the original situation as if the regulation had never existed (ex tunc). In the light of a decision of the latter nature, legitimate and individual interests can be further restored and the valuation of damages and liability will vary substantially, taking into account the time during which the invalid regulation has been preserved in the legal order.

\subsubsection{Constitutional Review}

Whereas the contentious administrative and tax jurisdictions preserve the legality of the regulations and decisions adopted by public authorities, the constitutional review defends the prevalence of the Constitution and the protection of the rights and guarantees enshrined in it. While in the first case, it rules about the constitutionally of laws and regulations of infra-legal status (abstract and concrete control of constitutionality), in the second it enforces the protection of constitutional rights through specific jurisdictional guarantees. ${ }^{124}$

Concerning the abstract control, Oyarte illustrates that the sole object of this action is to confront the rule at issue with the Constitution. This proceeding is resorted to by the "way of action", meaning that "due to the initiation of the process the subordinated rule is challenged". ${ }^{125}$ Concerning the concrete control, the review is prompted by "way of exception", since "in order to invoke the unconstitutionality of the precept whose review is sought, it is necessary that the same is applied in a concrete case before a judge or tribunal". ${ }^{126}$ Considering that the constitutional control in Ecuador is concentrated in the

$\mathrm{LJCA}^{123}$ - the judge was limited to the single declaration of nullity, while in the other, in addition to declaring the illegality -and hence the nullity- the subjective right infringed could be repaired (...)."

Benalcázar Guerrón (Juan Carlos), Derecho Procesal Administrativo Ecuatoriano: Jurisprudencia, dogmática y doctrina, Quito, 2007, 118.p.

${ }^{124}$ Writ of protection, habeas corpus, habeas data, access to public information, action for failure to comply, extraordinary action of protection.

125 Oyarte (Rafael), Derecho Constitutional: Ecuatoriano y comparado, Corporación de Estudios y Publicaciones, Quito, 2014, 862 p.

Free translation.

126 Oyarte (Rafael), Derecho Constitutional: Ecuatoriano y comparado, Corporación de Estudios y Publicaciones, Quito, 2014, 862 p.

Free translation 
Constitutional Court, the judge facing this situation has to consult or initiate the unconstitutionality issue, by requesting the Constitutional Court to perform the constitutional review that affects the outcome of the legal proceeding.

It has to be recalled that pursuant to its effects the Constitutional Court exercises prior and ex post facto control. Whereas in the first case the control's objective aims to prevent an unconstitutional treaty or rule from taking effect, the second case applies to existent provisions. $^{127}$

Among the constitutional remedies provided by the Constitution of 2008, the most effective and prompt mechanism for preventing constitutional violations is the writ of protection, which can be resolved by any judge ${ }^{128}$. The Organic Act on Jurisdictional Guarantees and Constitutional Control determines as eligibility requirements for filling this action: 1) the existence of a constitutional violation; 2) the violation must be caused by an action or omission of a non-judicial authority; 3) the absence of further judicial appropriate and effective mechanisms of redress for protecting the violated right (Art. 39). In the light of these procedural requirements, the Constitutional Court has normally relied on the nature of the issues brought as the basis of this action, observing in particular, whether the violation derives from aspects of legality or constitutionality. The binding precedent was established in the ruling N. 001-010-JPC-CC, and the Constitutional Court defined the contours of the action of protection:

[...] The jurisdictional guarantees, specifically the action of protection, proceed when the violation of constitutional rights derives from an act of non-judicial public authority, violation that must be declared by the judge through judicial ruling [...]

The action of protection is not appropriate when referring to aspects of mere legality, for which there are ordinary judicial proceedings for claiming rights and particularly administrative procedures. ${ }^{129}$

127 Oyarte (Rafael), Derecho Constitutional: Ecuatoriano y comparado, Corporación de Estudios y Publicaciones, Quito, 2014, 864 p.

Free translation.

128 Constitution of 2008 :

"Article 88. The action of protection shall be aimed at ensuring the direct and efficient safeguard of the rights enshrined in the Constitution and can be filed whenever there is a breach of constitutional rights as a result of deeds or omissions by any non-judiciary public authority against public policies when they involve removing the enjoyment or exercise of constitutional rights; and when the violation proceeds from a particular person, if the violation of the right causes severe damage, if it provides improper public services, if it acts by delegation or concession, or if the affected person is in a status of subordination, defenselessness or discrimination."

${ }^{129}$ Corte Constitucional para el Período de Transición. Sentencia n. ${ }^{\circ}$ 001-10-JPO-CC, de 22 diciembre 2010, dentro del Caso n. ${ }^{\circ}$ 999-09-JP. 
Later the Constitutional Court clarified this distinction:

[...] The writ of protection is the appropriate and effective guarantee that proceeds when the judge actually verifies a real violation of constitutional rights, thus, no other way to protect these rights is applicable but resorting to jurisdictional guarantees.

Not all violations of the law necessarily have room for debate on the constitutional sphere and these disputes about legality, count with appropriate and effective proceedings within the ordinary jurisdiction. ${ }^{130}$

The importance of this delimitation deals with the protective and urgent nature of jurisdictional guarantees. As Andrade points out, the abuse of this action would not only harm the parties and obstruct justice, but it also would violate the rights to legal certainty, due process and effective legal protection:

The writ of protection was not included in the legal system to absorb the ordinary courts, but to ensure direct and effective protection of constitutional rights. Therefore it is not valid to seek to extend a jurisdictional guarantee to other areas that are well regulated by the Ecuadorian legal system and also have their reason for being there. Trying to use this action to resolve issues of mere legality denatures the action and undermines the trust which aims to grant the Ecuadorian legal system when establishing a procedure for each type of action and when it gives every person the right to resort to court with the certainty that there is a due process itself, previously established and applied by the competent authority for the resolution of their disputes. ${ }^{131}$

In consequence, it is clear that the advocated change of constitutional paradigm when the Constitution of 2008 established a State of "rights and justice", is backed by the recognition of constitutional rights, scrutinized by constitutional actions of constitutional control and reinforced by constitutional or jurisdictional guarantees. This delimitation also reflects the effort to institutionalize the whole system of dispute settlement by

\footnotetext{
Andrade Quevedo (Karla), "La acción de protección desde la jurisprudencia constitucional" on Manual de justicia constitucional ecuatoriana, Coord. Benavides Ordóñez (Jorge) and Jhoel Escudero Solíz, Corte Constitucional, Quito, 2013.

Free translation.

${ }^{130}$ Corte Constitucional. Sentencia n. ${ }^{\circ}$ 016-13-SEP-CC, de 16 mayo 2013, dentro del Caso n. ${ }^{\circ} 1000-12-E P$. Andrade Quevedo (Karla), "La acción de protección desde la jurisprudencia constitucional" on Manual de justicia constitucional ecuatoriana, Coord. Benavides Ordóñez (Jorge) and Jhoel Escudero Solíz, Corte Constitucional, Quito, 2013, 118.p.

Free translation.

${ }^{131}$ Andrade Quevedo (Karla), "La acción de protección desde la jurisprudencia constitucional" on Manual de justicia constitucional ecuatoriana, Coord. Benavides Ordóñez (Jorge) and Jhoel Escudero Solíz, Corte Constitucional, Quito, 2013, 122.p.

Free translation.
} 
distinguishing the legal remedies available to each kind of controversy in the light of the right to due process and legal certainty.

Finally the binding ruling enacted by the Constitutional Court concerning the integral reparation of the rights violated by the breach of the Constitution should be noted:

According to the Ecuadorian Constitution, all violations of rights deserve integral reparation because in Ecuador, as constitutional State of rights and justice, the expectation of respect for the constitutional rights is greater since the shift of constitutional paradigm; therefore, it is expected that the repair of damages achieves a comprehensive dimension according to the interdependent nature of constitutional rights (Article 11, paragraph 6 of the Constitution). ${ }^{132}$

The particular case concerned an action of failure to comply brought by a citizen against the action of a consular agent, who did not observe its obligations in accordance with the Organic Law of Foreign Service and the Agreement between Ecuador and Colombia with relation to the transit of persons, vehicles, river and marine ships. The obligation at issue consisted of returning a car found in the area of the agent's jurisdiction to the owner bearing a legal title of the same. Due to negligent conduct, the consular agent returned the car to the wrong person, which according to the Constitutional Court, amounted to the violation of the rights of property and legal certainty of the claimant, namely the legitimate owner of the said vehicle ${ }^{133}$. This Court referred to the constitutional principles of Public Administration, specifically those concerning efficiency and efficacy to assess the fulfillment of obligation by this agent.

The Court found that the obligations "to do" of the agent at issue were not fulfilled and once it determined the violation of constitutional rights, imposed the obligation on the Ministry of Foreign Affairs to compensate the claimant with the commercial value of the car calculated at the time of the constitutional ruling. As a binding rule, the Constitutional Court clarified the relevant provision of the Organic Act on Jurisdictional Guarantees and Constitutional Control (Art. 19) concerning economic reparation, by establishing that the determination of the amount derived from monetary compensation has to be settled in a summary trial, in the case of individuals, and through the contentious administrative jurisdiction, in the case of public entities. The amount of economic compensation

\footnotetext{
${ }^{132}$ Sentencia N. 014-13-SEP-CC, Caso N. 2004-12-EP, Official Gazzette, June $21^{\text {st }}, 2013$. Free translation.

${ }^{133}$ Within this ruling, the Constitutional Court asserted that the action of failure to comply guarantees the principle of legal certainty, since its object, seeks the application of rules and their compliance. Sentencia N. 014-13-SEP-CC, Caso N. 2004-12-EP, Official Gazzette, June 21 ${ }^{\text {st }}, 2013$. Free translation.
} 
calculated is the exclusive object of these proceedings and against such a decision is only susceptible of recourse to appeal.

\subsubsection{Conclusions}

Concerning the exercise of regulatory powers, it is clear that the main source of public attributions derives from the Constitution and the law. Regarding a judicial review of public measures, the contentious administrative courts have limited their powers to verifying the conformity of this activity to the legal provisions: namely the enforcement of the principle of legality, both by regulations and acts with individual effects.

As Elliot illustrates, the central idea of this control implies "that the courts are merely doing Parliament's bidding by enforcing the limits upon power which are found (expressly or impliedly) in statute. ${ }^{134}$ Additionally, this jurisdiction also covers administrative contracts and any other relationships in which public entities exert their administrative attributions. In this regard, the grounds and objectives that the legislature attempted to achieve as expressed by the law limit this jurisdiction.

In relation to constitutional review, the strengthening of constitutional jurisdiction has also fuelled attempts for rationalizing the use of mechanisms for constitutional redress. In this regard, the writ of protection consists in the most effective remedy of constitutional redress for the restoration of constitutional rights violated by public entities or individuals; this redress can be resorted to in the absence of any other constitutional mechanism. As noted, the inauguration of constitutional guarantees to be enforced by judges - along with the centralization of constitutional control in the Constitutional Court - attempts to strengthen the rights to legal certainty, due process and effective legal protection.

Consequently, the value given to the Constitution and treaties of human rights - both by substantive and procedural obligations - cannot be denied. In this regard, there is no public or private activity that may overrule constitutional values.

134 Beatson, Matthews and Elliot's, Administrative Law: Text and Materials, Third Edition, Oxford University Press, 1999, 11 p. 


\subsection{Status of International Obligations in the Ecuadorian Constitutionalism}

\subsubsection{Constitutional Supremacy and International Obligations}

As Oyarte illustrates, the "constitution as a normative category was born through the theory of constituent power, but its enshrinement as rule is owed to the emergence of constitutional justice systems that enforce it". ${ }^{135}$

It is worth to note that the principle of constitutional supremacy was explicitly enshrined by the Constitution of 1845 . Concerning this principle, the same scholar illustrates that it "implies the existence of a rule promulgated which has a superior value over the other normative prescriptions and that achieves higher validity over them". ${ }^{136}$

As it has been remarked, the relentless expansion of constitutional rights along the Ecuadorian constitutional history has not necessarily involved the improvement of guarantees for their enforcement. Oyarte recalls that "habeas corpus" was the first constitutional guarantee and it was incorporated by the Constitution of 1929. It was not until the constitutional codification of 1996, that the "writ of amparo" and "habeas data" were established, with the further enlargement of guarantees provided by the Constitution of $2008 .{ }^{137}$ In any case, from early constitutional texts there may be observed robust albeit unenforceable provisions, which aim to guarantee constitutional supremacy.

From the Constitution of 1830, it is established that any provision or decision is valid as long as it is in conformity with the Constitution. The Constitution of 1845 was more explicit and determined that any decision that contradicts the Constitution should be null and void. The personal and civil liability of public servants arising from the violation of the Constitution was also early established. The system of control with relation to the formation of the laws has been applied since the Constitution of 1869. This constitution established a system of prior control, in case the President objects to a project of law submitted to its sanction by the Congress, being the Supreme Court entrusted to settle the

\footnotetext{
135 Oyarte (Rafael), Derecho Constitutional: Ecuatoriano y comparado, Corporación de Estudios y Publicacio nes, Quito, 2014, 1 p.

Free translation.

136 Oyarte (Rafael), Derecho Constitutional: Ecuatoriano y comparado, Corporación de Estudios y Publicaciones, Quito, 2014, 3 p.

Free translation.

137 Oyarte (Rafael), Derecho Constitutional: Ecuatoriano y comparado, Corporación de Estudios y Publicaciones, Quito, 2014, 3 p.

Free translation.
} 
conflict. An identical system of control was preserved by the Constitutions of 1906 and 1929 exercised by the Council of State. Oyarte underlines that the Constitution of 1929 brought two transcendent transformations concerning the consolidation of the principle of constitutional supremacy: 1) it determined the entity in charge of exercising the constitutional control, namely the Congress, and; 2) it banned the authorities from applying legal provisions by invoking their unconstitutionality, but it enabled them to not apply regulations different from laws ${ }^{138}$. It is unclear to which extent the authorities did exercise the latter attribution, though, bearing in mind the strong legalist tradition rooted in the country, it can be conjectured that it must have been performed in very limited cases. The main competence of the aforementioned council dealt with the control of legality concerning inferior regulations and administrative decisions, but this entity was abolished by the Constitution of 1967 .

The Constitution of 1945 created the Tribunal of Constitutional Guarantees but "the repressive control" rested on the Supreme Court, which was entitled to suspend unconstitutional regulations, until the Congress had decided about their conformity with the Constitution, in a definitive manner. This model remained until the Constitutional Codification of 1983, which conferred on the mentioned Tribunal the faculty of suspending the effects of unconstitutional regulations, preserving the final decision of their validity for the Congress's authority. The Codification of 1992 created the Constitutional Chamber of the Supreme Court, which replaced the Congress as the final instance for ruling about constitutional conformity. With the Constitutional Codification of 1996, the Constitutional Tribunal was created and it was given the competence to decide about the constitutionality of legal provisions or rulings with general effects, which was preserved by the Constitution of 1998. The evolution referred to, concerns the "abstract control" of the Constitution.

Until 1998, the "constitution's concrete control”, namely the possibility not to apply a legal provision or further regulations in contradiction with the Constitution within legal proceedings, was entrusted to the Supreme Court or tribunals of final instance. With the Constitution of 1998, the constitutional "diffuse or incidental control" was established and hence, all judges could exercise it. The exercise of "concrete control" requires the obligation of the judges to inform the Constitutional Tribunal or Court about the legal

138 Oyarte (Rafael), Derecho Constitutional: Ecuatoriano y comparado, Corporación de Estudios y Publicaciones, Quito, 2014, 851 p.

Free translation. 
provision or regulation being in apparent contradiction to the Constitution, in order that the same may issue a definitive decision concerning the expulsion of the relevant norm from the legal order.

Bearing in mind the supreme hierarchy of the Constitution (Art. 425, Constitution 2008), international treaties, as opposed to international treaties of human rights, are subordinated to constitutional provisions. The Constitutional Codification of 1997 took a step forward and prescribed that international treaties once ratified should conform to the internal legal order. This rule was preserved by the Constitution of 1998 and further modified by the Constitution of 2008 as explained below.

\subsubsection{Negotiation, Signature, Ratification and Denunciation of International Treaties}

Until the Constitution of 1998, the process for signing, approving and ratifying international treaties remained practically unaltered. Under the Ecuadorian constitutional tradition the President manages the external affairs and in consequence is entitled to negotiate, sign and ratify international treaties. This latter stage requires the treaty's approval by the Congress.

The Constitution of 1967 showed the first attempt for changing the aforementioned process by suppressing the requirement of Congress's approval in treaties that did not entail permanent duties for the State Budget, implied the obligation to accomodate the legal order or entailed obligations for the citizens. In these cases, the Tribunal of Constitutional Guarantees had to issue a prior ruling to enable the President to follow a direct procedure of ratification. Subsequently, the President had to inform the National Assembly about the use of this mechanism of direct ratification (Art. 184, 3). The Constitution of 1979 did not preserve this procedure and reincorporated the general rule of approval of treaties by the National Congress.

Later on, the Constitution of 1998 reinserted a similar procedure for the approbation of treaties as enshrined by the Constitution of 1967. First, it enlarged the categories of treaties that had to obtain Congress' approval (Art. 161). Second it established the requirement of the Constitutional Tribunal's prior ruling for the treaties that required Congress's approval (Art. 162).

The Constitution of 2008 did not change this procedure; however, it developed relevant rules concerning the categorization of the treaties, as well as their applicability, control and denounce. It also enlarged the category of treaties requiring Congress's approval, by 
aggregating those: 1) that refer to the rights and guarantees enshrined in the Constitution; 2) that compromise the State's economic policy established by the National Plan of Development with the conditions of international financial institutions and transnational enterprises, and; 3) that compromise the natural heritage and especially water, biodiversity and its genetic assets (Art. 419). The Constitution also prescribes that the ratification or rejection of a treaty can be made either by the President or by referendum. In the latter case, the citizens and not only the President are entitled to promote a referendum for the purposes of ratifying or denouncing a treaty (Art. 420).

It has to be noted that in those treaties where Congress's approval is not required, there is no obligation to request a prior ruling of the Constitutional Court for their ratification. The same procedure applies for denouncing treaties. In any case the Organic Act on Jurisdictional Guarantees and Constitutional Control conferred on the Constitutional Court the attribution to decide whether the treaties have to be submitted for the decision of the National Assembly either for its approval or denunciation (Articles 109,110, 111). ${ }^{139}$ A further guarantee to overcome an eventual arbitrary recourse of direct ratification, deals with the President's constitutional obligation to notify the National Assembly of all the signed treaties prior to their ratification (Art. 418).

In this context the Constitution envisions two categories of constitutional control regarding international treaties: ex ante and ex post facto. Whereas the first control attempts to prevent eventual contradictions with the Constitution before the treaty comes into force, the second implies the review of the conformity of existent treaties to the constitutional order. In the first case and in the event that the Constitutional Court found a lack of conformity of the treaty with the Constitution, it is forbidden to the National Assembly to approve the same until a constitutional reform takes place.

The Organic Act on Jurisdictional Guarantees and Constitutional Control provides that "ex post facto" control involves the duty of the relevant entity to initiate the process of denunciation of the international treaty. This provision is in conformity with the Vienna Convention on the Law on Treaties, which does not contemplate the unilateral declaration of invalidity of a treaty. Consequentially as underscored by Oyarte, "the Constitutional Court is not entitled to declare a treaty as unconstitutional, neither ex ante, nor ex post

139 Oyarte (Rafael), Derecho Constitutional: Ecuatoriano y comparado, Corporación de Estudios y Publicaciones, Quito, 2014, 688 p.

Free translation. 
facto to its approval or ratification, notwithstanding the defective wording of the law". ${ }^{140}$ Moreover Oyarte concludes:

Generally, the compared legal systems have not provided ex post facto control of the constitutionality of international treaties because, due to the principle of pacta sunt servanda, international instruments must be accomplished without being possible to oppose domestic rules to avoid these commitments. To this effect it is underlined that international treaties do not emanate from the unilateral will of States, unlike the internal legislation, so its binding force is not void by unilateral decisions. If the instrument lacks of consent, like the absence the representative's capacity that signed it, the invalidity may not be declared by the State's internal entities. ${ }^{141}$

The limitation introduced by the Constitution of 2008 to the direct applicability of international treaties should be noted. Whilst the Constitutional Codification of 1997 and the Constitution of 1998 established the incorporation of ratified international treaties to the internal legal order, the Constitution of 2008, restricted this application to human rights treaties. As noted, the current constitution consecrates, ensures, and guarantees human rights identical to the "liberty rights" prescribed in its text. Furthermore, in the case of contradiction between the Constitution and human right treaties, the latter will prevail (Articles 17, 18 and 19). Additionally, the direct application of these rights involves the possibility of recourse to constitutional remedies, like the action of protection for their enforcement (Art. 95).

In this context, Oyarte illustrates that in the case of contradiction between international human rights' treaties and the Constitution, neither the principle of hierarchy, nor the principle pacta sunt servanda as provided by the Vienna Convention on the Law of Treaties, are applicable. This scholar, summarizes the contradiction as follows:

Either one applies the Constitution and fails to comply with international obligations, incurring an international responsibility, or one applies the treaty disregarding the Constitution, whereby the principle of constitutional supremacy would be breached. ${ }^{142}$

\footnotetext{
${ }^{140}$ Organic Law on Jurisdictional Guarantees and Constitutional Control, Art 112.

141 Oyarte (Rafael), Derecho Constitutional: Ecuatoriano y comparado, Corporación de Estudios y Publicaciones, Quito, 2014, 683 p.

Free translation.

142 Oyarte (Rafael), Derecho Constitutional: Ecuatoriano y comparado, Corporación de Estudios y Publicaciones, Quito, 2014, 680 p.

Free translation.
} 
As a result, Oyarte holds that in the case of such a contradiction the situation should be settled by applying the provision more favourably to the effectiveness of the right in question, as prescribed by the same Constitution (Art. 11, 5). In his opinion, this solution would be aligned to the constitutional provision, which subordinates ratified international treaties to the Constitution, as well as upholds the application of the principles "pro homine", non-restriction of rights, direct applicability and open clause in treaties involving human rights' obligations. ${ }^{143}$

\subsubsection{Limitations to the Delegation of Sovereign Powers}

The Constitution devotes an extensive provision to the principles that govern Ecuador's relations to the international community in the light of the best interests of the citizens (Art. 416). It proclaims the independence and legal equality of the States, peaceful co-existence and the self-determination of the people, as well as co-operation, integration and solidarity. It advocates the peaceful settlement of disputes and international conflicts. It recognizes the rights of the different peoples that co-exist within the States, especially the right of promoting mechanisms that preserve and protect the diverse character of their societies. Additionally, it condemns all forms of imperialism, colonialism, and neo-colonialism and recognizes the right of peoples to resist and liberate themselves from all forms of oppression. Furthermore, it recognizes international law as a standard of conduct and calls for the democratization of international institutions and the equitable participation of States inside these institutions. Likewise, it declares the aspiration to foster:

"a new trade and investment system among States, one that is based on justice, solidarity, complementariness, the creation of international mechanisms to monitor multinational corporations and the establishment of an international financial system that is fair, transparent and equitable. It rejects turning disputes with foreign private companies into conflicts between States" (Art. 416, 12).

143 Constitution of 2008 :

“Art. 417.- Los tratados internacionales ratificados por el Ecuador se sujetarán a lo establecido en la Constitución. En el caso de los tratados y otros instrumentos internacionales de derechos humanos se aplicarán los principios pro ser humano, de no restricción de derechos, de aplicabilidad directa y de cláusula abierta establecidos en la Constitución.” 
Finally, it promotes the creation, ratification and enforcement of international instruments for the conservation and regeneration of the life cycles of the planet and biosphere. Under the principles set forth by this constitutional provision, the recognition of international law as a standard of conduct, which has been enshrined from the Constitution of 1945 is remarkable.

This recognition would link the scope of the abundant aspirational values inserted into the relationship of the country to the international community, to the standards developed by International Law. In addition, it should be noted that these principles must be read in conjunction with the category of treaties that due to their importance, are subject to a special mechanism of approval, which requires the decision of the National Assembly. Among the different categories of treaties that require the approval of the National Assembly and for the purposes of this chapter, there are to be noted: 1) the treaties that compromise the State to integration and trade agreements; 2) the treaties that grant attributions to international and supranational organizations; 3) the treaties that compromise the national economic policy, and; 4) the treaties that compromise natural heritage. Additionally, there are also transcendent constitutional provisions that prohibit the signature of treaties that waive sovereignty in favour of international arbitral tribunals and the application of treaties that diminish health rights, as well as the access to health goods and services. With relation to the treaties that deal with integration and trade, it is noteworthy that the Constitution of 1998 only required the special mechanism of approval to treaties of integration.

Concerning the attribution of competences to international and supranational organizations, it is clear that international legal personality derives from international constitutive treaties. Oyarte recalls that legal personality erga omnes is only recognized by the States:

These organizations aim to co-ordinate the activities of States, although in other cases their decision-making power will prevail over States' willpower, by settling a supranational body, which does not affect state sovereignty as long as it has been created by a treaty that establishes its powers; this instrument approved in the manner prescribed in the Constitution, also applies for integration processes of the international community. ${ }^{144}$

144 Oyarte (Rafael), Derecho Constitutional: Ecuatoriano y comparado, Corporación de Estudios y Publicaciones, Quito, 2014, 671 p.

Free translation. 
This limitation is directly linked to the provision that mandates the Congress's approval concerning treaties "that compromise the State's economic policy as established by the National Plan of Development with the conditions of international financial institutions or transnational companies" (Art. 419.5). Economic policy comprises financial, monetary, credit and exchange policies, the same that according to the Constitution are determined by the Executive Branch and further implemented by the National Central Bank. In consequence, the National Plan of Development only sets the main guidelines for economic policy design. This kind of limitation applies as long that the treaty at issue, subordinates the economic policies explicitly established in the National Plan of Development to the conditions of international financial institutions with an international legal personality, like the World Bank or International Monetary Fund. ${ }^{145}$ Hence, those treaties that could compromise economic policies not included in the National Development Plan, as well as those that could condition such policies to international entities lacking international legal personality, would be outside this limitation. Oyarte explains that international banks cannot be defined as "international institutions" "not only because they are not international organizations, but because they are local entities with a seat in a particular State". ${ }^{146}$ For similar reasons, he considers that it is unlikely that a treaty explicitly may establish limitations to the State's economic policy in favour of transnational companies, although it may be interpreted that the purposes of the treaty in question may be oriented to benefit transnational companies. ${ }^{147}$

It is clear that the intention behind this limitation consists of reaffirming the sovereignty of the State over the design and implementation of economic goals, which unfortunately sets aside other policy areas that are relevant to the relationships between the State and non-State entities. Whereas it may be understandable to avoid the influence of international financial institutions like the International Monetary Fund or the World Bank and the consequent subordination to their letters of intention or structural adjustments, respectively, the conditions that may be associated with relationships with

145 Oyarte (Rafael), Derecho Constitutional: Ecuatoriano y comparado, Corporación de Estudios y Publicaciones, Quito, 2014, 674 p.

Free translation.

146 Oyarte (Rafael), Derecho Constitutional: Ecuatoriano y comparado, Corporación de Estudios y Publicaciones, Quito, 2014, 674 p.

Free translation.

147 Oyarte (Rafael), Derecho Constitutional: Ecuatoriano y comparado, Corporación de Estudios y Publicaciones, Quito, 2014, 674 p.

Free translation. 
transnational companies, normally exceed the boundaries of economic policies. As long as the regulatory policies of the State affect the interests of a foreign investor protected by a Bilateral Investment Treaty, it is possible for these companies to invoke the breach of International Law. In consequence and due to the complex areas or domestic policy which do not only include economic policies, the constitutional provision at issue would not be sufficient to limit the boundaries of investment protection.

Congress`s approval also applies to treaties that "compromise the natural heritage, in special water, biodiversity and their genetic assets" (Art. 419, 8). Oyarte reads this limitation in conjunction with the constitutional provision that prohibits the State from entering into treaties or co-operation agreements, which include clauses "that diminish the conservation and sustainable management of biodiversity, human health, collective and nature 's rights" (Art. 403). In that regard, the Constitution would not prohibit the adoption of treaties that compromise these areas, as long as the same do not diminish their sustainable conservation and management. This assumption would be in line with the constitutional principles set forth for the promotion of integration processes, specifically those related to the achievement of joint strategies for the sustainable management of national heritage (Art. 423, 2).

Concerning the two prohibitions imposed on the signature of treaties stated above, the constitutional wording is also vague and leaves a large room for interpretation. As a general principle, the Constitution forbids the application of international commercial or trade instruments that diminish, directly or indirectly, the right to health, access to medicines, supplies and services, as well as to scientific or technological progress (Art. 421). From this provision, one can remark the reference to "trade and commercial instruments" which is constant among the identified constitutional attempts for limiting the influence of private entities in the exercise of regulatory powers. The ample reference to "international trade or commercial instruments" could include treaties, contracts and any kind of agreement imbued both with international and commercial characteristics. Additionally, the prohibition deals with the application of this kind of instruments, which would cover both existent and future obligations.

Finally and concerning the eventual threat to the right to health, it is clear that the interpretation of any provision, should ensure the compliance of human rights. The 
possible application of a "provision in terms that it violates fundamental rights is not only contrary to the Constitution in general, but also to International Law."148

From the constitutional provisions that attempt to limit the ratification and application of international treaties that have as result the waiver of sovereign powers in favour of international trade and financial organizations, the most explicit is the following:

Article 422- It shall not be possible to enter into international treaties or instruments in which the Ecuadorian State waives sovereign jurisdiction to international arbitration venues in contractual or commercial disputes between the State and private individuals or corporations.

Excepted from the foregoing are international treaties and instruments providing for dispute resolution between States and citizens of Latin America by regional arbitral venues or by jurisdictional organizations designated by the signatory countries. Judges from the states that as such or as nationals of those states are parties of the dispute cannot participate.

In the case of disputes relating to the foreign debt, the Ecuadorian State shall promote arbitral solutions in terms of the origin of the debt, subject to principles of transparency, equity and international justice.

A literal interpretation of the wording of this constitutional provision could lead to the conclusion that the same could be innefective to prevent the future ratification of international obligations of this nature. The simple reason is that international investment disputes do not derive from commercial or contractual disputes as provided for by this Article.

As a general principle, a State exercises its sovereignty either when it signs a treaty according to the meaning contained in the Vienna Convention on the Law of Treaties or when it concludes any other agreement made in accordance and subject to international law. Hence, a State may exercise and define the boundaries of its sovereignty through the signature of a treaty. Therefore, under International Investment Law, it is key distinguishing treaty-based arbitration and contract-based arbitration.

Having said this, it has to be underlined that contract based arbitration is a product of the agreement between the parties (in this case, State-private entity), whereas the existence and jurisdiction of international arbitration forums instituted through international treaties is not dependent upon the will of such parties; in consequence, it does not pre-suppose either a contractual link or the occurrence of a dispute between them.

148 Oyarte (Rafael), Derecho Constitutional: Ecuatoriano y comparado, Corporación de Estudios y Publicaciones, Quito, 2014, 676 p.

Free translation. 
Consequently, the effective performance and validity of contract rights has to be elucidated under the applicable law derived from the parties' expressed agreement. In the case of treaty- based arbitration, the rights created by treaty exist on the plane of international law. As a result, the allegation of breach of treaty constitutes a claim governed exclusively by international law. ${ }^{149}$

In short, the key feature of the Bilateral Investment Treaties in the field of international investment law is the alternative to recourse through binding arbitration, even in the absence of any contractual arbitration provision. ${ }^{150}$

Since this constitutional clause circumscribes the prohibition to treaties involving commercial and contractual disputes, controversies, which do not derive from such categories, would fall outside of the restriction set forth in Article 422 of the Constitution of Ecuador, namely the disputes that arise from the exercise of the sovereign authority of the State. A State may breach a treaty without breaching a contract and vice versa since the treaty sets an independent standard in accordance with Article 3 of the International Law Commission Draft.

In conclusion, according to the wording of the constitutional provision at issue and a literal interpretation of the same, it could be assumed that the execution and ratification of treaties involving arbitration in investment cases would be not forbidden. Following this argument, this constitutional provision would be also ineffective for prohibiting the submission of a State's disputes before foreign courts.

In light of the aforementioned, it must be recalled that although the Constitution's supremacy has been recognized from the nineteenth century, the creation of effective constitutional remedies and mechanisms of control for assuring its enforcement has just been developed from the Constitution of 1998. Concerning constitutional control with relation to international treaties the Constitution of 2008 comprises two mechanisms: ex ante and ex post facto.

The guidelines and especially the prohibitions concerning the contents of treaties' which the State is allowed to enter into, may evidence a strong distrust to international financial

\footnotetext{
149 Espinosa (Sebastian), "State Sovereignty in International Investment Law: the case of Ecuador", Maastricht University, 2011.

${ }^{150}$ It has to be recalled that under BITs, investors can submit contractual disputes with the host state or state entity to the arbitration mechanism in the investment treaty, even where the contract itself requires the resolution of disputes in another forum.
}

Van Harten (Gus), "Five Justification for Investment Treaties: A critical discussion", 2 Trade L \& Dev. 19. 2010,25 . p. 
institutions, banks and transnational companies. However, the defective wording of most of the provisions analyzed is unlikely to achieve the purposes of shielding the State from the future signature and application of international obligations, allegedly detrimental of sovereignty. For instance, this Constitution would not bar future governments from signing new bilateral investment treaties, under a literal interpretation of the constitutional provision at issue, if this process is prompted by a President and Legislature, in favour of enhancing the protection of investment as originally conceived. In any case and in terms of the internal procedure of approval of treaties, the values inserted, together with the subordination of international relations to the guidelines established by the National Plan of Development and the recognition of citizen actions for scrutinizing public activity, all this permits us to foresee a complex internal process for the approval and application of treaties.

Finally, the insertion of obligations for the application of current treaties, which imposes new burdens to right holders and which could diminish their constitutional rights, like the right to property, poses challenges to reconcile these new rules both with the protection of human rights and International Law. As it has been remarked, the invocation of the Constitution cannot be an exemption for avoiding a treaty's fulfillment; in consequence the effectiveness of prohibitions as analyzed would be conditional upon a lawful termination of international obligations.

\subsection{Conclusions}

The Ecuadorian constitutional evolution reveals the influence of a colonial period, exclusionary, autocratic and formalistic. The interrupted maturity of most constitutions that have ruled the country shows the implicit agreement that the constitution is deemed as the supreme law and the main source of authority, being used as the panacea for regularizing any political crisis and sanctifying any political project. The numerous constitutional guarantees progressively inserted cannot hide specific political and economic purposes that have inspired the promulgation of several constitutions.

Due to this positivist tradition, it is understandable that there is an obsession from social groups to specifically insert their demands in the constitutional text. If a specific interest is not written into the constitution and further developed by the law, it is simply deemed as non-existent. This could explain the regulatory design of the Ecuadorian 
constitutions that contain specific prescriptions and proscriptions rather than principles and values.

From the birth of the national State, the predominance of positive legality has been the hallmark of Ecuadorian legal tradition and thus the abundant enactment of constitutions has served circumstantial interests, mainly for resetting power relations, as well as for restoring democratic order. The average duration of each constitutional regime is certainly shocking and endorses how little significance the Constitution has as a set of substantive principles and values; as opposed to the high regard given to its formal importance as a source of legitimate allocation of power.

This formal importance explains the significance attributed to the constitutional text as the most important outcome derived from exceptional political conflicts. Therefore, and with the exclusion of a few constitutional frameworks like the Constitution of 1906 that instituted the secular State, the abundant constitutional texts have brought transformations of little significance. This could be the reason that explains Civil Law's place as the axis of the juridical system until the 1990's, when the respective constitutions progressively developed mechanisms to enforce the manifold guarantees accumulated along the succeeding constitutional frameworks.

Indeed, the Civil Code has traditionally governed personal, real and inheritance rights, as well as liabilities and contracts, being also the main source for the rules of interpretation of the law. This strong civil-based orientation has particularly strengthened the right to private property, while the enforcement of other types of property rights such as collective and community was still in its infancy.

Additionally, this deeply-rooted positivist approach influenced the low direct applicability of constitutional rights and guarantees until the end of the twentieth century, many of them enshrined from early constitutional frameworks, but in practice ineffective if legal provisions failed to develop their enforcement. Since written law has bound judges, their review has been confined to ascertain legislative mandates for particular cases before them.

Until the oil boom, governmental action was subsidiary, in contrast with the leading roles played by the Catholic Church and the municipalities in a variety of areas, like the provision of public services, health, education and the settlement of disputes.

The expansion of the State's influence diminished the strong influence of Civil Law from the 1960's and changed the landscape of the political struggle, initially influenced by the definition of the relationship between Church and State, and 
subsequently imbued by the demarcation of the State's role within the economy. In this regard, the oil boom provided the State with the financial resources to expand its influence and autonomy, which was translated into the growing demands of the different social layers - both for gaining access to the extractive activities' benefits and for participation in public decision-making.

The patrimonial-based tradition concerning rights and public powers aggravated the social groups' struggles for accessing the public decision spaces where the distribution of the State's wealth was decided. Open contradiction between the constitutional frameworks of 1998 and 2008 portrays the utilitarian value given to the constitution as the stamp for sanctifying decisions that may even disregard essential sovereign powers. However, using the constitution as a mechanism for merely vesting rules with supra-legal category has been proved to be a temporary answer. As soon as the political forces change, the new constitutional framework demolishes their effectiveness with a high democratic and institutional cost.

In any case, the insertion of the country into global public law, the predominance of human rights and the growing influence of social groups has reduced the concept of the State's absolute sovereignty. In this regard, the emergence of non-State actors and the enforceability of international obligations also limit the boundaries within which the State may act, and also the extension of the powers it may exercise and-in consequencewaive.

In the Ecuadorian context, a central planning system headed by the Executive has been consolidated, at the same time that the rights of citizens, collective groups and nature have been enlarged unlike any other period; and probably unlike any other comparable constitutional framework. While the reconstruction of the State's institutions demands strengthening the formal branches in which the public power is allocated, the recognition of values that govern social coexistence becomes the source and limit for the exercise of private autonomy and sovereign powers.

In consequence, the contours of the State's sovereignty are redefined by the recognition of rights and values that transcend the public sphere, such as the preservation of nature and the sustainable use of non-renewable resources, whose observance may be demanded by citizens. This empowerment-along with the reinforcement of jurisdictional mechanisms created for the enforcement of constitutional rights-limit, for instance, the scope of the sovereignty of the State over natural resources. 
Concerning international obligations, the profuse substantive obligations imposed on the State and individuals in a variety of matters that range from food sovereignty to biodiversity constrain the scope of duties which the country may agree upon, as it did before. The constitutional control of international treaties both ex ante and ex post facto is another obstacle for applying existent - and adopting future - obligations that may be related to these aspects, notwithstanding the defective wording of the provisions that attempt to limit the jurisdictional sovereignty of the State.

It is clear that "constitutionalism cannot be equated with constitution"151 and in this regard it is clear that the Ecuador is at a very preliminary stage for the construction of such ideal. It is undeniable that the current Constitution contains many provisions of statutory nature, but this reality does not lessens its significant democratic value. The overwhelming democratic approval, along with a heterogeneous participation in its design, legitimize this framework as well as its numerous values, backed by popular sovereignty.

In this context, the State - and particularly the government-faces an important dilemma. The progressive achievement of constitutional rights - specifically those of an economic nature - demand a significant availability of resources. In a country dependent on extractive activities, not only limitations concerning the protection of nature and the promotion of peoples' rights appear as obstacles, but also the feasibility to achieve long term agreements with international investors, taking into account the limitations imposed by the scope of such commitments.

Bearing in mind the current reluctance of Ecuador to limit its sovereignty space implicitly and explicitly, the extent to which the State will frame its future international obligations and apply the existent ones remains unclear, taking into consideration the new constitutional boundaries in which it exerts its powers.

\footnotetext{
${ }^{151}$ Dorsen (Norman), Rosenfeld (Michel), Sajó (András), Baer (Susanne), Comparative Constitutionalism:
} Cases and Materials, Second Edition, West, 2010, 37 p. 


\section{CHAPTER II: THE ARTICULATION OF THE SYSTEM OF INTERNATIONAL INVESTMENT PROTECTION IN ECUADOR}

\subsection{Introduction}

The historic evolutionary overview of the political, economic and legal milestones that shaped the evolution of the constitutional tradition in Ecuador revealed the utilitarian worth given to the numerous constitutions in a rooted positivist context. The short duration of each constitutional regime endorses the insignificance of the Constitution as a set of substantive principles and values, as opposed to the high regard given to its formal importance as a source of legitimate allocation of power.

This chapter will demonstrate how the domestic articulation of the investment protection regime is a strong proof of this reality, regretfully at the expense of the consolidation of democracy, rule of law and - most importantly_-justice.

The rhetorical significance historically conferred on the constitutional framework has been more eloquent regarding the delimitation of coexistence boundaries between domestic and international law. Such a lack of articulation has also been evident at an international level, in which the country's legal standing at the time of negotiating multilateral and bilateral obligations has been contradictory. Although it is undeniable that the presence of a notion that distinguishes regulatory and private space's contoursspecially when multilateral instruments have been concluded-is important, such understanding has vanished when it has involved bilateral treaties.

A well-rooted private-based tradition has shaped the understanding that the main source of conflicts involving the State and foreign private persons derives from contractual relationships. Unfortunately - and although the unfavourable investment awards faced by the country prove the contrary - the National Constituent Assembly and the current rule makers persist in this misconception. A flipside of this misunderstanding produces a State-centric conception of sovereignty that disregards the emergence of nonState actors, as well as obligations and values that transcend the State sphere and, in consequence, reshapes the frontiers within which international obligations have to be reviewed, negotiated and applied.

Although it is undisputed that the Constitution of 2008 embraces radical transformations that must be harmonized with international law, the irregular process of 
articulation of the international investment protection system in Ecuador suggests that its review had to be undertaken, regardless of the installation of a new constitutional regime.

In this regard, the Constitutional Court's stance advocating for an essential change of circumstances as a reason for such a review, rather than normative is factual, considering that - except for the recent incorporation of jurisdictional limitations - the unlimited breadth of commitments concluded under the analyzed regime were and still are in contradiction with long lasting constitutional and legal principles.

From a historical perspective, this chapter explores the different mechanisms applied to implement the protection of investments, how they were applied and the subsequent efforts for counter-balancing the unforeseen adverse effects of this complex network of legal, economic and political constraints.

This analysis comprehensively explores the construction of the system from the international and domestic law making levels, the regulatory decisions that enabled this machinery to be set into motion, as well as its defense mechanisms through the intervention of adjudicative bodies. By the same token, it analyzes a significant bulk of public decisions oriented to mitigate and overcome the aftermath produced by this regime.

Following a chronological order, this chapter describes the assimilation of international law by the Ecuadorian constitutional tradition, with emphasis on the protection of foreign investment. Subsequently, it analyzes the country's participation in the construction of the new global order after World War II and the affirmation of international rules of protection for foreign economic interests, in the midst of failed developing countries' attempts for overcoming the hegemony of developed countries. It continues with the assessment of a "market-friendly" State eruption, the boom of Bilateral Investment Treaties (BITs) and the avalanche of investment disputes. Finally, it studies the measures adopted for redefining the co-existence between the State and investors after the promulgation of the 2008 Constitution.

\subsection{Constitutional evolution, incorporation of International Law and protection of foreign investment}

As evidenced in Chapter I, many of the constitutional frameworks in Ecuador have been enacted as a means for regularizing the legal order's ruptures in the light of a strong formalistic and positivistic institutional culture. Most if not the totality of these constitutions may fall under Sartori's definition of "nominal constitutions": 
I call "nominal" the constitutions that bear the "name" constitution. This amounts to saying that nominal constitutions are merely organizational constitutions, i.e, the collection of rules, which organize but do not restrain the exercise of political power in a given polity. Actually, nominal constitutions do not really pretend to be "real constitutions". They frankly describe a system of limitless, unchecked power. ${ }^{152}$

The Ecuadorian constitutional evolution depicts a reliance on "nominal constitutions", infused with a strong formal category that privileges the hierarchical predominance of the Constitution as the highest norm of the legal framework over the progressive development of substantive values. In this positivistic scheme, the rules set forth by the first constitutions, attempted to delineate the organic structure of the State, as well as to affirm its sovereign and autonomous status before the global community. Understandably and due its colonial past, the XIX century's constitutional texts reiterate the Republic's independence and freedom from any alien power.

\subsubsection{The Configuration of National Institutionalism and First International Instruments for the Protection of Foreign Capital}

Concerning the incorporation of international law in the Ecuadorian constitutional evolution, the Constitution of 1830 promptly acknowledged international treaties, as source of obligations to the State and its agents. ${ }^{153}$ The reference by this Constitution to the treaties of friendship and commerce as the main instrument for establishing relationships with foreign countries reveal its importance during the XIX century. ${ }^{154}$ The first constitutional framework also recognized this kind of treaties, when it conferred on the Congress the attribution for approving international treaties ${ }^{155}$.

\footnotetext{
152 Sartori (Giovanni), “Constitutionalism: A Preliminary Discussion”, 56. AMER. POL. SCI. REV. 853, 853-857, 861-862 (1962) on Dorsen (Norman), Rosenfeld (Michel), Sajó (András), Baer (Susanne), Comparative Constitutionalism: Cases and Materials, Second Edition, West, 2010, 57- 58 pp.

${ }^{153}$ Constitution of 1830 :
}

“Art. 110.- Habrá en la capital de la República una Alta Corte de Justicia, cuyas atribuciones son:

1. Conocer de todos los negocios contenciosos de los Ministros Plenipotenciarios, Enviados y Agentes diplomáticos cerca del Gobierno de la República, conforme al derecho internacional o a los tratados que con ellos se hubieren celebrado (...)".

${ }^{154}$ Constitution of 1830 :

“Art. 4.- El Gobierno del Estado del Ecuador admitirá y establecerá relaciones en otros gobiernos amigos de Colombia, celebrando con ellos tratados de amistad y comercio."

155 Constitución de 1830: 
The Constitution of 1878 took a step forward and it did not only incorporate a specific provision that recognized treaties of friendship and commerce, but also advocated the intervention of friend powerful countries for arbitrating disputes derived therefrom. ${ }^{156}$ Provisions of this nature reveal a strong dependency focus towards international relationships and the recognition of a subordinate role within the global arena. It is worth recalling that this kind of treaties has been conceived as "a forerunner of modern bilateral investment treaties" 157 and accordingly, they laid down the pillars for the construction of an international network for foreign capital protection. Apparently, Ecuador signed its first treaty of friendship, commerce and navigation with the United States on $1839^{158}$. Its provisions comprise features further developed by Bilateral Investment Treaties, such as

"Art. 36.- Son atribuciones del Congreso:

15. Prestar su consentimiento y aprobación a los tratados de comercio, paz, amistad, alianza ofensiva y defensiva, neutralidad, enajenación, adquisición o cambio de territorio, concluidos por el Jefe del Ejecutivo."

${ }^{156}$ Constitución de 1878 :

"Art. 116.- En toda negociación para celebrar tratados internacionales de amistad y comercio, se propondrá que las diferencias entre las partes contratantes deban decidirse por arbitramiento de potencia o potencias amigas, sin apelar a la guerra."

${ }^{157}$ Miles (Kate), The Origins of International Investment Law: Empire, Environment and the Safeguarding of Capital, Cambridge University Press, 2013, 24.p.

${ }^{158}$ Treaty of Peace, Friendship, Navigation and Commerce between the United States of America and the Republic of Ecuador, Quito, June 13th, 1839.

It has to be warned that from the research made on Ecuador's professional legal databases, which comprise both derogated and current legislation, it was only possible to identify the Treaty of Friendship, Trade and Commerce subscribed with Colombia in 1905. A similar treaty subscribed beforehand (United States) was found in the official website of the Library of the US Congress. Unfortunately the manuscript is incomplete and lacks the full texts from Art. III to Art. XVI.

See,

http://memory.loc.gov/cgibin/ampage?collId=rbpe\&fileName=rbpe23/rbpe232/23202200/rbpe23202200. $\mathrm{db} \& \mathrm{recNum}=1 \&$ itemLink $=$ D?rbpebib:1:./temp/ ammem_s3I2::\&linkText $=0$

Website visited on May 2015. 
full protection and security ${ }^{159}$, most favoured nation principle ${ }^{160}$, national treatment ${ }^{161}$, free movement of goods ${ }^{162}$, prohibition of confiscation ${ }^{163}$ and survival clause ${ }^{164}$. At the

${ }^{159}$ Treaty of Peace, Friendship, Navigation and Commerce between the United States of America and the Republic of Ecuador:

"Article. I. There shall be a perfect, firm, and inviolable peace and sincere friendship between the United States of America and the Republic of Ecuador, in all the extent of their possessions and territories, and between their people and citizens, respectively, without distinction of persons or places."

${ }^{160}$ Treaty of Peace, Friendship, Navigation and Commerce between the United States of America and the Republic of Ecuador:

"Article II. The United States of America and the Republic of Ecuador, desiring to live in peace and harmony with all the other nations of the earth, by means of a policy, frank and equally friendly with all, engage mutually, not to grant any particular favour to other nations, in respect of commerce and navigation, which shall not immediately become common to the other party, who shall enjoy the freely, if the concession was freely made, or on allowing the same compensation, if the concession was conditional.

Article XXXIV. It is further agreed, that the words, "most favoured nation", that occur in this treaty shall not be so construed as to prevent either of the contracting parties from concluding any treaty or convention, with any other nation or state, it may think proper, as freely and as fully as though said words were not used: Provided however, That notwithstanding any such treaty or convention, the citizens of Mexico and of the other Hispano-American States, with which treaties have been, or may be, concluded; and that the citizens of Ecuador shall be entitled to enjoy, in the United States, the same rights and privileges, with respect to navigation and commerce, that the citizens of the United States enjoy, or shall enjoy, in Ecuador."

${ }^{161}$ Treaty of Peace, Friendship, Navigation and Commerce between the United States of America and the Republic of Ecuador:

"Article III. The two high contracting parties, being likewise desirous of placing the commerce and navigation of their respective countries on the liberal basis of perfect equality and reciprocity, mutually agree, that the citizens of each may frequent all the coasts and countries of the other; and reside and trade there, in all kinds of produce, manufactures and merchandise; and they shall all the rights, privileges and exemptions, in navigation and commerce, which native citizens do or shall enjoy, submitting, themselves to the laws (...)."

162 Treaty of Peace, Friendship, Navigation and Commerce between the United States of America and the Republic of Ecuador:

"Article XVII. This liberty of navigation and commerce shall extend to all kinds of merchandise, excepting those only which are distinguished by the name of contraband; and under this name of contraband, or prohibited goods, shall be comprehended:

1 st. Cannons, mortars, bowitzers, swivels, blunderbusses, muskets, fusees, rifles, carbines, pistols, pikes, swords, sabres, lances, spears, halberds, and grenades; bombs, powder, matches, balls, and all other things belonging to the use of these arms.

2d. Bucklers, helmets, breastplates, coats of mail, infantry belts, and clothes made up in military form, and for military use.

3d. Cavalry belts, and horses, with their furniture.

4th. And, generally, all kinds of arms, and instruments of iron, steel, brass, and copper, or of any other materials manufactured, prepared, and formed expressly to make war by sea or land.

Article XVIII. All other merchandises and things, not comprehended in the articles of contraband explicitly enumerated and classified as above, shall be held and considered as free, and subjects of free and lawful commerce, so that they may be carried and transported in the freest manner by the citizens of both the contracting parties, even to places belonging to an enemy, excepting only those places which are at that time besieged or blockaded; and to avoid all doubt in this particular, 
beginning of the twentieth, century Ecuador also subscribed to a treaty of the same nature with Colombia. ${ }^{165}$

According to Miles this sort of treaty "involved the granting of reciprocal commercial privileges, but also addressed a wide range of subjects relating to the treatment of national state parties" ${ }^{166}$ :

(...) These agreements created a network of reciprocal trade protection measures and formed a network for international protection of foreign capital. Extending the principles embodied in these agreements beyond Europe, however, altered

it is declared that those places only are besieged or blockaded which are actually attacked by a belligerant force capable of preventing the entry of a neutral."

163 Treaty of Peace, Friendship, Navigation and Commerce between the United States of America and the Republic of Ecuador:

"Article XXVII. Neither the debts due from individuals of the one nation to the individuals of the other, nor shares, nor moneys which they may have in public funds, nor in public nor private Banks, shalle ever, in any event of war, or of national difference, be sequestrated or confiscated."

164 Treaty of Peace, Friendship, Navigation and Commerce between the United States of America and the Republic of Ecuador:

\section{"Article XXXV.}

The United States of America and the Republic of Ecuador, desiring to make as durable, as circumstances will permit, the relations which are to be established between the two parties, by virtue of this treaty of peace, amity, commerce and navigation, have declared solemnly, and do agree to the following points:

1st. The present treaty shall remain in full force and virtue for the term of twelve years, to be counted from the day of exchange of the ratifications, and further, until the end of one year after either of the contracting parties shall have given notice to the other, of its intention to terminate the same; each of the contracting parties reserving to itself the right of giving such notice to the other at the end of said term of twelve years: And it is hereby agreed between them, that on the expiration of one year, after such notice shall have been received by either, from the other party, this treaty, in all its parts relative to commerce and navigation, shall altogether cease and determine, and in all those parts which relate to peace and friendship, it shall be perpetually and permanently binding on both powers.

$2 \mathrm{~d}$. If any one or more of the citizens of either party shall infringe any of the articles of this treaty, such citizen shall be held personally responsible for the same, and harmony and good correspondence between the two nations shall not be interrupted thereby, each party engaging in no way to protect the offender, or sanction such violation.

3d. If, (what indeed cannot be expected,) unfortunately, any of the articles contained in the present treaty, shall be violated or infringed in any way whatever, it is expressly stipulated, that neither of the contracting parties will order or authorize any act of reprisal, nor declare war against the other on complaints of injuries or damages, until the said party considering itself offended, shall first have presented to the other, a statement of such injuries or damages, verified by competent proofs, and demanded justice, and the same shall have been either refused or unreasonably delayed.

Nothing in this treaty shall, however, be construed or operate contrary to former and existing public treaties with other sovereigns and states."

165 Tratado de Amistad Comercio y Navegación celebrado con Colombia, Decreto Legislativo 1, Registro Oficial 26, 6 de octubre de 1905.

${ }^{166}$ Miles (Kate), The Origins of International Investment Law: Empire, Environment and the Safeguarding of Capital, Cambridge University Press, 2013, 24.p. 
their character from one of reciprocity to enforced compliance. Although initially concluded on equal terms, these agreements were also often the first steppingstone to establishing a more intrusive presence within non-European nations. As the political strength of the non-European partner waned, overly favorable investor interpretations of these treaties were imposed on the host state and incursions into their sovereignty systematically increased in scale and scope, so as to further trade and investment activity (...). ${ }^{167}$

As noted, these treaties implied the extraterritorial application of laws from European states and the United States of America, as a consequence of their progressive scope's expansion, which initially covered trade and commercial protection and with time, penetrated the exercise of all kinds of a State's sovereign powers.

From the Constitution of 1897 onwards, the Ecuadorian constitutions embraced the principle that any norm in contradiction to the constitutional framework should not have legal effect. ${ }^{168}$ Likewise this Constitution firmly established the "Calvo Doctrine"169, which, although it experienced slight variations among the succeeding constitutional texts, its draft has remained practically unaltered up to now. Also remarkable is the Congress' attribution for declaring the unconstitutionality of a law or legislative decree, which was in force until 1993. In the realm of the process of adoption of international treaties, the Legislative power for approving them before their ratification can be aligned to its exclusive duty for interpreting the Constitution and the conformity of inferior norms to its provisions.

Furthermore and with the exception of specific variations, the constitutional process for the formation of international treaties has been historically limited to the Executive and Legislative branches. Whereas the former was entitled to sign and ratify treaties, the latter enjoyed the constitutional responsibility for their approval. The constitutional control of international treaties by an entity different to the Executive and Legislative branches was first incorporated in the Constitution of 1967 and further reinserted on the Constitution of 1998, sharing the similarity of allowing the circumvention of congressional approval

\footnotetext{
${ }^{167}$ Miles (Kate), The Origins of International Investment Law: Empire, Environment and the Safeguarding of Capital, Cambridge University Press, 2013, 25.p.

168 Constitution of 1897 :

“Art. 132.- La Constitución es la Suprema Ley de la República, y cualesquiera leyes secundarias, decretos, reglamentos, órdenes, disposiciones o tratados públicos que estuvieren en contradicción, o se apartaren de su texto no surtirán efecto alguno."

${ }^{169}$ Constitution of 1897 :

"Art. 38.- Todo contrato que un extranjero celebre con el Gobierno o con un individuo particular, lleva implícitamente la condición de la renuncia a toda reclamación diplomática."
} 
for a specific category of treaties. As noted in the previous chapter, the Constitution of 2008 preserved a similar procedure as this but inserted two categories of constitutional control with relation to international treaties: ex ante and ex post facto. It has also to be recalled that from the Constitution of 1835 , foreigners' rights and property have been fully and equally protected pursuant to the national legal framework. ${ }^{170}$

In general terms, the Ecuadorian constitutions of the XIX century reveal a strong dependency focus through international relations, although at the domestic level they are clearly the first attempts for keeping control over activities carried out by foreigners under the blanket of sovereignty. This contrast could derive from a dualist approach that conceives international and national frameworks as isolated systems, although at the time, instruments like the Treaty of Peace, Friendship, Navigation and Commerce signed with the United States had already included direct enforceable obligations with implications at the domestic level. In any event, the constitutional references as previously quoted reveal a firm notion of a global order composed by peripheral and dominant countries.

During the XIX century, the most radical evidence of this digested subordination is owed to the controversial President Gabriel García Moreno, who in the midst of a severe political crisis, proposed the conversion of the Ecuadorian Republic into a French protectorate (1860). Fortunately, this attempt did not succeed, but the imposition of the geopolitical influence of the United States in the hemisphere would not delay in being channeled through regional agreements. Particularly, the influence of the Monroe Doctrine $^{171}$ was significant and shaped the position of Latin-American States in their insertion within the modern global order. This doctrine summarized with the expression: "America for the Americans", shows the dominant role assumed by the United States for setting the guidelines of the region's international affairs at the outset of independent republics and the realignment of international economic relationships, after LatinAmerican independence processes:

${ }^{170}$ Constitution of 1835 :

“Art. 107.- Todos los extranjeros serán admitidos en el Ecuador; y gozarán de la misma seguridad de los ecuatorianos, siempre que respeten las leyes de la República."

171 This doctrine inspired by the President James Monroe, articulated United States' policy on the new political order developing in the Americas, mainly delineating the role of Europe in the Western Hemisphere (James Monroe's address to Congress, December 2, 1823).

See: U.S Department of State, "Office of the Historian".

https:/history.state.gov/milestones/1801-1829/monroe

Website visited in May 2015. 
While Americans generally objected to European colonies in the New World, they also desired to increase United States influence and trading ties throughout the region to their south. European mercantilism posed the greatest obstacle to economic expansion. In particular, Americans feared that Spain and France might reassert colonialism over the Latin American peoples who had just overthrown European rule. Signs that Russia was expanding its presence southward from Alaska toward the Oregon Territory were also disconcerting. ${ }^{172}$

The Monroe Doctrine became a rooted pillar of United States foreign policy and constituted an unwritten principle that shaped the formation of common international affairs during the XIX and XX centuries:

The Monroe Doctrine was announced by the United States as a rule of policy and not as an international understanding. The European powers were not asked to agree to it. Had it been incorporated in a treaty, the terms of the agreement evidently would have been to the effect that, in consideration to the abstention of the United States from interference in the politics of Europe, the powers of Europe would engage to abstain from interference in the politics of America. But it was never protocolized. The fact that on certain occasions, such as that of the signing of the Hague Conventions, the United States in becoming party to certain nonpolitical engagements, has done so with the express understanding that it was not to be regarded as having yielded its traditional policy and that the engagements were not to be interpreted as having that effect. ${ }^{173}$

This logic governed the articulation of international governance inward and outward of the hemisphere and shaped the web of regional blocks built upon a particular axis of power, from which emerged the guidelines upon which the adherent countries would have to conduct themselves. In this regard, it is clear that the notion of absolute sovereignty was eroded from the beginning of the newly independent countries legal frameworks' construction. The force of the circumstances and the transposition of over-arching legal principles would progressively undervalue the declarative strength given to the autonomous exercise of sovereign powers.

\footnotetext{
${ }^{172}$ See: U.S Department of State, "Office of the Historian". https://history.state.gov/milestones/1801-1829/monroe Website visited on May 2015.

${ }^{173}$ Basset Moore (John), "The Monroe Doctrine", Annals of the American Academy of Political and Social Science, Vol. 96, The Place of the United States in a World Organization for the Maintenance of Peace (Jul., 1921), pp. 31-33.
} 


\subsubsection{The Construction of the Pan-American Order and the Hemispherical Protection of Cross-Border Interests}

The influence of the United States in the hemisphere would be formalized during the XIX century with the construction of the Pan-American order. The Organization of American States was founded in 1890, being the oldest regional international organization in the world ${ }^{174}$. Originally created for largely commercial purposes, its objectives evolved to the promotion of peace, prosperity and human rights, as subsequently stipulated in its charter of 1948. The strong weight of the United States for the creation and functioning of the system can be clearly observed from the statements of the First International Conference of American States held in Washington in 1889:

"for the purpose of discussing and recommending for adoption to their respective Governments some plan of arbitration for the settlement of disagreements and disputes that may hereafter arise between them, and for considering questions relating to the improvement of business intercourse and means of direct communication between said countries, and to encourage such reciprocal commercial relations as will be beneficial to all and secure more extensive markets for the products of each of the said countries." 175

The inextricable link between commerce and peace would become the milestone of democracy, development and human rights and as a consequence, the yardstick for evaluating a State's compliance with the Pan-American values. Understandably, one of the diplomatic goals of the United States' delegation was to incorporate compulsory arbitration within the incipient system. However this attempt was perceived with skepticism by Latin-American countries, not only because it appeared as a drastic surrender of sovereignty in favour of the United States to which such jurisdiction was unlikely to be applicable, but also because the tribunal sought to be established in Washington. The latter particularity raised the concerns of several Latin-American countries that perceived this territorial link as a direct threat to the tribunal's impartiality by the considerable influence that United States could exert over the same. Again, the indispensability for establishing an arbitral tribunal was founded on the advocated necessity for establishing a regional forum, mainly for facing the unsettled territorial

\footnotetext{
${ }^{174}$ U.S Permanent Mission to the Organization of American States.

See: http://diplomacy.state.gov/discoverdiplomacy/explorer/places/201578.htm

Website visited visited in May 2015.

175 Organization of the American States (OAS), "Our origins", Official website.

See: http://www.oas.org/en/about/our history.asp

Website visited in May 2015.
} 
disputes between Latin-American countries. In any case, the large number of delegates from the United States' industrial and commercial groups in this proposal's bargain, revealed the commercial motivation behind the attempted incorporation of this permanent dispute settlement forum. The bitterness of the interested groups on the failure of the United States' proposal as originally conceived was not long in appearing ${ }^{176}$, as it may been observed from the following communication of The American Peace Society (1890):

At a recent meeting of The American Peace Society, the undersigned were appointed a committee to confer with the above named conference and the second time to call their attention to the need of some definite recommendation by that conference of a system of American International Arbitration, such as was contemplated in Article VII of the official invitation of the United States Government under which the conference was convened.

In the absence of information as to what steps have been or may be taken in accordance with the article, we beg leave to assure you that a deep and widespread feeling of disappointment and dissatisfaction is sure to ensue among the people of the United States of America if the conference should terminate without a serious and earnest attempt to avert future wars between the American nations by the recommendation of a general system of arbitral treaties and courts. ${ }^{177+}$

Although the first attempt at establishing a regional general system of arbitration failed, specific efforts for assuring the protection of cross-border economic interests were further undertaken in the realm of the Pan-American system. In this regard, the founding cornerstones of the further named "inter-American system" overlaid the encouragement of reciprocal commercial relations and the strengthening of arbitration as the main mechanism for the settlement of disputes. As noticed, the early legal concerns of the first Conference that dealt with agreeing guidelines for the drafting of a treaty on arbitration, with the advocated purpose of avoiding recourse to war, were underpinned by a greater

176 The Plan of Arbitration's failure is summarized as follows:

The formulation of a Plan of Arbitration, the original intent of the 1888 Congressional authorization, was expected to be a treaty that could be adopted by the delegations who found that war was "the most cruel, the most fruitless, and the most dangerous expedient for the settlement of international differences." A plan was adopted in sessions held in mid-April 1890 but a formal treaty was drawn up after the conference ended. It was signed in April 28, 1890, by 11 States: Bolivia, Brazil, Ecuador, Guatemala, Haiti, Honduras, Nicaragua, El Salvador, United States, Uruguay and Venezuela. However, it lapsed through the failure of all its signatories to exchange ratifications within the required time and it never became operative.

McPherson (Alan) Editor, Encyclopedia of U.S Military Interventions in Latin America, First International American Conference, ABC-CLIO, LLC, Washington, 2013, 208 p.

177 Tobey (Edward S.), Miner (A.A), Howard (R.B), The American Peace Society, "Communication addressed to Hon. T. Jefferson Collidge and others", members of the International Conference of American Nations, Boston, Mass., March 2, 1890. 
goal to assure commercial interests involving an international dimension. José Martí, representative of Uruguay in the first conference, when stated its opposition to this proposal, rejected the creation of a regional system, alleging that it was built under the logic of a "pro-business model". ${ }^{178}$ In any case, the assumption that strengthening commercial ties contributes to the maintenance of peace remained unaltered in the further construction of the inter-American system' objectives, summarized as follows: "commercial concerns directed toward achieving greater integration; legal concerns with strengthening state and private sector ties in a peaceful environment of regional cooperation and security; and the establishment of specialized institutions in different spheres". ${ }^{179}$

Until April 1, 1938, 67 conventions were signed within the Pan-American system. The most remarkable ones for the purposes of this chapter were those related to the configuration of Codes of International Law ${ }^{180}$, the Practice of Learned Professions ${ }^{181}$, Protection of Literacy and Artistic Copyrights ${ }^{182}$, Patents Industrial Drawings and Models and Trade Marks ${ }^{183}$, Rights of Aliens ${ }^{184}$, Obligatory Arbitration ${ }^{185}$, Pecuniary Claims ${ }^{186}$,

\footnotetext{
178 Karras (Bill J.), “José Martí and the Pan- American Conference”, 1889-1891, Revista de Historia Americana, vol. 77 (1974), 77-100 pp.

${ }^{179}$ Organization of the American States (OAS), "Our origins", Official website.

See: http://www.oas.org/en/about/our history.asp

Page visited in May 2015.

180 Second Conference, (Mexico, 1901-1902).

During the Third Conference (Rio de Janeiro, 1905) a further agreement of International Law (Codification) was signed.

${ }^{181}$ Second Conference, (Mexico, 1901-1902).

${ }^{182}$ Second Conference, (Mexico, 1901-1902).

${ }^{183}$ Second Conference, (Mexico, 1901-1902).

During the Third Conference (Rio de Janeiro, 1905) a further agreement of Patents, Trade Marks, Literary and Artistic Property was subscribed. It is also noteworthy that specific agreements were further concluded on Patents, Trade Marks and Literary and Artistic Copyrights (Fourth Conference, Buenos Aires, 1910). Within the field of Intellectual Property, an additional agreement on Trade Marks and Commercial Names was celebrated on the Fifth Conference (Santiago, 1923).

${ }^{184}$ Second Conference, (Mexico, 1901-1902).

185 Second Conference, (Mexico, 1901-1902).

${ }^{186}$ Second Conference, (Mexico, 1901-1902).
} 
Commercial Aviation ${ }^{187}$, Private International Law ${ }^{188}$, Prevention of Controversies ${ }^{189}$, Good Offices and Mediation ${ }^{190}$, Inter-American Conciliation ${ }^{191}$, Inter-AmericanArbitration ${ }^{192}$, Progressive Arbitration-Protocol ${ }^{193}$, Most Favoured Nation Clause in Commercial Treaties ${ }^{194}$, Repression of Smuggling ${ }^{195}$, Declaration relative to Foreign Companies ${ }^{196}$, and Pan American Commercial Committee ${ }^{197}$.

After World War I, Latin America's struggle for finding its own space beyond the shadow of United States in international relations began to gain force:

As the result of the great war-time demand for their cereals, meats, sugar, nitrates and manganese, Latin Americans were led to change their attitude of mind towards the rest of the world. They discovered that their countries occupied an important place in the world economy, and this greatly increased their pride in their own continent and also their self-confidence. Then immediately after the war they were invited to join the League of Nations on a footing of equality with all other nations of the world, including the Great Powers of Europe. This further enhanced their self-esteem, courage and prestige. (...) Today they have a growing determination, and it is particularly strong on the part of the stronger and more progressive rates, to lead their own lives without acknowledging the tutelage of any other people of state. $^{198}$

The sentiment of Pan-Americanism declined due to different events like the Mexican revolution on 1914. Although this continental bond somewhat revived on the outbreak of World War I by the support of numerous Latin-American countries for the leadership of

\footnotetext{
187 Sixth Conference, (Habana, 1928).

188 Sixth Conference, (Habana, 1928).

${ }^{189}$ Conference for the Maintenance of Peace, (Buenos Aires, 1936).

${ }^{190}$ Conference for the Maintenance of Peace, (Buenos Aires, 1936).

${ }^{191}$ Washington, 1929.

192 Washington, 1929.

193 Washington, 1929.

${ }^{194}$ Washington, 1934.

${ }^{195}$ Washington, 1935.

196 Washington, 1936.

${ }^{197}$ Washington, 1936.

198 (Duggan Stephen P.), "Latin America, The League, and the United States", Foreign Affairs, Vol. 12, No. 2 (Jan., 1934), pp. 281-293.
} 
the United States ${ }^{199}$, the emergence of a new global order was seen by the young American republics as an opportunity to untangle their umbilical ties to this country and also for positioning their own interests at the international level. Moreover and as Duggan asserts: "the rejection of the Covenant of the League of Nations by the United States Senate was regarded by Latin America generally as a moral betrayal". ${ }^{200}$ In fact, it was unlikely that the United States enjoying at the moment a strong bargaining capacity for influencing the design of the rules of global governance would be willing to yield the powers it already enjoyed in the hemisphere, to an emerging international organization. The reassertion of the Monroe Doctrine within the League of Nations' context diminished all kinds of interest of Latin-American countries to resort to the system, favouring in practice, the dispute settlement mechanisms provided by the Organization of American States. The permanent Latin-American struggle for incorporating within the emerging systems of global governance, institutional instruments devoted exclusively for developing the particular affairs of the region was noticeable:

Partly to meet the insistent demand of the Latin American states for greater representation in the personnel of the Secretariat- a demand which has to been very successful- the League has established a separate Latin American bureau within the Secretariat called "Liaison with Latin America". ${ }^{201}$

At the end, the League of Nations did not erect a solid multi-lateral system and hence, it was not perceived as an effective means for the settlement of international disputes by Latin-American countries, which did not exhaust their efforts for extending their autonomous standing in the formative era of the current multi-lateral order. Undoubtedly, the parallel proliferation of agreements for the protection of private interests at the PanAmerican level portray the inexorable influence of the United States into the development and transposition of transnational legal principles to the Latin-American States' juridical framework. The advent of the United Nations after World War II would only amplify the resonance of the link between peace, trade and development.

\footnotetext{
${ }^{199}$ After the United States declared war on Germany on April 6, 1917, thirteen of Latin American republics, also either declared war on Germany or broke off diplomatic relations with her.

Duggan (Stephen P.), "Latin America, The League, and the United States", Foreign Affairs, Vol. 12, No. 2 (Jan., 1934), pp. 281-293

${ }^{200}$ Duggan (Stephen P.), "Latin America, The League, and the United States", Foreign Affairs, Vol. 12, No. 2 (Jan., 1934), pp. 281-293.

${ }^{201}$ Duggan (Stephen P.), "Latin America, The League, and the United States", Foreign Affairs, Vol. 12, No. 2 (Jan., 1934), pp. 281-293.
} 
When Calvin Coolidge, President of the United States, addressed the Pan-American Conference of Arbitration and Conciliation held in Washington on December $10^{\text {th }}, 1928$, he praised the benefits of the mechanisms of dispute settlement from a historical perspective:

(...) History clearly asserts that at this early period the Republics of America made both conciliation and arbitration integral parts of their national policy. What contributes even more remarkably to their force is the fact that this was done at a time when these two principles were practically unknown in other sections of the world.

Some of the countries here represented have added further strength to the principle of arbitration by making it a fundamental tenet of their political constitutions. Among these are Venezuela, Ecuador, the Dominican Republic, Brazil, and Uruguay, who have set an example by raising the arbitration of international disputes to the dignity of a mandatory constitutional principle.

It may be said, therefore, that the foundations for your work have been laid by the unbroken practice and policy of the American Republics. In the domain of investigation, mediation, conciliation, and arbitration, a long series of bilateral and multilateral treaties represent the milestones, which mark the way to future progress. The importance and significance of your work is enhanced by the recent movement for the renunciation of war as a principle of national policy, which by necessary implication involves recourse to the orderly processes leading up to arbitration.

It is by the adherence to such methods that nations as well as men develop a peaceful character. In a civilized community functioning under an established government the individual has no necessity for taking the law into his own hands. Tribunals have been established for the purpose of doing justice between man and man, so that when some one feels he has suffered a wrong he has a process by which those who have wronged him can be summoned to the bar of justice and ordered to make reparation. When this principle has been well established, when it has had the benefit of experience, it becomes so much a habit of thought that the people feel no inclination to resort to some method of direct and personal action. To do so would be to stamp themselves as dangerous persons, and they would feel active disapprobation, probably inflicted with the penalties which organized society bestows upon violators of the public will.

(...) These present prospects and these inspiring records of the past place upon us of this generation a heavy responsibility. We must not only maintain the traditional policy established by the founders of our republics, but we must also carry the procedure of conciliation and arbitration to a new and higher sphere. The world has the right to expect that the mission undertaken by the early statesmen of this continent shall be carried to completion. Our history, our national ideals, and the standards of our international intercourse make this a solemn obligation. ${ }^{202}$

202 Coolidge (Calvin), President of the United States, 1923-1929, “Address Before the Pan-American Conference on Arbitration and Conciliation”, Washington, D.C., December 10th, 1928.

See, http://www.presidency.ucsb.edu/ws/?pid=471

Website visited on May 2015. 
At the time that President Coolidge pronounced this speech, the Constitution of 1906 was in force in Ecuador and its text did not contain any explicit reference to the State's willingness for preferentially resorting to international arbitration as the Constitutions until 1878 did. In any event and without prejudice that the arbitration system acclaimed by Coolidge pertained to inter-governmental disputes, the mention of multilateral and bilateral treaties as key mechanisms for channeling dispute settlement' mechanisms would evidence a greater disposition for expanding its rules to the protection of private interests. As noted, the indissoluble interrelation between peace, rule of law, good will and commerce would become the mantra for the upcoming efforts for the development of transnational rules of conduct.

Before the articulation of the global order after World War II, Ecuador approved fourteen constitutions, yet the Constitution of 1938 never came into force. It is also noteworthy that the Constitution of 1945 was suddenly replaced by the Constitution of 1946. As noticed in Chapter I, the ten constitutions enacted during the XIX century portray the backlash of a colonial past through the construction of the incipient State by dominant groups, with an exclusionary logic. From the Constitution of 1895 can be observed a more coherent effort for institutionalizing the Public Sector and creating a boundary between the Church and the State. In this regard, the most notable progress for establishing a secular State arose from the Constitution of 1906, deemed as the Constitution of the liberalism. Additionally, the Constitution of 1929 set the landmark for consolidating the State's action in the economy, as well as embodying a non-exhaustive list of constitutional guarantees. $^{203}$ This Constitution complemented the Calvo Doctrine's provision, apart from prohibiting the resort to diplomatic protection, waiving jurisdiction in contracts signed in Ecuador between foreigners and the State, public entities and individuals (Art. 153) ${ }^{204}$. Moreover, the Constitution of 1945, in line with the global trend

\footnotetext{
${ }^{203}$ Constitution of 1929 :

“Art. 158.- La enumeración de garantías y derechos determinados por la Constitución no limita ni excluye otros que son inherentes a la personalidad humana o que se derivan del principio de la soberanía y de la forma republicana de gobierno."

${ }^{204}$ Constitution of 1929 :

“Art. 153.- Todo contrato que un extranjero o una compañía extranjera celebraren con el Gobierno, con corporaciones nacionales o con un individuo particular, llevará implícita la condición de la renuncia a toda reclamación diplomática.

En los contratos que celebraren los extranjeros con el Gobierno o con las corporaciones de Derecho Público en el Ecuador, no se podrá estipular, en ningún caso, la sujeción a una jurisdicción extraña."
} 
after World War II, comprised within the provisions that included the principles of State, sovereignty and form of government, the submission of the State both to International Law and to the judicial settlement of international disputes. It also proclaimed the cooperation and good neighbourhood principles as rules of conduct among States ${ }^{205}$. As described below, Ecuador promptly ratified the Charter of the United Nations and the Statute of the International Court of Justice on $1945^{206}$. Finally, the incorporation by the Constitutions of 1945 and 1946 of the provision that enables the State to agree with IberoAmerican States associations entrusted to defend common territorial, economic and cultural interests within the world community of nations can be highlighted. ${ }^{207}$

\subsubsection{Multilateral Attempts for Unifying Private International Law and the Growing influence of Arbitration as an International Mechanism of Dispute Settlement}

The emergence of overlapping international obligations which were promoted both at the Inter-American level and at the incipient global system, was characteristic during the first half of twentieth century. International arbitration, originally conceived as an intergovernmental mechanism for the settlement of disputes, progressively penetrated the boundaries of Private International Law. Although the application of treaties of Private International Law exerts, as a principle, effects over particular interests on the principle of private autonomy, at the jurisdictional level, they embody the States' acceptance of a law's extra-territorial application.

The importance of adopting regional rules concerning arbitration as already highlighted, was indefatigably promoted by the Organization of American States and its national organized groups with commercial interests throughout the region. Although a permanent arbitral forum for the compulsory submission of international disputes involving Pan-

205 Constitution of 1945 :

"Art. 6.- La República del Ecuador acata las normas del Derecho Internacional y proclama el principio de cooperación y buena vecindad entre los Estados y la solución, por métodos jurídicos, de las controversias internacionales.

${ }^{206}$ Ecuador signed the United Nations Charter and the Statute of the International Court of Justice on June $26^{\text {th }}, 1945$ and ratified the same on December $18^{\text {th }}, 1945$.

${ }^{207}$ Constitutions of 1945 and 1946:

"Art. 7.- El Ecuador, dentro de la comunidad mundial de naciones, y para la defensa de sus comunes intereses territoriales, económicos y culturales, colaborará especialmente con los Estados iberoamericanos, a los que está unido por vínculos de solidaridad e independencia, nacidos de la identidad de orígen y cultura. Podrá, en consecuencia, formar con dichos Estados, o con uno o más de ellos, asociaciones que tengan por objeto la defensa de tales intereses." 
American States could not be agreed due to the impossibility of reaching consent concerning the controversial scope of the arbitral jurisdiction, alternative measures were undertaken for the purpose of protecting cross-border commercial interests derived from the enforcement of judicial decisions and arbitral awards. The intention for drafting a single code of international law at the Pan-American level was manifested during the Congress of Lima in 1877 and further crystallized with the adoption of a single code of private international law, known as "Bustamante Code", at the Sixth International Conference of American States, held in Havana in 1928:

"Private international law has long been the instrument that has regulated the relations among our societies, facilitating the movement of persons, exchanges of goods and services, fostering integration, and combating illegal cross- border activities. The process of codification of private international law in the interAmerican context has been one of the ongoing legal activities of the American state since the closing decades of the 1880s. This work has taken different institutional forms and is currently being carried out as a legal process through the Specialized Conferences on Private International Law". ${ }^{208}$

The first attempt at the codification of held at the Congress of Lima endeavoured to unify both substantive and procedural law. However, the intention of covering substantive law in such codification did not reach enough supporters, given the assumption that doing so, would entail a significant waiver of sovereign space:

The Congress of Lima soon gave up the idea of drawing up a uniform code of substantive law, for it came to the conclusion that efforts to even out national rules on the conflict of laws and co-ordinate policies on inter-American litigation were more necessary and more likely to be attained than the unification of civil and commercial law. ${ }^{209}$

Ever since then, the subsequent Pan-American congresses made clear that the purpose of such meetings was the harmonization of rules of conflicts of law, rather than the unification of domestic substantive law. At the end of the nineteenth century, the Montevideo Congress ${ }^{210}$ produced significant outcomes and eight treaties on private and procedural international law were agreed upon. In any event, the most comprehensive

\footnotetext{
${ }^{208}$ Department of International Law, Organization of American States, "Development of International Law: The History of the Cidip Process" (Specialized Conferences on Private International Law").

See, http://www.oas.org/dil/PrivateIntLaw-HistDevPriLaw-Eng.htm Website visited on May 2015.

${ }^{209}$ Garro (Alejandro M.), "Unification and Harmonization of Private Law in Latin America", The American Journal of Comparative Law, Vol. 40, No.3 (Summer, 1992), 589 p.

${ }^{210}$ August 25, 1888.
} 
effort for codifying principles of law, jurisdiction and judgment recognition materialized through the Bustamante Code (1928) ${ }^{211}$. Garro contends that the apparent success of Bustamante Code $^{212}$ as a unification tool is deceptive, due to its excessive deferral to the local law of the member states. ${ }^{213}$ This scholar further asserts, that this concession encompassing the intention of easing wide hemispheric acceptance was in fact a serious threat for achieving the actual purpose of the convention, namely uniformity, and this could be the reason why Argentina, Colombia, Mexico, Paraguay, the United States 214 and Paraguay, refused to sign. ${ }^{215}$ Ecuador was one of the fifteen countries ${ }^{216}$ that ratified the Bustamante Code and it did not make any reservation. In accord with these developments, this Codification recognizes national treatment concerning the exercise of civil rights, without prejudice to the reservations Member States are entitled to make on the basis of public order. ${ }^{217}$ Additionally, this Code enables the legislation of each Member State to determine the rules about courts' jurisdiction, their organization,

\footnotetext{
211 Garro points out that Bustamante Code is a comprehensive document of 437 articles divided into a preliminary part and four books (international civil law, international commercial law, and international procedural law).
}

Garro (Alejandro M.), Unification and Harmonization of Private Law in Latin America, The American Journal of Comparative Law, Vol. 40, No.3 (Summer, 1992), 590-591 pp.

212 Garro indicates that of the fifteen countries that ratified the Bustamante Code, nine countries entered reservations of some kind and five out of those nine countries made crippling reservations exempting the application of the Code in all matters in which it conflicted with local law.

${ }^{213}$ Garro (Alejandro M.), Unification and Harmonization of Private Law in Latin America, The American Journal of Comparative Law, Vol. 40, No.3 (Summer, 1992), 591 p.

${ }^{214}$ It is worth to clarify that the real reason behind the United States' reluctance to sign the Bustamante Code was "that it was not within the jurisdiction of the federal government to enter into agreements on matters of private international law, such matters being within the exclusive jurisdiction of the state".

Garro (Alejandro M.), "Unification and Harmonization of Private Law in Latin America”, The American Journal of Comparative Law, Vol. 40, No.3 (Summer, 1992), 592 p.

${ }^{215}$ Garro (Alejandro M.), "Unification and Harmonization of Private Law in Latin America", The American Journal of Comparative Law, Vol. 40, No.3 (Summer, 1992), 591 p.

${ }^{216}$ Bolivia, Brazil. Chile Costa Rica, Cuba, Dominican Republic, Ecuador, El Salvador, Guatemala, Haiti, Honduras, Nicaragua, Panama, Peru, Venezuela.

${ }^{217}$ Código de Derecho Internacional Privado "Sánchez de Bustamante":

"Art. 1.- Los extranjeros que pertenezcan a cualesquiera de los Estados contratantes gozan, en el territorio de los demás, de los mismos derechos civiles que se concedan a los nacionales.

Cada Estado contratante puede, por razones de orden público, rehusar o subordinar a condiciones especiales el ejercicio de ciertos derechos civiles a los nacionales de los demás, y cualquiera de esos Estados puede, en tales casos, rehusar o subordinar el mismo ejercicio a los nacionales del primero." 
proceedings and execution of judgments, as well as in regard to mechanisms of appeal. ${ }^{218}$ It also prohibits the States, at international relations' level, from determining the rules of competence "ratione materiae" and "rationae personae" on the basis of nationality at the prejudice of the persons at issue. ${ }^{219}$ The Code also sets out the general rules for determining the competence concerning trade and civil disputes, especially with regard to the voluntary submission of controversies to foreign jurisdiction. ${ }^{220}$ With relation to the extraterritorial execution of civil and contentious administrative judgments, the Codification enlists the relevant requirements, establishing as the main substantive limitation to this process, the inconformity with public or the legal order of the State where such execution is sought. ${ }^{221}$ With regard to arbitration disputes, the same requirements to the execution of judgments apply, provided that the matter at issue is

${ }^{218}$ Código de Derecho Internacional Privado "Sánchez de Bustamante":

"Art. 314.- La ley de cada Estado contratante determina la competencia de los tribunales, así como su organización, las formas de enjuiciamiento y de ejecución de las sentencias y los recursos contra sus decisiones."

${ }^{219}$ Código de Derecho Internacional Privado "Sánchez de Bustamante":

"Art. 317.- La competencia ratione materiae y ratione personae, en el orden de las relaciones internacionales, no debe basarse por los Estados contratantes en la condición de nacionales o extranjeras de las personas interesadas, en perjuicio de éstas."

${ }^{220}$ Código de Derecho Internacional Privado "Sánchez de Bustamante":

"Art. 318.- Será en primer término juez competente para conocer de los pleitos a que de origen el ejercicio de las acciones civiles y mercantiles de toda clase, aquel a quien los litigantes se sometan expresa o tácitamente, siempre que uno de ellos por lo menos sea nacional del Estado contratante a que el juez pertenezca o tenga en el su domicilio y salvo el derecho local contrario. La sumisión no será posible para las acciones reales o mixtas sobre bienes inmuebles, si la prohíbe la ley de su situación.

Art. 321.- Se entenderá por sumisión expresa la hecha por los interesados renunciando clara y terminantemente a su fuero propio y designando con toda precisión el juez a quien se sometan.”

${ }^{221}$ Código de Derecho Internacional Privado "Sánchez de Bustamante":

"Art. 423.- Toda sentencia civil o contencioso - administrativa dictada en uno de los Estados contratantes, tendrá fuerza y podrá ejecutarse en los demás si reúne las siguientes condiciones: 1.- Que tenga competencia para conocer del asunto y juzgarlo, de acuerdo con las reglas de este Código, el juez o tribunal que la haya dictado;

2.- Que las partes hayan sido citadas personalmente o por su representante legal, para el juicio; 3.- Que el fallo no contravenga al orden público o al derecho público del país en que quiere ejecutarse;

4.- Que sea ejecutorio en el Estado en que se dicte;

5.- Que se traduzca autorizadamente por un funcionario o intérprete oficial del Estado en que ha de ejecutarse, si allí fuere distinto el idioma empleado;

6.- Que del documento en que conste reúna los requisitos necesarios para ser considerado como auténtico en el Estado de que proceda, y los que requiera, para que haga fe, la legislación del Estado en que se aspira a cumplir la sentencia." 
susceptible to transaction in accordance with the country where the same is requested ${ }^{222}$, namely commercial ${ }^{223}$ and civil ${ }^{224}$ controversies.

The leading role conferred to arbitration as the most suitable mechanism for the settlement of disputes involving commercial interests was reflected at the institutional level, with the creation of the Inter-American Commercial Arbitration Commission on September 1934. 225 This Commission's purpose consisted of the creation of an interAmerican system of commercial arbitration, since its relative objectives are:

(...) First, the establishment of arbitration facilities in each American country, for which purpose the Commission has appointed national committees in a number of Latin-American countries, responsible for organizing panels of arbitrators and for administering the standard rules of the Commission; secondly the modification of arbitration laws in order to facilitate the conduct of arbitration agreements and awards; thirdly, the familiarization of businessmen in the American countries with arbitration procedure and its advantages to exporters and importers in interAmerican trade; and fourthly, the arbitration or adjustment of differences of controversies, arising in the course of inter-American trade. ${ }^{226}$

The goals as described show a strong belief about the benefits of arbitration as a catalyst of inter-American trade. This notion reached its peak during the 1990s, as it may be observed from the national arbitration legislation developed during this period, which also expanded to disputes involving state's entities, formerly confined to the public law realm, fueled by a systematic discredit of the judicial system. In the Ecuadorian case,

${ }^{222}$ Código de Derecho Internacional Privado "Sánchez de Bustamante":

"Art. 432.- El procedimiento y los efectos regulados en los artículos anteriores, se aplicarán en los Estados contratantes a las sentencias dictadas en cualquiera de ellos por árbitros o amigables componedores, siempre que el asunto que las motiva pueda ser objeto de compromiso, conforme a la legislación del país en que la ejecución se solicite.

Art. 433.- Se aplicará también ese mismo procedimiento a las sentencias civiles dictadas en cualquiera de los Estados contratantes por un tribunal internacional, que se refieran a personas o intereses privados."

${ }^{223}$ Código de Derecho Internacional Privado "Sánchez de Bustamante":

"Art. 434.- Las disposiciones dictadas en actos de jurisdicción voluntaria en materia de comercio, por jueces o tribunales de un Estado contratante o por sus agentes consulares, se ejecutarán en los demás mediante los trámites y en la forma señalados en el capítulo anterior."

${ }^{224}$ Código de Derecho Internacional Privado "Sánchez de Bustamante":

"Art. 435.- Las resoluciones en los actos de jurisdicción voluntaria en materia civil procedentes de un Estado contratante, se aceptarán por los demás si reúnen las condiciones exigidas por este Código para la eficacia de los documentos otorgados en país extranjero y procedentes de juez o tribunal competente, y tendrán en consecuencia, eficacia extraterritorial."

225 The Commission was established as a non-governmental organization in September 1934, at the request of the Governing Board of the Pan-American Union, pursuant to resolution XLI of the Seventh International Conference of American States. It has its headquarters in New York.

${ }^{226}$ Report of the Secretary-General, Document A/6396, September $23^{\text {rd }}, 1966,15$. 
representatives of the chambers of industries and commerce composed the National Sections of this Commission, which founded centers of conciliation and arbitration attached to these organizations, and subsequently exerted significant influence on the legal recognition of such centres' jurisdiction over disputes containing public law issues.

Visibly, the little robustness that constitutionalism has been able to achieve along Ecuadorian republican history has also shaped the articulation of the State within international legal relationships. Whereas the Constitution has been conceived as a predominantly normative instrument for resetting and organizing domestic relationships, it has remained a dead letter with respect to the delimitation of boundaries involving international obligations. The fervent constitutional declarations of sovereignty and selfdetermination contrast with the early recognition of a global order composed of dominant and peripheral countries. By the same token, the domestic legal order's supremacy was deemed ineffective with the premature acknowledgement of treaties of friendship and commerce, which bursting on the XIX century already included the most powerful substantive features of the Bilateral Investment Treaties. The incoherence concerning the terms of co-existence between the international and the municipal legal orders also covered the construction of the multi-lateral and bilateral relations. The insertion of the former colonial Latin-American countries into the emerging global order was instilled by American tutelage. Several international legal obligations designed within the PanAmerican scope ran in parallel with similar proposals developed by the incipient multilateral order. From the first steps shaping regional and multi-lateral forums, the blending of concepts like commerce, peace, rule of law and delocalized dispute settlement as prerequisites for attracting prosperity to nations became clear. To be specific, arbitration initially promoted as a proper forum to settle inter-governmental disputes expanded its boundaries to private and cross-border operations. The influence of non-governmental organizations by positioning arbitration, as a neutral and specialized forum of dispute settlement, was crucial for the strengthening of transnational rules of conduct. In the conclusion of international and regional rules for the recognition and enforcement of international judgments and arbitral awards, the State's attempt for setting aside the disputes deriving from its sovereign capacity's exercise, became clear. Although oddly, the private and public distinction is indisputable on the regulatory design of these multilateral instruments. The strong notion of arbitration as a contractual link, derived from the exercise of private autonomy, might explain the further misconception of BITs' 
scope. The burdensome and time-consuming processes of negotiation of these multilateral obligations contrast with the expedited assumption of bilateral commitment.

\subsection{The Construction of the Global Order After World War II and the Transnational Protection of international Capital}

\subsubsection{Articulation of the UN System and Institutional Design for the Protection of Transnational Capital}

The development of the inter-American system was not shielded from the global geopolitical context, particularly concerning the regional support of the United States' position in the construction of a new international order. The attempted alignment of the hemisphere's international interests with the United States' agenda was clear both in the course of, and in the aftermath of, the Second World War, when a new global institutional order was established through the adoption of the United Nations Charter, on April $25^{\text {th }}$, 1945. In the construction of the United Nations system there was a common understanding that "peace needs to be secured by economic and social welfare and by the realization of human rights". 227 With the attempt to maximize the benefits of the building of a global institutional framework, developing countries and particularly, several Latin-American representatives strived for full recognition of the right to selfdetermination and the active engagement of developed countries for promoting the aforementioned objectives. Santacruz describes the effort to articulate the provisions of the UN Charter in the role and responsibilities both of UN organs and Member States with the aim of giving them effect:

With regard to economic and social cooperation, the Charter also included among its objectives "the creation of conditions of stability and well-being which are necessary for peaceful and friendly relations among nations" and the promotion of "higher standards of living, full employment, and conditions of economic and social progress development".

The exceptional importance, which the Charter attaches to these responsibilities, is further accentuated through the institutional change, which it introduced. It gave the Economic and Social Council the rank of a main organ of the United Nationswhereas Dumbarton Oaks proposals only gave it the status of a subsidiary body of the General Assembly- and entrusted it with "Responsibility for the discharge

227 Simma (Bruno), Erasmus Khan (Daniel), Nolte (Georg), Paulus (Andreas) Editors, The Charter of the United Nations, Oxford Commentaries on International Law, Oxford University Press, Third edition, United Kingdom, 2012, 1537 p. 
of functions of the Organization" in the areas in question, under the authority of the General Assembly. ${ }^{228}$

Although the Economic and Social Council had been conceived as the main institutional actor for operationalizing economic and social objectives pursuant to articles 55 and 62 of the UN Charter, it has been underlined that "in the long run it has been the General Assembly which has taken the more substantive and important decisions" ${ }^{229}$, specifically with the integration of the newly independent States in the 1950s and 1970s. In addition, the progressive boom of institutional bodies within the economic and social sector of the United Nations has expanded the boundaries of decision- making, as well as areas and concepts not initially foreseen in the constitutive legal instrument.

From the founding values of the United Nations system and the articulation of the postwar world order, one may observe the importance given to the integration, trade and the fostering of economic and social conditions, as a means for the attainment of peace and development. In the context of the creation of the United Nations system, Santa Cruz emphasises the Latin American nations' position to consolidate their autonomy and autodetermination, refusing the dependence of their interests to those of other States, especially developed States:

The Latin American countries, for their part, desired a world order in which there would be strong co-operation in the political and economic fields, within a context of the strictest respect for the principles of equality, non-intervention, freedom of decisions, solidarity and fraternity and other principles, which they considered to have been incorporated in international law, which they had helped to improve and sought to strengthen.

(...) The efforts to secure acceptance of the principle that the veto should not be operative in decisions on the peaceful settlement of disputes, in amendments to the Charter and in the struggle for the effective application of the concept of the self-determination of people, by creating mechanisms, which really did ensure the independence of former colonies, were defeated. (...) Nor were the Latin American countries in their proposals for an explicit definition of the term "aggression" and acceptance of the obligatory jurisdiction of the International Court Jurisdiction. ${ }^{230}$

\footnotetext{
${ }^{228}$ Simma (Bruno), Erasmus Khan (Daniel), Nolte (Georg), Paulus (Andreas) Editors, The Charter of the United Nations, Oxford Commentaries on International Law, Oxford University Press, Third edition, United Kingdom, 2012, 1544. P.

${ }^{229}$ Simma (Bruno), Erasmus Khan (Daniel), Nolte (Georg), Paulus (Andreas) Editors, The Charter of the United Nations, Oxford Commentaries on International Law, Oxford University Press, Third edition, United Kingdom, 2012, 1544 p.

${ }^{230}$ Santa Cruz (Hernán) “The creation of the United Nations and ECLAC", CEPAL Review 57, December, $1995,21 \mathrm{p}$.
} 
Santa Cruz highlights the strong influence of Latin American countries to strengthen the primary United Nations' roles concerning the protection of human rights and the promotion of social and economic rights ${ }^{231}$, apparently, secondary to the main geopolitical concerns of the United States, the Soviet Union and the United Kingdom focused on designing a system capable of keeping peace. ${ }^{232}$ As result, the extension of the concept of security superseded the mere prevention of conflicts and embraced the promotion of favourable conditions for the promotion and protection of peace.

The creation of the Economic and Social Council raised the attention of developing countries, which intended to take advantage of the system's opportunity for discussion to achieve an institutional solution specifically created for addressing the particulars needs of the region related to economic development. Latin-American countries advocated the creation of the Economic Commission for Latin American and Caribbean countries ("ECLAC"), succeeding in getting its proposal passed at the UN General Assembly. The working paper that preceded the creation of this Commission, summarizes the main intentions behind this proposal:

"It is not worth trying any remedy for the economic imbalances (of Latin America) unless it is based on a broad and co-ordinated policy of economic and social development designed to raise the standard of living of the population, to diversify the economies, to promote foreign trade, to modernize the technology used in agriculture, industry, transport and trade, to make the fullest use of the region's natural resources and promote intra and inter-regional trade, and to stimulate the formation, availability and proper use of capital".233

With relation to the negotiations that surrounded the creation of the ECLAC, Santa Cruz recalls the initial opposition of the United States for its establishment, with the argument of the potential overlapping functions among the existing organizations, specifically the Organization of American States, as asserted by its representative, Williard Thorp:

The United States will abstain, because voting for the establishment of this Commission could be taken to mean that it is not concerned over the possible duplication of functions with bodies of the Inter-American system, while voting

\footnotetext{
231 Santa Cruz recalls that international economic and social co-operation constitutes one of the central elements of the World Organizations' system in accordance to the preamble, purposes and principles (Art.1) and the whole chapter IX of the UN Charter.

See, Santa Cruz (Hernán) "The creation of the United Nations and ECLAC", CEPAL Review 57, December, 1995, 21 p.

${ }^{232}$ Santa Cruz (Hernán) "The creation of the United Nations and ECLAC”, CEPAL Review 57, December, $1995,32 \mathrm{p}$.

${ }^{233}$ Santa Cruz (Hernán) "The creation of the United Nations and ECLAC", CEPAL Review 57, December, $1995,30 \mathrm{p}$.
} 
against the motion could appear to indicate that it overlooks the fundamental problems that call for a solution. ${ }^{234}$

Although the creation of the ECLAC was finally approved by resolution of the Economic and Social Council on February $25^{\text {th }}$, 1948, this assertion shows the fragmentation of the international legal framework in the Latin-American region, progressively aggravated by the sub-regional attempts of integration and the historical influence exerted by the United States for keeping control over the speed and contents of the integration processes in harmony with its geopolitical interests.

Being one of the five regional commissions of the United Nations, the ECLAC 's main purpose consists of:

"contributing to the economic development of Latin America, co-ordinating actions directed towards this end, and reinforcing economic ties among countries and with other nations of the world. The promotion of the region's social development was later included among its primary objectives."

The first actions of this commission which were targeted towards the substitution of importants, inspired by the ideas of its first secretary, Raul Prebisch:

Raul Prebisch -Executive Secretary of the Economic Commission for Latin America and the Caribbean (ECLAC) at the time of its creation- proposed stimulating intergovernmental co-operation and industrialization, linking them to protectionism. The ultimate goal was to abolish the unequal trade and the deterioration of exchange terms, characteristic of the global economic structures. According to his analysis (Prebisch, 1948), industrialization through import substitution should be implemented at regional level and be subject to a plan directed towards complementarity. Within ECLAC a network of experts and intellectuals emerged, who were linked closely with national, regional and multilateral agencies, which conceived integration as an instrument for achieving both industrialization and economic development as the "insertion" of the region into the global economy. For them, regional integration would allow not only tackling underdevelopment but also for strengthening the bargaining power of Latin America countries before industrialized countries. Thus, reflections on Latin American integration were based on economic and political principles. ${ }^{235}$

These efforts may be well identified in the period of "Law and Developmental State" as coined by Trubek and Santos. Import substitution, complementarity and self-sustaining growth as economic concepts coexist more closely with political conceptions that struggle

\footnotetext{
${ }^{234}$ Santa Cruz (Hernán) “The creation of the United Nations and ECLAC”, CEPAL Review 57, December, $1995,32 \mathrm{p}$.

${ }^{235}$ Molano Cruz (Giovanni), "La integración andina: origen, transformaciones y estructuras", Instituto para la Integración de América Latina y el Caribe (BID-INTAL), N.33, Año 15, Julio-Diciembre 2011, 35 $36 \mathrm{pp}$.
} 
for autonomy, independence and self-determination. Consequentially, it is understandable that this model had achieved its peak during the period of the emergence of newly independent States.

In the meantime, what was remarkable, was the adoption of the Havana Charter (March, 1948), as an attempt to regulate comprehensively the economic relations in accordance with the rules earlier developed by the Economic and Social Council through the endeavour to create the International Trade Organization, which failed due to the refusal of the United States to ratify the same:

"In an attempt to rescue at least some of the negotiation results, the General Agreement on Tariffs and Trade (GATT) was adopted and proved to be quite successful in the limited area of activity of the agreement. It should, however, be noted that the GATT and its successor the World Trade Organization (WTO), as established in 1995 did not become part of the UN System but remained separate agencies, which were only loosed linked to the UN."236

Within this context, the influential expansion of international law and its institutionalization in the global arena was evident.

\subsubsection{The Bretton Woods Institutional System}

The picture of the new world order was completed with the globalization of the Bretton Woods system through the internationalization of its core institutions: the International Bank for Reconstruction and Development (hereinafter "IBRD") and the International Monetary Fund (hereinafter "IMF"), were both created in July 1944, almost at the same time that the institutional developments at the United Nation's system, stated above, took place:

The Bretton Woods institutions gradually expanded to include the whole noncommunist world. Between 1945 and the mid-1960s, decolonization brought into existence a world order of independent "nation" states. The old and new national elites of the periphery were free of direct, that is, jurisdictional control. Almost as important, without the gold standard, they were free to manipulate their currencies and national budgets for whatever sovereign purposes. They soon discovered, however, that they needed, for whatever purposes, access to world capital markets. This meant that they had to join the Bretton Woods system-either join this game strictly on the terms proposes, that is, within the structure of legal rules already in place, or starve in dark.

(...) The formal liberation and enfranchisement of un-free labour in Europe simply shifted the mechanism of exploitation from the transparency of imperial

\footnotetext{
${ }^{236}$ Simma (Bruno), Erasmus Khan (Daniel), Nolte (Georg), Paulus (Andreas) Editors, The Charter of the United Nations, Oxford Commentaries on International Law, Oxford University Press, Third edition, United Kingdom, 2012, 1548 p.
} 
rule to the mystification of neocolonialism. In place of the exploitative wage bargain, the modern international order worked through the unequal exchange of primary products from the Third World for industrial products from the First $(\ldots) .^{237}$

Whereas the IMF was conceived for the provision of "short-term balance or payments relief", the role of the IBRD was focused on facilitating long-term finance for "the development of productive resources". ${ }^{238}$ The original task entrusted to the IBRD was precisely reconstruction, besides addressing specific economic problems during the postwar period. The notion of development, initially not considered by the major proponents of the bank, was included due the insistence of developing countries:

(...) The developing countries attending the conference were concerned that if too high a priority was placed on reconstruction, limited resources would be available for development. The Latin American countries therefore proposed that in Articles of Agreement equal emphasis should be given to reconstruction and development. The United States conceded the inclusion of development functions in the Articles of Agreement so that Latin American countries would agree to join the IMF, access to the bank's lending being tied to the membership of the Fund. ${ }^{239}$

In this respect, the strong influence of the United States on the establishment of the Bretton Woods institutional framework and the early bargaining tendencies of the developing countries, mainly concerned for assuring a joint compromise for addressing developmental issues, was quite clear. Ecuador did not delay on approving and ratifying the agreements that instituted the IMF and the IBRD, signed in Bretton Woods on July $22^{\text {nd }}, 1944 .^{240}$

During the following years, the IBRD, commonly known as the World Bank and specific agencies of the UN conceived development and trade, as two faces of the same coin. The World Bank comprises four agencies:

The IBRD, established at Bretton Woods, makes loans linked to commercial rates of interest largely to middle-income developing countries. The International

\footnotetext{
${ }^{237}$ Kennedy (Duncan), “Three Globalizations of the Law and Legal Thought: 1850-2000”, in The New Law and Economic Development, Edited by David M. Trubek and Alvaro Santos, Cambridge University Press, New York, 2006, 57-58 pp.

${ }^{238}$ Williams (Marc), International Economic Organisations and the Third World, Harvester Wheatshead. Great Britain, 1994, 103 p.

${ }^{239}$ Williams (Marc), International Economic Organisations and the Third World, Harvester Wheatshead. Great Britain, 1994, 103 p.

${ }^{240}$ The National Congress approved the conventions that instituted the IMF and the IBRD on November 2, 1955.
} 
Development Association (IDA) ${ }^{241}$, created in 1960, is the soft loan affiliate of the IBRD and provides loans to the poorest developing countries on very favourable terms. The International Financial Corporation (IFC) ${ }^{242}$ was established in 1956 to assist economic development in poor countries through investing in private projects, supporting the growth of private capital markets and encouraging flows of domestic and foreign capital. The Multilateral Investment Guarantee Agency (MIGA) ${ }^{243}$, established in 1988 aims to encourage the flow of direct investment to developing countries through the lessening of non-commercial investment barriers. ${ }^{244}$

Ecuador ratified the relevant conventions that instituted these agencies shortly after their creation. Contrary to the ratification of the Convention Establishing the Multilateral Investment Guarantee Agency (MIGA) and the Convention on the Settlement of Investment Disputes Between States and Nationals of Other States (ICSID Convention), the international agreements ratified by Ecuador for the articulation of the Bretton Woods' system followed the constitutional process for the signature, approval and ratification of treaties, as it will be further explained.

In the outset of the new global order, there were recurrent the attempts by developing countries to push for the incorporation of their particular concerns to the incipient international institutional design. Taking into consideration the marginalization of the developing countries from decision-making within the Bretton Wood's system, several alternatives were attempted in the United Nations' framework, for supposedly balancing the institutional responses for addressing these countries' interests. It is affirmed that the creation of the United Nations Conference on Trade and Development (hereinafter "UNCTAD") was the response to this disenchantment and accordingly, in its early hours, this institution was perceived as "dominated by the developing countries". ${ }^{245}$ Williams explains the antecedents that surrounded the creation of UNCTAD in 1964:

The decision of the General Assembly in December 1962 to convene a conference on trade and development was the culmination of a process of intense debate in

\footnotetext{
241 The National Congress approved the Convention on August 20, 1961.

242 The Convention was signed on behalf of Ecuador on June 1, 1986, approved by the National Congress on November 2, 1955 and ratified by the President on April 13, 1956.

243 The Convention was signed on behalf of Ecuador on January 15, 1986. Published on the Official Gazette 389 , March $6^{\text {th }}, 1986$.

${ }^{244}$ Williams (Marc), International Economic Organisations and the Third World, Harvester Wheatshead. Great Britain, 1994, 101 p.

${ }^{245}$ Williams (Marc), International Economic Organisations and the Third World, Harvester Wheatshead. Great Britain, 1994, 179 p.
} 
the General Assembly and in the Economic Social Council (ECOSOC) begun at the sixteenth session of the General Assembly. This decision was a triumph for Third World pressure over western opposition. The Western states eventually gave up their opposition because of two factors. First a perceived Soviet interest in the creation of an international trade organization convinced the United States and its allies that they could not afford to let the developing countries and the communist bloc form an organization without them. Secondly, and perhaps most importantly, the increasing Third World majority in the UN left them no choice. (...) UNCTAD was created by the developing countries with the grudging acceptance of the developed world. For the developing countries a new organization was necessary in order to advance their interests in international economic reform. Throughout this period the developed states had insisted that existing organizations, in particular the GATT and the IMF could adequately incorporate Third World demands. They insisted that the creation of a separate organization would fragment and dissipate the problem of global poverty (...). ${ }^{246}$

Raul Prebisch shaped the emerging ideological features of UNCTAD, as its first Secretary. Having also inspired the conceptual pillars of ECLAC, Prebisch mimicked the same principles in his new office. From 1964 to 1992, UNCTAD embraced an organizational ideology, which was "a mix of global Keynesian and dependency theory". 247

However, the developing countries' hope for counter-balancing its perceived segregation from the decision-making power at Bretton Woods' institutions and GATT, would clash with the hegemonic discourse advocated by the latter entities, together with UNCTAD's structural and organizational flaws:

(...) UNCTAD's reformist mission was blocked by the norms and principles of the existing liberal economic order. The industrial countries used neo-classical economic theory to counter UNCTAD's reformist efforts. The strength of the intellectual challenge to UNCTAD was a function not only of technical superiority of the anti-UNCTAD critique but of the dominant position of those ideas in the international political economy. ${ }^{248}$

From its inception UNCTAD was limited to a pure forum of discussion, deprived of credibility and weight among developed States. As Williams underscores: "UNCTAD's dilemma lies in the fact that the realization of its goals depends on the willingness of the

\footnotetext{
${ }^{246}$ Williams (Marc), International Economic Organisations and the Third World, Harvester Wheatshead. Great Britain, 1994, 183 p.

${ }^{247}$ Williams (Marc), International Economic Organisations and the Third World, Harvester Wheatshead. Great Britain, 1994, $191 \mathrm{p}$.

${ }^{248}$ Williams (Marc), International Economic Organisations and the Third World, Harvester Wheatshead. Great Britain, 1994, 193 p.
} 
developed countries to agree and implement redistributive strategies". 249 The same scholar warns that if UNCTAD's success during its first 28 years, were evaluated as an effective forum of negotiated agreements, the outcome would be negative. ${ }^{250}$ On the contrary, if the focus were accentuated on "UNCTAD's catalytic and proselytising roles" ${ }^{251}$, the entity would obtain a fair score. ${ }^{252}$ In this frame, UNCTAD was intimately associated to the Group of $77^{253}$ and a leading promoter of the so -called "North-South" dialogue. It is worth recalling that UNCTAD`s resolutions do not have a legally binding effect, although they may bear strong normative implications in the event that such instruments comprise widely accepted aspects of State behaviour. ${ }^{254} \mathrm{In}$ sum, it is affirmed that until the 1990s, UNCTAD played a significant role for centralizing the efforts to "accelerate the pace of certain reforms favourable to the developing countries than it is

${ }^{249}$ Williams (Marc), International Economic Organisations and the Third World, Harvester Wheatshead. Great Britain, 1994, 195 p.

${ }^{250}$ Williams lists the substantive agreements that emerged from UNCTAD, many of them experiencing problems of ratification and implementation:

“(...) the Generalised System of Preferences (1970), the Code of Conduct for Liner Conferences (1974), the Common Fund for Commodities (1980), the Set of Multilaterally Agreed Equitable Principles and Rules for the Control of Business Practice (1980), the Convention of International Multimodal Transport of Goods (1980), the Convention on Conditions for Registration of Ships (1986), the Global System of Trade Preferences (1988)."

Williams (Marc), International Economic Organisations and the Third World, Harvester Wheatshead. Great Britain, 1994, 196.p.

${ }^{251}$ Dijk underlines the UNCTAD's high capability as "articulator, aggregator and communicator" of interests of the developing countries.

See: De Vey Mestdagh (K), "Supervision within the UN Conference for Trade and Development in Van Dijk (P), General Editor, Supervisory Mechanisms in International Economic Organisations: In the Perspective of a Restructuring of International Economic Order, Kluwer Law and Taxation Publishers, Deventer, The Netherlands, 1984, 331 p.

${ }^{252}$ Williams (Marc), International Economic Organisations and the Third World, Harvester Wheatshead. Great Britain, 1994, 197 p.

${ }^{253}$ The official website of the Group of 77 describes the historical background of its creation:

"The Group of 77 (G-77) was established on 15 June 1964 by seventy-seven developing countries signatories of the "Joint Declaration of the Seventy-Seven Developing Countries" issued at the end of the first session of the United Nations Conference on Trade and Development (UNCTAD) in Geneva."

It is also asserted that this group is the largest intergovernmental organization of developing countries in the United Nations comprising 134 countries to date.

See: http://www.g77.org/doc/

Website visited in May 2015.

${ }^{254}$ De Vey Mestdagh (K), "Supervision within the UN Conference for Trade and Development in Van Dijk (P), General Editor, Supervisory Mechanisms in International Economic Organisations: In the Perspective of a Restructuring of International Economic Order, Kluwer Law and Taxation Publishers, Deventer, The Netherlands, 1984, $295 \mathrm{p}$. 
to suggest that it produced these reforms". ${ }^{255}$ In the light of UNCTAD's effectiveness to generate ideas and policies on development and to act as a pressure group for influencing decisions of other international organizations, it is indebted to this institution for the incorporation of these concerns on the policy-design of IMF, World Bank and GATT. As Williamson describes:

(...) For example, Part IV of GATT of the developing countries in the negotiations on reform of the international monetary system (C-20) came about as a result of the pressure exerted through UNCTAD. ${ }^{256}$

In fact, the UNCTAD and the UNCTAD II Conferences first adopted the Generalised System of Preferences in 1968. ${ }^{257}$ GATT Contracting Parties further approved the "enabling clause" as an exception to the Most Favoured Nation (MFN) principle for assisting developing countries in their exports and development efforts, in 1971.

In the case of Latin-American countries, what is clear is the chaotic construction of their modern international legal framework, in one side, through the diverse obligations derived from the Pan-American system led by the influence of the United States, and in the other, through their insertion into an over-arching set of duties and institutional actors led by the United Nations' system in a variety of areas. Additionally, the proliferation of substantive and jurisdictional obligations, intensified by the subsequent adoption of multi-lateral and bilateral compromises with further international actors, were translated into the construction of a complex network of overlapping obligations. In this "spaghetti bowl" of international obligations, the enforcement mechanisms and their procedural particularities would make the difference for determining the jurisdictional appropriateness of an eventual conflict.

\footnotetext{
${ }^{255}$ De Vey Mestdagh (K), "Supervision within the UN Conference for Trade and Development in Van Dijk (P), General Editor, Supervisory Mechanisms in International Economic Organisations: In the Perspective of a Restructuring of International Economic Order, Kluwer Law and Taxation Publishers, Deventer, The Netherlands, 1984, $331 \mathrm{p}$.

256 Williams (Marc), International Economic Organisations and the Third World, Harvester Wheatshead. Great Britain, 1994, 197 p.

257 This scheme is described as: "a system of generalized, non-reciprocal and non-discriminatory preferences beneficial to the developing countries".
}

GATT, Differential and More Favourable Treatment, Reciprocity and Fuller Participation of Developing Countries, Decision of 28 of November 1979, L/4904 (December 3, 1979). 


\subsubsection{The Organization of American States}

It was precisely the prolific regulatory activity within the realm of the UN system during its first years of existence which was emulated at the inter-American level. In 1948, there was adopted the Charter of the Organization of American States ${ }^{258}$, which gave birth to the Organization of American States, institutionalizing the long-standing cooperation ties among the hemisphere. It is noteworthy that the antecedent of this initiative was the Inter-American Treaty of Reciprocal Assistance (Rio de Janeiro, 1947), motivated by the experience of World War II that called for the adoption of a system of collective security, which gradually evolved as an institutional response against the communist penetration of the hemisphere. At the same Conference, wherein the aforementioned constitutive charter was adopted, there were enacted the American Treaty of Pacific Settlement and the American Declaration on the Rights and Duties of Man. However in the same conference was approved the Economic Agreement of Bogotá, which sought to foster economic cooperation among American States, but it came never into force. The process of negotiation for the adoption of the said charter and its further instruments began in 1945, the same year when the Charter of the United Nations was adopted, the Organization of American States circumscribed itself as a regional agency 259 of the system of the United Nations ${ }^{260}$. This adaptation may also show as an attempt by the United States to not diminish the influence of the Monroe Doctrine within the UN system.

The dispute settlement procedures enshrined by the Charter of the Organization of American States and the American Treaty on Pacific Settlement comprise mediation,

\footnotetext{
258 Adopted by the Ninth International Conference of American States, Bogotá, 1948. Subsequently, the Charter was modified, via Protocols of Amendment: Buenos Aires (1967); Cartagena (1985); Washington (1992) and Managua (1993).

See: Organization of the American States (OAS), "Our origins”, Official website.

http://www.oas.org/en/about/our history.asp

Page visited in May 2015.

${ }^{259}$ Charter of the Organization of American States:

"Art. 1.- The American States establish by this Charter the international organization that they developed to achieve an order of peace and justice, to promote their solidarity, to strengthen their collaboration, and to defend their sovereignty, their territorial integrity, and their Independence. Within the United Nations, the Organization of American States is a regional agency.

The Organization of American States has no powers other than those expressly conferred upon it by this Charter, none of whose provisions authorizes it to intervene in matters that are within the internal jurisdiction of the Member States."

${ }^{260}$ Charter of the United Nations, Chapter VIII (Regional Arrangements).
} 
investigation and conciliation, good offices, arbitration and failing the aforementioned, recourse to the International Court of Justice. ${ }^{261}$

The variety of co-operation fields within the inter-American system reveals that the actions of the Member States were governed by ever-changing priorities, dependent on the United States' will. Before the approval of the Charter of American States in 1948, several institutions were created in diverse areas like health (1902), judicial affairs (1906), women rights (1927), children rights (1928), agriculture (1942) and defense (1942). After the establishment of the Organization of American States (1948), the fields of cooperation and institutional responses were enlarged, with the creation of several commissions and committees in areas like banking, drug abuse control, telecommunications, ports and judicial studies. However, the most salient institutions created within the system are the Inter-American Commission on Human Rights and the Inter-American Court of Human Rights. Whereas the Commission was created in 1959, the Court was instituted in 1979. It is worth recalling that the American Declaration of the Rights and Duties of Man -Pact of San Jose, Costa Rica ${ }^{262}$ - was the first human rights instrument of general nature, adopted in April 1948, only a few months before the promulgation of the Universal Declaration of Human Rights ${ }^{263}$. In any case the main substantive and procedural obligations concerning human rights in the hemisphere derive from the American Convention on Human Rights, adopted in 1969.264

It has been implied that the inter-American system has been normally conducted under the influence of the United States and for this reason it is curious, for example, that this country has not ratified the human rights' jurisdiction of the entities it contributed to create.

\footnotetext{
${ }^{261}$ Organization of the American States (OAS), "Our origins", Official website.

See: http://www.oas.org/en/about/our history.asp

Page visited in May 2015.

${ }^{262}$ Ratified by Executive Decree 1883, Official Gazette, October 27 $7^{\text {th }}, 1977$.

${ }^{263}$ Convenio 0, Registro Auténtico, 10 de diciembre de 1948.

${ }^{264}$ Organization of American States' official site indicates the countries that have ratified the binding jurisdiction of the inter-American system of human rights:
}

"The Convention entered into force in 1978. As of August of 1997, it has been ratified by 25 countries: Argentina, Barbados, Brazil, Bolivia, Chile, Colombia, Costa Rica, Dominica, Dominican Republic, Ecuador, El Salvador, Grenada, Guatemala, Haiti, Honduras, Jamaica, Mexico, Nicaragua, Panama, Paraguay, Peru, Suriname, Trinidad and Tobago, Uruguay and Venezuela."

See: http://www.oas.org/en/iachr/mandate/what.asp

Web page visited in May 2015. 
Finally and as previously noticed, the proliferation of institutions within the UN system, entrusted with specific mandates for achieving the objectives of economic and cultural rights' development, enlarged the number of relevant institutions, agencies structures and rules, under whose influence the Member States would have to modulate their conduct, with different degrees of command and control. The revisited influence of institutions, as UNCTAD, IMF and World Bank took the form over the approaching decades, of different mechanisms like "technical assistance", "letters of intention" and "programs of structural adjustment". It has to be reiterated that the UN institutional speech has inextricably unified the goals of development to the promotion of trade, qualifying the latter as "the main driver of development". ${ }^{265}$

\subsubsection{Development of International Rules for the Settlement of Disputes Involving Public and Private Interests}

At the end of the 1950s, a multilateral effort for unifying the rules concerning the recognition and enforcement of arbitral awards was undertaken, concluding on the Convention for the Recognition and Enforcement of Arbitral Awards (hereinafter "New York Convention") ${ }^{266}$ :

The United Nations Conference on International Commercial Arbitration, which was convened from May 20 to June 19, 1958, in New York, resulted from a proposal of the International Chamber of Commerce to the Economic and Social Council of the United Nations to conclude a convention on the enforcement of foreign awards. Previous international agreements on commercial arbitration, namely the Geneva Protocol on Arbitration Clauses of September 24, 1923, and the Convention on the Execution of Foreign Arbitral Awards of September 26, 1927 , were no longer adequate. ${ }^{267}$

\footnotetext{
${ }^{265}$ United Nations Conference on Trade and Development, Official Website, "About us". See: http://unctad.org/en/Pages/Statistics.aspx

Web page visited in May 2015.

${ }^{266}$ Done at New York, June $10^{\text {th }}, 1958$.

${ }^{267}$ Van den Berg abounds in the historical background that underpinned the signature of the Convention of New York, as well as its worldwide acceptance and effectiveness:
}

\footnotetext{
"The Convention on the Recognition and Enforcement of Foreign Arbitral Awards, done at New York, 10 June 1958 (the New York Convention), is described as the most successful treaty in private international law. It is adhered to by more than 140 nations. The more than 1,400 court decisions reported in the Yearbook: Commercial Arbitration show that enforcement of an arbitral award is granted in almost 90 per cent of the cases.

The Convention was established as a result of dissatisfaction with the Geneva Protocol on Arbitration Clauses of 1923 and the Geneva Convention on the Execution of Foreign Arbitral Awards of 1927. The initiative to replace the Geneva treaties came from the International Chamber of Commerce (ICC), which issued a preliminary draft convention in 1953. The ICC's initiative was taken over by the United Nations Economic and Social Council, which produced an amended
} 
It should be noted that great influence was conferred on the International Chamber of Commerce in the United Nations' policy design. On 1946, it was awarded the highestlevel consultative status with the United Nations. Founded in 1919, it promptly foresaw the importance for developing special rules of protection to merchants, with emphasis on dispute settlement. ${ }^{268}$

In the report submitted by the Ambassador of Ecuador in New York, with relation to the tasks undertaken by the Special Committee on the Recognition and Execution of Foreign Arbitral Awards, can be observed the categorical influence of the International Chamber of Commerce on the negotiations of the multi-lateral convention at issue. ${ }^{269}$ Additionally, there are obvious arguments brought by this non-governmental organization that placed arbitration not as the preferential but as the exclusive mechanism for the settlement of international commercial disputes, advocating that the failure of developing a "fair and legal" transnational instrument for achieving such an end, would undermine the progress of the economic relationships between States:

"5. Desde la iniciación de los trabajos de la Liga de las Naciones en Ginebra se hizo sentir la necesidad de elaborar un instrumento jurídico capaz de solucionar las numerosas dificultades que impiden el desarrollo del comercio internacional. Los comerciantes manifestaron siempre su preferencia por el arbitraje en todo conflicto relativo a sus intereses. Lentamente se han ido constituyendo en muchos países Cortes Especiales de Arbitraje, como la que existe en Londres; y los comerciantes se han sometido voluntariamente a la resolución arbitral por medio de jurados que han organizado las Cámaras de Comercio Internacional y la "American Arbitration Association", además de varias organizaciones comerciales independientes que funcionan en centros comerciales de los países marítimos. En el curso de este siglo se ha ido generalizando el uso de arbitraje en las controversias de naturaleza mercantil y no obstante de carecer de cierta protección legal obligatoria, el arbitraje se ha ido imponiendo de manera lenta y segura entre todos los países cultos que quieren fomentar relaciones sanas de comercio y garantizar el cumplimiento de los compromisos adquiridos. Después de todos los ensayos realizados parece que ha llegado el momento de verificar un

draft convention in 1955. That draft was discussed during a conference at the United Nations Headquarters in May-June 1958, which led to the establishment of the New York Convention."

Van den Berg (Albert Jan), Convention on the Recognition and Enforcement of Foreign Arbitral Awards, http://legal.un.org/avl/ha/crefaa/crefaa.html.

Website visited in May, 2015.

268 After a few years of its foundation, the International Court of Arbitration at the International Chamber of Commerce was created (1923).

${ }^{269}$ It is remarkable too, the early concern of the ICC in regard to the reparations and war debts suffered by its members (1920s), as well as its responses before the growing nationalistic trend during the 1930s, See, http://www.iccwbo.org/products-and-services/arbitration-and-adr/arbitration/

Website visited on May 2015. 
esfuerzo colectivo, redactar un instrumento internacional en el que se encuentren comprendidas todas las formas arbitrales adoptadas en los distintos sistemas jurídicos, de modo que pueda tal instrumento ser suscrito y ratificado por el mayor número de Estados. La Cámara de Comercio Internacional creyó que había llegado el momento de generalizar el uso de arbitraje ya que están participando en el comercio internacional muchos más individuos y empresas comerciales que antes de la segunda guerra mundial lo que significa un mayor número de controversias que si no encuentran la vía justa y legal por la que puedan resolver tales diferencias, producirían una crisis que detendría el fomento de las relaciones económicas entre los pueblos. Cree que es el momento de eliminar todos los obstáculos que se han presentado para resolver este problema de modo que es la hora de llamar a todos los gobiernos para que permitan a los comerciantes recurrir al arbitraje, respaldando con su autoridad la validez de los fallos y la seriedad de los compromisos." 270

In the report at hand, it is necessary to note the resonance of the arguments in favour of trade liberalization as a means of promoting peace, as well as their enthusiastic welcoming by developing countries like Ecuador, which refer to developed countries as "civilized countries". This reference portrays an acceptance of an inferior position before the global order, as well as the recognition of an under-developed legal framework capable of tackling commercial disputes, which contributes to the consolidation of the colonialist concept of "otherness", as coined by Miles and described below.

Although during the following decades the transnational institutional efforts would have been focused on the harmonization of international trade rules, the emergence of investment protection would underpin the efforts for incorporating a means for scrutinizing the exercise of sovereign powers. In practice, this reality would result in an inextricable co-existence between international commercial rules and international investment principles, especially concerning the arbitral tribunals' scope of review.

Together with the International Chamber of Commerce, the Hague Conference of Private International Law, the International Institute for the Unification of Private Law and the International Law Association of Legal Science, were non-governmental organizations, which also enjoyed a prominent role in the deliberations of the Conference. ${ }^{271}$ The most important procedural feature in comparison to the Geneva Protocol of 1923 consisted of the shift of the burden of proof on to the losing party, obliged to prove that the award did

\footnotetext{
${ }^{270}$ Embajada del Ecuador en Estados Unidos, Informe relativo a los trabajos del Comité Especial sobre la Ejecución de Sentencias Arbitrales Internacionales, Nueva York, Abril 4, 1955.

271 Domke (Martin), “The United Nations Conference on International Commercial Arbitration”, The American Journal of International Law, Vol.53, No.2, (Apr. 1959), 415 p.
} 
not become binding or was set aside or suspended. ${ }^{272}$ Concerning issues of international public law, the discussions were focused on the application either of the universality or of the reciprocity principle with respect to recognition and enforcement of awards, prevailing at the end, which was the latter principle. Probably, the most important reservation concerned the general authorization conferred on the countries to enforce awards deriving from disputes considered to be commercial under national law. In fact, Ecuador made the mentioned reservation, when it ratified the Convention:

Ecuador on the basis of reciprocity, will apply the Convention to the recognition and enforcement of arbitral awards made in the territory of another contracting State only if such awards have been made with respect to differences arising out of legal relationships, which are regulated as commercial under Ecuadorian law. ${ }^{273}$ Moreover, the existence of parallel multilateral and bilateral treaties governing recognition of arbitration agreements and enforcement of awards was also acknowledged and regulated:

Among to the final clauses those on the relationship between the new Convention and other arbitration treaties should be noted. Existing bilateral and multilateral treaties are covered by a saving clause (Article VII) of particular interest to the United States, in view of its recent treaties of friendship, commerce and

272 Clive M. Schmitthoff on the report made by request of the Secretary General, summarizes the main features of the Convention on the Recognition and Enforcement of Foreign Arbitral Awards of 1959:

\begin{abstract}
"The United Nations Convention represents a definite advance over the Geneva arrangements in that it facilitates to a considerable degree the enforcement of foreign arbitral awards. First, it abolishes, in principle, the, requirement of reciprocity, although a State may declare that it will apply the Convention to awards made only in the territory of other Contracting States (article I (3)). Secondly, it abolishes the requirement of double exequatur, which in many countries is a serious obstacle to the enforcement of foreign arbitral awards (article V (1) (e)). Thirdly, it is no clivelonger necessary for the recognition of an arbitration agreement or for the enforcement of an arbitral award that the parties should be subject to the jurisdiction of different contracting States (articles I (1) and II (1).”
\end{abstract}

Report submitted pursuant to resolution 2102 (XX), adopted by the General Assembly on 20 December 1965. Report of the Secretary-General, Document A/6396, September 23 ${ }^{\text {rd }}$, 1966, 9 p.

${ }^{273}$ The internal legal report issued at the Ministry of Foreign Affairs corroborates the restricted application of the Convention circumscribed to commercial disputes in accordance with Ecuadorian law:

“15. En el acto de la suscripción de la adhesión convendría declarar que la República, en base de reciprocidad, aplicará la Convención al reconocimiento y a la ejecución de los fallos arbitrales dictados en el territorio de otro Estado contratante únicamente, ya que no habría motivo para hacer extensivas las obligaciones de la República a más. Convendría igualmente declarar que el Ecuador aplicará la Convención sólo a los litigios surgidos de relaciones jurídicas consideradas como comerciales por el Derecho ecuatoriano, ya que esta clase de relaciones han sido principalmente el objeto de preocupación y estudios que han conducido a la celebración del a Convención.”

Ministerio de Relaciones Exteriores del Ecuador, Dictamen N. 154-ATJ, Quito, 13 de Octubre de 1958. 
navigation, which contain provisions for the mutual recognition of arbitration agreements and enforcement of awards. ${ }^{274}$

This statement depicts the "hybridization" of international investment law, as well as the early efforts of developed countries for isolating its development from the multi-lateral forums of governance. In this context, these forums have served, as vehicles for spreading alleged global shared values that would constitute undeniable indicators of "state maturity", embodied through multilateral economic treaties. ${ }^{275}$ However, these multilateral initiatives have been exclusively confined to procedural rules, setting aside substantive principles applied even in contradiction to the fundamental values that have justified the foundation of global institutionalism. As Chimni underscores, the global administrative project has been "shaped by a transnational capitalist class that seeks to legitimize unequal laws and institutions and deploy it to its advantage". ${ }^{276}$ Indeed, the development of International Investment Law has cherry picked the most effective procedural mechanisms built at the multilateral level, reserving to the bilateral and "reciprocal" space the determination of the content and extent of the substantive rules. The determination of the international liability of the State under the prism of commercial principles with a utilitarian use and interpretation of diverse international treaties from the perspective of investment protection, has been translated into an interested practice of picking and choosing legal provisions according to the best understanding of the players of the system, detached from any institutional links and accountability.

\subsubsection{Multilateral Measures for Unifying International Trade Rules}

During the 1960s, the global institutionalism for unifying international trade rules continued its consolidation and the United Nations Commission on International Trade Law, was created (hereinafter "UNCITRAL") 277 . In the report prepared at the request of

\footnotetext{
${ }^{274}$ Domke (Martin), "The United Nations Conference on International Commercial Arbitration", The American Journal of International Law, Vol.53, No.2, (Apr. 1959), 415 p.

275 See, Miles (Kate), The Origins of International Investment Law: Empire, Environment and the Safeguarding of Capital, Cambridge University Press, 2013, 334 p.

${ }^{276}$ Chimni, "Co-option", 806, in Miles (Kate), The Origins of International Investment Law: Empire, Environment and the Safeguarding of Capital, Cambridge University Press, 2013, 335 p.

${ }^{277}$ United Nations General Assembly, Resolution 2205 (XXI), $1497^{\text {th }}$ plenary meeting, December $17^{\text {th }}$, 1966.
} 
the Secretary General to the Professor Clive M. Schmitthoff ${ }^{278}$, concerning the suitability of establishing the commission at issue, they comprehensively analyzed the tasks undertaken already by international and regional institutions either public or private, as well as the corresponding rules for the purpose of harmonizing international trade practices. In this regard, this report started by delineating the concept's scope of "law of international trade":

(...) "The law of international trade" may be defined as the body of rules governing commercial relationships of a private law nature involving different countries. ${ }^{279}$

From its inception the report drew a line between international relations of private law and public law nature:

The scope of this report does not extend to international commercial relations on the level of public law, such as those relating to the attitude and behaviour of States when regulating, in the exercise of sovereign power, the conduct of trade affecting their territories. Illustrations of commercial relationships of this type are bilateral treaties of commerce or multilateral treaties such as the General Agreement on Tariffs and Trade (GATT) or the Rome Treaty establishing the European Community. International commodity arrangements are also excluded from the scope of this report. ${ }^{280}$

This definition contributed to the further consolidation of the conceptual delimitation of international investment law, based on the scrutiny of the exercise of sovereign powers,

${ }^{278}$ Report submitted pursuant to resolution 2102 (XX), adopted by rhe General Assembly on 20 December 1965. Report of the Secretary-General, Document A/6396, September 23 ${ }^{\text {rd }}$, 1966.

279 There were listed as topics falling within the scope of international trade:

“(a) International sale of goods;

(i) Formation of contracts;

(ii) Agency arrangements;

(iii) Exclusive sale arrangements.

(b) Negotiable instruments and banker's commercial credits.

(c) Laws relating to conduct of business activities pertaining to international trade.

(d) Insurance.

(e) Transportation:

(i) Carriage of goods by sea;

(ii) Carriage of goods by air;

(iii) Carriage of goods by road and rail;

(iv) Carriage of goods by inland waterways.

(f) Industrial property and copyright.

(g) Commercial arbitration."

Report of the Secretary-General, Document A/6396, September $23^{\text {rd }}, 1966,3$ p.

${ }^{280}$ Report of the Secretary-General, Document A/6396, September 23 ${ }^{\text {rd }}, 1966,3 \mathrm{p}$. 
an achievement already reached by the treaties of friendship, navigation and commerce. However the future application of the investment protection's regime would demonstrate that this apparent straightforward distinction would be very far from bringing certainty, given the commercial based approach that has prevailed over the settlement of investment arbitration disputes both at the procedural and substantive levels. The report advocates enthusiastically the universality of international commercial custom, firmly rooted in the medieval lex mercatoria and the development of widely accepted concepts indistinctly among countries of free enterprise and countries of centrally planned economy, as it was comparably observed from several municipal jurisdictions. ${ }^{281}$ Accordingly, it summarizes the pillars upon which is built the widely accepted notion of international trade:

The reason of this universal similarity of the law of international trade is that this branch of law is based on three fundamental propositions: first, that the parties are free, subject to limitations imposed by the national laws, to contract on whatever terms they are able to agree (principle of the autonomy of the parties' will); secondly, that once the parties have entered into a contract, that contract must be faithfully fulfilled (pacta sunt servanda) and only in very exceptional circumstances does the law excuse a party from performing his obligations; viz., if force majeure or frustration can be established and, thirdly, that arbitration is widely used in international trade for the settlement of disputes, and the awards of arbitration tribunals command far-reaching international recognition and are often capable of enforcement abroad. ${ }^{282}$

The parallel development of regional rules for the recognition and execution of foreign awards and judgments by the Treaties of Montevideo and the Bustamante Code in LatinAmerican countries was also acknowledged in the report at issue. There were also highlighted the efforts undertaken in the realm of the League of Nations for the unification of the law of international trade, as well as the expansion of rules of international arbitration, praising this mechanism: "as the most practical method of settling disputes arising from transactions of international trade". ${ }^{283}$

With relation to the Convention on the Settlement of Investment Disputes between States and Nationals of Other States (ICSID Convention), the report underscores the special and separate treatment that should be given to investment disputes, untying the attachment of investment law to the law of international trade:

Although investment disputes are generally settled through judicial, arbitral, or other procedures available under the laws of the country in which the investment

\footnotetext{
${ }^{281}$ Report of the Secretary-General, Document A/6396, September 23 ${ }^{\text {rd }}, 1966,5 p$.

${ }^{282}$ Report of the Secretary-General, Document A/6396, September 23 ${ }^{\text {rd }}, 1966,5 p$.

${ }^{283}$ Report of the Secretary-General, Document A/6396, September 23 ${ }^{\text {rd }}, 1966,9 \mathrm{p}$.
} 
was made, experience has shown that in many instances international machinery for the settlement of investment disputes is considered preferable by both States and investors.

(...) The jurisdiction of the Centre in disputes is dependent upon the written consent of the parties thereto and extends to "any legal dispute arising directly out of an investment" (article 25 (1)) between a contracting State or a constituent subdivision of a contracting State and a national of another contracting State, either natural or juridical person. Contracting States may, if they so desire, notify the Centre in advance as to the classes of disputes which they would, or would not, consider submitting to the jurisdiction of the Centre (article $25(4))(\ldots){ }^{284}$

As noted, the jurisdiction of the Centre with regard to the "legal" or "contractual" nature of the disputes has been a vibrant sticking point, concerning the arbitrators' power to rule over its own power for settling a controversy, especially due the recurrent commercial approach employed by them for achieving such a definition. In spite of the effort made in the report at issue for suppressing from the ambit of the law of international trade, the existing regulations pertaining to investment protection, it acknowledged that the Convention on the Settlement of Disputes between States and Nationals of other States sponsored by the IBRD would fall in the area of commercial arbitration. ${ }^{285}$

Particularly notable, are the shortcomings pointed out in the report in regard to obstacles encountered in the field of harmonization and unification of the law of international trade. First, it is asserted that "the progress made in the unification and harmonization of the law of international trade has been rather slow in relation to the amount of time and effort expended on it". ${ }^{286}$ Additionally, it underlines the little participation in this field by developing countries of recent independence, at the expense of their possibilities of gaining equality at international trade level. Moreover, it criticized the imbalance in the composition of agencies translated into the failure of achieving world-wide acceptance, due to the unequal representation conferred on the diverse factions opposing the construction of a common framework (countries of free enterprise economy, countries of

\footnotetext{
${ }^{284}$ Report of the Secretary-General, Document A/6396, September 23 ${ }^{\text {rd }}, 1966,12$ p.

285 Together with this Convention the report comprises within the area of commercial arbitration, the following international treaties:
}

"(...) The Geneva Protocol of 1923 and the Geneva Convention of 1927, both sponsored by the
League of Nations; the United Nations Convention on the Recognition and Enforcement of Foreign
Arbitral Awards of June 1958; the European Convention on International Commercial Arbitration,
sponsored by ECE; the Council of Europe Convention on International Commercial Arbitration
and on Uniform of Law on Arbitration, and; the ECAFE Centre for Commercial Arbitration (...)". Report of the Secretary-General, Document A/6396, September 23 ${ }^{\text {rd }}, 1966,21 \mathrm{p}$.

${ }^{286}$ Report of the Secretary-General, Document A/6396, September 23 ${ }^{\text {rd }}, 1966,22$ p. 
centrally planned economy, developed and developing countries). It used as a representative example the composition of UNIDROIT, whose membership was predominantly European. Finally, it pointed out the insufficient co-ordination and cooperation among formulating agencies meaning a waste of effort, confusion and overlapping attempts to achieve uniformity. ${ }^{287}$ Precisely, the signature of bilateral obligations entails succinct stages of deliberation that may circumvent most of the procedural shortcomings just mentioned, which in the case of BITs, constitute instruments of adherence with undetermined compromises, in whose design, host countries had no participation. It is surprising that the legitimacy concerns and the timeconsuming approbation procedures that surrounded the negotiations of the multilateral obligations which have been analyzed, was not replicated at the conclusion of BITs, where the sovereign space relinquished is undoubtedly larger.

\subsubsection{Consolidation of International Rules Regarding State Responsibility}

At the end of the 1960s, a period in which emerged the BITs, there was also concluded the Vienna Convention on the Law of Treaties (1969) ${ }^{288}$, being "the culmination of a twenty-year effort to codify customary rules of treaty law",289. Although Ecuador signed this convention in the same year it was approved, it was delayed for almost twenty-five years before concluding its internal process of ratification and it deposited its acceptance on 2005.

Upon signature:

In signing this Convention, Ecuador has not considered it necessary to make any reservation in regard to Article 4 of the Convention because it understands that the rules referred to in the first part of article 4 include the principle of the peaceful settlement of disputes, which is set forth in Article 2, paragraph 3 of the Charter of the United Nations and which, as jus cogens, has universal and mandatory force.

Ecuador also considers that the first part of article 4 is applicable to existing treaties.

It wishes to place on record, in this form, its view that the said article 4 incorporates the indisputable principle that, in cases where the Convention codifies rules of lex lata, these rules as pre-existing rules, may be invoked and applied to treaties signed before the entry into force of this Convention, which is the instrument codifying rules.

\footnotetext{
${ }^{287}$ Report of the Secretary-General, Document A/6396, September $23^{\text {rd }}, 1966,22 \mathrm{p}$.

${ }^{288}$ Ecuador signed the Vienna Convention on the Law of Treaties on May $23^{\text {rd }}, 1969$ but it ratified such instrument on July $28^{\text {th }}, 2003$.

Decreto Ejecutivo No.619, publicado en el Registro Oficial 134 de 28 de Julio de 2003.

${ }^{289}$ Dajani (Omar. M), “Contractualism in the Law of Treaties”, 34 Mich. J. Int'l L. 1 2012-2013, 3 p.
} 


\section{Upon ratification:}

In ratifying this Convention, Ecuador wishes to place on record its adherence to the principles, norms and methods of peaceful settlement of disputes provided for in the Charter of the United Nations and in the other international instruments on the subject, which hace been expressely included in the Ecuadorian legal system in article 4, paragraph 3, of the Political Constitution of the Republic..$^{290}$

Taking into consideration that within the regime of international investment protection the wrongful act of a State is determined in accordance with International law, such a convention mainly, and the Draft Articles of Responsibility of States for Internationally Wrongful Acts ${ }^{291}$, complementarily, set in general terms the yardstick against which, the sovereign action in question will be judged. For instance, as regards rules of interpretation enshrined in the VCLT, the main international courts have widely shared that they constitute binding universal rules reflecting customary international law, irrespective of whether the incumbent State is a party of such an international treaty:

Therefore its rules laid down in Arts. 31-33 reflect universal custom, they can in principle be applied to all treaties outside the scope of the Convention. This concerns, first, treaties concluded before the Convention entered into force (1980), and, second, treaties between States that are not all parties to the Convention, such as United States or France: the diplomatic practice of the US administration, as well as the overwhelming part of US court practice, reflects the view that the Arts. 31-33 VLCT do express binding customary norms. France has acknowledged the same at the occasion of arbitral proceedings. Third, the Convention rules on interpretation can as customary rules be applied to instruments that due to their character fall outside the scope of the Convention, such as unwritten treaties or treaties between States and other entities treated as subjects of international law. The provisions on treaty interpretation in the 1986 Vienna Convention are identical to those in the 1969 Convention, as in the ILC and the 1986 Conference the established rules were simply replicated and inserted into the text of the VLCT II without debate. ${ }^{292}$

\footnotetext{
${ }^{290}$ United Nations, Treaty Series, vol.1155, p.331, Vienna Convention on the Law of Treaties, Vienna 23 May 1969.

${ }^{291}$ The International Law Commission adopted at its fifty-third session (2001) the texts of the Articles on Responsibility for Internationally Responsibility, the same that were referred to the General Assembly for consideration. It is explained that in the case of such Articles the position assumed by the Commission has consisted of recommending to the General Assembly to consider a convention on state responsibility and some form of endorsement or taking note of the Articles. It is added that whereas the first alternative would bring durability and authority in the form of a multilateral treaty, the latter would allow greater flexibility and a continued process of legal development by international courts and tribunals. Finally, it is noted that the International Court of Justice and other tribunals have already referred to the Draft Articles, which shows that the same "may have a long-term influence even if they do not take the form of a convention.
}

See, Crawford (James), Peel (Jacqueline), Olleson (Simon), “The ILC's Articles on Responsibility of States for Internationally Wrongful Acts: Completion of the Second Reading”, EJIL 12 (2001), 969 p.

${ }^{292}$ Dorr (Oliver) and Schmalenbach (Kirsten), Editors, "Interpretation of Treaties", in Viena Convention on the Law of Treaties: A Commentary, Springer, 2012, 524.p. 
Apparently Ecuador's delay in ratifying the convention was founded on its wariness in regard to the impact of its application on the treaties that surrounded the unsettled territorial disputes maintained with Peru until 1998. In any case, the late ratification of Ecuador to the "constitution of treaties" acknowledged the pre-eminence of jus cogens principles, as well as those of good faith and peaceful settlement of disputes as enshrined by Article 2 of the Charter of the United Nations ${ }^{293}$. The overwhelming emergence of international investment disputes at the beginning of the XXI century, meaning the application of Public International Law principles in controversies involving private and commercial interests would abolish the firmly rooted "contractualist approach" assumed by Ecuador, based on the misunderstanding that the only source of an international conflict with regard to an investor, could derive from a contractual obligation. As previously noted, the reserve made by the country when it ratified the New York Convention for the Recognition and Enforcement of Arbitral Awards, as well as the binding ruling issued by the Constitutional Tribunal authorizing the approval of the ICSID Convention explained below, evidences the misleading conception of Ecuador with regard to the scope and nature of the controversies covered by BITs.

\subsubsection{Early Adoption of Bilateral Investment Treaties (BITs) by Ecuador}

In the midst of a boom of international obligations at the multilateral, inter-American and sub-regional levels, Ecuador, added to its already complex web of international

${ }^{293}$ Charter of the United Nations; Article 2:

"The Organization and its Members, in pursuit of the Purposes stated in Article 1, shall act in accordance with the following Principles.

1. The Organization is based on the principles of the sovereign equality of all its Members.

2. All Members, in order to ensure to all them the rights and benefits resulting from membership, shall fulfill in good faith the obligations assumed by them in accordance with the present Charter.

3. All Members shall settle their international disputes by peaceful means in such a manner that international peace and security, and justice, are not endangered.

4. All Members shall refrain in their international relations from the threat or use of force against the territorial integrity or political independence of any state, or in any other manner inconsistent with the Purposes of the United Nations.

5. All Members shall give the United Nations every assistance in any action it takes in accordance with the present Charter, and shall refrain from giving assistance to any state against which the United Nations is taking preventive or enforcement action.

6. The Organization shall ensure that states which are not Members of the United Nations act in accordance with these Principles so far as may be necessary for the maintenance of international peace and security.

7. Nothing contained in the present Charter shall authorize the United Nations to intervene in matters which are essentially within the domestic jurisdiction of any state or shall require the Members to submit such matters to settlement under the present Charter; but this principle shall not prejudice the application of enforcement measures under Chapter Vll." 
duties, Bilateral Investment Treaties. Being a pioneer in adopting all kinds of international treaties without undertaking a minimum "cost- benefit" analysis, the country embarked in this new trend, which after four decades, would even threaten its public finance's sustainability. In accordance with Ecuadorian practice, it is very rare to identify any reserve or attempt to define the scope of certain obligations. Normally, the country adheres to the treaties' contents; no matter whether they are multilateral or bilateral. Unfortunately, the policy- makers would detect too late the intrinsic disparity of investment protection as enshrined by BITs:

The colonial encounter created "otherness" in the concept of the host state, excluding it from the protective principles of international investment law. Thus, the host state was, and remains, unable to call upon the rules of international investment law to address damage suffered at the hands of foreign investor. It is important to appreciate that the principles of foreign investment protection law formed an integral part of European commercial and political expansionism in the eighteenth and nineteenth centuries, and they validated the use of force to achieve those wider objectives. ${ }^{294}$

In this context, Ecuador was the first South-American country that signed a BIT. The two BITs signed by Ecuador were concluded with the Federal Republic of Germany 295 $(1965)^{296}$ and Switzerland ${ }^{297}(1968)^{298}$. It is noteworthy that the signature of the first BITs by Ecuador, took place only 6 years after the first treaty of this nature was concluded (BIT between Federal Republic of Germany-Pakistan, 1959). Kujiper describes that the first motivations for the conclusion of the first BIT were the protection of investors' legal interests linked to the insurance and guarantee system for outward investment in the Federal Republic of Germany. In addition to this internal motivation, this treaty took a

\footnotetext{
${ }^{294}$ Miles (Kate), The Origins of International Investment Law: Empire, Environment and the Safeguarding of Capital, Cambridge University Press, 2013, 32-33.pp.

295 Germany has signed 134 BITs and 64 Investment Agreements.

See, UNCTAD, Investment Policy Hub, http://investmentpolicyhub.unctad.org/IIA/CountryBits/203\#iiaInnerMenu Website visited on May 2015.

296 BIT signed on June $28^{\text {th }}, 1965$.

${ }^{297}$ Switzerland is one of the worldwide most prominent promoters of BITs, as it can be observed from the 118 BITs it has concluded until 2015. See, UNCTAD, Investment Policy Hub, http://investmentpolicyhub.unctad.org/IIA/CountryBits/203\#iiaInnerMenu Website visited on May 2015.

${ }^{298}$ Subscribed on May $2^{\text {nd }}, 1968$. Treaty in force since September 11th, 1969.
} 
step forward compared to Friendship, Commerce and Navigation Treaties, by codifying customary law as conceived by Western capital exporting countries. ${ }^{299}$

From the preamble of the BIT signed between Ecuador and the Federal Republic of Germany, it is remarkable to note the origins of the investment protection scope as conceived by the relevant text:

"Recognizing that contractual protection and promotion of such capital investments is likely to promote private business initiative and to increase the welfare of both nations". 300

Pursuant to this provision, the early predisposition of investment protection to international commerce is clear. Apparently contractual protection would be confined to the scope of private autonomy, enjoying as a consequence, both parties stringent control of the obligations derived from the letter of the contract. However, the development of International Investment Law has left no grounds for this initial understanding, attaching the determination of a State's liability to the field of International Public Law. In this regard, the distinctive feature of International Investment Law has been summarized as follows:

${ }^{299}$ Kujiper summarizes the internal history of this treaty, which portraits the initial motivations for the signature of BITs:

The German parliamentary history of this Treaty reveals the main objectives behind its conclusion. The 1959 Budget Act contained a provision allowing the Ministry of Finance to provide guarantees or reinsurance for German foreign investments, provided that an agreement concerning treatment of the investment had been concluded, or, absent such agreement, the legal system of the respective state sufficiently guaranteed the safety of the investment. This provision would enable the German Government to foster development abroad through private investment. The Government recalled this legal requirement of guaranteed safety of investments when it presented the BIT with Pakistan to the Bundestag in the same year. Stating that the adoption of this treaty in itself fulfill the legal requirements of the relevant provision of the Budget Act, the Government added that this specialized investment treaty extended the economic aspects of the traditional FCN treaties and would at the same time create more favourable conditions for the German investors in Pakistan.

Kujiper (Peter Jan), "Study on Investment Protection Agreements as Instruments of International Economic Law", on Directorate-General for External Policies-Policy Department, Investor-State Dispute Settlement (ISDS) Provisions in the EU's International Investment Agreements, Volume 2-Studies, European Union, 2014, 9-10 pp.

${ }^{300}$ Preamble of the Agreement between the Federal Republic of Germany and the Republic of Ecuador to Promotion and Reciprocal Protection of Investments:

"Desiring to foster and strengthen economic co-operation between the Federal Republic of Germany and the Republic of Ecuador;

Intending to create favourable conditions for investment by nationals and companies to either Contracting Party in the territory to the other Contracting Party, and

Recognizing that contractual protection and promotion of such capital investments is likely to promote private business initiative and to increase the welfare of both nations." 
"(investor-state disputes are) to be distinguished from a typical commercial arbitration on the basis that a State (is) the Respondent, the issues (have) to be decided in accordance with a treaty and the principles of public international law and the principles of public law and a decision on the dispute could have a significant effect extending beyond the two Disputing Parties." 301

Blackaby explains that, whereas in commercial arbitration, the source of consent to arbitration normally rests on the arbitration clause, in investment arbitration, such consent is expressed through an open offer to arbitrate disputes with investors having the nationality of another state in relation to specific classes of investment. ${ }^{302}$ The definition of "arbitration without privity" as defined by Paulsson, describes the absence of need for a direct link between the state and the investor, when an investment dispute is brought ${ }^{303}$ Blackaby summarizes that a state is "unaware of the specific identity of potential disputants until they are notified of the existence of a dispute under the relevant Treaty". ${ }^{304}$ Later on, the BIT signed between Ecuador and Switzerland (1968) suppressed from the preamble the reference to contractual protection, delineating correctly the ongoing nature of investment law.

The treaties mentioned above include the main investment standards of protection like fair and equitable treatment ("FET"), national treatment, most favoured nation ("MFN"), non-discrimination and prohibition for direct and indirect measures of expropriation and nationalization without effective and adequate compensation.

In the first BIT signed between the Federal Republic of Germany and Ecuador, the definition of protected investment referred to "capital investments", although the list

${ }^{301}$ Methanex Corporation v. United States of America, NAFTA case, under UNCITRAL rules, Decision on Amicus Curiae, 15 January 2001, 9, para 7. Text available of the ITA website: http:)//ita.law.uvic.ca/chronological_list.htm.

Blackaby (Nigel), Investment Arbitration and Commercial Arbitration (Or the tale of the Dolphin and the Shark) on Pervasive Problems in International Arbitration, Ed. Mistelis (Loukas A.) and Lew (Julian D.M), Kluwer law International, The Netherlands, 2006, 218.p.

${ }^{302}$ Blackaby (Nigel), Investment Arbitration and Commercial Arbitration (Or the tale of the Dolphin and the Shark) on Pervasive Problems in International Arbitration, Ed. Mistelis (Loukas A.) and Lew (Julian D.M), Kluwer law International, The Netherlands, 2006, 219.p.

303 Paulsson (Jan), “Arbitration without Privity”, 10 ICSID Review-FILJ 232 (1995) on Blackaby (Nigel), Investment Arbitration and Commercial Arbitration (Or the tale of the Dolphin and the Shark) on Pervasive Problems in International Arbitration, Ed. Mistelis (Loukas A.) and Lew (Julian D.M), Kluwer Law International, The Netherlands, 2006, 219 p.

${ }^{304}$ Blackaby (Nigel), Investment Arbitration and Commercial Arbitration (Or the tale of the Dolphin and the Shark) on Pervasive Problems in International Arbitration, Ed. Mistelis (Loukas A.) and Lew (Julian D.M), Kluwer law International, The Netherlands, 2006, 219 p. 
provided for by the relevant article is not exhaustive and does not only include assets in the form of money. In this regard, the protected investments comprise tangible and intangible rights, intellectual property rights and concessions granted by public entities. ${ }^{305}$ In the case of the BIT between Ecuador and Switzerland the definition of investment did not rely on a specific category as the first BIT analyzed, but it similarly included a broad list of goods and rights, including several that pursuant to domestic law are not susceptible of transaction.

It is worth underlining that concessions in Ecuador constitute administrative acts and as such entail the manifestation of sovereign powers' exercise, being confined to Public Law. Therefore, concessions are subject to a special administrative regime beyond the will and parties' private autonomy. Although the terms under which the concession will be carried out can be stipulated by contract, any dispute related to a legal violation of the precepts that sustained the granting and the subsistence of this administrative act may not be subject to transaction, and hence, neither to arbitration. This notion derived from the Continental legal tradition embraced by Ecuador, and cannot be conceived from a private based approach and consequentially understood as an investor's asset.

At the time that the first BIT was signed, there was in force the Constitution of 1946, which entrusted to the Council of State the contentious administrative jurisdiction and correspondingly the power to rule about administrative action's lawfulness ${ }^{306}$. Shortly after the signature of the BIT between the Federal Republic of Germany and Ecuador, a new Constitution was enacted. ${ }^{307}$ This constitutional framework abolished the Council of

\footnotetext{
305 Tratado Bilateral de Inversiones suscrito entre la República del Ecuador y la República Federal de Alemania (1965), “Artículo VIII:

(1) El concepto de "inversiones de capital" comprende toda clase de bienes y en particular aunque no exclusivamente:

a) La propiedad de bienes muebles e inmuebles y demás derechos reales;

b) Participaciones en sociedades y otra clase de participaciones;

c) Reclamos monetarios o de prestaciones que tengan un valor económico;

d) Derechos de autor, derechos de propiedad industrial, procedimientos técnicos, nombres comerciales y valor comercial;

e) Concesiones otorgadas por entidades de derecho público, incluida las concesiones de exploración y beneficio.

Una modificación en la forma en que se inviertan los capitales, no afecta a su naturaleza como inversión de capital."

${ }^{306}$ Constitution of 1946 :

"Art. 146.- Son atribuciones y deberes del Consejo de Estado:

8. Conocer y decidir en las cuestiones contencioso administrativas."

${ }^{307}$ Constitución Política de la República del Ecuador, Registro Oficial 133 de 25 de mayo de 1967.
} 
State and vested with the contentious administrative $\mathrm{e}^{308}$ and $\operatorname{tax}^{309}$ matters judicial review of specialized tribunals. The BIT concluded between Switzerland and Ecuador took place during the rule of the Constitution of 1967 and shortly after, the new system of contentious and tax matters judicial control was established. ${ }^{310}$.

In parallel, it has to be recalled that the Constitution of 1967 enshrined as a fundamental concept of the State, the subordination to International Law. Correspondingly, it declared International Law as the rule of conduct among the States and their reciprocal relations. ${ }^{311}$ At this level, the constitutional framework instituted that the settlement of international disputes would be subject to judicial and peaceful means.

${ }^{308}$ Constitution of 1967 :

“Art. 213.- Tribunales de lo Contencioso.- Los Tribunales de lo Contencioso sede en Quito y jurisdicción en todo el territorio nacional, conocerán y decidirán de las cuestiones contencioso administrativas y contencioso tributarias.

Art. 215.- Atribuciones.- Al Tribunal de lo contencioso administrativo corresponde conocer las impugnaciones que las personas naturales o jurídicas hicieran contra los reglamentos, actos y resoluciones de la Administración Pública o de las entidades semipúblicas, y resolver acerca de su ilegalidad o inaplicabilidad; correspóndele igualmente conocer y resolver lo concerniente a las violaciones de la ley reguladora de la Carrera Administrativa, y declarar la responsabilidad, de la Administración, y de sus funcionarios y empleados.

La ley fijará el número de Salas y magistrados; determinará asimismo la organización y funcionamiento del Tribunal que deba conocer de lo contencioso general y del que conozca de lo contencioso tributario."

309 Constitution of 1967 :

“Art. 216.- El Tribunal Fiscal.- El Tribunal Fiscal conocerá y decidirá las cuestiones contencioso tributarias, inclusive las aduaneras y las que nazcan de la violación de sus leyes tributarias; también, las impugnaciones a las resoluciones de la Contraloría que establezcan responsabilidad económica en materia fiscal, en la gestión económica estatal, municipal, o de otras instituciones sometidas al control y juzgamiento de aquella, y las demás cuestiones cuya resolución le atribuya la ley."

${ }^{310}$ As a consequence, the Law on the Contentious Administrative Jurisdiction was promulgated Official Gazette 338, March 18, 1968.

${ }^{311}$ Constitution of 1967 :

“Art. 9.- Principios de Derecho Internacional.- El Estado Ecuatoriano proclama la paz y la cooperación como sistema de convivencia internacional y la igualdad jurídica de los Estados; condena el uso o la amenaza de la fuerza como medio de solución de los conflictos, y repudia el despojo bélico como fuente de derecho. Propugna la solución de las controversias internacionales por métodos jurídicos y pacíficos, y declara que el Derecho Internacional es norma de conducta de los Estados en sus relaciones recíprocas.

Propugna también la comunidad internacional, así como la estabilidad y fortalecimiento de sus organismos, y dentro de ella, la integración iberoamericana, como sistema eficaz para alcanzar el desarrollo de la comunidad de pueblos unidos por vínculos de solidaridad, nacidos de la identidad de origen y cultura.

El Ecuador podrá formar, con uno o más Estados, asociaciones para la promoción y defensa de los intereses nacionales y comunitarios." 
In correspondence with the firmly rooted principle of equal treatment subject to specific exceptions conferred to foreigners since the Constitution of 1835, the Constitution of 1946 proclaimed such a precept, with exclusion to the exercise of political rights and those guarantees that the constitutional provisions exclusively recognize in favor of Ecuadorians $^{312}$. Additionally, this constitution entrusted to the law to determine the borderline area, in which foreigners were forbidden to acquire or maintain land rights. ${ }^{313}$ In coherence with this treatment, the Constitution enshrined the principle of equality before law, forbidding conferring rights or imposing obligations, which may improve or worsen the condition of individuals before others ${ }^{314}$; the latter prohibition was first incorporated by the Constitution of 1929. In this context, it is clear that the Constitution as principle, tolerated the exclusion of foreigners concerning the enjoyment of specific rights, the same that did not expand either to the exercise of civil rights nor to the resort to mechanisms of constitutional, judicial or administrative redress. As consequence such constitutional exceptions did not diminish the principle of equality before the law. Conversely the admittance of an international legal framework of protection exclusively available to foreign investors could raise concerns with respect to the affectation of the mentioned principle.

Concerning the principle of equality before the law, the Constitution of 1967 regulated with more detail the coexistence of such a precept with the growing relationship with foreign investment. as the principle aspect, this Constitution set forth the equality of

312 Constitution of 1946 :

“Art. 180.- Los extranjeros gozan en el Ecuador, en los términos que exija la Ley, de los mismos derechos que los ecuatorianos, con excepción de los derechos políticos y de las garantías que la Constitución establece a favor de solo los ecuatorianos."

${ }^{313}$ Constitution of 1946 :

“Art. 184.- La ley determinará la zona fronteriza en la cual sea prohibido a los extranjeros adquirir o mantener derechos reales sobre inmuebles o administrarlos, bajo pena de perder tales derechos en beneficio del Estado. Esta prohibición no obstará a que haya extranjeros en el personal de las instituciones de carácter nacional, o que, por motivos de interés nacional, se establecieren en las regiones fronterizas, de acuerdo o por contrato con el Ejecutivo; siempre que el director y el representante legal de estas instituciones sean ecuatorianos."

314 Constitution of 1946 :

“Art. 169.- Para obtener el amparo de la Ley, todas las personas son iguales ante ella a nadie se le pueden conceder derechos ni imponer obligaciones que le hagan de mejor o peor condición que a los demás.

Nadie puede ser distraído de sus jueces naturales; ni penado sin juicio previo, conforme a una ley anterior al hecho materia del juzgamiento; ni juzgado por comisiones especiales; ni privado del derecho de defensa en cualquier estado del juicio." 
Ecuadorians before the law ${ }^{315}$. It enlarged the drafting of the prohibition to confer rights or imposing obligations, which may improve or worsen the condition of individuals before others, including the proscription of discrimination based on certain motives ${ }^{316}$. In coherence with the Constitution of 1946, it prescribed the equality before law between Ecuadorians and foreigners, with the exception of the constitutional guarantees and the political rights exclusively recognized to nationals, and further exclusions prescribed by the law. ${ }^{317}$ With relation to the treatment of private enterprises, the constitutional framework entrusted to the State the obligation to stimulate such activity, imposing the correlative duty, to prevent such enterprises from developing themselves at the expense of the common welfare or in prejudice to human security, freedom or dignity. The Constitution of 1967 authorized the grant of special protection to private investments devoted to infrastructure works. ${ }^{318}$ Particularly remarkable is the equal treatment guaranteed to national and foreign capital, with exception to those areas that the State may reserve to the former. ${ }^{319}$ Finally and in line with the objective for promoting private activity, the Constitution determined that the taxation laws should stimulate investment, reinvestment, and saving. ${ }^{320}$ Although the friendly constitutional approach for hosting

315 Constitution of 1967 :

"Art. 4.- Igualdad ante la ley.- Los ecuatorianos son iguales ante la ley."

${ }^{316}$ Constitution of 1967 :

"Art. 25.- Igualdad.- No se hará discriminación alguna basada en motivos tales como raza, sexo, filiación, idioma, religión, opinión política, posición económica o social. No se concederá prerrogativa alguna ni se impondrá obligaciones que hagan a unas personas de mejor o peor condición que otras. No hay dignidades ni empleos hereditarios, privilegios ni fueros personales. La honradez, la capacidad y otros méritos serán los únicos fundamentos de valoración personal.”

317 Constitution of 1967 :

"Art. 81.- Igualdad de derechos con los ecuatorianos. En ellos términos que fije la ley, los extranjeros gozarán de los mismos derechos que los ecuatorianos; se exceptúan las garantías constitucionales y los derechos políticos establecidos exclusivamente en favor de los ecuatorianos."

${ }^{318}$ Constitution of 1946:

“Art. 86.- Empresa privada.- La actividad privada recibirá estímulo del Estado para la creación de nuevas empresas, para su ampliación y reinversión de sus beneficios en actividades lucrativas. El Estado impedirá que tales empresas se desarrollen con mengua del bien común o en perjuicio de la seguridad, libertad o dignidad humanas.

De manera especial protegerá las inversiones privadas destinadas a obras de infraestructura."

${ }^{319}$ Constitution of 1946 :

"Art. 90.- Capitales nacionales o extranjeros.- En derechos y obligaciones, el capital extranjero se equipara al nacional; pero el Estado puede reservar al capital ecuatoriano determinados sectores de inversión."

${ }^{320}$ Constitution of 1946 : 
investments and the allegedly reciprocal nature of the BITs, the fact of setting up a separate judicial system with a different category of substantive and procedural rules exclusive to foreign investors, would seem to be a serious diminishment of the constitutional and democratic principle of equality before law.

\subsubsection{The Emerging Conflict Between Constitutional Provisions and International Investment Obligations}

\subsubsection{The Principle of Equality Before the Law}

Raineri and Trackman warn about the practical abolishment of the principle of equality before the law in favour of the interests of multinational corporations as one of the main flaws of the regime of international investment protection, aggravated by the absence of adequate institutional machinery that may be capable of dealing in an evenhanded way with abuses derived from the operations of such enterprises:

The rule-of-law argument in the context of the international law on investment does not even recognize the principles of equality, one of the basic tenets of the rule of law, in that it privileges the foreign investor over local entrepreneurs and the interests of the local citizenry. It does not permit the same access to foreign arbitration that the foreign investor has so that the home state could institute arbitrations against abusive conduct of multinational corporations. The Diceyan concept of the rule of law as requiring equality before the law is violated by the investment treaty system because it clearly privileges the foreign investor over domestic entrepreneurs and hinders the regulatory powers of the state to protect its citizens in times of crisis. ${ }^{321}$

It could be argued that the putative diminishment of the principle at issue would have to be tested against the standards provided by International Law rather than to those covered under the frame of Constitutional Law. Following this argument, the reciprocal protection provided by the BITs on the basis of the nationality of the investors, would determine the scope of the addressees of the corresponding legal prescriptions. Although the Ecuadorian experience shows that such protection has been invoked only in one way, it could be affirmed that the legal possibility of any Ecuadorian investor to resort to the application

“Art. 100.- Estímulo de inversiones.- Las leyes tributarias tenderán a estimular la inversión, la reinversión de capitales y el ahorro."

321 Trackman (Leon E.) and Rainieri (Nicola W.), Regionalism in International Investment Law, Oxford University Press, $491 \mathrm{p}$. 
of a duly adopted BIT, remains unaltered. The recognition of such a level of legal protection would operate as a mutual incentive for channelling investments between the contracting parties. Therefore any factual evidence that may corroborate the absence of Ecuadorian investment in the countries, with which such a level of protection has been accorded, would be futile under the letter of the law. In consequence the agreement of the Parties to establish an autonomous system of protection with special substantive and procedural rules in favour of their nationals falling within the category of foreign investors, would imply an acceptance that the benefits arising from the their activities are extraordinarily regarded, not only before those that may bring investment qualified as national, but also before foreign investment not covered by BITs. In theory, the reciprocal sacrifice of sovereign space translated in the differential treatment provided to investors covered by BITs, would serve the purpose of unifying a set of protection rules detached from domestic influence in favour of the predictability and security that these minimum international standards may bring to the investors.

Lucy explains that juridical equality has three components:

The first can be called the presumptive-identity component. It is so named because bourgeois or liberal law usually sees its addressees not in all their particularity but as identical abstract beings. Furthermore, addressees of the law are identical in two respects according to this component: they are regarded as if they were the same in terms of those capacities, both cognitive and physical, that enable humans to comply with achievable and intelligible legal standards; and they are taken to be identical in the sense of all having the same entitlement to the same bundle of 'formal' legal rights and abilities. ${ }^{322}$

Under International Investment Law, the addressees of the protection, would be the individuals defined as foreign investors, whose nationality would enable them to resort to the protection of a BIT. The same scholar adds:

The second component is the uniformity component, which entails that, generally speaking, bourgeois law judges its addressees by reference to general and objective standards equally applicable to all. The idea that the same laws should apply to all citizens or addressees of the law is so powerful that it casts suspicion upon laws that apply to particular persons or groups. This requirement, once apparently called 'isonomy,' is probably identical to some versions of the generality requirement of the 'rule of law' ideal. ${ }^{323}$

\footnotetext{
${ }^{322}$ Lucy (William), "Equality under and before the Law", The University of Toronto Law Journal, Vol. 61, No. 3 (Summer 2011), University of Toronto Press, 413 p.

${ }^{323}$ Lucy (William), "Equality under and before the Law", The University of Toronto Law Journal, Vol. 61, No. 3 (Summer 2011), University of Toronto Press, 413 p.
} 
Pursuant to this principle, the BITs and further sources of Public International Law employed for testing the State's liability would be applicable indiscriminately to persons, natural or juridical, qualified as foreign investors. Finally the third component as explained by Lucy is:

The limited- avoidability component is the third element of juridical equality. It highlights the fact that the application of the standards in play in the uniformity component is often mitigated only by a limited number and range of exculpatory claims.Exculpatory claims are limited in range because subject to reasonableness standards. So, for example, to successfully invoke the partial defence of provocation in criminal law, it is not enough simply to show that one is very bad tempered. One is held to a reasonableness standard here, as is the case in many other areas of both private and criminal law, and it usually matters not that one is unable to achieve such a standard. ${ }^{324}$

In the absence of an institutional system of international investment settlement of disputes, successfully invoking such exculpatory claims would depend on the letter of the BIT and complementary with the international standards of protection developed by Public International Law. The same scholar points out:

(...) Hence laws which name particular addressees or which benefit particular groups are prima facie troublesome in most legal systems, even though many laws have the latter effect. There are also laws in most legal systems that attempt to take account of the context or character or particularity of a specific class of claimants or defendants, but these, too, are often regarded as exceptional, as concessions to equity or mercy or some such allegedly non-legalistic virtue. ${ }^{325}$

Indeed and as contended by Raineri and Trackman the principle of equality as one of the basic pillars of the rule of law would be seriously undermined by the structure implied by the investment protection regime, especially concerning the differential treatment accorded to foreign investors before any other category of investors. Lucy differentiates between equality before the law and equality under the law. Whereas the former pertains to the scope of legal standards that apply to the law addressees, the latter concerns an "equality of application requirement". The equality before law includes:

The presumptive-identity component, in treating all addressees of the law as if they were the same in terms of both their capacities and their formal legal rights, is a means of ensuring equality before the law: all who stand before the law, making and rebutting legal claims, are prima facie of the same nature. The law, therefore, sees neither claimant nor defendant, neither accused nor victim, as the actual human beings they truly are, in all their detail and specificity. Neither does

\footnotetext{
${ }^{324}$ Lucy (William), "Equality under and before the Law", The University of Toronto Law Journal, Vol. 61, No. 3 (Summer 2011), University of Toronto Press, 414 p.

${ }^{325}$ Lucy (William), "Equality under and before the Law", The University of Toronto Law Journal, Vol. 61, No. 3 (Summer 2011), University of Toronto Press, 414 p.
} 
it often see or even notice the specific set of abilities or experiences those being judged have, nor recognize their different social, cultural, economic, or ethnic backgrounds. Unless legal doctrine requires otherwise, the law is ostensibly blind to these differences, treating duke and pauper, man and woman, Christian and non-Christian, homo- and heterosexual, aesthete and philistine alike. The law also obviously treats those brought before it alike, as the same, in that it regards all its addressees as having the same bundle of formal legal rights. ${ }^{326}$

By analogy, the specific set of abilities or experience shown by Lucy could be transposed to the assessment of the State's action. Re-affirming that the limited avoidability component serves both for reinforcing the principles of equality before and under the law as a hallmark of the uniformity component by subjecting all addressees of the law to reasonable standards, the mentioned scholar briefly explains such distinction as follows:

(..,) The analysis just provided shows that there is no reason to assume that equality before the law and equality under the law are the same. The former illuminates the assumed similarity of those whom the law judges, the latter the similarity of the standards by which they are judged. ${ }^{327}$

The former similarity would be guaranteed through the BITs, in principle, by the requirement of nationality and the verification that an investment may be protectable pursuant to such conventions. The latter similarity would be assured through the "equality of application" of the pertinent standards, without setting aside the limited-avoidability component and a reasonable standard of performance. In this regard, under International Investment Law, apparently, the addressees, namely foreign investors and States, would "stand in the same relation before and under the law". ${ }^{328}$ In consequence, the formal legal equality as structured by International Investment Law would be safeguarded. However in reality, the addressees both of the protections and of the burdens of the system would normally be developed countries' companies, in the former case, and developing countries' States in the latter. This imbalance rather of being a legal flaw of the system, responds to the logic of the global economic order:

Moreover, one's legal status as the equal of all other citizens, all being endowed with the same bundle of formal legal rights, is untouched by class-based social stratification except with regard to what can be called the actual realizable value of those rights. It is almost a universal truth in class-based capitalist societies that

\footnotetext{
${ }^{326}$ Lucy (William), "Equality under and before the Law", The University of Toronto Law Journal, Vol. 61, No. 3 (Summer 2011), University of Toronto Press, 414 p.

${ }^{327}$ Lucy (William), "Equality under and before the Law", The University of Toronto Law Journal, Vol. 61, No. 3 (Summer 2011), University of Toronto Press, 416 p.

${ }^{328}$ Lucy (William), "Equality under and before the Law", The University of Toronto Law Journal, Vol. 61, No. 3 (Summer 2011), University of Toronto Press, 414 p.
} 
those who are best placed in class terms get better value from their bundle of legal rights. Their legal rights do more work for members of advantaged groups in part because members of these groups are better educated, which usually entails better knowledge of rights and a greater capacity and willingness to act to uphold or realize them; and in part because their greater economic power ensures easier access to legal advice. In societies such as this, all have the same bundle of formal legal rights, the 'formality' here marking exactly the fact that the actual realizable value of those rights may well differ for different right-holders or groups of rightholders. Of course, discrepancies between the value identical bundles of rights have for different groups are troubling, but not because they contradict juridical equality. At least, there is no contradiction here provided that juridical equality, as we have maintained, is not necessarily a form of substantive equality that insists all get equal value from their rights. ${ }^{329}$

This formalistic legal approach suits perfectly the reality of the historical logic of International Investment Law, in the same way that although it would not contradict formal equality, it would actually undermine the substantive equality of the system. Within this formalistic perspective, the juridical equality of the addressees of International Investment Law, namely foreign investors and States, would have to be tested under the frame of this particular regime. Hence, national investors and foreign investors not protected by BITs could not claim a violation of the principle of juridical equality for not being entitled to resort to the protection of such a regime, due to the simple reason that they are outside this particular bundle of formal legal rights. In this regard, the exclusion of such standards of protection to national investors and to foreign investors not protected by a particular BIT correspond to the stage of law creation, and in consequence, the verification of the observance of the principles of equality before and under the law, would come after the particular framework is established.

As regards the equality of application within International Investment Law, arbitrators, first, have an extremely difficult task for assessing that the pre-conditions for resorting to the system are unquestionably fulfilled and as a consequence, the reasons for according a differential treatment are legitimate. Moreover, the absence of an institutional framework of adjudication would constitute a threat of uniform application of the law, and correspondingly of the principle of equality before the law. This risk is particularly plausible when the State's international liability assessment is made in contradiction to fundamental constitutional values, taking the BITs provisions as self-contained, isolated and mechanic. Indeed, providing "equal treatment in the face of pervasive differences is

\footnotetext{
${ }^{329}$ Lucy (William), "Equality under and before the Law", The University of Toronto Law Journal, Vol. 61, No. 3 (Summer 2011), University of Toronto Press, 444 p.
} 
simply a means of unequal treatment" ${ }^{\prime 30}$. In any case, at the international level it is clear that the uniformity component of juridical equality in the realm of International Investment Law, has disproportionally affected the countries and foreign investors involved, the former normally being developing countries and the latter, usually companies of capital exporting countries.

\subsubsection{Expropriation}

From internal reports of the Ministry of Foreign Affairs of Ecuador, it has been identified that the legal warnings were made by certain authorities alleging the contradiction of the provisions governing the scope of expropriation provided by the BITs concluded during the 1980s with the correlative constitutional precepts under which such conventions were ratified. The main argument invoked concerns the extension of the terms "public utility" and "social interest", as a basis for the administrative act of expropriation. It is contended that whereas the former concept would include activities directly related to the Public Administration's attributions for whose execution the right to property would have to be restricted or deprived, the former would embrace decisions that serve vaster social objectives not necessarily linked to a particular administrative activity, like the imposition of sanctions or the declaration of concessions' caducity or termination for restoring the legal order. Hence, the concept "public utility" set forth in the treaty analyzed, namely the BIT signed with Switzerland, would entail a restrictive notion on the grounds that the constitutional provisions actually allowed expropriating and lawfully limiting or depriving the right to property on situations different to nationalization. This internal report correctly underscores that in domestic law, there are several measures of deprivation of property that do not amount to expropriation and as such do not entail the obligation of compensation. In this context, it has to be recalled that under domestic law, not all the public measures that derive from the deprivation or limitation of the right to property are required to follow the procedure of expropriation, and for this reason, it is alleged that the concept of "social interest" would cover such actions (i.e, nationalization, extinction of property rights or reversion of concessions),

\footnotetext{
${ }^{330}$ Lucy (William), "Equality under and before the Law", The University of Toronto Law Journal, Vol. 61, No. 3 (Summer 2011), University of Toronto Press, 438 p.
} 
whereas the notion of "public utility" would only be circumscribed for the exercise of the sovereign act of expropriation. ${ }^{331}$

As noted in Chapter I, the Constitutional Court underlined that the concepts of public utility and social interest as a basis for exerting the sovereign act of expropriation cannot be taken as synonyms. The Court stated that, while the former concept concerns the general welfare, the latter is related to a specific group of people or collectivity, departing slightly from the arguments expressed in the report at issue. In any case, the Constitutional Court's ruling exclusively applies to the exercise of expropriation acts, leaving aside any other decision of limitation or deprivation of property not considered as expropriation.

\footnotetext{
${ }^{331}$ The General Direction of Treaties of the Ministry of Foreign Affairs of Ecuador prepared a report at the request of the Political Undersecretary of the same entity, concerning the convenience for maintaining or modifying the BIT signed with Switzerland pursuant to the Constitutional Codification of 1984. Article 3 of the said BIT prescribes:
}

"Acuerdo entre la República del Ecuador y la Confederación Suiza relativo a la protección y al fomento de inversiones":

Artículo 3.- Ninguna de las Altas Partes Contratantes podrá tomar medidas de expropiación, de nacionalización o de desposeimiento, directas o indirectas, contra bienes pertenecientes a nacionales o sociedades de la otra Parte, a no ser por razones de utilidad pública y a condición de que estas medidas den lugar al pago de una indemnización efectiva o adecuada, conforme el derecho internacional. El importe de esta indemnización, que deberá fijarse en el momento de la expropiación, de la nacionalización o del desposeimiento, será liquidada en moneda transferible y será entregada sin tardanza al derecho habiente, cualquiera sea su lugar de residencia o sede".

Concerning the alleged contradiction of the provision governing expropriation with the Constitutional Codification of 1984, the report states:

“6. El artículo 3 del Acuerdo, a juicio de la Dirección General de Tratados, entraña un problema de fondo en relación con lo que dispone la Constitución Política en vigencia y diversas leyes especiales que tienen que ver con el desarrollo económico del país y la salvaguardia de los derechos de sus habitantes. Por un lado, el Artículo al disponer que las Partes no podrán tomar medidas de expropiación, de nacionalización o desposeimiento, a no ser por razones de "utilidad pública" y previo el pago de "una indemnización efectiva y adecuada", contradice el espíritu del Artículo 47 de la Constitución Política, en el que se consagra el concepto de "orden social", más amplio que el de "utilidad pública" y que propicia el marco legal adecuado para los casos de reversión del Estado contemplados en las legislaciones especiales como la de Reforma Agraria, la Ley de Minería, etc. Por otro lado, al disponer que las medidas de expropiación, nacionalización o desposeimiento, no podrán tomarse sin que den lugar al pago de indemnización, se está obstaculizando la aplicación de leyes, como la Reforma Agraria, cuyo artículo 45 estipula precisamente que en casos como los de reversión y extinción del derecho de dominio, por tierras insuficientemente explotadas, el Estado no está obligado a pagar indemnización alguna, justamente en virtud del concepto de orden o función social que entrañan este tipo de acciones. Este conflicto se produciría también con otras legislaciones especiales que contemplan las figuras de concesión y correlativamente de reversión, como en el caso de la legislación minera."

Memorandum N/032-88 DCT submitted by the General Direction of Treaties to Politics Undersecretariat ; reference: Agreement between Ecuador and Switzerland Related to Protection and Promotion of Investments. 
The Constitution of 1946 was in force when the Treaty with the Federal Republic of Germany was signed (1965) and it recognized the right to property as long as it is concealed with its social function. ${ }^{332}$ Identically the Constitution of 1967 in force when the Treaty with Switzerland was signed, guaranteed the right to property with the same condition. With regard to expropriation, the Constitution of 1967 incorporated social interest reasons to the purposes of public utility ${ }^{333}$ already enshrined by the Constitution of 1946. The Constitution of 1967 also clarified that any expropriation included a fair compensation, except when the law stated otherwise. Pursuant to these constitutional provisions, it has to be recalled that the Ecuadorian legal tradition has historically recognized expropriation as a lawful administrative act having as effect the deprivation of the use, enjoyment or disposition of the right to property. However no restriction of the right to property has to be preceded by an expropriation and hence by fair compensation. Precisely this is a limitation that is derived from the social function of property and its submission to the legal order, in whose conditions the exercise of such a right can be restricted and even removed in the cases prescribed by the Constitution and the law.

\footnotetext{
${ }^{332}$ Constitution of 1946 :
}

“Art. 183.- Se garantiza el derecho de propiedad conciliándolo con su función social. Prohíbese la confiscación de bienes, la que, si de hecho llegare a producirse, no causará alteración alguna en el derecho de la parte perjudicada ni prescripción de ninguna clase y originará, contra la autoridad que la ordenarare y contra el Fisco, acción sumaria de daños y perjuicios.

Nadie puede ser privado de la propiedad, ni de la posesión de sus bienes, sino en virtud de mandato judicial o de expropiación, legalmente verificada, por causa de utilidad pública.

Solo el Fisco, las Municipalidades y las demás Instituciones de Derecho Público podrán promover expropiaciones por causa de utilidad pública.

La expropiación para construcción, ensanche y mejora de caminos, ferrovías, campos de aviación y poblaciones, se regirá por leyes especiales.

Solamente las autoridades que ejercen función judicial en cualquier orden que emane de la Ley, podrán dictar providencias que impidan u obsten la libre contratación, transferencia y transmisión de la propiedad. No surtirá efecto, ni será obedecida, orden alguna al respecto que dimane de otra autoridad."

${ }^{333}$ Constitution of 1967:

“Art. 49.- Expropiaciones.- Nadie puede ser privado de la propiedad ni de la posesión de sus bienes sino en virtud de mandato judicial o de expropiación legalmente efectuada por causa de utilidad pública o de razón social.

Solo el Estado y demás entidades de derecho público podrán decretar expropiaciones por causa de utilidad pública o de interés social, reconociendo la justa indemnización, salvo los casos en que la ley no la establezca." 
In line with the abovementioned, the main conflict would arise out from the fact that the BITs concluded by Ecuador have circumscribed any public measure that may affect the investor's right to property, as a decision that would have to follow the process of expropriation and correspondingly, compensation. ${ }^{334}$ Again, this submission contradicts the Ecuadorian constitutional tradition and the limitations provided to the right to property, whose lawful restriction or deprivation are not exclusively limited to an expropriation. This view is in line with the observation provided above, in regard to the private nature approach transposed to certain investor's assets such as administrative concessions, which under the Ecuadorian constitutional tradition would not be within the private sphere, and in consequence its restraint would not have to be tested in the scope of the right to property. In conclusion, the concepts of public utility and social interest would only have to be examined when the right to property and its components (use, enjoyment and disposition) were directly and deliberately removed. Any further restriction or limitation to the right to property prescribed by law would be in principle tolerable and any allegation against the constitutionality of such provisions would have to be assessed in the light of other constitutional provisions and values, not exclusively confined to the right to property. In conclusion, the compromise adopted by Ecuador through the BITs signed with the Federal Republic of Germany and Switzerland to subject to the process of expropriation any measure affecting directly or indirectly the investor`s right to property in accordance to International Law, overlooked the constitutional restrictions to this right historically enshrined by the former constitutional frameworks. These BITs also included further categories like "indirect expropriation" alien to the national constitutional tradition amounting to the self-restriction of sovereign powers' exercise, turning in practice investors' right to property into the predominant value to be protected by the legal order and the public actions.

${ }^{334}$ Constitución de 1967:

“Art. 48.- Confiscación de bienes.- Prohíbese la confiscación de bienes: si de hecho llegare esta a producirse, no causará prescripción ni alteración alguna en el derecho de la parte perjudicada, $\mathrm{y}$ originará contra la autoridad que la hubiere ordenado y contra el Estado, acción sumaria de daños y perjuicios.

Las multas, comisos y penas que afecten al dominio de bienes muebles serán determinados por la ley." 


\subsubsection{Scope of the Calvo Doctrine}

As illustrated above, since 1897, the different Ecuadorian constitutional frameworks have recognized the Calvo Doctrine. The Constitution of 1929 regulated with more detail the scope of such a doctrine and further prohibited waiver of jurisdiction in contracts signed in Ecuador between the State, public entities and individuals. In this context, the Constitutions of 1946 and 1967, by which the BITs with the Federal Republic of Germany and Switzerland were signed respectively, although they recognized the Calvo Doctrine, did not incorporate explicitly the aforementioned restriction. However, and bearing in mind the predominance of the Civil Code for governing the rules of legal interpretation and general prohibitions, it is remarkable to note the provision that declares an object illicit and in consequence null, everything that contradicts Ecuadorian Public Law. This provision in force, when the aforementioned BITs were adopted, declared that any promise of being subject in Ecuador to a jurisdiction not recognized by the Ecuadorian law would be null due to the illicit object of the agreement. ${ }^{335}$ Additionally, it prescribed an illicit object concerning the disposal of goods that are not in commerce, as well as to non-transferable rights and privileges. ${ }^{336}$ It has to be noted that in 1976, the governing board ruling the dictatorship regime, issued an interpretation of this provision, enabling contracts signed outside the national territory to be submitted to foreign jurisdiction. ${ }^{337}$

${ }^{335}$ Civil Code (1930):

“Art. 1452.- Hay objeto ilícito en todo lo que contraviene al Derecho Público ecuatoriano. Así, la promesa de someterse en el Ecuador a una jurisdicción no reconocida por las leyes ecuatorianas, es nula por vicio del objeto.”

Codificación 0, Registro Oficial Suplemento 352, 20 de junio de 1930.

${ }^{336}$ Civil Code (1930):

“Art. 1454.- Hay objeto ilícito en la enajenación:

1. De las cosas que no están en el comercio;

2. De los derechos o privilegios que no pueden transferirse a otra persona;

3. De las cosas embargadas por decreto judicial, a menos que el juez lo autorice, o el acreedor consienta en ello:

4. De especies cuya propiedad se litiga, si se ha hecho sin permiso del juez que conoce en el litigio."

Codificación 0, Registro Oficial Suplemento 352, 20 de junio de 1930.

${ }^{337}$ Supreme Decree No. 797 B:

"Art. 1.- Interprétese el art. 1505 del Código Civil de acuerdo con lo dispuesto en el inciso segundo del art. 153 de la Constitución Política ${ }^{337}$ en el sentido de que el convenio de sujetarse a una jurisdicción extraña procede únicamente cuando los correspondientes contratos se celebren fuera del territorio nacional."

Official Gazette 193, Supreme Decree No. 797 B, October 15, 1976. 
At the time the BIT with the Federal Republic of Gemany was adopted (1965), there did not exist the constitutional requirement to request to the Tribunal of Constitutional Guarantees to issue a binding ruling concerning the ratification of certain treaties, as did the Constitution of 1967, under which the Treaty with Switzerland was concluded (1968). For this reason, this BIT was approved by the Legislative Branch and further ratified by the President.

It has to be recalled that the Constitution of 1967 introduced for the first time the obligation for obtaining a prior constitutional ruling before the ratification of an international treaty, a requirement that was reinserted with certain changes as of the Constitution of 1998 . However this prior constitutional ruling set forth by the Constitution of 1967 was only required for the treaties that: 1) did not include permanent duties or burdens on the Public Budget or on the Ecuadorian citizens, and; 2) did not require the enactment of legislative measures for their application. ${ }^{338}$ It has not been possible to access the prior ruling issued by the Tribunal of Constitutional Guarantees whereby it authorized the ratification of the BIT with Switzerland. However and on the assumption that this convention falls under the categories stated above, it is probable that there could have been a contradiction of the treaty's provisions with several constitutional principles like those previously analyzed. In this way it seems that the adoption of this treaty could be against the Calvo Doctrine as incorporated by the Ecuadorian constitutional framework. Particularly, the dispute settlement provision applies to the Parties, namely Ecuador and Switzerland, meaning that any dispute involving an investor's right would have to be channelled through diplomatic protection, first resorting to diplomatic negotiations and subsequently through the constitution of an arbitral tribunal at the request of one of the parties. Accordingly, this BIT did not grant to the investors autonomous legal standing for directly bringing an international dispute against the State. The Calvo Doctrine as enshrined by the Ecuadorian constitutional tradition covers

${ }^{338}$ Constitution of 1967 :

“Art. 184.- Deberes y Atribuciones.- Al Presidente de la República corresponden los siguientes deberes y atribuciones:

(...) 3. Dirigir las relaciones internacionales y las negociaciones diplomáticas; celebrar tratados y ratificarlos, previa aprobación del Senado en los casos requeridos; canjear las ratificaciones y denunciar los tratados vigentes, conforme a los convenios internacionales celebrados por el Estado.

No están sujetos a aprobación del Senado los tratados que no supongan obligaciones o cargas permanentes para la Hacienda Pública o para los ciudadanos ecuatorianos ni en general, los que no exijan para su cumplimiento medidas legislativas. Estos tratados se someterán al dictamen del Tribunal de Garantías Constitucionales, y el Presidente de la República dará cuenta de ellos al Congreso en el próximo período de sesiones, con determinación de su carácter y contenido." 
contractual obligations, which in a literal interpretation, would suggest that diplomatic intervention could be tolerated in cases where the State exerts its sovereign powers. Following this reasoning the disputes arising out of the application of the BIT at issue would be restricted to those of a legal nature, since the State was banned from intervening in disputes derived from contractual controversies.

Although the proposed interpretation would not undermine the authority of the Calvo Doctrine as prescribed by the Constitution of 1967 provided that the nature of the disputes derived from the application of the BIT were not of a contractual nature, it can be identified as an additional peculiarity in regard to the hierarchy of international treaties. At the time that the BITs signed with the Federal Republic of Germany and Switzerland were concluded, international treaties were considered to have an inferior category in relation to national laws. In any case, no dispute concerning the conflict between the application of a BIT and municipal legislation occurred; this was understandable because the direct application of international treaties has been restrictively recognized in Ecuador, notwithstanding the developments brought by the Constitutions of 1998 and 2008 as explained below.

As previously asserted, the Civil Code generally proscribed the submission to jurisdiction not recognized by Ecuadorian laws. Bearing in mind that a BIT would not have direct applicability in the Ecuadorian legal framework, it is worth to note, that, in the decree signed by the President of Ecuador, publishing the ratification of the BIT with Switzerland in the Official Gazette, it was established that such a convention became the "law of the Republic". As a consequence, such a BIT would constitute a lawful source of substantive and procedural rights, whose effects enforced by the authorities invested with jurisdictional powers in accordance to the treaty, could have taken place in Ecuador. This, of course, does not mean that BITs are a source of Ecuadorian law capable of being given effect as internal law in Ecuadorian courts.

Therefore, it could not be considered that the denomination of the BIT with Switzerland as "law of the Republic" would automatically entail its transposition into internal law. The alleged inferior hierarchy of treaties broadly accepted at the domestic level during the period analyzed would be impractical for settling a conflict of norms, considering that international treaties and municipal law derive from different sources and operate at different levels. Furthermore, the fact that the application of BITs relies on international arbitral tribunals and that the core of the disputes consists in determining the State's international responsibility, weakens any possibility for settling an alleged contradiction 
between international and domestic law within the principle of hierarchy. Correspondingly, the limitation set forth by the Civil Code concerning the submission in Ecuador to jurisdictions not recognized by Ecuadorian laws, would be overcome through the signature of international treaties, which are considered to be part of the internal legal order, although its application is proscribed for national adjudicators.

Pursuant to the breadth of the Calvo Doctrine in accordance with the Constitution of 1967, it could be interpreted that under the relevant constitutional provision, no diplomatic intervention and in consequence, no jurisdiction over contractual disputes involving Ecuadorian nationals or the State of Ecuador with foreigners, should have been referred to international arbitral tribunals constituted under the frame of the BITs with the Federal Republic of Germany and Switzerland. ${ }^{339}$ It could be affirmed that the two BITs at issue regulated diplomatic intervention concerning investment disputes due to the reason that the Member States are exclusively entitled to activate the mechanisms of dispute settlement.

A literal interpretation of the constitutional provision that enshrines the Calvo Doctrine, could lead to the conclusion that the submission to a foreign jurisdictional forum concerning non-contractual disputes would be in conformity with the Constitution in force. However, further constitutional values like equality before the law and nondiscrimination could be fractured, due to the possibility of conferring a higher protection to investor's rights in regard to the burdens derived from sovereign decisions, which undoubtedly exceed the boundaries of any relationship that the State could agree upon as a contractor.

It is also noticeable that in the exchange of notes between the Ministries of Foreign Affairs of Ecuador and Switzerland, it was consented at the request of the first country that the admission of the investments and the activity of the investors had to be subject to the legal dispositions in force in each legal framework ${ }^{340}$. Similarly the Minister of

\footnotetext{
339 The same reasoning applies to the Treaty signed with the Federal Republic of Germany, because, on the one hand, the relevant constitutional provision of 1946 is identical to the relevant provision of the Constitution of 1967 and, in the other, the Member States are exclusively entitled to bring disputes in case of violation of the BIT.

340 Note submitted by the Extraordinary and Plenipotentiary Ambassador of Ecuador in Switzerland to the Director of the Commerce Division of the Federal Department of Public Economy of Switzerland, Ambassador, Peter Jolles:

"Señor Embajador:

Al momento de firmar el acuerdo de protección y fomento de inversiones entre nuestros dos países, este día, tengo el honor de precisar que según el sentido de este acuerdo, la admisión de las
} 
Foreign Affairs of Ecuador by communication sent to the President of the German Delegation clarified that the permits necessary for the activities which German nationals would aim to carry out in Ecuador, should be issued as long as they do not conflict with reasons of public order and security, as well as of public health and morality ${ }^{341}$. Concerning the requirement of investments' legality, it is worth to note that most of the BITs further signed by Ecuador recognize the protection of investments made in conformity with national law. Recently such a requirement has gained momentum, especially at the stage of the constitution of the arbitral tribunal's jurisdiction. For instance, the Tribunal in the case Incesysa v. El Salvador ${ }^{342}$ declared itself incompetent for deciding a dispute derived from an investment made in contradiction to the laws of the host State. By the same token, the tribunals in the cases Alasdair Ross Anderson Et Al. vs Costa Rica ${ }^{343}$ and Fraport AG Frankfurt Airport Services Worldwide vs. Filipinas ${ }^{344}$ applied a similar reasoning concerning "illegal investments"345. As Salgado Levy illustrates, the importance that national legislation has taken on with relation to the

inversiones y la actividad de los inversionistas, se entiende de conformidad con las disposiciones legales que rigen la materia en cada uno de los países (..)"

Berne, May 2, 1968.

${ }^{341}$ Communication sent by the Minister of Foreign Affairs, Rafael García Velasco to Dr. Bruno Toepfer, President of the German Delegation (28.06.1965):

"Con el propósito de facilitar y fomentar la realización y el desarrollo de inversiones de capital de nacionales o sociedad alemanas, la República del Ecuador concederá a los nacionales alemanes que, en relación con las inversiones de capital de nacionales o sociedades alemanes desearen ingresar a la República del Ecuador y permanecer en ella y trabajar en ella, los permisos que fueren necesarios siempre que no se opongan razones de orden y seguridad pública, de sanidad pública y moralidad."

${ }^{342}$ Inceysa Vallisoletana, S.L (Claimant) v. Republic of Salvador (Respondent):

"207. Based on the foregoing arguments, this Arbitral Tribunal considers that the consented granted by Spain and El Salvador in the BIT is limited to investments made in accordance with the laws of the host State of investment. Consequently, this Tribunal decides that the disputes that arise from an investment made illegally are outside the consent granted by the parties and, consequently, are not subject to the jurisdiction of the Centre, and that this Tribunal is not comeptent to resolve them, for failure to meet the requirments of Article 25 of the Convention and those of the BIT.'

International Centre for Settlement of Investment Disputes Washington, D.C., ICSID Case No. ARB/03/26, August 2, 2006.

343 Alasdair Ross Anderson Et Al. v. Costa Rica, ICSID Case NO. ARB(AF)/07/3, Award, May 19, 2010.

${ }^{344}$ Fraport AG Frankfurt Airport Services Worldwide v. Republic of the Philippines, Final Award, (ICISID Case No. ARB/03/25), Washington, August 16, 2007.

${ }^{345}$ Salgado Levy (Claudia), "La legalidad de las inversiones como un requisito para la protección de los tratados internacionales de inversiones", Revista de Derecho Foro, Universidad Andina Simón Bolívar, 2012, 109 p. 
assessment of this condition in the light of International Investment Law, does not depend on the definition of investment pursuant to municipal law, but to its performance. This implies, that the illegality of the investment concerns fundamental issues that deal with the way the investment has been made and not to its definition. ${ }^{346}$

\subsubsection{The Void Effect of International Norms in Contradiction to the Constitution}

Both constitutional frameworks of 1946 and 1967, under which the first BITs were signed, enshrined the supremacy of the Constitution, being in theory, the international treaties hierarchically subordinated to the constitutional provisions. According to this principle of supremacy, these constitutions declared as void any inferior norm being in contradiction with their provisions. ${ }^{347}$ The reference to international laws in the hierarchical normative order would imply its supremacy over laws and regulations enacted at the municipal level. Taking into consideration that an international treaty cannot be declared void by a municipal authority, the alleged contradiction of this instrument with the Constitution would have to pass through the formal process of termination of treaties at the international level. Even from a monist perspective that may grant direct effect to an international treaty without requiring any further law to be enacted for its application, the expulsion of the international obligation for purportedly violating

\footnotetext{
346 Salgado Levy (Claudia), "La legalidad de las inversiones como un requisito para la protección de los tratados internacionales de inversiones", Revista de Derecho Foro, Universidad Andina Simón Bolívar, $2012,110 \mathrm{p}$.

${ }^{347}$ Constitution of 1946 :

“Art. 189.- La Constitución es la una norma jurídica de la República. Por tanto, no tendrán valor alguno las Leyes, Decretos, Reglamentos, Ordenanzas, Disposiciones, Pactos o Tratados Públicos que, de cualquier modo, estuvieran en contradicción con ella o se apartaren de su texto.

Solo el Congreso tiene facultad de interpretar la Constitución de un modo generalmente obligatorio, y de resolver las dudas que se suscitaren sobre la inteligencia de alguno o algunos de sus preceptos.
}

Asimismo, solo al Congreso le corresponde declarar si una Ley o Decreto Legislativo son o no inconstitucionales."

Constitution of 1967 :

“Art. 257.- La Constitución es la suprema norma jurídica del Estado. Todas las demás deben mantener conformidad con los preceptos constitucionales. Por tanto, no tendrán valor alguno las leyes, decretos, reglamentos, ordenanzas, disposiciones y tratados públicos que, de cualquier modo, estuvieren en contradicción con ella.

Solo el Congreso tiene facultad de interpretar la Constitución de un modo generalmente obligatorio, y de resolver las dudas que se suscitaren sobre la inteligencia de sus preceptos." 
the Constitution's supremacy, would take effect after its formal denunciation. The rationality of this principle could only take place at a previous level, when the international treaty may be subject to internal approval, but not after this commitment has been ratified. In this regard, the assimilation of international treaties to the municipal legal order does not entail the faculty of any internal branch for declaring its invalidity and inapplicability. Only in the case that the State adopted the dualist approach, through the implementation of international obligations through statutory provisions, could the relevant internal authority challenge its internal effects in case of contradiction of the Constitution. And even in such event, the State would have to terminate the treaty at issue according to International Law. ${ }^{348}$

These treaties neither include an explicit offer to arbitration by reference to the investors, nor a specific forum for the submission of the relevant disputes. However a general provision determines the rules of arbitrators' appointment as well as the burden of arbitration costs, resorting to the final decision of the President of the International Court of Justice, in case the parties cannot reach an agreement concerning arbitrators' selection. From the BIT signed with the Federal Republic of Germany, it is remarkable that there was an acknowledgement of public policy, health and morality reasons as boundaries for the admission and performance of investments' activities. Additionally, the same treaty prescribes that international arbitration proceedings should not affect national courts' jurisdiction (Art. XI, 5) ${ }^{349}$.

\footnotetext{
348 Concerning the relationship between international and national law, the predominant theories, namely monist and dualist, distinguish the assimilation of international obligations by the domestic legal order with different effects. In this regard, the Supreme Court of Sri Lanka illustrates:

"The classic distinction of the two theories characterized as monist and dualist is that in terms of the monist theory, international law and municipal law conform to a single legal system. Therefore the generally recognized rules of international law constitute an integral part of the municipal law and produce direct legal effects without any further law being enacted within a country. According to the dualist theory, international law and municipal law are two separate and independent legal systems, one national and the other international. The latter, being international law regulates relations between States based on customary law and treaty law, whereas the former, national law, attributes rights and duties to individuals and legal persons deriving its force from the national Constitution."
}

Singarasa (Nallaratnam) v Attorney General, Application for judicial review, SC Spl (LA) No 182/99, ILDC 518 (LK 2006), 15th September 2006, Supreme Court.

${ }^{349}$ Art. XI, (5):

"El arbitraje estipulado en esta cláusula no afectará en forma alguna a la jurisdicción de los tribunales del país en el cual se haya efectuado la inversión." 


\subsubsection{The Andean Pact and the Establishment of a Regional Investment Regime}

The failure of the Latin American Free Trade Association (1960), underpinned the process of Andean integration. As Molano Cruz explains, the creation of a regional market attempted to exploit scale economies maximizing the efficient used of land, labour and capital. From the political perspective, the creation of a supranational body intended to reinforce the bargaining force of the Andean countries within the global economy. Following the same author, the Andean countries shared the regional concern to design effective tools to tackle North-American trade protectionism and improving the conditions of Latin-American exports, especially those of agriculture to the European Community. ${ }^{350}$ The Andean Pact (Cartagena Agreement) was signed on May 26 ${ }^{\text {th }}, 1969$ by Bolivia, Chile, Colombia, Ecuador and Peru. This constitutive treaty gave birth to Andean sub-regional integration, with the objective to create, first, a customs union and subsequently, a common market, capable of promoting the balanced and harmonic development of its Members through the improvement of the living conditions of its inhabitants. Venezuela joined the group in 1973, but withdrew in 2006 after Colombia and Peru signed free trade agreements with the USA. Chile resigned its membership in 1976, allegedly due to economic incompatibilities linked to the supranational resolution to unify the treatment of foreign capital, adopted by the Decision 24 of December $31^{\text {st }}$, 1970.

Among its objectives, the Cartagena Agreement acknowledges the allocation of resources in and outside the sub-region for financing the investments required for the integration process (Art. 3, g). Logically, the gradual harmonization of economic and social policies, through supranational and national instruments is one of the pillars of the integration process (Art. 3, b). Despite its early creation, the Andean Community could put into effect certain integration objectives just in the 1990s with the establishment of a Free Trade Area (1993) and a Customs Union (1995) ${ }^{351}$. Whereas in the latter case, the adoption of a Common External Tariff established an imperfect customs union due to the differential

\footnotetext{
${ }^{350}$ Molano Cruz (Giovanni), "La integración andina: origen, transformaciones y estructuras", Instituto para la Integración de América Latina y el Caribe (BID-INTAL), N.33, Año 15, Julio-Diciembre 2011, 37 p.

${ }^{351}$ Comisión del Acuerdo de Cartagena, Decisión 370-Arancel Externo Común, Sexagésimo-tercer período ordinario de sesiones de la Comisión, 25-26 de noviembre de 1994.
} 
treatment conferred to its application, in the former, the liberalization only covered goods of Andean origin. ${ }^{352}$

\subsubsection{Rise (Decisions 24 and Decision 220)}

Notably, the Andean Pact mandates the adoption of a common system for the treatment of foreign capital and on trademarks, licenses and royalties among others (Art.55); this provision was the basis for the adoption of the Decision $24(1970)^{353}$. This supranational decision was clearly inspired by a resistance towards direct foreign investment in the light of the impetus for strengthening national entities through strong state intervention. Consequently, foreign investment was conceived as a supplementary tool for putting into practice national plans of development, strongly invigorated by a tendency for reaffirming the exercise of sovereign powers.

This supranational instrument included direct applicable obligations that regulated exhaustively the admission, qualification, register and performance of foreign investment both for existing and future operations. O'Keefe summarizes the main features of Decision 24:

In an attempt to control the perceived pernicious effects of foreign investment, article 27 of the Cartagena Agreement called for the creation of a common Andean Pact policy vis-à-vis foreign investment, trademarks, patents, and licenses. (...) Decision 24 forbade foreign investment in activities already being carried out by enterprises from the Andean countries and prohibited foreigners from buying stock in Andean firms. Absent a rule by an individual member state permitting a higher amount, Decision 24 set 20 percent as the maximum amount of annual profits a foreign corporation could repatriate abroad. Decision 24 also required any foreign company not already operating within the Andean subregion as of January 1, 1974, to sell at least 51 percent of its shares to Andean Pact nationals to be considered a "mixed company" and therefore eligible to take advantage of the Pact's intraregional free trade scheme. Finally, in an attempt to prevent foreign controlled monopolies and restrictions on technology transfer, Decision 24 prohibited member states from granting licensing contracts to foreign companies that contained restrictive non-competition clauses. ${ }^{354}$

In this rigorous scheme, the foreign enterprises already in operation in the Andean Community and those arriving in the future willing to access to the advantages of the

\footnotetext{
352 Comisión del Acuerdo de Cartagena, Decisión 324-Arancel Interno Común, Programa de Liberación de Incentivos a las Exportaciones intra-subregionales, Lima, 25 de agosto de 1992.

${ }^{353}$ Decisión 24 de 31 de diciembre de 1970.

354 O'keefe (Thomas Andrew), "How the Andean Pact Transformed Itself into a Friend of Foreign Enterprise", The International Lawyer, Vol. 30, No. 4 (WINTER 1996), 811-824 pp.
} 
Andean Liberalization Program set forth in the Cartagena Agreement ${ }^{355}$, were obliged to transfer $51 \%$ of their stocks to nationals of the Andean countries according to the deadlines determined by the decision (Articles 27-31). Among to the restrictions imposed on the participation of foreign enterprises in certain economic sectors (Art. 38), there are also notable prohibitions established for foreign investment in finance, banking, insurance, transport, advertisement and media areas, together to the obligation to those already operating in the same, to becoming national entities within a specific deadline (Art. 42-44). Also remarkable are the stringent obligations for register and authorization of investments, as well as the qualification of foreign investments and investors by specialized national bodies. The detailed obligations imposed on the contracts of transfer of technology, patents and trademarks, as well as several restrictions like quota exports concerning certain products within this regime, evidence a strong tendency for reaffirming a strong State control over foreign investment, in the light of the objective of fortifying national enterprises. By the same token, this decision prohibited the Members from granting to foreign investors more favourable treatment than to national investors (Art. 50). Finally, it highlighted the ban on admitting foreign jurisdiction for the settlement of disputes derived from any investment or transfer of technology instruments, confining the same to the national jurisdiction of the host State (Art. 51).

Sooner or later, the inflexible structure of the Andean investment framework would start to show its first cracks:

355 Cartagena Agreement:

"Article 72.- The purpose of the Liberalization Program for goods is to eliminate duties and restrictions of all kinds levied on the importation of products originating in the territory of any Member Country.

Article 73.- "Duties" are understood to be the customs duties and any other charges with equivalent effects, whether of a fiscal, monetary or foreign exchange nature, that may affect imports. Not included in this concept are analogous assessments and surcharges that correspond to the approximate cost of the services rendered.

"Restrictions of all kinds" are understood to mean any administrative, financial, or foreign exchange measure whereby a Member Country, through a unilateral decision, obstructs or hinders imports. Not included in this concept are the adoption and enforcement of measures to:

a) Protect public morals;

b) Implement laws and regulations on security;

c) Regulate the import or export of weapons, ammunition, and other war materials, and, under special circumstances, all other military articles, provided that this does not interfere with the provisions of treaties in force between Member Countries relating to the freedom of unrestricted transit;

d) Protect the life and health of human beings, animals, and plants;

e) Import and export metallic gold and silver;

f) Protect national treasures with an artistic, historical, or archaeological value; and

g) Export, use and consume nuclear materials, radioactive products, or any other material that may be employed for the development and utilization of nuclear energy." 
In 1976 the Andean Pact experienced its first visible crisis when Chile withdrew over continued opposition to Decision 24 and the Pinochet dictatorship's decision to pursue aggressive free market style economic policies that clashed with the generally protectionist, state-led industrial development philosophy of the Andean Pact scheme. ${ }^{356}$

This withdrawal would be the beginning of a longstanding crisis that threatened the existence of the Andean Pact. Anderson summarizes the problems that followed Chile's retreat such as the failure of the remaining States to adapt the provisions set forth by the Cartagena Agreement to national law due to the resistance of nationalist groups' arising from short-term costs and benefits flowing from the integration process, unsolved territorial disputes between Peru and Ecuador that undermined the effectiveness of efforts to coordinate agricultural and industrial development programs, and finally, the oil shock of 1979 that drove the members to implement conflicting macro-economic policies. This author underlines:

In particular, the sharp rise in oil prices caused some of the Andean countries to face severe balance of payments problems. These problems developed as more money went out to pay for petroleum and less money came in from commodity exports, the prices of which also dropped due to a prolonged recession that began affecting the industrialized countries in 1980. In an attempt to increase exports and therefore expand their foreign currency exchanges, these Andean countries sharply devalued their currencies. In doing so, they made imports from oilproducing Ecuador and Venezuela, who were enjoying minibooms from the sharp hike in oil prices (which, in turn, contributed to an overvaluation of their currencies), more expensive and re-imposed an indirect tariff barrier on Ecuadorean and Venezuelan goods. For their part, Venezuela and Ecuador became swamped with the cheap manufactured goods of their Andean neighbors, and industrialists in both countries quickly put pressure on their respective governments to impose safeguard clauses to halt the import tide that threatened to bankrupt them. The sharp rise in international interest rates in 1982, which set off the infamous Latin American debt crisis and resulted in a subsequent halt in international lending to Latin America, only exacerbated the problem by making it impossible to "fund" the trade imbalances and drained the Andean institutional bodies (the CAF and the Andean Reserve Fund) of the capital that had been intended to alleviate trade imbalance problems. Consequently, whereas during the first ten years of the Andean Pact's existence intraregional trade had grown at an average annual rate of 28.2 percent, after 1979 there was virtually no increase, and by 1983 trade within the Andean sub region was actually showing signs of severe contraction. ${ }^{357}$

\footnotetext{
356 O'keefe (Thomas Andrew), "How the Andean Pact Transformed Itself into a Friend of Foreign Enterprise", The International Lawyer, Vol. 30, No. 4 (WINTER 1996), 811-824 pp.

357 O'keefe (Thomas Andrew), "How the Andean Pact Transformed Itself into a Friend of Foreign Enterprise”, The International Lawyer, Vol. 30, No. 4 (WINTER 1996), 811-824 pp.
} 
In this context, the weaknesses of the common regime for the treatment of foreign investment as originally conceived started to emerge. From the incorporation of the common investment regime by Decision 24 on 1971 to 1987 when Decision 220 was enacted $^{358}$, thirteen Decisions were adopted with the purpose to regulate the implementation of such a protectionist-oriented regime ${ }^{359}$. The definition of investment and its nationality, as well as percentages of stock ownership for the categorization of companies as foreign, national and mixed, were gradually modified. Other investments' admittance and performance requirements were developed in detail such as register, authorization, transfer of stocks, boards conformation and decision making, centralization of information, prohibition to operate in areas reserved for national companies, minimum guidelines for the models of contracts of transfer of technology, license and other intellectual property rights, as well as the modalities and restrictions for re-exporting profits. In this regard, Decision 220 was the last comprehensive effort for preserving this ambitious regime that had as its main purpose defining the limits of the entrance and performance of foreign investment for the consolidation of the Latin-American industry. The regulation of many of these requirements entrusted to the Commission of the Andean Community was progressively resigned in favour of the Member States, which undoubtedly constituted an indication of the gradual dismantling of the system. For instance, Decision 220 allowed each Member State to develop its own economic strategy for attracting foreign investment and consequentially suppressed from the attributions of the Commission, the definition of the sectors reserved for national enterprises enshrined in Decision 24. This retreat in terms of supranational powers' exercise was the result of the permanent requests of the Member countries for making flexible the application of the categorical declarative principles and directly enforceable provisions that regulated this system. Logically, this debilitation was also expressed in the requirements for the settlement of disputes derived from the application of such a regime. Whereas Decision 24 prohibited the incorporation of any clause suppressing from the national jurisdiction of the host country any controversy derived from the application of an investment

\footnotetext{
${ }^{358}$ Decisión 220, Comisión del Acuerdo de Cartagena, 11 de mayo de 1987.

${ }^{359}$ Decisiones 37, 37a, 47, 48, 70, 103, 109, 110, 118, 124, 125, 144 y 189.
} 
instrument ${ }^{360}$, Decisions $220^{361}$ and $291^{362}$ abolished this supranational limitation and enabled national legislations to manage the regulation of dispute settlement related to this matter.

This reality is one of the consequences derived from the crisis of state-directed economic growth policies manifested during the early 1980s that obliged the Andean members to shift the goals of the Andean Pact towards export-led measures. Accordingly, the Quito Protocol was signed in May of 1987, which relaxed the strict deadlines for establishing a free trade area and Common External Tariff, eliminated the industrial development programs, redirected the countries' efforts towards the consolidation of private initiatives and encouraged member states to reach bilateral agreements in order to accelerate investment flows.

\subsubsection{Fall (Decision 291)}

Consequently, Decisions 24 and 220 were perceived as a significant setback for adapting these new objectives and in consequence and after gradual changes rehearsed

360 Decision 24:

"Artículo 51.- En ningún instrumento relacionado con inversiones o transferencia de tecnología se admitirán cláusulas que sustraigan los posibles conflictos o controversias de la jurisdicción y competencia nacionales del país receptor o que permitan la subrogación por los Estados de los derechos y acciones de sus nacionales inversionistas.

Las discrepancias entre los Países Miembros del presente régimen con motivo de su interpretación o ejecución, serán resueltas siguiendo el procedimiento señalado en el Capítulo II, Sección D, "De la solución de controversias", del Acuerdo de Cartagena."

${ }^{361}$ Decision 220:

"Artículo 34.- En la solución de las controversias o conflictos derivados de las inversiones extranjeras directas o de la transferencia de tecnología extranjera, los Países Miembros aplicarán lo dispuesto en sus legislaciones internas."

362 Decisión 291:

"En la solución de controversias o conflictos derivados de las inversiones extranjeras directas o de inversionistas subregionales o de la transferencia de tecnología extranjera, los Países Miembros aplicarán lo dispuesto en sus legislaciones internas". 
by several decisions ${ }^{363}$, Decision $291^{364}$ established the new framework for foreign investment in the region:

In conjunction with the announcements emanating from the various presidential summits, the Andean Commission also began issuing decisions reflective of the deregulated and market-oriented direction of the new Andean Pact. In March of 1991, for example, the Commission adopted Decision 291, which superseded earlier decisions regarding foreign investment. Henceforth, there would, in principle, be no legal difference between foreign or domestic capital. Foreigners were generally free to repatriate investment capital and profits at will; any requirements of prior authorization or registration of foreign investments were abolished; and all foreign companies operating in the region (regardless of the percentage of Andean stockholders) could partake of the intra-regional free trade scheme. ${ }^{365}$

The adoption of this decision backed by a severe economic crisis and urgency for attracting capital, together with the strong influence of the plans idealized by Washington Consensus' institutions, underpinned the liberalization of rules for hosting investment and a sort of regulatory competition towards this end in Latin America. In the case of the Andean region, Ecuador, Bolivia ${ }^{366}$, Peru $^{367}$ and Venezuela $^{368}$ were extremely

${ }^{363}$ Before the adoption of Decision 291, gradual adjustments were implemented for structuring the new regional investment framework. Notwithstanding Decision 220 of May 18th, 1987 replaced Decision 24, Decisions 37, 37 , 103, 109 and 108 constitute the precedents for the transformation indicated.

See, Guerra Bello (Gustavo), "La negociación de acuerdos internacionales de inversión como instrumento para la promoción de inversiones en el Ecuador", Tesis de Maestría en Relaciones Internacionales, mención en negociaciones internacionales y manejos de conflictos, Universidad Andina Simón Bolívar, Quito, 2008, 24 p.

See: $\quad$ http://repositorio.uasb.edu.ec/bitstream/10644/489/1/T600-MRI-GuerraLa\%20negociación\%20de\%20acuerdos\%20internacionales\%20de\%20inversión\%20como\%20instrument o\%20para\%20la \%20promoción $\% 20 \ldots . . . p d f$

${ }^{364}$ Decisión $N^{\circ} 291$ que establece el Régimen Común de Tratamiento a los Capitales Extranjeros y sobre Marcas, Patentes, Licencias y Regalías, Comisión del Acuerdo de Cartagena, 21 de marzo de 1991.

365 O'keefe (Thomas Andrew), "How the Andean Pact Transformed Itself into a Friend of Foreign Enterprise", The International Lawyer, Vol. 30, No. 4 (WINTER 1996), 811-824 pp.

366 During the 1990s, Bolivia, signed 17 of the 23 BITs it has entered into. Among them, seven are terminated and two are not in force. Only one treaty was signed before the 19902 (BIT, BoliviaSwitzerland).

See: http://investmentpolicyhub.unctad.org/IIA/CountryBits/24

Page visited on May 2015.

${ }^{367}$ During the 1990s, Peru signed 26 of the 33 BITs it has been subject to. 29 of these 33 BITs are currently in force.

See: $\underline{\text { http://investmentpolicyhub.unctad.org/IIA/CountryBits/165 }}$

Page visited in May 2015.

${ }^{368}$ During the 1990s, Venezuela signed 23 of the 30 BITs it has entered into. Among them, one is terminated and two are not in force.

See: $\underline{\text { http://investmentpolicyhub.unctad.org/IIA/CountryBits/228\#iiaInnerMenu }}$

Page visited on May 2015. 
enthusiastic for signing BITs. Only Colombia ${ }^{369}$ took a more cautionary approach towards this unknown mechanism of investment protection.

From these countries, Ecuador was the first to sign BITs: two during the 1960s (Germany and Switzerland) and one during the 1980s (Uruguay).

This reality is in line with the Ecuadorian historical vocation for signing any sort of international obligations without assessing their effects with diligence. Although in the case of human rights obligations, this approach could be conceived as positive, in terms of the adoption of duties with a strong impact in terms of economic compromises, this keenness should have been preceded, at least, by a responsible cost-benefit analysis.

In conclusion, Decision 291 eliminated the main pillar of this regime that prohibited foreign investors from receiving more favorable treatment than that granted to national investors $^{370}$. The latter decision established the principle of equal treatment to foreign and national investors, except as otherwise provided by national legislations, which in practice meant the subordination of the supranational rules to national provisions, enabling the boom of investment instruments that granted special substantive and procedural rules of protection to foreign investors. This transformation also meant the amplification of the benefits derived from the Andean Commercial Liberation Program to foreign investors, which according to Decisions 24 and 220 had to pass through a process of transformation to national or mixed enterprises in order to take advantage of this scheme.

\subsubsection{Contradiction Between Andean Supranational obligations and BITs provisions}

Taking into account the periods when the first BITs adopted by Ecuador were concluded,

369 During the 1990s, Colombia signed four BITs with Cuba (not in force), Peru (terminated), Spain (terminated) and United Kindgdom (not in force). From 2000 to 2014, there were signed 13 BITs, entering into force only 5 of them.

See: http://investmentpolicyhub.unctad.org/IIA/CountryBits/45

Page visited on May 2015.

370 Decisión 24:

“Artículo 50.- Los Países Miembros no concederán a los inversionistas extranjeros ningún tratamiento más favorable que el que otorguen a los inversionistas nacionales."

Decisión 220:

“Artículo 33.- Los Países Miembros no concederán a los inversionistas extranjeros ningún tratamiento más favorable que el que otorguen a los inversionistas nacionales.” 
the instruments subscribed with Germany (1965) and Switzerland (1968) took force prior to the incorporation of the common regime for the treatment of investment. Ecuador did not take any measure for bringing such treaties' provisions into conformity with the obligations established by the regime at issue. Furthermore, in 1985 when Decision 24 was still in force and included categorical prohibitions in contradiction with the nature of the protection standards normally set forth by the BITs, a new treaty with Uruguay was concluded $^{371}$. This instrument considered as a BIT by the Government of Ecuador, was concluded by the exchange of notes between the Ministers of Foreign Affairs of Ecuador and Uruguay, meaning that the internal process for the approval and ratification of treaties set forth by the Ecuadorian Constitutional Codification of 1984 was not fulfilled. In view of the manifest violation of the constitutional order for the formation of treaties, as well as of the rules of customary law covered by the VCLT, it is unclear whether this action would have given birth to an international treaty. In any case, the conclusion of this "instrument of investment" abolishing reciprocal requirements concerning the prior authorization of investments, granting national treatment to investments and profits and incorporating standards such as fair and equitable treatment and full protection and security, meant the circumvention of the supranational regime analyzed in this section.

${ }^{371}$ Diplomatic note submitted by Dr.Edgar Terán Terán, Minister of Foreign Affairs of Ecuador to Enrique Iglesias, Minister of Foreign Affairs of the Republic of Uruguay, containing the compromises for reciprocal protection of foreign investment:

"Tengo el honor de dirigirme a Vuestra Excelencia con el objeto de manifestarle que el Gobierno del Ecuador, animado del deseo de crear condiciones favorables para incrementar inversiones de capital de las personas naturales o jurídicas del Uruguay en el Ecuador y viceversa, y reconociendo que el fomento y la protección recíproca de esas inversiones pueden contribuir para estimular la actividad económica y aumentar la prosperidad de ambos Estados, vería con agrado que las inversiones ecuatorianas y uruguayas nos requieras de autorización previa o gocen de una autorización general, por sectores, sin perjuicio del cumplimiento de las normas cambiarias y de registro vigentes en nuestros dos países, para efectos de la remisión del capital y sus beneficios.

Los Gobiernos de ambos países, de acuerdo con sus leyes, fomentarán y facilitarán las condiciones para que los nacionales de sus respectivos países puedan realizar inversiones en el territorio del otro Estado, concediéndoles un trato justo y equitativo y la plena protección y seguridad.

De conformidad con sus respectivas legislaciones, cada Gobierno otorgará en su territorio a las inversiones o rentas de los nacionales o sociedades del otro país, un tratamiento no menos favorable que aquél que concede a sus propios nacionales o sociedades, o a las inversiones o rentas de nacionales o sociedades de un tercer Estado.

Si los términos contenidos en la presente comunicación son aceptables para el Ilustrado Gobierno del Uruguay, me permito proponer que el texto de la presente comunicación y el de la repuesta de Vuestra Excelencia, constituyan acuerdo formal entre nuestros dos países.

Hago propicia la oportunidad para reiterar a Vuestra Excelencia las seguridades de mi más alta distinguida consideración".

Note No. 14/85 CN, Quito, July 31 ${ }^{\text {st }}, 1985$. 
Neither the infringement of procedures nor the cancellation actions regarding compliance with the aforementioned decisions against the Member States could have been identified from the database of the Andean Community. It has to be noticed that only States can bring non-compliance complaints. However, certain preliminary rulings of the Andean Tribunal of Justice (ATJ) $)^{372}$ interpreted the scope and evolution of such decisions, confirming the degradation of the supranational goals and attributions originally established by Decision 24, debilitated by Decision 220 and abolished by Decision $291^{373}$.

372 Article 42 of the Treaty of Creation of the Tribunal of Justice of the Andean Community (May 28, 1979) enshrines the mandatory, predominant and exclusive jurisdiction of the same over the control regarding the compliance of the norms that conform the communitarian legal framework:

"Tratado de Creación del Tribunal de Justicia de la Comunidad Andina.- Artículo 42.-Los Países Miembros no someterán ninguna controversia que surja con motivo de la aplicación de las normas que conforman el ordenamiento jurídico de la Comunidad Andina a ningún tribunal, sistema de arbitraje o procedimiento alguno distinto de los contemplados en el presente Tratado.

Los Países Miembros o los órganos e instituciones del Sistema Andino de Integración, en sus relaciones con terceros países o grupos de países, podrán someterse a lo previsto en el presente Tratado."

${ }^{373}$ The Tribunal in his preliminary ruling illustrated about such evolution:

La normativa comunitaria en materia de inversiones consagra un régimen común que ha evolucionado de un sistema con tendencia proteccionista hasta llegar a un régimen mucho más abierto. La Decisión 24 de la Comisión del Acuerdo de Cartagena, primera Decisión sobre el tema, fue derogada por la Decisión 220 y ésta, a su vez, derogada por la Decisión 291 de la Comisión del Acuerdo de Cartagena; esta última se presenta como una adecuación de la normativa comunitaria con las nuevas tendencias de apertura al comercio y a la inversión extranjera (...).

(...) Mientras la Decisión 24 de la Comisión del Acuerdo de Cartagena consagró como uno de los objetivos fundamentales "el fortalecimiento de las empresas nacionales, con el fin de habilitarlas para participar activamente en el mercado subregional", y se soportó en la política común de "dar preferencia en el desarrollo económico de la Subregión a capitales y empresas auténticamente nacionales de los Países Miembros", la Decisión 291 en sus considerandos expresó que los Presidentes de los Países Miembros del Acuerdo de Cartagena, en la reunión celebrada en la ciudad de La Paz, Bolivia, los días 29 y 30 de noviembre de 1990, acordaron remover los obstáculos para la inversión extranjera e incentivar la libre circulación de capitales subregionales.

Entre las Decisiones 24 y la 291 se expidió la Decisión 220 de la Comisión del Acuerdo de Cartagena, mediante la cual se reformó algunos asuntos puntuales de la Decisión 24, pero, en términos generales, siguió mantenido la misma línea en relación con la inversión extranjera. El Tribunal de Justicia de la Comunidad Andina en Interpretación Prejudicial del 26 de octubre de 1989 dentro del proceso 5-IP-89, analizó el anterior cambio normativo de la siguiente manera: “(...) Asimismo, en la parte declarativa de la Decisión 24, se hace constar que 'las normas comunes deben contemplar mecanismos y procedimientos suficientemente eficaces para hacer posible una participación creciente del capital nacional en las empresas extranjeras existentes o que se establezcan en los Países Miembros, en tal forma que se llegue a la creación de empresas mixtas en que el capital nacional sea mayoritario, y en que los intereses nacionales tengan capacidad para participar en forma determinante en las decisiones fundamentales de dichas empresas (...)'. Estas declaraciones de la Decisión 24 fueron reproducidas en la Decisión 220, que es la normativa que ahora regula la inversión extranjera en la Subregión.”

See: Tribunal of Justice of the Andean Community, Proceeding 158-IP-2006. 
In his preliminary ruling in regard to the application's scope of the Decision 291, the Andean Tribunal of Justice (ATJ) referred the modifications to the common regime for the treatment of foreign capital submitted by the Board of the Andean Community to the Commission through the proposal 228 of March $6^{\text {th }}, 1991$, wherein the main purposes of such transformation are listed:

"En este contexto, se plantea un cambio normativo que al presente se ha venido traduciendo en una nueva orientación de las reglamentaciones internas de los países de la región que incluye posibilidades como las siguientes: la de conceder 'trato nacional' a los inversionistas extranjeros; una mayor apertura al ingreso de la inversión a ciertos sectores económicos antes vedados; mayor flexibilidad en las posibilidades de financiamiento local, reinversión, remesas y reexportación de capitales; la de remitirse a leyes extranjeras y foros arbitrales en materia de solución de controversias; $\mathrm{y}$, la de contemplar la regulación de las nuevas formas de inversión, como los contratos joint venture. Ello en síntesis, implica la sustitución de un esquema basado en la 'protección' por uno basado en la 'promoción', sin por ello olvidar los necesarios mecanismos de control que todo esquema debe contemplar." 374

The "necessary mechanisms of control" attached to the new regime based on the "promotion" of investments were neither identified nor activated in relation to the conduct of the Member States with regard to the adoption of international treaties covering foreign investment. It has to be recalled that Decision 291 set the general guidelines for the promotion of investment enabling the Member States to incorporate exceptions to the general standards like the principle of national treatment by domestic legislation ${ }^{375}$. In any case, it preserved the obligation to register foreign investment before the relevant national authorities and set the capital percentages for defining an investor as foreign, sub-regional or national. In the case at issue, the ATJ allowed the national judicial authority (provincial court of Ecuador) to assess whether the supranational provision enshrining the principle of national treatment as set forth by Decision 291 was fulfilled

\footnotetext{
${ }^{374}$ See: Tribunal of Justice of the Andean Community, Proceeding 158-IP-2006.

375 See: Tribunal of Justice of the Andean Community, Proceeding 158-IP-2006:

"El artículo 2 de la Decisión 291 es un desarrollo del principio de trato nacional o de no discriminación, ya que dispone que "los inversionistas extranjeros tendrán los mismos derechos que los inversionistas nacionales, salvo lo dispuesto en las legislaciones de cada País Miembro.” La anterior norma si bien establece como principio general que no puede haber un trato diferencial o discriminatorio entre los inversionistas extranjeros y los nacionales, a reglón seguido establece una excepción al principio: "salvo lo dispuesto en las legislaciones de cada País Miembro". Se consagra así un régimen exceptivo al principio de trato nacional de conformidad con las regulaciones que sobre la materia establezcan los Países Miembros.

De conformidad con lo anterior, se evidencia la idea de que la Decisión 291 actúa como un marco dispositivo para que los Países Miembros diseñen su propia política de inversión extranjera, acatando por su puesto las regulaciones marco del actual régimen."
} 
in regard to the allegation of the claimant who asserted that its "foreign products" were accorded less favourable treatment compared to those of its nationals. In his ruling, the ATJ concluded that in the case of contradiction between the Andean Law and the municipal law, the former prevails, in the same way that it predominates over any further provisions of International Law:

"En caso de presentarse antinomias entre el Derecho Comunitario Andino y el derecho interno de los Países Miembros, prevalece el primero, al igual que al presentarse antinomias entre el Derecho Comunitario y las demás normas de derecho internacional; lo anterior tiene como efecto inmediato la inaplicabilidad de la norma contraria al Derecho Comunitario Andino.

Para que las normas de derecho interno, de conformidad con el principio del complemento indispensable, puedan desarrollar o reglamentar las normas comunitarias, es preciso que dicha reglamentación sea necesaria para su correcta ejecución. No obstante lo anterior, no se autoriza a los Países Miembros para establecer nuevos derechos $\mathrm{u}$ obligaciones o modificar los ya existentes y previstos en la citada Decisión." 376

This interpretation is in conformity with the supremacy given to the communitarian law and the need for assuring a coherent and uniform application of the supranational obligations as a prerequisite for achieving integration goals. A previous preliminary ruling within the frame of Decision 220, the same that operationalized the reallocation of the supranational attribution for determining the areas restricted to foreign investment into Member States, made clear the compromise of the signatories to not adopt any measure contrary to supranational laws or capable of hindering their application. Hence, the supremacy and direct applicability of communitarian provisions were both reiterated at the Andean level. With regard to the communitarian legal framework's autonomy, the ATJ, in a controversy involving the application of the TRIPS Agreement, determined that the same was not binding for the Community and in consequence it lacked direct enforceability at this level:

"En este contexto, cabe reiterar que el ordenamiento comunitario no deriva del ordenamiento de los Países Miembros, sea éste de origen interno o internacional, sino del Tratado Constitutivo de la Comunidad. Así, y por virtud de su autonomía, se ratifica que el ordenamiento jurídico de la Comunidad -tanto el primario como el derivado- no depende ni se halla subordinado al ordenamiento interno, de origen internacional, de dichos Países. En consecuencia, los tratados internacionales que celebren los Países Miembros por propia iniciativa, como el del Acuerdo sobre los ADPIC, no vinculan a la Comunidad, ni surten efecto directo en ella, sin perjuicio de la fuerza vinculante que tales instrumentos posean en las relaciones entre los citados Países Miembros y terceros países u organizaciones

\footnotetext{
${ }^{376}$ See, Tribunal of Justice of the Andean Community, Proceeding 158-IP-2006.
} 
internacionales." 377

The incompatibility between certain BITs' provisions adopted by Ecuador with several restrictions imposed by Decisions 24 and 220 seems to be manifest, considering the imbalance between the allocation of rights and obligations among States and investors implied by these two different categories of international treaties. For instance, the abolition of any restriction by the referred BITs to the transfer of capital and performance standards contradicts the thresholds and further procedural investment requirements inserted by the aforementioned supranational decisions in relation to the same matters. With the adoption of Decision 291, the Andean Community paved the way for the uncontrolable trend of trade and investment liberalization, which was translated into the virtual resignation of its enforcement powers by privileging the good will of the Member States to negotiate bilateral agreements without affecting the supranational legal order. The progressive decline of the Parties' willingness to coordinate a common external trade policy with the consequence of gradually isolating from the Andean context the individual obligations acquired in commercial and investment matters with third countries, was recognized by further supranational instruments such as Decision 598, motivated by Colombia and Peru's resolution for negotiating free trade agreements with Europe and the United States. This decision, while encouraging the State members to jointly negotiate international treaties with third countries in matters included in the Andean legal framework, also compelled the signatories to preserve the supranational legal order. In any case this attempt at conciliating supranational and bilateral obligations with the purpose of facilitating the negotiation of the aforementioned free-trade agreements was perceived by Venezuela as the coup de grace to the Andean Community and as a result it decided to terminate its membership in $2006 .{ }^{378}$

\footnotetext{
377 Proceeding 01-AI-200,Judgment of June 27, 2002, published in the Official Gazette of the Cartagena Agreement $\mathrm{N}^{\circ}$ 818, of July 23, 2002.

${ }^{378}$ Decision 598:

"Artículo 2.- De no ser posible, por cualquier motivo, negociar comunitariamente, los Países Miembros podrán adelantar negociaciones bilaterales con terceros países. En este caso, los Países Miembros participantes deberán:

a) Preservar el ordenamiento jurídico andino en las relaciones entre los Países Miembros de la Comunidad Andina.

b) Tomar en cuenta las sensibilidades comerciales presentadas por los otros socios andinos, en las ofertas de liberación comercial.

c) Mantener un apropiado intercambio de información y consultas en el desarrollo de las negociaciones, en un marco de transparencia y solidaridad."
}

Andean Council of Foreign Affairs Ministers, Quito, July 11, 2004. 
In view of the aforementioned, it is evident that the articulation of the global institutional system post World War II reinforced the notion that subordinated peace, development and the rule of law to the attainment of the liberalization of trade, promotion of foreign investment and protection of private rights. Although the UN system served as an escape valve for the growing demands of the developing countries and newly independent States, as it can be shown with the early orientation of UNCTAD, these institutional responses were of little impact for outweighing the real power exerted by developed countries and specially, the United States jointly through the institutions of Bretton Woods and internal outward economic policies. In the case of Latin America, the United States was reluctant to waive influence in favour of the UN system, maintaining the development of inter-American institutions and rules. In this line and notwithstanding the co-ordinated responses of developing countries for advocating differential treatment at the multilateral level, for instance, by achieving the recognition of the enabling clause as an exception to the MFN principle, there emerged a denser web of international commitments that diluted such accomplishments. The development of International Investment Law after the end of the 1950s borrowed the conceptual milestones underpinned at the multilateral level, as well as its most effective procedural features, reserving for the bilateral and reciprocal space, the definition of the substantive rules. Until the beginning of the 1990s the international machinery for the settlement of disputes grew silently in the shadow of the failed attempts at constructing multilateral and regional systems of governance that could duly take into account developing countries' concerns, ranging from the right of self-determination to the protection of infant industries. With the demolition of such institutional endeavours and the irruption of the neo-liberal agenda, the implementation of the investment protection framework was ready. The Ecuadorian case reveals eagerness both for adopting multilateral and bilateral international obligations, at the expense of constitutional provisions and further commitments adopted at the international level, as is evident, for instance, from the supranational duties disregarded when the first BITs were concluded. Although the abundant constitutional texts approved since Ecuador signed its first BIT acknowledged International Law as the rule of conduct among the States, the national authorities did not make any effort to make compatible well settled constitutional principles with the standards of protection created though these international treaties. Perhaps with the exception of the BIT concluded with China, all the BITs adopted by Ecuador from 1965 to 2001 conflict with the Constitutions within which they were concluded due to the 
extension of the standards of protection they enshrined, especially through umbrella clauses.

\subsection{The Liberalization Trend and the Privatization of Justice}

The import substitution strategy as the main driver of the Andean integration disappeared from the sub-regional agenda during the 1990s, when the State members following the dominant global trend, embraced the neo-liberal Washington Consensus. In the frame of investment and trade policy, Decision 291 paved the way for the liberalization of markets and foreign capital flow. This shift of direction revived the goal of building a common market at the Andean level, whose main achievements resulted in the creation of the Free Trade Zone (1993), agreeing upon a common external tariff (1994) and consenting to completing the common market (1997). Along with these integrationist efforts, the development of supranational rules of intellectual property law was conceived as one of the fundamental pillars of economic harmonization and its application became one of the issues that most affected the jurisdiction of the ATJ through the endorsement of preliminary rulings. Again, the different levels of application of the supranational rules implied that, while certain areas like intellectual property deserved great attention both at the legislative and adjudicative level, others such as investment and international trade, undoubtedly crucial for the achievement of economic harmonization, were suppressed from the Andean agenda. As a consequence, Andean States eager for embarking on the new path of development, started to implement individually structured reforms capable of materializing Washington Consensus' suggestions.

A key feature of neo-liberalism has been positioning a hegemonic narrative that blends both political and economic components as indivisible factors for achieving growth. Within this frame, adopting a variety of international obligations that contribute for the presentation of a "market-friendly" state, were assumed to be strong signals of "good governance" and "state effectiveness" as coined by multilateral institutions like the World Bank, which encompassed and subordinated the role of the State to the overall free market model inspired by Washington Consensus' principles. ${ }^{379}$ As a consequence, the $1990 \mathrm{~s}$ witnessed a redefinition of the State's role as an instrument subordinated to market

\footnotetext{
${ }^{379}$ Crawford (Gordon), "The World Bank and good governance: Rethinking the state or consolidating neoliberalism?", in The IMF, World Bank and Policy Reform, Ed. Paloni (Alberto) and Zanardi (Maurizio), Routledge, New York, 2006, 115 p.
} 
mechanisms. The concepts of "good governance" and "state effectiveness", in the words of Crawford, were "presented as technical in nature, underpinned by the presumption of a neutral state", although this alleged neutrality is a key conception of the liberal political theory and as such they are guided by "pro-free market assumptions". ${ }^{380}$ In this line, Trubek and Santos illustrate that the development of law during the consolidation of neoliberalism was focused on strengthening private law with the aim of protecting property and facilitating contractual exchange. Hence, law was used for delimiting the boundaries of state intervention and ensuring equal treatment for foreign capital and the judiciary's role was confined to restraining the state and facilitating markets. ${ }^{381}$ With the aim to provide fidelity and predictability to the law in co-existence with the proper functioning of markets and free trade, a "one size fits all” package of measures were employed to put countries on the neoliberal path. ${ }^{382}$

The application of neo-orthodox economic adjustments stood for outward-oriented trade policies, reductions in the role of the state, and public sector reforms. The strong intervention of Bretton Woods Institutions assumed this trend as the economic dogma of the Western World and created insurmountable conditions and inducements that pushed the adoption of market reforms by several countries tipping the balance in favour of deregulation and privatization policies. ${ }^{383}$

The influential intervention of the abovementioned institutions, especially through the important legal reforms led by the World Bank in developing countries, with the aim of applying structural adjustments in a period of trade liberalization of the 1980s, included the development of a lending practice that made the allocation of loans conditional upon

\footnotetext{
${ }^{380}$ Crawford (Gordon), "The World Bank and good governance: Rethinking the state or consolidating neoliberalism?", in The IMF, World Bank and Policy Reform, Ed. Paloni (Alberto) and Zanardi (Maurizio), Routledge, New York, 2006, 118 p.

381 Trubek (David M) and Santos (Álvaro), Introduction: The Third Moment in Law and Development Theory and the Emergence of a New Practical in The New Law and Development: A Critical Appraisal, Cambridge University Press, USA, 2006, p.6.

382 Trubek (David M) and Santos (Álvaro), Introduction: The Third Moment in Law and Development Theory and the Emergence of a New Practical in The New Law and Development: A Critical Appraisal, Cambridge University Press, USA, 2006, p.6.

${ }^{383}$ Manzetti (Luigi), "The Politics of Privatization and Deregulation in Latin America", The Quarterly Review of Economics and Finance, Vol. 34, Special Issue, Summer 1996, pages 43-76.
} 
the implementation of reform programs in macro-economic and financial management. ${ }^{384}$ Álvaro Santos points out three main areas that this strategy sought to articulate:

(...) 1) macro-economic management (realistic exchange rates, positive real interest rates, trade liberalization), efficient resource allocation (replacement of price controls with competitive markets) and the creation of supportive legal and regulatory framework (reducing costs of doing business and encouraging competition, streamlining procedures and reforming tax, labor, investment, credit and corporate laws), 2) privatization or restructuring of state- owned enterprises to guarantee efficient provision of infrastructure and services (reducing or eliminating public monopolies, privatization and contracting out), and 3) developing financial systems that mobilize and allocate financial resources efficiently (develop strong financial markets, strengthen institutions promoting the private sector, and assisting micro enterprises, small-scale agriculture, and the informal sector). ${ }^{385}$

The discussions that supported the privatization trend during 1980s and 1990s, underpinned by the ideological framework of the Washington Consensus and the technical assistance and supervision of its core institutions such as the World Bank and International Monetary Fund, especially in Latin American countries, placed the elimination of politically motivated resource allocation and the deficiencies derived from it, such as corruption and inefficiency as the principal benefits of this process. As is well known, the dramatic failure of this process, particularly in Latin America was not only caused by the endogenous motivations mentioned above, which vary from country to country. It is evident that privatization processes are not immune to corruption as in any human activity. These drawbacks, combined with the absence of competition and incentives to innovate, the incapacity of the governments to regulate properly market failures, patronage and political unrest, did not allow the crystallization of this process, as originally intended. ${ }^{386}$

As is well known, when the last century came to end, reactions to neo-liberal programs in development economics grew, since many developing countries that adopted these policies experienced severe economic crises. As Trubek and Santos point out, "the devastating experience with market-shock therapy in Russia, the severe economic

\footnotetext{
384 (Santos) Álvaro, "The World Bank's Uses of the "Rule of Law" Promise in Economic Development" in The New Law and Development: A Critical Appraisal, Cambridge University Press, 267 p.

385 (Santos) Álvaro, "The World Bank's Uses of the "Rule of Law" Promise in Economic Development" in The New Law and Development: A Critical Appraisal, Cambridge University Press, 268 p.

${ }^{386}$ Schiffler (Andrei), State versus Private Ownership, National Bureau of Economic Research, Working Paper 6665, Cambridge, July, 1998.
} 
emergency experienced by a number of Latin American countries, and the Asian financial crisis made clear that markets do not create the conditions for their own success". 387

As the same authors emphasize, people started to recognize that unrestricted markets were often inefficient and that state intervention was necessary to correct such market failures as transaction costs or information asymmetries. In fact, the recognition of the limits of markets moderated dogmas such as unlimited deregulation, liberalization of borders and unconditional faith in free trade. Although the strong neo-liberal presumption against regulation has been overcome, it is still accepted that the view of the primary role of law is limiting the relationship between markets and state intervention in the pursuit of economic growth. ${ }^{388}$

As a consequence of the categorical failure of the experiments commonly associated with neo-liberal policies, it is not surprising to find the aggressive resurgence of economic nationalism among many of the countries that passed through such a process, and the consequential restoration of the importance of the role of the state in order to recover "sovereignty" and control over strategic sectors.

Although a multi-lateral attempt for globally regulating international investment failed in the past, the exponential proliferation of BITs after 1989, determined the construction of a dense and decentralized web of over-arching obligations assumed by the States encompassing substantive and procedural rights without parallel in International Law. encompassing substantive and procedural rights without parallel in International Law. Investors - as new bearers of international rights - were given powers for challenging the exercise of the most essential and ample sovereign powers as any other actor in the global arena. Bandelj and Mahutga affirm that the alignment of BITs with the worldwide diffusion of legitimate policy guidelines diffused during the early 1990s, underpinned the developing States' willingness for signing these international instruments, conceived as new pillars of desirable economic governance. ${ }^{389}$ The same authors underline the decisive role played by UNCTAD for the promotion of BITs, which radically opposes its early concerns for advocating protectionist and differential measures that take into account

\footnotetext{
${ }^{387}$ Schiffler (Andrei), State versus Private Ownership, National Bureau of Economic Research, Working Paper 6665, Cambridge, July, 1998, 6 p.

${ }^{388}$ Schiffler (Andrei), State versus Private Ownership, National Bureau of Economic Research, Working Paper 6665, Cambridge, July, 1998.13 p.

389 Bandelj (Nina) and Matthew C (Mahutga), "Structures of globalization: Evidence from worldwide network of bilateral investment treaties (1959-2009)", International Journal of Comparative Sociology 54 (2) $95-123,101 \mathrm{p}$.
} 
developing countries' particularities for their insertion into the global economy:

Indeed, a chapter of the United Nations, one of the central organizations in the population of NGOs that shape world-polity, plays a critical role in attempting to both construct and diffuse BITs as a policy script. UNCTAD, the UN's chapter on trade and development, launched a BIT initiative supported by its Trust Fund on International Investment Agreement (financed by contributions from the European Commission, France, Germany, Japan, the Netherlands, Norway, Switzerland, and the United Kingdom) in the early 1990s. UNCTAD organized meetings at which interested countries could negotiate BITs, which often led to real treaty adoptions. At four meetings organized in 1999 and 2000, for example, 35 BITs were signed (UNCTAD, 2000). UNCTAD's intervention is a concrete example of a more general process of institutional isomorphism across countries in which world polity actors frame bilateral investment treaties as a key feature of responsible state behavior, and promote their adoption to individual nationstates. $^{390}$

As noted, the boom of BITs in Ecuador took place in the 1990's. Twenty seven of the thirty BITs signed by the country, were concluded between 1992 and 2002. With the increasing influence of Bretton Woods' institutions from the early 1980s, the diverse instruments for implementing their policies began to temper the scope of public policies in the country. From the letters of intent of the International Monetary Fund to the programs of structural adjustment of the World Bank, these tools included the institutional goals and the governmental duties aimed at economic liberalization. As Crawford highlights, several of the World Bank's documents like the World Development Report (1997) and the World Development Report: Building Institutions for Markets (2002) enshrine an inextricable association "between notions of governance and freemarket economy" confirming the presence of "the heavily loaded assumption that a free market system is both desirable and superior". ${ }^{391}$ The subjection of the role of the State to the private sector was firmly expressed in the development of the notion of the rule of law. Legal rules and institutions were transcendental as long as they were useful for the proper performance of the pro-business model. The scope of concepts like corruption, accountability and transparency were confined to public sector's activities, while undesirable private conducts such as anti-competitive behaviour, collusion and bribery remained unregulated. The pro-market governance underpinned by the World Bank as

\footnotetext{
390 Bandelj (Nina) and Matthew C (Mahutga), "Structures of globalization: Evidence from worldwide network of bilateral investment treaties (1959-2009)", International Journal of Comparative Sociology 54 (2) $95-123,100-101 \mathrm{pp}$.

${ }^{391}$ Crawford (Gordon), "The World Bank and good governance: Rethinking the state or consolidating neoliberalism?", in The IMF, World Bank and Policy Reform, Ed. Paloni (Alberto) and Zanardi (Maurizio), Routledge, New York, 2006, 119 p.
} 
examined by Collingwood determined the predominance of the protection of property rights' as the State's main duty:

The Bank has tended to place law on the side of markets rather than empowering individuals.... Law is viewed as a means of protecting businesses....As such, the Bank has mostly addressed issues relating to economic efficiency and property rights, rather that distributional considerations, questions of access to justice, the enforcing of political and civil rights, and the strengthening of criminal law. ${ }^{392}$

Also, the concept of the minimal State was inseparably associated with the achievement of the highest degree of freedom by citizens. The presence of "a minimal, yet enabling state" would be the key for setting a complex set of rules presided over by the intangibility of property rights. At the time that a pro-business model advocates a minimal state, it requires its public strength for enforcing and punishing rules protective of property rights. Crawford portrays this contradiction stating: "the minimal state also needs to be a strong state in order to realize the (neo-) liberal project. ${ }^{393}$ In this regard, the good governance agenda, as underscored by the same scholar, "continues to display an unbalanced and asymmetrical response to state and market actors, amounting to promarket governance". 394 This alleged imbalance, which is constructed upon the assumption that an active state intervention is detrimental to a "market-friendly" and free society, and as a consequence, would constitute the central problem for developing countries, has set aside the exercise of basic public prerogatives for the achievement of socially desirable goals:

At no point does the World Bank express any qualifications or reservations about private ownership of the means of production. We are informed of the necessity for secure property "rights", but not of the privileges and benefits enjoyed by the owners of private capital, at the expense of the rest of the population. The problem of excessive state power is repeatedly emphasized, including its "arbitrary" and "capricious" use by state officials and the opportunities thereby for corruption, but the economic and political power appropriated by the owners of private capital is never mentioned. An association between the strength of property rights and economic growth is claimed (ibid.), but massive inequalities in the accumulation

\footnotetext{
${ }^{392}$ Crawford (Gordon), "The World Bank and good governance: Rethinking the state or consolidating neoliberalism?", in The IMF, World Bank and Policy Reform, Ed. Paloni (Alberto) and Zanardi (Maurizio), Routledge, New York, 2006, 130 p.

${ }^{393}$ Crawford (Gordon), "The World Bank and good governance: Rethinking the state or consolidating neoliberalism?", in The IMF, World Bank and Policy Reform, Ed. Paloni (Alberto) and Zanardi (Maurizio), Routledge, New York, 2006, 131 p.

${ }^{394}$ Crawford (Gordon), "The World Bank and good governance: Rethinking the state or consolidating neoliberalism?", in The IMF, World Bank and Policy Reform, Ed. Paloni (Alberto) and Zanardi (Maurizio), Routledge, New York, 2006, 121 p.
} 
of wealth are ignored, as is the potential role of the state in the redistribution of wealth through progressive taxation and welfare provision. ${ }^{395}$

In short, the role of the State within this frame is justified as soon as it provides a supportive role for maximizing private sector gain. ${ }^{396}$ Consequently, the state"minimizing-agenda" relies on strong governmental action for promoting free market development, providing public goods and enforcing private rights, but weak regulatory performance in crucial areas that may affect its unrestricted functioning, such as protection of the labour force, promotion of collective rights, incorporation of environmental standards and control of the distortion of economic forces. Crawford further explains the construction of the state and the rule of law in the service of the private sector and a free market development model:

(...) It is contended here that the capitalist class, notably international capital, benefits in two distinct ways from the World Bank's model of the state: from what it does and from what it does not do. First, the business class gains from the reconfiguration of the state into the service of private capital, making available those "public goods" that the private sector requires, such as transport and energy infrastructure and a healthy, educated workforce, thus providing the "enable environment" for private profits to be maximized. Second, the capitalist class also benefits from the state's continued withdrawal from intervention in a number of key areas. ${ }^{397}$

This utilitarian notion modeling the State's action is particularly notable in the sudden development of International Investment Law and the incipient delimitation of the tribunals with relation to the scope of vague protection standards. Concepts such as legitimate expectations and investors' representations for establishing their operations in a host State heavily rely on an ancillary State's role exclusively devoted to the purpose of facilitating private enterprise. The insulation of key areas of economic policy from public and political influence on the assumption that an alleged neutral, technocratic and independent management would assure stability and objective decision-making

\footnotetext{
${ }^{395}$ Crawford (Gordon), "The World Bank and good governance: Rethinking the state or consolidating neoliberalism?", in The IMF, World Bank and Policy Reform, Ed. Paloni (Alberto) and Zanardi (Maurizio), Routledge, New York, 2006, 129 p.

${ }^{396}$ Crawford (Gordon), "The World Bank and good governance: Rethinking the state or consolidating neoliberalism?", in The IMF, World Bank and Policy Reform, Ed. Paloni (Alberto) and Zanardi (Maurizio), Routledge, New York, 2006, 121 p.

${ }^{397}$ Crawford (Gordon), "The World Bank and good governance: Rethinking the state or consolidating neoliberalism?", in The IMF, World Bank and Policy Reform, Ed. Paloni (Alberto) and Zanardi (Maurizio), Routledge, New York, 2006, 126 p.
} 
constitutes in itself a position that favours a particular political ideology, namely, liberalism. As noted in chapter 1, a good example of this conceptual construction concerns the independence of the Central Bank in Ecuador as enshrined by the Constitution of 1998, which deprived democratically elected governments of exercising key monetary and economic policies. The systematic down-grading of the value of public actions as opposed to the desirability of favouring private activities imposed a heavy burden on the legitimacy of regulatory decisions, which particularly remains remarkable in Investment Law's frame. In this sense Crawford indicates:

The overwhelming impression is of a state-scepticism that driven by neo-liberal ideology-fundamentally the state and public officials are not to be trusted and must be subjected to market forces. In contrast, there is little or no criticism of private sector actors.

Santos notes that this strong and uncontested bias was consolidated by the premise that "an independent and effective judiciary is a necessary pre-condition for economic development". ${ }^{398}$ Prompt enforcement of property rights and contractual obligations through independent and effective courts was advocated as a pre-condition for attracting investments and boosting economic transactions with predictability and calculability. Potent examples of these dogmas of influence, as pillars for the establishment of transnational rules of business protection, can be identified in certain projects of judicial reform sponsored by the World Bank. For instance, the World Bank's report assessing the state of the judicial system in Ecuador (1996) attributed the stagnation of economic growth to weak legal and judicial systems:

In the 1990's, structural reforms have included an agenda to modernize the economy through private sector development, public sector reform as well as improve social conditions. One of the key objectives of the Government is to help create an enabling and competitive business environment for the private sector and attract foreign direct investment. On the critical path improving this environment is to strengthen the legal and judicial systems. The legal principles supporting the prevailing economic system in Ecuador are based on the freedom to exercise individual rights and property rights. Protection of these rights requires clearly defined rules of law and effective mechanisms to enforce them. This would in turn provide the necessary foundation for a stable legal environment for economic decisions to be made in a predictable way. In an effort to promote socioeconomic development, economic decisions should be based on economic criteria-market efficiency and the realization of the growth potential in the economy. Economic risk can be calculated, but uncertainties as to the legal

\footnotetext{
398 (Santos) Álvaro, "The World Bank's Uses of the "Rule of Law" Promise in Economic Development" in
} The New Law and Development: A Critical Appraisal, Cambridge University Press, 282 p. 
framework and its enforcement should not enter into such calculations. Such legal uncertainties do, however, play a major role in economic decisions in Ecuador. The results of the 68 enterprises surveyed indicate that the judicial system is considered to be the sixth most significant constraint to private sector development. This environment affects the private sector as a whole. ${ }^{399}$

Interestingly, Santos forewarns that this assessment confirms the evidence that the effectiveness of judiciaries constitutes a minor entrepreneur's concern when it comes to choosing the countries they invest in, being preceded by political instability, inflation and price instability, lack of skilled labour, lack of infrastructure and a high level of taxation. ${ }^{400}$ The same scholar underscores the obvious fact that "investors and business actors are driven by returns and consequentially rely on informal mechanisms of enforcement where reputation and expectations of future transactions substitute for formal mechanisms to ensure compliance". ${ }^{401}$ Accordingly the legal system and the effectiveness of judiciaries, identical to the signature of BITs, have been proved to be of marginal importance for affecting entrepreneurs' interest to invest in small countries. In any event, it has to be recalled, that in the case of mid-size economies like Mexico a free trade agreement conferring strong privileges to investors and allowing them to bypass national courts, could be a major factor in attracting investment. In this context, Santos adds:

The legal system could represent a marginal advantage for very small countries having little else to offer. Creating market-friendly legal enclaves of weak consumer protection, minimum labour, and employment rights or low standards of environmental protection could represent an attraction for investors. But more attractive may be special concessions to entrepreneurs in the usual form of tax exemptions, public services, and bureaucratic ease. In neither case, however, does judicial reform come high in the list. ${ }^{402}$

Although the international promotion and protection of investors rights differs substantively and jurisdictionally from the correlative domestic rules, the conceptual

\footnotetext{
399 (Santos) Álvaro, "The World Bank's Uses of the "Rule of Law" Promise in Economic Development" in The New Law and Development: A Critical Appraisal, Cambridge University Press, 283 p.

400 (Santos) Álvaro, "The World Bank's Uses of the "Rule of Law" Promise in Economic Development" in The New Law and Development: A Critical Appraisal, Cambridge University Press,283 p.

401 (Santos) Álvaro, "The World Bank's Uses of the "Rule of Law" Promise in Economic Development" in The New Law and Development: A Critical Appraisal, Cambridge University Press, 283 p.

402 (Santos) Álvaro, "The World Bank's Uses of the "Rule of Law" Promise in Economic Development" in The New Law and Development: A Critical Appraisal, Cambridge University Press,283 p.
} 
justifications for underpinning the State's action towards its transformation into a market friendly destination by upgrading its legal commitments for embracing private interests, are the same both for undertaking judicial reform projects and for adopting international investment and trade treaties. However, taking into consideration that the core matter in investment arbitration consists of assessing state conduct, judging the conformity of domestic legal rules' contents and their way of enforcement of these undetermined transnational legal standards of transparency and legitimacy, demands the articulation of national and international actions into a pattern governed by dominant presumptions such as the aforementioned. In short, an international investment dispute arises, provided that the state adopts public internal actions that challenge the premises referred to. In this context, Crawford contends that under the influence of the most powerful multilateral institutions and influential legal scholarship "good policies equate to neo-liberal policies" and undoubtedly these conceptions have permeated the development of the core notions of International Investment Law:

(...) This is precisely the manner by which proponents of neo-liberalism, such as the World Bank, seek to construct hegemonic control. The attainment of hegemonic status by a particular body of ideas means that such is its dominance that it is subject to little questioning or challenge. Its proponents have been successful in presenting their ideas as rational, objective and universally beneficial as "good policies" for instance, to the extent that there is "no alternative". In neoliberalism's case, its drive for hegemony entails creating the impression that there is no alternative to the politics of economic liberalization, trade liberalization and integration into the world economy. ${ }^{403}$

Ecuador is no different from other Latin-American countries, and was caught by this dominant mainstream and consequentially speeded up all kind of measures for opening up its economy to transnational actors, both at the international and internal level. The diverse legal reforms adopted after the enactment of Decision 291, linked to the countries' willingness to adopt wide international obligations was based on the understanding that attracting investment and promoting economic growth were the only means for overcoming under-development. The "race to the bottom" deregulatory efforts of the government were sanctified by the Constitution of 1998 that consented to subordinate any public state action to investment commitments formalized by public contracts.

\footnotetext{
${ }^{403}$ Crawford (Gordon), "The World Bank and good governance: Rethinking the state or consolidating neoliberalism?", in The IMF, World Bank and Policy Reform, Ed. Paloni (Alberto) and Zanardi (Maurizio), Routledge, New York, 2006, 125 p.
} 
Understandably, with a constitutional and legal framework depriving the State of its key powers, the constraint for constructing an alternative model of development departing from neo-liberal dogmas, and also shielded by over-arching international commitments, would be practically impossible. Camp Keith, referring to Shapiro highlights the conceptual adaption of the notion of rule of law to market friendly States:

Shapiro observes that "an international epistemic community of investment bankers and lawyers acting through entities ranging from American law schools to the World Bank has been busy trying to persuade the world that one key to national economic success is the 'rule of law' enforced by independent judiciaries" (327) and he concluded that even authoritarian regimes "anxious to attract foreign investment...can be persuaded to institutionalize relatively independent and effective courts to assure investors of legal protection (330). ${ }^{404}$

In the field of international investment law, Miles asserts that the construction of this firmly settled doctrinal patterns dates back to the nineteenth century, as result of the clash of post-colonial states for regaining control over natural resources, many of which were under the control of foreign-owned concessions:

(...) The resulting investor claims led to the development of arbitral jurisprudence that reaffirmed the traditional position of capital-exporting states and left the postcolonial nations with few practical avenues to benefit from concessioncontrolled natural resources and rebuild their economies. The central doctrines through which investors and their home states sought to submit these disputes to international arbitration were those of 'internationalised contract' and acquired rights. However, in the face of increasing post-colonial nationalisations and call for reforms to international economic frameworks, a more systematic approach to ensuring investor protection was developed-bilateral investment treaties and ICSID. In this way, the modern architecture for international investment law was constructed through politico-legal processes of assertion and response as between capital-importing and investor home states. ${ }^{405}$

The post-colonial States' attempts at re-appraising the obligations' permanence acquired during the colonial period were resisted by the development of arbitral jurisprudence that safeguarded the position of capital-exporting States, detaching from the national jurisdiction the settlement of controversies arising from it. This outcome as explained by Miles, is indebted to the sanctification of alleged well-established rules of international law that required post-colonial states to honour the concessions or pay full compensation

\footnotetext{
${ }^{404}$ Camp Keith (Linda), Political Repression: Courts and the Law, University of Penssylvania Press, 2012, $131 \mathrm{p}$.

${ }^{405}$ Miles (Kate), The Origins of International Investment Law: Empire, Environment and the Safeguarding of Capital, Cambridge University Press, 2013, 78-79 pp.
} 
for any nationalization of foreign-owned assets in the light of international principles of state succession that did not extinguish the new State's obligation to fulfill commitments agreed under colonial authority. ${ }^{406}$ Moreover, the abrupt development of principles of the internationalization of concession contracts underpinned by a weak rational basis that attributed the need for their delocalization to their supposed complexity, transposed the privileged application of international standards of protection over the rules provided by domestic law:

(...) Creating a novel international legal instrument was also an adopted technique, through which concession contracts were framed as forming a distinctive category of economic development agreement or 'quasi-treaty'. References in the concession agreement to dispute resolution through 'international arbitration' were taken to import the new international law of contracts as the substantive law governing the contract. Sources of public international law, such as 'general principles of law', were considered applicable to the contract and arbitral awards identified key principles for this new field of law. Significantly, however, the general principles regarded as relevant in the context of such disputes consisted of respect for private property, respect for acquired rights, and compensation for unjust enrichment on denial of concessionaire's rights. ${ }^{407}$

The jurisprudential development of these novel principles would be transposed to the wording of the incipient BITs and their effectiveness would also be complemented by the further incorporation of vague standards modulated by arbitral law making. It is important to note the steadiness of the regulation and interpretation of the aforementioned principles through the consolidation and expansion of modern standards like fair and equitable treatment, legitimate expectations and novel requirements of stability and predictability. Following Sornarajah, Miles asserts that the expansive interpretation of these apparently reasonable obligations which extended protection well beyond the international minimum standard's original scope of bad faith and outrageous or egregious conduct, reflects the inherent bias of investment treaty arbitration towards foreign investors' interests. ${ }^{408}$ In this context, it is not surprising that Latin-American countries like Ecuador after passing through an aggressive reform of economic liberalization with the subsequent

\footnotetext{
${ }^{406}$ Miles (Kate), The Origins of International Investment Law: Empire, Environment and the Safeguarding of Capital, Cambridge University Press, 2013, 80. p.

${ }^{407}$ Miles (Kate), The Origins of International Investment Law: Empire, Environment and the Safeguarding of Capital, Cambridge University Press, 2013, 80-81. pp.

${ }^{408}$ Miles (Kate), The Origins of International Investment Law: Empire, Environment and the Safeguarding of Capital, Cambridge University Press, 2013, 83 p.
} 
subordination of the State's prerogatives to investor's protection are constrained by a straitjacket in a similar manner to post-colonial countries after establishing themselves as new independent countries. In conclusion, the language of universality and neutrality in the development of international standards of investor protection has been proved to largely favour capital-exporting states under the significant influence of multi-lateral institutions.

\subsubsection{Public Measures Adopted for Attracting Foreign Direct Investment and Liberalizing the Market}

The hegemony of neo-liberalism ideas was indisputably reaffirmed during the 1990s. Multilateral entities, governments and academia reinforced the presumption that economic liberalization was the sole alternative for tackling global challenges. During the beginning of the decade, Ecuador was highly dependent on external debt and with an strong necessity for liquidity, so it resorted to the credits of the IMF, World Bank and Inter-American Development Bank. Under the dominance of Washington Consensus' principles and the urgency for bringing the Ecuadorian legal and institutional framework into conformity with a market friendly model, the letters of intention issued by the IMF, ${ }^{409}$ and the programs of structural adjustment sponsored by the World Bank, reveal an omnipotent influence of neo-liberal assumptions on the reform of the State's role. For instance, the World Bank`s Ecuador Assistance Strategy (1993), as noted by Mancero, incorporates among its demands:

"a strategy of development based on a public sector more dynamic and less heavy, and a major dependency on the strength of the private sector as engine of development". ${ }^{410}$

In Ecuador the articulation of Washington Consensus' policies would be covered by the blanket term "modernization", which was framed within the hegemonic neo-liberal rhetoric, signalled a desirable and unquestionable process of good policies' to be implemented in pursuit of a free market economy, formerly repressed by an alleged inefficient and arbitrary State. The government of President Sixto Durán Ballén (19921996) embraced with enthusiasm these paradigms and consequently, businessmen filled

\footnotetext{
${ }^{409}$ From 1983 to 2003, Ecuador signed 13 letters of intention with the IMF.

${ }^{410}$ Mancero (Piedad), "El Debilitamiento Institucional en la Década de los 90: Investigación y análisis del préstamo BIRF-3822-EC/Proyecto de Modernización del Estado”, Quito, Diciembre de 2006, Versión revisada en septiembre de 2008, 17 p. Free translation
} 
its main cabinet positions. Immediately, the transformation of the State's role became the governmental priority. Two months after the new government took office (August, 1992), the Minister of Industry, Commerce and Integration announced the liberalization of the whole regime governing foreign investment, which included the suppression to all restrictions on it in any economic activity, the recognition of equal treatment for national and foreign investments, the free repatriation of profits and dividends and the establishment of additional guarantees for the protection of foreign investors. In the same announcement, this authority anticipated that under the new regime of foreign investment, the Ministry would encourage the adoption of international agreements including investor protection mechanisms against political risks, expropriation, currency convertibility and suspension of payments. ${ }^{411}$ Shortly after, there were published the regulatory norms for foreign investment and technology transfer, trademarks, patents, licenses and royalty contracts. ${ }^{412}$ It is worth to recall, that Decision 291, remained as the general common framework containing guidelines for the regulation of investments, enabling the States to establish the corresponding rules and exemptions. Within this enabling framework, the Executive Branch was entitled to enact and apply the regulations for the promotion and protection of investment through Executive Decree ${ }^{413}$. Particularly notable are the provisions, which embraced the presumption that the signature of international treaties

\footnotetext{
${ }^{411}$ Diario Hoy, "Apertura total al capital extranjero", 28 de octubre de 1992.

See, http://www.explored.com.ec/noticias-ecuador/apertura-total-al-capital-extranjero-55813.html

412 "Normas reglamentarias sobre inversión extranjera y sobre contratos de transferencia de tecnología, marcas patentes, licencias y regalías”, Official Gazette, January 13, 1993.

413 Accurately, the World Bank has pointed out that significant changes with impact on foreign investment were undertaken through executive decrees. Although Durán Ballén's government underpinned comprehensive legal reforms to operationalize privatization and liberalization of markets, it initially attempted to speed up such changes employing executive decrees:
}

" 17. Reforms have taken place essentially only in a few areas where there was substantial political
consensus or where changes could be effected by executive decrees. In the area of private sector
development, the most evident example was the liberalization and restructuring of financial
markets, where new legislation governing the capital markets and financial institutions have led
to the introduction of new financial instruments, the expansion of stock markets and growing
financial intermediation. Executive decrees were also used to modify several regulations that
previously hindered private sector development, e.g. in the mining sector, and to accord similar
treatment to foreign investment as that to domestic investment."

See: World Bank, Report No.15419-EC, "Memorandum of the President of the International Bank for Reconstruction and Development to the Executive Director on a Country Assistance Strategy of the World Bank Group for Ecuador, March 13, 1996. 
for the protection of investments and double taxation actually attract foreign money ${ }^{414}$ and the early recognition of the State's prerogative to submit to international arbitration the controversies derived from such a regime in accordance to the international agreements reached by Ecuador. ${ }^{415}$ This deregulatory fever was powered by a robust discourse that entwined liberalization with poverty alleviation as noted in the World Bank's Ecuador report (1996) devoted to reinforcing the reforms towards macro-economic stability, modernizing the state and developing the private sector for sustained growth underpinned since 1992:

3. The proposed Bank assistance strategy is designed to respond to the long-term challenge of poverty reduction through higher economic growth and greater provision of basic services to the poor. The Bank will continue to assist the reform program based on preserving macroeconomic stability, modernizing the state, and promoting private sector development, since these elements provide the conditions for accelerated economic growth and employment creation and are key contributors to poverty alleviation. In addition, to accommodate the likely expansion of the country's development agenda, the Bank's new operations will focus on social sector reforms and targeted poverty alleviation programs, particularly in the rural areas. ${ }^{416}$

The same report highlighted the structural reform's key legislation, within which were conferred vast incentives to promote foreign direct investment. As will be explained

\footnotetext{
${ }^{414}$ Normas reglamentarias sobre inversión extranjera y sobre contratos de transferencia de tecnología, marcas patentes, licencias y regalías":

“Art. 16.- El MICIP coordinará con el Ministerio de Relaciones Exteriores la celebración de Convenios para promover la captación de inversiones y celebrar Convenios para evitar la doble tributación. Las representaciones diplomáticas y consulares en el Exterior apoyarán activamente los programas de promoción tendientes a captar inversión extranjera, así como la información y orientación al inversionista."
}

See: Official Gazette, January 13, 1993.

${ }^{415}$ Normas reglamentarias sobre inversión extranjera y sobre contratos de transferencia de tecnología, marcas patentes, licencias y regalías:

“Art. 18-El Estado podrá someter las controversias que se suscitaren por la aplicación del Régimen Común de Tratamiento a los Capitales Extranjeros y sobre Marcas, Patentes, Licencias y Regalías a Tribunales Arbitrales constituidos en virtud de tratados internacionales de los cuales sea parte el Ecuador."

See: Official Gazette, January 13, 1993.

416 Memorandum of the President of the National Bank for Reconstruction and Development to the Executive Directors on a Country Assistance Strategy of the World Bank Group for Ecuador, Report 15419EC, March 13, 1996. 
below, when attempts were made to modify the conditions of this generous context, foreign investors resorted to the protection of the BITs for preserving them. The key laws referred to by the World Bank ${ }^{417}$ are the Budget Law (1992) ${ }^{418}$, Capital Markets Law $(1993)^{419}$, Hydrocarbon Law $(1993)^{420}$, Modernization of State Law $(1993)^{421}$, Tax Reform Law (1993) ${ }^{422}$, Customs Law (1994) ${ }^{423}$, Agricultural Development Law (1994) ${ }^{424}$, Financial Institutions Law (1994) ${ }^{425}$ and Telecommunications Law (1994). ${ }^{426}$ In conjunction with the IMF and the IDB tasks for implementing the structural adjustment plan, the World Bank foresaw the continuation of the reform agenda to support the overall policy framework begun by Durán Ballén's government in 1992. ${ }^{427}$ Later, the World

\footnotetext{
417 Memorandum of the President of the National Bank for Reconstruction and Development to the Executive Directors on a Country Assistance Strategy of the World Bank Group for Ecuador, Report 15419EC, March 13, 1996, 6 p.

418 "Integrates public sector financial and management systems into consolidated Budget". See, Report
} 15419-EC, March 13, 1996, 5 p.

419 "Encourages development of equity markets and long-term financing instruments". See, Report 15419EC, March 13, 1996, 5 p.

420 "Liberalized prices, encourages private participation in exploration and marketing". See, Report 15419EC, March 13, 1996, 5 p.

421 "Framework for civil service reform and privatization of public enterprises". See, Report 15419-EC, March 13, 1996, 5 p.

422 "Reduced taxes on savings and enhances tax enforcement capabilities". See, Report 15419-EC, March 13, 1996, 5 p. See, Report 15419-EC, March 13, 1996, 5 p.

423 "Simplified procedures and encourages private participation in the sector". See, Report 15419-EC, March 13, 1996, 5 p.

424 "Establishes protection of land property rights and facilitates trade of land". See, Report 15419-EC, March 13, 1996, 5 p.

425 "Improves efficiency of financial intermediation by allowing introduction of new financial instruments, establishes basis for full service banking, and standarizes operating rules for different kinds of financial institutions". See, Report 15419-EC, March 13, 1996, 5 p.

426 "Framework for privatization of 35 percent of telephone company (with majority holding) and new regulatory body." See, Report 15419-EC, March 13, 1996, 5 p.

427 The articulation of the aid programs on clearly defined áreas by the World Bank and the IDB, is stressed out in the report:

"97. In the areas where the reform agenda of the Government will require further support, both institutions will continue to focus individually on those areas closely linked to on-going sector or structural adjustment loans. The World Bank will maintain its significant involvement in the areas of budget reforms, public sector restructuring and telecommunications privatization, while the IDB will help to sustain the Govern institutional development and reform efforts in several areas, especially in the financial, social security, agricultural and transport sectors. "

See: Report 15419-EC, March 13, 1996, 32 p. 
Bank granted Ecuador a Debt and Debt Service Loan designed to support the Debt and Debt Service agreement, reached between Ecuador and its commercial bank creditors in August 1994 and implemented in February 1995. ${ }^{428}$ Among the objectives of this operation, the corresponding Implementation Completion Report highlights the improvement of "economic environment for attracting foreign investments". ${ }^{429}$ Continuing serving the external debt in a prompt manner was stressed as being essential for achieving financial, trade and investment liberalization. ${ }^{430}$ Moreover, this report does not leave any doubt concerning the strong influence of the World Bank, the IDB and AID for designing the contents of the aforementioned laws, and the privatization and concessions programs, as well as their respective instruments of implementation. ${ }^{431}$ Two paradigmatic assistance programs were the Modernization of the State Technical Assistance Project- MOSTA and the Public Enterprise Reform Technical Assistance Loan-PERTAL, both remembered as complete failures. Furthermore this report is categorical in emphasizing the State's obligation "to regain greater investor confidence

\footnotetext{
${ }^{428}$ World Bank, Implementation Completion Report, Ecuador, Debt and Debt Service Reduction Loan
} (Loan 3820-EC), Report 16187, December 18, 1996.

${ }^{429}$ The World Bank links the country's ability to continue to service the external debt with the preservation of the reforms that favor financial, trade and investment liberalization:

"The ability to continue to service the external debt in a prompt manner will also depend on the success of the reform and stabilization program started by the current administration. The debt reduction agreement was part of a program of public and private sector reforms that included financial, trade and investment liberalization; all of which are quite recent and will have to be continued in the future to produce the anticipated results (...)."

See: World Bank, Implementation Completion Report, Ecuador, Debt and Debt Service Reduction Loan (Loan 3820-EC), Report 16187, December 18, 1996.

431 The comprehensive program of reforms underpinned by the referred institutions, as well as their corresponding responsibilities are illustrated in the report:

"18. Structural reforms. During the first two years of its term, while negotiating the debt reduction agreement, the Administration also took steps to reform and modernize the economy through a series of legislative and executive measures. Building upon previous reform efforts, the Administration gained Congressional approval for new legislation that served as basis for the structural reform program. The legislation included an umbrella Modernization of the State Law, which provided the legal framework for public sector reforms, a Public Sector Budget Law, an amendment of the Hydrocarbons Law, a Tax Reform Law, Customs Law, Capital Markets Law and Financial Institutions law. The Government also created a Council for the Modernization of the State (CONAM), comprising the minister of Finance and several other ministers, to define strategy, norms and procedures for all modernization of the state efforts, including the program of privatization and granting concessions. The Bank, the IDB and AID provided technical assistance to CONAM and other government entities on the design of several programs to implement the aforementioned laws."

See, World Bank, Implementation Completion Report, Ecuador, Debt and Debt Service Reduction Loan (Loan 3820-EC), Report 16187, December 18, 1996, 4 p. 
and the ability to attract foreign capital" based on strengthening the policies built since $1992 .{ }^{432}$

It is worth noting the importance given to arbitration as the preferential mechanism of dispute settlement encompassed in the legal reforms mentioned above, as it can be observed for instance, in Hydrocarbon ${ }^{433}$ and Electricity Sector ${ }^{434}$ Laws. It has to be underlined that in the case of the Hydrocarbon Law, until the reform that enabled contractual disputes to be submitted to arbitration, the foreign companies were obliged to be established in the country and to be subject to the national courts, resigning to any

${ }^{432}$ World Bank, Implementation Completion Report, Ecuador, Debt and Debt Service Reduction Loan (Loan 3820-EC), Report 16187, December 18, 1996, ii p.

433 Reform to Hydrocarbon Law (1993) :

"Art. 3- Sustitúyase el artículo 10 por el siguiente:

El Ministro de Energía y Minas es la instancia superior administrativa en los reclamos que se originen por actos o resoluciones de la Dirección Nacional de Hidrocarburos. Sin embargo, el usuario tendrá el derecho de acudir directamente ante el Tribunal Distrital de lo Contencioso Administrativo, órgano jurisdiccional competente para conocer las reclamaciones directas o para resolver las apelaciones de las decisiones del Ministro.

Las controversias que se deriven de los contratos se substanciarán ante las Cortes Superiores de Justicia, en trámite verbal sumario, o por el procedimiento de arbitraje reconocido por la Ley ecuatoriana, de acuerdo a lo establecido en los contratos. En el ejercicio de jurisdicción legal, la primera instancia se tramitará ante el respectivo Presidente de la Corte Superior y la segunda instancia ante una de sus salas".

See, Official Gazette 326, November 29, 1993.

${ }^{434}$ Reform to the Electricity Sector Law (1996):

"Art. 21.- Controversias.- Toda controversia que se suscite entre: generadores, el transmisor, distribuidores, consumidores, el Centro Nacional de Control de Energía, con motivo del suministro de energía eléctrica o de los servicios públicos de transmisión y distribución de electricidad podrá ser sometida al procedimiento de arbitraje de conformidad con la Ley o ser sometidos al conocimiento y resolución del Director Ejecutivo del CONELEC. Las resoluciones que este adopte podrán ser apeladas ante el CONELEC. Esta resolución podrá ser impugnada ante los jueces competentes.

En todo caso el CONELEC será informado por las partes de las razones de la controversia.

De conformidad con la Constitución Política de la República, la Ley y las convenciones internacionales vigentes, en los contratos de concesión las partes podrán acordar que sus controversias sean resueltas de manera definitiva por el mecanismo del arbitraje, nacional o internacional. Si las partes decidieren someter la controversia al arbitraje no podrán recurrir sobre el mismo tema a los tribunales jurisdiccionales.

Los Tribunales Distritales de lo Contencioso Administrativo serán, en general, los órganos competentes para conocer y resolver de cualquier pretensión jurídica que tenga por objeto asuntos relacionados con o derivados de las relaciones entre la entidad pública concedente y la empresa concesionaria. En cuanto al procedimiento a seguirse se estará al que determinen las respectivas leyes."

See, Official Gazette Suplement 43, October 10, 1996. 
diplomatic protection. ${ }^{435}$ In the same vein, the contract-model for hydrocarbons' exploration and exploitation included the same limitation. ${ }^{436}$

Alongside the suppression of the Contractors' obligation of paying royalties, entrance fees, surface rights and contributions to compensation funds, as well as for the promotion of technological and scientific development in the hydrocarbon's field ${ }^{437}$, the Hydrocarbon Law's reform (1993) incorporated a new modality of contract, namely the participation contract. In this new contractual model, the private companies assumed the exploration and exploitation activities, as well as the risk, investments, costs and expenses necessary to undertake this delegation. Bustamante and Zapata explain that the profits derived therefrom were obtained from participation in the volume of the extracted oil, from whose total amount at least $12 \% 5$ percent corresponded to the minimum participation of the State. Additionally, the Parties' participation in the volume produced was valued on the crude oil reference price, which could not be inferior to the minimum reference price established in the contract. In addition, from the company's profit were deducted income tax, workers' participation and additional minor taxes. Unfortunately,

${ }^{435}$ Hydrocarbon Law (1978):

"Art. 26.- Las empresas extranjeras que deseen celebrar contratos contemplados en esta Ley deberán domiciliarse en el País y cumplir con todos los requisitos previstos en las leyes.

Estas empresas extranjeras se sujetarán a los tribunales del País y renunciarán expresamente a toda reclamación por vía diplomática. Aquella sujeción y esta renuncia se considerarán implícitas en todo contrato con el Estado o con CEPE."

See,Official Gazette 711, November 15, 1978.

${ }^{436}$ Contract model for the exploration and exploitation of hydrocarbons (1973):

“CLAUSULA 57.- Jurisdicción y Arbitraje

57.1 El Contratista se somete a las leyes, jueces y tribunales del Ecuador, al trámite verbal sumario y renuncia expresamente a toda reclamación por vía diplomática.

57.2 Para los fines de este contrato, se fija como domicilio la ciudad de Quito, Capital de la República del Ecuador.

57.3 Para lo civil y laboral serán también competentes los funcionarios del lugar en donde se realicen los hechos materia de la contienda judicial."

See: Supreme Decree, Official Gazette 283, April 10, 1973.

${ }^{437}$ Reform to Hydrocarbon Law (1993):

"Añádase, como segundo inciso del Artículo 54, el siguiente:

Las contratistas que tuvieren contratos de servicios específicos de exploración y explotación adicional de campos marginales o contratos de participación para la exploración y explotación de hidrocarburos, están exentos de pago de regalías, primas de entrada, derechos superficiarios, aportes en obras de compensación y la contribución prevista en el inciso exterior". 
the participation contracts concluded during the 1990s did not contemplate any formula for adjusting the State participation's fraction due to extraordinary profits resulting from oil price increases. ${ }^{438}$ According to Llanes, with this contractual model in force until 2008 , the State's profit participation was between $12.5 \%$ and $18.5 \%$, whereas the companies perceived an average not inferior to $81.5 \% .{ }^{439}$ As noted below, the modification of these rules was the basis for the majority of the investment disputes faced by the country.

In harmony with the deepening of the liberalization reform, the system of foreign trade and investment protection was overhauled under the name of the Foreign Trade and Investment $\mathrm{Law}^{440}$ and the Investments' Promotion and Guarantee Law, both enacted in 1997. From the former law can be noted the incorporation of the principle of fiscal neutrality, the establishment of rules devoted to implementing the recent accession of the country to the WTO and the creation of the institutional framework in the field of trade and investment. Consistent with the trend of this period, the minister was subordinated to a council composed in its majority by delegates of the private sector, which determined the policies and regulations of the sector. The latter legal framework specifically addressed the implementation of foreign investment promotion as a national priority ${ }^{441}$, thereby, embracing as a condition indispensable for this purpose, guaranteeing legal

\footnotetext{
${ }^{438}$ Bustamante (Teodoro) and Zapata Ríos (Oscar), "Características de los contratos petroleros" in Detrás de la cortina de humo: dinámicas sociales y petróleo en el Ecuador, Ed. Bustamante Teodoro, FLACSO, Ecuador, $142 \mathrm{p}$.

${ }^{439}$ Llanes (Henry), "Correa radicalizaría las concesiones petroleras", June 30, 2010.

See, https://redciecuador.wordpress.com/2010/06/30/correa-radicalizaria-las-concesiones-petroleras/

Website visited on June 2015.
}

On July 12, 2018, it was issued the Executive Decree 449 bringing the Participation Contract back to life. As one of the main justifications for this decision, this Decree points out the almost non-existent investment made during the last years in the oil sector, being it necessary to develop an "equitable and competitive" contract that facilitates the increase of oil reserves through the reactivation of private investment in the exploration of new areas. Summarizing, the new contract sets at $12.5 \%$ the minimum State's participation over the total production audited in the contract's area. Whereas in the former regulation governing the terms of the Participation Contract, the minimum State's participation rate depended solely in the production volume, the Decree at hand added the element of price adjustment to the calculation of such participation.

${ }^{440}$ Ley de Comercio Exterior e Inversiones, Suplement of the Official Gazzette 82, June 9, 1997.

${ }^{441}$ Ley de Promoción y Garantía de Inversiones (1997):

"Art. 2.- Se declara a la inversión en los sectores productivos y de servicios como prioridad nacional". 
certainty and stability. ${ }^{442}$ It also recognized equal treatment to national and foreign investment, abolishing any previous authorization for establishment and performance, with the exception of strategic sectors ${ }^{443}$. It enshrined as guarantees to foreign direct investment duly registered in the country, free transfer of dividends and profits, access to the advantages derived from the Andean Community Liberalization Program, as well as to the national financial and stock market, together with mechanisms of promotion, technical assistance and co-operation provided to the national investors. Additionally, it also reaffirmed, as foreign and national investors' guarantees, the right to property and tax stability in accordance with the thresholds set forth in this framework ${ }^{444}$. This law included as investors' obligations, compliance with the national regulations, especially those related to labour and environment, being obliged in the case of violating the latter, to compensate the resulting damages. In the case of environmental damage or natural resources degradation, the Minister was entitled to request the Council of Foreign Trade and Investment to prohibit partially or totally the operation of the company at fault. It is unclear whether the Council did ever exercise its authority concerning the enforcement of environmental damages compensation and prohibition of companies' operations.

It has to be emphasised that the concession of benefits was not conditional upon the signature of a contract with the State. Concerning dispute settlement this legal framework reinforced the commitment of the country to fully respect the already adopted BITs as well as double taxation agreements, reaffirming the foreign investors' right to submit the

${ }^{442}$ Ley de Promoción y Garantía de Inversiones, preámbulo (1997):

"Que se debe propiciar y promover el ingreso de inversión extranjera para que, sumada a la inversión nacional, coadyuve al proceso de desarrollo económico, garantizándole la seguridad jurídica requerida para un adecuado desenvolvimiento, basada en un marco legal e institucional, estable;"

${ }^{443}$ Ley de Promoción y Garantía de Inversiones (1997):

"Art. 13.- Las inversiones extranjeras directas, subregionales o neutras, podrán efectuarse en todos los sectores económicos, sin autorización previa del Ministerio de Comercio Exterior, Industrialización y Pesca o de cualquier otro organismo del Estado, en las mismas condiciones en que pueden hacerse las inversiones de personas naturales o jurídicas ecuatorianas. Se exceptúa de lo dispuesto en el inciso anterior, a los sectores relacionados con las áreas estratégicas del Estado."

${ }^{444}$ Ley de Promoción y Garantía de Inversiones (1997):

"Art. 23.- Para propósito de la aplicación de la estabilidad tributaria, solo se considerarán con derecho a tal tratamiento a las inversiones registradas a partir de un monto equivalente en sucres a los US\$ 500.000,00 (quinientos mil dólares de los Estados Unidos), para la fecha del Registro o de la fecha efectiva de la inversión, contada a partir de la puesta en marcha o inicio de la operación de la empresa en la que se haya realizado la inversión, en el caso de proyectos nuevos, y a partir de la fecha del Registro o realización efectiva de la inversión en el caso de empresas existentes." 
conflicts derived from the application of this law to international arbitration tribunals. In this regard the State's consent to arbitration already given in most of the BITs signed up to this period, was reiterated in the law at issue. It is worth stressing that, in the case of the State's consent given through this law, the wording of the relevant provision confined it to the disputes arising out of the application of the law in question. ${ }^{445}$ This would include the consequence that an investor deprived of a contractual relationship with the State could submit to international investment arbitration the disputes falling within the boundaries of protection prescribed by the relevant treaties and this law through the forums expressly recognized by the BIT of its nationality. This suggests that an investor covered by a BIT was not only entitled to bring international investment disputes derived from an alleged violation of such treaty's substantive standards, but also from those derived from the application of the law at issue. This treaty and legal based protection conferred on investors protected by the blanket of a BIT was reinforced when the same additionally signed investment contracts with the State.

Within this framework, the State concluded nine contracts, whose object and scope of protection amply surpassed the terms enshrined in the Law for the Promotion and Protection of Investment and its regulation of application. ${ }^{446}$ On the basis of these normative instruments, the Minister of Foreign Trade, Industries and Fisheries issued the investment contract model, which structured the obligations of the State towards investors. Whereas the law and regulation at issue contemplated the concession of tax stability, the contracts based on this model, with an average renewable period from ten to twenty years, incorporated also regulatory stability ${ }^{447}$. Moreover, the investors'

${ }^{445}$ Ley de Promoción y Garantía de Inversiones:

“Art. 32.- El Estado y los inversionistas extranjeros podrán someter las controversias que se suscitaren por la aplicación de esta Ley a Tribunales Arbitrales constituidos en virtud de Tratados Internacionales de los cuales sea parte el Ecuador o a los procedimientos específicamente acordados o estipulados en los convenios bilaterales o multilaterales firmados y ratificados por el País.”

\footnotetext{
${ }^{446}$ Investment Contracts signed with: 1) Oleoducto de Crudos Pesados; 2) Machala Power Cia. Ltda.; 3) Termoriente Cia.Ltda.; 4) Termoriente, Modificación de Contrato; 5) Quiport S.A.; 6) Grunenthal Ecuatoriana Cia. Ltda.; 7) General Motors S.A.; 8) IPAC S.A.; 9) Hidroabanico S.A.; 10) San Carlos S.A.

${ }^{447}$ Contrato de Inversión que celebran el Estado ecuatoriano representado por el Ministerio de Comercio Exterior, Industrialización, Pesca y Competitividad; Samedan Oil Corporation y la Compañía MACHALAPOWER Cía. Ltda, 15 de octubre de 2001:
}

“TRES PUNTO UNO PUNTO DOS (3.1.2) Estabilidad Jurídica Específica.- El Estado garantiza al Inversionista y a la Empresa Receptora que este Contrato de Inversión, el Contrato Base, 
guarantees exhaustively enlisted in the law were enlarged to any relationship that could surround their operations. The model contract referred to, whereby the State conceded unusual resignations, incorporated the mandatory International Centre for Settlement of Investment Disputes' arbitral jurisdiction to the disputes arising under the regime of investment protection, without imposing any prior requirements either to exhaust local remedies or to resort to a previous stage of negotiations. ${ }^{448}$ Curiously this mandatory

cualquier otro contrato celebrado con el Estado o cualquier Institución del Estado y las autorizaciones o permisos concedidos por el Estado o cualquier Institución del Estado, en cada caso en relación con la Inversión o el Proyecto, gozarán de absoluta estabilidad legal conforme al Marco Legal Vigente, por lo que, (i) no podrán ser modificados unilateralmente por leyes u otras disposiciones de cualquier clase que los afecten, ni por cambios en la interpretación o aplicación de las mismas, (ii) no podrán ser modificados unilateralmente por leyes u otras disposiciones de cualquier clase que los afecten, ni por cambios en la interpretación o aplicación de las mismas, (ii) sólo podrán ser modificados mediante mutuo acuerdo escrito de las Partes que evidencie de forma expresa tales modificaciones.- El Estado garantiza que (i) el Marco Legal Vigente se mantendrá estable en relación con este Contrato de Inversión, el Contrato de Autorización, cualquier otro contrato celebrado con el Estado o cualquier Institución del Estado y las autorizaciones o permisos concedidos por el Estado o cualquier otra Institución del Estado, en cada caso, en relación con la Inversión o el Proyecto, y (ii) que las modificaciones relevantes del Marco Legal Vigente, no podrán afectar, alterar o modificar los derechos obligaciones, garantías y protecciones del Inversionista o de la Empresa Receptora amparados por dicho Marco Legal Vigente u otorgado por este Contrato de Inversión o por el Contrato Base, ni las condiciones económicas y financieras consideradas para el Proyecto y la Inversión, salvo cuando se trate de modificaciones que por su naturaleza, no sean significativas, ya sea individual o conjuntamente consideradas. Por lo tanto, ni el Inversionista ni la Empresa Receptora se verán afectados por cualquier cambio en el Marco Legal Vigente, ya sea éste en leyes, decretos, ordenanzas, reglamentos, regulaciones, resoluciones o autorizaciones, de cualquier naturaleza, incluyendo interpretaciones legislativa, judicial, administrativa o cualquier otra dada a dichas normas por cualquier Institución del Estado, y las políticas o prácticas adoptadas para su aplicación que afecte a los derechos o a las obligaciones del Inversionista o de la Empresa Receptora según este Contrato de Inversión, el Contrato Base, cualquier otro contrato celebrado con el Estado o cualquier Institución del Estado y las autorizaciones o permisos concedidos por el Estado o cualquier Institución del Estado, en cada caso, en relación con la Inversión del Proyecto y según el Marco Legal Vigente.”

${ }^{448}$ Formato Básico Común del Contrato de Inversión:

“UNDÉCIMA.- Arbitraje:

a) Las Partes acuerdan que cuando surja una controversia relativa a la Inversión o a la ejecución del Contrato de Inversión, el (Inversionista y/o la Empresa Receptora), con el concurso del MICIP, procurarán resolverla mediante consultas $\mathrm{y}$ negociaciones con las entidades directa $\mathrm{O}$ indirectamente relacionadas con el conflicto;

b) De ser aplicable, las Controversias que no hayan podido ser amigablemente resueltas se someterán al arbitraje ante el Centro Internacional de Arreglo de Diferencias Relativas a Inversiones (CIADI) establecido por el Convenio sobre el Arreglo de Diferencias Relativas a Inversiones entre Estados y Nacionales de otros Estados, suscrito por el Estado, como "Estado Miembro" del Banco Internacional de Reconstrucción y Fomento, publicado en el Registro Oficial No. 386 el 3 de marzo de 1986. El arbitraje según esta cláusula tendrá lugar en ,Estado que es parte en la Convención de las Naciones Unidas sobre el Reconocimiento y la Ejecución de las Sentencias Arbitrales Extranjeras, publicada en el Registro Oficial No. 43 de 29 de diciembre de 1961;

c) En todo procedimiento de resolución de una Controversia en materia de Inversión, no podrá argumentarse como defensa, reconvención, derecho de contrarreclamación o de cualquier otro modo, el hecho de que el (Inversionista y/o la Empresa Receptora) haya (n) recibido ) recibirá (n), 
arbitral jurisdiction and this contract model were put into force before the Legislature approved the Convention on the Settlement of Investment Disputes between States and Nationals of Other States (hereinafter "Washington Convention" or "ICSID Convention"). ${ }^{449}$ For instance, it is noteworthy that the billionaire investment contract for constructing Ecuador's heavy crude oil pipeline included an arbitration clause including the unconditional consent to submit legal and contractual disputes to ICSID jurisdiction, although the Convention enabling the same was not internally approved. ${ }^{450}$ In this line, it has to be warned that this inclusion is the result of an irregular practice coined by the Ecuadorian government during the 1990s, particularly evident in the arbitration clauses inserted into the exploration and exploitation hydrocarbon contracts. Although these contracts were not specifically contemplated within the legal framework of promotion and protection of investment, they comprised conditional arbitral clauses recognizing ICSID jurisdiction and the corresponding possibility of submitting the disputes arising therefrom, once the Legislature ratified the Washington Convention. ${ }^{451}$

según los términos de un contrato de seguro o de garantía o cualquier otro convenio suscrito por el Inversionista y/o la Empresa Receptora, alguna indemnización u otra compensación por los daños reclamados o por el Inversionista y/o la Empresa Receptora; y,

d) De conformidad con lo previsto en el inciso final del artículo 42 de la Ley de Arbitraje y Mediación, los laudos dictados dentro de procedimientos de arbitraje internacional tendrán los mismos efectos y serán ejecutados de la misma forma que los laudos dictados en un procedimiento arbitral nacional y, en consecuencia, tendrán el efecto de sentencia ejecutoriada y de cosa juzgada y se ejecutarán del mismo modo que las sentencias de última instancia, siguiendo la vía de apremio, aunque hayan sido dictados contra el Estado o cualquier Institución del Estado, según lo dispuesto por el artículo 39 de la Ley de Modernización."

Official Gazette 255, January 30, 2001.

${ }^{449}$ Executive Decree No. 1417-B, Official Gazette 309, April 19, 2001.

450 "Contrato de Inversión entre el Estado ecuatoriano, representado por el Ministerio de Comercio, Industrialización y Pesca con las Compañías Oleoducto de Crudos Pesados (OCP) Ltd. y Oleoducto de Crudos Pesados (OCP) Ecuador S.A.”, February 15, 2001.

451 "Contrato de Participación para la Exploración y Explotación de Hidrocarburos (Petróleo C) entre el Estado Ecuatoriano-PETROECUADOR y las compañías City Oriente Ltd, y Consolidated Ramrod Gold Corporation", March 29, 1995:

"VEINTE TRES (20.3).- No obstante lo dispuesto anteriormente, desde la fecha en que el Convenio sobre Arreglo de Diferencias Relativas a Inversiones entre Estados y Nacionales de otros Estados (el "Convenio"), suscrito por la República del Ecuador, como Estado Miembro del Banco Internacional de Reconstrucción y Fomento, el quince de enero de mil novecientos ochenta y seis y publicado en el Registro Oficial número trescientos ochenta y seis el tres de marzo de mil novecientos ochenta y seis, sea aprobado por el Congreso Ecuatoriano, las Partes se obligan a someter las controversias o divergencias que tengan relación o surjan de la ejecución de este Contrato de Participación, a la jurisdicción y competencias del Centro Internacional de Arreglo de Diferencias Relativas a Inversiones (el "CIADI") para que sean arregladas y resueltas de conformidad con lo dispuesto en dicho Convenio. Bajo este sistema de arbitraje se aplicarán las siguientes disposiciones (...). 
As noted in the subsequent section, this chapter contends that Ecuador has been internationally bound to the ICSID Convention since the deposit of its instrument of ratification on January 15, 1986.

\subsubsection{The Irregular Contractual Submission to ICSID Jurisdiction}

In the light of the aforementioned situation, it would be a matter to be decided by domestic law the legality of the contractual stipulations that incorporated the conditional submission to ICSID jurisdiction. Therefore, they must be tested against the conditions in force prior and after the constitutional reform of 1996 that enabled the transformations set forth by Arbitration and Mediation Law (1997). In the first case, it is clear that pursuant to the constitutional codification of $1993^{452}$ and the provision of the Civil Code in force, the fact that these contracts were signed in Ecuador and encompassed the conditional submission of disputes to an international jurisdiction (ICSID) not recognized by the national law, would nullify the arbitration agreement. ${ }^{453}$ Taking into consideration the well-rooted constitutional principle of legality, within which the public institutions and authorities are exclusively entitled to exercise the functions exhaustively enlisted in the Constitution and the law and the fact that investment disputes challenge the exercise of sovereign powers, subordinating the effectiveness of this policy choice to a future

VEINTE.TRES.UNO . (20.3.1).- Las Partes acuerdan que la constitución de la comisión de arbitraje y el procedimiento de arbitraje se regirán por las Reglas de Iniciación, las Reglas de Arbitraje y cualquier disposición pertinente del Convenio sobre Arreglo de Diferencias Relativas a Inversiones entre Estados y Nacionales de otros Estados y del Reglamento Administrativo y Financiero, que se encuentran en las partes C,D,A y B, respectivamente del documento "CIADI/quince (15)" de enero de mil novecientos ochenta y cinco (1985)".

${ }^{452}$ Constitución Política de la República, Codificación 1993:

"Art. 16.- Los contratos celebrados por el Gobierno o por entidades públicas con personas naturales o jurídicas extranjeras, llevarán implícita la renuncia a toda reclamación diplomática; si tales contratos fueren celebrados en el territorio del Ecuador, no se podrá convenir la sujeción a una jurisdicción extraña."

See, Official Gazette 183, May 5, 1993.

${ }^{453}$ Constitución Política de la República, Codificación 1993:

“Art. 16.- Los contratos celebrados por el Gobierno o por entidades públicas con personas naturales o jurídicas extranjeras, llevarán implícita la renuncia a toda reclamación diplomática; si tales contratos fueren celebrados en el territorio del Ecuador, no se podrá convenir la sujeción a una jurisdicción extraña."

See, Official Gazette 183, May 5, 1993. 
legislative decision, it clearly requires exercising public functions without a normative foundation.

In the second case, the constitutional reform of 1996 enabled the international jurisdictional submission in contracts signed in Ecuadorian territory as long as an international treaty provided $\mathrm{so}^{454}$. Accordingly, the conditional consent to submit contractual disputes to ICSID agreed by the State, perfected once the legislative approval of the Washington Convention was obtained, was neither lawful, taking into account that this treaty was not made in accordance with the domestic constitutional framework. In this context, the attempt to enlarge investors' protection beyond the BITs' boundaries, and also inserting within ICSID's jurisdiction contractual controversies, would also have been void ${ }^{455}$. For the same reason, those contractors deprived of the protection of a BIT but invested with a contractual stipulation to submit disputes to ICSID provided that the Congress approved the Washington Convention, renders consent to this conditional submission ineffective. ${ }^{456}$

As emphasized, the principle of legality requires that public authority stems from the Constitution and the law and in this regard, the exercise of a sovereign act, namely the

${ }^{454}$ Constitución Política de la República, Codificación 1996:

"Art. 16.- Los contratos celebrados por el Gobierno o por entidades públicas con personas naturales o jurídicas extranjeras llevarán implícita la renuncia a toda reclamación diplomática. $\mathrm{Si}$ tales contratos fueren celebrados en el territorio del Ecuador, no se podrá convenir la sujeción a una jurisdicción extraña, salvo el caso de convenios internacionales."

Registro Oficial 969, 18 de junio de 1996.

455 The State's Attorney General in the binding consultation concerning the possibility to subordinate a contract involving a state entity to the laws of England and Wales affirmed the unfeasibility of perfecting such submission on the basis of Article 16 of the Constitution of 1998. As noted, this constitutional provision authorizes such submission when an international treaty enables the same. In such consultation, the Attorney GeneralAttorney general established:

“(...) El contrato objeto de la consulta va a celebrarse entre una entidad del sector público e INTELSAT, como persona jurídica de derecho privado extranjera, no amparada en un convenio internacional, y su ejecución tiene efectos jurídicos y técnicos en el país. Por tanto, además de estar redactado en castellano, debe sujetarse a la jurisdicción ecuatoriana, sin que puedan someterse las controversias derivadas del mismo a una jurisdicción extranjera."

See, Oficio PGE 0436, 11 de septiembre de 2007, Resolución de la Procuraduría General del Estado, Registro Oficial 257, 22 de enero de 2008.

${ }^{456}$ Notwithstanding hydrocarbons contractual regime has been traditionally governed by its own special legislation and the reforms to this sector implemented in 1993, enabled the submission of controversies to arbitration in accordance to the procedure set forth in the national framework, this reference implies that the constitutional limitations to submit disputes to foreign jurisdiction, are also applicable to this field. 
contractual jurisdictional resignation to settle international regulatory disputes, could not be endorsed by a future and uncertain legislative decision that aims to supplement the legal scope within which these contracts were concluded. ${ }^{457}$ This interpretation is more categorical acknowledging that these conditional jurisdictional submissions attempted to overcome an express constitutional prohibition. In conjunction with this precept, the Civil Code prescribes the invalidity of any act in contradiction with Ecuadorian Public Law ${ }^{458}$. Indeed, these legal and legitimacy concerns would be more resounding bearing in mind the legal nature of the disputes aired before ICSID jurisdiction that constitute a form of public law adjudication. In this realm the consent of the State derives from the exercise of its sovereign authority and as such it has to be founded on the legal framework in force. ${ }^{459}$ Unfortunately, during the period when such a bundle of complex obligations was concluded, the dominant notion about arbitration in the national legal sphere, was that the consent to settle disputes through this mechanism derived from the will of the parties, acting in their private capacity. In this context the understanding was that the State was entitled to sign contracts under the assumption that it was acting in its commercial and

\footnotetext{
${ }^{457}$ Until 2008, the conclusion of administrative contracts exceeding a certain threshold required the prior authorizations of the Attorney General and General Comptroller of the State. In the case of the contracts concluded before the Washington Convention's legislative approval, it could be assumed that being bound by such prior authorizations, the conditional recognition of ICSID jurisdiction in the respective contracts was not objected neither by the Attorney General nor by the General Comptroller of the State.
}

See, Article 11, Ley del Ministerio Público (Gaceta oficial 871 de 10 de Julio de 1979) and Article 65, Ley de Contratación Pública (Gaceta Oficial 501, 16 de agosto de 1990).

458 Civil Code (1970):

"Hay objeto ilícito en todo lo que contraviene al Derecho Público Ecuatoriano".

See: Official Gazette 104, November 20, 1970.

${ }^{459}$ Van Harten draws a clear distinction between international commercial and investment arbitration:

Thus, in international commercial arbitration, a party's consent to arbitrate takes place within the private sphere not because the consent is irrelevant to the public in general but because the disputing parties -acting in a private capacity- have agreed to use a particular method dispute resolution in dispute arising between themselves. They have agreed, in a manner endorsed by the State, to insulate the adjudication of their dispute from the courts and subject it instead to arbitration. In contrast, the submission of governmental decisions to review by a particular adjudicative process is a policy choice by the State to use that method of adjudication as part of the governing apparatus. Public law adjudication is distinct from reciprocally consensual adjudication in the private sphere because the State acts in a sovereign capacity when it consents to the adjudication and because the relevant dispute arises from the exercise of sovereign authority by the State (...)."

Van Harten (Gus), "The Public-Private Distinction in the International Arbitration of Individual Claims against the State", International and Comparative Law Quarterly, 56, 377 p. 
private capacity (iure gestione), which also included its authority to submit the disputes derived therefrom to an arbitral forum. In this way, the Supreme Court ruled in the early 1990s, that the submission of the State to national ad-hoc arbitration did not violate the constitutional provision that barred the contractual subordination of the State to "alien jurisdiction". In the opinion of the Court, since arbitration and other mechanisms of dispute settlement recognized by the Ecuadorian legal framework, such as submission, did not imply the subordination of the State to an "alien" or foreign jurisdiction but only the resort to a particular system of dispute resolution. ${ }^{460}$ Apparently, the disputes limited to the "private sphere of the state's activity", as coined by Van Harten could have been permitted as long as they were not subordinated to a foreign jurisdiction. ${ }^{461}$ Following the reasoning of the Supreme Court, it could be affirmed that the recognition of the national legal framework to international law would not have barred the State from submitting disputes to international arbitral tribunals, which apply standards of international law for the settlement of disputes. Therefore, the prohibition would be confined to subjecting the State to the jurisdiction of another sovereign State. ${ }^{462}$ Nonetheless, this provocative

460 The Constitutional Chamber of the Supreme Court of Justice reaffirmed that the constitutional prohibition to contractually submit the State to "alien" jurisdiction was exclusively referred to the laws or jurisdiction of a foreign country:

“Tanto en la interpretación legal o auténtica y en la doctrinal como el Art. 16 de la Constitución , la palabra extraña ha sido utilizada en relación con país extranjero y que es, además, el que le da el Diccionario de la Real Academia de la Lengua Española. La prohibición de la norma constitucional contenida en el Art. 16, cuya vigencia es materia de control por esta Sala, no alcanza por lo tanto al arbitraje previsto en el Decreto ley 580 para resolver los desacuerdos contables entre EMELEC y el Estado. Dicha disposición del decreto ley 580 no implica la sujeción del Ecuador al ordenamiento jurídico de otro Estado soberano, sino a un sistema de solución de conflictos que es ampliamente aceptado por nuestro país como es el arbitraje. El arbitraje es reiteradamente reconocido por leyes y convenios internacionales de los que el Ecuador es parte.”

See, Gaceta Judicial. Año XCV. Serie XVI. Nro. 2. Pág. 524, 7 de febrero de 1994.

${ }^{461}$ See: Van Harten (Gus), "The Public-Private Distinction in the International Arbitration of Individual Claims against the State", International and Comparative Law Quarterly, 56, 377 p.

${ }^{462}$ In the same ruling the Constitution Chamber of the Supreme Court of Justice concluded:

(...) El fallo del Tribunal se basa en la premisa que el arbitraje constituye una "jurisdicción extraña" por lo que a élla no caben someterse los desacuerdos contables entre el Estado y EMELEC. Dicha premisa es sin embargo, inexacta e inaceptable desde el punto de vista estrictamente jurídico. La prohibición que establece la Constitución en el citado artículo refiérese al sometimiento del Estado ecuatoriano o de sus entidades públicas a las leyes, jueces y procedimientos propios de otro Estado soberano en contratos celebrados en el Ecuador con personas naturales o jurídicas extranjeras (...)

See, Gaceta Judicial. Año XCV. Serie XVI. Nro. 2. Pág. 524, 7 de febrero de 1994. 
interpretation would still leave unanswered the legal and legitimacy concerns about providing consent to contract-based arbitration of regulatory disputes. When it comes to international arbitration the "private-public distinction" might be somewhat artificial and in consequence, the form will tend to take precedence over the substance. For instance, in the dispute at issue settled by the Supreme Court of Justice, although the arbitral jurisdiction was supposedly confined to accounting disputes, the way the contractual concession was drafted, meant that almost any issue derived from the retribution of the monopolist service provided by the concession holder, could be channelled through this mechanism. Considering that any regulatory measure could have an impact on the economic performance of the concession holder, even more when a minimum profit was guaranteed over 65 years, it is clear that the possible emerging disputes would mix actions located in the public and private spheres. In any case, the majority's court opinion relied on a formalistic interpretation focused on the nature of this "voluntary jurisdiction" exercised by the arbitral tribunal, overlooking the real effects of such a concessionary agreement.

It has to be emphasized that it is not strange in international law, that a State agrees a consent clause before the conditions ratione personae for the Centre's jurisdiction are met, having taken as the date of consent, the date on which all conditions have been met. ${ }^{463}$ It is clear that Ecuador did not exercise such a conditional possibility at the international level, at which the ICSID Convention was ratified through the deposit of the corresponding instrument on January 1986. In this regard, the delayed process of legislative approval of the treaty at issue, along with the conditional contractual submissions analyzed, attempted to regularize a procedure of treaty creation at the national level; hence, the effects derived therefrom are merely domestic. In the case of the contracts containing a conditional consent to the ICSID Convention attached to the occurrence of a domestic event-namely the Congress'convention approval-, the rules governing such stipulations are domestic. Considering that domestic law prohibited such a waiver of jurisdiction, this would be reason enough for annulling such arbitration agreements. Taking into consideration the internal process of treaty creation, the Congress' approval had to be succeeded by the President's ratification through Executive Decree, which occurred on 2001. Of course, a subsequent deposit of this ratification did

\footnotetext{
${ }^{463}$ See: http://unctad.org/es/Docs/edmmisc232add2 en.pdf, p. 25.
} 
not happen, considering that Ecuador had already done it irregularly in January 1986, giving full international effect to the ICSID Convention ever since then. Within the constitutional frame, an international treaty would enter into force provided that the process of signature, approval and ratification would have followed the domestic and international procedure for its formation. In the absence of a new instrument of deposit that concluded this internal process of regularization, it is unclear whether such an omission would bind the State internally. Particularly and pursuant to the ICSID Convention that establishes the entry into force of this treaty, 30 days after the date of the corresponding deposit, the lawfulness of a State's contractual consent to ICSID jurisdiction in the light of the constitutional restriction analyzed, would have been linked to the fulfillment of such a period.

Even, with the hypothesis consented to by the national rule makers that assumed the ICSID Convention was still not in force in the absence of the Congress's approval and that the conditional contractual consent submissions to such jurisdiction were lawful, subordinating the effectiveness of the same to an internal sovereign act also constitutes a misconception in accordance with Articles 26 and 27 of the Vienna Convention on the Law of Treaties ${ }^{464}$. Within this particular presumption, this misconstruction brings certain practical problems, for instance in the event that the President would have delayed the convention's ratification. Under the supposition, that the Ecuadorian State would have failed to ratify the ICSID Convention regardless the Congress' approval was performed, the contractors would have had to resort to the ICSID`s complementary mechanism as long as their countries of origin were parties to the ICSID Convention. In this regard, the most salient consequences of this hypothesis would have involved: 1) the difficulty of determining the jurisdiction of the tribunal and the legal nature of the disputes considering that the same could have been merely confined to contractual obligations; 2) the need to resort to the New York Convention for the recognition and enforcement of awards instead

${ }^{464}$ In this regard, Aust concludes:

“(...) Although it may be tempting, a state cannot plead that is waiting for its legislature to legislate."

Aust (Anthony), Modern Treaty Law and Practice, Third Edition, Cambridge University Press, 2013, 161 p. 
of the mechanisms provided by the ICSID Convention, which bestows faster ways of execution.

Overall, this evidently inconvenient practice contains serious legitimacy flaws and the clear intention of this period's rule makers to create a dense web of investment protection although the constitutional and legal framework of the time did not allow adopting such decisions of public policy. When the hydrocarbon exploration and exploitation contracts that incorporated conditional jurisdictional resignations, are analysed, it is not absurd to imagine the economic and political pressures faced by the succeeding governments to approve the ICSID Convention. In any event it is clear that the defective drafting of the contractual clauses at issue entailed a greater State commitment since the recognition of the ICSID jurisdiction was conditional upon an internal sovereign act and not on the entry into force of the Washington Convention in accordance to Public International Law, as it is explained in the next section.

To complete the picture of the review of the generous environment of investment promotion and protection, the State implemented in parallel many legal reforms for the purpose of increasing the scope for private participation in public services and promoting flexibility in labour markets ${ }^{465}$. This huge bundle of reforms confronted serious political and legal opposition and has been qualified as the most aggressive regulatory attempt for consolidating the neo-liberal model. Whereas such resistance was fruitful in the case of privatizations, the process of speeding up labour markets' flexibility could not be

${ }^{465}$ In Republic of Ecuador Country Assistance Strategy's executive summary, the World Bank underscores:
"With or without dollarization, a series of structural reforms became essential in Ecuador to increase economic growth, share the benefits of growth more evenly, and to improve governance, making government services accessible to all. The government of former President Noboa took several steps to implement reforms, including the so-called Trole I and Trole II laws of 2000, that established the basis for dollarization and began to increase flexibility in labor markets and increase the scope for private participation in services long provided by public enterprises. In addition, the Fiscal Responsibility Law approved in 2002 set clear limits on expenditure growth and indebtedness, as dollarization imposes a new discipline on the country (Section II.C). The improved fiscal position relative to the pre-dollarization period, the progressive unfreezing of deposits, and improved oil prices, together with a more stable environment under dollarization, led to a recovery in economic growth that still needs to be consolidated over the next few years."

World Bank, "Report and Recommendation of the President of the International Bank for Reconstruction and Development and the International Finance Corporation to the Executive Director on a Country Assistance Strategy for the Republic of Ecuador", Bolivia-Ecuador-Peru-Venezuela Country Management Unit, Report No. 25817 EC, April 29, 2003, 1 p. 
restrained $^{466}$. The overhauled Constitutional Tribunal, invested with adjudicative powers by the Constitution of 1998, dealt with an avalanche of unconstitutionality claims. Particularly notable to this analysis is the ruling issued by this tribunal declaring as unconstitutional the compulsory incorporation of arbitral agreements in the public services' delegation contracts established by Trole II Law. ${ }^{467}$ In the context of the unlimited protection conferred on private counterparties enshrined in the Constitution of 1998, the referred legal reforms and the contractual implementation of the subordination of sovereign powers, it is not surprising that the delegation of public services, initially restricted to specific sectors, was opened without any bounds. ${ }^{468}$ For instance, out of these

\footnotetext{
${ }^{466}$ In the preamble of the Law "Trole II", there were pointed out as the effects sought by the reforms the following:

\begin{abstract}
"Código del Trabajo:
Uno de los problemas más cruciales por los que atraviesa el país es la carencia de fuentes de trabajo que permitan ingresos dignos a la población, constituyendo esta circunstancia una de las mayores preocupaciones del Gobierno Nacional. Sin duda alguna, la reactivación económica y promoción de inversiones es la acción más importante y directa que se puede realizar en este sentido. Para conseguir nuevas fuentes de empleo es necesario flexibilizar y actualizar ciertas normas que pudieran impedir la apertura de nuevas oportunidades a los ecuatorianos. Este es el principio que alienta las reformas que se proponen en el marco del Código de Trabajo".
\end{abstract}

See, Ley para la Promoción de la Inversión y de la Participación Ciudadana, Suplemento del Registro Oficial 144, 18 de agosto de 2000.

467 The Constitutional Tribunal ruled inconstitutional the final paragraph of the article incorporated by the "Ley para la Promoción de la Inversión y la Participación Ciudadana" (Trole II) reforming Art. 46 of the "Ley para la Modernización del Estado" (1993):

"Todo contrato de delegación incluirá, necesariamente, una cláusula de arbitraje para la solución de controversias".

See, Resolución del Tribunal Constitucional 193, Registro Oficial Suplemento 231, 26 de diciembre de 2000 .

468 The reform introduced by the "Ley para la Promoción de la Inversión y la Participación Ciudadana (Trole II)" to the "Ley de Modernización del Estado" facilitated the possibility to delegate any public service through the supression of the original provision of the latter law by the following:

"Art. 3.- El artículo 6 dirá:

El Estado podrá delegar a empresas mixtas o privadas la prestación de servicios públicos y la exploración y explotación de recursos naturales no renovables de su propiedad. Esta delegación se hará por cualesquiera de los medios establecidos en la Constitución garantizando que, si se tratare de servicios públicos, éstos respondan a principios de eficiencia, responsabilidad, universalidad, accesibilidad, continuidad y calidad, con especial énfasis en la determinación equitativa de precios y tarifas; y si se tratare de la exploración y explotación de recursos, se realice en función de los intereses nacionales."

See, Ley para la Promoción de la Inversión y de la Participación Ciudadana, Suplemento del Registro Oficial 144, 18 de agosto de 2000.

The original provision restricted the possibility to delegate to specific sectors and regulated in detail the obligation of the concessionaires: 
comprehensive reforms, the former president, Rafael Correa criticizes those incorporated to the mining legal framework through which the payment of royalties was eliminated. Instead, there was established the obligation to pay surface rights in accordance to the size of the area delegated regardless the value of the commodity exploited. Following the same pattern and the possibility to delegate any public service and activity, there were enacted several laws that established privatization and other forms of delegation as mandatory. Without dwelling on examples that demonstrated the harmful terms of participation consented to by the State and that were aimed at accentuating its position as a private party by overlooking, for example, the public investments required to put such projects into effect, it is scandalous to perpetuate such conditions through contractual commitments with unreasonable periods varying from 15 to 50 years. From this analysis it is undeniable that public policy is aligned towards the achievement of unprecedented thresholds of private interests' protection through normative, regulatory and contractual mechanisms. To this end, it was indispensable to configure a malleable concept to delineate the State's actions, whose entities, enabled by a lax legal framework, allegedly acted in their private capacity for resigning to ample spaces of sovereign exercise both at the substantive and jurisdictional levels. In contrast to the "constitutionalization" of the

“Art. 6-DELEGACION- De acuerdo a lo establecido en el numeral uno del artículo 46 de la Constitución Políticas de la República, y sin perjuicio de lo dispuesto en otras leyes, podrá delegarse a la iniciativa privada por excepción mediante concesión, el ejercicio de las siguientes actividades:

1) La producción, el transporte, el almacenamiento y comercialización de los hidrocarburos y demás minerales;

2) La generación, la distribución y comercialización de fuerza eléctrica;

3) Los servicios de telecomunicaciones; $y$,

4) La producción y distribución de agua potable.

Esta delegación podrá hacerse en los casos en que dichas actividades se encuentren en uno o más de las siguientes circunstancias:

a) Cuando la administración de las citadas actividades económicas tengan un impacto negativo en el presupuesto del sector publico;

b) Cuando la administración de las citadas actividades económicas o servicios públicos acusen un retraso tecnológico tal que impida un acelerado desarrollo económico y social del país;

c) Cuando el nivel de los gastos de inversión de las entidades que han asumido las citadas actividades económicas o la prestación de servicios públicos esté por debajo del treinta por ciento de su presupuesto;

ch) Cuando la posición financiera de dichas entidades determine la incapacidad de acometer de manera autosuficiente un proceso de inversiones necesarias para cumplir con sus objetivos.

Las entidades u organismos que integran la administración provincial o cantonal dentro del régimen seccional o las personas jurídicas creadas por un acto legislativo seccional para la prestación de servicios públicos, que resolvieren, previa decisión de sus órganos competentes, delegar a terceros la gestión de algún servicio púbico o actividad económica que hayan asumido, se sujetarán a las disposiciones de esta Ley."

See, Ley para la Modernización del Estado, Registro Oficial 349, 31 de diciembre de 1993, (Derogated). 
private law underpinned by the Constitution of 2008, the 1990s witnessed the opposite phenomenon, namely the "contractualization" of public law.

\subsubsection{Boom of Bilateral Investment Treaties}

The boom of BITs adoption reached a peak during the 1990's. The diversity of countries with which such treaties were concluded suggests the strength of the assumption that these instruments automatically attract foreign investment flows. Moreover the absence of official evidence that indicates a prior cost-benefit analysis surrounding the negotiation of these instruments, re-inforces the presumption that this massive trend was underpinned by the groundless belief that unlimited pro-market governance'measures would certainly bring economic growth and general welfare. In addition, the fast track discussions held in the National Congress which ignored the pre-existing constitutional constraints for the unlimited protection of investors, indicated the strong pro-business ideological orientation of the ruling parties of this decade, anxious to establish a neoliberal model. Last but not least, the misunderstanding concerning the scope of protection provided by such treaties is evident from the scarce public files that register the discussions prior to their approval. Nonetheless, any minor legal concern was subordinated to the ideological mainstream which advocated that any regulatory measure, either at the national or international level, had to be oriented for the purpose of making the legal framework attractive to international investors.

As noted the BITs with the Federal Republic of Germany, Switzerland and Uruguay were signed before 1992. In 1992, a BIT with Egypt was concluded but the same expired three years afterwards, due to the lack of renewal by the Parties. Undoubtedly, the most active period of initiating BITs was between 1993 and 2002, in harmony with the domestic regulatory reforms and contractual mechanisms underpinned for liberalizing the economy, attracting investment and privatizing the provisions of public services and exploitation of strategic sectors. Out of the $30 \mathrm{BITs}^{469}$ concluded by Ecuador, that include

\footnotetext{
469 The 30 BITs signed by Ecuador are listed in chronological order: 1. Switzerland; 2. Uruguay; 3. Egypt; 4. United States; 5. Chile; 6. Venezuela; 7. Paraguay; 8. Argentina; 9. China; 10. United Kingdom and Northern Ireland; 11. El Salvador; 12. France; 13. Panama; 14. Romania; 15. Russia; 16. Bolivia; 17. Germany; 18. Canada; 19. Spain; 20. Cuba; 21. Dominican Republic; 22. Peru; 23. Netherlands; 24. Nicaragua; 25. Honduras; 26. Finland; 27. Sweden; 28. Italy; 29. Costa Rica, 30. Guatemala.
} 
the three international conventions adopted before $1993^{470}$, sixteen ${ }^{471}$ were signed during the presidential term of Sixto Durán Ballén (1992-1996), two ${ }^{472}$ during the interim term of Fabián Alarcón (1997-1998), two ${ }^{473}$ during the term of the sacked President Jamil Mahuad (1998-1999) and seven ${ }^{474}$ during the service of Gustavo Noboa Bejarano (20002003), former vice president of Jamil Mahuad. From this bulk of BITs, it has to be noticed that those subscribed with Costa Rica, Panama and Russia, did not enter into force due to a lack of ratification.

From a regional perspective, it can be observed that nine BITs were concluded with European Union country members, eight with Center-American and Caribbean countries, seven with South-American countries, two with North American countries and one with Switzerland, China, Egypt and Russia, respectively. After the constitutional reform of 1998, eight treaties were signed, circumventing the Legislative's approval, due to the provision that allowed the President to omit such a step in treaties that did not fall within the propositions in which the Constitution established such a requirement. ${ }^{475}$ No institutional branch disputed this presidential self-judging authority ${ }^{476}$ based on which,

${ }^{470}$ It has to be underlined that among these 30 treaties, the BIT signed with the Federal Republic of Germany on 1965 and 1996 is counted once. The latter BIT is in force.

${ }^{471}$ In chronological order, the following treaties were signed: 1. United States; 2. Chile; 3. Venezuela; 4. Paraguay; 5. Argentina; 6. China; 7. United Kingdom and Northern Ireland; 8. El Salvador; 9. France; 10. Panama, 11. Romania; 12. Russia; 13. Bolivia; 14. Federal Republic of Germany; 15. Canada; 16. Spain. ${ }^{472}$ In chronological order, the following treaties were signed: 1. Cuba, and; 2. Dominican Republic.

${ }^{473}$ In chronological order, the following treaties were signed: 1 . Netherlands, and; Peru.

${ }^{474}$ In chronological order, the following treaties were signed: 1. Nicaragua; 2. Honduras; 3. Finland; 4. Sweden; 5. Italy; 6. Costa Rica; 7. Guatemala.

475 Constitución de 1998:

"Art. 171.- Serán atribuciones y deberes del Presidente de la República los siguientes:

12. Definir la política exterior, dirigir las relaciones internacionales, celebrar y ratificar los tratados y convenios internacionales, previa aprobación del Congreso Nacional, cuando la Constitución lo exija."

${ }^{476}$ Memorandum submitted by the Secretary General of the Minister of Foreign Affairs to the internal legal counselor, by which he requests his opinion for determining whether the Bilateral Investment Treaties fall under Article 161 of the Constitution of 1998. Subsequently the minister's legal counselor agreed with the secretary's criterion and the BITs bypassed the Congress's approval:

“(...) Es criterio de esta Secretaría General/Dirección General de Tratados, que los tres Acuerdos anteriormente señalados, no necesitan de la aprobación del H. Congreso Nacional puesto que no se encuentran incursos en ninguno de los numerales del artículo 161 de la Constitución Política del Ecuador en vigencia.

Con los antecedentes descritos, se considera que dichos Instrumentos Internacionales no están comprendidos en ninguno de los presupuestos contenidos en el artículo 161 de la Constitución Política del Estado, y que consecuentemente, no precisan el trámite de aprobación o improbación 
the Executive further ratified those treaties without requiring prior approval from the National Congress ${ }^{477}$. From the normative hypotheses enshrined in the constitutional provision that requires legislative approval before a treaty is ratified, the most notable with regard to the implementation of BITs would be the one that makes it necessary to take that step when the exercise of powers derived from the Constitution or the law is conferred on an international or supranational organization. In general the BITs signed by Ecuador establish three different forums for the settlement of investment disputes, namely, domestic courts, ad hoc arbitration panels constituted under UNCITRAL arbitration rules ${ }^{478}$ and ICSID dispute settlement tribunals. From a formal interpretation, the BITs do not confer direct domestic adjudicative powers on any particular international organization or entity. Additionally, and considering that the restriction at issue is confined to the attribution of powers derived from the Constitution or the law to an international organization, it is clear that the specialized duty of international arbitral tribunals to determine a state's liability derived from a breach of treaty, is a power, which does not stem either from the Constitution or from the law. In the case of such treaties' reference to ICSID it has to be recalled that this jurisdiction derives from an independent treaty. In view of this, the presidential decision to directly sign and ratify BITs without resorting to the legislative consent would derive from the understanding that the constitutional restriction applies to the attribution of powers enshrined in the Constitution and the law, to organizations vested with an international legal personality. Although the

Legislativa por lo que sería suficiente que, conforme al artículo 171, numeral 12, de la Carta Magna, el Ejecutivo lo ratifique.”

Memorandum No.426 SG/DGT, 2 de enero de 2001.

${ }^{477}$ Constitución de 1998:

“Art. 161.- El Congreso Nacional aprobará o improbará los siguientes tratados y convenios internacionales:

1. Los que se refieran a materia territorial o de límites.

2. Los que establezcan alianzas políticas o militares.

3. Los que comprometan al país en acuerdos de integración.

4. Los que atribuyan a un organismo internacional o supranacional el ejercicio de competencias derivadas de la Constitución o la ley.

5. Los que se refieran a los derechos y deberes fundamentales de las personas y a los derechos colectivos.

6. Los que contengan el compromiso de expedir, modificar o derogar alguna ley."

${ }^{478}$ It is noteworthy that although the BITs signed by Ecuador refer in general to the application of UNICTRAL Rules, they do not identify a particular institutional mechanism to conduct the same. According to the rules referred, the absence of appointing authority and the impossibility of the parties to appoint arbitrators, entitles the Secretary General of the Permanent Court of Arbitration in The Hague to perform such task. 
latter definition could be claimed as too formalistic considering that the decisions taken by any international tribunal settling investment disputes would indeed entail the adoption of acts with "autonomous effects at the international level"479, the limitation of the analyzed constitutional requirement to the exercise of internal competences, would relegate the actions of adjudication bodies established under the frame of BITs. However, this analysis would have had to be done on a case by case basis, even more, when several BITs foresee the application of national law by the arbitral tribunals.

The laxity of the Ecuadorian government in the invisible process of negotiation and signature of the treaties may be appreciated in the general lack of clarity of the clauses that include these instruments. In contrast to countries like United States and China that imposed specific limitations on the substantive standards and sectors of protection, Ecuador never exercised such reserves, suggesting its adhesion to texts previously offered by the incumbent countries. In general, ample definitions of investment and investors, alongside standards of protection like national treatment ${ }^{480}$, fair and equitable treatment, expropriation, settlement of disputes rules and survival clauses are incorporated in such treaties, with slight differences. Particularly eloquent for corroborating the absence of a coherent practice of the Ecuadorian State with regard to the content and scope of the BITs, are the dispute settlement provisions. Only in a few cases, were the disputes confined to the application of the treaty`s provisions ${ }^{481}$, being generalized as ample protection to any difference in the matter of investments. In two treaties, the disputes were limited to those

\footnotetext{
${ }^{479}$ D'Aspremont and Brölmann illustrate about the generally identical effects of the decisions taken by ad hoc and treaty based tribunals:

"While treaty-based tribunals are usually considered international organizations with independent
international legal personality, ad hoc tribunals constitute organs of the United Nations created by an
"act" of the latter. As a result, assessing an order, decision, judgment, or even the statute of an ad hoc
tribunal formally amounts to reviewing an act of the United Nations. However, despite the different
legal bases of ad hoc tribunals and treaty-based tribunals, from a different and equally valid perspective
these tribunals may be seen as international courts capable of adopting certain acts with autonomous
judicial effect at the international level. This is why some of the lessons learnt from this practice may
provide useful insights for possible future cases of review of the action of the ICC by domestic courts."

See, D’Aspremont (Jean) and Brölmann (Catherine), "Challenging International Criminal Tribunals Before Domestic Courts" in Challenging Acts of International Organizations Before National Courts, Edited by August Reinisch, Oxford University Press, New York, First published, 2010, 112-113 pp.

${ }^{480}$ The BITs with China and Spain do not incorporate national treatment provisions.

${ }^{481}$ BITs with Cuba, El Salvador, Spain, Nicaragua, Panamá.
} 
of a legal nature $\mathrm{A}^{482}$ and to the determination of the amount of expropriation ${ }^{483}$. With exception to the four investment treaties adopted before 1992 and the BITs signed with Cuba and China, the whole treaties incorporate the ICSID dispute settlement mechanism. With few exemptions, the treaties referring to ICSID jurisdiction, also contemplate the alternative submission of disputes under UNCITRAL rules and national courts, at the election of investors. In the latter alternative, certain treaties contain an absolute and partial "fork in the road" provision, which entitle the investor to desist from a national proceeding and resorting to international arbitration in the event of excessive delays or before the final ruling is issued. With respect to international arbitration, these provisions in general vest the tribunals with the power to apply international and national law without exceptions. It is also curious that in the BIT with Germany, the relevant provision also entitles the national courts to apply the provisions of this treaty. As to the execution of the awards, the provisions are neither uniform, devising the awards as final and definitive and as such enforceable in accordance to the investment host country's legislation. In other cases, further references to the application of the New York Convention on the Recognition and Enforcement of Foreign Arbitral Awards (hereinafter "New York Convention") are made, as well as the requirement to determine as seat of arbitration countries signatories of this treaty. In view of a comparative analysis of the provisions at issue, it may be affirmed the non-uniformity of the country's practice at the time of adopting international investment obligations both from the substantive and procedural perspective, whose divergence among the different treaties adopted lacks of objective criteria. Moreover it has to be underlined that the processes of signature, approval and ratification of the whole BITs did not entirely pass through a prior review of constitutional conformity, either because the constitutional frameworks in force entrusted this attribution to a political body, namely the National Congress or subsequently, because the Constitution of 1998 allowed the President to judge for himself whether a particular category of international treaties should be put under consideration of the Legislature.

From the analysis of the minutes of the National Congress, dominated at the time by political parties that clearly advocated economic liberalization, it can be seen as a common pattern, not only the absence of discussion in the plenary session about the legal and economic implications of these treaties, but also the insufficient motivation of the

\footnotetext{
${ }^{482}$ BIT with The Netherlands.

${ }^{483}$ BIT with The People's Republic of China.
} 
prior reports issued by the members of the Legislative Commission of Foreign Affairs, which were the sole basis for these abrupt approvals. In the absence of a prior economic and constitutional analysis entrusted to congressmen with different backgrounds ${ }^{484}$, the sole motivation backing such prior reports, was based on the assumption that the signature of BITs, was indispensable for allowing the country to enter into new markets and also attracting new investments ${ }^{485}$. With the exception of the discussion of the BIT with the United States that was delayed due to the fierce opposition of a leftwing congressman, only the reports at issue were put under consideration of the plenary, disregarding the discussion and even the reading of the text of the different BITs before their approval. This malpractice allowed, for instance, that a single prior report could contain the recommendation for signing a bundle of BITs, based on two brief factual generalizations: 1) that these treaties were not in contradiction with the Constitution and the law; and, 2) that this adoption would be beneficial for opening markets to Ecuadorian investors and reciprocally, attracting foreign investment to the country. Regretfully, only in the discussion for the approval of the BIT with the United States, emerged certain concerns

\footnotetext{
${ }^{484}$ By virtue of the principle of separation of powers, the Legislative Branch was entitled to issue its own internal regulation and rules. In absence of a specialized mechanism of prior judicial control of treaties, the Permanent Specialized Commissions, in this case, the Commission of Foreign Affairs had the attribution to determine the constitutionality and convenience of the treaties. The corresponding report was discussed before the Plenary of the National Congress:
}

“Artículo 92.- Los informes de las comisiones legislativas internas y ocasionales deberán referirse, obligatoriamente, tanto a la constitucionalidad como a la conveniencia de los proyectos de leyes, decretos o asuntos sometidos a su estudio, expresando las observaciones o modificaciones que juzguen necesario introducir. “

Adoptado por el Congreso Nacional del Proyecto de Ley Orgánica de la Función Legislativa que fue aprobado por el Congreso Nacional, objetada totalmente por el Ejecutivo en noviembre de 1979; armonizándola con la Codificación de la Constitución Política publicada en el Registro Oficial 569 de 1 de septiembre de 1983 y actualizada con las reformas de que fue objeto el 17 septiembre de 1990. Departamento de Publicaciones del Congreso Nacional (1997).

${ }^{485}$ Extract of the report of the Commission of International Affairs of the Ecuadorian National Congress, recommending to the Plenary the approval of the Bilateral Investment Treaty with el Salvador:

"La solución de controversias sobre situaciones de inversión entre los dos países tienen una instancia arbitral y, según el Artículo noveno, luego de seis meses, puede recurrirse a la jurisdicción nacional, es decir una gradación jurídica que en nada perjudica a lo dispuesto en la Constitución de la República. Por otro costado, El Salvador, es un país en pleno desarrollo y un nuevo mercado para posibles productos ecuatorianos de tipo industrial y debe aprobarse el presente Convenio por convenir al interés nacional y no oponerse al ordenamiento jurídico ecuatoriano."

Congreso Nacional, sesión vespertina de Congreso Ordinario, Acta 26, 25 de septiembre de 1995. 
regarding the legitimacy and constitutionality of this kind of international instruments. ${ }^{486}$ The opposition's congressman, Diego Delgado, claimed that there was a lack of conformity of the dispute settlement provisions with the constitutional provision that prohibits the submission of the State to foreign jurisdiction through contracts. Additionally, he criticized the parties' commitment to adopt the most effective means to make the BIT's provisions operative, which in view of the economic relationships between the contracting parties would entail an imbalance of rights and obligations. Through this commitment, Delgado contended that the United States would have been entitled not only to the ample standards of protection enshrined in the BIT, but also to exert supplementary means of pressure and diplomatic intervention prohibited by the Ecuadorian Constitution. Moreover, he condemned the reservation made by the United States that excluded from the ambit of the BIT, almost the totality of its economic sectors when investments were made in its territory; such exceptions of course did not apply to investments made in Ecuador, the same which were afforded unlimited protection. In any case, he cynically under-estimated such an exception, given that it was unlikely that substantial Ecuadorian economic investment flows could land in the United States. Such an exception, in his opinion, only portrayed the absence of legal and economic reciprocity in these treaties. Despite these observations on the contents of the BIT and the procedure of approval of the same, which was inconsistently motivated since the constitutional provisions invoked in the report corresponded to a completely different topic, the plenary of the Congress insisted in its approval ${ }^{487}$. As noted, those BITs ratified after the Constitution of 1998 did not pass through legislative approval and similarly to the Congress's motivation, the brief executive decree through which three treaties ${ }^{488}$ were ratified, only mentioned the convenience of this decision for bringing prosperity to the Nations. ${ }^{489}$

\footnotetext{
486 Congreso Nacional del Ecuador, sesión vespertina de Congreso Ordinario, Acta 38, 4 de octubre de 1994.

${ }^{487}$ Congreso Nacional del Ecuador, sesión vespertina de Congreso Ordinario, Acta 38, 4 de octubre de 1994.

${ }^{488}$ Bilateral Investment Treaties subscribed between Ecuador and Dominican Republican, The Netherlands and Nicaragua.

${ }^{489}$ Executive Decree No. 1412-C through which, Gustavo Noboa Bejarano, President of the Republic of Ecuador, ratified the Bilateral Investment Treaties subscribed between Ecuador and Dominican Republican, The Netherlands and Nicaragua. In the chapeau of this decree, it is pointed out:
} 
Finally, and it will be explained in the next section, these provisions show the uncertainty concerning Ecuador's adherence to the Washington Convention. Certain treaties confirm the country's membership to the ICSID Convention and others put this fact in doubt, when refer to the application of ICSID complementary rules, provided that one of the parties did not ratify it.

\subsubsection{The Internal Procedure of Approval of the ICSID Convention}

The meteoric and chaotic procedure of signature and internal approval of the BITs was underpinned by an even more controversial process of Washington Convention's implementation. As it was pointed out, except for Cuba and China, the totality of BITs adopted after 1992, incorporated by reference ICSID jurisdiction provided the parties ratified the Washington Convention. According to Ecuadorian official records and ICSID's public information, the Government of Ecuador signed and deposited the instrument of ratification of the aforementioned treaty on the same day, namely, January 15, 1986. Although the practice of signing and depositing the instrument of ratification of the relevant convention is not strange in ICSID practice, it definitely raises eyebrows concerning the well-rooted practice of internal approval and ratification of treaties in Ecuador. The constitutional codification (1984) in force at this time required unconditionally the legislative approval of any international treaty. Taking into consideration that the BITs concluded prior to 1992, did not include the State's offer to submit the corresponding investment disputes to ICSID jurisdiction, it is clear that the sudden signing and ratification of the Washington Convention attempted to pave the way for making effective the subsequent BITs which the country entered into through the attractive jurisdictional features of the ICSID dispute settlement system. Although, most of the BITs signed during the aforementioned period contained several jurisdictional alternatives for settling disputes, certain of them, intended as the sole forum of adjudication, the arbitral tribunals constituted under the frame of Washington Convention. Since investment arbitration is the most potent characteristic of this kind of treaty, it is not reckless to assume that the signature of the BITs enshrining ICSID

\footnotetext{
"Que dichos instrumentos Bilaterales, tienen el propósito de incrementar condiciones más favorables para los inversionistas, estimulando así el movimiento de capital privado, produciendo de ésta forma la prosperidad entre las Partes;

Que luego de examinar los referidos instrumentos internacionales los considera convenientes para los intereses del país."
} 
jurisdiction as the sole forum of arbitration, entailed a strong commitment of the Ecuadorian government, to put into effect this particular regime. As noted in the previous section, the reference to the applicability of ICSID jurisdiction in Ecuador at the time it signed the corresponding BITs was inconsistent. This lack of definition was also projected on the national normative and contractual stipulations that incorporated either conditional submission commitments to such a forum or also acknowledged its validity prior to the legislative approval of the corresponding treaty. The public registers recording the signature and ratification of Ecuador to the Washington Convention leave no doubt with respect to the date these international acts were performed. Therefore, this treaty did not pass through the decision of the Congress, before its ratification, circumventing the constitutional process that to this date unequivocally required this requirement. ${ }^{490}$ Unquestionable proof of this domestic violation constitutes the precipitous publication of this treaty in the National Gazette, which is the step that concludes the internal process of formation of treaties. ${ }^{491}$

On the international scene the convention at issue entered into force in February 14, 1986, in accordance with articles 68 (2) and 73 of the said convention, as corroborated by the Deputy Secretary of the World Bank. ${ }^{492}$ Soon after the signature and deposit of this international treaty, the Ecuadorian Government performed several actions, confirming its full and unconditional membership to the Convention, like the appointment of representatives to ICSID's administrative council, the list of mediators and arbitrators' submission and more importantly, the designation of the main state petroleum company

\section{${ }^{490}$ Constitución de 1984 (Codificación):}

“Art. 59.- El Congreso Nacional se reúne en pleno, sin necesidad de convocatoria, en Quito, el 10 de agosto de cada año y sesiona durante sesenta días improrrogables, para conocer exclusivamente de los siguientes asuntos:

h) Aprobar o desaprobar los tratados públicos y demás convenciones internacionales (..)

Art. 78.- Son atribuciones y deberes del Presidente de la República:

f) Determinar la política exterior y dirigir las relaciones internacionales; celebrar tratados y demás convenios internacionales de conformidad con la Constitución y leyes; (...)"

${ }^{491}$ Registro Oficial 386, 3 de marzo de 1986.

492 Serena H. Clarke, Deputy Secretary of the World Bank, depositary of the Washington Convention, sent the following letter to Edgar Terán Terán, Minister of Foreign Affairs of Ecuador on February 19, 1986: "I wish to confirm that on January 15, 1986, the Instrument dated January 15, 1986 and signed by you, ratifying and accepting the Convention on the Settlement of Investment Disputes between States and Nationals of Other States on behalf of Ecuador, was deposited with the Bank pursuant to Article 73 of said Convention. Pursuant to Article 68 (2), the Convention enters into force for your Government 30 days after the date of such deposit, that is to say, on February 14, 1986." 
(PETROECUADOR) as an agency subordinated to the ICSID dispute settlement in accordance to Article 25 of the Washington Convention. The domestic uncertainty concerning the validity of this international treaty was manifest in view of the exchange of communications between authorities and interested actors that contained contradictory opinions, which was more fluent after the reform of the hydrocarbon regime and the massive adoption of BITs, starting in 1993. For instance, several communications of the Ministry of Foreign Affairs confirmed that the treaty was in force and did not require legislative approval because it was an accessory instrument that permitted the due application of the Convention that instituted the International Bank for Reconstruction and Development ${ }^{493}$.

It is even suggested; that the constitutional reform to the well-established provision that prohibited the surrender of jurisdiction in contracts signed between the State and private persons in Ecuador was underpinned by the need to regularize the fraudulent process of the adoption of Washington's Convention and its incorporation within hydrocarbon contracts. Once this constitutional reform was achieved on 1996, the Ministry of Foreign Affairs took a different approach and oriented its actions towards the legislative approval of this treaty, arguing that the recent BITs adopted already recognized ICSID's jurisdiction and that Ecuador was one of the few Latin American countries relegated from the application of the same due to its lack of ratification ${ }^{494}$. This intentional misrepresentation before the branches in charge of internally regularizing the process of the treaty's approval did not only disguise the previous Ministry's position regarding its validity but also contradicted the fact that for the ICSID and its members, Ecuador had been bound to this convention since $1986 .{ }^{495}$

In 2000, while the Constitution of 1998 was stll in force, the President, on the basis of the Congress' request ${ }^{496}$ that categorized the Washington Convention as an international

\footnotetext{
${ }^{493}$ See, "Auditoría integral ciudadana de los tratados de protección recíproca de inversiones y del sistema de arbitraje en materia de inversiones en Ecuador: Informe ejecutivo", May 2017.

${ }^{494}$ See, "Auditoría integral ciudadana de los tratados de protección recíproca de inversiones y del sistema de arbitraje en materia de inversiones en Ecuador: Informe ejecutivo", May 2017.

495 The ICSID'S arbitral award in the dispute between EMELEC and Ecuador confirmed that the Washington Convention entered into force on February 14, 1986.

Award issued on May 22, 2009.

496 Through the communication No. 4543-SCN of May 24, 2000, the Secretary of the National Congress requested the President to consul the Constitutional Tribunal about his ruling with relation to the Washington Convention, before its legislative approval in accordance to Art. 162 of the Constitution of 1998.
} 
treaty that required legislative approval ${ }^{497}$, solicited the prior ruling of the Constitutional Tribunal concerning the conformity of the same to the Constitution. ${ }^{498}$ Consequently, the Constitutional Tribunal issued its positive prior ruling, enabling the Congress to discuss and further approve this Convention. ${ }^{499}$ No different from the already defective official interpretations regarding the nature and scope of the treaty-based investment protection, the Constitutional Tribunal overlooked both the irregular process of the treaty's international ratification and more importantly, its effects on the national legal framework. In the first case, it argued that nonetheless the Constitution of 1998 came after the Constitutional Control Law and the latter did not enshrine a specific process for constitutional control of treaties, so there was no identified substantial procedural omission that might invalidate the official actions undertaken to date. Concerning the treaty's substantive analysis, the Tribunal founded its favourable decision both on constitutional and legal provisions. First, it invoked the constitutional provision that delineated the attributions of the State within a social market economy, underlining its obligation to guarantee the development of economic activities through an institutional and legal framework that promote and encourage them, in addition to building confidence. The same provision set forth equal legal treatment to public and private business activities and guaranteed foreign and national investment protection in the same conditions. ${ }^{500}$ Furthermore, the Tribunal resorted to the constitutional provision that mandated the State to guarantee national and foreign capital invested in production, enabled the law to confer special treatment to public and private investment in the least developed areas or national interest activities, and authorized the State to establish special

\footnotetext{
497 The Congress's Foreign Affairs Commission concluded that Washington Convention had to pass through legislative approval in accordance to Article 161, paragraphs 2 and 4, that required such procedure when the treaty attributed to a supranational or international organization the exercise of the competences derived from the Constitution or the law, and include the commitment to enact, modify or derogate a law, respectively.
}

498 Through the communication No. 00-550-DAJ.T.332 of June 5, 2000, the President requested the Constitutional Tribunal to issue the prior ruling with regards Washington Convention's approval.

${ }^{499}$ Resolution N. 171-2000-TP, September 28, 2000.

${ }^{500}$ Constitución Política de la República de 1998:

"Art. 244.- Dentro del sistema de economía social de mercado al Estado le corresponderá:

1. Garantizar el desarrollo de las actividades económicas, mediante un orden jurídico e instituciones que las promuevan, fomenten y generen confianza. Las actividades empresariales pública y privada recibirán el mismo tratamiento legal. Se garantizarán la inversión nacional y extranjera en iguales condiciones." 
guarantees and safeguards within contracts concluded with investors with the aim that the same might not be modified by laws or any further dispositions of any nature that affected the corresponding stipulations. ${ }^{501}$ In addition, it appealed to the constitutional provision that recognized arbitration, mediation and further alternative dispute settlement disputes pursuant to the law. ${ }^{502}$ In this way, the Tribunal acknowledged the validity of the Law on Arbitration and Mediation, enacted prior to the Constitution of 1998, which establishes: 1) without prejudice to the provisions enshrined in international treaties, an arbitration dispute may be international when the parties have agreed so, insofar as any of the specific requirements of domicile, place of obligations' fulfillment or the litigation's object concern an operation of international commerce; 2) international arbitration is regulated by international treaties, conventions, protocols and further international law' acts subscribed to and ratified by Ecuador. ${ }^{503}$ Regretfully the Tribunal did not read both provisions together, ignoring the clear legal isolation of treaty based arbitration from the domestic scope. As a result of this misunderstanding, it concluded

${ }^{501}$ Constitución Política del República de 1998:

"Art. 271.- El Estado garantizará los capitales nacionales y extranjeros que se inviertan en la producción, destinada especialmente al consumo interno y a la exportación. La ley podrá conceder tratamientos especiales a la inversión pública y privada en las zonas menos desarrolladas o en actividades de interés nacional.

El Estado, en contratos celebrados con inversionistas, podrá establecer garantías y seguridades especiales, a fin de que los convenios no sean modificados por leyes u otras disposiciones de cualquier clase que afecten sus cláusulas."

${ }^{502}$ Ley de Arbitraje y Mediación de 1997:

“Art. 191.- El ejercicio de la potestad judicial corresponderá a los órganos de la Función Judicial. Se establecerá la unidad jurisdiccional (...)

(...)Se reconocerán el arbitraje, la mediación y otros procedimientos alternativos para la resolución de conflictos, con sujeción a la ley.”

Registro Oficial 145 de 04-sep.-1997.

${ }^{503}$ Ley de Arbitraje y Mediación de 1997:

"Art. 41.- Sin perjuicio de lo dispuesto en los tratados internacionales un arbitraje podrá ser internacional cuando las partes así lo hubieren pactado, siempre y cuando se cumplan cualquiera de los siguientes requisitos:

a) Que las partes al momento de la celebración del convenio arbitral, tengan sus domicilios en estados diferentes; $\mathrm{o}$,

b) Cuando el lugar de cumplimiento de una parte sustancial de las obligaciones o el lugar en el cual el objeto del litigio tenga una relación más estrecha, esté situado fuera del estado en que, por lo menos una de las partes, tiene su domicilio; o,

c) Cuando el objeto del litigio se refiera a una operación de comercio internacional que sea susceptible de transacción y que no afecte o lesione los intereses Nacionales o de la colectividad." 
that the Washington Convention was not in contradiction with the provisions of the Constitution and the Law based on the following argument: 1) to resort to the ICSID dispute settlement system, it is indispensable that the Ecuadorian State, through the representative of the Executive Branch, gives its consent at the moment of the contract's signature; 2) that any of the requirements provided by the Law on Arbitration and Mediation for resorting to international arbitration would be accomplished under this hypothesis, considering that the same require that one of the parties is national from another State and that this party is domiciled abroad. While, the first reasoning disregards completely the extra-contractual nature of treaty-based arbitration, the second one, confuses the notion of nationality with domicile. Indeed, the Tribunal did not have the necessity to blend two completely different categories, if it had been aware that article 4 of the law being analyzed prescribed that the arbitration pursuant to this framework was confined to contractual relationships. ${ }^{504}$ In the light of well-settled public law principles, this legal definition removes from arbitration any controversies derived from the exercise of sovereign powers (regulations, administrative acts and sanctions, tax determinations, among others).

To be precise, the Law on Arbitration and Mediation incorporated the criteria which the Constitutional Tribunal invokes, in order to qualify an arbitration dispute as national or international, regardless of whether it involves private or public entities, since the notion of nationality is of no use for these purposes. Reaffirming that treaty based arbitration would be sidelined from this domestic regime, it is clear that this law would restrict the scope of the State's commitments when it contractually consents to submit a dispute to

${ }^{504}$ Ley de Arbitraje y Mediación de 1997:

“Art. 4.- Podrán someterse al arbitraje regulado en esta Ley las personas naturales o jurídicas que tengan capacidad para transigir, cumpliendo con los requisitos que establece la misma.

Para que las diferentes entidades que conforman el sector público puedan someterse al arbitraje, además de cumplir con los requisitos que establece esta Ley, tendrán que cumplir los siguientes requisitos adicionales:

Pactar un convenio arbitral, con anterioridad al surgimiento de la controversia; en caso de que se quisiera firmar el convenio una vez surgida la controversia, deberá consultarse al Procurador General del Estado, dictamen que será de obligatorio cumplimiento;

La relación jurídica al cual se refiere el convenio deberá ser de carácter contractual;

En el convenio arbitral deberá incluirse la forma de selección de los árbitros; y, El convenio arbitral, por medio del cual la Institución del sector público renuncia a la jurisdicción ordinaria, deberá ser firmado por la persona autorizada para contratar a nombre de dicha Institución.

El incumplimiento de los requisitos señalados acarreará la nulidad del convenio arbitral.”

Registro Oficial 145 de 04-sep.-1997. 
international arbitration. From a literal reading of these legal provisions, in the case that a dispute did not concern an obligation to be fulfilled outside Ecuadorian territory or to an operation of international commerce, the State could only contractually consent to international arbitration in the event that the contractor was domiciled abroad. For all the above mentioned, the criteria at issue would apply when the State exercises its private capacity in the frame of "lex mercatoria". This interpretation would be in line with the constitutional proscription to waive sovereign jurisdiction in contracts signed by the State and private persons, unless an international treaty enables them to do so. In this constitutional frame and the scope of international commercial arbitration as regulated by the Law on Arbitration and Mediation, the State acting in its private capacity would be enabled to contractually consent to a particular mechanism of dispute resolution in disputes limited to the private and commercial domain. Consequently, the State's consent to submit to international commercial arbitration disputes of a mere commercial nature would not imply the surrender of sovereign jurisdiction and therefore this action would not fall within the aforementioned constitutional prohibition. Although the Tribunal did not refer to this constitutional provision, incorporated on the reforms undertaken in 1996, it has to be underlined that the BITs do not regulate the mechanisms by which the State would have to give consent to submit a dispute to the different forums enshrined therein, since the same already include the State's offer to arbitrate investment disputes. In contrast with the BITs, the ICSID convention could be conceived as an enabling framework that also permits the State to contractually consent to the submission of investment disputes to arbitration. This would require that contracts including the State's consent to submit to international arbitration regulatory disputes expanding those standards covered by the BITs, could exclusively be settled through ICSID jurisdiction, duly instituted by an international convention. Conversely, the contractual submission of regulatory disputes to different arbitral forums not constituted by an international treaty would not be permitted in accordance to the constitutional restriction at issue. The practical consequence of this interpretation would require that, in the absence of the ICSID Convention, the State`s arbitration contractual consent would be limited to the violations of the protection standards prescribed in the BITs, being disregarded regulatory disputes or further standards of protection provided in the investment contract. This situation would entail a higher threshold for the claims of violation of the treaty, to which end, any further regulatory or contractual breach would be set aside. 
Besides overlooking the fact that "investment treaty arbitration is a form of public law adjudication" as explained by Van Harten, the Constitutional Tribunal added that the Washington Convention was not in contradiction with the Constitution of 1998 based on the following reasons: 1) that the Convention sets forth in the preamble that the mere fact of its ratification does not deem the State to be under any obligation to submit any dispute to arbitration without its consent; 2) that articles 1 and 2 require the submission of disputes in accordance to the provisions of the Convention; 3 ) that article 23 (sic) restricts to ICSID's jurisdiction legal disputes, which the parties to the dispute consent to in writing. As noticed the consent to submit investment disputes to arbitration was already given in the BITs concluded by Ecuador before the internal approval of the ICSID Convention. The Tribunal asserted that the provisions referred were in conformity with the Constitution, because "they subordinate the submission to the jurisdiction of the Center to the existence of the parties' written consent, understood that one of them has to be given by the Contracting State". ${ }^{505}$ As to the consent, the Tribunal misrepresented that the same would have to be given contractually by the representative of the Executive Branch $^{506}$. This defective reasoning also disregards basic notions of State responsibility, which includes the whole branches and any action of any public authority, which is more categorical in international investment law, where the disputes are not linked to a contractual relationship.

\footnotetext{
505 The main Tribunal's argument for issuing its positive ruling for the approval of the Washington Convention can be summed up as follows:

“(...) Que como se expresó, las disposiciones transcritas del Convenio guardan conformidad con el texto constitucional en cuanto condiciona el sometimiento a la jurisdicción del Centro a la existencia de un consentimiento escrito de las partes, se entiende que una de ellas se refiere al Estado contratante; (...)"
}

Tribunal Constitucional, Resolución Nro. 171-2000-TP, 26 de septiembre de 2000, Registro Oficial 180 de 10 de octubre de 2000.

${ }^{506}$ Incorrectly, the Tribunal interpreted that ICSID jurisdiction activates once consent is given contractually by the President:

“(...) Que, de las normas de la Constitución y de la ley respectiva se observa que el Convenio, que desea ratificar el Ecuador, no está en contraposición por cuanto para acudir al órgano creado por dicho Convenio es indispensable que -en este caso- el Estado ecuatoriano, a través del titular del Ejecutivo, dé su consentimiento al momento de suscribir un contrato; y, por otro lado, se estaría cumpliendo con algunos de los tres requisitos (los literales a/ y b/ ) señalados en la Ley de Arbitraje respectiva en cuanto a que para ir al arbitraje u otro medio similar es necesario que se trate de un nacional de otro Estado (o sea que debe ser extranjero) frente al Estado ecuatoriano y que este nacional extranjero esté domiciliado fuera del Ecuador; (...)"

Tribunal Constitucional, Resolución Nro. 171-2000-TP, 26 de septiembre de 2000, Registro Oficial 180 de 10 de octubre de 2000 . 
In conclusion, the Tribunal omitted to analyze the scope within which the State is authorized to surrender jurisdiction and how regulatory disputes would have to be dealt with by a delocalized tribunal. With this standing, the Tribunal not only disdained the most important constitutional provision regulating the possibility of surrendering international jurisdiction but it also buried the preceding State's practice concerning its scope of commitments regarding international disputes with private parties. As noted, in the ratification of the New York Convention and the Inter-American Convention on International Arbitration, Ecuador reserved its application to commercial disputes and removed public entities from such jurisdiction, respectively.

Pursuant to the favourable constitutional ruling, the National Congress on the basis of the report prepared by the Legislative Commission for Foreign Affairs swiftly approved the ICSID Convention. ${ }^{507}$ During the reading of the succinct report before the plenary session, it was pointed out that the representatives of the Minister of Foreign Affairs corroborated that the treaty's provisions were not in contradiction with the Constitution and furthermore, the national interest was safeguarded in the light of Article 26 of the convention, which allowed the States to require the exhaustion of local remedies as a condition for submitting the corresponding disputes to arbitration. What the authorities that analyzed this convention omitted to analyze is that the State never exercised this possibility either when it concluded the BITs or when it consented to ICSID jurisdiction through investment and strategic sector's contracts. ${ }^{508}$

\subsubsection{The Avalanche of Investment Disputes at the Outset of the XXI Century}

Only six months elapsed, between the sui generis procedure of ICSID Convention approval and the first notice of arbitration, filled by the Spanish investor, REPSOL YPF. ${ }^{509}$ The claim was founded on the alleged PETROECUADOR's contractual breach due to its lack of payment for the contractor's services. In this way, the investor perfected the conditional contractual consent given by the State to submit disputes to ICSID jurisdiction, once the National Congress had approved the same. As a result, the State would experience its first of many defeats in international investment litigation. After

\footnotetext{
${ }^{507}$ National Congress of Ecuador, Minute 51, February 7, 2001.

${ }^{508}$ National Congress of Ecuador, Minute 51, February 7, 2001.

509 The dispute was registered by ICSID Secretariat, on October 5, 2001.
} 
2001, the investment disputes faced by Ecuador have achieved the colossal sum of US\$ 21.223'947.079 million dollars. ${ }^{510}$

In the following year, the American investor, IBM World Trade Corporation, whole owner of IBM del Ecuador S.A., resorted to ICSID jurisdiction, claiming violation of USA-Ecuador BIT, allegedly caused by the lack of fulfillment of the concession contract signed between the company and the Ministry of Economy and Finance, derived from the failure to pay by the latter for the goods and services provided by the claimant. In this case, the investor relied on the unlimited definition of investment and the "umbrella clause" 511 , stemming from this BIT to equate the breach of contract as a violation of treaty. ${ }^{512}$ The dispute was discontinued due to the settlement reached by the Parties, once the State paid compensation agreed by the company.

Subsequently and under the blanket of the ample protection provided by the USAEcuador BIT, the oil company Occidental filed an investment claim against Ecuador, arguing that the denial of tax credits and reimbursements for Value Added Tax (VAT) paid as a result of the importation or local acquisition of goods and services, constituted an unlawful modification of the legal framework on which the investor relied when it made its investments in Ecuador, impairing as a consequence, the economic basis of the same. Specifically, the investor claimed that Ecuador has failed to honour its obligations to accord fair and equitable treatment, full protection and security and treatment no less favourable than that required by international law. In addition it argued, that the decisions at issue constituted arbitrary and discriminatory measures, amounting to indirect expropriation and less favourable treatment than that accorded in similar situations to investment or associated activities of its own national companies or of nationals or companies of any third country. The investor demanded that the resolutions of the tax authority were in contradiction with the legal provision in force at the time of the execution of the contract and within which oil companies were entitled to VAT credits. ${ }^{513}$

\footnotetext{
510 See, "Auditoría integral ciudadana de los tratados de protección recíproca de inversiones y del sistema de arbitraje en materia de inversiones en Ecuador: Informe ejecutivo”, May 2017, 61 p.

${ }^{511}$ Investment Treaty between Ecuador and the United States of America:

"3. (c) Each Party shall observe any obligation it may have entered into with regard to investments."

512 The dispute was registered by ICSID Secretariat on September 6, 2002.

513 Internal Tax Regime Law:

"Art. 65, 1: Value-Added Tax payers engaged in the production or marketing of goods for the domestic market or for exportation, or in the provision of services taxed at a rate of ten percent
} 
This provision was further modified with the attempt to clarify that the VAT reimbursement applied to the "manufacture of exported products". 514 The Claimant convinced the Tribunal that the tax authority denied applying reimbursements which it had already granted over an extended period and that it discriminated against foreign gas and oil companies engaged in petroleum exploration and production before other companies, whose right to enjoy tax credit as a result of importation or exportation of goods and services, was never disputed. This is the first case whereby an investor disputed regulatory measures, which resulted in an alleged limitation of the economic benefits of a contract and the frustration of the investor's legitimate expectations. Indeed, the Tribunal determined that the Claimant was entitled to the refund of all VAT paid and concluded that the Respondent breached its obligations, in particular that of maintaining a stable legal and business environment, as well as according: 1) no less favourable treatment than that accorded to national and other companies under the standard of national treatment, and; 2) fair and equitable treatment and guarantee against arbitrariness. In addition, it determined that the investor was entitled to invoke the most favoured nation clause enshrined in the BITs made with Ecuador and Spain, whereby the standard of national treatment was not qualified by reference to "in like situations", diluting the Respondent's argument that the national treatment standard was not violated since the VAT refund applied to other sectors than oil and gas production. There are also notable decisions of the Tribunal touching upon municipal regulatory measures. First, it mandated that any resolution ordering the return of the amounts retained by the investor as result of the VAT reimbursed by the tax agency should be held without legal effect, identically to any internal proceeding sought by the investor to obtain the tax recovery. Second, it instructed the municipal authorities to follow in the future, "the procedures

$(10 \%)$, shall have a right to a tax credit for all of the VAT paid in local acquisitions or the importation of goods that become part of their fixed assets, of raw materials or supplies and of services."

514 Internal Tax Regime Law:

"Art. 69 A: Natural persons and companies having paid the VAT in local acquisitions or importation of goods employed in the manufacture of exported products, are entitled to a refund for said tax, without interest. The refund shall be made in a term not to exceed ninety (90) days, and shall be in the form of a note of credit, check or other means of payment.

Interest shall be paid if said term expires and VAT has not been refunded. The SRI must refund the payment when the taxpayer's legal representatives formally file a declaration attaching certified copies ofthe invoices documenting VAT payment."

Law 99-24, Official Gazette 181-S, April 30, 1999. 
and scrutiny provided under Ecuadorian Tax Law", in regards to the requests for VAT reimbursement.

By the end of 2002, M.C.I. POWER GROUP L.C. and New Turbine INC., resorted to the protection of the USA-Ecuador BIT, claiming that Ecuador failed to meet its obligations pursuant to International Law, due to the alleged unlawful conduct of the Ecuadorian Institute of Electrification, which among others, terminated unilaterally the contract with the investor, applied penalties for delays purportedly outside the investor's control, did not act in good faith when the Liquidation Commission performed its contractual duties and finally, refused to sign a long term contract. As a consequence of these contended investor's contractual breaches, its permit was revoked by the Superintendent of Companies, on the basis that it was no longer carrying out any activity related to its corporate purpose. In any event, the main claims of the investor stemmed from the breach of contractual obligations protected by the umbrella clause, around which revolved the arguments that were intended to demonstrate the violation of the BIT's protection standards. ${ }^{515}$ In his award, the Tribunal ruled in favour of Ecuador arguing that the controversy arose prior the BIT's entry into force.

On 2003, EnCana Corporation, Canadian national, as indirect owner of the subsidiaries AEC Ecuador Ltd., and City Oriente Limited, both constituted in Barbados, requested arbitration under UNCITRAL arbitration rules on the basis of an identical claim concerning tax credit entitlements, as that previously analyzed in the case of Occidental. Besides invoking the violation of similar standards of investment protection as Occidental did, it specifically disputed the tax measures at issue as set forth by the specific provision of the Ecuador- Canada BIT. ${ }^{516}$ Pursuant to the wording of the latter provision, the

\footnotetext{
${ }^{515}$ Additionally, the investor claimed the violation of the following standards: a) fair and equitable treatment, full protection and security and minimum treatment in accordance to International Law; 2) arbitrary and discriminatory measures, notwithstanding it has or had exercised the opportunity to review such measure in the courts or administrative tribunals; 3 ) the obligation to treat investment and activities associated therewith on a basis no less favourable than that accorded in like situations to investment or associated activities of its own nationals or of national or companies of any third country; 4) expropriation without just compensation.

${ }^{516}$ Agreement between the Government of Canada and the Government of the Republic of Ecuador for the Promotion and Reciprocal Protection of Investments:

"ARTICLE XII, Taxation Measures:

1. Except as set out in this Article, nothing in this Agreement shall apply to taxation measures.

2. Subject to paragraph (2), a claim by an investor that a tax measure of a Contracting Party is in breach of an agreement between the central government authorities of a Contracting Party and the investor concerning an investment shall be considered a claim for breach of this Agreement unless the taxation authorities of the Contracting Parties, no later than six months after being notified of the claim by the investor, jointly determine that the measure does not contravene such agreement.
} 
Tribunal declared that it did not have jurisdiction over the taxation measure's claim, because there was neither a breach of any agreement between the Ecuadorian central government authorities and EnCana, nor a breach of the participation agreements. It added that the participation contracts were not concluded with the tax authority but with Petroecuador (state owned oil company) and further, they were not concluded by EnCana, but by "its third State incorporated subsidiaries". Conversely, it assumed jurisdiction over the expropriation issue and found that the taxation authorities of the two States made no joint determination on the matter of expropriation, in the absence of this particular claim by the investor. When dealing with the issue of indirect expropriation, it analyzed whether the denial of the refunds had such a significant impact on the subsidiaries as to be equivalent to expropriation of the investment. In the context of direct and indirect expropriation, the Tribunal concluded concerning the former:

"173. This way of putting the claim faces a double difficulty. In the first place, foreign investments like other activities are subject to the taxes and charges imposed by the host State. In the absence of a specific commitment from the host State, the foreign investor has neither the right nor any legitimate expectation that the tax regime will not change, perhaps to its disadvantage, during the period of the investment. Of its nature all taxation reduces the economic benefits an enterprise would otherwise derive from the investment; it will only be in an extreme case that a tax which is general in its incidence could be judged as equivalent in its effect to an expropriation of the enterprise which is taxed.

174. In the second place, although the EnCana subsidiaries suffered financially from the denial of VAT and the recovery of VAT refunds wrongly made, they were nonetheless able to continue to function profitably and to engage in the normal range of activities, extracting and exporting oil (the price of which increased during the period under consideration). There is nothing in the record which suggests that the change in VAT laws or their interpretation brought the companies to a standstill or rendered the value to be derived from their activities so marginal or unprofitable as effectively to deprive them of their character as investments."

As to the issue of direct expropriation, the Tribunal embraced the assumptions made by Occidental tribunal, which both recognized the oil and gas companies' right under

3. Article VIII may be applied to a taxation measure unless the taxation authorities of the Contracting Parties, no later than six months after being notified by an investor that he disputes a taxation measure, jointly determine that the measure is not an expropriation.

4. If the taxation authorities of the Contracting Parties fail to reach the joint determinations specified in paragraphs (3) and (4) within six months after being notified, the investor may submit its claim for resolution under Article XIll. “ 
Ecuadorian law to VAT in respect to purchases of goods and services and presumed that the policy decision of the tax agency was oriented to irretrievably deny refunds to oil companies. In view of the facts that confirmed that the oil companies could challenge the tax agency's ruling in courts, the prompt accomplishment of such court decisions by the agency, the undisputed good faith of the tax agency's representative and the absence of evidence of non- independence or bias of the court decisions, the Tribunal dismissed the claim. It declared that the policy of a tax authority was not reviewable under the relevant treaty provision (Ar. VIII), "unless that policy in itself amounts to an actual and effective repudiation of legal rights".

On 2004, Duke Energy Electroquil Partners and Electroquil S.A submitted its request for Arbitration to ICSID with respect to the dispute stemming from contracts entered into between the parties for electrical power generation in Ecuador. In their complaint, the Claimants attributed to the Respondent: 1) late and inappropriate implementation of payment trusts; 2) non-payment of interest on late payments; 3) wrongful imposition of fines and penalties; 4) disregard of customs duties application; and; 5) failure to entertain the Claimant's suits under local arbitration. Derived from these acts, the claimants argued that Ecuador: 1) failed to meet its obligation to establish the payment trusts prior to commercial operation, by not complying with the calendar and manner of performing payments, aggravated by the misapplication of the penalty and custom regimes, which violate its general obligation of good faith; 2) failed to observe the umbrella clause, which includes contractual obligations; 3) failed to treat the investment fairly and equitably; 4) impaired the investment by arbitrary conduct; 5) failed to provide the claimants with effective means of asserting claims and enforcing rights with respect to their investment, which amounts to a denial of justice. In this case, the Tribunal faced the combination of different bases for ICSID jurisdiction, namely the arbitration agreement the primary basis and alternatively the BIT, in the event of lack of jurisdiction, with respect to the former. The Tribunal confirmed its cumulative jurisdiction by applying the Arbitration Agreement over the contractual claims and the BIT over those controversies outside the latter scope, particularly that concerning the implementation of payment trusts and custom duties. On the basis of an extensive arbitration agreement, the Tribunal acknowledged the open and general offer for ICSID arbitration in the USA-Ecuador BIT, accepted by the claimants when the proceedings were instituted. In his analysis of the merits, the Tribunal first reviewed the contractual issues under Ecuadorian law and afterwards, the compliance with BIT standards. The complexity of the relationship 
between the parties, was not only clear from the sophisticated arbitration agreement, which included a compound choice of law, but also from the interaction of mechanisms, whereby the State acted both through its private and sovereign capacity. In its analysis the Tribunal found that the Ecuadorian Institute for Electrification and Ecuador violated the contractual provisions and Ecuadorian law "by the late establishment and the poor implementation of the Payment Trusts, the irregular imposition of certain fees and penalties, and the non-payment of interest in connection with the amounts due under the Liquidation Agreement". ${ }^{517}$ When the Tribunal addressed whether such violations constituted breaches of the BIT standards, it noted that the broad umbrella clause together with the express agreement of the parties to apply the BIT within contract disputes in connection with the ample definition of investments provided in the treaty, enabled it to undertake such an assessment; as a result, it confirmed the State's umbrella clause breach. Additionally, it reached the conclusion that the State by not implementing a particular payment guarantee deceived Duke Energy's reasonable expectations, breaching the guarantee of fair and equitable treatment.

At the end of the same year, EMELEC, a corporation constituted in the State of Maine, United States, presented its request for arbitration, alleging the taking of its whole investment, including bank accounts, real estate and other kind of properties within the Ecuadorian territory. Since 1925, EMELEC was the concessionaire for the provision of the electricity service in Guayaquil, for a 60 years period, which was "de facto" extended, after the same elapsed. Ecuador successfully disputed the jurisdiction of the Tribunal claiming the lack of legal standing of the representatives that acted on behalf of the investor, through a trust constituted by an Ecuadorian banker, who was bankrupted during the financial crisis of the end of the 1990s. This trust was irregularly constituted and attempted to replace a previous irrevocable one, created with the purpose of honouring the debts derived from the bank's bankruptcy. In view of the irregular constitution of the later trust, the Tribunal confirmed that its representatives lacked legal standing for bringing an investment dispute.

In 2005, Noble Energy brought its claim together with its local subsidiary, Machala Power, on the basis of the USA-Ecuador BIT and two contracts, one investment agreement signed with the Ecuadorian government pursuant to the Law on Promotion and

\footnotetext{
${ }^{517}$ International Centre for Settlement of Investment Disputes (ICSID), Duke Energy Electroquil Partners \& Electroquil S.A. v Republic of Ecuador, ICSID Case No. ARB/04/19, Award.
} 
Protection of Investments and a 31 year concession signed between the subsidiary referred to and Ecuador's electricity regulator. In the light of the concurrence of treaty and contract claims, the tribunal decided to consolidate them, when it ruled over its jurisdiction. Mainly, the investor argued that the regulations enacted after the governmental attempts to privatize the electricity sector prompted in 1996, resulted on discrimination against the Machala plant and affected its competitiveness, particularly the agreements concluded between Ecuador and Colombia that allegedly granted preferential treatment to Colombian electricity suppliers. This dispute was discontinued on 2009 due to the settlement reached between the parties, whereby Ecuador agreed to pay US\$ 70 million, substantially lower, than the investor's original pretension, fixed at US\$ 370 million. ${ }^{518}$

2006 was a hectic year concerning investment disputes, with 4 lawsuits launched by oil companies, three under the USA-Ecuador BIT and one under the Spain-Ecuador BIT. The paradigmatic OXY II case, triggered by the government's resolution to declare the caducity of the corresponding contract due to undisputed breaches of legal and contractual obligations by the investor, resulted on the highest award granted in the frame of ICSID history. Additionally, the North-American investor, City Oriente, brought the first of a further avalanche of investment disputes derived from the enactment of the Law 2006-42 that raised the State's participation over the extraordinary prices of oil. The Spanish investor, Técnicas Reunidas S.A., founded its claim before ICSID on the breach of contractual stipulations reached with the state owned company, PETROECUADOR and the Ministry of Energy and Mines on 1995. It alleged that the unreasonable delay and further, the lack of payment of the obligations as stipulated in the liquidation act on 2002 resulted in the violation of the corresponding BIT, and specifically the standards of fair and equitable treatment, discrimination, expropriation and the umbrella clause. As response, the State argued that the investor did not perform several contractual obligations, which sustained its reluctance to complete the payments requested by the investor. On 2008, the parties reached an agreement and discontinued the dispute.

The American investor, Chevron Corporation and Texpet Petroleum Company, on the basis of the USA-Ecuador BIT, alleged that the undue delay in the adjudication of seven commercial cases that were filed by TexPet against the Government of Ecuador between 1991 and 1994, which to the date of the institution of the arbitral proceedings under

\footnotetext{
${ }^{518}$ See, Global Arbitration Review, "Nobel and Ecuador settle as port dispute looms”, January 12, 2009.
} 
UNCITRAL Rules, were not yet judged, amounted to a denial of justice ${ }^{519}$. It added that the significant amount of money at stake, more than US\$700 million, incentivized the undue influence of the government, one of whose organs was defendant in the case. Together with the allegation of denial of justice, the investor argued that also breached were: the standards of fair and equitable treatment, full protection and security, failure to comply with the obligations undertaken with respect to investments, failure to provide effective means of asserting claims and enforcing rights, impairment of enjoyment of property through arbitrary and discriminatory measures, expropriation through measures tantamount to expropriation and violation of the investment agreement. On 2010, the Tribunal concluded that Ecuador was liable for breaching Art. II (7) of the BIT, which contains the obligation to provide effective means of asserting rights and claims with respect to investment, investment agreements and any investment authorizations. The Tribunal asserted that nonetheless the disputes were clearly of contractual nature, the gross delay of the proceedings justified exempting the requirement of local remedies exhaustion. In this line, the analysis undertaken by the Tribunal is noteworthy with regard to the institutional crisis that affected the State and especially, the judiciary branch from 2004, paying particular attention to the establishment of the Constituent Assembly in 2008 and the further resolution taking for reorganizing the courts. With respect to the compensation, the Tribunal shared the respondent's position, which claimed that any sum of money that could be recognized in favour of the company had to be subject to the application of the 87,31\% Unified Tax. This tax was in force as part of the Ecuadorian law both on the date when the breaches occurred and when the notice of arbitration was filed. Besides, such a percentage was expressly recognized in the corresponding contract and as a result, the initial quantification of US\$ 700 million dropped to US\$ 96 million. Subsequent actions for annulment had been followed by Ecuador before the courts of the seat of arbitration, namely, the Netherlands. In the meantime, Chevron initiated the process of recognition and enforcement of the award in the United States.

519 International Centre for Settlement of Investment Disputes (ICSID), Chevron Corporation (USA) and Texaco Petroleum Company (USA) v Republic of Ecuador, Partial Award on the Merits, March 30, 2010.

“232. Of TexPet's seven Ecuadorian court cases at issue, one remains pending at first instance, two are the subject of pending appeals, two have been dismissed and are now closed, and two have been the subject of recent decisions. Several of the cases have seen action subsequent to service of the Notice of Arbitration in the present case." 
In contrast to 2007, which was a quiet year concerning international investment disputes and the start of the first presidential period of Rafael Correa, 2008 witnessed a flood of claims launched exclusively by oil companies. During this year the Constituent Assembly approved a new constitutional framework, which reflects an understandable antipathy towards international investment disputes. Two American companies, Burlington and Murphy, together with Petrobras, Perenco and Repsol, Argentinian, French and Spanish, respectively, initiated arbitral proceedings before ICSID. The dispute was connected to the Law 42-2006 ${ }^{520}$, which amended the Hydrocarbons Law, along with implementing regulations, which initially assigned to the State the 50 and then the 99 per cent from oil sales above a determined reference price, considered as extraordinary profits. Consent to such disputes was given in the relevant BITs and the different participation contracts, whose fundamental terms were claimed as breached together with the standards of legitimate expectations, non-discrimination and expropriation without compensation. The main argument of the oil companies was that according to the contractual modality agreed upon, they were entitled to a share in the oil production from their blocks pursuant to a formula in which the market price of crude oil was not included. The companies also disputed the presidential decision announced on 2008 that resulted in the modification of production-sharing agreements to a new contractual model of provision of services. It is noteworthy that the disputes at issue revolved around two regulatory actions enacted within two different constitutional frameworks. The enabling law that changed the State's participation over the extraordinary profits was issued within the frame of the Constitution of 1998, which enshrined unprecedented thresholds of protection to private interests. The implementing regulations that increased such participation, which finally urged the modification of the contractual modality and were only accepted by the minority of the oil companies, were framed under the Constitution of 2008. The

\footnotetext{
${ }^{520}$ Law 42 which amended Hydrocrabons Law may be read as follows:

"Participation of the State in the excess of oil prices not agreed to or foreseen:

When the effective monthly medium price of FOB sale of Ecuadorian oil petroleum goes above the monthly average prices in effect at the time of the execution of the contract ... [contracting companies] will recognize in favor of the Ecuadorian state a participation of at least $50 \%$ of the extraordinary income generated by the difference in price.

The price of crude oil as of the date of the contract used as a reference for calculation of the difference shall be adjusted, considering the Consumer Price Index of the United States of America, published by the Central Bank of Ecuador.2
}

International Centre for Settlement of Investment Disputes (ICSID), Perenco Ecuador Ltd. v Republic of Ecuador and Empresas Estatal de Petróleos del Ecuador (Petroecuador), ICSID Case No. ARB/08/6), Decision on Jurisdiction, March 30, 2010. 
reluctance of companies like Burlington to pay such a tax as provided by the national authorities were derived from seizure and sanctioning proceedings, which ended up with caducity decrees terminating the same. From the different claims of the investors, there are notably those that request the tribunal to declare null and void the regulatory measures undertaken as well as those that are required to preserve the validity of the participation contracts. Also to be highlighted is the claimants' reliance on the multiple regulatory reforms undertaken during the 1990s with the aim to liberalize the hydrocarbons sector. For instance, Burlington's request for arbitration identified a succinct analysis of this strategy that blended international and municipal measures and whose sharpness was praised in renowned magazines like "The Economist", which ranked Ecuador among "the 35 most liberal countries in the world in terms of commerce and investment, ahead of Colombia, Chile and Mexico" and "described the changes in Ecuador's business climate a as a silent revolution in foreign commerce". 521

2009 was also a very active year in terms of investment disputes, encompassing heterogeneous controversies and nationalities. Undoubtedly, the most paradigmatic dispute was launched by Chevron (Chevron III) under UNCITRAL Arbitration Rules. Although the investor previously succeeded on employing the BIT for scrutinizing the judiciary branch's performance (Chevron II), this time it took a step forward and argued the pursuit of a co-ordinated strategy between environmental litigators (Lago Agrio plaintiffs) and various organs of the State with the aim to improperly shift the latter's liability to Chevron for any environmental impacts derived from its operations prior to 1992. Although the Ecuador-USA BIT entered into force in 1997, the claimants relied on the ample definition of investment disputes incorporated by this treaty, as well as in the categorization of the controversial settlement of environmental agreements and subsequent releases $(1995,1996,1998)$, to validate the scope of the dispute and specifically, for attempting to avoid its liability over the Lago Agrio Complaint, whose amount was set first in US\$ 19.000 and then in $\$ 9.500$ million dollar by the National Justice Court (former Supreme Court of Justice). The Claimants claimed the breach of the standards of fair and equitable treatment, full protection and security and the obligation to provide effective means of enforcing claimant's rights. In the course of the process, the Arbitral Tribunal reached an interim decision, whereby it determined that the

${ }^{521}$ Request for arbitration Burlington Resources Inc, April, 21, 2008.

As reported on the official website of the Permanent Mission of Ecuador to the United Nations, see http://www.ecuadoronu.com/html!economia.htmlhttp://www.ecuadoronu.com/html!economia.htrnl. 
Lago Agrio Complaint and as such the plaintiffs' individual claims do not fall within the scope of the settlement agreements, through which the investor alleged the legal and contractual release of its overall liability. The three remaining cases brought by Ulysseas Inc., Quiport and Unete Comunicaciones S.A encompass claims that were channelled towards the contended violation of BIT standards associated with changes in the legal and regulatory framework; in reality they disputed the modification of contractual economic expectations, founded on sovereign concessions underpinned during the period of the strategic sector's liberalization. In the proceeding launched by the American investor, Ulysseas, under UNCITRAL Arbitration Rules, the Arbitral Tribunal did not uphold the claimant's standing that attempted to attribute to the State the actions imposed by the National Electric Council within a commercial contract, after a comprehensive assessment of the ILC Articles. Again the dispute arose out of the application of contractual stipulations agreed upon within the frame of the Electricity Sector Law enacted on 1996 that attempted to liberalize the sector and create a competitive electricity market through aggressive public aid. This regime was further modified by legal amendments and regulations oriented to bring it into conformity with the new constitutional provisions of 2008, whereby the provision of such services was conferred on public enterprises. Similarly, the Bolivian investors, Unete Telecomunicaciones S.A. and Clay Pacific, as owners of the company Globalnet, concessionaire for the provision of the public service of telecommunications through the establishment of community telecenters in rural areas within a project financed by the World Bank, initiated arbitration proceedings under UNCITRAL Rules. According to the investors, the liberal telecommunications regulatory framework, prompted by the Special Law on Telecommunications of 1992, the Law for Modernization of the State (1993) and further implementing regulations undertaking to attract the private sector's participation, together with the promissory perspective of Ecuador's economic development and the World Bank's sponsorship of the project, made them rely on the convenience of the business and its stability. The Council of Modernization of the State signed the concession contract agreeing among other stipulations to preserve the economic equilibrium of the same and assuring unconditional legal stability. Due to problems in the performance of the contract, which according to the investors were prompted by the failure of the telecommunications regulators to issue mandatory orders of interconnection with the acting private and public telecommunication companies, the National Telecommunications Council terminated unilaterally the concession contract. During the 
arbitral proceedings Ecuador contended that the investors' claims were merely contractual and attributed criminal conduct during their operation in Ecuador. Without prejudice of the actions sought by the national authorities against Globalnet at the municipal level, the parties sent a joint letter to the arbitral tribunal informing it of the discontinuation of the dispute. Interestingly the Quiport case, involved a legal dispute arising from an investment contract, concluded within the frame of the Investments' Promotion and Guarantee Law. The issue derived from the request of the General Comptroller of the State to the Constitutional Court to rule on the constitutionality of the Attorney General's authorization, which enabled it to include within the financing structure of the project for the construction of the new airport of Quito, the collection of airport charges by the concessionaire to which was entrusted the operation of the old airport as a fundamental part of the deal. Reversing the Attorney General's opinion, the Constitutional Court declared that these charges were not private but public funds "which shall only be paid to, retained and managed by the State, and therefore not by Quiport". ${ }^{52}$ This decision not only reaffirmed the overhauled position of the Constitutional Court as the maximum adjudicator concerning the conformity of any action to the Constitution, but also unveiled the detrimental economic terms through which this kind of projects were bargained, counterfeiting the real nature of the funds. Rafael Correa contended that the direct monetary contribution of the concessionaire for the project was only US\$ 74 million, since the State was the main financer through the airport charges, which represented more than three times the capital paid by the investor, who additionally backed the 35 years concession with loans to be paid with guaranteed cash flows obtained from the income of the new airport's operation. Such economic terms, in Correa's opinion also disregarded the concession of a natural monopoly, through which the State even made the commitment to desist from the development of similar projects that might compete with the new airport in nearby areas, besides the significant public investments required for the operation of the new airport. ${ }^{523}$ This situation obliged the parties to renegotiate the investment contract taking into consideration the constitutional ruling and accordingly, they discontinued the dispute. ${ }^{524}$ In 2010 and 2011, most of the investment disputes pertained to the mining sector and derived from

\footnotetext{
${ }^{522}$ Notice of ICSID Arbitration, Corporación Quiport S.A. and Others against Ecuador, 18 December 2009.

${ }^{523}$ Correa (Rafael), Ecuador de Banana Republica a la No República, Debolsillo, Colombia, 2012, 57 p.

${ }^{524}$ Corporación QUIPORT S.A. and others v. Republic of Ecuador, ICSID Case No. Arb/09/23, Order of Discontinuance (november 11, 2011)
} 
constitutional mandates issued by the Constituent Assembly and further regulations, that according to Canadian investors like Zamora Gold Corporation, Cooper Mesa and RSM, resulted in unfair and inequitable treatment and amounted to the expropriation of mining licenses and sites. The constitutional mandates at issue declared the extinction of the mining concessions. Since it was at the exploration phase, it did not account for any investment over a certain period, did not undertake prior environmental assessments and did not make prior consultation with indigenous peoples. These rights were conferred under the Mining Law of 1991, which also attempted to liberalize the sector and attract foreign investments by practically suppressing any regulation. In the opinion of the authorities, this deregulated frame underpinned fraudulent and speculative practices, whereby the right holders preserved their concessions without making any substantial investment, which erected expensive entry barriers to companies capable of exploring and exploiting minerals. In the case of the claims of Zamora Gold Corporation, the dispute was focused on the constitutionality of the mandate issued by the Constituent Assembly that declared that certain resolutions of seizure taken by the Deposit Guarantee Agency were not susceptible to any legal action seeking constitutional redress. Arising from the latter decision, the agency in question, which was created for recovering the debts from the bankruptcy of banks at the end of the 1990s, took definitive control over the shares of Zamora Corporation and its assets. Finally, in 2011, Merck Sharp \& Dohme Corporation, an American investor, initiated arbitral proceedings against Ecuador, alleging that a pending judicial proceeding and its existing outcomes related to a civil dispute between this company and a national pharmaceutical corporation resulting in a miscarriage of justice. By denouncing the courts of Ecuador as vulnerable to corruption and outside interference, the investor claimed a breach of the Ecuador-USA BIT, specifically, the obligation of the State to provide investors with access to a judicial process, ensuring minimum requirements of due process.

Finally and within the investment disputes referred to, the three different proceedings brought by the American investor Murphy (Murphy I, Murphy II and Murphy III) need mentioning. In the first one, the ICSID Tribunal determined that it had no jurisdiction since the six months "cooling off" period was not fulfilled. Subsequently, the investor attempted to initiate fresh arbitral proceedings before ICSID (Murphy II), but soon after it withdrew its request announcing the presentation of a new one under UNCITRAL Arbitration Rules (Murphy III). 
In parallel and starting on 2009, Ecuador has been served with several notices of arbitration, which have not moved forward due to different circumstances. The corresponding claims show a resort to the system as a parallel mechanism for compelling the State to desist from particular actions, not only from the different standards of protection invoked, but especially from the heterogeneous nature of the disputes. From ten notices of arbitration, three stand out, brought by the shareholders of the company "El Universo", which publishes the daily newspaper of the same name. The controversy arose out the criminal lawsuit filed by President Correa against an editorial published by the claimant, which concluded on a judgment, confirmed by the National Court of Justice, that found the crime of defamation and awarded $\$ 40$ million dollars in damages and fines. The claimant alleged violation of due process and denial of justice under the frame of international human rights law and international investment law. The claimant alleged that the contended measures deprived the value of the investment, which "rather than serving a public purpose, the Republic's measure had the sole purpose of silencing a newspaper that has been critical of the Government". ${ }^{525}$

Also notable is the controversy launched by the Spanish investor, CIRSA International Corporation, whose corporate activity relates to the gambling business. This business was absolutely forbidden as result of the referendum held in May 2011, which incorporated among its eleven questions, one related to the prohibition of casinos, gambling and shows involving animal suffering, like bull and cockfighting. The investor contended that the referendum with respect to the purpose of banning gambling activities, was clearly influenced by the governmental machinery towards their dissolution and furthermore, the implementing regulations were disproportionate, arbitrary and disregarded the due process, the economic reality of the investments and the legitimate expectations of the investors. On the other hand, the notice brought by Noble Energy, was founded on the claimed non-fulfillment of transaction agreements reached with Ecuador for discontinuing investment disputes. In addition, two Argentinian oil companies, Petrobras and CGC, claimed a breach of the relevant BIT, due to the application of Law 2006-42 in the former case, and the violation of the standard of full protection and security, given the opposition of the communities in the extraction area to the company's activities in the latter. Furthermore, the English investor, Development Delivery International Limited also sustained its notice of arbitration on denial of justice, due to the asserted conduct of

\footnotetext{
${ }^{525}$ Notice of Arbitration file by Carlos Nicolás Pérez Lapentti, 3 October 2011.
} 
public authorities to delay the enforcement of three national commercial arbitral awards, in which the Minister of Agriculture was the losing party. To conclude, Suelopetrol and the Consortium GLP, Venezuelan and Spanish investors, filed their notices of arbitration on the basis of controversies that affected their long-term contracts concluded with public companies, Petroecuador EP and Flopec EP, under the regulatory regime of the Constitution of 2008.

Noticeably, the abolishment of supranational rules with respect to international investment treatment on the beginning of the 1990s launched the race of the Andean countries for implementing Washington Consensus' proposals. Among these countries, it can be affirmed that Ecuador, after Argentina, underwent the most aggressive attempt for liberalizing the economy and strictly applying the structural adjustments oriented to attract private investment, through several constitutional and legal reforms, secured with vast contractual commitments. The hegemonic speech towards the construction of a "market-friendly" State was not only adopted by the multi-lateral institutions that sponsored the relevant reforms, but also by the domestic ruling authorities, press and academia. This unquestionable belief would explain the fast track procedures of BITs approval, which circumvented the formal proceedings of approval, lacked cost-benefit analysis and omitted prior constitutional conformity assessments. Paradoxically, the demolition of the State required the co-ordination of many sovereign actions to put the same into the service of private capital. The speed of the reforms at the international and national level ensured that these were focused on enabling privatization and the recognition of international jurisdiction for the settlement of disputes, overlooking substantive restrictions historically enshrined in the Ecuadorian constitutional tradition., A paradigmatic example of the legitimacy crisis surrounding the articulation of this system was the attempt for regularizing the process of deposit of the ICSID Convention, which promptly was followed by an avalanche of disputes covered by the umbrella clause. As noted below, the unprecedented breadth of disputes involving claims that even challenged the inauguration of the Constituent Assembly put in evidence the inaccurate analysis undertaken during the process of internal approval of the BITs and ICSID Convention. 


\subsection{Towards the Re-Definition of the Coexistence Between the State and the Investors}

\subsubsection{The Process of Disengagement from International investment Obligations}

From the overview of the different investment disputes and notices of arbitration that did not result in the commencement of arbitral proceedings, a vast and creative list of claims constructed by the investors may be observed, ranging from the breach of reciprocal investment agreements that marked Ecuador's debut in international investment arbitration to the scrutiny of the judicial system through the increasing invocation of the standard of denial of justice in high impact cases like those brought by Chevron. Interestingly, most of the disputes that escalated to investment arbitration proceedings were triggered by actions, commitments and omissions performed within the frame of the Constitution of 1998 and the corresponding State's branches, which in general, did not dispute the implementation of a pro-business model. For instance the termination (caducidad) of Occidental's oil contract and the enactment of the Law 422006 occurred when the Constituent Assembly that enacted the Constitution of 2008, was still not installed. However, what is very eloquent from the claims, is the unlimited scrutiny powers, which the investors attempted to perform, encouraged by the overarching drafting of the BITs. In several cases, they disputed the lawfulness of "sui generis" decisions, approved in democratic elections, such as the process of approval of the new Constitution and the further resolutions that put it into force its mandates by alleging, for instance, the deterioration of the rule of law and human rights, whose obligation to respect according to the investors, is normally framed within the omnipresent obligations of assuring fair and equitable treatment and providing means of asserting claims and enforcing rights. Looking at the breadth of the claims and in some cases of the decisions and awards, there is no doubt that certain investment arbitral tribunals have reached decisions on consolidated issues that transcend the sphere of the jurisdiction ever entrusted to any international adjudication body.

The public awareness about the muscle of the system of investment protection emerged with the dispute surrounding the termination (caducidad) of the Occidental contract, which suddenly became a matter of public interest that caused politicians, social leaders, unions and indigenous movements to rally to the defense of national sovereignty, allegedly diminished by the open and undisputed breach of the national law by the American oil company. This company claimed that this severe decision was used as 
retaliation for the successful outcome that it reached with respect to the return of VAT credits. In any event, the negative perception about the imbalances of the system as an illegitimate concession of neo-liberal governments permeated the public speech and influenced forthcoming decisions. The ample spectre provided by the system of investment protection as enshrined by the expansive standards of protection incorporated in the BITs concluded by Ecuador, suggests that a constitutional transformation that prioritizes the State's action, as opposed to its ancillary status on the regulatory decisions taken steadily since 1992, also involves an alteration to the terms of co-existence between the international and municipal obligations with impact on the scope of investment. And this room, as set forth by the different BITs, would be as extensive as the incidence that an action, public or private, may exert over an investor's economic interests.

This "destroy and rebuild" Ecuadorian strategy in the field of international investment law, as coined by Nowrot ${ }^{526}$ can be traced back to the notice submitted by Ecuador to ICSID on 29 October 2007, in which the country announced its decision to exclude from the jurisdiction of this Centre, those disputes over non-renewable resources. With this decision, the brand-new nationalistic government sent a strong message concerning the modification of the rules in which the economic interests of the State, as representative of the people, are at stake. Shortly after the National Constituent Assembly (NCA) was installed and expectedly, it was not indifferent to the risks of the system, especially due to the avalanche of investment disputes that the country faced in 2008, as a result of the application of the Law 2006-42. In harmony with this antipathy, the leftist majority of the Members of the NCA supported the virtual abolition of any agreement that involved a diminishment of sovereignty, except in cases of Latin-American integration. This view is evident from the minutes of the NCA:

“Article 8 [now 422] takes up an aspiration having had much national support as a consequence of the abuses that have impaired Ecuador's juridical sovereignty. That provision expressly states that it will not be possible to enter into international conventions or treaties compelling the Ecuadorian State to waive jurisdiction to international arbitration venues involving contractual or commercial matters. Historically, Ecuador has executed treaties that have been considered detrimental for the country's interests because they transfer

\footnotetext{
${ }^{526}$ Nowrot undersocres the variety of measures undertaken by Ecuador in the domestic and international realm to materialize the State's intention to exit the system and to establish a new scheme of international investment protection at the regional level.

Nowrot (Karsten), "International Investment Law and the Republic of Ecuador: From Arbitral Multilateralism to Judicial Regionalism", Institute of Economic Law Transnational Economic Law Research Center (TELC) School of Law Martin Luther University Halle-Wittenberg, Heft 96, May 2010, $6 \mathrm{p}$.
} 
jurisdiction and venue in cases of disputes originating from contractual or commercial relations with transnational companies to supranational arbitration venues where, it seems, the states are placed at the same level as a commercial company." 527

It is very complex to ascertain whether the NCA representatives and the advisors of the working groups in charge of the draft of the Article 422 did understand the legal implications of limiting this constitutional prohibition to the scope of the signature of international treaties involving only contractual or commercial controversies between the State and private persons. It is also difficult to determine whether the intentions and the effects pursued by the NCA's Members with the inclusion of such a limitation are accurately reflected in the terms expressed in Article 422 of the Constitution. For instance, the former assembly Member of the NCA, Dr. Leon Roldós, has accused the fraudulent modification of several provisions legally voted by the Members of the $\mathrm{NCA}^{528}$ He has alleged that in the final session of approbation of the whole text of the new Constitution, in which no discussion or alteration of the articles already voted, was allowed, the main Board of the NCA controlled by "Alianza País", the political party whose leader is the President Rafael Correa, suppressed the final paragraph of Article 307529. The current Constitutional text provides in Art. 307 the following: "Contracts entered into by State entities and foreign nationals or corporations shall entail the renunciation of diplomatic protection."

According to Dr. León Roldós, the paragraph illicitly eliminated, prescribed:

"It shall not be possible that the State be subject to any foreign jurisdiction, with exception to the arbitral procedures derived from Latin-American integration, as set forth in this Constitution."

Although these serious accusations have never been investigated, this kind of controversy show the great divergences that have surrounded the definition of the legal framework for

\footnotetext{
${ }^{527}$ Taken from the report from the majority in Working Group 9, NCA, 14 April 2008, in Robalino Orellana (Javier) and Jijón Letort (Rodrigo), "National and International Arbitration in Ecuador" in The Arbitration Review of the Americas, www.globalarbitrationreview, 2010, 47 p.

528 Roldós (León), "Rajá Perro" in Diario el Universo, October, 25th, 2010. http://www.eluniverso.com/2010/10/25/1/1363/raja-perro.html?p=1363\&m=788

${ }^{529}$ Constitución de la República del Ecuador; “Art. 307.- Los contratos celebrados por el Estado con personas naturales o jurídicas extranjeras llevarán implícita la renuncia de éstas a toda reclamación diplomática, salvo contrataciones que correspondan al servicio diplomático."

${ }^{530}$ Non official translation of the paragraph:- "El Estado ecuatoriano no podrá someterse a jurisdicción extranjera, salvo los procedimientos arbitrales de integración latinoamericana, previstos en esta Constitución".
} 
the regime of investment protection and international arbitration since the approbation of the Constitution of 2008. Regrettably, the subsequent official announcements and the decisions of the national authorities have not been able to clarify the scope of the said limitation when the State is the counterparty of international arbitrations, as it is evident from the seventeen Constitutional Court's rulings which recommended denouncing the whole BITs.

With the inauguration of a new constitutional framework, the denunciation of the ICSID Convention was a matter of time. On July $6^{\text {th }} 2009$, the President derogated the executive decree issued in $2001^{531}$, upon which Ecuador ratified domestically its status of signatory to the Washington Convention. On the official letter submitted by President Rafael Correa to the President of the National Assembly requesting permission to denounce the Convention in accordance with Article $419^{532}$ of the Constitution of Ecuador, it was stated that:

"(...) I manifest you, Mr. President, that I consider convenient for the Ecuadorian State, the denunciation of the ICSID Convention, given that it violates the prohibition prescribed in article 422 of the Constitution of the Republic. For that reason I also require from you, in accordance to what has been established in article 419 aforementioned, that the National Assembly approves the denunciation of the International Convention for the Settlement of Investment Disputes among States and nationals from other States, through the most convenient mechanism, in order to proceed with the notification of this denunciation to the corresponding organism." 533

${ }^{531}$ Executive Decree No. 1417-B, published on the Official Gazette No. 309 of Thursday, April $19^{\text {th }}, 2001$ in accordance to the Legislative Resolution No. R-22-053 of February $7^{\text {th }}, 2001$, by which the National Congress approved the ICSID Convention.

532 Constitution of Ecuador (2008):

Article 419: The ratification or denunciation of international treaties shall require prior approval by the National Assembly in the following cases:

1. When referring to territorial or border delimitation matters.

2. When establishing political or military alliances.

3. When they involve a commitment to enact, amend or repeal a law.

4. When they refer to the rights and guarantees provided for in the Constitution.

5. When they bind the State's economic policy in its National Development Plan to conditions of international financial institutions or transnational companies.

6. When they commit the country to integration and trade agreements.

7. When they attribute powers of domestic legal nature to an international or supranational organization.

8. When they compromise the country's natural heritage and especially its water, biodiversity and genetic assets.

See, http://www.mmrree.gob.ec/pol_exterior/constit_eng.pdf

${ }^{533}$ Non- Official Translation, Official letter sent by President of the Republic of Ecuador Rafael Correa to the President of the National Assembly Fernando Cordero No. T.4484-SGJ-09-1431, Quito, June $3^{\text {rd }}, 2009$ in Viteri Torres (Cristina), ICSID withdrawal: A thorn in one's side, Original version of the thesis for the 
In principle, the categorical assertion of President Rafael Correa concerning the incompatibility of the ICSID Convention with Article 422 of the Constitution of Ecuador could have been interpreted as a strong signal against the further adoption of all sort of agreements concerning State-investor arbitration. The time demonstrated that this position would have been much more pragmatic and moderated. In this context, it has to be mentioned that the process of ICSID Convention's denunciation did not pass through the filter of the Constitutional Court because the Organic Act of the Legislative Branch and the Organic Act on Jurisdictional Guarantees and Constitutional Control, which establish such a requirement were enacted after this decision took effect. Equally important is the fact that the BITs concluded with Chile, Germany, France, the United Kingdom and Romania were deprived of an international arbitration forum due to the reason that they only contemplated ICSID jurisdiction and local tribunals for the settlement of investment disputes.

Due regard should be paid to the antecedent that in 2008 Ecuador terminated nine BITs with Cuba, the Dominican Republic, El Salvador, Guatemala, Honduras, Nicaragua, Paraguay, Romania and Uruguay pursuant to the provisions set forth in the Constitution of $1998 .{ }^{534}$ Accordingly, the Ministry of Foreign Affairs directly submitted the decision of denunciation to these countries, without requesting the prior ruling of the Constitutional Court and the approval of the National Congress.

In contrast, according to Article 438 (1) of the Constitution of 2008, the Constitutional Court will issue a prior and binding ruling of constitutionality, in addition to those prescribed by the law, prior to the "ratification" of international treaties by the National Assembly. Article 108 of the Organic Law of the Legislative Function entitles the Constitutional Court to control the constitutionality of the international treaties. ${ }^{535}$

\footnotetext{
Master of Law at the Graduate Institute at the Geneva University, Geneva 2009, under the supervision of Prof. Gabrielle Kaufmann-Kohler.

${ }^{534}$ United Nations Conference on Trade and Development (UNCTAD), "Denunciation of the ICSID Convention and BITs: Impact on Investor-State Claims”, Issues Note (IIA)-N.2, December 2010, 1 p.

${ }^{535}$ Ley Orgánica de la Función Legislativa, Registro Oficial-Suplemento, 27 de julio de 2009.

“Art. 108.- Tratados que requieren aprobación de la Asamblea Nacional.- La ratificación o denuncia de los tratados y otras normas internacionales requerirá la aprobación previa de la Asamblea Nacional en los casos que:

1. Se refieran a materia territorial o de límites;

2. Establezcan alianzas políticas o militares;

3. Contengan el compromiso de expedir, modificar o derogar una ley;

4. Se refieran a los derechos y garantías establecidas en la Constitución;
} 
Besides the prior ruling of the Constitutional Court, Article 419 (7) of the Constitution of Ecuador compels the President to request the prior approval of the National Assembly either for the ratification or for the rejection of an international treaty that attributes powers of a domestic legal nature to an international or supranational organization.

Keeping in mind the procedure referred to, a few days before the discussion and approval of the Codes of Production, Commerce and Investment and Planning and Public Finance referred below, the Constitutional Court started the analysis of the remaining BITs' constitutionality in response to the request made by the President to initiate the process of rejection of such treaties. The Constitutional Court issued seventeen constitutional prior rulings recommending without exception, the continuation of the denunciation processes, due to the contradiction of the relevant arbitration provisions both State- State and State-investor, to the Constitution of 2008, specifically to its articles 416 and 422. From the seventeen constitutional rulings, the National Assembly approved the denunciation of thirteen BITs, without initially reaching the necessary votes on the treaties concluded with China, Chile, the Netherlands and Venezuela. Notwithstanding these pronouncements and the consent of the National Assembly to denounce most of these treaties, the President only concluded the process of denunciation with Finland, deferring until May 2017 the termination of the further treaties.

It has to be underlined that the brief rulings of the Constitutional Court, besides relying on the aforementioned provisions, incorporate certain assumptions that produce important effects, both at the international and national level. First, this Court did not dispute the constitutionality of the said treaties at the time they were signed, by simply stating that the Constitutions in force did not prohibit concluding this kind of treaties.

5. Comprometan la política económica del Estado establecida en su Plan Nacional de Desarrollo a condiciones de instituciones financieras internacionales o empresas transnacionales;

6. Comprometan al país en acuerdos de integración y de comercio;

7. Atribuyan competencias propias del orden jurídico interno a un organismo internacional o supranacional; $\mathrm{y}$,

8. Comprometan el patrimonio natural y en especial el agua, la biodiversidad y su patrimonio genético.

En todos estos casos, en un plazo máximo de diez días después de que se emita el dictamen previo y vinculante de constitucionalidad expedido por la Corte Constitucional, la Presidencia de la República deberá remitir a la Asamblea Nacional, el tratado u otra norma internacional junto con el referido dictamen.

En este caso, la Presidenta o Presidente de la Asamblea Nacional, verificará la documentación correspondiente y remitirá el tratado a la comisión especializada, para que en el plazo máximo de veinte días, emita el informe que será puesto a conocimiento del Pleno.

La aprobación de estos tratados requerirá el voto de la mayoría absoluta de las y los miembros de la Asamblea Nacional." 
Second and as a consequence of declaring the validity of the international obligations assumed through these treaties in the light of the principle pacta sunt servanda, the Constitutional Court determined that the profound change of circumstances at the political, legal and economic spheres as expressed in the new constitutional framework, would impede the future fulfillment of such duties and in consequence, they would have to be brought into conformity with the new legal order. In certain rulings, the Constitutional Court made express reference to the principle "rebús sic stantibus", avoiding clarifying the practical effects arising from the transformation of the conditions that prior to the inauguration of the new constitutional regime, enabled the adoption of such treaties.

Taking into account that the ratification and termination of international treaties constitute an exclusive prerogative of the President according to the Article 418 of the Constitution 2008, the Minister Coordinator of Production, Employment and Competitiveness, Mrs. Nathaly Celi, announced that the government decided not to proceed with the denunciation of the BITs until the approval of the Organic Code of Production, Commerce and Investment. ${ }^{536}$ More than seven years have elapsed since this codification was approved and the denunciation processes concerning most of the abovementioned BITs were crystallized. Apparently, this is the consequence of a chaotic legal procedure of termination of treaties under which the existence of constitutional rulings corroborating the non-conformity of international obligations with the Constitution, in reality, do not diminish the constitutional and political prerogatives of the National Assembly and the President, to decide about the convenience of yielding the right of way for the conclusion of these processes. Logically, it was uncomfortable, to postpone a political decision, which preserved for a long period the existence of obligations, allegedely, in contradiction with the Constitution.

Moreover it is relevant to note that these instruments contain "survival provisions" 537 that in most cases guarantee the effectiveness of the rights granted to the investors for

\footnotetext{
536 "Ecuador evita denuncia de tratados de inversión y alista Código de la Producción”, September 16th, 2010.See:

http://www.ecuadorinmediato.com/Noticias/news user view/ecuador evita denuncia de tratados de in version y alista codigo de produccion--134048

${ }^{537}$ For example, the Ecuador-United States BIT provides:

"ARTICLE XII

[... 2. Either Party may, by giving one year's written notice to the other Party, terminate this Treaty at the end of the initial ten-year period or at any time thereafter.

3. With respect to investments made or acquired prior to the date of termination of this Treaty and to which this Treaty otherwise applies, the provisions of all of the other Articles of this Treaty
} 
periods even longer to those originally consented. Surprisingly the Constitutional Court acknowledged the validity of such clauses without any reservation, although it invoked the "rebús sic stantibus" principle, which at least, could have challenged the unconditional application of this survival period. Following this reasoning it is unclear whether the principles "pacta sunt servanda" and "rebús sic stantibus" could peacefully coexist, if there is consent for the further application of treaty obligations even though they have been found to be in contradiction with the Constitution and in certain cases, would have been terminated pursuant to Public International Law.

\subsubsection{Relevant Official Actions for Redefining the Relationship Between the State and the Investors}

The scope of the putative absolute prohibition enshrined by the Constitution of 2008 to prevent the State from yielding "sovereign jurisdiction" in disputes involving foreign investors did not delay to be "de facto" demarcated. As noted, the official standing in conjunction with the normative instruments adopted reveal the lack of consistency between the hostile political speeches against foreign investors and the measures adopted in practice to retain and attract them.

In response to the several opinions that challenged the coherence of the legal stance of the Attorney General ${ }^{538}$, with regard to the scope of Article 422 during the negotiations of international arbitration clauses with organisms such as the International Bank of Development and the Chinese public company "Petrochina"539, he submitted a

shall thereafter continue to be effective for a further period of $\underline{\text { ten years }}$ from such date of termination." (emphasis added)

${ }^{538}$ Official translation of the Constitution of Ecuador:

"Art. 235 - The Office of the Attorney General of the State is a public, technical, and legal body, with administrative, budgetary and financial autonomy, directed and represented by the Attorney General, who is appointed for a four-years term."

"Art. 237.- The following duties shall be performed by the Attorney General, in addition to others provided by law:

1. To represent the State in the judiciary.

2. To defend the State and its institutions.

3. To provide legal counsel and binding responses to legal queries from public sector bodies and institutions on the interpretation and application of the law on those issues where the Constitution or the laws do not grant competences to other authorities or bodies.

4. To monitor, subject to the law, the documents and contracts signed by public sector bodies and institutions."

See, http://www.mmrree.gob.ec/pol_exterior/constit_eng.pdf

539 In response to the request made by the President of the state-owned company "Petroecuador EP" concerning the modification of the contractual clause which contained an arbitration agreement with the 
clarification to the newspaper "Diario Hoy", published on October $20^{\text {th }}, 2010$, which stated:

"In opinion of the Attorney General, since the prohibition set out in Article 422 of the Constitution is restricted only to "treaties or international instruments", it does not extend to the signing of contracts, in which the State, as general rule of international commerce ${ }^{540}$, does not exercise its sovereign authority. In this context, the State is subject to the rules of the international contracts". ${ }^{541}$

Thus, it is clear that in the opinion of the Attorney General, the prohibition comprised in Article 422 only applies for the signing of treaties. ${ }^{542}$ Consecutively, the legal opinion of the Attorney General was incorporated in the fifth general provision of the Code of Planning and Public Finances approved on October $22^{\text {nd }} 2010$ :

"Prior Authorization: Upon prior authorization from the Attorney General, it may be accepted other jurisdiction and legislation for the settlement of differences or disputes concerning contracts between the State or state entities and foreign governments, foreign public entities or foreign private entities."

With the aim of reinforcing this position, the Organic Code of Production, Commerce and Investment approved on December $29^{\text {th }}$ 2010, determined in its Article 27 that within

public company "Petrochina", the Attorney General issued his binding prior authorization without making any reference to the prohibition contained in Article 422 of the Constitution.

This position could be explained by the fact that the said prohibition refers to contractual or commercial matters where the state is the counterparty of private persons. Accordingly, the legal basis invoked for the authorization of the aforementioned modification, was based on Articles 190 of the Constitution and 4 and 42 of the Organic Law of the Attorney's General Office, law that was enacted before the approval of the Constitution of 2008

${ }^{540}$ Following the reasoning of the Attorney General, it should be implied that the prohibition of Article 422 of the Constitution does not apply to controversies derived from relationships of commercial nature, including international commercial arbitration. In this sense, it is worth to refer to footnote of Article 1(1) of the UNCITRAL Model Law on International Commercial Arbitration (1985), which shed some light when seeking to ascertain the meaning of the word "commercial":

The term "commercial" should be given a wide interpretation so as to cover matters arising from all relationships of a commercial nature, whether contractual or not,

Relationships of a commercial nature include, but are not limited to, the following transactions: any trade transaction for the supply or exchange of goods or services; distribution agreement, commercial representation or agency; factoring; leasing; construction of works; consulting; engineering; licensing; investment; financing; banking; insurance; exploitation; agreement or concession; joint venture and other forms of industrial or business co-operation; carriage of goods or passengers by air, sea, rail or road.

${ }^{541}$ Non official translation of the statement of the Attorney General of the State, Dr. Diego García Carrión: "A criterio de la Procuraduría General del Estado, esta prohibición se refiere únicamente a los 'tratados o instrumentos internacionales' y no se extiende a la firma de contratos, en los cuales, como norma general en las relaciones de comercio internacional, el Estado no actúa en su capacidad soberana, sino regido por las reglas de la contratación internacional."

${ }^{542}$ Article 190 of the Constitution of Ecuador recognizes legal arbitration in public biding processes upon a favorable ruling by the Attorney General: 
the investment contracts signed with international investors, arbitral clauses could have agreed upon in order to solve disputes arisen between the State and foreign investors. ${ }^{543}$ In conjunction with the wording of the $5^{\text {th }}$ general disposition of the Code of Planning and Public Finances mentioned above, Article 190 of the Ecuadorian Constitution recognizes legal arbitration within public procurement upon prior authorization of the Attorney General:

"Art. 190. - Arbitration, mediation and other alternative procedures for dispute settlement are recognized. These procedures shall be applied subject to the law in those areas, where, because of their nature, compromises can be reached.

In public procurement, legal arbitration shall be accepted after a favorable ruling by the Attorney General Office's, in conformity with conditions provided for by law."

By the same token, the the Organic Code of Production, Commerce and Investment determined that disputes arising from the investment contracts between investor and State may be submitted to international arbitration in accordance with the treaties of which Ecuador is a signatory. In both cases, the treaties that may be in connection with investments are expressly recognized. This recognition would clash with the position of the Constitutional Court, which has found that the clauses of settlement of disputes of the BITs even violate the constitutional prohibition of turning disputes with foreign private companies into conflicts between States, as it has been stated for instance, in the BIT signed between Ecuador and the Netherlands. In any case the categorical prohibition of Article 422 in the terms analyzed would prevent the signature of new treaties that involve the surrender of sovereignty to international arbitration entities concerning contractual

\footnotetext{
543 This procedure was reserved to investment contracts requesting first, the exhaustion of administrative remedies, conciliation and mediation before instituting the arbitration proceedings ( 6 months). In the event, that concluded the mediation, the controversy could not be settled, the conflict could be subject to national or international arbitration venues in accordance with the treaties signed by Ecuador. Ecuadorian legislation was set forth as the applicable law for the disputes to be settled by international arbitral tribunals. Once such local administrative procedure was exhausted and the parties neither reached an amicable settlement nor decided to subject the controversy to an arbitral venue, the conflict had to be brought before the National Courts. Taxation disputes were excluded from arbitration.

This provision was enshrined in the Article 27 of the Organic Code of Production, Commerce and Investment, which was derogated by the "Organic Act on Productive Promotion, Investment Attraction, Employment Creation and Fiscal Balance and Stability". This Act made international arbitration compulsory within investment contracts with relation to any controversy related to the investment and abolished the requirements of exhaustion of administrative remedies, conciliation and mediation before instituting the arbitration proceedings.
}

See, Ley Orgánica para el Fomento Productivo, Atracción de Inversiones, Generación de Empleo, y Estabilidad y Equilibrio Fiscal, Ley 0, Official Gazette Suplement 309, August $21^{\text {st }}, 2018$. 
and commercial disputes. It is undeniable that the unfortunate draft of the Article 422 of the Constitution of Ecuador differs with the clarity of Article 320 of the Bolivian Constitution that clearly prohibits the State's participation in international arbitration proceedings. ${ }^{544}$

In this context, it is clear that both the Attorney General and the Constitutional Court have reduced their juridical assessment merely to verify whether the adoption of an agreement falls within the scope of a treaty or a contract to determine the extent of the vague Article 422 of the Constitution of Ecuador. Consequentially, the legal and constitutional analysis is incomplete and leaves unanswered questions.

In this sense, it is worth referring to the opinion of the national expert, Dr. Alberto Wray, who has accurately underlined that the tension between arbitration and sovereignty is derived neither from the matter of arbitration, nor from the procedural aspects or institutional circumstances of the entity that administers the procedure, but from the substantive provisions that the tribunals, arbitral or not, would be enabled to apply. In fact, the violation of the duties imposed by these substantive provisions gives rise to the State's responsibility and the tribunal, arbitral or not, has to determine the violation at issue, in order to declare the existence of the State's liability and to compel the reparation of any injury done. ${ }^{545}$ In this sense, it would be more effective to redefine the scope and coverage of these substantive provisions, for example, by expressly removing from the ambit of expropriation, the adoption of non-discriminatory measures designed to protect legitimate public welfare objectives, as it may be observed in the Free Trade Agreement signed between the United States of America and Chile. ${ }^{546}$ As underscored by Wray, the

${ }^{544}$ Constitución Política del Estado Plurinacional de Bolivia; Artículo 320:

I. La inversión boliviana se priorizará frente a la inversión extranjera.

II. Toda inversión extranjera será sometida a la jurisdicción, a las leyes y a las autoridades bolivianas, y nadie podrá invocar situación de excepción, ni apelar a reclamaciones diplomáticas para obtener un tratamiento más favorable. (Emphasis added)

III. Las relaciones con Estados o empresas extranjeras se realizarán en condiciones de independencia, respeto mutuo y equidad. No se podrá otorgar a Estados o a empresas extranjeras condiciones más favorables que las establecidas para los bolivianos.

IV. El Estado es independiente en todas las decisiones de política económica interna, y no aceptará imposiciones ni condicionamientos sobre esta política por parte de estados, bancos o instituciones financieras bolivianas o extranjeras, entidades multilaterales ni empresas transnacionales.

V. Las políticas públicas promocionarán el consumo interno de productos hechos en Bolivia.

545 Wray (Alberto), "La soberanía del Estado frente al arbitraje internacional”, 8/12/2008, www.cywlegal.com.

${ }^{546}$ Chile-United States, Free Trade Agreement:

Annex 10-D Expropriation

The Parties confirm their shared understanding that: 
further inclusion of such definitions and due attention to the case law that has recently affirmed the right of the States to exercise regulatory powers ${ }^{547}$ would constitute the best actions to defend the sovereignty of the State and not the measures that have been adopted by the main public authorities, which are characterized by ignorance and negligence ${ }^{548}$. Finally, it has to be remarked that in line with the abundant governmental attempts to redefine the country's infamous position as a result of the motion of the investment protection regime, the President created on May 2013 the Commission for a Comprehensive Audit of Investment Protection Treaties and of the International Arbitration System on Investments (CAITISA). This commission consisting of highly renowned international experts finally handed over its final report in May 2017. In this line, there are also noteworthy the enthusiastic yet doubtfully efficient, political statements which attempt to counterbalance the pernicious effects of the system, like the resolution of the National Assembly, which declared as state policy the defence of the country with respect to the dispute with the American investor, Occidental. On the basis of the principle of "procedural efficiency", it required the Constitutional Court to issue the constitutional ruling that enables the Legislature to denounce the Ecuador-USA BIT, although this is a presidential attribution and the Court had already done it, a year before this pronouncement.

With the approval of the General Organic Code of Processes, there was incorporated a special procedure for the recognition of judgments and arbitral awards against the State that was short time in force. Before its derogation, any foreign judgement or arbitral award involving the State had to pass through a test of conformity to constitutional and legal provisions, as well as international treaties and conventions in force. ${ }^{549}$ Finally,

4. The second situation addressed by Article 10.9(1) is indirect expropriation, where an action or series of actions by a Party has an effect equivalent to direct expropriation without formal transfer of title or outright seizure.

(b) Except in rare circumstances, non-discriminatory regulatory actions by a Party that are designed and applied to protect legitimate public welfare objectives, such as public health, safety, and the environment, do not constitute indirect expropriations

547 See Metalclad v. Mexico (2001), Methanex v. United States (2005), Continental Casualty Company v. Argentine Republic, ICISID Case No. ARB/03/09 (Award, 5 September 2008) on Wray (Alberto), "La soberanía del Estado frente al arbitraje internacional”, 8/12/2008, www.cywlegal.com.

548 Wray (Alberto), "La soberanía del Estado frente al arbitraje internacional”, 8/12/2008, www.cywlegal.com.

${ }^{549}$ Código General de Procesos:

“Art. 104.- Homologación de sentencias, laudos arbitrales y actas de mediación expedidos en el extranjero. Para la homologación de sentencias, laudos arbitrales y actas de mediación expedidos en el extranjero, la sala competente de la Corte Provincial deberá verificar: 
Ecuador concluded the negotiations of a free trade agreement with the European Union, which although it does not comprise a chapter concerning investment, relies on the existence of BITs with several Member States. Also noteworthy, is the discussion of Private-Public Partnerships Law, approved as an economic urgency bill, which expands the issues of arbitration in qualified investments.

As analysed, the variety of disputes launched by the investors exposes the enormous distance between certain authorities' understanding when consenting to the adoption of international investment protection, and the breadth of the claims the State has had to respond to since the beginning of the century. Neither the local courts, nor international adjudication bodies have ever scrutinized the exercise of sovereign powers extended to international tribunals in matter of investments. The unlimited frame of the BIT's protection enables the arbitrators to settle any claim touching upon any economic interest, conferred or affected by a public action formally or informally manifested. Although several public commitments might be tainted by legality or legitimacy flaws, the BITs have operated as a shield to perpetuate foreign investors' rights although they have initially relied on weak regulatory schemes, active diplomatic intervention and close relationships with the authorities to set up their operations. For instance, the misuse of nationality for resorting to the protection of BITs, as well as the abuse of procedural avenues to make the investors' interests prevail, confirm the subordination of any social

1. Que tengan las formalidades externas necesarias para ser considerados auténticos en el Estado de origen.

2. Que la sentencia pasó en autoridad de cosa juzgada conforme con las leyes del país en donde fue dictada y la documentación anexa necesaria está debidamente legalizada. 3. Que de ser el caso, estén traducidos.

4. Que se acredite con las piezas procesales y certificaciones pertinentes que la parte demandada fue legalmente notificada y que se haya asegurado la debida defensa de las partes. 5. Que la solicitud indique el lugar de citación de la persona natural o jurídica contra quien se quiere hacer valer la resolución expedida en el extranjero.

Para efectos del reconocimiento de las sentencias y laudos arbitrales en contra del Estado, por no tratarse de asuntos comerciales, deberá además demostrarse que no contrarían las disposiciones de la Constitución y la ley, y que estén arregladas a los tratados y convenios internacionales vigentes. A falta de tratados y convenios internacionales se cumplirán si constan en el exhorto respectivo o la ley nacional del país de origen reconoce su eficacia y validez."

Official Gazette Suplement 506, May 22, 2015.

The recently enacted "Act on Productive Promotion, Investment Attraction, Employment Creation and Fiscal Balance and Stability" derogated the internal process for recognition of foreign judgements and arbitration awards, by giving foreign arbitration awards the same effect as domestic arbitration awards.

See, Ley Orgánica para el Fomento Productivo, Atracción de Inversiones, Generación de Empleo, y Estabilidad y Equilibrio Fiscal, Ley 0, Official Gazette Suplement 309, August 21 ${ }^{\text {st }}, 2018$. 
activity to the preservation of such private rights. With exception to the denunciation of the ICSID Convention and certain BITs, the public actions oriented to diminish the effects of the international investment protection regime have had little impact in terms of enhancing the State's standing before this framework. Still, the notion that investment disputes are governed by commercial and not by international public law both at the regulatory and the adjudicative levels conspires against the achievement of a solution that may weigh properly the legal contingencies arising out the existing rules. Moreover, the intersection of economic and geopolitical interests excessively delayed the conclusion of the constitutional process of termination of treaties. Finally, the constitutional rulings mandating the termination of the BITs besides lacking a comprehensive legal analysis beyond the doubtful interpretation with respect to the alleged prohibition of sovereign jurisdiction's waiver put on the table a conclusion, whose external and internal effects have not yet been properly explored, namely, the fundamental change of circumstances.

\subsection{Conclusions}

The overview of the international investment regime articulation in Ecuador unveils a puzzling reality regarding the mechanisms developed for protecting private interests under the failed promise of reciprocally increasing capital flows for the achievement of greater social values. From the outset of the Latin American republics, there are evidently strong mechanisms of protection provided to North American investors through formal and informal mechanisms, especially through the treaties of peace, friendship, navigation and commerce, which already included the main substantive features of the BITs.

Although the cross-border mandatory arbitration was an early attempt at a PanAmerican level, it only succeeded with regard to certain inter-governmental disputes. However, the expansion of such dispute settlement mechanisms spread globally along with the construction of the multilateral institutional system. Well-organized international non-governmental organizations, such as the International Chamber of Commerce and the American Peace Society, were pivotal for underpinning "universal" rules of conduct that also shaped the policies of the incipient global institutions.

Without disregarding certain developing countries' achievements for incorporating their concerns within the global regulatory design, it can be identified as a common set of values that enlisted free trade, attraction of foreign investment, rule of law, legal stability and delocalized settlement of disputes as inseparable concepts for the 
construction of good policies and democratic institutions. The resounding failure of regional frameworks attempting to improve inter-governmental co-operation and industrialization by developing common rules of trade and promotion of investment eased the invasion of neo-liberal principles almost without limits.

Contrary to neo-liberal speech, the advocated construction of a minimal State required assuring strong public intervention for the enforcement of rules that were protective of property rights. In this context, Ecuador gave an unprecedented example by approving the Constitution of 1998 that subordinated any action-public or private-to the contractual commitments reached with foreign investors, who in several cases, also emjoyed the protection of BITs. Claiming for the stagnation of such commitments called into question the rationality of the system.

The Ecuadorian case reveals a profound crisis of lawfulness and legitimacy in the articulation of the investment protection system through the interested and utilitarian use of the rule of law for the purpose of perpetuating private interests. This misuse of the law, diplomacy and multilateral platforms, aggravated by the poor judgment of domestic authorities - due to their lack of awareness concerning the scope of investment ruleserode basic global rules of sovereign equality and justice.

In sum, the Ecuadorian experience - as international investment law considersconstitutes a good example of transnational legality consolidation-albeit a very bad one-concerning the strengthen of transnational justice. Despite the alleged fundamental change of circumstances due to the inauguration of a new constitutional order, the breadth of the substantive standards of protection enshrined in the BITs was already in conflict with the constitutions in force at the time they were adopted. For this reason and without injury to the failed attempt to prohibit the surrendering of jurisdiction to international arbitral venues, as defectively prescribed in the current Constitution, the referred standards remain in contradiction with the current constitutional framework. Judging by official actions from the past decade, a definitive and effective exit from the system under these leonine rules seems to be far from being achieved. 


\section{CHAPTER III: THE REFORM OF INTERNATIONAL INVESTMENT PROTECTION IN A CONTEXT OF INSTABILITY}

\subsection{Introduction}

This chapter addresses a bulk of relevant responses given at different governance levels when the decision to resist the system and, ultimately, to pull out from it was unstoppable.

Albeit chaotic, the coordination of different players to advocate-from their competence areas - the pernicious nature of the system, as well as prompting - through different mechanisms - hurdles to its deployment at a national level is is remarkable. The variety of such responses stressed out political sensitivity and distrust towards the current rules of investment protection and the dislike towards foreign investors and adjudicators, which unveils not only the incapability of domestic remedies to protect core values, but also the unsuitability of International Investment Law to actually depoliticize disputes through a proper consideration of the delicate issues it comes to settle.

In this regard, the permeation of such distrust is noted through the various reforms which occurred in the context of foreign relations, rule-making and contractual design. However, the progressive relaxation of early non-negotiable positions, such as the possibility to submit a great range of disputes to international venues is also clear. In addition, there is also a plausible conclusion of a tortuous report process of Bilateral Investment Treaties, which sets a new scenario of expectations once the stage of resistance and complaint has passed; claiming a proactive, realistic and comprehensive approach for improving the State's position within the international context, and acknowledging the importance of foreign investment as a vehicle to achieve social goals.

Considering the aforementioned, this chapter confronts the perceptions, responses and proposals tried out within the context of reform and rebuilding of the relationships with foreign investors against the transformations recently developed at the international level. To this end, it analyzes the incidence and performance of the Ecuadorian State as respondent of international investment disputes, as well as the self-assessment made by key actors like the Attorney General and the international audit commission for auditing the investment regime and the system of international arbitration (CAITISA).

Afterwards it analyzes the evolution of the regulatory mechanisms adopted for implementing the revisited stance towards foreign investment protection. Related to the aforementioned assessment, it examines the shortcomings of restoring rejected concepts 
calling for a primary involvement of domestic courts within International Law disputes and highlights the potential of domestic measures as mechanisms to avoid the unrestrained deployment of rules still in force.

\subsection{The Attempt to Reshape Investment Protection Rules in the Battlefield}

The longstanding opacity of the conditions for oil exploitation officially upheld and socially endorsed since the first oil boom in the 1970s meant that the decisions undertaken for its governance were mainly oriented to satisfy the patronage demands of emergent unions willing to take part in the distribution of the benefits. Thus, the usual conflicts involved domestic organizations either public or private and the State entities in charge of determining the distribution of the revenue. Although the first investment dispute involving the Ecuadorian State, took place in $2001^{550}$, political awareness concerning the reach of the system grew during $2006^{551}$, after a second conflict arose with the petroleum company Occidental. Several NGOs, indigenous groups and politicians, among whom stood out, the future President, Rafael Correa, organized demonstrations demanding principally, the expulsion of the oil company Occidental for allegedly breaching Ecuadorian Law due to the unauthorized transfer of interests and obligations from its Participation Contract to Alberta Energy Company. They also requested the political impeachment of the authorities, who supposedly delayed the measures to give effect to the applicable termination procedure. ${ }^{552}$ From then on, the association of transnationals

\footnotetext{
${ }^{550}$ Occidental Exploration and Production Company v. The Republic of Ecuador, LCIA Case No. UN3467.

551 Occidental Petroleum Corporation and Occidental Exploration and Production Company v. The Republic of Ecuador, ICSID Case No. ARB/06/11

552 The Occidental Award took note of the political outcry surrounding the procedure of termination of the Participation Contract with Occidental, which undeniably was used as a platform for emergent politicians thriving for public attention. Apparently, also the Attorney General handled imprudently the arising issue:
}

“196. On 15 March 2006, President Palacio’s press secretary stated that the administration feared a coup d'État as a result of strikes and demonstrations which had closed the highways in the north and center of the country. On 22 March 2006, the strike's leader issued a statement, promising that: "If caducity of the Occidental contract is declared, we will lift the strike."

197. In late April 2006, Minister Rodríguez sent the Attorney General a letter asking him to confirm whether or not the law permitted a settlement with OEPC. On 2 May 2006, following a second request from the Minister, the Attorney General responded to the Minister's letter that the law did allow a settlement. He gave the same information to PetroEcuador. The Attorney General's opinion sparked a public outcry in the country.

198. On 9 May 2006, the then candidate for President, Dr. Rafael Correa, led a demonstration outside OEPC's offices in which he and other demonstrators called for a symbolic "closure forever" of OEPC. The same day, various social organizations in Ecuador declared that they would 
and international arbitration with the violation of sovereignty became inseparable in the dominant political speeches. As remarked, this notion permeated the further decisions reforming the terms of distribution of oil profits, the constitutional design, the reform of contracts on non-renewable resources, the plans of national development and the revisited constitutional and judicial review. The restrictive notion of sovereignty was perceived as a dispossessed value that had to be recovered by a new set of regulatory measures harmonized with the reconceptualization of foreign investment terms. For instance, the Plan for National Development (2013-2017) set forth as one of the national priorities, the replacement of the "unilateral logic of international engagement" with a reciprocal logic, since the treaty based arbitrations are an expression of such imbalance at a "potentially high fiscal cost". ${ }^{553}$ Specifically, the mentioned Plan established as national policies, "ensuring sovereignty and peace, deepening the strategic insertion in the world and Latin-American integration" (policy 12.1), as well as "promoting the construction of a new democratic multi-lateralism on the basis of solidarity, and sovereign and pacific

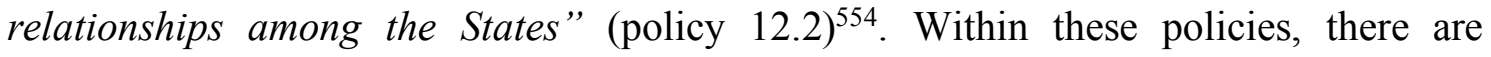
remarkable the goals for: "i) promoting the institutional strength of Latin-American integration organizations; ii) consolidating the bargaining power of the region's countries within multilateral negotiations; iii) establishing alternative mechanisms of regional arbitration for investment dispute settlement; $i v)$ defending the national interest over the corporative or particular interests; v) promoting shared processes for denouncing international interests contrary to State sovereignty and/or to citizens' rights; and, vi) creating a strategic high level team of international treaty negotiators.".555 As from the first National Plan of Development (2007-2010), there is obvious the concern

demand the impeachment of both President Palacio for considering a settlement agreement with OEPC, and Attorney General Borja for opining that such an agreement was legally possible."

See, Award, Occidental Exploration and Production Company v. The Republic of Ecuador, (ICSID Case No. ARB/06/11), October 5, 2012.

${ }^{553}$ National Plan for Good Living (2013-2017), Objective 8, "Strengthen the solidarity, and social economic system in a sustainable manner”, Secretaría Nacional de Planificación y Desarrollo, 2013, 260 p.

See, www.buenvivir.gob.ec

554 These "policies and strategic guidelines" are circumscribed to Objective 12: "Ensuring sovereignty and peace, deepening the strategic insertion within the world and the Latin-American Integration".

See, National Plan for Good Living (2013-2017), Secretaría Nacional de Planificación y Desarrollo, 2013.

555 See, National Plan for Good Living (2013-2017), Secretaría Nacional de Planificación y Desarrollo, 2013, 345-347 pp. 
for revisiting treaties providing for investment dispute settlement ${ }^{556}$, which further escalated into categorical criticism of the illegitimacy of the system reflected in the concrete goals of the subsequent national plans (2009-2013/2013-2017). These rising critics revolved consistently around the claim of lost sovereignty, thus, being an imperative aligning the foreign policy with the domestic policy, through actions fostering the accountability towards the citizens. This aspiration was linked to the efforts of consolidating institutional mechanisms of regional integration with the aim of strengthening a co-ordinated stance of negotiation before other regional blocks. As to the State-investor disputes, the following strategies are enlightening:

- "Strengthening the legal framework, in accordance with the State's attributions, through the promulgation and application of national legislation and bilateral agreements of the country's interest, with the end of having adequate rules capable of avoiding disputes related to foreign capital's investments. The legal certainty has to favour both the investor and the State."

- Concerning the relationships with the USA and the EU, the plan advocates for: "i) Full respect for the principles of equal sovereignty among the States; ii) Maintaining a transparent relationship between the European and American investors and the Ecuadorian Government, so that any differences between them and their Ecuadorian partners, national companies or the same State, may be settled by the competent courts ("jurisdictional organs"), without any political interference and full respect for the principles of legal certainty, in order to prevent conflicts between private parties from affecting the interState relationships." 557

Further on, the ICSID was categorized as illegitimate and one of the "main global market tools to orientate free trade"; also highlighted was the need of disengaging investment arbitration from sovereign debt ${ }^{558}$. As noticed in the further chapters, along with the

\footnotetext{
${ }^{556}$ For instance, among the strategies of international economic relationships there are remarkable: the strengthening of the South American Community of Nations (lately UNASUR); the promotion of foreign investment that increase the economy's industrial productivity; the diversification of the destination and composition of Ecuadorian exportations; and, the promotion of foreign direct investment in areas lacking of domestic capital, provided the contribution to sustainable productive processes respectful of indigenous peoples rights and local communities. There are particularly notable the strategies prioritizing the negotiation of economic issues within multilateral organizations, leaving as a mechanism of last resort bilateral negotiations.
}

See, Plan Nacional de Desarrollo (2007-2010)-Planificación para la Revolución Ciudadana”, Policy 5.5.

${ }^{557}$ See, Plan Nacional de Desarrollo (2007-2010)-Planificación para la Revolución Ciudadana", Policy 5.5. "Aligning foreign policy with domestic policy and fostering accountability to the citizens", 191-193 pp.

${ }^{558}$ The supreme instrument of public policy clearly shows the antipathy towards international investment arbitration claiming the risk of bringing sovereign debt disputes before ICSID:

“(...) Therefore, we must find how to disengage international arbitration from financial debt policy, because new creditors attempt to obtain arbitral awards in illegitimate venues like the International Center for the Settlement of International Disputes (ICSID) of the World Bank, with 
constitutional review of BITs, there were underpinned a variety of measures purportedly oriented to establish a new set of co-existence terms between the State and foreign investors like the design of new investment regulations, the legislative reform to specific sectors, manifold contractual modifications and different initiatives at the international and especially, at regional levels ${ }^{559}$. As noticed, former President, Rafael Correa established in 2013 an international audit commission for auditing the investment regime and the system of international arbitration (CAITISA) ${ }^{560}$, whose results were made public in April 2017. ${ }^{561}$

\subsubsection{Confronting Ecuador's reformistic impetus with the logic of Investor- State Dispute Settlement}

This reformistic logic was also strengthened with the amplest assortment of political reactions ranging from legislative declarations condemning the awards or declaring as a matter of national interest the defence within paradigmatic cases (i.e., Occidental and Chevron), to major domestic and international campaigns which included spots within the weekly presidential broadcast bitterly denouncing Chevron's

the harmful consequences that public finances and the development plans of the region's countries may suffer."

Plan Nacional para el Buen Vivir (2013-2017), Consejo Nacional de Planificación, www.buenvivir.gob.ec.

559 When the Ecuadorian State notified the Republic of Paraguay with the decision to terminate the BIT, it indicated that it was undertaking a review of the legal framework regulating the foreign and national policies of investment and that the impact assessment of such treaty in the national economy showed the no achievement of its main goal, which is attracting bilateral flows of bilateral investments. It furthered stressed out, that Ecuador would prioritize the treatment of if investment issues in the context of broader frameworks of economic integration:

El MINISTERIO DE RELACIONES EXTERIORES, COMERCIO E INTEGRACION, se permite señalar que el Gobierno de la República del Ecuador, se encuentra realizando una revisión de su sistema jurídico y de la política nacional e internacional en materia de inversiones. En ese sentido, se ha evaluado el impacto de los Convenio de Promoción y Protección Recíproca de Inversiones sobre la economía nacional y se ha concluido que el Acuerdo con Paraguay no ha logrado alcanzar su objetivo fundamental, es decir, motivar la atracción de capitales para la inversión productiva bilateral.

EL MINISTERIO DE RELACIONES EXTERIORES, COMERCIO E INTEGRACION, augura que tan pronto se haya definido el nuevo marco jurídico y se podría retomar la negociación de instrumentos similares. Asimismo, el Ecuador privilegiará el tratamiento de temas de inversión en el contexto de esquemas de integración económicos más amplios.

See, Nota N. 5084/GVM/DGPEI/DGT08, Quito 30 de enero de 2008.

${ }^{560}$ Commission for the Integral Citizens' Audit of the Treaties of Reciprocal Protection of Investments and of the International Arbitral System on the Subject of Investments established by Executive Decree 1506 and signed by the president on May 6, 2013.

${ }^{561}$ See, “Auditoría integral ciudadana de los tratados de protección recíproca de inversiones y del sistema de arbitraje en materia de inversiones en Ecuador: Informe ejecutivo, Mayo 2017. 
misbehaviour ${ }^{562}$. For instance, the Attorney General's Office launched a "fictional" film and a website where the facts and defence arguments pursuant to her strategy within the Chevron litigation cases are characterized by national actors. ${ }^{563}$ Certainly, the concurrence of arbitral awards with significant monetary compensation in favour of the investors amid an economic crisis and the earthquake disaster which occurred in April 2016, have further aggravated the political opposition towards the system. ${ }^{564}$

Shortly before, the decision on the annulment of the Occidental award had been published (November 2015), Correa severely criticized the outcome as a violation of the country's sovereignty allowed by the proliferation of BITs, signed during the "sad and long neo-liberal night". Anyhow and from a pragmatic perspective, he reaffirmed the country's willingness to negotiate with the company, which was successful. As noticed, the vehement discontent with the system has been seasoned since 2006 and spread along the rule-makers and public opinion through different mechanisms. In international and domestic forums, Correa has demonstrated his sophisticated understanding of the contemporary flaws of the system and has especially used the weaknesses of the Occidental award and the multiple investment disputes brought by Chevron to attack it. For instance, during 2014 when the Attorney General released the book of the country's defence within the Occidental case, he analyzed the investment treaty based protection regime and the alleged award's shortcomings ${ }^{565}$. Correa started defining the system as a hegemonic tool of powerful countries, conveniently used by arbitrators for their personal economic benefit, affirming that their sympathy towards investors' interests, defines their

\footnotetext{
562 The governmental campaign "The Dirty Hand of Chevron" was released by President Correa on September 17, 2013. See, http://www.thedirtyhand.com Last visited on November 2016.

563 The film was released on October 12, 2016. See, http://www.eljuegosucio.com Last visited on November 2016.

564 When asked about the alleged aggressive external debt incurred by the country, Correa has counterclaimed that the spurious awards against Ecuador to be paid during 2016 (Occidental and Chevron I, USD 1 billion and USD 140 million, respectively), in conjunction with el Niño phenomenon, the increased activity of EL Cotopaxi volcano and the major Manabí's earthquake, caused the perfect storm, obliging the State to ask urgently for external loans and issuing sovereign bonds at high rates. See, Entrevista al Presidente Rafael Correa by Andrés Carrión, Teleamazonas, October 17, 2016. https://www.youtube.com/watch?v=fK4Dh-djCnE. Last visited in November 2016.
}

${ }^{565}$ See, Speech of the President Rafael Correa in the release of the book "Caso Oxy: Defensa Jurídica de una Decisión Soberana y en Derecho del Estado Ecuatoriano", organized by the Attorney General's Office, October 17, 2014. 
appointment. ${ }^{566}$ Criticizing the Oxy award that fully disregarded the domestic law and the contractual obligations, due, among other reasons, to the disproportionality of the effect statutorily given to the disputed breach, Correa claimed that pursuant to International Law, no State must justify the rigorousness of its legislation, especially when it comes to natural resources which are not a simple commodity. In this line, he condemned the system and the tribunal's partiality in favour of the investors, underscoring the Occidental Tribunal's interpretation that subordinated well settled legal obligations, like that, making it necessary to request authorization to transfer stock to the "business reality". As transcribed below, the Tribunal qualified the former obligations as "legal niceties":

347. On the other hand, the proponents of Version B, probably the lawyers, advocated that it was prudent to ask for "prior approval" for the "earn-in" phase. They had obviously carried out a cursory examination of the agreements at issue. But tellingly, the proponents of Version B were not dogmatic about the requirement of ministerial authorization. As noted earlier, the key paragraph of their draft concluded "... or else indicate that no such approval is required for such transaction."

348. Members of the Version A clan prevailed. They did not heed the sound advice of the lawyers and, in doing so, may have acted unwisely and been imprudent. Their proposed course of action may have been risky, as later events confirmed, but, for the reasons set forth in more detail below, the Tribunal fails to see any evidence that their views were driven by bad faith. They were business people, seasoned oilmen, for whom legal niceties were not as important as the business realities of the deal. Their behaviour, unfortunately for the Claimants, was to have dire consequences. ${ }^{567}$

Following these paragraphs, Correa contended:

What the Tribunal said, is that the legal formalities were not as important as the business realities of the transaction. So, the award wants us to believe that one of the most powerful companies in the world with hundreds of national and international lawyers, acted in ignorance and in good faith; even if such were the case, the company wouldn't be exempted of liability. But all of us know that this is impossible; this insults our intelligence, and the reality is only these companies despise our laws and countries availed by a tradition of abuses and impunity. The award is not grounded on a legal basis, but on an evident empathy towards the

\footnotetext{
566 See, Speech of the President Rafael Correa in the release of the book "Caso Oxy: Defensa Jurídica de una Decisión Soberana y en Derecho del Estado Ecuatoriano", organized by the Attorney General's Office, October 17, 2014.

https://www.youtube.com/watch?v=ZbQUMBEz5Po. Last visited on November 2016.
}

${ }^{567}$ See, Award, Occidental Exploration and Production Company v. The Republic of Ecuador, (ICSID Case No. ARB/06/11), October 5, 2012. Emphasis added. 
transnational company, which they (the Tribunal) considered very injuried, because in their opinion our laws are too harsh. Again, this is inadmissible. ${ }^{568}$

Insisting on the award's flaws to criticize both the gross disregard of the legal and contractual obligations by the tribunal and the absence of reciprocity of the treaties, the President invited the audience to imagine how unfeasible would have been a similar defense, in the case that an Ecuadorian investor in the United States would have tried to excuse his responsibility for the breach of the law appealing to his own imprudence and the legal framework's severity before American courts:

Imagine for a moment that an Ecuadorian company in the United States, opposes as defense that it committed the infraction, but that it was not aware of the law and besides, the law is too harsh. Which American judge would take seriously such nonsensical legal defense? When will a country like United States accept that foreign venues or ad hoc tribunals rule over their own legislation? But this is precisely what the Arbitral Tribunal is doing in the Oxy case. In addition, this award against Ecuador grants the transnational complainant one of the highest monetary awards in the history of international arbitration and it does so, based on a cash flow model, which infringes the International Law principles applicable to the valuation of damages. In the award, it is sought that Ecuador pays in favour of Oxy, without interest- because including interest, this would surpass USD 2 billion- the astronomical compensation of USD 1.7 billion, much more than our annual health budget, although it is acknowledged that Ecuador is legally right, because this company without any doubt, as is expressly recognized in the award, breached in our country the terms of the Contract signed with the Ecuadorian State, as well as the Ecuadorian law. Such is the excess that the Tribunal awarded higher amounts than those claimed by Oxy, at least initially, because the award is based on $100 \%$ of the company stock, disregarding the $40 \%$ of stock transferred to Alberta Energy Corporation, which was what triggered the termination (caducidad). The latter, as manifested in the dissenting opinion, means that the award grants compensation over the $40 \%$ of the stock to Alberta Energy, which was unduly transferred by $\mathrm{Oxy}$; it grants compensation to this company, thus, it compensates a company that did not litigate and did never ask for any compensation. The theft is so evident that upon this award, it has been manifested; I quote: "illicit acts by Oxy that violate the Ecuadorian Law; it has been grossly underestimated and it has not been taking adequately into account the importance that each State attaches to the compliance to its legal framework by foreign companies". I close quoting remarks. I keep quoting: "the majority award is so outrageous and contradictory under legal terms, that I do not have any alternative than manifesting my disagreement". I close quoting remarks. These quotes and expressions are not the indignant clamour of a patriot civil servant of the Ecuadorian government, but the unusual dissenting opinion of the arbitrator, Brigitte Stern, astonished by the effrontery of the irked ruling. Do not be deceived compatriots! The Treaties for Investment Protection, the famous BITs and the

${ }^{568}$ See, Speech of the President Rafael Correa in the release of the book "Caso Oxy: Defensa Jurídica de una Decisión Soberana y en Derecho del Estado Ecuatoriano”, organized by the Attorney General's Office, October 17, 2014.

https://www.youtube.com/watch?v=ZbQUMBEz5Po. Last visited on November 2016. 
arbitration centers are solely the expression of a global order not only unfair but immoral, where everything is built up to serve the capital. In fact, in LatinAmerica, as I have already said, the capital has more rights than the human beings, because if a violation to human rights is committed here, before reaching the InterAmerican Court in San José de Costa Rica, all the local remedies must be exhausted. But a transnational company without any formalities, may bring a sovereign State pursuant to these BITs to arbitration venues where all is subordinated to the huge capital. ${ }^{569}$

Presciently and although the award was not fully annulled, the decision reduced the compensation in $40 \%$ corresponding to the stock transferred to Alberta Energy Company. As it has been observed, the criticism revolves around a claimed dispossession of sovereignty materialized through BITs and enforced by a biased system of dispute settlement. This repetitive narrative has barely transcended the criticism of substantial standards of protection and has lacked a deep comparative analysis. It is true that the United States has never been found liable for breaching her international obligations within the investment regime, but it is not true that it has not been sued, as the handful of NAFTA cases show. What it is undeniable is that this recurring disapproval has been effective to avoid an exercise of self-criticism pointing out the domestic actions that have triggered these disputes, as well as the mechanisms of dispute prevention and reaction. By the same token, exacerbating the patriotic sentiment to condense a common opposition to investment arbitration has also been employed to fuel further political interests, such as a renewed trend of anti-Americanism driven by a claimed CIA plot to overturn "progressive governments of the region" 570 . Indisputably, the unexpectedly widespread effects of the foreign investment regime, due to the evolving arbitral interpretations, have touched upon political sensitivities, probably as no branch of International Law has done.

\footnotetext{
${ }^{569}$ See, Speech of the President Rafael Correa in the release of the book "Caso Oxy: Defensa Jurídica de una Decisión Soberana y en Derecho del Estado Ecuatoriano", organized by the Attorney General's Office, October 17, 2014.

https://www.youtube.com/watch?v=ZbQUMBEz5Po. Last visited on November 2016.

${ }^{570}$ For instance, Congresswoman María Augusta Calle, former President of the Commission on Foreign Affairs of the National Constituent Assembly and of the same National Assembly's Commission (legislative branch) and as such mainly responsible for the constitutional design of the provisions related to treaty making, foreign relations and foreign investment, has channeled her criticism to the system focusing on the dispute settlement mechanisms. But she has gone further, listing among the new mechanisms of American domination, the aggressive foreign debt, external support to private media groups, the establishment of military bases and ultimately, the signature of BITs. Pursuant to this logic, she contended that the Oxy and Chevron awards are attempts to "economically bury Ecuador" by "depriving it of all its resources" to prompt the "failure of the political project that revitalizes the motherland".

See, Telesur, "La CIA en Ecuador", June 6, 2016.

https://www.youtube.com/watch?v=mLbV1vy4Egk. Last visited November, 2016.
} 
Perhaps, the deceitful labeling of the BITs as instruments for "reciprocal promotion and protection of investments" has slowed down the understanding of the host countries that the core of these treaties rests on the treaty-based standards of governance tested against regulatory actions rather than in the specific conditions and actions deployed to facilitate the flow of capital. ${ }^{571}$

The previous chapter briefly addressed several investment disputes brought against Ecuador, the underlying conflicts and the main claims asserted by the investors. Until the release of the book "A Critical View of Investment Arbitration Based on Ecuadorian Experience" (2017), the State Attorney General's Office registered 28 investment arbitrations, 18 of which were concluded and 10 which were still active. The statistics divide the results in 1) favorable end; 2) partially favourable end; 3 ) unfavourable end; 4) ended in a friendly settlement, and 5) ended by withdrawal.

\section{Figure $6^{572}$}

${ }^{571}$ In his landmark work, Paulsen stresses the doubtful rationality of a vast amount of governments when they were caught by the fever of signing BITs, facing years later the deployment of vague treaty provisions, inconsistently shaped by arbitrators:

The presumption must be that ignorance of the law is no excuse for breaking the law, as in most national legal systems. So although many treaty drafters did not appreciate BITs' far-reaching repercussions and over-estimated their benefits, arbitrators could argue this is irrelevant for the adjudication of investment disputes. For whether the contracting parties were bounded rational or not, they still have to adhere to the principle of pacta sunt servanda - promises shall be kept.

But whereas ignorance may not be a legitimate defense, it could be relevant for the interpretation of certain treaty design decisions. This is particularly the case given the vague nature of several core investment treaty provisions. Even if we disregard interpretive inconsistency among tribunals, it was far from clear during the 1990s which promises should be kept when agreeing to a standard such as fair and equitable treatment.

So if there are strong reasons to believe a party quickly signed off on a 'default rule' based on a superficial set of negotiations, then arbitrators should perhaps be less forceful in their assumptions about the specific intent behind the scope of a vague provision. Often-heard arguments that if party $\mathrm{X}$ wanted to restrict provision $\mathrm{Y}$ it would explicitly and unequivocally have stated so in the treaty text' could be difficult to sustain.

So perhaps it is time for arbitrators to pay attention to, rather than ignore, the political realities of the treaty-making process.

Skovgaard Poulsen, (L.N.), Bounded Rationality and Economic Diplomacy: The Politics of Investment Treaties in Developing Countries. (2015), 193 p.

572 Procuraduría General del Estado, “A Critical View of Investment Arbitration Based On Ecuadorian Experience”, Management 2008-2016, García Carrión (Diego), Gómez de la Torre (Blanca) and Gaybor, Quito (Christel), August 2016, 18-19 pp.

http://www.pge.gob.ec/images/publicaciones/2016/libroArbitraje/Ingles low.pdf. Last visited, May 2017. 


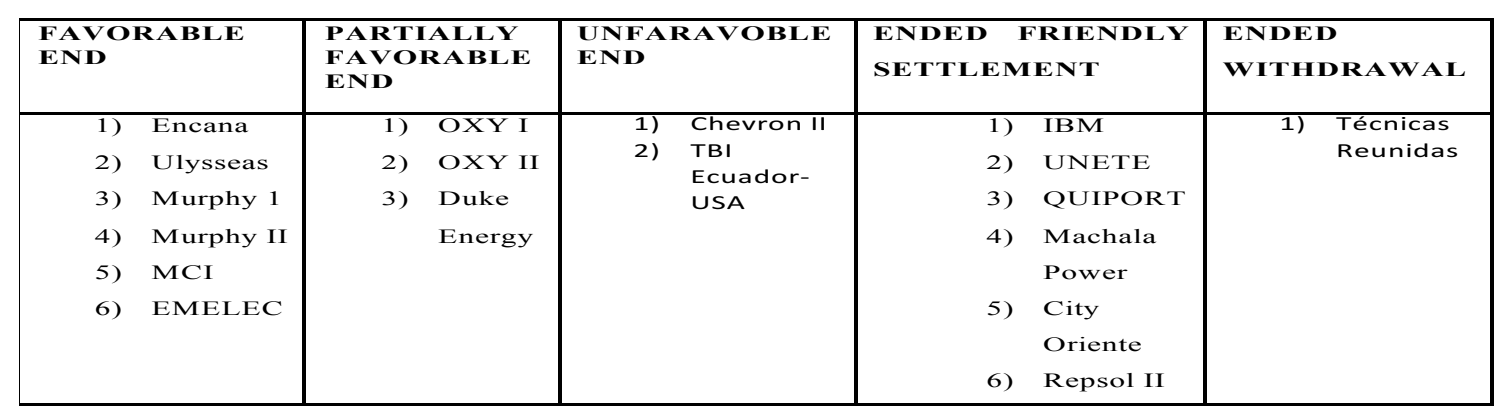

It is unclear which criteria the Attorney General's Office used to include within such classification the category "partially favourable end". Looking at UNCTAD's statistical criteria, such a category is not considered, thus being exclusively included: "1) Decided in favour of the State; 2) Decided in favour of investor; 3) Decided in favour of neither party (liability found but no damages awarded); 4) Settled; 5) Discontinued". 573 The insertion of this novel category seems to alter the uniformity of the analysis as compared with specialized studies, like that produced by Polanco Lazo. It must be noted that this author's leaves aside the State to State dispute (BIT Ecuador-USA), taking into consideration the 17 State-investor concluded disputes.

Figure $7^{574}$

\begin{tabular}{lll}
\hline Outcome & Number of cases & Basis \\
\hline In favour of the investor & 5 & Award \\
In favour of the state & 5 & Decision on Jurisdiction / Award \\
Settled & 5 & Settlement \\
$\begin{array}{l}\text { Discontinuance at request } \\
\text { of a party }\end{array}$ & 2 & Request of the Claimant \\
\end{tabular}

SOURCE: ICSID AND ITALAW ${ }^{92}$

Contrasting the charts above, it can be noted that there are two major differences. The first one concerns to the number of disputes in favour of the investor, wherein the

\footnotetext{
573 According to the latest UNCTAD's statistics out of 471 concluded know treaty based arbitrations $36,7 \%$ have been decided in favor of the State, $26 \%$ have been decided in favor of the investor, $24,2 \%$ have been settled, $10,2 \%$ have been discontinued and the rest have been decided in favor of neither party.

See, UNCTAD's Investment Policy Hub, http://investmentpolicyhub.unctad.org/ISDS.

Last visited November 2016.

${ }^{574}$ Polanco Lazo (Rodrigo), "Systems of Legal Defence Used by Latin American Countries in Investment Disputes”, Journal of World Investment \& Trade 17 (2016) 562-593, 579 p.
} 
Attorney General's office deems as favourable, the case Murphy II, which was withdrawn by the investor. The second difference concerns the cases ruled in favour of the investor, within which the domestic official statistics refuse to include those categorized as entailing a "partially favourable end" to the State. Although these awards have not fully upheld the investors' claims they have determined the State's liability and as such should be considered as favouring the investor, as Polanco Lazo's chart indicates. Visibly, the categorization of victories and loses within the system bears a significant component of subjectivity. For instance, the most radical criticizers of the system contend that since the States are the sole Respondents within investment disputes, they lose invariably whenever a dispute is brought ${ }^{575}$. Anyway, the way that States as active respondents of the system interpret the outcomes of the proceedings may reveal their perceptions towards the dispute settlement mechanisms put into action. In this way, the manner in which Ecuadorian statistics are construed, seems to indicate an absence of criticism concerning the size of the investment claims, whose exorbitance has been identified as one of the system's flaws. It has been ascertained, that frivolous and inflated claims have been used as a way of exerting pressure against the governments in order to bring them to the negotiating table in order to work out friendly settlements, that could lead to higher compensations than those allowed to be awarded under domestic legislation. ${ }^{576}$ This perception could also influence the manner that legal fees for external representation are being bargained, because in those cases that full or partial success fees are agreed upon, a substantial reduction in the amount claimed could lead to higher legal representation costs, without taking into account the cost for hearings, legal experts, document production, written legal submissions, etc. The Attorney General's Office statistics display as a positive outcome that out of USD 10 claimed against Ecuador, it has avoided the payment of USD 7, as shown in the left side of the charter below.

Figure $8^{577}$ :

\footnotetext{
575 See, Pérez Rocha (Manuel), "When Corporations Sue Governments", The New York Times, December $3^{\text {rd }}, 2014$, https://www.nytimes.com/2014/12/04/opinion/when-corporations-sue-governments.html

576 Out of 84 investment arbitration disputes surveyed, 52 resulted in damages determination for treatybased claims. According to this study, the difference between the average amounts claimed and awarded was approximately US\$ 333 million (damages claimed: \$343,430,685); damages awarded \$10,389,459). $59 \mathrm{p}$.

577 Procuraduría General del Estado, Dirección de Asuntos Internacionales, "Síntesis de Gestión (2015)".

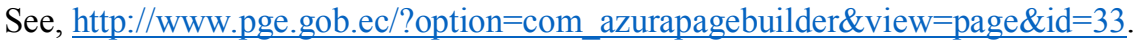

Last visited, November 2016.
} 


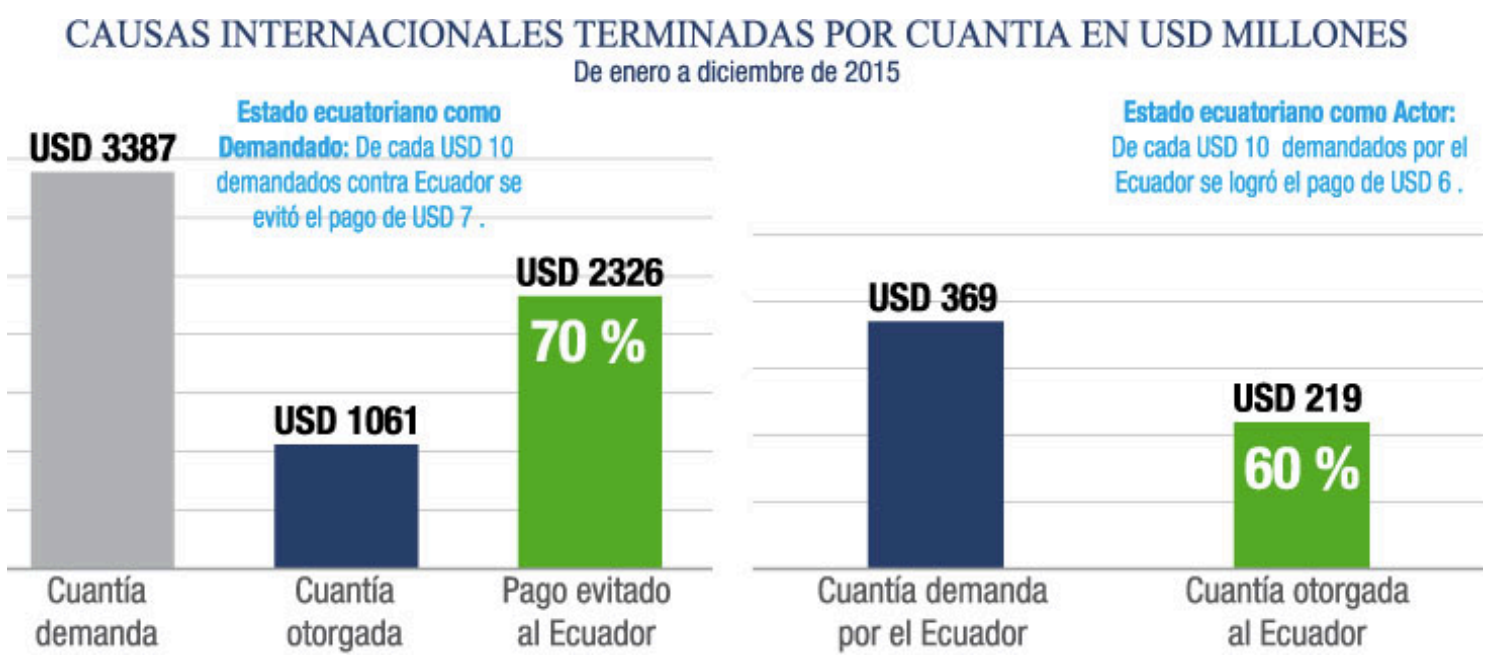

Until 2015, it was estimated that the Attorney General's Office spent around USD 200 million dollars in external legal representation costs associated to investment disputes. ${ }^{578}$ For example, the disproportionate fiscal burden of these expenses may be appraised against the budget fixed for the General Prosecutor's Office, the Public Defender's Office and the Constitutional Court, which together reached the sum aforementioned in $2016^{579}$. Recalling that several disputes like Chevron II and III, Duke Energy and Merck have been focused on the standards of access to justice, fair procedure and denial of justice, it is paradoxical that the the costs incurred in outsourcing legal services represent half of the budget of the Judiciary Branch ${ }^{580}$ to the detriment of the State's efforts for improving the quality of the system of administration of justice and consequentially reducing the State's exposure to such kinds of international conflicts.

The abundant bulk of investment disputes faced by Ecuador equate to the diversity of the formal and informal responses given at the political levels for opposing the regime. Although there is an institutional predecessor to the creation of "CAITISA", it could be admitted that the latter constitutes the most ambitious attempt to tackle the complexities of the system of investment protection from an argued technical and participative

\footnotetext{
${ }^{578}$ See, Mancero (Piedad), "Results of an audit to treaties mutual investment protection and arbitration system on investment" in Investment chapters in Trade Agreements, Submitted at the World Social Forum by Invitation of Friedrich-Ebert-Stiftung, Berlin, September 13, 2016.

See, http://www.cadtm.org/Investment-chapters-in-Trade Last visited November, 2016.

579 These figures correspond to the State's General Budget of 2016 and the breakdown is the following:

1.General Prosecutor's Office: USD 140,314,015.13

2. Public Defender's Office: USD 36,357,337.94

3. Constitutional Court: USD. 10,116,916.70
}

${ }^{580}$ According to the State's General Budget of 2016, Judiciary Branch's budget was USD. 445,931,216.17. 
perspective. ${ }^{581}$ It is noteworthy, that together with the public authorities and international experts as members of the referred commission, the Attorney General and a representative of the Judiciary Branch were omitted. While the new initiatives to reforming the system have understandably rested in the Executive Branch, either through the Ministry of Foreign Affairs or the Ministry of Trade, further decisions with an impact on the amendment and application of the regime, like long term agreements and the international legal representation of the State have surpassed the scope of foreign relations. It may be affirmed that the misalignment between foreign affairs and domestic actions impacting external interests could have aggravated the State's exposure to international investment conflicts. Although a co-ordinated approach could militate in favour of a more effective response in terms of the prevention and reaction to disputes, it must underscore the overarching scope of investment treaties, which properly regulate the compliance of the rule of law pursuant to the specific standards developed by the international investment regime. And no action or omission attributable to the State is exempted from such scrutiny ${ }^{582}$. As Frank García, recapitulates: “investment treaties are about justice" 583. This scholar highlights the allocative effects of the regime which go beyond the conferral of privileges and burdens between investors and host countries, transcending any framework involving the allocation of social sources. ${ }^{584}$ Remarkably, García contends

\footnotetext{
581 The extinct Council on Foreign Trade and Investments (COMEXI) created the Interinstitutional Consultancy Committee for the Analysis of the Bilateral Investment Treaties on the Promotion and Protection of Investment and the Treaties for the Avoidance of Double Taxation. Due to its nature, the contributions of this intergovernmental group may have supported decisions of public policy, which have not been made public.

See, Resolución No. 290 del COMEXI, published in the Official Gazette No. 487, December 22, 2004.

582 See, Articles 4 and 5, Draft Articles on Responsibility of States for Internationally Wrongful Acts, with commentaries, 2001, International Law Commission, http://legal.un.org/ilc/texts/instruments/english/commentaries/9 6 2001.pdf

${ }^{583}$ Garcia (Frank J.) 'Investment treaties are about justice', Columbia FDI Perspectives, No. 185, October 24, 2016.

${ }^{584}$ García points out:
}

Such allocative effects render investment law a matter of justice. This is not new- allocative effects subject many other areas of law (e.g., banking, taxation, trade) to principles of justice — but it is under-acknowledged in investment law. Recognizing allocative effects makes it clear that investment law does not operate outside the bounds of justice. Rather, managing capital for the benefit of capital owners and the larger society is inherently about justice, for all affected stakeholders and not investors alone.

Recognizing that investment law is a matter of justice is a paradigm shift with profound implications for investment law and policy. Essentially, it requires that we examine the investment law regime in terms of the fairness norms we would apply to any system of governance allocating economic rights and resources across a range of settings. Ensuring a secure return on investment is fair, but this does not necessarily exhaust what fairness requires of investment law. Discovering 
that the initiatives to develop transparency provisions, balancing social clauses or ensuring the attribution to regulate "cannot be rejected as unwelcome "intrusions" into a private ordering system ". ${ }^{585}$ In this regard, the effects deployed by the system still seem to overwhelm any regulatory response aimed to neutralize it, taking into consideration that this view precisely cover the conformity of such sovereign manifestations to the internationally agreed standards of protection. Therefore, understanding the manifold mechanisms of investment protection as tools for enforcing standards of good governance is fundamental for anticipating the effects that domestic measures and decisions with implications for foreign affairs are likely to exert when the State's liability comes to be scrutinized. Putting into motion investment standards of protection implies testing how regulatory measures undertaken within a specific social, political and economic context are in line with investment based protection standards. In this context, the case of Ecuador is appealing, considering the concurrence of two different and to some extent, divergent constitutional regimes (i.e., Constitutions of 1998 and 2008), within single disputes ${ }^{586}$.

what fairness means in investment law is what contemporary policy debates and treaty negotiations are about $(\ldots)$

Garcia (Frank J.) 'Investment treaties are about justice', Columbia FDI Perspectives, No. 185, October 24, 2016.

${ }^{585}$ Garcia (Frank J.) 'Investment treaties are about justice', Columbia FDI Perspectives, No. 185, October 24, 2016.

${ }^{586}$ For instance, the Perenco Tribunal addressed Ecuador's counterclaim regarding Perenco's environmental liability in a separate decision, drawing a line between the periods prior and after the enactment of the Constitution. Levine explains this complex relationship developed in the Tribunal's interim decision, as Levine illustrates:

"With regards to any contamination in excess of regulatory standards shown to have occurred between September 4, 2002 (when Perenco acquired its interests in the blocks) and October 19, 2008 (when Ecuador's current Constitution was promulgated), the tribunal found that a fault-based regime must apply. However, liability for any excess contamination shown to have occurred after October 20, 2008 should be assessed on the basis of strict liability, in accordance with the 2008 Constitution's regime for environmental damage.

(...) In principle, the tribunal also noted the issue of whether the 2008 Constitution's strict liability regime could be applied to Perenco's pre-2008 activities. Having found that the 2008 Constitution could not in and of itself establish technical standards, the tribunal found that it must look to the specific regulations enacted "on the ground" by the Ecuadorian state both before and after 2008."

See, Levine (Matthew), 'ICSID tribunal renders interim decision on Ecuador's environmental counterclaim in long-running dispute', Investment Treaty News, November 26, 2015, https://www.iisd.org/itn/2015/11/26/icsid-tribunal-renders-interim-decision-on-ecuadors-environmentalcounterclaim-in-long-running-dispute-perenco-ecuador-limited-v-republic-of-ecuador-icsid-case-no-arb$\underline{08-6 / .}$ Last visited in November 2016.

Perenco Ecuador Limited v Republic of Ecuador, ICSID Case No. ARB/08/6, Interim Decision on the Environmental Counterclaim (Interim Decision), August 11, 2015. 
Moreover, the ongoing controversies reveal several institutional flaws and defective patterns of decision making that apparently persist despite the efforts for strengthening the State's control and accountability in areas normally exempted from public scrutiny. Hence, it is astonishing for example, to find the inexistence of French BIT's travaux préparatoires $^{587}$ in the Ecuadorian records or the reference to an "Ecuadorian BIT Model" 588 , which apparently has been completely ignored by the current authorities.

\subsubsection{Appraising the Ecuadorian Litigation Experience Against Comparative Standards}

CAITISA's report provides a clear overview about the way the system of investment arbitration has operated within the Ecuadorian context. Out of the twentyseven BITs entered into force, only six were invoked for bringing investment disputes. The USA-Ecuador BIT was resorted to sixteen times, followed by Canada-Ecuador BIT, and, by Spain-Ecuador BIT, raised in four and three disputes respectively. At the bottom of the list, there are Argentina, Bolivia and France BITs, with one dispute each. ${ }^{589}$ The

${ }^{587}$ In view of the fact that Ecuador, as Respondent had little in possession for showing the negotiating story of the BIT, the Tribunal instructed the Parties to approach the French authorities in order to gather such information:

494. During the earlier jurisdictional phase, some argument was led in respect of the travaux préparatoires of the Treaty and the Tribunal decided to defer its decision on the direct/indirect control issue for the time being. Given that the Respondent apparently had little in the way of the negotiating history within its possession and without expressing a view as to whether it was appropriate or not in the circumstances to have recourse to supplementary means of interpretation pursuant to Article 32 of the Vienna Convention on the Law of Treaties (the "Vienna Convention" or the "VCLT"), the Tribunal instructed the parties to approach the French authorities with a view to obtaining any travaux préparatoires and to return to this issue in the next phase of the proceeding in the light of any such negotiating history

See, Perenco Ecuador Limited vs. The Republic of Ecuador, ICSID Case No. Arb/08/6, Decision On Remaining Issues Of Jurisdiction And Liability, September 12, 2014.

${ }^{588}$ Pursuant to Ecuador's argument, the Tribunal acknowledges the apparent existence of an Ecuadorian BIT model:

493. After a hiatus of some 8 years, negotiations between France and Ecuador resumed. By that time, Ecuador had developed its own model BIT and the approach taken by that instrument was to confine the standing to bring a claim upon natural persons who were nationals of either of the two Contracting Parties and legal persons that were incorporated under the law of either of the two Contracting Parties and whose seat was located in the territory of a Contracting Party. On this approach, legal persons incorporated under the law of a third State would have no standing to bring a claim.

See, Perenco Ecuador Limited vs. The Republic of Ecuador, ICSID Case No. Arb/08/6, Decision On Remaining Issues Of Jurisdiction And Liability, September 12, 2014.

${ }^{589}$ See, “Auditoría integral ciudadana de los tratados de protección recíproca de inversiones y del sistema de arbitraje en materia de inversiones en Ecuador: Informe ejecutivo”, May 2017, 31 p. 
preliminary results of this report, officially published on May 2017, were leaked on January $2016^{590}$. It must be noted, that this document was initially produced with data available until the first half of 2015, taking into consideration that pursuant to the Decree of Creation of the Commission ${ }^{591}$, its duration was limited to a maximum period of sixteen months. Hence, it is understandable that during the period between the conclusion of the Commission's assignation and the official publication of its report, the data registered therein, did differ with the data registered by the Attorney General's Office, considering that the latter regularly updates international disputes' information ${ }^{592}$.

\footnotetext{
${ }^{590}$ Extra-officially, the governmental delay to publish the report was due to the proximity of the accession of Ecuador's accession to the EU- Andean Free Trade Agreement.

Ecuador's accession agreement was signed on 11 November 2016 and has been provisionally applied since 1 January 2017.

${ }^{591}$ See, Executive Decree 1506, Official Gazette 1506, May 21, 2013.

592 The Attorney General's Direction of International Affairs and Arbitration regularly updates the list of notices of investment claims. For instance, $t$ may be observed the significant raise of disputes invoking the Ecuador-Kingdom of Spain BIT:
}

\begin{tabular}{|c|c|c|c|}
\hline Matter & Claimant & Date & $\begin{array}{l}\text { BIT- } \\
\text { Nationality }\end{array}$ \\
\hline $\begin{array}{l}\text { Other (denial of } \\
\text { justice, defamation } \\
\text { dispute brought by }\end{array}$ & $\begin{array}{l}\text { N. Perez Holdings LLC, N. Pérez investments, } \\
\text { LLC, Carlos Nicolás Pérez Lapentti }\end{array}$ & 03.10 .2011 & American \\
\hline $\begin{array}{l}\text { President } \\
\text { against }\end{array}$ & & & \\
\hline Petroleum & Petrobras Argentina S.A. (PESA) & 08.12 .2011 & Argentinian \\
\hline Other (gambling) & CIRSA International Gaming Corporation & 27.09.2012 & Spanish \\
\hline Petroleum & Suelopetrol & 27.05 .2013 & Venezuelan \\
\hline Electricity & Solarig & 20.05 .2014 & Spanish \\
\hline Mining & Doug W. Cannaday & 13.08 .2014 & Canadian \\
\hline Electricity & $\begin{array}{l}\text { Pontia Assett Management S.L. ( } 2 \text { notices } \\
\text { related to the contracts: Santa Elena Project } \\
\text { and Imbabura-Pimán Project) }\end{array}$ & 06.11 .2014 & \\
\hline Electricity & $\begin{array}{l}\text { Grupo TEC Servicios Avanzados S.A. ( } 2 \\
\text { notices related to the contracts: Santa Elena } \\
\text { Project and Imbabura-Pimán Project) }\end{array}$ & 06.11 .2014 & Spanish \\
\hline Electricity & $\begin{array}{l}\text { Gespatco S.L. (2 notices related to the } \\
\text { contracts: Santa Elena Project and Imbabura- } \\
\text { Pimán Project) }\end{array}$ & 06.11 .2014 & Spanish \\
\hline Electricity & AUSABI LLC (2 notices) & 20.11 .2014 & American \\
\hline Other (Posorja port) & $\begin{array}{l}\text { SOCIEDADES DEL GRUPO ALBACORA } \\
\text { S.A. }\end{array}$ & 03.03 .2015 & Spanish \\
\hline Telecommunications & Internexa Peru S.A. & 25.05 .2015 & Peruvian \\
\hline Construction & PROMOCALEDONIAN & 22.07 .2015 & Spanish \\
\hline Other & Pfizer Ireland Pharmaceuticals & 27.04.2016 & $\begin{array}{l}\text { Irish/BIT Great } \\
\text { Britain }\end{array}$ \\
\hline Other & $\begin{array}{l}\text { The Antillean Finance Company B.V. y } \\
\text { Sapias Holding B.V. }\end{array}$ & 03.08 .2016 & $\begin{array}{l}\text { BIT- } \\
\text { Netherlands }\end{array}$ \\
\hline
\end{tabular}


Whereas CAITISA's report computes twenty - six treaty based disputes ${ }^{593}$, the Attorney General's listed twenty-eight controversies up to August 2016 594 . The latter report includes Repsol I case and the State to State dispute brought by Ecuador against the USA, excluded by CAITISA, apparently because the former was a contract based dispute and the latter was an interstate controversy. CAITISA's report also underscores the exponential growth of disputes as from 2006:

15. Ecuador has been sued 26 times based on a BIT; most of the claimant corporations perform in the oil sector $(50 \%)$. Other areas where most of the claimants operate, include electricity (19\%) and mining (12\%). The period during which such claims have been brought started when the governmental policy changes towards the recovery of sovereignty over the exploitation of natural resources were announced. ${ }^{595}$

The referred report follows that out of the twenty-six investment disputes, in seventeen occasions the Tribunals declared the State`s liability or have concluded by agreement, explaining:

Currently, 16 cases have concluded, while 10 proceedings remain open in different arbitral stages or execution processes. In 14 cases, it has been declared a kind of payment or financial compensation to be paid by the Ecuadorian State; in 8 cases by an arbitral award; in 6 cases as result of a settlement. In five cases, the Tribunal found that the State did not breach the BIT or did not admit jurisdiction. ${ }^{596}$

Other

Casinos Boulevard

03.10 .2016

See, http:/www.pge.gob.ec/images/2017/casos/Cuadro de Casos DNAIyA 2103 2017.pdf. Last visited, May 2017.

593 CAITISA's report underscores that out of the 26 investment disputes registered against Ecuador, 16 have concluded and 10 are still open. Out of the 10 ongoing arbitral proceedings, the quantum of the disputes amount USD. 11.188'966.571, without considering RSM and Zamora Gold cases, whose sum has not been possible to identify.

See, “Auditoría integral ciudadana de los tratados de protección recíproca de inversiones y del sistema de arbitraje en materia de inversiones en Ecuador: Informe ejecutivo", May 2017, 94 p.

594 Procuraduría General del Estado, “A Critical View of Investment Arbitration Based On Ecuadorian Experience”, Management 2008-2016, García Carrión (Diego), Gómez de la Torre (Blanca) and Gaybor (Christel), Quito, August $\quad 2016, \quad 18-19 \quad$ pp, http://www.pge.gob.ec/images/publicaciones/2016/libroArbitraje/Ingles low.pdf. Last visited, May 2017.

595 See, “Auditoría integral ciudadana de los tratados de protección recíproca de inversiones y del sistema de arbitraje en materia de inversiones en Ecuador: Informe ejecutivo", May 2017, 94 p. Free translation.

${ }^{596}$ See, "Auditoría integral ciudadana de los tratados de protección recíproca de inversiones y del sistema de arbitraje en materia de inversiones en Ecuador: Informe ejecutivo”, May 2017, 32 p. Free translation. 
It is also noteworthy that only in two cases did the tribunals decline jurisdiction. This numbers deserve to be briefly contrasted with studies that examine more thoroughly the statistics available, bearing in mind the different phases of the dispute, namely, jurisdiction, merits, quantum and costs. ${ }^{597}$ For instance from a research consisting on 231 international investment arbitrations, it is categorical investor's prevalence over the State in the three major phases, namely jurisdiction (73\%), merits $(60 \%)$ and quantum (at least, $80 \%)^{598}$.

Taking into consideration the sixteen Ecuadorian investment disputes assumed as concluded by CAITISA's report ${ }^{599}$, it must be noted that thirteen cases advanced through the jurisdictional phase, which means that the Tribunals asserted jurisdiction in $81.25 \%$ of the cases ${ }^{600}$. Out of the eight terminated disputes that advanced through the merits

${ }^{597}$ Franck and Wylie clarify that the statistics, when public information is available, rely on the "awards" defined as:

"[a] tribunal decision creating a dispositive and binding determination on a substantive phase, namely decisions on (1) jurisdiction; (2) merits; (3) quantum of damages; (4) allocation of costs; or (5) settlement agreements or other orders indicating a dismissal or discontinuance."

Franck (Susan D.) and Wylie (Lindsey E.), "Predicting Outcomes in Investment Treaty Arbitration", 473, 474, $482 \mathrm{pp}$, http://scholarship.law.duke.edu/dlj/.

598 Out of the 231 international investment arbitration cases employed by Tucker, the outcomes are divided by the three major phases as follows:

"Jurisdiction- Case proceeds to merits: 169; State wins jurisdiction: 62;

Merits- Case proceeds to quantum: 101; State wins at merits:68;

Quantum- State loses at quantum: 80; No public quantum:14 ; State wins at quantum: 7.”

Tucker (Todd), Development matters: Emerging trends in investment treaty arbitration, Vale Columbia Center/Ecuadoran Embassy Conference on Investment, Washington, DC-April 8, 2014.

See, https://issuu.com/embajadaecuusa/docs/tucker 2014 ecuador talk pp-tucker. Last visited November 2016.

599 This finding is based on the CAITISA`s report listed 16 terminated disputes:

“1) Corporación Quiport; 2) Duke Energy; 3) Empresa Elécrica del Ecuador (EMELEC); 4) ENCANA; 5) GLOBAL-Unete Telecomunicaiones S.A. y Clay Pacific S.R.L., 6) IBM; 7) M.C.I. Power Group; 8) Murphy Exploration (I); 9) Murphy Exploration (II); 10) Noble Energy and Machala Power; 11) Occidental (Oxy 1); 12) Ecuador TLC/Petrobras Argentina (PESA); 13) Técnicas Reunidas; 14) Ulysseas; 15) Chevron II, and; 16) Oxy II.”

Out of these 16 disputes, 8 ended with an award on merits, 6 were ended by agreement, 1 was withdrawn by the investors and 1 terminated by the Tribunals' refusal to jurisdiction.

See, "Auditoría integral ciudadana de los tratados de protección recíproca de inversiones y del sistema de arbitraje en materia de inversiones en Ecuador: Informe ejecutivo", May 2017, 32 p. Free translation.

${ }^{600}$ The Tribunals asserted jurisdiction over the following disputes: 1) Duke Energy; 2) Empresa Elécrica del Ecuador (EMELEC); 3) ENCANA; 4) GLOBAL-Unete Telecomunicaciones S.A. y Clay Pacific 
phase and ended with an award, the State was held liable for investment obligations' breaches in $50 \%$ of the cases. ${ }^{601}$

Notwithstanding the decision to set aside from CAITISA's report the disputes registered as open either because they are subject to requests of annulment or at the stage of damages quantification $^{602}$, it must be noted that these decisions passed the phase of merits, where the State has been held liable for breaching treaty obligations; this fact would diminish the rate of success of the country's defense. In this way, it can be affirmed that out of the disputes that matured into awards on merits, the rate of investor's success would increase from $50 \%$ to $63,6 \% .{ }^{603}$ These percentages contrasted with ICSID 2016 'statistics, which reveal Ecuador's higher exposure compared to the average, where the awards upholding jurisdiction rate at $76 \%$ and those upholding claims in part or in full, amount to $46 \% .{ }^{604}$ Among the seven cases (open and terminated) upholding claims in part or in full reported by CAITISA, the Tribunals determined that the State violated the "investors' rights", as follows ${ }^{605}$ :

S.R.L., 5) IBM; 6) M.C.I. Power Group; 7) Noble Energy and Machala Power; 8) Occidental (Oxy 1); 9) Ulysseas; 10) Chevron II; 11) Ecuador TLC/Petrobras Argentina (PESA); 12) Occidental (Oxy II); 13) Chevron II.

The Tribunal declined jurisdiction in the following cases: 1) Murphy I, and; 2) EMELEC (award on merits and jurisdiction).

${ }^{601}$ The State was held liable for breaching investment obligations in the following cases (terminated and open): 1) Duke Energy; 2) Occidental (Oxy 1); 3) Occidental II (Oxy II); 4) Chevron II; 5) Burlington; 6) Murphy (III); 7) Cooper Mesa.

It is noteworthy that the cases Burlington, Murphy (III) and Cooper Mesa are still open either due to requests of annulment or because they are at the stage of quantification of damages.

The Tribunal did not find the State liable in the following cases: 8) Empresa Eléctrica del Ecuador (EMELEC); 9) ENCANA, 10) M.C.I. Power Group; 11) Ulysseas.

${ }^{602}$ CAITISA' s report based on Attorney General's office data considers open Burlington, Murphy (III) and Cooper Mesa cases. The State was held liable of breaching treaty obligations in all this cases.

${ }^{603}$ The awards on merits considered by CAITISA along its report are those corresponding to terminated cases: 1) Empresa Elécrica del Ecuador (EMELEC); 2) ENCANA; 3) M.C.I. Power Group; 4) Ulysseas; 5) Duke Energy: 6) Occidental (Oxy I); 7) Chevron II; 8 Oxy (II).

However, and looking at the methodology regularly used by authoritative scholarly sources, there should be taken into consideration all the cases that have created a binding determination capable of affecting permanently any of the Parties' rights. In this regard, the cases Burlington, Murphy (III) and Cooper Mesa are disputes concluded at the phase of merits and consequentially, they should be taken into accpunt.

${ }^{604}$ International Centre for Settlement of Investment Disputes, 'The ICSID Caseload-Statistics' (Issue 2016-1), $14 \mathrm{p}$.

See,https://icsid.worldbank.org/apps/ICSIDWEB/resources/Documents/ICSID $\% 20$ Web\%20Stats\%20201 6-1\%20(English)\%20final.pdf. Last visited in November, 2016.

${ }^{605}$ This charter follows CAITISA's leaked report and adds the standards of protection deemed as breached by the Tribunals in Burlington, Murphy III and Cooper Mesa cases. 
Figure 9

\section{Standard of Protection}

Fair and equitable treatment

Direct/Indirect Expropriation

Denial of Justice

Non-discriminatory and arbitrary treatment

Full protection and security (included, Oxy I, Cooper Mesa

establishment, acquisition and protection of

investments)

National Treatment

\section{Cases}

Oxy I, Oxy II, Duke Energy, Perenco, Murphy

III

Oxy II, Burlington, Perenco, Cooper Mesa

Chevron II

Oxy I

Indeed, fair and equitable treatment is "the most invoked standard in investment disputes", being also the standard most successfully upheld within international investment litigation ${ }^{606}$. This arguably autonomous concept has been closely related to rule of law, good faith and due process; understandably, this over-arching definition touches upon the core of the exercise of sovereign powers. Although it is ambiguous, the evolution of this standard has reaffirmed its strong role towards the enforcement of Western good governance concepts like transparency, non-discrimination and proportionality. In this vein, the cases' pattern together with specific statistics show that the development status of the respondent countries plays a significant function taking into consideration that decision making quality and technical capacities will be scrutinized when the violation of such standard is claimed.

A thorough empirical analysis of investment case law produced by Behn, concludes that, whilst the development status of the claimants does not show a pattern as to the outcome of the awards, this is not the case when it comes to the respondents:

Of the 110 fully resolved cases in the data set, the outcomes related to the respondent's development status are as follows:(1) where the respondent is a developed state, the claimant wins $13 \%$ of the time; (2) where the respondent is

See, Comisión para la Auditoría Integral Ciudadana de los Tratados de Protección Recíproca de Inversiones y del Sistema de Arbitraje en Materia de Inversiones, Eje 2 "El Sistema de Arbitraje de Inversiones y casos contra el Ecuador", https://issuu.com/periodicodiagonal/docs/conclusiones caitisa. Last visited, April 2016. Free translation.

See also, http://investmentpolicyhub.unctad.org/ISDS. Last visited, November 2016.

${ }^{606}$ See, "Auditoría integral ciudadana de los tratados de protección recíproca de inversiones y del sistema de arbitraje en materia de inversiones en Ecuador: Informe ejecutivo", May 2017, 39 p. Free translation. 
an emerging economy state, the claimant wins $30 \%$ of the time; (3) where the respondent is a developing state, the claimant wins $37 \%$ of the time; and (4) where the respondent is an LDC, the claimant wins $33 \%$ of the time (see Table 27 below). ${ }^{607}$

Pursuant to this scholar's classification, Ecuador would be a developing State. As it can be appraised, the rate of success of the claimants against Ecuador is substantially higher than the average, irrespective of the statistical criteria employed. For this reason, it might be understandable that the Attorney General's Office does nuance the claims partially upheld, as "partially favourable outcomes". In this line, Behn underscores the importance of governance and capacity as crucial factors influencing the disputes' outcomes:

From these numbers, there is one pattern that is very telling: developed state respondents do not lose as many cases as other types of states. In the data set, a developed state respondent only lost two cases and in both of these cases the respondent was a developed state from Eastern Europe (Lithuania and Slovakia). In the last three years (the data set), no developed states from North America or Western Europe have lost an investment treaty arbitration. There are at least two explanations for this phenomenon: (1) developed states have stronger regulatory governance structures (i.e., due process, transparency, non-discrimination, etc.) than developing states, and therefore it is less likely for a treaty violation to be found, or (2) developed states have more capacity (legal, bureaucratic, and financial) to successfully defend investment treaty claims. Either way, there does seem to be a strong correlation between level of economic development and the likelihood of successfully defending an investment treaty claim. ${ }^{608}$

In harmony with this assessment, what should concern the adjudicators is the development status of the respondent and the circumstances in which the major investment decisions and regulatory actions triggering a dispute were undertaken. However, as noticed by the fiercest challengers of the system, the strong commercial inclination of the main investment litigation players has resulted in the subordination of well-settled domestic regulatory conceptions to business-oriented notions. This inclination in conjunction with the vagueness of the most invoked standard, namely, fair and equitable treatment, has produced unforeseen outcomes, apparently unintended by the creators of the system (especially the respondent States), arguably unwilling to provide a higher protection than the minimum standard of treatment. Behn explains this critical concern of legitimacy, taking into consideration the furious reaction of the

\footnotetext{
607 Behn (Daniel), Legitimacy, "Evolution, and Growth in Investment Treaty Arbitration: Empirically Evaluating the State-Of-The-Art", Georgetown Journal of International Law, 405 p.

608 Behn (Daniel), Legitimacy, "Evolution, and Growth in Investment Treaty Arbitration: Empirically Evaluating the State-Of-The-Art", Georgetown Journal of International Law, 406 p.
} 
Respondents, which have roughly circumscribed their criticisms within the frame of lost sovereignty:

Of all the empirical evidence presented in this Article, the fact that developed states only infrequently lose investment treaty claims is of great concern from a legitimacy perspective. It indicates that governance and capacity are a major determinant of the outcome in investment treaty arbitration. This means that any respondent state that does not meet a certain governance standard will be at a distinct disadvantage in any investment treaty arbitration even where the alleged violation of the relevant treaty may be both legitimate and reasonable. The question for investment treaty arbitration is whether developing states are held to the same standard of governance as a developed state or whether there should be differentiated standards in evaluating treaty breaches that are sensitive to development status. ${ }^{609}$

If one looks at the narrative of the opponents to the system, especially the politicians, there is a strong concern towards the labelling of the treaties, namely, the reciprocity of the protection and promotion of investments, in view of the one-sided use of the mechanisms of protection by exporting capital corporations (normally incorporated in developed countries). Aligning the criticisms towards the lack of reciprocal flows of investment, as well as to the alleged disagreeable conduct of arbitrators, leave unattended core concepts that allow the unrestrained deployment of the system, like the real nature of the disputes and the scope of the standards of protection. In spite of the recent spread of knowledge about the regulatory nature of investment disputes, most of the domestic decision makers influencing the change of the State's stance towards the system, persist in complaining about the "publification" of "commercial" or "contractual" disputes. Van Harten developed authoritative scholarly documents that clearly encapsulated the essence of the investment disputes and explained how the corresponding mechanisms of dispute settlement at the time that evolved beyond the boundaries of commercial arbitration, did take advantage of its architecture of enforecement to settle regulatory disputes between private persons and the State. ${ }^{610}$ This favourable procedural architecture and the

609 Behn (Daniel)," Legitimacy, Evolution, and Growth in Investment Treaty Arbitration: Empirically Evaluating the State-Of-The-Art", Georgetown Journal of International Law, 407 p.

${ }^{610}$ In this context, Van Harten argues:

The jurisdiction of a commercial arbitration tribunal did not normally extend to regulatory disputes arising from the state's exercise of public authority with respect to foreign nationals, including foreign investors. A key aspect of the investment treaty arbitration is that it transplants this private adjudicative model from the commercial sphere into the realm of government, thereby giving privately-contracted arbitrators the authority to make what are in essence governmental decisions. This is achieved because investment treaties incorporate arbitration treaties in order to provide an institutional forum and procedural framework for investment arbitration. Investment treaties also rely on arbitration treaties for the enforcement of arbitration awards by domestic courts. Thus, 
extrapolation of key concepts of commercial arbitration, especially the possibility that the arbitrators rule over its own jurisdiction (principle kompetenz-kompetenz), has prompted controversial decisions fuelled by the vagueness of the treaties' wording, whose interpretation may be strongly influenced by the adjudicators' background. In the case of Ecuador, CAITISA's report points out that $69 \%$ of the arbitrators acting in disputes involving the country are specialized in commercial arbitration. ${ }^{611}$ This report also highlights the decisions that in the Commission's criteria would be unacceptable for manifestly disregarding the wording of the treaties through expansive and inventive ways of interpretation. Through this practice, the Tribunals have arguably rendered ineffective exhaustive rules not susceptible to expansive interpretations, like fork in the $\operatorname{road}^{612}$, non-

when it came to the drafting of investment treaties, the previously established arrangements of arbitration treaties were simply incorporated as part of the architecture of investment arbitration. In the process, the procedural framework and enforcement structure of international commercial arbitration that provided the basis for the use of a private model of adjudication was extended to resolve regulatory disputes between individuals and the state.

Van Harten (Gus) and Loughin (Martin), "Investment Treaty Arbitration as a Species of Global Administrative Law", The European Journal of International Law, EJIL (2006), Vol. 17 No. 1, 121-150, $126 \mathrm{p}$.

See, Comisión para la Auditoría Integral Ciudadana de los Tratados de Protección Recíproca de Inversiones y del Sistema de Arbitraje en Materia de Inversiones, Eje 2 "El Sistema de Arbitraje de Inversiones y casos contra el Ecuador", https://issuu.com/periodicodiagonal/docs/conclusiones caitisa. Last visited, November 2016. Free translation.

611 The report further develops the statistics concerning the arbitrators involved in investment cases against Ecuador:

45 arbitrators have acted in cases against Ecuador, and it is notable that:

- $\quad 64 \%$ come from developed countries.

- $\quad$ At least in $50 \%$ of the cases, the State has appointed arbitrators specialized in the field of commercial arbitration.

- In $89 \%$ of the cases, the investors have appointed arbitrators specialized in the field of commercial arbitration

- $\quad 62,5 \%$ of arbitrators, who have been appointed as President of the tribunals for the different cases, come from the field of commercial arbitration.

See, Comisión para la Auditoría Integral Ciudadana de los Tratados de Protección Recíproca de Inversiones y del Sistema de Arbitraje en Materia de Inversiones, "Auditoría integral ciudadana de los tratados de protección recíproca de inversiones y del sistema de arbitraje en materia de inversiones en Ecuador: Informe ejecutivo", May 2017, 50-52 pp. Free translation.

612 The report criticizes the Tribunals' decisions within the cases Oxy I, IBM and MCI Power, because the corporations brought parallel proceedings before domestic courts and ICSID. Pursuant to US-Ecuador BIT, the election of one forum should be definitive, but the Tribunals by distinguishing a treaty based dispute from a statute based dispute, asserted jurisdiction over the former claims, thereby making ineffective the treaty provision.

See, Comisión para la Auditoría Integral Ciudadana de los Tratados de Protección Recíproca de Inversiones y del Sistema de Arbitraje en Materia de Inversiones, "Auditoría integral ciudadana de los tratados de protección recíproca de inversiones y del sistema de arbitraje en materia de inversiones en Ecuador: Informe ejecutivo", May 2017, 35 p. Free translation. 
retroactivity of treaties ${ }^{613}$ and exclusion of taxation matters ${ }^{614}$. As to application of the fair and equitable treatment, also the aspect most repetitively invoked and successfully upheld by the Tribunals in cases involving Ecuador, CAITISA's report concluded:

Five cases against Ecuador have taken place as consequence of the same Law 42 (Hydrocarbons Law). In three of the five cases, the Tribunal has ruled over the violation of the fair and equitable treatment standard. Although the circumstances are almost identical in all the cases, and the cause triggering the claim is the same, the arbitrators' decisions have been very different. In the Perenco case, the Tribunal considered that the fair and equitable treatment of the investor was violated when the State increased to $99 \%$ the fiscal share over the extraordinary oil income. Nonetheless, in the case of Occidental, the Tribunal considered that the violation was caused in the moment that the State increased to $50 \%$ the income retention fee that the petroleum companies obtained from the participation contracts. In the Burlington case, the Tribunal considered that neither the 50\% increase nor the $99 \%$ constituted violations of the fair and equitable treatment standard. ${ }^{615}$

In the frame of the disputes triggered by the application of Law 42, it must be added Murphy III case, where the country was also deemed liable for violating this standard. Similar to the Perenco case, the Tribunal at Murphy III concluded that Ecuador breached the US-Ecuador's FET standard, when it applied the Law 42, not at $50 \%$ but at $99 \%$. Naturally, this conclusion has important consequences over the amount of the compensation. 616

\footnotetext{
${ }^{613}$ The report alludes to the Chevron II case, wherein the Tribunal ruled that the US-Ecuador BIT could be invoked by the claimant although it terminated its operations in Ecuador, approximately five years before the treaty entered into force.
}

${ }^{614}$ The report makes reference to the Oxy I case, which was based on the US-Ecuador BIT. Although this BIT excludes taxation matters and the dispute was based on the reimbursement of VAT, the Tribunal asserted jurisdiction over the controversy.

${ }^{615}$ Following the logic of the statistics presented by the Commission, the five cases referred should be: 1) Murphy I; 2) Murphy II; 3) Burlington; 4) Perenco; 5) Occidental II. The three cases where the State has found liable to breach the FET standard are 1) Perenco, 2) Burlington; 3) Occidental II.

See, Comisión para la Auditoría Integral Ciudadana de los Tratados de Protección Recíproca de Inversiones y del Sistema de Arbitraje en Materia de Inversiones, "Auditoría integral ciudadana de los tratados de protección recíproca de inversiones y del sistema de arbitraje en materia de inversiones en Ecuador: Informe ejecutivo", May 2017, 40 p. Free translation.

${ }^{616}$ The amount claimed by the investor was USD. 355 million. By applying a scenario where Law 42 at $50 \%$ should be considered lawful and in consequence the amounts derived thereto should be taxable, the Tribunal awarded a compensation of approximately USD. 20 million:

441. The Tribunal has determined that Ecuador violated the Treaty when it enacted Law 42 at 99\%. The Tribunal does not consider that Ecuador violated the Treaty when it enacted Law 42 at $50 \%$. The Tribunal finds that therefore Murphy is entitled to compensation for the historical Law 42 payments that Murphy Ecuador made at 99\%. Murphy Ecuador paid a total of USD 55,986,233 of payments under Law 42 at $99 \%$ for the period November 2007 to March 2008. Murphy Ecuador would have paid only USD 28,275,875 over that same period had Law 42 remained at 50\%. The 


\subsection{Learning by Doing: The Evolution of Regulatory Mechanisms to Avoid the State's exposure to International Investment Disputes}

\subsubsection{Arbitral Experimentalism and Development of Substantive Standards in the Ecuadorian Disputes}

The criticisms of the vagueness of the FET standard vastly grounded in the USEcuador BIT may be well understood in the interpretation provided in the Murphy III award:

207. Protecting the stability and predictability of the host State's legal and business framework also underpins the modern customary international law standard. The CMS Gas Transmission Corporation v. Argentine Republic tribunal, for example, decided that "the Treaty standard of fair and equitable treatment and its connection with the required stability and predictability of the business environment, founded on solemn legal and contractual commitments, is not different from the international law minimum standard and its evolution under customary law. Other tribunals interpreting the customary international law obligation have repeatedly embraced a less stringent standard and have emphasized that they were dealing with an evolving concept that embraces the application and interpretation of the treaty FET standard. The Mondev International Ltd. v. United States of America tribunal interpreted the Free Trade Commission statement regarding the content and standard of Article 1105 of NAFTA as "incorporating current international law, whose content is shaped by the conclusions of more than two thousand bilateral investment treaties and many treaties of friendship and commerce. Those treaties largely and concordantly provide for 'fair and equitable treatment' of, and for 'full protection and security' for, the foreign investor and his investments. The ADF Group Inc.v. United States of America tribunal, affirming the observations made in Mondev, stated further that the constantly evolving international standard 'must be disciplined by being based upon State practice and judicial or arbitral case law or other sources of customary or general international law' ${ }^{617}$

\footnotetext{
Tribunal finds that Murphy is entitled to compensation for the difference between those two amounts, i.e., USD 27,710,358.

(...) 451. Accordingly, the Tribunal determines that Murphy is entitled to compensation under this head of claim for the difference between the total amount paid by Murphy Ecuador at $99 \%$ for the period November 2007 to March 2008 and what it would have paid over the same period had Law 42 remained at $50 \%$. That amount totals USD $27,710,358$. An actualisation rate of $12 \%$ applied to that amount results in a total of USD 31,327,544. After a consolidated tax rate of $36.25 \%$ (labour tax at $15 \%$ and income tax at $25 \%$ ) is applied to the amount of USD $31,327,544$, the total amount of compensation due to Murphy under this head of claim is USD 19,971,309.
}

See, Murphy Exploration \& Production Company- International v. The Republic of Ecuador, Partial Final Award, 6 May 2016.

${ }^{617}$ See ${ }_{2}$ Murphy Exploration \& Production Company- International v. The Republic of Ecuador, Partial Final Award, 6 May 2016. 
Undoubtedly each of the cases derived from the application of Law 42 bears its own specificities that may affect the decision of the Tribunal, whose composition on its own also influences the outcome of the disputes. However, it is certainly striking that disputes based on similar regulatory measures and the same BIT's provision result in such diverse interpretations. In this line, the ample meaning given by the Murphy III Tribunal to the FET standard, whose content is far from being uniform, is at least controversial. The fact that the main bulk of BITs and treaties of friendship and commerce embody such a standard does not mean that it equates the threshold provided by the minimum standard of treatment, even more when several of such treaties regulate these concepts separately. Precisely, the wording of NAFTA's Article 1105 that detaches the FET standard from the minimum standard of treatment should indicate that both constitute autonomous concepts. As Yalkin notes, both standards differ drastically, both at the procedural and substantial levels:

First, the international minimum standard knows no "investor". (...) It is important to note that this might make some difference with respect to certain investment claims. Because of the focus on alien rather than investor, the international minimum standard may exclude cases such as Tokios Tokelés $v$. Ukraine, in which a shell company had been incorporated in a foreign jurisdiction by a local investor (...).

Second, it seems bullish to suggest, in light of both the statement in Neer and the existing established components of the international minimum standard, that in the absence of a treaty obligation, most investor protections would constitute violation of customary international law (...).

Third, even when one considers the status of expropriation as a component of the standard, the conclusion remains somewhat unclear (...). The hesitation expressed with respect to the existence of expropriation as a component of the international minimum standard does not bode well for its extension to other property rights. (...) The minimum standard is, by definition, a principle of general international law, and as such binding on all States irrespective of their bilateral or multilateral obligations. It would seem unlikely that in the absence of treaty obligations States would feel entitled to exercise diplomatic protection on behalf of one of their citizens for the failure of a host State to treat that foreign citizen's property fairly and equitably. ${ }^{618}$

This very clear notion coincides with more severe criticisms of the unexpected development of this standard arguably inexistent until the end of the 1990s. Perhaps, Sornarajah is the severest detractor of this "dormant" and "amorphous" standard:

\footnotetext{
${ }^{618}$ Yalkin (Tolga), "The International Minimum Standard and Investment Law: The Proof is in the Pudding”, EJIL:Talk!, August 3, 2009.
}

See, http://www.ejiltalk.org/author/tyalkin/. Last visited, November 2016. 
(...) The most glamorous change through expansionist interpretation concerns the fair and equitable treatment standard. When I wrote the first edition of my book, the International Law on Foreign Investment in 1994, I researched the standard and found that it was without any substantive content. I dealt with that standard in two pages. The international minimum standard had been around for over 100 years, and beyond the notion of denial of justice and the standards for a lawful expropriation, the standard had no definite content.

(...) Yet, this dormant standard once without concrete content has sprouted into life. Suddenly, we are told that is the ceiling with the old international minimum standard being the floor. This is new wisdom that did not exist previously. The standard acquires new meaning which no state making investment treaties or no writer in earlier times could have contemplated. Created by magic wands a select group of arbitrators, this amorphous standard assumed strange meanings that very competent lawyers could not have dreamed it had. In 1999, there was an exhaustive study of the fair and equitable standard in the British Yearbook of International Law. In it, Stephen Vasciannie concluded by saying that the standard had no precise content. Yet, in five short years from that study, Christoph Schreuer wrote saying that the standard had now become an autonomous standard with definite content. Clearly, there was law-creation that had taken place by persons who were vested with no power to create law. The legitimacy of their power to do so is greatly suspect. Yet, there was no way that this arrogation of power could be challenged within the system. ${ }^{619}$

The weight given by Murphy III Tribunal to this "catch-all" provision, portrays the dogmatic reliance of several investment adjudicators to this standard of governance:

208. The international minimum standard and the treaty standard continue to influence each other, and, in the view of the Tribunal, these standards are increasingly aligned. This view is reflected in the jurisprudence constant not only of NAFTA caselaw, as discussed above, but also in the arbitral caselaw associated with bilateral investment treaties. Some tribunals have gone so far as to say that the standards are essentially the same. The Tribunal finds that there is no material difference between the customary international law standard and the FET standard under the present BIT. Certainly, the FET standard of the BIT is not lower than the international minimum standard. The Tribunal does not find it necessary to determine for the purposes of the present case whether the FET standard reflects an autonomous standard above the customary international law standard. ${ }^{620}$

Contrasting this reasoning with the well settled foundations of the minimum standard of treatment ${ }^{621}$, added to the undisputed fact that Investment Law lacks "jurisprudence

\footnotetext{
619 Sornarajah (M.), "International Investment Law as Development Law: The Obsolescence of a Fraudulent System”, Springer International Publishing, Switzerland, 2016, 220-221 pp.

${ }^{620}$ See, Murphy Exploration \& Production Company- International v. The Republic of Ecuador, Partial Final Award, 6 May 2016.

${ }^{621}$ A UNCTAD's report the divergent interpretations surrounding the relationship between the fair and equitable treatment standard and the minimum standard of treatment:
}

"Tribunals established under IIAs other than NAFTA and applying FET clauses not linked to the minimum standard of treatment of aliens have on the whole been paying less attention to the 
constante" as a source of formal precedent, explains the criticisms of the decisions of the arbitrators overstepping not only the ordinary meaning of the treaties but also the boundaries of the system within the realm of Public International Law. In view of the paragraph transcribed above, it also seems that the Tribunal equates jurisprudence constante to precedent. In this line, influential scholars like James Crawford dismisses the existence both of precedence and jurisprudence constante within investment arbitration, among other reasons, because of the different circumstances and formulations of the texts, the principle that the decisions reached by the tribunals are only binding on the parties and the lack of a central authority within this "wilderness of single instances" 622 :

A more sensible approach which this common lawyer finds is the principle of jurisprudence constante-the general sense of the way decisions should be made in relation to similarly formulated provisions. But the problem is that we do not have a jurisprudence constante in relation to core issues of investment arbitrations at present. We do not have a jurisprudence constante on fair and equitable treatment, though one is perhaps starting to emerge. We do not have a jurisprudence constante in relation to the role of legitimate expectations. We do not have $a$ jurisprudence constante in the relationship between quantification of breaches of the fair and equitable treatment standard and that of the standard of expropriation: the two tend to be conflated. And we do not have a jurisprudence constante in relation to umbrella clauses specifically, or more generally the relation between treaty and contract.

The only way we are going to get it, bearing in mind that this is my third elementary piece of guidance, is for arbitrators to pay decent regard to the opinions of other investment arbitrators. Let us pay decent regard to what other people say. One may have to disagree, but if so it is better to say one is disagreeing and to make it clear why, than simply to ignore contrary decisions, as has happened in a number of cases. ${ }^{623}$

discussion of the applicable liability threshold. Some of them have suggested that it is "a high one"; others held the view that it is lower than under the minimum standard of treatment, while most did not address the matter. At the same time, non-NAFTA tribunals have tended to allow some inefficiency, trial and error, and imperfection in a government's conduct and have accepted that a violation by the host State of an investment contract or of its own domestic law does not necessarily amount to a breach of the FET standard."

See, United Nations Conference on Trade and Development, "Fair and Equitable Treatment- UNCTAD Series on Issues in International Investment Agreements II”, United Nations, New York and Geneva, 2012, $\mathrm{xV}$.

${ }^{622}$ Crawford borrowed this saying from the English poet, Alfred, Lord Tennyson, Aylmer's Field (1864) See, Crawford (James), "Similarity of Issues in Disputes Arising under the Same or Similarly Drafted Investment Treaties", in Precedent in International Arbitration, General Editor: Emmanuel Gaillard, Edited by Yas Banifatemi, International Arbitration Institute, IAI Seminar, Paris-December 14, 2007, 99 p.

${ }^{623}$ Crawford (James), "Similarity of Issues in Disputes Arising under the Same or Similarly Drafted Investment Treaties", in Precedent in International Arbitration, General Editor: Emmanuel Gaillard, Edited by Yas Banifatemi, International Arbitration Institute, IAI Seminar, Paris-December 14, 2007, 102-103 pp. 
The next chapter further elaborates the change of circumstances in the oil market prices and the extent of the capability of the State to react to such variations. Although reaching several outcomes as to the rate at which the State breached its treaty and contractual obligations as a consequence of the Law 42-2006 and the measures undertaken within this frame, the common pattern of reasoning concerning the weight given to regulatory stability, legitimate expectations, representations and public statements is notable. Interestingly, the Murphy III Tribunal refers to a fundamental change in the nature of the investment when the participation contracts (former production contracts) created the right to share in oil production. This observation is notable because it briefly assesses the evolution of the investor's legitimate expectations in a timeline of almost a decade, since the original investment was made within a frame of different contractual arrangements, in the absence of BIT protection and a greater deference over the exercise of regulatory powers:

250. Notwithstanding that the Claimant's original investment was made in 1987, the legal framework in Ecuador as it applied to foreign investors generally, and the contractual arrangements that applied to the Claimant's investment specifically, changed significantly in the mid-1990s. When the Claimant entered into the Participation Contract in January 1997, the nature of its investment changed in a fundamental way; it gained the right to a share in oil production. Under the new contract, it bore exploration, development and production costs, and thus, inherently, the risk of low oil prices. It also stood to gain from an increase in oil prices through sales of its share in production. Given the significantly different legal framework that existed at the time of the Claimant's original investment in the Block 16 Service Contract and its subsequent investment in the Participation Contract, the Tribunal finds that it is relevant to assess the Claimant's legitimate expectations as of 1997. Indeed, this is how the Parties have pleaded the case. ${ }^{624}$

As analyzed in the previous chapters, the aggressive measures undertaken with the aim of privatizing strategic sectors and liberalizing the economy were specifically targeted to attract investment at any cost without replicating the same kind of efforts in updating related statutes, building technical capacities or strengthening the judiciary branch. At the end, the flaws derived from the functioning of the State were allegedly not foreseen by the investors, but were decisive for determining the breach of international obligations. In short, the upgraded protection deployed by the BITs, implied that the contractual commitments and the exercise of regulatory powers would be subject to evolving and

${ }^{624}$ See, Murphy Exploration \& Production Company- International v. The Republic of Ecuador, Partial Final Award, 6 May 2016. 
unsettled standards of governance weighed by adjudicators setting, for instance, the international minimum standard of treatment as a floor and not as ceiling of protection.

In this fashion, the exercise of regulatory powers is pushed to abide by indeterminate global standards of governance, irrespective of the limitations, legal tradition, economic, political or social circumstances that a country may be undergoing. While it is true that the BITs are designed both for protecting investments and questionably also the States from the undue resort to diplomatic protection, the awards in the cases entailing the application of Law 42 show in general, a disturbing sympathy towards the arguments of the investors, which would be very difficult to sell to an average domestic practitioner. The influential oil companies involved in the investment disputes normally rely on global and coordinated systems of information that allow them to distribute the risks of their chained investments worldwide, as well as to fairly measuring and internalizing the costs derived from operations in a specific country. In such a capacity, they are well equipped to develop complex mechanisms to maximize their stance among the different regulatory schemes they are operating in, which are well expressed in their corporate structure, tax planning and forum shopping. In developing countries, the high dependence of the economy to the presence of such corporations entails an informal recognition of political power for their representatives. Normally, their executives and lawyers are former high ranking authorities who well know the peculiarities, advantages and disadvantages of investing in the country and in its key areas. As the Ecuadorian experience has shown, the phenomenon of "revolving doors" is unavoidable and it is not strange that the same counselor does change radically his mind depending on the side he must serve. As evidenced in chapter II, there is nothing strange about the cases involving former authorities who acted in key governmental positions prompting the articulation of the system of investment protection and afterwards profiting from the same, as counsellors of the claimants. Probably no constitution in the world acknowledged to the degree the Ecuadorian Constitution did, the protection of foreign investors:

260. In addition, in August 1998, Ecuador amended its Constitution. It further committed to provide a stable and reliable legal and institutional framework to promote the development of all economic activities. It also authorised Ecuador to include stabilisation clauses in contracts so that such contracts would not be affected by any future changes in the laws. ${ }^{625}$

${ }^{625}$ See, Murphy Exploration \& Production Company- International v. The Republic of Ecuador, Partial Final Award, 6 May 2016. 
The interpretation of this constitutional provision would entail the indefinite abdication of one of the most basic tenet of an organized society, which is the capacity to enact rules. As noted by Salacuse, the purpose of stabilization clauses does not restrain a country from As noted by Salacuse, the purpose of stabilization clauses does not restrain a country from making regulatory changes but obliges it to restore the financial equilibrium if such a transformation adversely affects the foreign investment project. ${ }^{626}$ And, apparently, this assessment should be much more careful than simply verifying a normative variation. Indeed, the wording of the constitutional provision invoked does not seem to embrace the superlative protection interpreted by the arbitral tribunals. The relevant paragraph acknowledges the State's attribution to establish guarantees and special securities with "the aim that the agreements may not be modified by statutes or further rules of any class that may affect their clauses" ${ }^{627}$. The guarantees and special securities referred to may reasonably take the form of political risk insurances or monetary compensations that again, may reasonably restore the equilibrium mutually agreed when the investment was made. From a basic notion of realism, in a long-term agreement the equilibrium of a mutual relationship invariably evolves. Defending inflexibly the opposite would fall foul the principle of limited government and seminal notions of trans-generational responsibility. Moreover, such stabilization guarantees were not a constitutional right but a constitutive benefit that the State might have created through a specific investment contract, which none of the claimants in the disputes derived from Law 42-2006 enjoyed.

\subsubsection{The Discursive Battle Surrounding the Reform of International Investment Protection}

Before the official release of CAITISA's report, its leaked report (executive summary) had echoed among the most prominent domestic law firms active in investment arbitration. Normally these local firms, acting in partnership with global law firms,

\footnotetext{
626 See, Salacuse (Jeswald W.), The Three Laws of International Investment: National Contractual and International Frameworks for Foreign Capital, Oxford University Press, 2013, 285 p.

${ }^{627}$ Constitution of 1998 :
}

“Art. 271.- El Estado garantizará los capitales nacionales y extranjeros que se inviertan en la producción, destinada especialmente al consumo interno y a la exportación.

La ley podrá conceder tratamientos especiales a la inversión pública y privada en las zonas menos desarrolladas o en actividades de interés nacional.

El Estado, en contratos celebrados con inversionistas, podrá establecer garantías y seguridades especiales, a fin de que los convenios no sean modificados por leyes u otras disposiciones de cualquier clase que afecten sus cláusulas. " 
provide thorough legal representation for the admission and performance of multinational corporations. As observed in the Ecuadorian investment disputes, such a relationship has militated in favour of a coherent line of litigation strategy with coordinated arguments developed by the same leading practitioners and domestic experts. One of the international litigation department's partners of one of the biggest Ecuadorian law firms representing multinational companies in the country analyzed the outcomes of the leaked CAITISA's report, noting the negative political bias of the commissioners towards the regime. Remarkably, this national practitioner criticizes the report because it "does not analyze the State's conduct that triggered the arbitrations". ${ }^{628}$ This has been a repetitive critic of domestic lawyers active in the arbitration system probably based on the heavy weight given by the arbitrators to the political statements surrounding the regulatory decisions that purportedly engendered the disputes. While the authorities suggest that these disputes could have only been routed through a system illegitimately construed, the private actors resorting to its protection contend that such controversies could have been avoided if the sovereign powers had not been exercised arbitrarily and in violation of the commitments originally agreed upon. The discursive dichotomy between sovereignty's reassertion and legal certainty is strongly rooted in the Ecuadorian political arena, leading to sum zero dialogues. On one side, the private actors with great influence in the media, professional chambers and academia, advocate inalienable tools of investment and property protection, and on the other, the governmental authorities claim that the way in which such mechanisms have been articulated and currently applied, subordinate the general interest to the private benefit. Of course, a higher lenience towards self-criticism would be desirable for both parties. In this regard, there have been more plausible efforts made by the public sector as compared to the private sector with the aim of developing objective elements for the discussion revolving around the scope of investment protection, as the CAITISA's report shows. Private actors have been very effective both global and locally in creating an inextricable link between the concepts of legal certainty, freedom, economic development and human rights. This position does not contribute to stimulating an evidence-based dialogue that touches upon the structural flaws of the system, thereby raising dogmatic notions that reduce the discussion to placing

\footnotetext{
${ }^{628}$ Marchán (Juan Manuel), “Conclusiones de CAITISA según sus ejes de acción”, Pérez Bustamante \& Ponce.

See,

http://www.ecamcham.com/site/cam/conferencias/2016/Hallazgo_de_la_CAITISA_Juan_Manuel_Merch an.pdf. Last visited, January 2017.
} 
the guardians of freedom on one side, and the guardians of the statitism on the other. Drawing attention over the wrong issues provokes for instance odd official decisions, like the Ecuadorian Constitutional Court's rulings, which condemn without nuances the system of arbitration (even State to State and State-investor arbitration) disregarding the vagueness of the substantive standards of protection or the regional decision to create a regional court of investment ("UNASUR"), which would not depart significantly from ICSID's structure ${ }^{629}$. Overlooking the real scope of the system also harms the further development of alternative responses of public policy like "regulatory experimentalism" ${ }^{630}$, contractual design, mechanisms of political risk insurance, publicprivate partnerships, among others. In short, not asking the right questions as to the rationale and real extent of the system protection, as well as to the historical and legal robustness of the standards and the incentives of the actors, has forced the solutions proposed be based on beliefs rather than on evidence. Sornarajah exemplifies this shortcoming underscoring the unjustified authority given by investment arbitrators and scholars to the FET standard, a dormant concept not a long time ago:

Armies of young $\mathrm{PhD}$ students will write theses, some of them already published, without questioning the legitimacy of how this principle had come to be such a major part of modern investment protection law. It is symbolic of the malaise in legal academia that no young scholar has dared to question the basis of the doctrine. The theses usually assume that the proposition regarding legitimate expectations is well-founded. How does a young scholar invest years of her life in a project to substantiate an assumption whose base is not tested out? How does a doctoral supervisor, (appropriately, 'Doktorvater' in Germany) fulfill his fiduciary function towards such a person writing on an area that is based on fraudulent assumptions? Academia has been caught up in this whirl-wind fraud, subverted by simple greed. It should have been seen as an uncertain basis on which to establish what one young author called the "core standard" of investment protection. It was an ephemeral phenomenon built on error that would soon be ended. ${ }^{631}$

\footnotetext{
${ }^{629}$ See, (Polanco Lazo) Rodrigo, "Beyond ICSID Arbitration: The Center for Settlement of Investment Disputes of UNASUR" in Yearbook on International Law and Policy, 2014-2015.

630 See, (Ruiz-Fabri) Helene, "Bilateral or Multilateral Courts, Arbitration, or State-to-State Dispute Settlement: thinking about an optimal system for international investment disputes" (Forthcoming_, ed. International Law and Litigation, Nomos Press, 2017.

631 Sornarajah (M.), "International Investment Law: The Obsolescence of a Fraudulent System" in M. Bugenberg ey al. (eds.), European Yearbook of International Economic Law 7, 2016, 222-223 pp.
} 
The aggressive intrusion of these novel principles of public international law, like legitimate expectations and indirect expropriation in conjunction with unexplored and unsound mechanisms of treaty interpretation, may explain the difficulty which several rule makers had in grasping the core of the system protection. And this is well reflected in the responses given to arguably minimize the State's exposure to the system. As explained in detail in the following chapter, the Ecuadorian constitutional provisions supposedly paving the way for the definitive dismantling of the exorbitant mechanisms of foreign investment protection seem to leave a gap between the traditional Calvo doctrine and the novel prohibition on concluding international investment agreements. Compared to the former wording framing the Calvo doctrine, the current provision omits the odd prohibition to transfer jurisdiction to foreign adjudication bodies (either courts or arbitral tribunals) in contracts signed within the Ecuadorian territory. It exclusively sets forth that the contracts signed between the State and foreign persons implies resigning to diplomatic protection. By reading this provision in conjunction with the apparent constitutional prohibition to sign treaties "yielding" jurisdiction to arbitral tribunals in disputes with foreign persons in contractual or commercial issues, it seems that the Constitution reserved the State's authority to submit to international dispute settlement venues any sort of disputes conventionally agreed upon. Pursuant to the Constitution, it should not be necessary for the Attorney General's authorization to submit disputes to arbitration in matters other than public procurement. In any case, the Code of Planning and Public Finances expanded the Attorney General's authority to the arbitration clauses involving the State within any matter. The widespread sensitive assimilation of the restrictive notion of sovereignty has provoked for instance, influential politicians to accuse any submission to international arbitration as a threat to the Nation and a violation of the Constitution. ${ }^{632}$ This irascible pre-disposition may be well attributed to the discursive mechanisms developed and replicated by governmental officials that have put within the same basket of "lost sovereignty" any foreign adjudicator's decision that State's officials do not like (normally equating the government's interest with the public interest). As noted, neither the Constitution nor the Ecuadorian legal tradition have prohibited the submission of disputes involving the State to foreign jurisdictions, except for: a) disputes triggering treaty based arbitration under personal and material limitations provided for in the Constitution (Art.422, Constitution); b) disputes non arbitrable in

632 See footnote 528. 
accordance to domestic law (Art. 190, Constitucion). Therefore, the radical statements made by the Constitutional Court criticizing without distinction, international arbitration as a tool that despises the domestic system of administration of justice does not correspond to a steady official practice recognizing arbitration as an appropriate mechanism of dispute settlement. Anyway, it must be recalled that prior to the BITs' boom and the successive constitutional reforms made during the 1990s for facilitating their deployment, the State had a stricter control over the disputes it may have been exposed to, both internationally and domestically. As examined in chapter II, the main hurdles imposed to the contractual State's submission to "alien jurisdiction", dealt in one hand, with the odd territorial prohibition that forbade such a kind of agreements when the contract was signed within national territory and in the other, with the restricted list of arbitrable disputes, that left aside those derived from the exercise of regulatory powers. For instance, the Hydrocarbons Law allowed submitting to arbitration contractual disputes in accordance with Ecuadorian Law (1993). ${ }^{633}$

\subsubsection{Reformist Pragmatism and the Omnipresence of International Legal Concepts}

Although cryptic, the relevant constitutional provisions governing the submission of the State to international jurisdiction, suggest the aim to curtail the consequences of internationally wrongful acts in disputes arguably involving the "treatyfication" of mere private interests and not rights. The chosen solution entails foreclosing the capacity of adopting primary rules that may confer on private parties the right to directly bring disputes against the State in "commercial or contractual" controversies. As noted, the Ecuadorian constitutional design and the regional reforms have mainly targeted the mechanisms for dispute settlement, disregarding the importance of reforming the substantive primary rules. Therefore, it is notable that the Constitutional Court had barely

${ }^{633}$ Reform to Hydrocarbon Law (1993):

"Art. 3- Sustitúyase el artículo 10 por el siguiente:

El Ministro de Energía y Minas es la instancia superior administrativa en los reclamos que se originen por actos o resoluciones de la Dirección Nacional de Hidrocarburos. Sin embargo, el usuario tendrá el derecho de acudir directamente ante el Tribunal Distrital de lo Contencioso Administrativo, órgano jurisdiccional competente para conocer las reclamaciones directas o para resolver las apelaciones de las decisiones del Ministro.

Las controversias que se deriven de los contratos se substanciarán ante las Cortes Superiores de Justicia, en trámite verbal sumario, o por el procedimiento de arbitraje reconocido por la Ley ecuatoriana, de acuerdo a lo establecido en los contratos. En el ejercicio de jurisdicción legal, la primera instancia se tramitará ante el respectivo Presidente de la Corte Superior y la segunda instancia ante una de sus salas". 
impeached the constitutionality of the BITs substantive standards, and that the regional attempts of reform were mainly aligned to change the system of dispute settlement. In turn, the authority of the vague concepts embodied by the standards spread through thousands of BITs has been neglected, as it can be seen for instance, with the impact of the methods for determining the amount of compensation. ${ }^{634}$

The determination to debunk the system of investment protection as built during the 1990s took momentum in 2010, following the denunciation of the Washington Convention and several BITs in 2009. This decision was domestically complemented by the presidential request to initiate the process for denouncing the remaining BITs, while the new legal framework embracing thoroughly trade and investment matters was concluded. As a result, the "Organic Code on Production, Trade and Investment" 335 was supposed to become the main legal framework governing the relationships between the State and the investors (foreign and national), both by derogating the 1990s investment rules and by terminating the BITs. In contrast to the coherent set of measures fostered to levelling the playing field with investors by replacing treaty based protection with a more balanced contract based protection ${ }^{636}$, the measures required at the international level for perfecting this reformation cycle (i.e., the notification of the termination of treaties) had

${ }^{634}$ As stated by the CAITISA's report:

There have also been questions about the erroneous interpretation and application of the compensation rules when damages are awarded. The general character and the lack of objectivity of such render turn them inapplicable in specific situations, because they are not able to adapt to the particular situation of each case and each State. Furthermore, they contravene the national legislation that prohibits compound interest ("anatocismo")

It must be noted, that the Constitution of Ecuador addresses specifically the prohibition of "interest compound" in two provisions. With relation to public debt, it prohibits that the re-negotiation agreements contain expressly or tacitly, any form of usury or "compound interest" (Art. 289, 4). It also prohibits collusion, usury and "compound interest" in the financial and credit sector (Art. 308).

See, Comisión para la Auditoría Integral Ciudadana de los Tratados de Protección Recíproca de Inversiones y del Sistema de Arbitraje en Materia de Inversiones, "Auditoría integral ciudadana de los tratados de protección recíproca de inversiones y del sistema de arbitraje en materia de inversiones en Ecuador: Informe ejecutivo", May 2017, 94 p. Free translation.

${ }^{635}$ Código Orgánico de la Producción Comercio e Inversiones, Official Gazette, Supplement, December 29, 2010.

An English translation is available at the World Intellectual Property Organization website, http://www.wipo.int/edocs/lexdocs/laws/en/ec/ec050en.pdf. Last visited, January 2016.

${ }^{636}$ See footnote 543 . 
to be interrupted due to alleged external pressures. ${ }^{637}$ The prolific regulatory activity the country underwent after the promulgation of the Constitution of 2008 was possible thanks to the undisputed leadership of the former President Rafael Correa, and his political party "Alianza País", which enjoyed a qualified legislative majority as of the National Constituent Assembly's inauguration in 2007 to the conformation of the National Assembly (legislative branch). This authority has assured a consistent approach in the regulatory design as it may be observed in the diverse statutory provisions dealing with or related to foreign direct investment. From the relevant provisions set forth in the "Organic Act on Public Enterprises" "38, "Organic Law on Encouragement of Public Private Associations and Foreign Investment" 639 and "General Organic Code of Processes" ${ }^{640}$, there may be seen an articulated pattern towards modulating the "arbitrability" of disputes involving the State. By doing so, these measures seemed to seek the limitation of the State's exposure to international responsibility on one hand, by paving the way for the comprehensive denunciation of the treaties supporting the system, and, in the other, by statutorily defining the areas, matters and boundaries within which international arbitration is permitted. Anyhow, it must be noted that the numerous arbitration clauses which the State or its entities have entered into, after the Constitution of 2008 far from indicating a reluctance to international arbitration, denote a constant resort to this mechanism in areas not restricted to investment or private public

\footnotetext{
${ }^{637}$ Since the ratification and denunciation of international treaties constitute an exclusive prerogative of the President per the Article 418 of the Ecuadorian Constitution, the Minister Coordinator of Production, Employment and Competitiveness, Mrs. Nathaly Cely, announced that the government decided not to proceed with the denunciation of the BITs until the approval of the Organic Code of Production, Commerce and Investment. Nevertheless, that the denunciation processes concerning most of the abovementioned BITs are still paralyzed, it is relevant to note that these instruments contain "survival provisions" that in most cases guarantee the effectiveness of the rights granted to the investors. The survival period of these clauses lasts from 10 to 20 years; consequentially Ecuador would not be able to avoid the obligations of such treaties immediately.

See, "Ecuador evita denuncia de tratados de inversión y alista Código de la Producción", September 16th, 2010.See:

http://www.ecuadorinmediato.com/Noticias/news user view/ecuador evita denuncia de tratados de in version y alista codigo de produccion--134048

See, Diario El Universo, "Solo con Finlandia se ha llegado a finalizar el tratado de inversiones", Ecuador, April 16, 2011.

${ }^{638}$ Ley Orgánica de Empresas Públicas, Official Gazette, Supplement 48, October 16, 2009.

${ }^{639}$ Ley Orgánica de Incentivos para Asociaciones Público Privadas, Official Gazette, Supplement 652, December 18, 2015.

${ }^{640}$ Código Orgánico General de Procesos, Official Gazette Supplement 506, December 9, 2016.
} 
partnerships ${ }^{641}$. Such authorizations include a wide range of disputes extending from regulatory issues to financial and pure commercial matters. To date, this indulgence has not been not replicated in national arbitration, especially when it comes to the Executive Branch and its entities, where it was practically prohibited the signature of contractual arbitration clauses by order of the former Secretary of Legal Affairs:

Pursuant to the instruction of the Constitutional President of the Republic, hereby I communicate that the diverse contracts subscribed from now on, shall be subject to the jurisdiction of the ordinary courts and not to that of the arbitral tribunals.

An exception shall be made to foreign enterprises' contracts covered by International Investment Treaties still in force. ${ }^{642}$

It has to be highlighted, that this decision did not bind other municipal entities, like provincial governments, branches different from or entities not circumscribed to the Executive. ${ }^{643}$ While, this administrative instruction does not clarify whether this prohibition also covers international contracts, the application of the general rule that permits the submission of contractual disputes to foreign jurisdiction prior the Attorney General's authorization (Code of Planning and Public Finances), would indicate that this is not forbidden. By the same token, the exception included in the instruction's second paragraph should not be read as if the same were applicable only to contracts wherein the private party has the nationality of one of the International Treaties still in force. In any case, it is remarkable that both the statutes referred to as well as the administrative instructions, acknowledge the applicability of the limitations insofar as they do not clash with the international commitments in force, thereby attempting to pay due regard to Public International Law. Therefore, the initial aspirations of annihilating the rules of investment protection as designed during the 1990s could be effective with relation to the derogated domestic norms, as opposite to international agreements, whose protection can still be resorted to, while the denunciation of the relevant treaties was not notified and the survival clauses cease to apply. The plausible attempt of perfecting a comprehensive reform inwards and outwards with the aim of pulling out from the former system of investment protection, without concluding the processes of termination of treaties may

\footnotetext{
${ }^{641}$ Between 2008 and 2016, the General Attorney authorized 748 international arbitration clauses .

${ }^{642}$ (Mera Giler) Alexis, National Secretary of Legal Affairs, "Presidencia de la República del Ecuador", Oficio No. T.1.-C.1-SMJ-12-1134, October 5th, 2012.

643 The Organic Code on Territorial Organization, Autonomy and Decentralization, the main legal framework for the provincial, cantonal and sub-territorial governments, authorizes the provision of services and execution of public works directly or through delegated management (Articles 274, 276, 279 and 283)
} 
trigger odd situations. In any case, both the regulatory instruments touching upon investors' interests as well as the new investment and public partnership contracts show an improved degree of sophistication and awareness as to the type of disputes that should be avoided and as such, will be expressly defined and carved out from such instruments. In this regard, the different statutes and contracts reassert the subordination of the economic, fiscal and trade policies to the National Plan of Development, as well as the supplementary character of foreign investment to the domestic investment. ${ }^{644}$ In this sense, it is remarkable that legal stability becomes a a well-defined entitlement conferred by the government to qualified investors involved in specific activities and restrictively applicable to sectorial regulations qualified as essential ${ }^{645}$, thereby reasonably nuancing the vague predominant notion of legal stability. Legal certainty and legal stability are concepts that have been dogmatically treated as if they were synonyms. Whereas the former is a constitutional right, the latter is a concession that the State may or not may

${ }^{644}$ Constitution 2008:

"Article 339. The State shall encourage domestic and foreign investment, and shall establish specific regulations according to investment types, giving priority to domestic investment. Investments shall be made on the basis of criteria of diversification of production, technological innovation, and striking a balance between regions and sectors.

Foreign direct investment shall supplement domestic investment; it shall abide strictly by the country's legal framework and regulations, and the application of rights, and shall be aimed at meeting the needs and priorities laid down in the National Development Plan, as well as in the various development plans of the decentralized autonomous governments.

Public investment shall be aimed at meeting the objectives of the development structure enshrined in the Constitution, and shall be implemented within the framework of national and local development plans, and of the respective investment plans."

See, http://pdba.georgetown.edu/Constitutions/Ecuador/english08.html. Last visited November, 2016.

It is also notable the defined purpose of the "Organic Code on Production, Trade and Investment":

"Art. 3.- Purpose. - The present code has as its objective regulating the productive process on its stages of manufacture, distribution, interchange, trade, consuming, handling of externalities and productive investments leaning towards the execution of the Plan for Well-Living.

The normative also seeks to generate and consolidate the regulations that boost, move forward and incentivize production with more value added; seeks to establish the conditions for increasing productivity and for promoting the transformation of the productive matrix seeks to aid in the implementation of instruments for productive, fair, ecologically efficient development and sustainable in the care of Nature".

See, http://www.wipo.int/wipolex/en/text.jsp?file id=252399. Last visited December, 2016.

${ }^{645}$ Organic Code on Production, Trade and Investment:

“ Art. (...).Estabilidad jurídica de la inversión. Además de la estabilidad tributaria que se garantiza en este Código, se podrá otorgar estabilidad jurídica de la normativa sectorial específica que hubiese sido declarada como esencial en los correspondientes contratos de concesión u otros títulos habilitantes para la gestión de sectores estratégicos o la provisión de servicios públicos. El plazo de vigencia de dicha estabilidad jurídica será el mismo plazo del contrato de inversión.”

Reformado por el num. 6. de la Disposición Reformatoria Primera de la Ley s/n, R.O. 652S, 18XII2015). 
confer in exhaustive conditions. The 1990s reforms sought to equate both concepts with regulatory stagnation and elevate the category of legal stability to a right, unconditionally and unlimitedly ensured by the State to any foreign investor. The generous sovereign commitments found in the investment contracts signed within the framework of the Constitution of 1998 and the Law on the Promotion and Guarantee of Investments (1997), whereby it has illegitimately frozen any forthcoming public action, has nothing to do with either legal certainty or with legal stability. The extensive definition of "legal stability" froze as of the contract's signature, not only the whole regulatory framework, but also judicial interpretations, instructions and rulings of further State branches, thereby openly violating the principle of separation of powers. ${ }^{646}$ Moreover, the contractual definitions

646 The investment contracts signed under the frame of the Constitution of 1998 and the Law on Foreign Trade and Investments ("Ley de Comercio Exterior e Inversiones-1997 "LEXI"), and its Regulation, extended the concept of legal stability to "legal stagnation", as read in the following contractual stipulation: “Tres Punto Cuarenta y Cinco.- Marco Legal Vigente significa (a) la Constitución, (b) los tratados y convenios internacionales ratificados por el Estado conforme a las normas pertinentes, (c) los códigos, leyes, actos normativos, normas, reglamentos, ordenanzas, resoluciones, decretos, dictámenes o sentencias de cualquier naturaleza, del Estado o cualquier Institución del Estado, incluyendo, en cada caso, las interpretaciones o aplicaciones de ellas, (e) las opiniones, declaraciones y dictámenes del Servicio de Rentas Internas, la Corporación Aduanera Ecuatoriana, el Ministerio del Trabajo y la Procuraduría General del Estado, que emitan o se entreguen con relación al Proyecto y los Acuerdos del Proyecto, y, (f) todas las autorizaciones otorgadas por el Estado o por Instituciones del Estado; en cualquier caso relativas o aplicables a este Contrato de Inversión, cualquiera de los Acuerdos del Proyecto o cualquier otro contrato, licencia, autorización u otro acto administrativo de cualquier naturaleza mediante los cuales el Estado o una Institución del Estado confiera a los Inversionistas o la Empresa Receptora derechos para ejecutar cualquier actividad económica o comercial relacionada con la ejecución del Proyecto, y en todos los casos que se encuentren vigentes a la Fecha de Suscripción. Cuando en este Contrato de Inversión se haga referencia a una disposición legal específica, se entenderá que se refiere a la correspondiente norma en vigor en la Fecha de Suscripción, a menos que en el propio texto de este Contrato de Inversión se indique otra cosa. »

See, Investment Contract signed between the Ecuadorian State and the Ministry of Foreign Trade, Industrialization, Fisheries and Competitiveness and the companies AECON Construction Group Inc., ADC Management LTD., and Quiport Corporation S.A. June, 242003. 
of "political events" 647 and "expropriation" 648 did extend well beyond any acceptable standard usually found in international contractual practice, since the former included any regulatory change regardless of its hierarchy and in latter, any loss or benefit derived from any investment connected to the project.

By the same token, it is notable that there is recurring mention of investments, productive activities and provision of services "socially desirable" and "environmentally acceptable". ${ }^{649}$ Equally important are the detailed definitions provided for by the "Organic Code on Production, Trade and Investment" to "productive investment", "new investment", "foreign investment", "national investment" and "investor", as well as the standards of protection and investors' rights ${ }^{650}$, applicable both for domestic and foreign

${ }^{647}$ The generous definition of "political event" covered any State's action or fault which may adversely change the economic or legal stance of the company:

"Tres Punto Treinta Uno.- Evento Político significa cualquier hecho o circunstancia (a) que sea el resultado (i) cualquier acción por parte del Estado, o (ii) cualquier falta del Estado o de cualquier Institución del Estado, o (ii) cualquier falta del Estado o de cualquier Institución del Estado en actuar de conformidad con las leyes, normas, reglamentos y decretos aplicables, o con cualquier Autorización de Institución del Estado, o con las opiniones, declaraciones y directrices del Servicio de Rentas Internas, la Corporación Aduanera Ecuatoriana, el Ministerio del Trabajo y el Procurador General del Estado, que se presenten o entreguen con relación a los Acuerdos del Proyecto; y (b) que substancial y adversamente cambie la posición legal o económica de los Inversionistas y/o de la Compañía Receptora de la que existía en la Fecha de Suscripción, o de la que es o hubiese sido si no hubiera sucedido dicho hecho o circunstancia."

See, Investment Contract signed between the Ecuadorian State and the Ministry of Foreign Trade, Industrialization, Fisheries and Competitiveness and the companies AECON Construction Group Inc., ADC Management LTD., and Quiport Corporation S.A. June, 242003.

${ }^{648}$ The ample definition of expropriation covered any kind of loss suffered by the investors as consequence of any State's action, including the breach or unilateral termination of the contract:

Tres Punto Treinta y Tres.- Expropiación significa, sujeta a los términos de los artículos seis (Art. 6) y quince (Art. 15) del Reglamento, cualquier pérdida sufrida por los Inversionistas o la Empresa Receptora en la propiedad, posesión o control de (a) las Inversiones o cualquiera de ellas, (b) el Proyecto o cualquier parte del mismo; (c) cualquier Bien Tangible; (d) cualquier Bien Intangible, o (e) cualquier beneficio real y substancial derivado de cualquier Inversión, el Proyecto o cualquier parte del mismo, cualquier Bien Tangible, en todo caso como consecuencia de cualquier acción o serie de acciones del Estado o de cualquier Institución del Estado, incluyendo, entre otros, cualquier acción o series de acciones que impliquen la apropiación, de cualquier Activo, incluyendo el incumplimiento o la terminación unilateral de este Contrato de Inversión o cualquier Acuerdo del Proyecto. Para que se produzca una Expropiación podrá mediar o no un procedimiento administrativo o judicial previo.

See, Investment Contract signed between the Ecuadorian State and the Ministry of Foreign Trade, Industrialization, Fisheries and Competitiveness and the companies AECON Construction Group Inc., ADC Management LTD., and Quiport Corporation S.A. June, 242003.

${ }^{649}$ Organic Code on Production, Trade and Investment, Art. 4, g.

${ }^{650}$ Organic Code on Production, Trade and Investment:

"Art. 19.- Rights of the Investors. - The following rights shall be recognized to the investors: 
investors. ${ }^{651}$ In this way, the regulatory reforms concerning the substantive and procedural matters should be labelled neither chauvinistic nor retrograde, since they

\begin{abstract}
a. Freedom of production and commercialization of licit goods and services, socially desirable and environmentally sustainable, as well as freedom of pricing, with the exception of those goods and services for which the production and commercialization are regulated by the law.

b. Access to administrative and control actions that the State establishes to avoid any speculative practice of private monopoly or oligopoly, or abuse of market dominance and other disloyal competition practices;

c. Freedom of import and export of goods and services, with the exceptions of those limits established in the norm and in accordance with the international agreements in which Ecuador partakes;

d. Free transfer abroad, in currency, of the periodical earnings or profits that come from registered private investment, once the duties concerning the workers' share, tax obligations, and others established in this code are complied with.

e. Freedom to send resources that are obtained through total or partial liquidation of the companies in which the registered foreign investment was made, or through the sale of shares, participations, or acquired rights because of investments made, once the tributary obligations as well as other pertaining responsibilities, as established in legal norms;

f. Freedom to acquire, transfer or transfer ownership of shares participations or rights of ownership to third parties, in the country or abroad, abiding by the formalities provided in the law;

g. Freedom of access to the national financial system and to the stock market, to obtain long, midor, long term financial resources.

h. Freedom of access to the mechanisms for promotional, technical, co-operation, technological assistance and other equivalents; and,

i. Access to the rest of general benefits and incentives provided for in this Code, other laws and applicable normative."
\end{abstract}

An English translation is available at the World Intellectual Property Organization website, http://www.wipo.int/edocs/lexdocs/laws/en/ec/ec050en.pdf. Last visited, January 2016.

${ }^{651}$ Organic Code on Production, Trade and Investment:

"Art. 17.- Non-Discriminatory Conduct.- National and foreign investors; societies, companies or entities from the co-operative, popular, and supportive economy, in which these partake as well as well as their legally established investments in Ecuador, with the limitations provided by in the Constitution of the Republic, shall have equality of conditions with respect to administration operation, expansion, and transfer of their investments, and shall not be the subject of discriminatory or arbitrary measures. Foreign investors and investments shall have full protection and equal protection of the law, in such way that they shall have the same protection that Ecuadorean nationals receive within the national territory.

The State in all its governmental levels, exercising their public authority, could give differentiated treatment, as a way of incentives, in favour of new and productive investments, which will be given in function of sectors, geographical location, or other parameters which they will have to comply with, according to the terms provisioned in this Code and its Regulations.

Foreign investments shall have a direct complementary role in the strategic sectors of the economy that require investment and financing to reach the objectives of the National Development plan, and subject to applicable legislation. In the rest of the economy's sectors, foreign investors can directly participate without the need of previous or additional authorisation provided for national investors.

Governmental entities shall promote in a priority way the attraction of direct foreign investment according to the needs of, and priorities defined in, the National Plan for Development, the Productive Transformation Agenda, as well as in the different developmental plans of the decentralized autonomous governments. Additionally, the investments made in other sectors of the economy will have the same benefits from State policies of productive stimulus, in terms of the present norm.

Art. 18.- Ownership Rights. - The property of investors shall be protected in the terms established in the Constitution and other pertinent laws. The

The Constitution prohibits all manners of confiscation. Therefore, confiscation of national or foreign investments shall not be decreed or executed. 
expressly and consistently acknowledge the authority of international treaties and the mechanisms of dispute settlement set forth therein. The format of contract developed under the Organic Code of Production, Trade and Investment addresses in detail the different mechanisms to be resorted to once a dispute arises. Pursuant to this position, the effort to draw a line between the disputes stems from the exercise of regulatory powers and those derived from contractual controversies is remarkable. From the statutory and contractual limitations of taxation disputes, it can be affirmed that Ecuadorian rule makers, rather than being frozen by "regulatory chill" have attempted to identify the kind of disputes more likely to occur with investors, either by sidelining categories, introducing intermediate stages for negotiation after certain changes occur or by incorporating procedural hurdles thereby assuring a greater and more flexible sovereign space. The investment contracts' format embodies an extensive dispute settlement clause, which includes an administrative procedure ${ }^{652}$, direct negotiations, mandatory mediation

\footnotetext{
The State can declare, exceptionally and in accordance with the Constitution, the expropriation of real estate with the sole purpose of executing social development plans, environmental sustainable management, and collective well-being, following the legally established procedures in a nondiscriminatory way, with previous assessment of value, and the payment of fair and adequate indemnification in compliance with the law.

Art. 21.- Obligatory Standards. - National and foreign investors and their investments, in general shall be subject to observance and faithful compliance of the laws of this country, and especially the ones relating to the labour, environmental, tributary and social security aspects in use.
}

An English translation is available at the World Intellectual Property Organization website, http://www.wipo.int/edocs/lexdocs/laws/en/ec/ec050en.pdf. Last visited, January 2016.

652 The Investment Contract for the mining project « Mirador » suscribed between the Coordinator Minister for the Production, Employment and Competitiveness, representing the Ecuadorian State and

Ecuacorriente S.A, defines the procedures available for the investor in case of the conflicts stated therein : "CLAUSULA TRIGESIMA PRIMERA: RECURSOS DE LOS INVERSIONISTAS Y DE LA EMPRESA RECEPTORA.- El Inversionista y la Sociedad Receptora tienen derecho a interponer los recursos que correspondan en caso de incumplimiento por parte del Estado de las obligaciones y compromisos asumidos por éste en el Contrato de Inversión y en la Legislación Aplicable conforme lo previsto en el Artículo veinte y dos número once del Reglamento de Inversiones; así como por violación o incumplimiento de los derechos establecidos en la Constitución, convenios internacionales y demás Legislación Aplicable, tales como las establecidas en los Artículos once, ochenta y dos, doscientos veinte y seis y trescientos treinta y nueve de la Constitución. Toda resolución que dicte la Secretaría Técnica será objeto de los recursos previstos en el Estatuto del Régimen Jurídico y Administrativo de la Función Ejecutiva y Legislación Aplicable, pudiendo ser impugnada ante el Consejo Sectorial."

"CLAUSULA VIGESIMO SEPTIMA: REVOCATORIA DE LOS INCENTIVOS Y LOS BENEFICIOS ESTABLECIDOS A FAVOR DE LA SOCIEDAD RECEPTORA.- Sin perjuicio de las acciones civiles o penales a que hubiere lugar, la comisión de cualquiera de las acciones $u$ omisiones señaladas en esta cláusula, de acuerdo con lo establecido en el Artículo 31 del COPCI podrá generar la revocatoria de los incentivos tributarios otorgados y de los beneficios señalados en la cláusula Décima Sexta de este Contrato: a) Incumplimiento por parte de la Sociedad Receptora de efectuar oportunamente los aportes o adquisiciones, dentro del plazo previsto para el efecto en el Proyecto de Inversión, este Contrato y según lo establecido en los Planes General y 
and international arbitration. ${ }^{653}$ With relation to international arbitration, this can be initiated six months after the administrative procedure had been concluded, under the

\begin{abstract}
Anuales de Trabajos e Inversiones; b) Retiro de la totalidad o parte de la Inversión, siempre que esto implique incumplimiento de obligaciones legales o contractuales; c) Incumplimiento por parte de la Sociedad Receptora en ejecutar las condiciones mínimas de la Inversión que han sido autorizadas conforme a la Cláusula Vigésima Primera (Parámetros Aplicables al Proyecto de Inversión) de este Contrato; d) Cesión de la Inversión, sin cumplir con los requisitos y condiciones previstos en la Legislación Aplicable; e) Incumplimiento doloso comprobado por autoridad competente, de las leyes laborales, tributarias, de seguridad social o ambientales del país, y demás normas que regulan la inversión; f) Falsedad comprobada judicialmente en los documentos o información proporcionada, que sirvió de base para obtener los incentivos a la inversión; g) Impedir o dificultar las comprobaciones de los funcionarios de las entidades del Estado, competentes en esta materia, o recurrir a medios de cualquier clase para inducir a error a estas entidades o sus funcionarios oficiales, con el objetivo de beneficiarse de los incentivos que reconoce el COPCI; h) Cohecho o intento de cohecho a los servidores públicos encargados del control y supervisión de los beneficios reconocidos por esta normativa, declarado judicialmente, sin perjuicio de la acción penal a que hubiere lugar; e, i) Que hayan sido beneficiados de los incentivos quienes estén prohibidos por ley. En los casos de los literales a) y c) de esta Cláusula, no se considerará como infracción el incumplimiento o modificación de las Inversiones y, por lo tanto, no pueden dar lugar a la revocatoria de los incentivos: (i) cuando se trate de suspensión de actividades producida por Fuerza Mayor o Caso Fortuito debidamente comprobadas: o, (ii) por razones técnicas o de mercado conforme lo establecido en el CEM y en este Contrato; o, (iii) cundo las Inversiones hayan sido realizadas de acuerdo con los Planes Anuales de Trabajo e Inversiones e Informes de Ejecución de dichos Planes."
\end{abstract}

${ }^{653}$ The Investment Contract for the mining project « Mirador » suscribed between the Coordinator Minister for the Production, Employment and Competitiveness, representing the Ecuadorian State and Ecuacorriente S.A, also stipulates the mechanisms for the settlement of disputes providing for a process of : 1) direct negotiations ; 2) compulsory mediation ; 3) international arbitration.

"Cláusula Trigésimo Segunda: Solución de Controversias: De acuerdo con el Artículo veinte y siete del COPCI, las controversias que surjan de este Contrato entre la Sociedad Receptora y/o los Inversionistas con el Estado Ecuatoriano, que se hubieren agotado completamente por la vía administrativa, intentarán solucionarse de manera amistosa, con diálogos y negociaciones directas por un término de sesenta (60) días. Si no se llegase a una solución directa entre las Partes, deberá existir una instancia obligatoria de mediación dentro de los tres (3) meses siguientes a la fecha de inicio formal de las negociaciones directas. Si luego de esta instancia de mediación la controversia subsiste, el conflicto será sometido a arbitraje internacional, de conformidad con los tratados e instrumentos internacionales vigentes, de los que Ecuador forma parte. Las decisiones de ese Tribunal serán en derecho, la legislación aplicable será la ecuatoriana y los laudos serán obligatorios y definitivos para las partes. Si luego del término de seis (6) meses de agotada la vía administrativa, las Partes no han llegado a un acuerdo amistoso, ni la hubieren sometido a jurisdicción arbitral para la solución de sus conflictos, la controversia se someterá a conocimiento de la justicia ordinaria nacional. No se someterán a arbitraje los asuntos tributarios, Se entenderá que se ha agotado la vía administrativa cuando el acto o hecho que origine la controversia se encuentre firme, sea por falta de impugnación o por resolución de última instancia en dicha vía. Todas las controversias o reclamos surgidos de este Contrato de Inversión, a excepción de aquellos en materia tributaria, se resolverán según el mecanismo de solución de controversias previsto en esta cláusula. 32.1. Diálogos y negociaciones directas. -Las Partes deberán primero tratar de solucionar la controversia de manera amistosa mediante diálogos y negociaciones directas entre ellas, de acuerdo con el Artículo veinte y siete del COPCI y Artículo veinte y siete del Reglamento de Inversiones. a) Para tal efecto, el Inversionista y/o la Sociedad Receptora deberá solicitar por escrito a la autoridad nacional en materia de inversiones, el inicio de un proceso de diálogos y negociaciones directas entre las Partes y otras entidades involucradas, respecto de la medida o actuación que considere que ha violado o incumplido el presente Contrato o la Legislación Aplicable. La fecha de presentación de esta solicitud se considerará como la fecha de inicio formal de los diálogos y negociaciones directas. b) Los diálogos y negociaciones directas intentarán realizarse de manera presencial o por cualquier medio tecnológico disponible para las Partes, por 
administration of the Permanent Court of Arbitration and pursuant to the UNCITRAL Arbitration Rules. The seat of arbitration is Chile, the language, Spanish, and the governing law is Ecuadorian. The clause analyzed, opportunely reiterates the exclusion from arbitration of disputes not arbitrable as set forth by Ecuadorian Law at the time of

un término de sesenta días. c) Cuando se hubiere llegado a un acuerdo total o parcial, el o los Inversionistas y/o la Sociedad Receptora, respectivamente, no podrán someter los acuerdos alcanzados al procedimiento de solución de controversias bajo las demás disposiciones de esta cláusula, salvo que dicho acuerdo haya sido incumplido por cualquiera de las Partes o que dicho acuerdo hubiese sido parcial sobre su reclamo.-3.2 Mediación obligatoria.- Si durante el período de diálogos y negociaciones directas las Partes no alcanzaren una solución total o el acuerdo fuere parcial respecto a las reclamaciones de el o LOS Inversionistas y/o la Sociedad Receptora, la controversia surgida de este Contrato de Inversión, será sometida a un procedimiento de mediación obligatoria, conforme a las reglas de la Ley de Arbitraje y Mediación, en cualquier centro de mediación registrado en el Consejo de la Judicatura a elección de la Parte reclamante. La solicitud de mediación deberá presentarse en cualquier momento dentro del mes siguiente a la terminación del período de diálogos y negociaciones directas. El mediador designado por el referido Centro y el procedimiento respectivo se someterá a las reglas administrativas y de funcionamiento, previstas para la sustanciación de este tipo de procesos. El procedimiento de mediación deberá desarrollarse en un plazo máximo inexorable de un (1) mes contado desde la presentación de la solicitud de mediación. Si dentro de dicho plazo, por cualquier causa, no se llegara a un acuerdo total e integral entre las Partes o se llegara a tramitar o terminar el proceso de mediación; la controversia podrá tramitarse conforme los previsto en el numeral treinta y dos punto tres de esta cláusula. Para tal efecto, no se requerirá de la constancia de imposibilidad de mediación ni de ninguna otra formalidad o certificación, sino tan sólo la declaración simple de cualquiera de las Partes de que dentro del plazo de un (mes) no se ha llegado a un acuerdo final." 
the contract's signature. ${ }^{654}$ Furthermore, the investor waives through the contract resorting to diplomatic protection. ${ }^{655}$

${ }^{654}$ The Investment Contract for the mining project « Mirador » suscribed between the Coordinator Minister for the Production, Employment and Competitiveness, representing the Ecuadorian State and Ecuacorriente S.A provides for the mechanism of international arbitration before the Permanent Court of Arbitration, defining as its seat, the Hague :

32.3 Arbitraje Internacional. - Las disposiciones que se incluyen en este numeral serán aplicables en caso de que las controversias o reclamos surgidos de este Contrato de Inversión, no hubieren sido resueltos conforme a lo establecido en los numerales treinta y dos punto uno y treinta y dos punto dos. El Arbitraje deberá ser iniciado por cualquiera de las Partes antes de los seis (6) meses de agotada la vía administrativa. El procedimiento arbitral se llevará a cabo de acuerdo con las siguientes reglas: El arbitraje internacional se llevará a cabo al amparo del Reglamento de Arbitraje de la Comisión de las Nacionales Unidas para el Derecho Mercantil Internacional, CNUMDI de mil novecientos noventa y setenta y seis, y será administrado por la Corte Permanente de Arbitraje con sede en La Haya. Uno. Lugar de Arbitraje. La sede de arbitraje será Santiago de Chile, Chile. Dos. Idioma. El idioma del procedimiento será el castellano. Cualquier Parte podrá presentar pruebas testimoniales o documentales en un idioma distinto al castellano, siempre que esa Parte le provea a la otra Parte una traducción escrita al castellano de dicha prueba testimonial o documental. Tres. Arbitraje en Derecho. El arbitraje será en Derecho y la normativa aplicable al fondo de la controversia, será el Derecho Ecuatoriano. Cuatro. Constitución del Tribunal Arbitral. El Tribunal Arbitral estará compuesto por tres miembros Cada una de las Partes designará a un árbitro, y el tercero, que actuará como Presidente del Tribunal Arbitral, será designado de común acuerdo por las Partes. Si una Parte no designara a un árbitro o llegaren a un acuerdo sobre el nombramiento del Presidente dentro de los noventa días contados a partir de la notificación del inicio del procedimiento, el nombramiento será hecho por el Secretario de la Corte Permanente de Arbitraje con sede en La Haya quien actuará como autoridad nominadora. Salvo pacto en contrario, los árbitros no deberán tener la misma nacionalidad de las Partes. Cinco. Elección y renuncia. El arbitraje previsto en la presente Cláusula valdrá como elección de la vía para la resolución de las desavenencias derivadas del presente Contrato. Seis. Exclusión de ciertas materias del ámbito del arbitraje y atribución de jurisdicción a tribunales y cortes nacionales. No podrán ser resueltas mediante arbitraje y deberán ser resueltas por los tribunales competentes del Ecuador disputas sobre las materias que no son transigibles y, por lo tanto, no son arbitrables de conformidad con las Legislación Aplicable vigente a la fecha de suscripción de este Contrato de Inversión. Siete. Costos. Los costos del procedimiento serán cubiertos en partes iguales, a no ser que el Tribunal en su laudo, decida lo contrario. Ocho. Ejecución del laudo. El laudo que dicte el Tribunal Arbitral será de cumplimiento obligatorio para las Partes y será ejecutado ante los jueces o cortes competentes.

${ }^{655}$ Investment Contract for the mining project « Mirador » suscribed between the Coordinator Minister for the Production, Employment and Competitiveness, representing the Ecuadorian State and

Ecuacorriente S.A:

CAPITULO IV.-DISPOSICIONES GENERALES.- CLAUSULA TRIGESIMA TERCERA.GENERALIDADES.- Las Partes acuerdan de manera expresa que: a) Si en cualquier momento, durante la vigencia de este Contrato, alguna de sus estipulaciones se considera que se torna ilegal, inválida o inejecutable: (a) esta circunstancia no afectará a legalidad, validez o ejecutabilidad de este Contrato de Inversión o de las restantes estipulaciones del mismo, y (b) las Partes substituirán dicha estipulación con otra estipulación, válida, legal y ejecutable.-b) Este Contrato de Inversión no puede ser substituido, renunciado, revocado, modificado o terminado, a menos que dicha substitución, renuncia, modificación o terminación se haga de conformidad con la Legislación Aplicable y este Contrato.- c) Cada una de las Partes declara y garantiza, para beneficio de las otras Partes: (a) que la celebración y ejecución de este Contrato de Inversión por dicha Parte, no viola ni contradice ni se halla en incumplimiento con sus documentos constitutivos, ni con cualquier contrato o documento mediante el cual dicha Parte esté obligada, ni ninguna disposición del ordenamiento jurídico nacional, y (b) que ha obtenido todos los permisos, consentimientos, informes y autorizaciones de toda otra Institución según legalmente se requieran o fueran necesarios, a fin de que dicha parte celebre este Contrato de Inversión. - d) El Inversionista y/o la 


\subsection{Drawing the New Boundaries of Investor- State Conflict Management}

\subsubsection{Influencing Investment Commitments through Domestic Measures}

The swinging pendulum between idealism and pragmatism has been the rule in the regulatory design of the normative framework applicable to investments. In late 2015, the government struck by a growing economic crisis, had to relax its outspoken reluctance towards concessions and prompted the promulgation of the Organic Law on Encouragement of Public Private Associations and Foreign Investment (OLEPPAThis organic law introduced a noteworthy innovation departing from the constitutional relevant wording (Art. 422, CRE) and tolerating without nuances international arbitration insofar as the venue is Latin-American ${ }^{656}$. The contract based arbitration provision reads as follows:

Sociedad Receptora renuncian expresamente a toda reclamación diplomática, en los términos establecidos en el Artículo trescientos siete de la Constitución de la República.

${ }^{656}$ The leaked Cable 235229 summarizes the main legal concerns of several Ambassadors representing the countries with which Ecuador signed BITs, subject to the domestic process of termination. The Minister of Foreign Affairs at the time, Fander Falconí together with his main legal counselor, Marco Albuja, explained the scope of the legal and policy reasons behind the government's action to terminate the BITs, as well as the transition process. The leaked report shows the strong governmental stance towards recognizing investment disputes through arbitration as long as they were conducted in a national or regional forum. The time has shown in one hand, that the supervening circumstances influenced in the moderation of the government's reluctance to submit disputes to arbitration beyond the Latin-American boundaries, and in the other, the unsolved issues pointed out by the Ambassadors that have made difficult the operationalization of regional venues that replace the dominant venues of arbitration like ICSID:

10. (SBU) With regard to international arbitration, Abuja stated that Article 422 of Ecuador's Constitution does not permit Ecuador to enter into international agreements in which the State would be subject to rulings by international dispute settlement bodies in State-investor disputes. According to Abuja, the Constitution requires that State-investor disputes only be heard before national or regional dispute settlement bodies. Ecuador aims to develop a new arbitration mechanism that guarantees equity and equal conditions for all parties within UNASUR or ALBA. Abuja also mentioned that the Organization of American States (OAS) is considering the establishment of a dispute settlement body in Central America or the Caribbean. Abuja noted that the restriction regarding international arbitration did not apply in cases of State-State disputes. After Abuja's presentation, the Canadian ambassador commented that Canadian investors were very concerned with the GoE's decision and pointed out that it would be impossible to negotiate a new investment agreement calling for regional arbitration when these regional dispute settlement bodies do not yet even exist. The German ambassador challenged Abuja's interpretation of Article 422 claiming that even regional arbitration did not appear to extend to nationals that were not citizens within Latin American. Abuja claimed that the GoE interpretation of the article was that it applied to investors of any nationality. (Note, the EU representative affirmed during the meeting that any new investment agreement would be negotiated between Ecuador and the EU, rather than with individual EU member states.) 
"Art. 19.- General Rule. - If the disputes are submitted to international arbitration, the proceedings must be conducted before a Latin-American arbitration venue. The contractual Parties may appoint the arbitral jurisdictional entities in the LatinAmerican region." 657

Learning from the dogma that assuring unconditional access to international arbitration is a prerequisite for attracting foreign investment, one of the national leading practitioners in the field of investment arbitration criticized the abovementioned provision, together with the obligation to exhaust administrative remedies already enshrined by the Organic Code on Production, Trade and Investment:

Despite OLEPPA's positive features, its requirements and limitations regarding arbitration may undermine the legislative intent of attracting foreign investors. For example, the requirement to exhaust administrative remedies as a condition to initiate the arbitration process seems to be an unnecessary burden for investors. The exhaustion of administrative remedies may cause delays and create needless uncertainties for the investor.

Moreover, the requirement that international arbitration take place in Latin America is rather odd. The government has agreed to settle disputes with foreign parties before such institutions as the London Court of International Arbitration, so it is unclear why OLEPPA does not treat foreign investors which sign a partnership association with the state in the same manner. Finally, the exclusion of tax matters from arbitration seems to contradict one of the key features of the law: granting tax exemptions to the operations of investors. ${ }^{658}$

The latter criticism is well founded considering the need to develop a consistent governmental approach to the treatment of disputes that amalgamate key sovereign commitments. Therefore, due to the constitutional orientation towards strengthening regional integration in areas like international arbitration, where allegedly, the predominant rules have grossly disregarded the unfair relations of power which are

See, Cable 235229, 11/17/2009, Reference to November 12 meeting with Embassy representatives of the affected countries, http://www.eluniverso.com/2011/04/26/1/1355/cable-235229.html. Last visited, January 2017.

${ }^{657}$ The Organic Law on Encouragement for Public Private Associations and Foreign Investment sets forth:

"Art. 19.- Norma General. En el caso de que se sometan las controversias contractuales al arbitraje internacional, este se realizará ante una instancia arbitral regional latinoamericana. Las partes contractuales podrán designar los órganos jurisdiccionales arbitrales en la Región Latinoamericana."

658 Pérez Loose (Hernán), "International arbitration in public-private partnership", International Law Office, January 21, 2016.

See,http://www.internationallawoffice.com/Newsletters/Arbitration-ADR/Ecuador/CoronelPrez/International-arbitration-in-public-private-partnerships. Last visited, December 2016. 
unfavourable to the sovereign stance of Latin-American countries, it could be inferred that this effort would seek to assure the participation of adjudicators familiar with the regional legal, economic and social context. ${ }^{659}$ Additionally, and in view of the enormous sums driven by the industry of arbitration, specializing in regional institutions as hubs for dispute settlement would make sense from an economic perspective. Following this path, the Regulation on the Organic Law on Encouragement of Public Private Associations and Foreign Investment took a step forward and besides reaffirming Ecuadorian Law as applicable to the merits, it prescribed Spanish, as the language to conduct arbitration proceedings. Although this should not be an insurmountable requirement for top arbitration practitioners normally fluent in several languages, introducing this constraint to disputes involving public private-partnerships gives a strong signal as to the attempt of the State to reduce the group of counselors engaged in this kind of proceedings. Pérez Loose criticizes the obligation of exhausting administrative remedies before commencing arbitration, on the presumption that submitting disputes to arbitration in accordance with this framework entails the waiver of treaty based protection and the exclusion of tax matters from arbitration. ${ }^{660}$ Indeed, one may dispute the effectiveness of the mentioned regulatory procedural impediment to treaty based arbitration, if the party elects contract based arbitration, thereby attempting to incorporate a domestic "fork in the road" provision. This regulation also sets forth the rules to national arbitration despite the practical prohibition on central government's entities from entering into arbitration

659 Regulation on the Organic Law on Encouragement for Public Private Associations and Foreign Investment:

"Art. 22.- International Arbitration. - International arbitration shall be in law, in Spanish language and the law applicable to the merits of the dispute shall be Ecuadorian law. In these processes the following rules should also be considered:

1. Election and waiver. - In disputes arising out or in connection with the PPP Contract, the election to arbitration shall be definitive pursuant to any Treaty on the Promotion and Protection of Investments that may be invoked by the investor.

2. All disputes relating directly or indirectly to tax matters may not be settled by arbitration and shall be processed before the courts of the Republic of Ecuador."

See, Reglamento General de Aplicación de la Ley Orgánica de Incentivos para Asociaciones PúblicoPrivadas y la Inversión Extranjera. Free translation.

660 Pérez Loose (Hernán), "Executive regulations for arbitration in public-private partnerships",

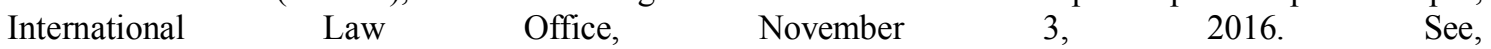
http://www.internationallawoffice.com/Newsletters/Arbitration-ADR/Ecuador/Coronel-Prez/Executiveregulations-for-arbitration-in-public-private-partnerships. Last visited, December 2016. 
clauses with domestic contractors as mentioned above. ${ }^{661}$ Regretfully, this is not the only issue wherein the government has had to circumvent its own regulations; therefore, it is difficult to understand why it keeps adding requirements that it will not further comply with. This is the case for instance of the 50 years' public-private association agreed upon with a Turkish investor for building, operating and managing a port, which embodies an ICC arbitration clause providing for Paris as the seat of arbitration and the proceedings to be conducted in English. ${ }^{662}$

Evidently, the extralegal influences embedding strategic investments tip the balance in favour of the choice of international forums to the settlement of disputes. This logic rooted on the management of interstate claims, confirms the unusual recourse to national forums for the settlement of disputes involving foreign interests, either public or private:

For interstate claims the principles of standing are relatively well-established. A state can bring a claim against another state that allegedly did not perform an international obligation if the former State is legally injured by that nonperformance. A state is legally injured if the obligation that was breached was owed to it.

The almost complete absence of interstate claims in domestic courts casts serious doubt on the degree to which the major actors in the international legal order see domestic courts as institutions that can be relied upon to make a significant and trustworthy contribution to the international rule of law. Indeed, it supports the proposition that the application of internal law by domestic courts leads to a bifurcation of international law, where some parts of international legal orders mingle with domestic legal orders, and are thereby strengthened in terms of their legal quality, whereas other, more traditional parts remain stuck in the interstate model with accompanying weak enforcement. ${ }^{663}$

In this context, it seems unrealistic that the attempt to recover sovereign space expressed in the confinement of disputes involving foreign interests to local courts will be achievable in developing countries, dependent on FDI flows, mainly devoted to extractive

\footnotetext{
${ }^{661}$ See, Artículo 21, Reglamento General de Aplicación de la Ley Orgánica de Incentivos para Asociaciones Público-Privadas y la Inversión Extranjera.

Free translation.

662 "Yildrim Holding Set on Investing USD 750 Min in Ecuador", World Maritime News, February 16, 2016. See, http://worldmaritimenews.com/archives/183136/yildirim-holding-set-on-investing-usd-750mln-in-ecuador/. Last visited December, 2016.

"Gobierno firma concesión para modernizar Puerto Bolívar", El Telégrafo, 8 de Agosto de 2016. See, http://www.eltelegrafo.com.ec/noticias/economia/8/gobierno-firma-concesion-para-modernizacion-depuerto-bolivar. Last visited, December 2016.
}

${ }^{663}$ Nollkaemper (André), National Courts and the International Rule of Law, Oxford University Press, Great Britain, 2011, 97 p. 
industries. This reality in combination with the international commitments agreed upon by the State, renders ineffective any nationalistic measure promoted within the domestic arena. Moreover, taking a regulatory measure considering exclusively its domestic effects, instead of improving the State's legal stance before the international community could make it worse. The attempts of reforming the State-investor relationships must take into consideration the different layers of influence that a regulatory measure may touch upon either at the domestic or international context. Divorcing the national reforms from the decisions entailing foreign affairs involve reputational costs, the upset of country risk indicators and the diminishment of political legitimacy, both indoors and outdoors. Indeed, the aggressive Ecuadorian attempt to reform the system of treaty based protection was received with scepticism by the international community, which considered the change of constitution to be insufficient as a reason to trigger the termination of BITs, as the diplomatic cable reporting the position of the former Minister of Foreign Affairs, Fander Falconi, shows:

(SBU) Minister Falconi then turned the meeting over to MFA legal advisor, Marco Abuja, and departed. Abuja claimed the administration was working with urgency on its plan to renegotiate all the investment treaties out of concern that the existing treaties are vulnerable to a constitutional challenge that could render them null and void. On this point, the EU representative expressed concern that the Constitution, a document limited to internal affairs, could be used to void an international treaty.

While noting respect for Ecuador's sovereignty, he opined that provisions of the Constitution represent internal issues and should not affect bilateral treaties. ${ }^{664}$

This statement shows the interplay of actors and rules in the investment field. International treaties, domestic regulations, contractual commitments and political statements constitute a set of signs, functionally invoked by public authorities and investors to obtain specific results. ${ }^{665}$ In this context, the agreement to arbitrate before

\footnotetext{
${ }^{664}$ See, Cable 235229, 11/17/2009, Reference to November 12 meeting with Embassy representatives of the affected countries, http://www.eluniverso.com/2011/04/26/1/1355/cable-235229.html. Last visited, January 2017.

${ }^{665}$ Schreuer explains the particularities of the investment regime, by highlighting the ineptitude of the domestic forums to entertain international law claims like the lack of courts' objectivity, principles of sovereign immunity and the possible recourse to diplomatic protection:

"Litigation in the host State's domestic courts is often seen as lacking the objectivity that the investor desires. In addition, domestic courts are bound to apply domestic law even if that law falls short of the standards provided by international law.

Litigation in the domestic courts of States other than the host State is liable to lead to problems like State immunity, the act of State doctrine and territorial jurisdiction. Therefore, it was never a promising alternative.

International arbitration is the most rational way to close this procedural gap between the traditional international law remedy of diplomatic protection and proceedings in domestic courts.
} 
international venues not only entails the acknowledgment of a forum more convenient than the national courts to settle a dispute, but is also a signal of commitment to foreign capital. This also implies endorsing the alleged benefits of international arbitration like specialization, impartiality, swiftness and confidentiality, supposedly absent at the domestic level. Outsourcing counselling and adjudicative tasks, with the significant economic costs it entails, also implies the recognition of scarce internal capacities. Opposing the set of regulatory measures undertaken by the Ecuadorian State to reform the rules of engagement with foreign investors to the most recent arbitration agreements concluded, would denote an abdication of his reluctant initial stance on market realities. Although contractual arbitration clauses preserve to a higher extent the sovereign space, it is noteworthy that consenting to such a submission is part of the most sensible issues surrounding a bargaining deal. Dispute settlement agreements would be included within the package of the most valuable government's commitments when contractual terms are bargained:

Even in the cases where there are a number of important guidelines that governments can follow to ensure they get better value for their assets: Institutions should always be strengthened before engaging in privatization; patience should be practiced; it is sometimes better to keep oil wealth in the ground than to sell it badly; provisions should be identified for contract renegotiation ex ante; contracts should be minimally complex and evaluated on the basis of the incentives they generate and their performance in different scenarios; finally, the timing of payments should be a function of the ability of the state to bear the risk. Whatever the approach, the aim of government decisions should be to ensure transparency, ownership and fairness. ${ }^{666}$

The improved governance in the process of contract negotiation has failed to strengthen the open access to the relevant information displaying the criteria applied to select different arbitration forums in very similar contracts. In any case, deepening the use of contractual formulas with further mitigating risk mechanisms would better enable the State's commitments to be construed in view of the circumstances of each investment:

It offers an objective international judicial procedure on the basis of internationally accepted standards that grants direct access to the investor without having to depend on its State of nationality."

See, Schreuer (Christopher), "The Relevance of Public International Law in International Commercial Arbitration: Investment Disputes", http:/www.univie.ac.at/intlaw/pdf/csunpublpaper 1.pdf. Last visited, January 2017.

${ }^{666}$ Stiglitz (Joseph E.), "What is the Role of the State?" in Escaping the Resource Curse, (Ed.) Humpreys (Macartan), Sachs (Jeffrey D.) and Stiglitz (Joseph E.), Initiative for Policy Dialogue at Columbia, Columbia University Press, New York, 2007, 23 p. 
Other legal instruments could have alleviated investor concerns about political risks, however, yet allowed host states to moderate their commitments on a caseby-case basis. Investor-state contracts governed by international law can secure individual investments with the same standards as investment treaties, including recourse to international arbitration backed by the New York or ICSID Conventions (Yackee 2009; Alvarez 2011). Combined with the existence of other risk-mitigating instruments - including insurance and various market-based mechanisms - it is no surprise that foreign investors only rarely take investment treaties into account, when deciding where and how much to invest abroad (Yackee 2011). In practice, it is almost only after disputes have arisen that foreign investors and their insurance agencies begin caring about treaty protections (Poulsen 2010). ${ }^{667}$

Indeed, there could be identified a fair assumption among Ecuadorian rule makers and governmental officers that investment treaties do little to incentivize foreign direct investments. ${ }^{668} \mathrm{As}$ it has been noted, the clarity of this policy statement contrasts with the burdensome and inextricable mechanisms established to pull out of the system. The efficacy to neutralize the regime's effects is neither immediate nor direct. Accordingly, the decision makers must look to the universe of measures, either treaty, statutorily or contractually based, to minimize any possible violation or breach. The same logic applies when the State-investor relationships are reframed; therefore, the State must carefully weigh the scope of its commitments either as treaty party, regulator or contractor. Although that the system's stakeholders, especially the politicians and public opinion still have difficulties to distinguish the differences between treaty and contract based commitments, it is undeniable that the technical understanding of the rule-makers has been developed, thanks to the bitter and costly experiences experienced by the country at the international investment law arena. The Ecuadorian State's stance to face the effects

667 Poulsen (Lauge N. Skovgaard), "Bounded Rationality and the Diffusion of Modern Investment Treaties”, International Studies Quarterly (2014) 58, 1-14, 1 p.

668 The Minister of Foreign Affairs, Dr. Fander Falconi stressed out the negligible importance given by investors to BITs when they decide to invest in the country:

"7. (SBU) In order to provide context for the GoE's actions, Falconi outlined events leading up to Correa's letter to the Assembly. Falconi said review of the country's investment policies began before the Correa Administration, noting the work of a COMEXI advisory council in 2004 to analyze the commercial and policy impacts of the country's existing BITs. In 2007, a report found little correlation between the existence of a BIT and decisions made by investors. According to Falconi, the report concluded that issues such as taxation, market size, labour laws, political stability and legal security were instead the major determinants of investment decisions."

See, Cable 235229, 11/17/2009, Reference to November 12 meeting with Embassy representatives of the affected countries, http://www.eluniverso.com/2011/04/26/1/1355/cable-235229.html. Last visited, January 2017. 
and reform of the system has been multifarious and vigorous. Over the time rule makers have understood that this kind of response needs to consider the multiple levels that investment interests influence, looking carefully at the particularities of the specific players and rules that represent each scope. At the domestic level, the media, private universities and interested groups like chambers of commerce and industries, have uncritically advocated that any attempt of reform, withdrawal or refrain from negotiating investment protection treaties, diminishes legal certainty and upsets foreign investments. In this context, the processes of denunciation of BITs could have never been put into motion without the legislative and executive branches coordinating their work thanks to their political closeness ${ }^{669}$. At the diplomatic level, Ecuador has worked intensively towards reforming the investment protection framework, leading the UN working group for drafting the binding instrument on Human Rights and Transnational Corporations ${ }^{670}$, commanding the regional proposals for establishing alternative Investor State Dispute Settlement rules and forums (i.e, UNASUR Arbitration Centre and "Observatorio" on Transnational Investment ${ }^{671}$ ) and recently, advocating the proposal for the International Court for Environmental Justice ${ }^{672}$. Finally, at the adjudicative level, the country's exposure to international investment disputes has turned it into a sort of "guinea pig" for testing in one side, the malleability and applicability of several concepts and in the other, to evidence, the structural cracks of the regime. A good example of the former category are the environmental counterclaims brought by Ecuador against the investors Perenco ${ }^{673}$ and Burlington ${ }^{674}$, whereas the second pitfall, can be well depicted by the frenetic signature of BITs during the 1990s, the divergent outcomes in "Law 42" arbitrations and

669 , in view that the President and the absolute majority of the National Assembly, belong to the same political party. The members of the Constitutional Court also share the President and National Assembly's animadversion towards treaty based investment protection.

670 Ministry of Foreign Affairs and Human Mobility, "Ecuador leads the proposed creation of an International Instrument on Human Rights and Transnational Corporations". See, http:/www.cancilleria.gob.ec/ecuador-leads-the-proposed-creation-of-an-international-instrument-onhuman-rights-and-transnational-corporations/. Last visited, January 2017.

671 Ministry of Foreign Affairs and Human Mobility, "Southern States Organize Observatory on Transnational Investment”. See, http://www.telesurtv.net/english/news/Ecuadors-Correa-Proposes-WorldCourt-of-Environment-Justice-20151130-0007.html. Last visited, January 2017.

${ }^{672}$ Telesur TV, “Ecuador's Correa Proposes International Court of Environment Justice at COP21”. See, http://www.telesurtv.net/english/news/Ecuadors-Correa-Proposes-World-Court-of-Environment-Justice20151130-0007.html. Last visited, January 2017.

${ }^{673}$ Perenco Ecuador Ltd v Republic of Ecuador, ICSID Case No ARB/08/6

${ }^{674}$ Burlington Resources Inc. v Republic of Ecuador, ICSID Case No. ARB/08/5 
the paradigmatic Chevron III $^{675}$ case. In this context, the still unreleased potential of investment treaty counter-claims has raised concerns among the international legal community, reaffirming the vagueness of the boundaries capable of restraining international investment adjudication. Succeeding in investment treaty counterclaims creates the predominant effect of reducing and even wiping out the Claimant's compensation-if any-. In Burlington Resources Inc. v Republic of Ecuador, the Tribunal awarded, in parallel, to the investor damages ${ }^{676}$, approximately 42 million dollars to Ecuador, calculated as the costs for environmental remediation, thereby declaring the investor and its operation partner's liability ${ }^{677}$. In Urbasser v. Argentina, although the Respondent's counterclaim regarding the violation of the human right to water ${ }^{678}$ failed in the merits, the decision of the Tribunal to entertain jurisdiction over the same and its analysis related to key aspects of general international law and its relationship to international investment law have revolutionized the landscape of the field, especially with relation to the status of non-State actors in International $\mathrm{Law}^{679}$, the application of

${ }^{675}$ Chevron Corporation and Texaco Petroleum Corporation v. The Republic of Ecuador, UNCITRAL, PCA Case No. 2009-23.

676 The investor claimed the compensation of USD. 1.515 603.095. The Tribunal awarded USD. 379'802.267, plus interests. The Attorney General, Diego García Carrión, highlighted the State's successful legal defense, which reduced the amount of the compensation in $78 \%$, considering the quantum claimed by the investor.

See, Procuraduria General del Estado, "Caso Burlington: Tribunal arbitral emite laudo final y acepta contrademanda ambiental de Ecuador, Boletín de Prensa, Quito, 08 de febrero de 2017, CS/03, http://www.pge.gob.ec/index.php/component/k2/item/887-caso-burlington-tribunal-arbitral-emite-laudofinal-y-acepta-la-reconvencion-ambiental-del-ecuador. Last visited, March 2017.

${ }^{677}$ In her counterclaim, Ecuador sought the compensation of USD. \$ 2.8 billion. Nonetheless the substantial reduction of the compensation sought, the decision upholding the counterclaim is unprecedented.

See, Herbert Smith Freehills Arbitration Notes, "Urbaser v. Argentina and Burlington v. Ecuador: Investment arbitration is not over the counterclaims yet", March 14, 2017, http://hsfnotes.com/arbitration/2017/03/14/urbaser-v-argentina-and-burlington-v-ecuador-investmentarbitration-is-not-over-the-counterclaims-yet/. Last visited, March 2017.

${ }^{678}$ Urbaser S.A. and Consorcio de Aguas Bilbao Bizkaia, Bilbao Biskaia Ur Partzuergoa v The Argentine Republic, ICSID Case No. ARB/07/26.

${ }^{679}$ The Tribunal has stressed out the obsolescence of the conception that a international law obligations are exclusively applicable to States or intergovernmental organizations:

"1194. A principle may be invoked in this regard according to which corporations are by nature not able to be subjects of international law and therefore not capable of holding obligations as if they would be participants in the State-to-State relations governed by international law. While such a principle had its importance in the past, it has lost its impact and relevance in similar terms and conditions as this applies to individuals. A simple look at the MFN Clause of Article VII of the BIT shows that the Contracting States accepted at least one hypothesis where investors are entitled to invoke rights resulting from international law (in addition to the rights resulting from Article X). If the BIT therefore is not based on a corporation's incapacity of holding rights under international law, it cannot be admitted that it would reject by necessity any idea that a foreign investor company could not be subject to international law obligations." 
peremptory norms in investment matters ${ }^{680}$ and the attribution of obligations involving human rights to corporations. In the context of the reformistic efforts considered in this section, it is worth paying attention to the Tribunal's elucidation as to the interplay of further rules of international law with international investment law provisions, especially, with regard to the confinement of several commitments to perform that belong to the realm of the domestic law as opposed to widespread assumptions that locate them in the international legal level ${ }^{681}$.

See, Urbaser S.A. and Consorcio de Aguas Bilbao Bizkaia, Bilbao Biskaia Ur Partzuergoav The Argentine Republic, ICSID Case No. ARB/07/26

${ }^{680}$ The Tribunal further notes the predominant application of peremptory norms to any contrary provision governing any obligation of international law:

"1203. Another illustration is given by peremptory norms of general international law (ius cogens) to the extent they may be of interest in an investment matter. If so, such norms must certainly prevail over any contrary provision of the BIT, as per the express statement in Article 53 of the Vienna Convention."

See, Urbaser S.A. and Consorcio de Aguas Bilbao Bizkaia, Bilbao Biskaia Ur Partzuergoa v The Argentine Republic, ICSID Case No. ARB/07/26

${ }^{681}$ Reaffirming the obligation of all parts to ensure human rights and the obligation that the BITs be construed in harmony with other rules of international law, the Tribunal clarified that in the dispute at issue, the scope of the investor's obligations related to the provision of water (obligation to perform) had it source in the concession agreement and hence, in domestic law:

"1199. At this juncture, it is therefore to be admitted that the human right for everyone's dignity and its right for adequate housing and living conditions are complemented by an obligation on all parts, public and private parties, not to engage in activity aimed at destroying such rights.

(...) 1200. The Tribunal further retains that the Convention has to be interpreted in the light of the rules set out in the Vienna Convention on the Law of Treaties of May 23, 1969, and that Article $31 \S 3$ (c) of that Treaty indicates that account is to be taken of "any relevant rules of international law applicable in the relations between the parties." The BIT cannot be interpreted and applied in a vacuum. The Tribunal must certainly be mindful of the BIT's special purpose as a Treaty promoting foreign investments, but it cannot do so without taking the relevant rules of international law into account. The BIT has to be construed in harmony with other rules of international law of which it forms part, including those relating to human rights.

(...) 1210. While it is thus correct to state that the State's obligation is based on its obligation to enforce the human right to water of all individuals under its jurisdiction, this is not the case for the investors who pursue, it is true, the same goal, but on the basis of the Concession and not under an obligation derived from the human right to water. Indeed, the enforcement of the human right to water represents an obligation to perform. Such an obligation is imposed upon States. It cannot be imposed on any company knowledgeable in the field of provision of water and sanitation services. In order to have such an obligation to perform applicable to a particular investor, a contract or similar legal relationship of civil and commercial law is required. In such a case, the investor's obligation to perform has as its source domestic law; it does not find its legal ground in general international law. The situation would be different in case an obligation to abstain, like a prohibition to commit acts violating human rights would be at stake. Such an obligation can be of immediate application, not only upon States, but equally to individuals and other private parties. This is not a matter for concern in thecurrent case."

See, Urbaser S.A. and Consorcio de Aguas Bilbao Bizkaia, Bilbao Biskaia Ur Partzuergoa v The Argentine Republic, ICSID Case No. ARB/07/26 


\subsubsection{The System of Investment Protection as Neutralizer of Core Legal Values}

The negotiation of Transnational Trade and Investment Partnership (TTIP) involving the main players of Investor-State Dispute Settlement arena, concentrated the most comprehensive efforts to tackle the structural imbalances of the regime, historically ignored by many of the country members' stakeholders, due to the traditional one sided protection afforded by $\mathrm{it}^{682}$. There have been very rare if not inexistent, occasions where American, German or French taxpayers have witnessed that a significant part of their contributions had been devoted to pay monetary compensations derived from arbitral awards, as it has occurred with Ecuadorian or Argentinian citizens. The indisputed assumption that the accountable, independent and qualified systems of governance and justice in the developed countries would bar the deployment of treaty based protection, originally designed to guarantee investors' rights from undue influence in developing countries, was challenged by seminal cases like Vattenfall v. Germany ${ }^{683}$, Micula v. Romania $^{684}$, and Eli Lilly and Company v. Government of Canada ${ }^{685}$. The proposal of an Investment Court System within the TTIP context is far from being achieved, due to the incidence of major political events, like the shift in US Trade Policy ${ }^{686}$ and Brexit ${ }^{687}$. However, the creation of an investment court strongly supported by the European Commission might be materialized through the Comprehensive Economic and Trade

682 The WTO's Director General, Roberto Azevêdo stressed the proliferation of Regional Trade Agreements, indicating that there are 267 of such instruments notified to the WTO and in force as of September 2016.

See, Azevêdo (Roberto), Book Launch: "Regional Trade Agreements and the Multilateral Trading System", Speeches-DG Roberto $\quad$ Azevêdo, $\quad$ September $\quad 29, \quad 2016$, https://www.wto.org/english/news e/spra e/spra138 e.htm?utm source=dlvr.it\&utm medium=twitter. Last visited. March 2017.

${ }^{683}$ Vattenfall AB and others v. Federal Republic of Germany, ICSID Case No. ARB/12/12 (Vattenfall II).

${ }^{684}$ Ioan Micula, Viorel Micula, S.C. European Food S.A., S.C.Starmill S.R.L. and S.C. Multipack S.R.L. V. Romania, ICSID Case No. ARB/05/20.

${ }^{685}$ Eli Lilly and Company v. Canada, ICSID Case No. UNCT/14/2.

${ }^{686}$ See, Graceffo (Antonio), “Trump's New Protectionism: Economic and Strategic Impact”, Foreign Policy Journal, Feb 1, 2017, https://www.foreignpolicyjournal.com/2017/02/01/trumps-new-protectionismeconomic-and-strategic-impact/. Last visited, March 2017.

687 See, "El 'Brexit' y la guerra de Apple complican un pacto sobre el TTIP", Diario El Mundo, http://www.elmundo.es/economia/2016/09/29/57e3f2a5468aeb9b028b4631.html, Last visited, March 2017.

See also, Herbert Smith Freehills: Dispute Resolution-Arbitration Notes, "Brexit-the future of state, investor-state and domestic dispute resolution", http://hsfnotes.com/arbitration/2017/03/02/brexit-thefuture-of-state-to-state-investor-state-and-domestic-dispute-resolution/ Last visited, March 2017. 
Agreement (CETA), provided that the EU Court of Justice confirms its compatibility with EU law ${ }^{688}$. Although sophisticated and comprehensive, the attempts to establish an investment court system ${ }^{689}$ far from reducing the influence of investors in public policy does enlarge it, putting in the forefront of the State's priorities the legitimization and institutionalization of private interests. In this context, Kahale, briefly recalls the philosophy behind the proliferation of investment treaties in the 1990s, that subordinated the role of the state to the promotion and protection of private investment:

Second, although investor-state arbitration is not brand new, the proliferation of cases over the last twenty years as investment treaties, of which there are now around 2700, has effected a sea change, overshadowing commercial arbitration and attracting both practitioners and students all over the world for the first time looking to specialize in the field. When all this began in the 1990s, we were still in the age of privatization, with the prevailing philosophy being that everything private must be good and the role of the state should be to promote and protect private investment at all costs. Little was heard of the most popular concepts of the 1960s and 1970s, such as Permanent Sovereignty over Natural Resources. In the environment of the 1990s, where states in effect were aligned with investors, it was natural for the pro-investor school of thought to predominate. ${ }^{690}$

The dense web of investment treaties would show a global and widespread notion that treaty based protection is irreplaceable and that any attempt to pull out of the system would run foul the mainstream. Hence, it seems simpler and painless agreeing on overhauling the system of dispute settlement rather than questioning, in the first place, the legitimacy of the regime as a whole. It also seems that the set of acquired substantial and procedural rights conferred on investors may only be nuanced and in no case,

\footnotetext{
${ }^{688}$ See, Gouiffes (Laurent), Imad Khan (M.) and Smith (Jennifer), "CETA paves the way for Investment Court System", http://www.lexology.com/library/detail.aspx?g=cddc2b70-9425-418f-bcf1512cb8483100. Last visited, March 2017.

On January 2019, the advocate general of the Court of Justice of the European Union advised that the investor-state dispute settlement provisions in the EU-Canada free trade agreement CETA are compatible with EU law.

See, Perry (Sebastian), "EU court adviser endorses ISDS in CETA", 29 January 2019; https://globalarbitrationreview.com/print article/gar/article/1179785/eu-court-adviser-endorses-isds-inceta?print=true

689 The proposal seeks to establish a Multilateral Investment Court and Multilateral Appeal Tribunal. See, Malmström (Cecilia), "Proposing an Investment Court System", European Commissioners Blog, September 16, 2015, https:/ec.europa.eu/commission/commissioners/20142019/malmstrom/blog/proposing-investment-court-system en Last visited, March 2017.
}

See also, Commission draft text TTIP-investment, "Transatlantic Trade and Investment Partnership: Trade in Services, Investment and E-Commerce, http://trade.ec.europa.eu/doclib/docs/2015/september/tradoc 153807.pdf Last visited, March 2017.

${ }^{690}$ Kahale (G.) III, “Is Investor State Arbitration Broken?”, Transnational Dispute Management, Vol.9, issue 7, December 2012, 5-6 pp. 
withdrawn. In this line, the responses given by the adjudicators to the extensive discontent concerning the over-riding boundaries of the system, rather than limit its impact, does broaden it, as seen with the rise of counter-claims and the arrival of sensitive issues like environmental and human right issues, which may have been improbably foreseen and consented to by the enthusiastic treaty negotiators of the 1990s. In any event and notwithstanding the renewed protectionist impetus and the apparent reluctance towards renewing ISDS commitments, the conclusion of international treaties embodying investment protection rules and, specifically ISDS seems far from disappearing ${ }^{691}$. The

${ }^{691}$ For instance, Australia has been portrayed by countries and NGOs demanding the reform,and even abolition, of the system, as a prominent example to follow, when it comes to the limitation of access to ISDS. However, the country's initial stance to exclude Investor-State arbitration from any further treaty, has been moderated, through a case by case approach. While in Japan-Australia Economic Partnership Agreement, ISDS norms were excluded, in the Free Trade Agreement Between the Government of Australia and the Government of the People's Republic of China, detailed ISDS rules were agreed upon containing clear access' limitations:

“ARTICLE 9.11: CONSULTATIONS

(...) 4. Measures of a Party that are non-discriminatory and for the legitimate public welfare objectives of public health, safety, the environment, public morals or public order shall not be the subject of a claim under this Section.

5. The respondent may, within 30 days of the date on which it receives a request for consultations (as provided for in paragraph 1), state that it considers that a measure alleged to be in breach of an obligation under Section A is of the kind described in paragraph 4, by delivering to the claimant and to the non-disputing Party a notice specifying the basis for its position (a 'public welfare notice').

6. The issuance of a public welfare notice shall trigger a 90 day period during which the respondent and the non-disputing Party shall consult. The dispute resolution procedure contemplated by this Section shall be automatically suspended for this 90 day period.

7. The issuance of a public welfare notice is without prejudice to the respondent's right to invoke the procedures described in Article 9.16.5 or Article 9.16.6. The respondent shall promptly inform the claimant, and make available to the public, the outcome of any consultations.

8. In any proceeding brought pursuant to this Section, the tribunal shall not draw any adverse inference from the non-issuance of a public welfare notice by the respondent, or from the absence of any decision between the respondent and the non- disputing Party as to whether a measure is of a kind described in paragraph $4 . "$

ARTICLE 9.12: SUBMISSION OF A CLAIM TO ARBITRATION

1. This Section applies where there is a dispute between a Party and an investor of the other Party relating to a covered investment made in accordance with the Party's laws, regulations and investment policies.

2. In the event that an investment dispute cannot be settled by consultations under Article 9.11 within 120 days after the date of receipt of the request for consultations,

(a) the claimant, on its own behalf, may submit to arbitration under this Section a claim:

1. (i) that the respondent has breached an obligation in Article 9.3; and

2. (ii) that the claimant has incurred loss or damage by reason of, or arising out of, that breach; or

(b) the claimant, on behalf of an enterprise of the respondent that is a juridical person that the claimant owns or controls directly or indirectly, may submit to arbitration under this Section a claim:

1. (i) that the respondent has breached an obligation under Article 9.3; and

2. (ii) that the enterprise has incurred loss or damage by reason of, or arising out of, that breach.

3. A claimant cannot submit or continue to pursue a claim under this Section where the investment of the claimant in the territory of the respondent is owned or controlled indirectly by an investor of a nonparty, and the investor of the non-party submits or has submitted a claim with respect to the same measure or event within any agreement between the respondent and that non-party. 
progressive moderation of irreconcilable stances vigorously manifested by countries like

Australia, which initially advocated the exclusion of ISDS provisions in further trade or

4. A claimant may submit a claim referred to in paragraph 2:

1. (a) under the ICSID Convention and the ICSID Rules of Procedure for Arbitration Proceedings, provided that both the respondent and the non-disputing Party are parties to the ICSID Convention;

2. (b) under the ICSID Additional Facility Rules, provided that either the respondent or the non-disputing Party is a party to the ICSID Convention;

3. (c) under the UNCITRAL Arbitration Rules, except as modified by this Agreement and the Side Letter on Transparency Rules Applicable to ISDS; or

4. (d) if the claimant and respondent agree, to any other arbitration institution or under any other arbitration rules.

5. Where a claim is submitted to arbitration under paragraph 4(b), (c) and (d) (except where a claim is submitted to any other arbitration institution under paragraph 4(d)), the disputing parties and the tribunal constituted thereunder shall request ICSID to provide administrative services for the arbitration proceedings. Both Parties shall endeavour to make proper institutional arrangements with ICSID to accommodate such requests following the entry into force of this Agreement.

6. A claim shall be deemed submitted to arbitration under this Section when the claimant's notice of or request for arbitration ("notice of arbitration") has been received:

(a) referred to in paragraph 1 of Article 36 of the ICSID Convention is received by the SecretaryGeneral;

(b) referred to in Article 2 of Schedule C of the ICSID Additional Facility Rules is received by the Secretary-General;

(c) referred to in Article 3 of the UNCITRAL Arbitration Rules, together with the statement of claim referred to in Article 20 of the UNCITRAL Arbitration Rules, are received by the respondent; or

(d) referred to under any arbitral institution or arbitral rules selected under paragraph 4(d) is received by the respondent, provided that no claim shall be deemed submitted under this Section if that claim is asserted by the claimant for the first time after such notice of arbitration is submitted.

7. A notice of arbitration shall:

1. (a) specify the name and address of the claimant and, where a claim is submitted on behalf of an enterprise of the respondent that is a juridical person that the claimant owns or controls directly or indirectly, the name, address, and place of incorporation of the enterprise;

2. (b) for each claim, identify the provision of this Chapter alleged to have been breached and any other relevant provisions;

3. (c) for each claim, identify the measure or event giving rise to the claim;

4. (d) for each claim, indicate whether the claim is made on the claimant's own behalf or on behalf of an enterprise;

5. (e) for each claim, provide a brief summary of the legal and factual basis sufficient to present the problem clearly; and

6. (f) specify the relief sought, the approximate amount of damages claimed and its standard or basis for calculation.

8. The claimant shall provide with the notice of arbitration:

1. (a) the name of the arbitrator that the claimant appoints; or

2. (b) the claimant's written consent for the Secretary-General to appoint that arbitrator.

9. The arbitration rules applicable under paragraph 4, and in effect on the date the claim or claims were submitted to arbitration under this Section, shall govern the arbitration except to the extent modified by this Agreement and the Side Letter on Transparency Rules Applicable to ISDS."

See, Full Text of Agreement, Chapters 1 to 17 of the China-Australia Free Trade Agreement, http://dfat.gov.au/trade/agreements/chafta/official-documents/Documents/chafta-agreement-text.pdf. Last visited, March 2017.

See, Nottage (Luke), Investor-State Arbitration: Not in the Australia-Japan Free Trade Agreement, and Not Ever for Australia, https://sydney.edu.au/law/anjel/documents/2014/ZJR 3805 Nottage 8.pdf, Last visited, March 2017.

See, Hepburn (Jarrod) and Huber (Mark), An Assessment of Australia's Parliamentary Report on ISDS in the TPP, Kluwer Arbitration Blog, January 5, 2017, http://kluwerarbitrationblog.com/2017/01/05/reservedan-assessment-of-australias-parliamentary-report-on-isds-in-the-tpp/?print=pdf, Last visited, March 2017. 
investment agreements ${ }^{692}$, shows the strong leverage of certain players of the field and their capacity of reaction to overshadow the challenges to the system through institutional mechanisms that engage sovereign decisions. Benvenisti clarifies the dynamic relationship among the actors of global governance institutions, normally governed by the same group of State actors and influenced by similar interest groups, who ultimately shape and funnel the changes demanded by factions displeased with the system's effects. ${ }^{693}$ The widespread discontent embedded in the system of investment protection may be also a manifestation of the crisis suffered by global rules, impregnated with a strong pro-market bias. As noted, the reaction of investment arbitrators to the system's legitimacy crisis has been translated into expansive interpretations, with a renewed sympathy towards further fundamental values, like environmental protection and human rights. And neither investment treaties nor the predominant arbitration venues were designed for that purpose, having as effect, that both the international rule of law and the domestic rule of law become strongly influenced by the progressive usurpation of such matters by ad hoc adjudicators. In this context, Rob Howse unfolds the rationales supporting the treaty based investment protection $^{694}$, thereby wounding seriously the well

${ }^{692}$ See, Hepburn (Jarrod) and Huber (Mark), An Assessment of Australia's Parliamentary Report on ISDS
in the TPP, Kluwer Arbitration Blog, January http://kluwerarbitrationblog.com/2017/01/05/reserved-an-assessment-of-australias-parliamentary-reporton-isds-in-the-tpp/?print=pdf, Last visited, March 2017.

${ }^{693}$ In this context, Benvenisti further elaborates:

"Although global governance institutions are distinct from each other and seek to maintain their uniqueness, many of them are governed by the same set of State actors or are influenced by similar interest groups originating from the same affluent democracies seeking similar gains and concessions. While these forces would tend to limit accountability mechanisms, there are other external actors who have demonstrated both interest and ability to impose administrative law requirements on global bodies. Although "peer review" between global governance bodies is still limited, some actors are seeking convergence of the standards of review (such as arbitrators who seek to create a general framework in international law or international investment law). There are also important domestic actors that are quite effective in reacting to unaccountable global governance. National courts have shown concern over the bleeding of decision-making power away from the State, and are sometimes in a position to impose discipline on recalcitrant global actors."

Benvenisti (Eyal), The Law of Global Governance, Hague Academy of International Law, 2014, 199-200.

${ }^{694}$ Howse points out four distinct rationales for international legal protection:

"1) incentivizing increases in foreign investment through the host state insuring the investor against certain kinds of political risk (implicit insurance contract); 2) a substitute for domestic rule of law where it is weak or based on a political or economic system unacceptable to investors and the countries they come from; 3) international justice (fairness in the treatment of aliens); 4) antiprotectionism (a continuity of disciplines against protectionism across external contracting (trade) and internal contracting (investment) of the firm." 
rooted beliefs underpinning its claimed benefits. From a developing country's perspective, it seems that the detriments outweigh the benefits and that the passivity towards the system's harmful effects perpetuates the impossibility of reasonably exercising the right of self- determination through manifold regulatory tools. Neither from the standpoint of investor's regulatory sheltering from political risk, nor from a substitute of the rule of law and robust domestic institutions, the permanence of BITs in developing countries, as designed during the 1990s, could be justified. Without endorsing the mechanisms towards which the Ecuadorian State attempted to retrieve regulatory influence under a framework of undetermined commitments as from 2007, challenging the permanence of the same, even with the very costly bill their breaches have entailed, was unavoidable to overcome a set of rules designed for a minimal State. In this line, Howse warns about the perniciousness of isolating foreign investors from the effects of regulatory reforms:

Yet it has been plausibly argued that if the rule of law is weak in a particular state, the more logical answer is to strengthen the rule of law there, not simply insulate foreign investors from the effects of bad governance. And it has been suggested that there is evidence that protecting one constituency, foreign investors, from the impact of weak rule of law actually reduces pressures for more general salutary governance reforms. At the same time, there is evidence that BITs "only have a positive impact on FDI flows as complements to, not substitutes for, the domestic investment environment...Poor countries cannot bootstrap an aggressive program of entering into BITs into a major increase in FDI. They cannot avoid the hard work of improving their own domestic environment for investment.

(...) In sum, from an economic development perspective, BITs where they reduce pressure for domestic governance reforms, are doubly harmful: they both make it less likely that what really matters actually increases in FDI, and also to the ability of the state to exploit FDI as a ladder to economic growth and development. ${ }^{695}$

In other words, Ecuador's attempt to pull out from the system by replacing it with a new framework of investment protection and promotion and undertaking comprehensive measures like the development of new rules for public private partnerships, the overhaul of the system of justice administration, and lately, the conclusion of the free trade

Howse (Rob), "Bilateral or Multilateral Courts, Arbitration, or State-to-State Dispute Settlement: thinking about an optimal system for international investment disputes", Forthcoming, Helene Ruiz-Fabri, ed. International Law and Litigation, Nomos Press, 2017, 23-24 pp.

695 Howse (Rob), "Bilateral or Multilateral Courts, Arbitration, or State-to-State Dispute Settlement: thinking about an optimal system for international investment disputes", Forthcoming, Helene Ruiz-Fabri, ed. International Law and Litigation, Nomos Press, 2017, 12 p. 
agreement with the European Union, has clashed with the reality due to an extended impossibility of closing the proceedings for termination of BITs, especially with developed countries. This obstacle was finally overcome when the National Assembly ${ }^{696}$ and the former President Rafael Correa, decided to conclude the pending processes of BITs denunciation a few days before their terms come to an end. The National Assembly discussed the scope of each of the twelve BITs, whose legislative approval to terminate was pending, strongly relying, on one hand, on the Constitutional Court's rulings, and in the other, on CAITISA's report findings, which to that date, was still unofficial ${ }^{697}$. Subsequently, the former President concluded the process of termination of all the remaining BITs (16), issuing the corresponding decrees both of termination of the twelve BITs, whose denunciation was recently approved by the National Assembly, including four BITs, awaiting to conclude such process. ${ }^{698}$ Such decrees contain identical reasons for termination, proclaiming in their relevant part:

“(...) That these international arbitral tribunals have turned inconvenient for the interests of Ecuador, since the arbitrators generally have interests in the companies that invest in Ecuador, especially in the energetic sector;

That in view of the natural bias of these arbitral tribunals, the State through the Executive Decree 1506 of May 6, 2013, created the Commission for the Comprehensive Audit of Investment Protection Treaties and of the International Arbitration System on Investments, CAITISA, commission which among the conclusions of her final report, that was delivered on May 8, 2017, recommended denouncing bilateral treaties on the protection of investments;"

These decrees show the certainty about the perniciousness of the system and the generalized misconduct of the arbitrators from the perspective of Ecuadorian decision makers. ${ }^{699}$ As shown, this position is the result of a chain of unfortunate decisions of

696 On May 3, 2017, the plenary of the National Assembly voted 12 favorable opinions issued by the Commission of Sovereignty, Integration, Foreign Affairs and Integral Security, to denounce the BITs with the following countries: 1) Popular Republic of China; 2) Chile; 3) Venezuela; 4) Kingdom of Netherlands; 5) Swiss Confederation; 6) Canada; 7) Argentina; 8) United States of America; 9) Kingdom of Spain; 10) Peru; 11) Bolivia; 12) Italy.

${ }^{697}$ The official release of CAITISA's report took place on May 8, 2017. See the official presidential ceremony, https://www.youtube.com/watch?v=JxjbTdm19Rc. Last visited, May 2017.

698 On May 16, 2017, the President, Rafael Correa, issued sixteen decrees terminating the BITs with the following countries: 1) Popular Republic of China; 2) Chile; 3) Venezuela; 4) Kingdom of Netherlands; 5) Swiss Confederation; 6) Canada; 7) Argentina; 8) United States of America; 9) Kingdom of Spain; 10) Peru; 11) Bolivia; 12) Italy; 13) Sweden; 14) Germany; 15) Great Britain; 16) France.

${ }^{699}$ Luque Macías underscores the effects of the termination of treaties by Ecuador: 
public policy over the course of more than two decades. Since the records show the absence of negotiation during the stage of signature of treaties provoked by a gross misunderstanding of their scope, motivated by an incestuous relationship between decision makers and foreign interests, it is understandable that the Ecuadorian State decided to denounce and not to renegotiate the treaties at issue. Besides this historic decision, it is undeniable that the aggressive set of regulatory reforms undertaken under the blanket of the Constitution of 2008 has changed the landmark within which the relationships and the eventual conflicts with investors evolve. These circumstances in conjunction with the outspoken official opposition to the system, at least in certain SouthAmerican countries beaten by numerous investment claims, would mean that any resort to investment arbitration would be perceived as an open attack on the country's sovereignty, thereby neutralizing one of the system's rationales, namely the possibility of lessening political and diplomatic tensions through a depoliticized mechanism of dispute settlement. Therefore, the introduction of regulatory obstacles to hamper the resort to treaty based protection should not be overlooked, even when the same may be considered as facts in the context of international disputes, bearing in mind their capability to limit investors' expectations when carrying out activities in a specific context ${ }^{700}$. However, one should not overlook the impact that this kind of decisions caused in the international markets, considering its strong association to well rooted Western concepts, like good governance and legal certainty, whose disturbance has direct effects, for instance, in the country risk analysis and diplomatic relations, notwithstanding the existence of mechanisms that may minimize political or regulatory risk. As noted, guarantees and

Whether or not the preliminary findings of CAITISA yield a definite departure of Ecuador from IIAs, and thus its complete reliance on investor-State contracts, Ecuador will still remain subject to fulfil its obligations under the denunciated BITs. After their termination, the automatic renewal clauses of these BITs commonly extend their duration for a certain period of time. In case, nevertheless, it decides to start the conclusion or the renegotiation of BITs, the two different models of IIAs described above still exist at its disposal.

Luque Macías (María José), "Reliance on Alternative Methods for Investment Protection trhough National Laws, Investment Contracts and Regional Institutions in Latin America", in Shifting Paradigms in International Investment Law: More Balanced, Less Isolated, Increasingly Diversified, Hindelang (Steffen) and Krajewsky (Markus), Editors, Oxford University Press, 2016, 303 p.

${ }^{700}$ For instance, the Monetary and Financial Organic Code, among the requirements to establish branches or representation offices in Ecuador, imposes on the foreign financial entities, the obligation to expressly acknowledge: 1) the subordination to the jurisdiction, laws, courts and authorities of the country; 2) waiver of diplomatic protection; 3 ) that the rights enshrined in any commercial or investment protection treaty do not limit in any manner the exercise of regulatory powers, the levy of sanctions or responsibilities as prescribed by this Code, thereby accepting equal and national treatment in similar circumstances.

See, Código Orgánico Monetario y Financiero, Libro I, Art. 181, 7. 
special securities enshrined in treaties may reasonably take the form of political risk insurance or monetary compensation that may reasonably restore the equilibrium mutually agreed when the investment was made ${ }^{701}$. Additionally, it must be highlighted that the prolific adoption of these treaties without strengthening local institutions brings the worst of two worlds in terms of building institutions, which means, a large and neverending sacrifice of regulatory space, with a progressive resignation to technical capacities capable of monitoring that the conduct performed by protected foreign investors contributes to the country's prosperity and people's well-being. Unfortunately, Ecuadorian experience not only shows that the treaties adopted did not play a role in increasing foreign investment ${ }^{702}$, but were employed as a tool to assure the impunity of corporations, at a very high cost to the public finances, governance strengthening and more important, peoples' rights. For instance, CAITISA's report shows how BITs have been resorted to as a shield to under-report profits through practices like transfer

${ }^{701}$ Regarding this issue, CAITISA's reports underlines:

" 22 . The state contracts in the matter of investments often include clauses that reflect the same standards of protection provided for by the BITs, including the transfer of jurisdiction to international arbitral tribunals. The regulations related to public procurement lack dispositions that protect the general interest, within an equitable regime of foreign investments."

See, "Auditoría integral ciudadana de los tratados de protección recíproca de inversiones y del sistema de arbitraje en materia de inversiones en Ecuador: Informe ejecutivo", May 2017.

702 See footnote 863 . 
pricing $^{703}$, in detriment to the country's development and the provinces ${ }^{704}$, where foreign investors' operations were located ${ }^{705}$.

When CAITISA's initiative was launched in 2013, it was certainly not possible to foresee the meteoric evolution that the critics to the system of investment protection would take.

On one hand the over-arching approach adopted, for instance in the discussions of the TTIP, CETA and EU-Singapore Free Trade Agreement ${ }^{706}$ attempting to pave the way for

${ }^{703}$ Regarding this issue, CAITISA's reports points out:

"Among the audit findings, it is relevant to note the figure of under-capitalization, through which capital flows are registered as credits instead of investments, being used by foreign companies in a repetitive and progressive way since the 1990s. It is also presumed that the establishment of consortiums and subsidiaries will hide or disguise capital flows. In view of such indications, it is advisable to set up investigation venues that consider these cases in detail, even through judicial proceedings, to determine the magnitude of the damages caused to the State during foreign investors' operations."

See, “Auditoría integral ciudadana de los tratados de protección recíproca de inversiones y del sistema de arbitraje en materia de inversiones en Ecuador: Informe ejecutivo", May 2017, 108 p.

"33. In the assessment of economic impacts caused by foreign companies, which invoking a BIT have brought disputes against Ecuador before international arbitration tribunals, the official statistics show a low dynamism of the global production, in the provinces where their investments were located; at least, during the periods when they operated. Effectively, between 1993 and 2005, when the major foreign intervention took place, the influence zones remained under conditions of low productive expansion."

See, “Auditoría integral ciudadana de los tratados de protección recíproca de inversiones y del sistema de arbitraje en materia de inversiones en Ecuador: Informe ejecutivo", May 2017.

${ }^{705}$ CAITISA's reports condemns the little influence of foreign investment in the improvement of the local conditions of living:

"36. The social indicators of the population located in the influential areas of the claimant companies reveal a precarious situation in health, education, illiteracy, in the access to services of drinking water, electricity, sanitation, during the permanence of the foreign investors. The contrast is evident, and is confirmed with the numbers, when the peoples and communities obtain fair and compensatory attention as it happens with the current State administration. "

See, “Auditoría integral ciudadana de los tratados de protección recíproca de inversiones y del sistema de arbitraje en materia de inversiones en Ecuador: Informe ejecutivo", May 2017-

${ }^{706}$ In her analysis about the ECJ's opinion tackling whether the European Union enjoyed exclusive competence to enter in free trade agreements related to EU-Singapore FTA, Anthea Roberts considers that such decision, which ruled that the same is a shared competence, since the possibility to submit disputes to international arbitration has the effect of removing disputes from the jurisdiction of the Member States' courts, is aligned to "the latest development in a series of setbacks to ISDS clauses", as her following examples, show:

- "Brazil, which has never ratified an investment treaty providing for investor-state dispute settlement has more recently, started signing Co-operation and Investment Facilitation Agreements that encourage the use of alternative dispute resolution mechanisms, such as conciliatory settlement of disputes through Ombudsmen that are subject to a Joint Committee of the treaty parties, and ultimately permit state-to-state arbitration but not investor-state arbitration. 
the creation of an international investment court, despite making visible the imbalances and incoherencies of the current regime, were not capable to question whether foreign investors deserve such generous standards of protection in the first place ${ }^{707}$. On the other hand, it may be assumed that the main guardians and even the most virulent opponents to the system could have not ever imagined the twist that international affairs would take, with major events like Brexit, Donald Trump's election and the progressive raise of rightist anti-global movements, which ultimately buried the possibilities of institutionalising an overhauled regime of investment protection. This, of course, has not

- South Africa,began a process of terminating its investment treaties in 2012 and in their place has passed the Protection of Investment Act 22 of 2015, which gives primacy to domestic remedies, including mediation and domestic courts. This Act provides that South Africa may consent to international arbitration over an investment dispute, but this would be subject to exhaustion of domestic remedies and would also take place on a state-to-state, rather than an investor-state, basis.

- India, which radically revised its Model BIT in 2015, to significantly limit access to ISDS. Before an investor can bring an investor-state claim within the Indian Model, it must first seek to exhaust domestic remedies for a period of up to five years. It may then proceed to arbitration, subject to a six-month negotiation period, provided that it brings the claim within six years of knowing about the measure that it is complaining about. These tribunals are also not permitted to review the merits of a decision made by domestic courts.

- Australia, which has adopted some FTAs (e.g., with the United States and Japan) that do not include ISDS clauses."

- Ecuador, which recently terminated 16 of its investment treaties, following the recommendation of a national Commission that Ecuador pursue new treaties which exclude investor-state dispute settlement mechanism and instead provide investors with access to national courts."

Roberts (Anthea), "A Turning of the Tide against ISDS?, EJIL: Talk!, Blog of the European Journal of International Law, May 19, 2017, https://www.ejiltalk.org/a-turning-of-the-tide-against-isds/. Last visited, June 2016.

${ }^{707}$ From a constitutional perspective, Stoll and Holtherhuls question the additional protection provided to foreign investors as compared to domestic investors:

"While the point has hardly played a role in academic analysis so far, discrimination against domestic investors surfaces as a major concern when looking on international investment law from a constitutional perspective. Evidently, exclusively foreign investors benefit from international investment law. While foreign investors who face adverse State measures on a national level are regularly entitled to take legal action under international investment law as well as the particular national law, domestic investors are limited to pursue their interests via the particular national law alone.Regardless of the particular extent of substantive protection granted by the applicable investment treaties and/or national laws, foreign investors hence usually have an additional procedural option that domestic companies don't. Whatever option to define the relation between domestic courts and international investment arbitration as discussed above will be chosen, domestic investors will, hence, face a considerable disadvantage."

Tobias-Stoll (Peter) and Holterhus (Till Patrik), “The 'Generalization' of International Investment Law in Constitutional Perspective", Shifting Paradigms in International Investment Law, More Balanced, Less Isolated, Increasingly Diversified, Edited by Steefen Hidenlang and Markus Krawjewsky, Oxford University Press, 2016. 
been translated into lower standards of protection to foreign interests, which count on diverse regulatory, contractual and market tools to safeguard them, exerting a strong leverage on governmental decisions. In the matter of international settlement of disputes, resorting to international commercial arbitration has twisted the answer to overcome such political events, to the detriment of intergovernmental responses appropriate to incorporate public values and transparency. While the transnational approach to decision making and dispute settlement consolidates an international coordinated response that may tackle common priorities wherein international law could play a seminal role seems to be blurred. And in the same manner that signing treaties of investment protection without consolidating internal capacities led to unfortunate results, denouncing treaties without advocating intergovernmental solutions capable to counter-balance the enormous power of non-State actors, will hardly improve the position of the least developed and developing countries strongly dependent on foreign investment flows. Although plausible, the effort to incorporate major legitimacy concerns and desirable common values in the new investment protection design seems to subordinate the enforcement of seminal common values like human rights and environmental protection to the logic of investor rights protection, inconveniently making the latter a meta-value. In this sense, States should be aware about the effects of the international obligations they seek to adopt or reform in the context of international investment regimes, considering its hybrid nature and the ever-growing influence of private actors on creating and influencing public regulation, which may distort not only an already weakened public-private distinction, but also the matters that States have agreed to submit to international adjudication. As Alvarez, recalls, it is undeniable that what happens inside one State matters, especially when it comes to aliens. ${ }^{708}$

\footnotetext{
${ }^{708}$ In an academic conference, José Alvarez tackled the progressive use of human rights principles in international investment law:
}

“Max Planck Fellow's question: I share pretty much your sentiments that perhaps the language in norms of human rights is being used a bit too promiscuously in ideas of international dispute settlement that might have nothing to do with the concerns of the human rights movement. From what I understand your preferred solution to this would be to actually pay more close attention to the actual language of the treaties and the negotiating history behind that. I completely applaud this, but I think doing this alone might be enough, because it might even lead to a very fissiparous unprincipled way of development of the subject, I might suggest that, what we might have to do is conduct a kind of mapping of International Law; if we do so, we might find several areas of what we call, what we think, what we describe early as the much of Public International Law, might do actually belong to that at all, like human rights would actually be constitutional law, because it relates to the relations between authorities and subjects, so that is a fiduciary relationship and the way you analyze a fiduciary norm is very different from the way you analyze 
In any case, few if any international law commitments or institutional arrangements have prevented States from creatively circumventing this framework and privileging the resort

to transnational tools and private bodies for the management of such relationships and the settlement of disputes ${ }^{709}$. Therefore, the mechanisms of decision making, considering

a contractual norm, such as that between treaties, between States. And that might also be different from the way you analyze a relationship between a public actor and a non-subject private person. And that might not be international Law. I just try to say that we have to think the different kind of relationships that we call, that going to this giant mash called Public International law.

José Alvarez's answer: I am not sure about the mapping part, but I guess one thing that I want to at least defend a little bit is that unlike the WTO, which is hard to change because it is one treaty and you have 150 States who agree. At least the advantage of a bilateral regime which is most of the treaties here, is that States do change their treaties and that is what we have seen, we have seen States withdrawn from them, we have seen States stopped negotiating them, we have seen States modify their terms, including in some cases to put in human rights, in various forms, including in the preamble and I will be the first one to say that if you are facing a treaty that says: this is to be read in light of the following treaty obligations as some do, that is what you are supposed to do and that opens the door. So, what that is going back to my view, is that the design matters because is different because exit and voice is different with respect to WTO and investor-State. So, when a WTO Appellate Body does more activist stuff in a regime that is almost impossible to change and has built an appellate mechanism, that is understandable, when an ad hoc arbitrator tries to acquire power to basically amend the treaty before him or her. I think that this is a different kettle of fish, it may or may be not appropriate but it is not the same story, I think exit and voice is part of it. With respect to what States are doing, I do think that States created human rights treaties and called them that, knowing specially, when they created regional human rights court attached to it and providing remedies to human beings, to have remedies that they included that, in their international responsibilities. I don't think that Klu Hanken was wrong to say that human rights law has fundamentally challenged the contractual State vs State model. It has purposely and consciously, albeit hypocritically, changed it to mix States inside out. That is what happens inside your State matters. And it does matter for international adjudication when you have signed a treaty that provides for it. And I do think that for a longer period of time, the States have agreed that, what happens to aliens who happen to be in your territory is also something that international law cares about. They did it through international rules of state responsibility, they did it within customary law for prompt, adequate and effective compensation, and what the treaties do jump on to, is that old customary law. So, whether or not your mapping exercise makes sense, I would still say that States have agreed to put some international obligations, between I agree, are fundamentally different kind of treaties. I do disagree with you however, with this sort of French idea: public is over here and private is over here and never they two shall meet. I know how you are tested to be a lawyer in France- that is your problem, it does not have to be mine-. And I think that investor State happens to be one of the many hybrids that exist when you are drawing on private law for certainly the procedures and I would argue for some of the substance and that I don't want to pinhole any of these regimes necessarily into one, where the States themselves or other State holders have already broken free this public-private artificiality. This is the world where much of the public regulation is now being done by private actors."

See, Alvarez (José), "The Use and Misuse of European Human Rights Law in Investor State Arbitration", Max Planck Institute Luxembourg for Procedural Law, Max Planck Lecture Series, May 3, 2017, https://www.youtube.com/watch?v=LUSzYFquVx0\&app=desktop. Last Visited, June 2017,.

709 The International Chamber of Commerce celebrates the record achieved in 2016 thanks to the record of new arbitral proceedings:

"According to preliminary statistics, a total of 966 new cases administered by the Court were filed in 2016 - involving 3,099 parties from 137 countries. Constituting a record year for the Court in its 94-year history, the figures reflect continuing growth of the world's leading arbitral institution and its ongoing efforts to make ICC dispute resolution services more accessible worldwide." 
their potential impact both at the national and international levels should be closely monitored from the very beginning, regardless of their source (i.e, treaty, statutory regulatory or contractually based). In this regard, preserving positive features of the current regime of treaty based protection like public access to arbitral decisions or limited resort to diplomatic protection ${ }^{710}$ should be generalized with the aim of achieving a transparent and objective means of decision making ${ }^{711}$. In this sense, it can be concluded that many of the current proposals for reforming the system of investment protection are circumscribed within a rent-seeking and pro-market perspective, that should be moderated in view of the multiplicity of conflicts that the imbalanced application of the current rules bring to global coexistence. ${ }^{712}$ In this line, there has already been a warning

International Chamber of Commerce, ICC reveals record number of new Arbitration cases filed in 2016, https://iccwbo.org/media-wall/news-speeches/icc-reveals-record-number-new-arbitration-cases-filed2016/. Last visited, June 2016.

${ }^{710}$ Among others, José Alvarez, highlights the contribution that well-crafted arbitral awards make to legitimacy, transparency and development of international law concepts:

\begin{abstract}
"Arbitral awards are also more likely to offer useful guidance than the diplomat actions of selfinterested States. Arbitral awards, at least the public ones, are easier to find. While it is possible for modern interpreters of the law to engage in the kind of historical survey of diplomatic State practice undertaken by, for example, the judges of the US Supreme Court in the famous Paquete Habana case, choosing to focus as that court did on the correspondence of States is timeconsuming and, given the varied abilities of States to record their views in this fashion, is likely to lead to charges that only some States' practices are accorded weight.

(...) As this suggests, the investment regime provides public international lawyers with potent caveats on the relative merits of treaty, custom, and general principles of law- some of which may run counter to accepted wisdom. It may also challenge those who still insist that these positivist sources- and the traditional ways in which they are defined-are the sum total of what is legally relevant in the modern world."
\end{abstract}

Alvarez (José), The Public International Law Regime Governing International Investment, Hague Academy of International Law, 2011, 232-235 pp.

${ }^{711}$ Among the multiple efforts coming from different stakeholders with the aim to reshape the boundaries of Investor-State Arbitration, the United Nations Convention on Transparency in Treaty- based InvestorState Arbitration (Mauritius Convention) is remarkable. This Convention will enter into force in on 18 October 2017 and it has been ratified by Canada, Mauritius and Switzerland. This Convention has been signed by Belgium, Cameroon, Congo, Finland, France, Gabon, Germany, Iraq, Italy, Luxembourg, Madagascar, Netherlands, Sweden, Syria, United Kingdom and the United States.

United Nations Information Service, "Cameroon signs the United Nations Convention on Transparency in Treaty-based Investor-State Arbitration”, May 12, 2017.

See, http://www.unis.unvienna.org/unis/en/pressrels/2017/unisl245.html. Last visited, June 2017.

${ }^{712}$ Given the over-arching latitude of investment protection rules with constitutional like principles and their undeniable influence in extractive industries related disputes, there are remarkable proposals such as renewing the "fiscal social contract", reassessing the value and not only the cost, of improving transparency in the distribution of revenue: 
about the improper incursion of investment law-related adjudication in aspects like human rights, taxation, health and environmental issues that may slow down and even hamper the materialization of desirable reforms. ${ }^{713}$ Again and looking at the Ecuadorian experience, it seems that good intentions advocated from a wide range of stakeholders, could not be materialized if the demands from State and non-State actors, as well as the dynamics of international dispute settlement are not properly interpreted. Accordingly, returning to a restrictive approach attempting to air any kind of foreign investor-related disputes within domestic forums, besides not being pragmatic, would incentivize the use of further mechanisms of international dispute settlement, that may formalise the settlement of regulatory disputes behind closed doors.

\title{
3.4.3. The Necessity to Bury the Calvo doctrine in Order to Achieve Realistic and Balanced Reforms
}

\section{CAITISA's report states:}

The Commission recommends that the disputes between the State and investors be resolved, primarily, in national courts. Ecuador has a judicial system capable

\begin{abstract}
"Because the roots of this trap are largely political and institutional, overcoming the perverse impacts of oil-led development must begin with political and institutional arrangements. As we shall see, this requires a "big push" in the direction of a far-reaching "fiscal social contract" based on transparency, transparency that creates incentives to change the rent-seeking behaviour of all actors, both international and domestic, involved in the oil game. The initial step in this fiscal social contract is in effect a broad-based agreement among nations and their citizens, companies, and international financial institutions to be more open about the allocation of oil rents so that their distribution can become fairer. This would also permit the eventual transition to alternative energy forms to be made in an orderly and less conflict-laden fashion. Its outlines are already discernible in the energy convergence over the importance of transparency as a first step in overcoming the resource curse."
\end{abstract}

Lynn Karl (Terry), "Ensuring Fairness: The Case for a Transparent Fiscal Social Contract" in Escaping the Resource Curse, Humpfreys (Macartan), Sachs (Jeffrey D.) and Stiglitz (Joseph E.), Editors, 257 p.

${ }^{713}$ For instance, it has been warned about the investment treaty based litigation risks associated to the implementation of initiatives like the Base Erosion and Profit Shifting (BEPS):

"New national measures on taxation, voluntarily implementing the BEPS, could impose new obligations on investors and potentially collide with the respective rights and obligations provided for by BITs and other international investment agreements. More precisely, changes in tax rules that would affect either the profits or the assets of foreign investors could lead to claims for breaches of investment treaty clauses such as free transfer of funds, fair and equitable treatment (FET), national treatment (NT), most-favoured-nation (MFN) treatment and expropriation. In these situations, conflicts arise between the taxation and the investment fields."

Chaisse (Julien) and Marisi (Flavia), "Another Conflict of Norms: How BEPS and International Taxation Relate to Investment Treaties", June 12 ${ }^{\text {th }}, 2017$, http:/www.iisd.org/itn/2017/06/12/another-conflictnorms-how-beps-international-taxation-relate-investment-treaties-julien-chaisse-flaviamarisi/?utm source $=$ newsletter-itn\&utm medium $=$ email\&utm campaign $=$ itn-june-17. Last visited, June 2017. 
of entertaining and settling the eventual claims of foreign investors with transparency and impartiality. ${ }^{714}$

Although transparency and impartiality would be core values that any court system should ensure to settle any kind of disputes, it is necessary to recall the complexity of foreign investment related issues, which require further guarantees like depoliticized and specialized adjudicators, capable to act within the boundaries of their mandate, especially when it comes to entertain claims based on international law. Moreover, the report referred to does not specify whether the disputes that the domestic courts would entertain would be based in national or international law. It must be noted that national courts are rarely empowered to adjudicate international claims, which means that domestic judicial decisions even in matters related to alien interests, would be probably based, procedurally and substantially, on national law. An exception to this assertion would be the obligation to exhaust local remedies prior to submitting a claim to international adjudication, based on a treaty based obligation, which apparently would be the recommendation of the report previously mentioned. In any case, this could not be considered as a substitute for an international dispute settlement body's decision:

It should be noted also that while the construction of substitution may be a conceptual stretch, international courts can fulfill a critical function in relation to national legal systems. In those cases where international courts have a role in reviewing and assessing national law and national decision-making for instance by investment arbitration and international human rights courts, they may promote the rule of law at the national level, both in individual cases and at a more structural level.

(...) In principle then, the task of international courts is not so much to substitute for a national court, but to review decisions of national courts against international law. They act if and to the extent that domestic courts have failed to apply (the substance of) international law properly. The rejection by the ECtHR of the construction that it would be the fourth instance court, likewise indicates that the court cannot be seen as a substitution for what a national court should have done. ${ }^{715}$

Reading the CAITISA report recommendation in conjunction with these doctrinaire constructions and the scope of the Ecuadorian constitutional boundaries to investor-state

\footnotetext{
${ }^{714}$ See, "Auditoría integral ciudadana de los tratados de protección recíproca de inversiones y del sistema de arbitraje en materia de inversiones en Ecuador: Informe ejecutivo", May 2017, 104 p.

${ }^{715}$ Nollkaemper (André) in The Oxford Handbook of International Adjudication, Ed. Romano (Cesare Pr), Alter (Karen J) and Shany (Yuval), "Conversations among Courts: Domestic and International Adjudicators", Oxford University Press, 2015, 541-542 pp.
} 
treaty based commitments, would lead to the conclusion that the domestic decision makers' intention rather than neutralizing the possibility to set aside regulatory disputes involving foreign investors from International Law, seek to limit the procedural avenues and the standards of protection that an international dispute settlement body may entertain. Just to mention a few parameters that may serve for these purposes, Ecuador could carve out several kinds of disputes from investor treaty based protection, providing exclusively for the minimum standard of protection standard and requiring the exhaustion of local remedies before submitting claims to the corresponding international dispute settlement bodies.

The recent evolution of awareness concerning the risks involving foreign investment protection has developed bold perspectives, certainly unforeseeable a few years ago. These suggestions for instance, advocate setting aside investment from trade deals, changing in 180 degrees the foundations upon which, regional trade agreements have been lately bargained, like the TTIP and CETA. ${ }^{716}$ However, this apparent retreat should not be understood as a degradation of investment protection rules, but the reinforcement of bilateral negotiations that, on one side, would eclipse regional approaches and on the other, would invigorate the diplomatic weight of the incumbent States reassessing their relevant mechanisms of protection, and stressing the highly politicized roots of foreign investment guarantees. ${ }^{717}$ In the meantime, there should not be overlooked several outcomes, which contribute to pacify the legitimate unrest of several stakeholders, as well as to highlight the incoherencies of the system, like the efforts to bring transparency to investment $\operatorname{arbitration}^{718}$, the developed assessment of

\footnotetext{
716 See the statement from the EU Commissioner for Jobs, Growth and Investment, Jyrki Katainen, "Katainen suggests dropping investment from trade deals", Euroactiv with AFP, July 10, 2017; http://www.euractiv.com/section/economy-jobs/news/katainen-suggests-dropping-investment-from-tradedeals/. Last visited, July 2017.

${ }^{717}$ See for example, the talks' deadlock between India and the United States, concerning the decision of the former on implementing its BIT Model limiting substantially investor state dispute settlement, allocating strong powers to local courts.

The Hindu Business Line, Basu (Nayamina), “US junks Bilateral Investment Treaty talks”, June 28, 2017; http://m.thehindubusinessline.com/economy/policy/us-junks-bilateral-investment-treatytalks/article9740501.ece. Last visited, July 2017.

718 At the request of several countries, including the European Union and its Member States, the UNCITRAL has agreed on working on a the issue of a multilateral reform of investment dispute settlement, with a special accent on transparency.
} 
public policy concerns by rule makers and adjudicators ${ }^{719}$ and the relevance of regional and domestic courts on defining the limits of recognition and enforcement of investment arbitration awards ${ }^{720}$. In any case, these developments should shed light on the players pushing for a reform of the particular rules concerning the complexity and the variety of responses that should be considered in order to avoid the repetition of mistakes, especially with relation to the exposure to State responsibility, preservation of regulatory space, and transparency.

As noted, it seems that politicians from developing countries have used the legitimate criticisms of the system of investment protection as a catalyst for restoring further mechanisms of protection, usually contract based, at the expense of transparency and the development of global values, deserving the protection of international law. There is an undesirable inclination to label as an assault on sovereignty and the right of selfdetermination, and as such, as a matter of State interest, outcomes that restrain short term governmental action. In countries with deficient governance, the attempt to channel all investment disputes through domestic adjudication, besides being unrealistic and inwardlooking, does not favour the balanced protection of common interests of the international community and inconveniently shields domestic decision makers from stronger standards of accountability. While it may be affirmed that in a significant amount of cases, International Investment Law might have been used, or even abused, to serve causes it was not created for, it might also have been asserted that International Law might have been unfairly beaten by this legitimacy crisis, being blamed for deficiencies for which it

See, European Commission-DG Trade, "UN agrees to start to work on multilateral reform of investment

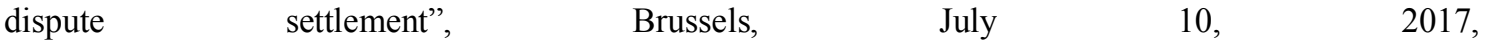
http://trade.ec.europa.eu/doclib/docs/2017/july/tradoc 155744.pdf. Last visited July 2017.

${ }^{719}$ See, the ruling of the panel of arbitration that ordered Philip Morris Asia to pay Australia's legal costs, as well as its cynical defense claiming for an overcharge of these fees, considering that the defence was mainly handled by modest government lawyers.

The Guardian, Knaus (Christopher), "Philip Morris cigarettes charged millions after losing plain packaging case against Australia", July 10, 2017; https://www.theguardian.com/business/2017/jul/10/philip-morriscigarettes-charged-millions-after-losing-plain-packaging-case-against-australia. Last visited, July 2017.

${ }^{720}$ See for example, the complex litigation surrounding the Micula ICSID Award, whose enforcement has been stayed by the English High Court and in parallel, a decision from the European Court of Justice is awaited concerning the EU Commission's decision that the payment of the award by Romania would constitute a new state aid.

Herbert Smith Freehills, "English Court Stays Enforcement of Micula Award Against Romania", Arbitration Notes, July 7, 2017, http://hsfnotes.com/arbitration/2017/07/07/english-court-staysenforcement-of-micula-icsid-award-against-romania/. Last visited, July 2017. 
is not responsible. And more important, this position might relegate one of the main features of International Law, namely co-operation, which is a more suitable approach to give voice to those who do not enjoy dominant positions. ${ }^{721}$

As some specialists argue, although one can understand the resistance's advancement of Latin-American countries concerning the current deployment of foreign investment protection rules, it is indispensable to detach it from the Calvo doctrine ${ }^{722}$, in order to rebuild a discourse capable of bridging legal concepts that may sustain the rationality of investment adjudication in the context of the interaction of a set of different global regimes. Identifying general principles of law traditionally enshrined in Latin-American constitutions with corresponding standards of protection included within a foreign investment regime allegedly could be a useful tool for reinforcing legitimacy in this

\footnotetext{
${ }^{721}$ To clarify the need of international law, Lowe transcribed the statement of the British Foreign Secretary, Douglas Hurd, which highlights the irreplaceable importance of co-operation:
}

[N]ation states are ... incompetent. Not one of them, not even the United States as the single remaining super-power, can adequately provide for the needs that its citizens now articulate. The extent of that incompetence has become sharply clearer during this century. The inadequacies of national governments to provide security, prosperity or a decent environment has brought into being a huge array of international rules, conferences and institutions; the only answer to the puzzle of the immortal but incompetent nation state is effective co-operation between those states for all the purposes that lie beyond the reach of any of them.

Hurd (Douglas), The Search for Peace (London: Warner Books, 1997), p. 6 in , Lowe (Vaughan), International Law, Oxford Press, 2007, 1 p.

722 Prieto Muñoz clarifies the little realism involving the proposal of returning to a domestic based regulation and adjudication for foreign investment related issues, based on the following three reasons (1) the necessity to gather a large group of States deciding to pull out from the regime; 2) the permanence of sunset clauses; 3 ) the interconnection of the world society):

Nevertheless, it seems to be a hard enterprise to use the fundamentals of Calvo doctrine and to bring the legal regulation of foreign investment back to the nation-State in the current global legal setting for at least three reasons. To begin with, this would require a large majority of States to simultaneously pull out of the international regime of investment protection. This is not likely to happen because a prisoner's dilemma exists among developing countries, whereby the need to attract capital and technology leads to compete with each other. Secondly, even in the unlikely scenario that a large majority of States do withdraw from the network of international investment agreements, these treaties contain sunset or survival clauses. These clauses extend the treaty's protection to investors for periods which can last up to 25 years after the denunciation of the treaty. Finally, the world society is too interconnected this century, which was not the case in the years of Calvo.

Prieto Muñoz (José Gustavo), "The Rise of Common Principles for Investment in Latin America: Proposing a Methodological Shift for Investor-State Dispute Settlement", Journal of World Investment \& Trade (2016), 620-621 pp. 
context. ${ }^{723}$ As Prieto Muñoz underlines, such an exercise would increase the moral and social acceptance of adjudicators ${ }^{724}$, for instance, by internalizing in their decisions, principles like transparency and inclusion in the context of the social and economic particularities of the countries as stakeholders of the regime.

In any case, it should be noted that the application of international law lies in great part on the functioning of national law, whose ultimate subjects of protection should be mainly the people and neither the States, nor their rulers. In this regard, the legitimacy crisis should not be solved through the recentralization of power but in the opposite, through its decentralization, with the different actors being guardians of common values enshrined in interdependent tools both of rule-making and adjudication. To this end, transparency is indispensable in all the stages of decision making. The reassessment of the rules for investment protection should be an opportunity to consider in the first place which purposes International Law serves and how domestic law and its core fundamentals adjust to a revisited social pact that should privilege co-operation over bilateralization. In the meantime, the State should re-evaluate integrally and publicly the international obligations it has adopted and reinvigorate the forums within which several values like human rights and environmental protection are more suitable of being justiciable. In addition, it is indispensable to reinforce internal capacities of governance, capable of being tested reasonably against any international or transnational threshold, as well as to consider co-ordinated responses both internally and regionally either treaty, regulatory or

723 A good example of this indispensable exercise entails the proper weight of the domestic principles tested against the claimed breach of International Law in light of the principle of proportionality:

The tribunal needs to determine with precision the international legal obligation whose breach gives rise to the State's international responsibility. However, additional reference to 'principles' and 'important norms' of the host State and the region can enhance, without a doubt, the argumentative strength of an award. For example, the Occidental v Ecuador tribunal advanced a far-reaching concept of proportionality, perceiving it also in light of the Ecuadorian Constitution. It is in other words important to draw the link between, on the one hand, concepts developed in international law and international investment dispute settlement, and on the other hand, principles of the State.

Prieto Muñoz (José Gustavo), "The Rise of Common Principles for Investment in Latin America: Proposing a Methodological Shift for Investor-State Dispute Settlement", Journal of World Investment \& Trade (2016), 624 p.

${ }^{724}$ See, Prieto Muñoz (José Gustavo), "The Rise of Common Principles for Investment in Latin America: Proposing a Methodological Shift for Investor-State Dispute Settlement”, Journal of World Investment \& Trade (2016), $626 \mathrm{p}$. 
contract based, to prevent the State's exposure to international litigation, while a new set of multilevel reforms is being bargained.

\subsection{Conclusions}

The Ecuadorian experience shows the complexity and highly politicized nature of the foreign investment protection context. The still vague framework of substantive standards combined with relaxed procedural avenues, especially when it comes to BITs, has prompted a mixed range of responses at the political and legal levels aimed at resisting the pernicious effects of the system.

In many cases, demagogic approaches unable to tackle the real shortcomings of consenting to special rules and forums related to foreign investors' interests have prevailed. However, this should not diminish the overhauled awareness of countries such as Ecuador concerning the far-reaching effects of the system and its multi-sectorial approach to resist them by incorporating constitutional, statutory, regulatory and contractual-based hurdles, in combination with costly decisions at the diplomatic levelsuch as denouncing treaties while multilateral solutions are sought. These responsesalthough systematic - are far from being co-ordinated and do take little account of the close interaction between domestic and international law.

In this regard, a comprehensive resistance approach should not only be accompanied by a set of integral reforms encompassing treaties, statutes, regulations and contracts, but also by an assessment of the internal structure of governance, prioritizing the creation of technical capacities among the main actors of the system and the identification of the regulatory actions that have often triggered investment disputes. To this end, it is essential to understand that investment protection deals with the exercise of regulatory powers. Therefore, it is key to anticipate the effects that domestic measures and decisions involving foreign affairs would likely exert regarding the State's international responsibility.

In view of the unforeseeable shape that the current proposals of multilateral reforms may take, it is more realistic to boost preventive reforms from inwards matching with the new terms that should govern revisited international obligations, rather than demagogically claiming the restoration of restricted notions of sovereignty.

This assessment should take into account that the ultimate addressees of any rule at the international or domestic levels should be the individuals and the protection of global 
legal values. Otherwise, the legitimacy crisis of international law and social unrest linked to the preservation of unfair rules would lead to the adoption of insular and centralized responses at the expense of transparency and relaxation of the accountability standards. 


\section{CHAPTER IV: THE IMPLEMENTATION OF INTERNATIONAL INVESTMENT OBLIGATIONS IN A NEW CONSTITUTIONAL CONTEXT}

\subsection{New Constitutional Context and Pre-existing International Investment Agreements}

The previous chapters addressed the turbulent Ecuadorian constitutional development, the evolution of the boundaries within which regulatory attributions and private interests have interplayed, the emergence of new stakeholders and rights to the public sphere, and the penetration of international investment rules into the domestic framework. Although treaties have been targeted as the most notable tools for subordinating the public goals and regulatory powers to particular private interests, further effective mechanisms for achieving such a result like domestic regulations, official representations and contracts have been overlooked. Consequentially, the causes and the complexity linked to the high exposure of the State to apparently unintended effects stemming from the operation of this complex array of instruments, have also been misinterpreted.

From the viewpoint of the fundamental change of circumstances doctrine, this chapter analyzes the application of international investment obligations in a new constitutional context. To this end, it primarily addresses the scope of the constitutional control of treaties as a mechanism that opens the relationship between international and domestic law. In this perspective, it also examines the narrative of the Constitutional Court regarding the extension of the concept of sovereignty and the way that it interprets Public International Law and International Investment Rules under alleged changed circumstances. The second section advances with the application of this doctrine in the international sphere and analyzes the substantive and procedural hurdles that the State had to face in the event of terminating treaties according to this principle, specific treaty provisions or further grounds by the operation of law.

This analysis is made in light of primary and secondary obligations of International Law. It examines the impact of a new constitutional context in the regulatory space where investors' interests interact. Furthermore, it approaches the allocation of contractual rights considering revisited mechanisms of constitutional control and changed circumstances, as well as the feasibility of resorting to regulatory and contractual waivers with the aim of reducing the influence of treaty-based protection. 


\subsection{Constitutional Control in a Context of Instability}

\subsubsection{The Principle of Constitutional Supremacy into Motion}

The American House of Representatives Committee of Foreign Affairs elegantly categorised Ecuador as reminiscent of "Alice in Wonderland", in a context of colonial racism, political and regional instability as well as a solid distrust to foreigners. ${ }^{725}$ Since the foundation of the republic, the elite intra-classic struggles that went out of control, escalated into "revolutions" which could only be mitigated by the conclusion of a new written agreement denominated constitution. The falsification of the notion of constitutionalism in Ecuador has not meant the absence of a system in which the exercise of authority and the enforcement of rights had not been developed. The sound failure of Ecuador to build a credible constitutional tradition responds to a well-rooted misuse of the constituent processes as the most sought-after solution to settle outstanding political conflicts, normally called "revolutions". Typically the main "revolutionary" transformations are encountered in the appointment mechanisms of representative organs and in the transitional provisions, which implement the political bargains agreed upon after a crisis. Therefore it is understandable that in aspects of individual rights and guarantees, as well as in the extension of regulatory powers, the succeeding constitutional texts are practically identical. ${ }^{726}$ It can be affirmed that in such cases the constitutional

725 On the 1960's, this Committee stressed Ecuador's structural problems focusing its diagnosis on the profound inequalities based on the racial composition of the population as well as the unsettled disputes among the regional elites:

"Whatever the actual proportion of the different elements in the population, Ecuador definitely falls in the category of the Indo-American countries. As such, Ecuador suffers all the problems inherent in the existence of large masses of Indians who speak their native tongues, cling to their ancient traditions and primitive beliefs, and view outsiders with deep distrust born of centuries of ruthless exploitation. The Indians are regarded by many of their fellow citizens as little more than beasts of burden.

(...) Historians have virtually lost count of the resulting revolutions. One count shows that Ecuador had a rapid succession of 40 presidents, dictators, and juntas during the first 95 years of its independence. In the following 1925 to 1948 period no president was able to complete his term of office and there was a total of 22 presidents or chiefs of state. The last three presidents who preceded the present incumbent remained in office for 4-years terms.

The chronic instability which has marked Ecuador's history has produced a situation reminiscent of "Alice in Wonderland". Heated political battles rage, but seldom with regard to the nation's real and pressing problems-of which there are many."

See, House of Representatives- Committee of Foreign Affairs, Special Study Mission to Latin America: Peru, Ecuador, Colombia, Panama, Costa Rica, 88 $8^{\text {th }}$ Congress, $1^{\text {st }}$ Session, Washington, 1963, 20 - 22 pp.

726 Blanksten depicts the curious obsession of Ecuadorian rule-makers to repetitively enact written constitutions, which greatly differ from reality: 
texts have not seriously affected the different frameworks within which well-settled statutory provisions have been invariably applied by the judiciary ${ }^{727}$. The strong positivistic inclination of rule makers and adjudicative authorities to the written rule means that the scope and maturity of a principle or right had historically to be tested against infra-constitutional rules rather than the Constitution itself. In consequence, it can be affirmed that in the Ecuadorian context, the constitutional dimension has played a supplementary role when the exercise of sovereign powers is under scrutiny.

Without disregarding the sovereign wrongdoings that normally might trigger investment disputes, it can be affirmed that the high exposure of developing countries like Ecuador to the rigor of the system responds to the undetermined breadth of protection of its rules, which in nature are "constitution-like" and as such clash and ultimately override, key domestic legal principles. Schneiderman condenses the main feature of international investment regime:

\begin{abstract}
"Ecuadorian constitutions have traditionally leaned heavily in the "paper" direction, with or without combination. No trend away from this tradition has been evident in recent years, and Ecuadorians have not been without reason in saying that the "paper-revolutionary" Constitution of 1945 and the "paper conservative" Constitution of 1946 have been divorced from reality. The normally wide divergence between the "real" and the written constitutions of Ecuador has found partial expression in the frequency with which governments have changed in ways which were independent of, and in violation of, the text of the written constitutions. These changes accomplished with or without violence, have been known as "revolutions", and have been an integral part of the Ecuadorian political process. The lower classes of the republic have not participated in the country`s revolutions: these occurrences are but one phase of the "whites" intraclassic struggle."
\end{abstract}

See, Blanksten (George I.), Ecuador: Constitutions and Caudillos, University of California Press, Berkeley and Los Angeles, 1951, $171 \mathrm{p}$.

${ }^{727}$ On a thorough assessment of the state of the judiciary in Ecuador in 1990, Laura Chinchilla approaches the institutionalized social inequalities, which echo in the judicial practice. The distinction drawn to the courts on one side, as agents arbitrating political processes and on the other, as adjudicators of individual rights has to be underlined. While in the latter case the peripheral role of the courts contributed to the development of a consistent practice, specially with respect to civil law related aspects, in the former, the invariable politicization of the courts aggravated institutional crisis. Verner, as quoted by Chinchilla portrays the stubborn court's role:

"Based on a bibliographic review of pre-1979 sources, Verner classifies the Ecuador judiciary as "minimalist", that is, one with institutional continuity, but with little independence with respect to other government agencies. As Verner comments, "these courts function, in the main, to legitimate, to rubber-stamp decisions made elsewhere in the political process". While the Ecuadorian judiciary before 1979 appears to have been freer from overt political intervention than in many Latin American countries, this situation was due primarily to the largely peripheral role of the courts. Joel G. Verner, "The Independence of Supreme Courts in Latin America A Review of the Literature", Journal of Latin American Studies, Vol.16, Part 2, November 1984, pp.494-497."

See, Chinchilla (Laura) and Schodt (David), The Administration of Justice in Ecuador, Center for the Administration of Justice, Florida International University, 1987, 76-77 pp. 
It has as its object the placing of legal limits on the authority of government, isolating economic from political power, and assigning to investment interests the highest possible protection- $(\ldots) .{ }^{728}$

The renewed impetus towards the recovery of sovereign space underpinned by overhauled mechanisms of constitutional control may be the result of succeeding political crises that have pushed for the consolidation of a framework in which key social values, fundamental personal liberties and main principles of democratic co-existence can be guaranteed and developed. However, the usual limited authority given to the Constitution as a vivid set of values, capable of infusing legitimacy to the social pact, suggests that the construction of the notion of constitutionalism is a titanic task, whose realization still depends in the Ecuadorian context. It is noteworthy that, not a long time ago, the execution of the Constitution was conditioned by the promulgation of implementing legal norms.

As noted alongside the previous chapters, the return to democracy in 1979, the sustained growth of the middle class, the resurgence of political parties and the emergence of social groups like the indigenous movement, pressed for the reallocation of powers and the recognition of new social realities expressed in revisited social pacts. Although the Constitution of 1978 and its successive reforms of 1984, 1993, 1996 and 1997 are strongly imbued with guidelines favouring the status quo and the operationalization of circumstantial political interests, the progressive prioritization of fundamental rights and declarative mechanisms of constitutional control paved the way for their further enforceability.

It has to be recalled that the first attempts to put into action mechanisms of constitutional control were materialized through the Constitution of 1967 and the subsequent promulgation of the Organic Law of the Tribunal of Constitutional Guarantees issued in 1967, whereby the weak competences of the abolished State Council were assumed by this brand new institution. ${ }^{729}$ In any case, the solid positivistic tradition

\footnotetext{
728 Schneiderman (David), Constitutionalizing Economic Globalization: Investment Rules and Democracy's Promise, Cambridge University Press, United Kingdom, 2008, 4 p.

${ }^{729}$ The pre-dominant hortatory attributions conferred to a political body as set forth by the Organic Law of the Tribunal of Constitutional Guarantees promulgated in 1967 in light of the Constitution of the same year, can be summarized as follows: 1) Seeking the compliance of the Constitution and urging the authorities to rectify actions and situations in contradiction with the same; 2) Observing the laws, decrees, regulations and resolutions issued in contradiction with the Constitution, after hearing the authority provoking the alleged unconstitutionality; 3) Processing the complaints of any person concerning the violation of the Constitution and if such irregularity is confirmed, admonishing the respective authority to amend the action. In case of non-compliance, the Tribunal could report the same to the National Congress; 4) Suspending
} 
of the State was translated into the rule makers' reluctance to confer jurisdictional attributions to this tribunal, reserving the competence to rule about the constitutionality of normative acts to the National Congress. As of the Constitutional Codification of 1993, the aforementioned control was entrusted to the newly created Constitutional Chamber of the National Supreme Court. This Chamber was suddenly replaced by the Constitutional Tribunal created by the Constitutional Codification of 1996 and finally vested with jurisdictional attributions, denied to its predecessor. Contrary to what might be inferred, a process of trial and error did not underpin the progressive consolidation of the system of jurisdictional control, but critical episodes of political dispute. For instance and in spite of the fact that the Constitutional Codification of 1984 bestowed on the Tribunal of Constitutional Guarantees the power to suspend the effects of the application of norms allegedly unconstitutional, this competence and even the whole functioning of such an institution was put under discussion on the allegation that the Organic Law of the Tribunal of Constitutional Guarantees promulgated under the Constitution of 1967 was no longer available in the light of a questionable legal interpretation of the Attorney General. ${ }^{730}$ In any case, the National Congress preserved the final say on constitutional

total or partially by request or by its own motion the effects of any norm or resolution against the Constitution. In case of ordering the suspension of a norm, such a decision had to be upheld by the National Congress.

See, Moscoso Álvarez (Raúl), Apología del Tribunal de Garantías Constitucionales, Fundación Ecuatoriana de Estudios Sociales, Quito, 1993, 15 p.

${ }^{730}$ On March 23th, 1987, at request of the President, León Febres Cordero, the Attorney General, Jorge Gómez Renella, on the basis of his competence to interpret legal provisions, concluded that the Organic Law of the Tribunal of Constitutional Guarantees promulgated in 1968 in accordance to the Constitution of 1967, was not in force. As a consequence, the acting Tribunal of Constitutional Guarantees with which the President had bitter conflicts at the time, was not legally entitled to exercise his constitutional attributions until the a new Law and Regulation regularising his attributions was promulgated. In view of this argument, the Attorney General concluded:

"Usted, señor Presidente, en su consulta, solicita se absuelvan dos asuntos:

1. Se ha dictado, se encuentra vigente la Ley Orgánica del Tribunal de Garantías Constitucionales?

Por las razones y fundamentaciones jurídicas y de hecho, establecidas en los Nos. IV, V, VI y VII, y sobre todo en éste último, no se ha dictado, ni se encuentra vigente ninguna Ley Orgánica del Tribunal de Garantías Constitucionales, ya que la Ley de 1968, se expidió conforme a la Constitución de 1967, que al dejar de tener vigencia por el golpe dictatorial del Dr. José María Velasco Ibarra, igualmente quedaron sin vigencia y derogadas los organismos y leyes establecidos en la misma; $y$,

2. En caso negativo, existe alguna resolución o reglamento que, operando legalmente, determine el funcionamiento y los procedimientos para la actuación del Tribunal de Garantías Constitucionales? 
matters, both by upholding the suspension of the disputed decisions and by declaring a norm as unconstitutional. The gradual rise of hybrid institutional responses for operationalizing the interminable prerogatives integrated in the successive constitutional texts, beyond the traditional boundaries dominated by the executive and parliamentary branches, shows the rule makers' reluctance to decentralize the mechanisms of institutional bargaining from the Legislature and most important, for paving the way for making the constitutional provisions actually enforceable. Until the Constitution of 2008, the National Congress had also the power to appoint the members of the Constitutional Tribunal. It is also noteworthy that as the constitutional reform of 1993 the requirement of holding a law degree was introduced for members of the Tribunal of Constitutional Guarantees, which stresses the long-standing understanding of the Constitution, as a programmatic text setting the guidelines of political co-existence and allocation of powers rather than an enforceable legal source. The cumbersome and unparalleled institutional designs for the allocation of powers regarding constitutional control attempted on the constitutional reforms from 1979 to 1998, depicts the indefatigable National Congress's reluctance to yield its authority to rule over constitutional issues. ${ }^{731}$

Por lo expuesto en la respuesta que antecede, y, porque sólo el Parlamento puede expedir la Ley Orgánica del preindicado Tribunal, no puede tomarse ninguna resolución, ni expedirse reglamento alguno, mientras no se dicte la Ley.

Finalmente, debo dejar constancia que la Carta Fundamental vigente, establece la existencia jurídica y constitucional del Tribunal de Garantías Constitucionales; su integración y sus atribuciones conforme a los Arts. 140 y 141 ibidem, cuya aplicación rigurosa y jurídica, sólo procede realizar, hasta tanto se expidan la Ley y el Reglamento correspondientes. »

See, Tribunal de Garantías funciona sin Ley, Impreso en los Talleres de la Editora Nacional, QuitoEcuador, 1987.

${ }^{731}$ As expected, the wording from the practical application of the constitutional organic provisions differed ostensibly. The interpretation and control of the constitutional supremacy rested on the will of one single political organ, namely the National Congress:

\footnotetext{
"The destabilizing conflicts among the executive, legislative, and judicial branches of government resulted primarily from idiosyncrasies of Ecuador's institutional structure. For example, the judiciary, despite being independent, lacked the authority needed to serve as an effective check on the abuse of presidential powers. Although the Supreme Court of Justice (Corte Suprema de Justicia-CSJ) carried out many judicial duties normally expected of a nation's highest court, it did not rule on constitutional issues. A non-judicial appendage of the National Congress (Congreso Nacional-hereafter, Congress), the Tribunal of Constitutional Guarantees-TGC), exercised that function, thereby giving the legislative body the power to, in effect, control interpretation of the Constitution."
}

See, Ecuador a country study, Federal Research Division, Edited by M. Hanratty (Dennis), Research completed December 1989, $156 \mathrm{p}$. 
The system of designation of the members of the Tribunal of Constitutional Guarantees also demonstrates the exacerbated political hallmark of this entity. The National Congress designated the members of the tribunal from among the lists of nominees made by an amalgam of actors both governmental and non-governmental, ranging from the President to provincial and local governments, trade-unions, representatives from the society, chambers of production and commerce and ultimately, unions of peasants and indigenous organizations. As expected, the nominators slightly changed with the inexorable constitutional amends taking place between 1978 and 1996, but the most decisive upgrade of the tribunal's hortatory attributions to jurisdictional ones, became effective in the latter year.

This picture captures the traditional struggle of the lobby groups to accommodate their interests into institutional formulas, designed to settle circumstantial disputes. In this context, a specialized mechanism of constitutional interpretation and control is not well established, although it has to be acknowledged, that big steps were taken towards the specialization of such powers since 1998 .

\subsubsection{Constitutional Control of Treaties}

The negligible constitutional control of international treaties remained in the legislative realm until the Constitution of 1998, when a formal mechanism for their constitutional conformity was introduced. It has to be recalled that the first attempt at incorporating the mechanism of ex ante control of treaties was taken by the Constitution of $1967^{732}$ and further reinserted and overhauled by the Constitution of $1998^{733}$. This

\footnotetext{
${ }^{732}$ Constitución Política de 1967:

“Art. 184.- Deberes y Atribuciones.- Al Presidente de la República corresponden los siguientes deberes y atribuciones:

(...) 3 Dirigir las relaciones internacionales y las negociaciones diplomáticas; celebrar tratados y ratificarlos, previa aprobación del Senado en los casos requeridos; canjear las ratificaciones y denunciar los tratados vigentes, conforme a los convenios internacionales celebrados por el Estado.
}

No están sujetos a aprobación del Senado los tratados que no supongan obligaciones o cargas permanentes para la Hacienda Pública o para los ciudadanos ecuatorianos ni en general, los que no exijan para su cumplimiento medidas legislativas. Estos tratados se someterán al dictamen del Tribunal de Garantías Constitucionales, y el Presidente de la República dará cuenta de ellos al Congreso en el próximo período de sesiones, con determinación de su carácter y contenido."

${ }^{733}$ Constitución Política de 1998: 
mechanism was preserved by the Constitution of 2008, which aggregated the ex post facto control of international treaties.

The mechanism of prior constitutional control of international treaties entrusted to the Tribunal of Constitutional Guarantees provided for by the Constitution of 1967 lived scarcely long enough to be properly tested. President Velasco Ibarra's seizure of power in 1970 suspended the Constitution of $1967^{734}$. The Constitution of 1979 suppressed any reference to a specific mechanism, prior or posterior, regarding the constitutional control of international treaties. In any event, the wording of the ever-existent constitutional supremacy principle has always encompassed the ample category of "any public treaties and pacts", in which it was fair to assume, that international treaties also fell. The Constitution of 1979 clarified such an omission and incorporated in the provision enshrining its supremacy, "international treaties or agreements", declaring that they would be void, should they be in contradiction with the Constitution..$^{735}$

As noted, monitoring the materialization of this declarative principle was weakly entrusted to a particular entity, namely the Tribunal of Constitutional Guarantees, as of the Constitution of 1945. The parochial assimilation of International Law as an exclusive issue reserved to diplomatic relations explains the literal and concrete exclusion of international treaties as a category of constitutional and judicial review. Even after the constitutional reform of 1996, which importantly, overhauled the jurisdictional powers of the Constitutional Tribunal and incorporated international treaties into the domestic legal framework insofar as they were in conformity with the Constitution and the Law, neither a normative nor a procedural mechanism providing the corresponding judicial review was

\footnotetext{
“Art. 162.- La aprobación de los tratados y convenios, se hará en un solo debate y con el voto conforme de la mayoría de los miembros del Congreso.

Previamente, se solicitará el dictamen del Tribunal Constitucional respecto a la conformidad del tratado o convenio con la Constitución.

La aprobación de un tratado o convenio que exija una reforma constitucional, no podrá hacerse sin que antes se haya expedido dicha reforma."
}

734 This virtual abolishment did not change with the military coup of 1972, whereby the armed forces under the leadership of Rodriguez Lara took power and re-established the Constitution of 1945 until 1974, when it was suspended. In 1976, a new military board overthrew Rodríguez Lara and reinstated the Constitution of 1945, which remained in force until a new Constitution was promulgated in 1979.

${ }^{735}$ Constitución Política de 1979:

“Art. 137.- La Constitución es la ley suprema de Estado. Las normas secundarias y las demás de menor jerarquía deben mantener conformidad con los preceptos constitucionales. No tienen valor alguno las leyes, decretos, ordenanzas, disposiciones y tratados o acuerdos internacionales que, de cualquier modo, estuvieren en contradicción la Constitución o alteraren sus prescripciones." 
developed. ${ }^{736}$ This omission led to the incoherent outcome that despite the monist conception of International Law being constitutionally introduced, there was not a mechanism to review the conformity of pre-existing treaties incorporated to into the domestic legal framework. ${ }^{737}$ Correlatively, it was enacted the Law of Constitutional Control in 1997, omitting the incorporation of a particular process to test the conformity of international treaties with the Constitution. Nevertheless the corresponding statutory provisions, encompassed the principle of constitutional supremacy, declaring as void any inferior norms contradicting the Constitution ${ }^{738}$, the legal attributions vested in the Constitutional Tribunal excluded from their wording any reference to the control of international treaties. ${ }^{739}$

\footnotetext{
${ }^{736}$ Constitución de la República del Ecuador, Codificación 1996:

"Art. 94.- Las normas contenidas en los tratados y demás convenios internacionales que no se opongan a la Constitución y Leyes, luego de promulgados, forman parte del ordenamiento jurídico de la República."
}

See, Registro Oficial 969 de 18 de junio de 1996.

${ }^{737}$ Itzíar Goméz observed the unbridgeable contradiction stemming from such assimilation, in absence of a mechanism of constitutional control of the pre-existing treaties. In case of contradiction between constitutional provisions and international obligations, the State was compelled to assess whether to violate the Constitution or the International Law. The State normally favored the former option:

\begin{abstract}
"Si solo los tratados del art. 161 CPE van a pasar por el control previo del Tribunal, eso supone que entrarán al ordenamiento ecuatoriano una buena cantidad de tratados que no podrán jamás ser sometidos a control de constitucionalidad, porque ni están en la lista del art. 161 CPE que define el objeto de control previo, ni se contempla la posibilidad en el sistema ecuatoriano de someter a control sucesivo los tratados válidamente incorporados al ordenamiento."
\end{abstract}

See, Gómez Fernández (Itzíar), "Los tratados internacionales en el ordenamiento jurídico ecuatoriano: su función como objeto y parámetro de control de constitucionalidad" en Pablo Pérez Tremps coord., Derecho Procesal Constitucional, Quito, Corporación Editora Nacional, pp. 151 - 188, 2005.

${ }^{738}$ Ley de Control Constitucional:

"Art. 1.- El control constitucional tiene por objeto asegurar la eficacia de las normas constitucionales en especial de los derechos y garantías establecidos en favor de las personas, los cuales son plenamente aplicables e invocables ante cualquier juez, tribunal o autoridad pública.

Art. 2.- Carecen de valor las normas de menor jerarquía que se opongan a los preceptos constitucionales. Sin embargo, los derechos y garantías señalados en la Constitución no excluyen el que, mediante ley, tratados o convenios internacionales y las resoluciones del Tribunal Constitucional, se perfeccionen los reconocidos o incluyan cuantos fueren necesarios para el pleno desenvolvimiento moral y material que deriva de la naturaleza de la persona."

${ }^{739}$ Ley de Control Constitucional:

"Art. 12.- Son atribuciones y deberes del Tribunal Constitucional:

1. Conocer y resolver las demandas de inconstitucionalidad, por el fondo o por la forma, de leyes, decretos-leyes, decretos, reglamentos y ordenanzas; y de ser el caso, suspender total o parcialmente sus efectos;

4. Resolver respecto de las objeciones de inconstitucionalidad que haya hecho el Presidente de la República, en el proceso de formación de las leyes;

6. Conocer los informes que se le presenten sobre declaratorias de inconstitucionalidad pronunciadas por las salas de la Corte Suprema de Justicia o por los demás tribunales de última 
In this way, the mechanism of prior constitutional control of international treaties was reinserted by the Constitution 1998. Inconveniently, this mechanism only required the prior constitutional control of those treaties, whose category fell outside the list set out by the Constitution ${ }^{740}$. Should the treaty not fall under such boundaries according to the President's self-assessment, it could be directly ratified being exempted from prior constitutional control and legislative approval. As noted in chapter II, the application of such a mechanism meant for instance, that ICSID Convention was subject to legislative approval, whereas a handful of BITs had been directly ratified. This kind of treaties contains the State's obligations, which could arguably fall under mere implementing obligations exempted from legislative approval and constitutional scrutiny. This twofold procedure shows the political reluctance to fully entrust the constitutional tribunal with exclusive powers to exert constitutional control over international treaties. The democratic and juridical deficit of such exclusion is serious considering that according to the Constitution of 1998, the international treaties ratified and published in the Official Gazette even prior to this year, became part of the national legal framework, prevailing over laws and other norms of inferior hierarchy. Furthermore, the Constitution of 1998 entitled any judge or court not to apply norms or legal precept in contradiction with international treaties. ${ }^{741}$ This cosmopolitan pre-disposition to international treaties in

instancia; y resolver con carácter de obligatoriedad general la inaplicabilidad de un precepto legal si fuere contrario a la Constitución. Tal resolución no tendrá efectos sobre el fallo.

Para el cumplimiento de lo prescrito en el inciso anterior, la sala de la Corte Suprema o el respectivo tribunal de última instancia, remitirá al Tribunal Constitucional el correspondiente informe, dentro de los siguientes treinta días de haberse ejecutoriado la sentencia o auto; y,

740 Constitución de 1998:

“Art. 161.- El Congreso Nacional aprobará o improbará los siguientes tratados y convenios internacionales:

1. Los que se refieran a materia territorial o de límites.

2. Los que establezcan alianzas políticas o militares.

3.Los que comprometan al país en acuerdos de integración.

4. Los que atribuyan a un organismo internacional o supranacional el ejercicio de competencias derivadas de la Constitución o la ley.

5. Los que se refieran a los derechos y deberes fundamentales de las personas y a los derechos colectivos.

6. Los que contengan el compromiso de expedir, modificar o derogar alguna ley."

${ }^{741}$ Constitución de 1998:

“Art. 274.- Cualquier juez o tribunal, en las causas que conozca, podrá declarar inaplicable, de oficio o a petición de parte, un precepto jurídico contrario a las normas de la Constitución o de los tratados y convenios internacionales, sin perjuicio de fallar sobre el asunto controvertido.

Esta declaración no tendrá fuerza obligatoria sino en las causas en que se pronuncie. El juez, tribunal o sala presentará un informe sobre la declaratoria de inconstitucionalidad, para que el Tribunal Constitucional resuelva con carácter general y obligatorio. 
conjunction with a relaxed mechanism of treaty approval eased the speedy adoption of market friendly international obligations, especially during the second half of the 1990s.

The futility of the aforementioned mechanism of constitutional control was corroborated when the Constitutional Tribunal ruled over the claim of unconstitutionality regarding the agreement of military cooperation concluded between Ecuador and US. Under this treaty, Ecuador conferred the control of a strategic coastal strip of land to the US Army for the purported fight against drugs. The entry into force of this agreement avoided Congress's approval, since the President of the time, judged that it did not fall into the category of treaties which were compelled to follow this process. When the Constitutional Tribunal dismissed the claim of unconstitutionality, it founded its decision in two arguments: 1) that the agreement at issue did not fall under any of the categories which constitutionally required Congress's approval; 2) that neither the Constitution nor the law bestowed this Tribunal with powers to control the constitutionality of an international treaty. In the first case, the Tribunal, relying on a very literal interpretation of the agreement, refuted that the same involved either a military alliance or any territorial commitment, which could threaten the exercise of Ecuadorian sovereign powers. It concluded that this was a "co-operation agreement" to fight against drug trafficking derived from the countries' mutual obligations enshrined in the United Nations Convention against the Illicit Traffic in Narcotic Drugs and Psychotropic Substances. Interestingly, the dissenting opinions remarked on the exclusion of Ecuadorian jurisdiction from damages to persons and property inflicted by foreigners serving the base's military operations. Of course, these exclusions do not seem to correspond to operative instructions normally contained in executive agreements exempted both from prior constitutional control and legislative approval. In the second argument, the Tribunal rubber-stamped the structural incoherence that preserved the subsistence of international treaties in contradiction with the Constitution by declaring itself incompetent for deciding about the constitutionality of a ratified treaty. ${ }^{742}$

\footnotetext{
742 The Constitutional Tribunal declared itself non-competent to rule over the constitutionality of treaties, stressing that the Constitution only provided for the prior control of those treaties subject to legislative approval as enlisted therein:

“ (...)Que, el control de constitucionalidad de instrumentos internacionales previsto en los artículos 162, inciso segundo, y 276, número 5, del texto constitucional es el llamado control preventivo de constitucionalidad, el mismo que compete a este Tribunal sólo de forma previa a su aprobación por parte del Congreso Nacional y, por ende, tan sólo en los casos en los que se requiera de aprobación legislativa;

Que, por otra parte, el artículo 276 la Constitución Política reserva el control represivo de constitucionalidad, en su número 1, respecto de leyes orgánicas y ordinarias, decretos-leyes,
} 
This decision closed the doors to further challenging the conformity of an international treaty with the Constitution, except under the claim that the President had directly ratified a treaty, which according to its category would have to follow the process of approval enshrined by the Constitution. This interpretation implied that the only possibility to contest a substantive contradiction between a treaty obligation and the Constitution might be channelled through a procedural violation for the approval of the treaties as exhaustively listed therein. Importantly, this possible challenge was confined to those treaties signed after the Constitution of 1998, when this mechanism of prior review was inserted. Should the alleged treaty not fall within the categories prescribed by the Constitution according to the Tribunal's interpretation, there was not a mechanism to review either a formal or a substantial possible violation. Moreover, high courts had the power not to apply a "legal precept" contrary to the Constitution in concrete cases, resting in the Constitutional Tribunal's decision to uphold such a finding with general effects. The Constitutional Codification of 1996 and the Constitution of 1998 ranked international treaties above domestic law, but suppressed them from the constitutional provision that regulates constitutional supremacy in cases of normative hierarchy conflicts $^{743}$. Consequentially and although the courts had the power to make treaties prevail in the case of contradiction with domestic rules, they did not have the power to disregard the application of the same, in the case of contradiction with the Constitution. In short, neither the Constitutional Tribunal nor the courts had the power to declare a treaty void or refuse its application. ${ }^{744}$ This situation was translated into the Executive's abuse of the

decretos, ordenanzas, estatutos, reglamentos y resoluciones, emitidos por órganos de las instituciones del Estado y, en su número 2, respecto de actos administrativos;

Que, la Constitución no le otorga competencia a este Tribunal para conocer y resolver demandas de inconstitucionalidad de tratados o convenios internacionales; (...)"

See, Casos acumulados Nos. 032-2000-TC, 035-2000-TC y 051-2000-TC, Official Gazette 260-S, February 6, 2001.

${ }^{743}$ Constitución de 1998:

“Art. 272.- La Constitución prevalece sobre cualquier otra norma legal. Las disposiciones de leyes orgánicas y ordinarias, decretos - leyes, decretos, estatutos, ordenanzas, reglamentos, resoluciones y otros actos de los poderes públicos, deberán mantener conformidad con sus disposiciones y no tendrán valor si, de algún modo, estuvieren en contradicción con ella o alteraren sus prescripciones.

Si hubiere conflicto entre normas de distinta jerarquía, las cortes, tribunales, jueces y autoridades administrativas lo resolverán, mediante la aplicación de la norma jerárquicamente superior."

${ }^{744}$ Constitución de 1998: 
prerogative to circumvent the treaty's legislative approval, incentivized by its weak constitutional and legal liability to prompt the review of treaties in contradiction with the Constitution. ${ }^{745}$ Inconveniently, the Constitution of 2008 preserved this bifurcated system of treaty adoption, despite the Constitutional Court's authority to control the constitutionality of a ratified treaty.

\subsection{Constitutional Control of International Investment Agreements}

\subsubsection{The Review Process of Bilateral Investment Treaties}

The inconvenience of preserving the dual mechanism of treaty approval in the light of the categorization of international treaties prescribed by the Constitution is eloquent from the constitutional rulings that declared the Bilateral Investment Treaties (BITs) to not be in conformity with the Constitution. Notwithstanding the similarity of BITs and the consolidated President's request consulting whether the termination of 17 BITs required the National Assembly's approval, the Constitutional Court following its internal regulation ${ }^{746}$, distributed among several justices the task to verify such a requirement. ${ }^{747}$ Should this be the case, the justices had to additionally verify the conformity of the whole

“Art. 274.- Cualquier juez o tribunal, en las causas que conozca, podrá declarar inaplicable, de oficio o a petición de parte, un precepto jurídico contrario a las normas de la Constitución o de los tratados y convenios internacionales, sin perjuicio de fallar sobre el asunto controvertido.

Esta declaración no tendrá fuerza obligatoria sino en las causas en que se pronuncie. El juez, tribunal o sala presentará un informe sobre la declaratoria de inconstitucionalidad, para que el Tribunal Constitucional resuelva con carácter general y obligatorio."

${ }^{745}$ Constitución de 1998:

“Art. 171.- Serán atribuciones y deberes del Presidente de la República los siguientes:

1. Cumplir y hacer cumplir la Constitución, las leyes, los tratados y los convenios internacionales y demás normas jurídicas dentro del ámbito de su competencia. (...)”

${ }^{746}$ See, Reglamento de Sustanciación de Procesos de la Corte Constitucional, Registro Oficial-Suplemento 591, 21de Septiembre de 2015.

${ }^{747}$ Ley Orgánica de Garantías Jurisdiccionales y Control Constitucional:

“Art. 107.- Modalidades de control constitucional de los tratados internacionales.- Para efectos del control constitucional de los tratados internacionales, la Corte Constitucional intervendrá a través de los siguientes mecanismos:

1. Dictamen sobre la necesidad de aprobación legislativa;

2. Control constitucional previo a la aprobación legislativa; $y$,

3. Control sobre las resoluciones mediante las que se imparte la aprobación legislativa." 
treaty with the Constitution ("automatic control of constitutionality"748). The outcome consisted in several projects of judgments delivered by the incumbent justices, which were further considered, and ultimately approved by the Court's plenary session. Although slight divergences are normally expected to arise in such drafts, the similarity of the wording of these first generation BITs, would preclude any major discrepancy with respect to the main legal arguments that are the basis for the constitutional review. Moreover and bearing in mind that these drafts become binding rulings after the Plenary's approval, the constitutional provisions invoked and the arguments elicited in the respective rulings should be alike if not identical given the similarity of such treaties, whose review is centralized through a single adjudication body. Unfortunately, this was not the case in the constitutional assessment of the 17 BITs, wherein the Constitutional Court failed to: 1) subsume uniformly the BITs to a single category of treaties, whose termination or ratification require Congress' approval; 2) identifying homogenously the treaties' clauses allegedly in contradiction with the Constitution, with the exception of the dispute settlement provisions; 3) assessing the conformity of the substantive provisions to the Constitution.

The categorization of the BITs among the list of international treaties provided for by the Constitution should not be a trivial assessment, as this determination conditioned the procedure of treaty termination and influenced the scope of the analysis concerning the provisions allegedly in contradiction with the Constitution. The constitutional rulings assumed that the BITs assessed, fell indistinctly in one of the following three categories of treaties, which either: 1) Compromise the State's economic policy set forth in the National Plan of Development to conditions determined by international financial institutions or transnational enterprises (Art. 419, 5); 2) Compromise the country to integration of trade agreements (Art. 419,6); 3) Confer attributions of the domestic legal framework to international or supranational entities (Art. 419, 7). As it was observed in Chapter I, a strict confrontation of the wording of these provisions with the BITs' scope of protection would have corroborated that none of these treaties did fall within any of the aforementioned categories. It is also noteworthy, that the Constitutional Court had

\footnotetext{
${ }^{748}$ Ley Orgánica de Garantías Jurisdiccionales y Control Constitucional :

"Art. 112.- Efectos de las sentencias y dictámenes.- Las sentencias y dictámenes correspondientes tendrán los mismos efectos de las de constitucionalidad abstracta en general, y en particular, los siguientes:

(...) 4. Cuando se declara la inconstitucionalidad de un tratado ya ratificado, el Estado deberá denunciar el tratado ante el órgano correspondiente, la orden de promover la renegociación del tratado, o promover la enmienda, reforma o cambio constitucional."
} 
limited its analysis to the presumed unconstitutionality of dispute settlement provisions, including inter-State arbitration. Only in the BIT with Finland, was the said clause not found in contradiction with the Constitution. In addition, only in the analysis of the BIT with Germany was identified an attempt for disputing the constitutionality of certain substantive provisions, like Most Favoured Nation (MFN) treatment and the retroactive protection of investments. Further indications of defective review can be found in the ruling of the BIT with Canada, where the Court also found that the provision prescribing the exchange of enquiries and information was against the Constitution. Apparently this was an unnoticed mistake due to the wrong identification of the provision's number. When the Constitutional Court undertook the abstract control of constitutionality of the BITs, it was entitled not only to impeach those who caused the conflicts singled out by the President when it requested the prior ruling, but also the conformity of the whole treaty provisions to the constitutional framework. Disregarding more favourable principles of constitutional interpretation that determine that declaring a norm as unconstitutional is a remedy of last resort, the Court censured the clauses providing for arbitration. It could be assumed that the omission to declare substantive standards of protection like expropriation, fair and equitable treatment and the definitions of investment and investor as contrary to the Constitution, would allow further agreements to embody such clauses without offending the constitutional framework in the light of the principle of integral control. ${ }^{749}$

\footnotetext{
749 The Organic Act on Jurisdictional Guarantees and Constitutional Control sets forth that declaring the unconstitutionality of a norm is a remedy of last resort providing for several principles of interpretation that may be employed in first place. Remarkably, the Constitutional Court is entitled to harmonize the constitutional provisions with international obligations. It is also mandatory to the Court to confront the norms allegedly in contradiction with the Constitution not only with constitutional provisions expressly invoked but also with the whole constitutional framework:

“Art. 76.- Principios y reglas generales.- El control abstracto de constitucionalidad se regirá por los principios generales del control constitucional previstos por la Constitución y las normas constitucionales, la jurisprudencia y la doctrina. En particular, se regirá por los siguientes principios:

1. Control integral.- Se deberá confrontar la disposición acusada con todas las normas constitucionales, incluso por aquellas que no fueron invocadas expresamente por el demandante.

2. Presunción de constitucionalidad de las disposiciones jurídicas.- Se presume la constitucionalidad de las disposiciones jurídicas.

5. Interpretación conforme.- Cuando exista una interpretación de la disposición jurídica que sea compatible con las normas constitucionales, no se declarará la inconstitucionalidad y en su lugar se fijará la interpretación obligatoria compatible con aquella. De igual modo, cuando una parte de una disposición jurídica la torne en su integridad inconstitucional, no se declarará la inconstitucionalidad de toda ella, sino que se invalidará la parte inconstitucional y dejará vigente la disposición así reformada.
} 


\subsubsection{Constitutional Control of Treaties in Changed Circumstances}

The Constitutional Court's approach to the principle of fundamental change of circumstances is neither uniform nor consistent. Not all the rulings tackle this concept and its definition varies depending on the justice delivering the project of ruling. For instance, the justice, Ruth Seni, addressed the concept of fundamental change of circumstances when she delivered two projects of rulings, concerning the BITs with Chile and Switzerland. In this way, she contended that the compliance of international treaties is subordinated to the permanence of the "situations" that motivated and allowed the conclusion of the same. In her opinion, essential elements like the promulgation of a new constitutional framework would configure a "significant" change of circumstances with respect to "the operationalization and efficacy of an international instrument". ${ }^{750}$ In harmony with this argument, justice, Antonio Gagliardo Loor, touched upon the principle pacta sunt servanda to sustain the necessity of denouncing such treaties. By intermingling contract and treaty-based obligations, he stressed that the BIT with Italy was adopted before the promulgation of the constitutional framework in force. Therefore and given that BITs similarly to the Vienna Convention on the Law of Treaties (VCLT) set forth the possibility of denouncing such obligations, it would suffice for "the simple

6. Declaratoria de inconstitucionalidad como último recurso.- Se declarará la inconstitucionalidad de las disposiciones jurídicas cuando exista una contradicción normativa, y por vía interpretativa no sea posible la adecuación al ordenamiento constitucional. “

${ }^{750}$ The justice Ruth Seni Pinoargote, summarized her arguments grounding an alleged fundamental change of circumstances as follows:

“1) Los tratados y convenios internacionales son de estricto cumplimiento para las partes, siempre y cuando las situaciones que motivaron y permitieron la realización de dichos instrumentos internacionales se mantengan; por ende, elementos esenciales como la adopción de un nuevo marco constitucional constituyen un cambio significativo de circunstancias en lo que respecta a la operatividad y eficacia de la aplicación de un instrumento internacional.

2) El contenido del artículo 422 claramente deja establecido las condiciones que tienen que cumplir los instrumentos internacionales para que puedan pasar a formar parte de la normativa ecuatoriana en el caso de instituir algún método arbitral de solución de controversias; y,

3) Las disposiciones contenidas en el acuerdo analizado son claramente contrarias a la Constitución de la República por lo que se hace evidente la necesidad de que se prosiga con su denuncia, por cuanto se está cediendo una competencia propia del orden jurídico interno del Estado ecuatoriano a instancias internacionales de resolución de conflictos, que no cumplen con los requisitos establecidos en el artículo 422 de la máxima norma jurídica del Ecuador."

See, Dictamen No. 040-10-DTI-CC, Caso No. 0012-10-TI, “Tratado entre la República del Ecuador y la Confederación Suiza sobre Protección y Fomento de las Inversiones", Registro Oficial 331, 30 de Noviembre 2010. 
notification of the Ecuadorian State to terminate the commitment assumed in the said agreement". ${ }^{751}$ Importantly, he regarded as evident that the "commitments and investments acquired before the date of termination would remain in force during an additional period of five years". ${ }^{752}$ In this context, it is notable the assumption that conceives the transformation of the national legal framework due to the promulgation of a new Constitution as the sole reason to review and bringing into conformity with the latter, the "pre-constitutional" treaties ${ }^{753}$. Along with the alleged "undeniable incompatibility" of the mentioned BIT with the Constitution and the new State model, there are remarkable strong political assertions that merely claim new challenges in the political, legal and economic fields, which altogether would motivate the necessity of denouncing such international instruments. In the context of this very succinct legal analysis, the Court did little to analyze for instance, the tension that endorsing the validity of the survival clauses would create with respect to preserving the constitutional supremacy. By the same token and without disregarding the domestic effects of the constitutional rulings, espousing an alleged fundamental change of circumstances to an obligation to denounce a treaty divests the strong practical effects that unilaterally claiming such an exceptional principle would imply for suspending the operation of such treaties. As noted, the hybrid process of termination of treaties, requiring subsequently the approval of the National Assembly and the further denunciation of the treaty by the President leaves a large space for political deliberation that ultimately subordinates the efficacy of such constitutional rulings.

From a comparative perspective, international treaties different to those promoting and protecting human rights are inferior to the Ecuadorian Constitution, just as they are in German and American legal systems. As Nolte points out:

751 See, Dictamen No.022-13-DTI-CC, Caso No. 0022-13-DTI-CC, “Convenio entre el Gobierno de la República del Ecuador y el Gobierno de la República de Italia sobre la promoción y protección de inversión”, Registro Oficial Suplemento, 22 de Agosto de 2013.

752 See, Dictamen No. 022-13-DTI-CC, Caso No. 0022-13-DTI-CC, “Convenio entre el Gobierno de la República del Ecuador y el Gobierno de la República de Italia sobre la promoción y protección de inversión", Registro Oficial Suplemento 64 de 22 de agosto de 2013.

753 In order to operationalize the well-rooted principle of constitutional supremacy, the Organic Act on Constitutional Guarantees and Constitutional Control incorporated a general provision whereby the treaties concluded prior to the Constitution of 2008 that did not pass through a prior control of constitutional conformity before their entry into force might be challenged only on substantive and not formal grounds.

"Décimo tercera.- Los tratados internacionales ratificados con anterioridad a la entrada en vigencia de la Constitución y sobre cuya constitucionalidad no haya existido pronunciamiento judicial previo, podrán ser demandados ante la Corte Constitucional únicamente por vicios de fondo." 
"if treaty rules or decisions by treaty organs violate norms of the constitution, they are declared inapplicable in both the United States and in Germany no matter whether such a declaration constitutes a violation of a the treaty under international law". ${ }^{754}$

In any case and as noted by Nolte, the German Constitutional Court would be inclined to harmonize the constitutional provisions with international obligations. The incipient and still precarious constitutional control tradition in Ecuador does not allow for instance, for determining conclusively whether the supra-legal stance given to the international treaties in accordance to the Constitution of 2008, makes the same self - executing. This Constitution refers explicitly to the direct applicability of international treaties of human rights, recognizing them as a source of judicial adjudication, which apparently would deprive other international treaties of such effects. However when it establishes the hierarchical order of normative application, it grants the Constitutional Court, judges and any administrative authority the authority to settle any conflict of norms following the ranking prescribed. It is noteworthy, that this constitutional provision embraces the "principle of competence", whereby the aforementioned application would have to consider the attributions of the organs involved in a possible normative conflict. In principle, the application of BITs would seek to determine the State's responsibility under Public International Law, since the national authorities are exempted from accomplishing such a task. However and taking into consideration that first generation treaties such as those signed by Ecuador contemplate both domestic and international venues of adjudication, entering into play restrictions as "fork in the road" clause, it is unclear whether the national courts in the case of entertaining such international jurisdiction at the request of the investor, would be prone to resort to the BIT as the law applicable to the dispute. ${ }^{755}$ Continuing with the analysis of the aforementioned Ecuadorian constitutional rulings, it could be affirmed that nonetheless such declarations leave a large room of political bargaining until the termination of the treaty takes place, the "automatic control" of constitutionality performed by the Constitutional Court, could bar the

See, Ley Orgánica de Garantías Jurisdiccionales y Control Constitucional, Segundo Suplemento, Registro Oficial 52, 22 de Octubre de 2009.

${ }^{754}$ Nolte (Georg), "Constitutional Implications of German Participation in Treaty Regimes" in Delegating State Powers: The Effect of Treaty Regimes on Democracy and Sovereignty, Edited by Thomas M. Franck, Transnational Publishers, United States of America, 267 p.

755 The Constitutional Codifications of 1996 and 1997, when developed the principle of "jurisdictional unity", acknowledged the power to administer justice of the courts and judges established in the Constitution, the Law and the International Treaties. 
domestic courts from the application of these BITs in the national context. In any case, there are no records that an Ecuadorian court had ever seized jurisdiction over a treaty based dispute.

\subsubsection{Domestic Effects of BITs Provisions Declared Incompatible with the Consittution}

By performing the "automatic control" of the BITs' constitutionality, the Constitutional Court, followed devotedly the Executive's position that assumes that the most injurious feature of these instruments rests on the possibility of submitting the disputes arising therefrom to international arbitration. In spite of the "abstract and automatic control" of the Constitutional Court resulting in the declaration of the BITs as contrary to the Constitution, the legal effect would not entail their automatic repeal from the legal framework. Such treaties would fall within a status of "implied repeal" which would still bind the State internationally, but none of its organs or people, domestically. ${ }^{756}$ As to the actions to be taken to restore the constitutional framework allegedly affected by such international treaties, three mechanisms are available for the branches vested with treaty making powers; curiously the Constitutional Court elects which of them should operate on a case-by-case basis. If the Court sought to influence the scope of the treaty at the international level, it should choose to recommend to terminate or to renegotiate the treaty. On the contrary, if the intention would have been bringing the domestic provisions into conformity with the international regime, it should support a constitutional amendment or reform. From the constitutional rulings analyzed, the Constitutional Court did exclusively consider the possibility of denunciation in tune with the President request. In four cases, the Court recommended to reject solely those clauses found in contradiction with the Constitution, to the detriment of the integrity of the BITs. It is hard to ascertain whether the Constitutional Court had been predominantly pressured to recommend the renegotiation of substantive standards rather than the whole denunciation of the BITs, supposing its analysis had not been exclusively confined to the dispute settlement provisions. It has to be noted that the National Federation of Chambers of Commerce fruitlessly tried to persuade the Court to instruct the Government to renegotiate the

\footnotetext{
756 The Ecuadorian Constitution obliges the President to comply with and ensure the compliance of the constitutional provisions and international treaties, since the latter obligation is the exclusive attribution of the Executive Branch.

See, Schutze Robert, "The Treaty Power and Parliamentary democracy: comparative perspective" in Foreign Affairs and the EU Constitution, Cambridge University Press, 2014, 380 p
} 
treaties or resort to State to State arbitration ${ }^{757}$. In any case, it has to be recalled that the Court was bound by the statutory procedure activated by the President, who politically left himself with little room of manoeuvre to resort to a different solution, rather than denunciation. There is evidence of the normative incoherence of subordinating straightforward constitutional rulings to further political decisions, which are contingent upon uncertain domestic and external events. This has provoked the paradoxical outcome that the President, being the authority putting into motion the referred procedure of constitutional review, had further unreasonably delayed the treaties' denunciation due to foreign policy reasons. By omitting to exercise their attributions of bringing to an end the BITs found in contradiction with the Constitution, both the National Assembly and the President within their respective scope of attributions preserved the State's exposure to international investment arbitration disputes. The hortatory nature of the constitutional rulings implies that either the legislative or presidential omissions to approve and notify the denunciation of international treaties found to be unconstitutional did not bear any immediate consequence. Nonetheless and taking into account the domestic effects of the constitutional rulings, it has to be noted that as from their publication, any action of an internal authority acknowledging the validity of the same as positive source of legal obligations, for instance, by reference or incorporation of their clauses, should be deemed void. At the international plane, the BITs remain as source of international State responsibility.

Within this context, it is worth referring to the Colombian experience, whose model of constitutional control, has been to an important extent mimicked by the Constitution of 2008. When the Constitutional Court of Colombia reviewed during the first half of the

\footnotetext{
${ }^{757}$ The National Federation of Chambers of Commerce requested the Constitutional Court to: 1) Abstaining from issuing prior rulings deciding about the constitutionality of the BITs; 2) Instructing the Government to re-negotiate the BITs and in the absence of such a possibility to resort to State to State arbitration as provided for by the same treaties:

(..) Conforme a los criterios expuestos, el representante legal de la Federación Nacional de Cámaras de Comercio del Ecuador solicita a la Corte Constitucional que: "1.- Se abstenga de emitir dictamen previo y vinculante de constitucionalidad de los Acuerdos Bilaterales de Protección Recíproca de Inversiones suscritos por la República del Ecuador con (...) Venezuela (...); y, 2.- Se instruya al Gobierno ecuatoriano se renegocien los tratados internacionales referidos utilizando para ello las disposiciones contenidas en los mismos, para lo cual se iniciarán las negociaciones diplomáticas pertinentes y en caso de que ello no ocurra se presenten los arbitrajes necesarios para solucionar las diferencias en cuanto al contenido y alcance de las disciplinas jurídicas contenidas en los referidos acuerdos de inversión.
}

See, Dictamen No. 041-10-DTI-CC, Caso No. 041-10-DTI-CC, Registro Oficial Suplemento 342, 16 de diciembre de 2010. 
1990s the conformity of certain bilateral investment treaties to the Constitution, prior to their approval and ratification, it objected to their adoption on the basis of the terms provided for expropriation. Given that under the Constitution of Colombia not all the expropriations had to be compensated, a constitutional reform was undertaken on 1999 in order that compensation applied to all cases resulting in total or partial, property deprivation. This way, such a constitutional obstacle was overcome and Colombia became an active signatory of international investment agreements. Anyway, the divergence in the interpretative approach between both courts evidences the risk of the Ecuadorian Constitutional Court's stance, which does little to curtail the exorbitant substantive protection of foreign private interests, still enforceable through dispute settlement mechanisms different to investment arbitration. Furthermore, when the Ecuadorian justices undertook the "automatic control of constitutionality", they assessed the formal and material conformity of the treaties, briefly asserting that the same were constitutional at the time they were ratified under the blanket of the constitutional frameworks promulgated from 1967 to 1998.

As to the BITs signed and ratified after the Constitution of 1998, a light has to be put on the similarity of the relevant provision enshrined therein with that of the Constitution of 2008, listing the treaties subject to legislative approval. In this context, the misinterpretation of the rules of investment protection whereupon such BITs were released from legislative approval, upsets the conclusion that such international instruments were in accordance with the constitutional framework of 1998, both materially and formally. If the justices had looked closer at the substantive standards of protection, namely the clauses of expropriation and the ample definition of investment, just to mention a few, reaching such a conclusion would have been somewhat unworkable.

\subsection{The Coexistence of Two Constitutional Like Regimes}

From the Ecuadorian experience, it can be seen that whereas the Constitution of 1998 had a strong monist orientation, the Constitution of 2008 moderates such a position. The current Constitution seems to be monist concerning treaties, by affording supraconstitutional nature to human rights treaties and a supra-legal category to all the other 
treaties. ${ }^{758}$. In the latter case, the application of such treaties would settle a possible hierarchical conflict of norms, regardless of whether the same provided or not a direct cause of action. Thus, it is implied that treaties come to integrate the domestic legal framework after their ratification. ${ }^{759}$ Consequently, as to the structure of the Ecuadorian legal framework, there can be identified a strong influence of Kelsen's monism, which disregards the complex interaction between international and national law and which is particularly notable in the vague dominion of International Investment Law. To this particular field of Public International Law, it seems to fit more appropriately the alternative approach of Fizmaurice and Rosseau as referred by Boas, who argues that "international law and national law lack of common field of operation, never operating within the same sphere, or dealing with the subject matter". 760 The mentioned approach according to Brownlie, as quoted by Boas "might be preferred as coming close to the facts", as "each system is supreme in its own field, and neither has a hegemony over the

${ }^{758}$ In the constitutional ruling related to the BIT with the United Kingdom, the Constitutional Court corroborated that with the exception of human rights treaties, which are supra constitutional, all international treaties are supra-legal:

"Del análisis material de la Constitución de la República caben al menos dos cuestiones por considerar: en la actualidad, el derecho internacional no concerniente a Derechos Humanos tiene rango supra legal, pero infra constitucional; en cambio, cada día se acepta ampliamente que los instrumentos internacionales referidos a los derechos de las personas naturales tienen rango constitucional."

See, Dictamen No.020-10-DTI-CC, Caso No. 008-10-TI, Registro Oficial Suplemento, 24 de junio de 2010.

${ }^{759}$ The Constitutional Court concluded that the ratified treaties become part of the national legal framework and consequentially of the "constitutionality block" (bloque de constitucionalidad):

\begin{abstract}
"Si bien el artículo 438 de la Constitución señala que la Corte Constitucional emitirá dictamen previo y vinculante de constitucionalidad en relación a los tratados internacionales que requieren de ("ratificación") aprobación de la Asamblea Nacional, y no establece que se requerirá este dictamen previo en relación a la denuncia de los tratados, cabría hacer un análisis interpretativo del alcance de esta norma constitucional, partiendo de que con la ratificación nace a la vida un instrumento, que pasa a formar parte de la legislación interna, y con la denuncia deja de tener vida jurídica un determinado instrumento, y sale del bloque de constitucionalidad; y tanto para el un caso como para el otro, se requiere el dictamen de constitucionalidad de la Corte."
\end{abstract}

See, Dictamen No.020-10-DTI-CC, Caso No. 008-10-TI, Registro Oficial Suplemento, 24 de junio de 2010 (BIT with United Kingdom).

${ }^{760}$ Fitzmaurice (G.), "The General Principles of International Law Considered from the Standpoint of the Rule of Law" (1957-II) 92 Hague Recueil 68-94; Shaw, above note 6, 132-3; Brownlie, ibid., 33 in Boas (Gideon), Public International Law: Contemporary Principles and Perspectives, Edwar Elgar Publishing Limited, UK, 2012, 122 p. 
other". ${ }^{761}$ This conception militates in favour of the interpretation that an act which is illegal according to national law does not necessarily imply a breach of international law which is a corollary of the supremacy of international law as recognized by the Vienna Convention on the Law of Treaties. In any event, the regulatory nature of international investment disputes and the specific attribution conferred to the adjudicators to apply both international and domestic law in the form enshrined in the BITs, portraits the difficulty of conciliating the boundaries of both systems within this regime. ${ }^{762}$

It has to be recalled that historically, the manifold Ecuadorian Constitutions have been particularly open to international law, acknowledging for instance, treaties of commerce and navigation in the XIX century constitutions and refining progressively its obligations towards the international community. The pendulum has swung between stretching the boundaries of self-determination and sovereignty at least declaratively during prosperity, and jumping rashly on the globalization train by suddenly relaxing rules for attracting investment during the fall of commodity prices. Irrespective of the inexorable lyricism of the Ecuadorian Constitutions, as from 1945 it deference of the country to International Law, as well as to the international legal mechanisms of dispute settlement (Art. 6) was explicitly acknowledged ${ }^{763}$. As noted, the current Constitution establishes a large set of international relationship principles, which denote the renewed regionalist and nationalist impetus of the rule makers, as well as a fierce non-conformity regarding the existing terms of global exchange. Among these principles it are woven novel international concerns with respect to fair trade and investment, environmental protection, control of transnational corporations and ill-will towards any means of neo-colonialism. At the time that it acknowledges International Law as an imperative of the State's conduct, it rejects the idea that conflicts involving foreign private companies, escalate to State-to-State

761 Brownlie (Ian), Principles of International Public Law (Oxford: Oxford University Press, 2008, 7th edn), 31 in Gideon) Boas, Public International Law: Contemporary Principles and Perspectives, Edwar Elgar Publishing Limited, UK, 2012, 122 p.

762 As highlighted in Chapter II, there are notable arbitral decisions touching upon municipal regulatory measures, as it can be observed in the case Occidental Exploration and Production Company v. The Republic of Ecuador. The Tribunal held without legal effects any action or resolution ordering the investor's tax recovery, as well as it instructed the domestic authorities to abide by the "the procedures and scrutiny provided under Ecuadorian Tax Law", in relation to the requests to VAT reimbursement.

See, Final Award in the matter of UNCITRAL Arbitration, London Court of International Arbitration Administered Case No. UN 3467.

${ }^{763}$ Constitución Política de 1945:

“Art. 6.- La República del Ecuador acata las normas del Derecho Internacional y proclama el principio de cooperación y buena vecindad entre los Estados y la solución, por métodos jurídicos, de las controversias internacionales." 
disputes (Art. 416). As opposed to the Constitutional Court that relies on this constitutional precept to censure the direct access of investors to a particular dispute settlement mechanism, Roberts suggest that this attribute actually bars the underlying disputes involving merely investors' rights from falling within the realm of politics and diplomacy. ${ }^{764}$

The most crucial constitutional provision for finding the BITs in contradiction with the Constitution proscribes the surrender of sovereignty through international instruments or treaties in favour of international arbitral venues with respect to contractual or commercial disputes between the State and natural persons or private entities (Art. 422). It has been pointed out that the defective wording of this constitutional provision overlooks the real nature of investment disputes, which are properly of a regulatory rather than of commercial or contractual nature. The minutes of the National Constituent Assembly, that registered the debate concerning the limitations to the submission of international disputes involving the State, illustrate the modification of the relevant provisions wording between the first, second and final approval debates, reaching completely opposite effects. From the outset, the inclination towards the absolute proscription of submitting the State to international jurisdiction in "commercial and private" disputes both through treaties and contracts is crystal clear. ${ }^{765}$ Although this inflexibility was further moderated, there can be observed several warnings concerning the inconvenient constitutional treatment of issues involving a waiver of State jurisdiction. In the case of contracts, there was fruitless criticism of the curious limitation, prohibiting the surrender of jurisdiction only to contracts signed within Ecuadorian territory. ${ }^{766}$ In any case, it is clear that, notwithstanding the ineffective wording of the

\footnotetext{
${ }^{764}$ See, Roberts (Anthea), "Triangular treaties: the nature and limits to investment treaty rights", Harvard International Law Journal, 56 (2), ISSN 0017-8063, 389-390 pp.

765 The first drafting approved by the National Constituent Assembly Plenary contained a general prohibition to submit the State to foreign jurisdiction, with exception to arbitral proceedings within the Latin-American integration context:
}

“Artículo 6. Los contratos celebrados por el Estado con personas naturales o jurídicas extranjeras llevarán implícita la renuncia de estas a toda reclamación diplomática, salvo contrataciones que correspondan al servicio diplomático. El Estado ecuatoriano no podrá someterse a jurisdicción extranjera, salvo los procedimientos arbitrales de integración latinoamericana, previstos en esta Constitución".

See, Acta 85, 90 votos afirmativos; 11 negativos; 3 blancos; 6 abstenciones, 23 p.

${ }^{766}$ Leon Rodós was quite critical regarding the preservation of the futile territorial restriction attempting to limit State's waiver of jurisdiction: 
provision attempting to bar treaty based arbitration, the Constituent Assembly Members were slightly aware that treaties and contracts are different sources of obligations ${ }^{767}$. Interestingly, from the different drafts that sought to regulate the waiver of State jurisdiction either normative or contractual, it can be seen that the final constitutional provisions developed separately such procedural avenues. The wording of both mechanisms seems to be restrictive of the State's submission to international jurisdiction, but a sound legal assessment suggests that their legal effects are quite the opposite. In the best-case scenario, the prohibition against "waiving sovereign jurisdiction" through treaties or international instruments in commercial or private disputes involving the State and foreign persons would cover controversies including umbrella or catch all provisions that may include contractual breaches. In consequence, the effects achieved, differ greatly from the intention sought by the legislators.

It is clear that the understanding of the rule makers and adjudicators regarding the current effects of International Law is outdated and ignores the stretching of traditional boundaries delimitating public order on the one hand, and private autonomy, on the other.

\begin{abstract}
"El otro tema que quiero referirme es el artículo seis, los contratos celebrados por el Estado, con persona natural o juridica extranjera llevarán implícita la renuncia de ésta a toda reclamación diplomática. Hasta ahí el tema es absolutamente claro, pero luego viene un agregado que yo personalmente siempre he cuestionado, si tales contratos fueron celebrados en el territorio del Ecuador, no podrán someterse a jurisdicción extranjera. Toda la trama está en comprar unos pasajes para Nueva York, y entonces se someten a la legislación norteamericana. Uno de estos casos, es el famoso convenio de renegociación de la deuda externa del Ecuador. Esto es el principio de que para someternos a legislaciones y jueces extranjeros, lo que tenemos es que comprar un pasaje e irnos a Nueva York o irnos a Londres, esto es repudiable como ecuatoriano. Yo creo, que tenemos que asumir lo mismo que ya asumimos respecto a tratados y convenios internacionales. Establecer una normativa procesal, pues, si lo firma en Quito, tiene que ser sometido a la ley y a la jurisdicción ecuatoriana. Si el Estado, estamos hablando del Estado, si el Estado lo firma en el Nueva York, a la legislación y a los jueces norteamericanos, eso es una burla, eso es una farsa, no consagremos otra vez la misma farsa, porque ésta ha sido la historia de casi todos los contratos que el Ecuador ha celebrado en el exterior. Basta celebrarlo en Nueva York y arreglado el problema del sometimiento y la dependencia a otra legislación y jurisdicción. Gracias.”
\end{abstract}

See, National Constituent Assembly, Acta 068, León Roldós, 174 p.

767 The President of the Commission of Sovereignty and International Affairs of the National Constituent Assembly, María Augusta Calle, left little doubt with respect to the different treatment given to international treaties and international contracts, regulated through distinct constitutional provisions:

(...) Para terminar, señor Presidente, el artículo seis. Nosotros creemos que es necesario que se apruebe ahora, que se lo apruebe en el Plenario, pero que sea incluido en el capítulo referido a soberanía económica. Es el que tiene que ver con contratos celebrados por el Estado con personas naturales y extranjeras. Aquí hubo alguna confusión. Varios colegas, dijeron que este artículo ya estaba contemplado en el de tratados internacionales. Decimos que no, el articulado referido a tratados internacionales trata, justamente, de tratados y convenios internacionales Y aquí estamos, específicamente hablando de contratos (...)

See, National Constituent Assembly, Acta 85, María Augusta Calle, 19. p. 
For better comprehension of the effects of trans-boundary commitments and the multiplicity of the actors and sources they array, relying solely on the traditional public/private distinction impairs a proper judgment consistent with the world's reality. Such a misconception, at the time that produces defective policy decisions, involving high reputational and conflict costs, hampers the State's capacity for improving the effects of ongoing and future commitments agreed upon either in treaties or contracts. This situation militates against the constitutional goal, which seeks to achieve the country's strategic insertion in the international context (Art. 276, paragraph 5).

\subsubsection{National Perceptions Defining the International Investment Law Regime}

The scope of protection derived from International Investment Agreements has disrupted the rigid legal mindset of domestic rule makers and adjudicators, alien to the effects derived from international State responsibility. In addition, the absence of binding precedents and the transposition of commercial notions into public policy matters bring little certainty as to the category of conduct and omissions that could trigger a state's international responsibilities. Consequentially, the emergence of "global governance" permeates "almost all areas of public and private life" 768 due to the massive delegation of regulatory functions to international organizations either public or private:

The transfer of regulatory authority from the domestic to the international has been a vehicle for a handful of powerful countries to escape the domestic structural checks and balances, such as the separation of powers, court independence, and limited government, that have played a role in safeguarding democratic deliberation and human rights within States. ${ }^{769}$

As result of this diagnosis, Benvenisti contends that the growing transfer of regulatory powers has had very often the effect of eroding to varying degrees "the traditional constitutional checks and balances found in many democracies, as well as other domestic oversight and monitoring mechanisms of executive discretion". ${ }^{770}$ In the Ecuadorian case, the practical absence of "travaux préparatoires" concerning the BITs and the ICSID Convention does not allow the exchange of views, if any, with respect to the nature of the

\footnotetext{
${ }^{768}$ Benvenisti (Eyal), The Law of Global Governance, Hague Academy of International Law, 2014, 25 p.

${ }^{769}$ Benvenisti (Eyal), The Law of Global Governance, Hague Academy of International Law, 2014, 17 p.

${ }^{770}$ Benvenisti(Eyal), The Law of Global Governance, Hague Academy of International Law, 2014, 18 p.
} 
functions delegated. The Constitutional Court took a step forward and defined the BITs as "adherence agreements", bitterly criticizing their reciprocity in view of the status of Ecuador as a developing country deprived of any investments in the territories of his counterparties. ${ }^{771}$

In any case, the underlying domestic rulings and international disputes corroborate the misconception about the extent of the commitments made, normally by the host countries. This additionally suggests information asymmetries both at the rule making and implementation stages, which are also evident at the multi-lateral level. ${ }^{772}$ Moreover, the presumption that international bodies are better equipped to efficiently and neutrally fulfill any task by guaranteeing its supremacy and autonomy has justified the implicit immunity granted to their decisions, shielded from judicial review. ${ }^{773}$ Such features are particularly notable with the unparalleled invasion of International Investment Law, whose rules have affected essential foundations of public international and domestic law,

771 When the Court analyzed the provision establishing State to State binding arbitration, seized the opportunity to criticize the procedure of negotiation and signature of international investment agreements:

(...) Disposición que instituye al arbitraje como un mecanismo de solución de las posibles controversias que se puedan presentar entre las Altas Partes contratantes; sin embargo, hay que tener en consideración que este tipo de "Tratados Bilaterales de Inversión" o TBIs, ponen al Estado ecuatoriano en una condición pasiva y poco propositiva, por cuanto son tratados adoptados sin ningún proceso de negociación; al contrario, se han constituido en convenios de adhesión. Habría además que analizar si estos Tratados que ha suscrito el Ecuador han otorgado una actitud recíproca para con los inversionistas ecuatorianos o qué tipo de ventajas nos han sido concedidas por encontrarnos en una condición especial y diferente a la de los países desarrollados.

En lo principal, los arbitrajes a nivel internacional pueden llevarse en varias instituciones que prestan este servicio para las controversias que se susciten entre los Estados parte de un Convenio. Encontramos de esta forma a la UNCITRAL, al CIADI y a los otros mecanismos ad-hoc que se han presentado como una posibilidad por común acuerdo de las partes. Estas cortes son de carácter privado y no responden a ningún interés colectivo (3).

See, Dictamen No. 040-10-DTI-CC, Caso No. 0012-10-TI, "Tratado entre la República del Ecuador y la Confederación Suiza sobre Protección y Fomento de las Inversiones", Registro Oficial Suplemento 331 de 30 de noviembre de 2010.

${ }^{772}$ Benvenisti points out the little capacity of developing countries both for influencing and fulfilling the scope of international obligations they agreed upon:

Developing countries, in particular, often lack the administrative capacity to meet new regulatory standards, much less possess the expertise and political clout necessary to influence the character of those standards or that agencies are reliably fulfilling their mandates. Even diffuse constituencies in developed countries are disadvantaged by international organizations`opaque decision processes, which limit their opportunity to participate and the shape outcomes

See, Benvenisti (Eyal), The Law of Global Governance, Hague Academy of International Law, 2014, 20 $21 \mathrm{pp}$.

${ }^{773}$ Benvenisti (Eyal), The Law of Global Governance, Hague Academy of International Law, 2014, 21 p. 
meaning that its scope goes way beyond merely determining State responsibility for the breach of International Law.

In a context of "unequal arms" in the construction of international obligations, it seems that the expression of consent to be bound by the same is far from being duly weighed. According to Benvenisti, a State's consent is strongly influenced by the economic forces of globalization, characterized by a fierce competition of small and medium size States to access to foreign investment and foreign markets, as well as by their heterogeneity that impedes collective action. This situation is normally used by strong economic political actors, which practice "divide and rule strategies against the State" 774 :

This is the traditional response of international lawyers: the State party is bound to what it agreed. This is the weakest possible justification, for several reasons. First, this justification begs the question of what did the State party consent to? In the light of the tendency of international tribunals to interpret treaties creatively and expansively, thereby increasing the authority of IGOs while downplaying the treaty's text and the travaux preparatoires, this argument rings hollow. ${ }^{775}$

Apart of the criticized expansive role of the international treaties, these so called adherence agreements are deemed as practically non-exit commitments:

Increasingly international regimes... are negotiated on a take-it-or-leave-it basis.... But for most States both the Take it is fictitious and the Leave it is even more so. The consent given by these 'sovereign' states is not much different to the 'consent' that each of us gives, when we upgrade the operating system of our computer and blithely click 'I Agree' button on the Microsoft Terms and Conditions. One cannot afford to be out, and one cannot afford to leave. ${ }^{776}$

In this line, it has to be underscored that in the Ecuadorian case, there may be identified several BITs, which entrust domestic courts with entertaining disputes related to protected investments. Although the relevant provisions establish that the election of a forum is definitive, the different causes of action underlying either from a statutory or a treaty claim would render such an effect inapplicable, even more so when the national courts are neither competent nor technically equipped to determine the breach of

\footnotetext{
${ }^{774}$ Benvenisti (Eyal), The Law of Global Governance, Hague Academy of International Law, 2014, 208 p.

775 Benvenisti (Eyal), The Law of Global Governance, Hague Academy of International Law, 2014, 208 p.

${ }^{776}$ Weiler (Joseph H.H.), “The Geology of International Law-Governance, Democracy and Legitimacy", 64 Heidelberg J. Int'L. 547, 557 (2004) in Benvenisti (Eyal), The Law of Global Governance, Hague Academy of International Law, 2014, 209 p.
} 
international law by its own State. ${ }^{777}$. On the other hand and it will be noted below, the way that international arbitral tribunals interpret domestic law is also remarkable ${ }^{778}$

The consolidation of global administrative law has been underpinned mostly by bilateral rather than multi-lateral commitments that have institutionalized " $a$ version of constitutionalism"779. This over-arching protection in the field of international investment protection, can be observed from the extension of the commitments, the mechanisms of enforcement and the constraints to modify and terminate the agreements:

Constitutionalism encompasses, in part, those formal institutional arrangements that give binding effect to the basic norms by which a political community is organized. In so far as the investment rules regime reflects constitutional characteristics, the norms of democratizing constitutionalism, of pluralism and of self-government, make this new form of constitutionalism suspect. The regime freezes existing distributions of wealth and privileges "status quo neutrality"

${ }^{777}$ For instance the BIT Ecuador -Peru, provides for the forums amenable to settle an investment dispute, being the election of one of them, in theory, definitive:

“Art. 8.- Arreglo de Controversias entre una Parte Contratante y un Inversionista de la otra Parte Contratante

1. Las controversias que surgieren entre una de las Partes Contratantes y un inversionista de la otra Parte Contratante en relación con las inversiones realizadas de conformidad con el presente Convenio deberán, en lo posible, ser amigablemente dirimidas entre las partes en la controversia. 2. Si una controversia en el sentido del párrafo (1) no pudiera ser resuelta dentro del plazo de seis meses, contado desde la fecha en que una de las partes en la controversia la haya notificado a la Otra, será sometida:

(a) Al tribunal competente de la Parte Contratante en cuyo territorio se hubiera efectuado la inversión; o,

(b) A arbitraje internacional del Centro Internacional de Arreglo de Diferencias relativas a Inversiones (CIADI), creado por el "Convenio sobre Arreglo de Diferencias relativas a las Inversiones entre Estados y Nacionales de otros Estados", firmado en Washington el 18 de marzo de 1965.

3. Una vez que se haya sometido la controversia al tribunal competente de la Parte Contratante en cuyo territorio se hubiere efectuado la inversión o arbitraje internacional, la elección de uno u otro procedimiento será definitiva.

4. El laudo arbitral será definitivo y vinculante."

See, Convenio entre el Gobierno de la República del Ecuador y el Gobierno de la República del Perú sobre la Promoción y Protección Recíproca de Inversiones, 1999.

778 The BIT with Chile enables the arbitral tribunal to apply the law of the Party involved in the dispute: ARTICULO X

Solución de controversias entre un inversionista y la Parte Contratante receptora de la inversión. “(...) (4) El órgano arbitral decidirá en base a las disposiciones del Presente Convenio; al derecho de la Parte Contratante involucrada en la controversia incluidas las normas relativas a conflictos de leyes; a los términos de eventuales acuerdos particulares concluidos con relación a la inversión y a los principios del Derecho Internacional aplicables en la materia (...)”

See, Convenio entre la República del Ecuador y el Gobierno de la República de Chile para la Promoción y Protección Recíprocas de Inversiones, 1993.

${ }^{779}$ Schneiderman (David), Constitutionalizing Economic Globalization: Investment Rules and Democracy's Promise, Cambridge University Press, United Kingdom, 2008, 69 p. 
(Sunstein 1993). It does not merely commit citizens to predetermined institutions and rules through which political objectives are realized but also institutionalizes a legal incapacity to act in a variety of economic matters. It is not an enabling precommitment strategy; rather, it is largely a disabling one. At the bottom, the investment rules regime represents a form of constitutional pre-commitment binding across generations that unreasonably constrains the capacity for selfgovernment. The constraining model of constitutionalism (as I have described in the Introduction) resolves the tension between majoritarian democracy and the protection of minority interests in favor of limits on government action. The investment rules regime similarly resolves this tension in favor of foreign investors by rendering them equivalent to vulnerable minority groups. ${ }^{780}$

The institutionalization of the legal incapacity to act was well deployed in Ecuador during the 1990 s when these pre-commitment strategies loosely determined in the BITs, were further enforced through domestic regulations and long term contractual agreements. In this line, the investment regime would isolate certain matters from the range of public regulation in favour of "market efficiency, discipline and confidence"781 putting on an equal footing public policy deliberation processes with transnational business interests. In its rulings assessing the constitutionality of the BITs, the Constitutional Court at the time that echoed the predominant critics against the international investment regime, fiercely attacked the former State model, allegedly governed by "neo-liberal policies". In the Court's opinion, assuring the full application of neo-liberal principles like "free competition", meant at the same time, resigning both to the self-determination in the management of natural resources and to the sovereignty of the control of alternative mechanisms of dispute settlement. It is also interesting, that the Court considered as an event showing a fundamental "change of paradigm", the transformation of the constitutional procedural and substantive mechanisms for signing and ratifying international treaties. ${ }^{782}$

\footnotetext{
${ }^{780}$ Schneiderman (David), Constitutionalizing Economic Globalization: Investment Rules and Democracy's Promise, Cambridge University Press, United Kingdom, 2008, 37-38 pp.

781 Schneiderman (David), Constitutionalizing Economic Globalization: Investment Rules and Democracy's Promise, Cambridge University Press, United Kingdom, 2008, 38 p.

${ }^{782}$ It is remarkable the enthusiast activism in favor of the "Latin-American constitutional trend", around which revolves the Ecuadorian Constitution of "rights and justice". According the Court, this new Constitution rather "than serve hegemonic economic interests, prioritizes a social axis, which has as vortex the human being, acknowledging his diversity and vulnerability":

"A partir del 20 de octubre del 2008 entró en vigencia la nueva Constitución de la República; se inscribe en el ámbito de la corriente constitucionalista latinoamericana que define al Estado como Constitucional de derechos y justicia, estructurado ya no para servir intereses económicos hegemónicos, sino priorizando un eje social que tiene como su vértice al ser humano mirado desde su diversidad, y vulnerabilidad. Deja atrás una concepción del Estado que se definía como social de mercado, impartía políticas neoliberales en las que se imponían reglas como la libre
} 


\subsubsection{First Measures Challenging the Effects of International Investment Agreements}

The dense web of international commitments embodying the interests of capitalexporting states suggests that the constitutional responses facing their impacts might operate at distinct levels. In consequence, such measures far from neutralizing the effects of the rules of investment protection could actually worsen the State's exposure to international disputes. Remarkably, the most effective reactions to counter the effects of the system of investment protection, namely denouncing the ICSID Convention ${ }^{783}$ and terminating several BITs, were implemented by swift presidential initiatives, disregarding the intervention of the Constitutional Court. At the same time, the presidential delay to take the final step for denouncing the existing BITs with the most powerful capital exporting countries reveals the weak bargaining power of Ecuador at the international level. One has yet to see the effectiveness of recent domestic measures attempting to curtail the reach of investment protection rules, either through legislation or contracts, whereby the investor in theory, would be deemed to waive the protection provided by treaties. In any case, this is a sign that portrays the practical complexity of exiting such a regime:

“(...) Unlike ordinary legislative measures, the investment rules regime ensures certainty in the long run by making onerous any withdrawal from investment disciplines. (...) In sum termination, is made not only legally onerous but also practically impossible. The less economically powerful parties to the BIT regime are not likely to want to incur the wrath of more powerful economic forces in the developed world. Structural adjustments, therefore, are set in motion within the

competencia, la pérdida de autodeterminación en el manejo de los recursos y la cesión de soberanía en el manejo de mecanismos alternativos de solución de conflictos. En consecuencia, han cambiado sustancialmente las circunstancias que si bien hicieron posible hace 16 años la suscripción del Convenio materia de estudio, actualmente asistimos a un cambio fundamental con la entrada en vigor de la nueva Ley Fundamental o Carta Política del Estado desde el año 2008, a la cual debe sujetarse todo el ordenamiento jurídico, incluidos los tratados internacionales, así como el procedimiento y condiciones para la suscripción y ratificación de los convenios internacionales."

See, Dictamen No.020-10-DTI-CC, Caso No. 008-10-TI, Registro Oficial Suplemento, 24 de junio de 2010.

783 The denunciation of the ICSID Convention passed through the approval of the Legislative Commission of the National Constituent Assembly in July 12, 2009.

See, Diario El Universo, "Ecuador renunció ayer al CIADI por decision de la Comisión Legislativa", 13 de junio de 2009.

Website: http://www.eluniverso.com/2009/06/13/1/1355/0A1B8191EE3E40D5A2337486894A24F7.html Visited on August 2016. 
investment rules regime that are difficult to reverse and increasingly costly to abrogate." 784

In the case of Ecuador, the negotiations with the European Union to sign a free trade agreement, together with the renewal of generalized scheme of preferences to export to the United States, as well as the growing credit lines and strategic projects with China, have been apparently used as leverage for pressing the Executive Branch not to terminate BITs. ${ }^{785}$ Additionally, other mechanisms of pressure exerted by Non State Actors, like country risk qualifications and international market perceptions that impact upon the accessibility and cost of credit of the country willing to impose any kind of reform, are constraints that also impede changing the system rules. In consequence, the "constitutionalization of economic globalization" "786 gives the States little power to perform democratic mandates that in most of the cases come up against internationally protected interests. Thus, the reasons elicited by the Constitutional Court justices to terminate the BITs according to their "undeniable incompatibility" with the Constitution, by relying mostly on an apparent prohibition to waive sovereign jurisdiction in the light of an alleged transformation of the State model and its orientation towards international relationships, seem to ignore the supra-constitutional effects of substantive investment rules. As noticed, no single analysis was made of the conflict that may arise between the application of the substantive standards of protection enshrined in the BITs, and the exercise of regulatory powers for the achievement of a public purpose or the right of the indigenous communities to rule in certain aspects in their territories, just to mention a few tensions. Therefore it is surprising that the BITs at issue had been found unconstitutional exclusively for the extension of their dispute settlement provisions, thereby presuming

\footnotetext{
784 Schneiderman (David), Constitutionalizing Economic Globalization: Investment Rules and Democracy's Promise, Cambridge University Press, United Kingdom, 2008, 37 p.

785 Due to the concern of European and American investors with respect to the virtually concluded process for the denunciation of Bilateral Investment Treaties, the former Minister Coordinator of Production, Employment and Competitiveness, Mrs. Nathaly Celi, announced that the government decided to suspend such decision at the international level, until the Organic Code of Production, Commerce and Investment had been promulgated. Six years later the denunciation of 17 BITs is still suspended.

See, "Ecuador evita denuncia de tratados de inversión y alista Código de la Producción", September 16th, 2010.

http://www.ecuadorinmediato.com/Noticias/news user_view/ecuador_evita denuncia de tratados de in version y alista codigo de produccion--134048
}

786 See, Schneiderman (David), Constitutionalizing Economic Globalization: Investment Rules and Democracy's Promise, Cambridge University Press, United Kingdom, 2008. 
that the substantive provisions should be aligned with the Constitution. ${ }^{787}$ This narrow understanding disregards certain democratic threats that have been linked to the operationalization of the system:

"The desire to render national economies the subject of uniform trade and investment regulation submerges the capacity to experiment politically and reduces citizenship to a single, uniform conception organized around the values of the market." 788

If anyways the constitutional rulings express a clear political inclination towards the retrieval of sovereign powers through a revisited State model with a strong influence on the economy and unlimited mechanisms of constitutional control, the Constitutional Court could have better weighted the over-arching constraints that this regime includes in the exercise of public authority and self-determination. Schneiderman has stressed the overlapping relationship of international investment rules with constitutional provisions due to the similarity of their commitments and wording:

The ensemble of rules and institutions is a form of pre-commitment strategy that binds future generations, through the instrumentality of national states, to certain institutional forms and substantive norms through which politics is practiced. Like constitutions, they are difficult to amend, include binding enforcement mechanisms together with judicial review, and often are drawn from the language of national constitutions. ${ }^{789}$

\footnotetext{
${ }^{787}$ For instance, it is remarkable that the Constitutional Court had conceived as "not feasible" the denunciation of the whole treaty in the cases of Sweden and Venezuela, instructing the legislative branch to establish dispute settlement mechanisms, in accordance to best common understanding of the Parties, having due regard to the limits of the constitutional precepts. The constitutional rulings concerning both BITs embody the same paragraph:

"En virtud de que únicamente los artículos VIII y IX del Convenio Internacional están en
contradicción y afectan al texto de la Constitución de la República, esta Corte considera que no es
factible denunciar todo el tratado internacional, sino exclusivamente los artículos que no guardan
armonía con el texto constitucional, previniendo al órgano legislativo que dentro de aquel
Convenio Internacional es de vital trascendencia establecer los mecanismos de solución de las
diferencias o conflictos, los cuales deberán sujetarse al común acuerdo de las partes contratantes
y respetando los preceptos constitucionales."
}

See, Dictamen No. 041-10-DTI-CC, Caso No. 041-10-DTI-CC, Registro Oficial Suplemento 342, 16 de diciembre de 2010 (Venezuela).

See, Dictamen No. 029-10-DTI-CC, Caso No.002-10-TI, Registro Oficial Suplemento 294, 6 de octubre de 2010 (Suecia).

788 Schneiderman (David), Constitutionalizing Economic Globalization: Investment Rules and Democracy's Promise, Cambridge University Press, United Kingdom, 2008, 9 p.

789 Schneiderman (David), Constitutionalizing Economic Globalization: Investment Rules and Democracy's Promise, Cambridge University Press, United Kingdom, 2008, 4 p. 
The undeniable "constitutional alike rules" comprised by the international investment protection system as coined by Scheneiderman does not diminish the fact that their operation should be confined to the realm of Public International Law, specifically to determine the international responsibility of the State. The contended legitimacy crisis of the system due among other reasons, to the undetermined powers asserted by the arbitrators in applying vague standards of protection, is not a sufficient basis to release the State from its international obligations. Moreover, and looking at the Ecuadorian case, what is clear is the technical difficulties faced by the Constitutional Court when it comes to the interpretation of international treaties, which could aggravate in certain cases the State's stance within an international conflict. Such limitation in conjunction with a radical conception of sovereignty does little to foster effectively a shift in the way international investment rules have being applied to several Ecuadorian regulatory actions.

\subsubsection{Revisiting the Notions of Sovereignty in the light of Public International Law}

The restrictive concept of sovereignty as written in the Ecuadorian Constitution and further elaborated by the Constitutional Court differs from the interpretation given by the International Court of Justice to such a seminal attribute. Pursuant to the landmark Wimbledon Case ${ }^{790}$, Pellet contends that signing international treaties is an assertion rather than a surrender of sovereignty:

(...) as explained above, sovereignty is the very criterion of statehood; it can be neither "transferred" nor "limited". A State cannot be "half-sovereign"; if it is a State, it enjoys sovereignty; if it transfers its sovereignty, it is no more a State. As the Permanent Court explained in its first Judgment, "the right of entering into international engagements is an attribute of State sovereignty" and the "conclusion of any treaty by which a State undertakes to perform or refrain from performing a particular act (cannot be seen as) an abandonment of sovereignty. In other words sovereignty is the basis of states competencies and, by concluding a treaty, a State does not limit, or abandon, or transfer sovereignty; it exercises the rights deriving from its sovereignty.

For this same reason, I have some reservations regarding the title of this study. States may delegate powers, or, rather, the exercise of some of their powers, but they cannot "delegate" their sovereignty. ${ }^{791}$

\footnotetext{
${ }^{790}$ S.S Wimbledon Case, P.C.I.J., (ser. A) No. 1 at 25. See, (Allain) Pellet, "A French Constitutional Perspective on Treaty Implementation" in Delegating State Powers: The Effect of Treaty Regimes on Democracy and Sovereignty, $283 \mathrm{p}$.

${ }^{791}$ Pellet, (Allain), “A French Constitutional Perspective on Treaty Implementation” in Delegating State Powers: The Effect of Treaty Regimes on Democracy and Sovereignty, $283 \mathrm{p}$.
} 
Under a strict application of BITs, the State makes commitments whose compliance has to be tested according to the rules of interpretation of Public International Law. Given that domestic courts are not vested with the jurisdiction to ascertain such assessment, in theory, it would be inaccurate to affirm that subjecting the exercise of regulatory powers to the standards provided for by the BIT and rules of customary law, would amount to relinquishing sovereignty.

(...) Inside the State, sovereignty means a supreme and (legally) unchallenged power and, as Professor Prosper Weil put in his outstanding introduction to French administrative law, "the very existence of administrative law is a kind of miracle". By contrast, at the international level, sovereignties are equal which necessarily implies that each State's jurisdiction is limited by the equal rights belonging to all other States. ${ }^{792}$

This reasoning implies that the States, through international investment agreements do not transfer sovereignty, but limit its exercise to standards developed by International Law in matters related to International Investment Law. This notion falls foul of the wording of the Ecuadorian constitutional provision that forbids "yielding sovereign jurisdiction" to international arbitration venues through international treaties or instruments involving the State in commercial or contractual disputes with foreign private parties (Art. 422).

Furthermore, the absence of specialized constitutional scrutiny to the treaties adopted prior to the Constitution of 1998 means that Ecuador is very likely to be still a party to treaties that could be deemed as contrary to the constitutional framework, as observed in the case of BITs. Pellet, following the Permanent Court of Justice in the Polish Upper Silesia ${ }^{793}$ case, disregards the importance of an alleged conflict between national and international obligations because "from the standpoint of international law, domestic law, including national constitutions, are merely facts". ${ }^{794}$ In this context, this scholar criticizes the inconsistency of the Conseil d'Etat, when challenged by a steady line of interpretation regarding the impossibility to dispute the validity of treaties once they are in force. In its interpretation, the General Assembly of the Conseil d'Etat

\footnotetext{
${ }^{792}$ Pellet (Allain), “A French Constitutional Perspective on Treaty Implementation" in Delegating State Powers: The Effect of Treaty Regimes on Democracy and Sovereignty, $283 \mathrm{p}$.

793 Polish Upper Silesia, P.C.I.J., (ser.A) No. 7, ay 19, in Pellet (Allain), “A French Constitutional Perspective on Treaty Implementation" in Delegating State Powers: The Effect of Treaty Regimes on Democracy and Sovereignty, $290 \mathrm{p}$.

${ }^{794}$ Pellet (Allain), “A French Constitutional Perspective on Treaty Implementation" in Delegating State Powers: The Effect of Treaty Regimes on Democracy and Sovereignty, $290 \mathrm{p}$.
} 
concluded that the supremacy conferred on international commitments "does not apply, in the domestic order to provisions of a constitutional nature". ${ }^{795}$ Anyway, the domestic effects of this ruling do not release the State from international responsibility if the treaty was found to be breached.

\subsubsection{Developing National Legislation to Resist the Effects of International Investment Law}

The notion of State responsibility is utterly important, when analyzing the apparent Ecuadorian constitutional proscription of keeping in force and further adopting international investment agreements, granting a State or a foreign investor direct access to international arbitration to settle "contractual or commercial" disputes. In this line, it is difficult to foresee which sources of law would the Constitutional Court resort to, when it does face the obligation to define the scope of commercial disputes within the context of the referred provision (Art. 422), considering that those of a contractual nature would not, in principle, bring major interpretative challenges. The Court did not tackle such a crucial definition when it examined the BITs' constitutionality. The rulemakers willing to resume the signature of BITs encompassing investor-State arbitration clauses, have foreseen as a way to lift this apparent obstacle, to require the Constitutional Court to interpret the scope of "contractual and commercial disputes". ${ }^{796}$ The desired outcome would be that the Court affirms that investment disputes indeed do not correspond to contractual or commercial disputes, in which case, the Government would be allegedly enabled to signed international investment agreements including a clause of investorState arbitration. In this case, it is very likely that the Court will rely on domestic legal sources for reaching such a response. Domestically "lex mercatoria" has been subject to steady regulation, control and special judicial adjudication. The Ecuadorian Commercial Code and also the Civil Code have historically regulated commerce both subjectively and materially, with the State and any of its acts excluded from this framework.

\footnotetext{
795 As consequence of the judgment in the case re Sarran (1998) issued by the General Assembly of the Counseil d' Etat, Pellet warns that the French judges would be enabled to "disregard a treaty already in force, if they find it contrary the Constitution and, in particular with the principle of national sovereignty or the essential conditions to the exercise of sovereignty".

See, Pellet (Allain), “A French Constitutional Perspective on Treaty Implementation” in Delegating State Powers: The Effect of Treaty Regimes on Democracy and Sovereignty, 291 p.

${ }^{796}$ See footnote 1034.
} 
According to the Constitution of 2008, the State is enabled to enter into contracts through any of its entities and to carry out commercial activities through public enterprises, which are regulated by its own law ${ }^{797}$. Should the State be involved in contractual or commercial controversies and in the absence of an arbitration agreement, their settlement concerns the contentious administrative jurisdiction. Oddly, the Constitution agrees that public procurement disputes prior to the authorization of the Attorney General can go to arbitration, although this is not the exclusive tool whereby the State assumes contractual obligations in matters not governed by the Public Procurement Act. This was the interpretation of the Constitutional Court when it ruled the conformity of ex aqueo et bono arbitration in a loan contract signed between the Ministry of Finance and the Inter-American Development Bank. ${ }^{798}$ As noted and in order to overcome such uncertainty, the Code of Planning and Public Finances inserted a general disposition whereby the Attorney General's prior authorization is required in any contractual arbitration agreement accorded between the State and any public or private entity either domestic or foreign. Before the promulgation of such a Code and due to the criticisms concerning the submission of disputes to international arbitral venues in contracts signed by the State, the Attorney General published his opinion concerning the scope of the constitutional provision at issue. ${ }^{799} \mathrm{He}$ asserted that the prohibition was confined to treaties and not to contracts, in which the State does not exercise "its sovereign capacity", thereby, being subject to the rules of international commerce. While the mentioned authority considered contracts as a subcategory of commercial relationships, the General Organic Code of Processes categorized the judgments and arbitral awards against the State as "non-commercial" 800 . By doing so, the legislator apparently had the intention of

\footnotetext{
797 See, Ley Orgánica del Sistema Nacional de Contratación Pública, Suplemento de Registro Oficial 395, 4 de agosto de 2008.

798 See, Sentencia Interpretativa del Art. 422 de la Constitución (N.0001-09-SIC-CC), Caso 0005-09-IC, Suplemento de Registro Oficial 549, 16 de marzo de 2009.

${ }^{799}$ See, footnote 541.

${ }^{800}$ Código Orgánico General de Procesos:
}

“Artículo 104.- Homologación de sentencias, laudos arbitrales y actas de mediación expedidos en el extranjero. Para la homologación de sentencias, laudos arbitrales y actas de mediación expedidos en el extranjero, la sala competente de la Corte Provincial deberá verificar:

(...) Para efectos del reconocimiento de las sentencias y laudos arbitrales en contra del Estado, por no tratarse de asuntos comerciales, deberá además demostrarse que no contrarían las disposiciones de la Constitución y la ley, y que estén arregladas a los tratados y convenios internacionales 
taking advantage of the reservation made in the New York Convention, limiting its application to awards and judgments on commercial matters in accordance with domestic legislation. From the wording of the latter statutory provision, it could be interpreted that although the dispute pertained to "commercial" matters insofar as the State is the losing party, the resulting award or judgment had to be tested against the Constitution and the law. And this extensive review seemed to extend to the procedure and the merits. In consequence, the winning party of an international commercial litigation involving the Ecuadorian State allegedly had little assurance of obtaining a swift recognition of its award in Ecuador. Therefore it could be affirmed that the New York Convention may not apply to the recognition of any judgment or award in which the State is the losing party, irrespective of the matter. Conversely, it appears that in the event the State is the winning party in commercial and non-commercial matters, the recognition would be released from that review. The limitation at issue is not set forth concerning the enforcement of such judgments and awards. Whilst the recognition of awards concerns to the Superior Court (provincial Court), the enforcement pertains to a first instance court. Therefore, it could be probable that in the latter case, a judge could have entertained the request for enforcement of a judgment or award against the State duly recognized abroad. It suffices to say that such limitations have no impact on the recognition and enforcement of a judgment or award in a country other than Ecuador.

\subsection{Constitutional Boundaries Allowing the State's Submission to International Arbitration Involving Private Parties}

It has been repeatedly underlined that due to the regulatory nature of investment disputes, the wording limiting the surrender of "sovereign jurisdiction" in favour of international arbitral venues to contractual or commercial disputes is not appropriate. Therefore, if the cause of action provided by a treaty or an international instrument is

vigentes. A falta de tratados y convenios internacionales se cumplirán si constan en el exhorto respectivo o la ley nacional del país de origen reconoce su eficacia y validez."

See, Suplemento del Registro Oficial 506, 22 Mayo de 2015.

The Organic Act on Productive Promotion, Investment Attraction and Employment Creation derogated these provisions. By this fashion, foreign arbitral awards have the same status as a national judgement:

See, Ley Orgánica para el Fomento Productivo, Atracción de Inversiones, Generación de Empleo, y Estabilidad y Equilibrio Fiscal, Ley 0, Official Gazette Suplement 309, August 21 ${ }^{\text {st }}, 2018$. 
neither commercial nor contractual, an arbitral venue could settle a dispute in the matter of investment or any other matter different to the two mentioned without offending the Constitution. Moreover it has to be taken into account that the vague reference to "sovereign jurisdiction" seems to allude exclusively to the exercise of adjudicatory powers, although the larger scope of such a concept, is illustrated by Beale:

"The power of a sovereign to affect the rights of persons whether by legislation, by executive decree, or by the judgment of a court, is called jurisdiction". 801

The unintelligible line of reasoning following the constitutional rulings at issue does not allow the categoric conclusion of which type of jurisdiction the Court assumes is yielded through this kind of treaty. Although it could be affirmed that the most salient feature of international investment agreements is the mechanism of dispute settlement, it has to be recalled that treaties like NAFTA provide for binding executive interpretation of its provisions, which properly implies the exercise of normative powers. In any event, in the constitutional ruling involving the BIT with Peru, it was stated that vesting an international tribunal with the power to adjudicate disputes with foreign investors, involves "surrounding jurisdiction". Such power of adjudication is considered one of the most important manifestations of "territorial sovereignty" as it refers to the power of the State courts to "administer justice". ${ }^{802}$ Dorsett and McVeigh challenge the radical concept of "territorial sovereignty" as the determining element of jurisdiction, since place does not constitute "a matter of a legally bounded area of physical space, but rather it is the work of legal ordering and relationship". ${ }^{803}$

\footnotetext{
${ }^{801}$ Beale (Joseph H.), “The Jurisdiction of a Sovereign State”, Harvard Law Review, Vol. XXXVI, No.3, 1923, $241 \mathrm{p}$.

802 The justice, Ruth Seni Pinoargote delivered this prior ruling and conceived jurisdiction as the function of administering justice:

\begin{abstract}
"En el presente caso, el contenido del artículo 9 numeral 3 del Convenio, puesto en conocimiento de esta Corte, somete al Ecuador a un Tribunal Arbitral ad hoc, para la resolución de controversias surgidas con un inversionista (persona natural o jurídica) que tenga la nacionalidad de la República del Perú, lo que implica renunciar a la "Jurisdicción del Estado", considerada como una de las manifestaciones más importantes de la soberanía territorial y que se refiere a la administración de justicia por tribunales del Estado (8) (Ecuador); por tanto, la citada norma del Convenio objeto de análisis contraviene lo preceptuado en el primer inciso del artículo 422 del texto constitucional, por lo que es procedente su denuncia."
\end{abstract}

See, Dictamen No. 032-13-DTI-CC, Caso No. 0016-13-DTI-CC, 26 de noviembre de 2013.

${ }^{803}$ Taking one of such scholars' historical examples, namely "lex mercatoria", it is illustrated that it gradually evolved as a uniform cross-boundary jurisdiction, based on reciprocity and administered by its own court system: 
Following Beale, the answer to ascertain whether the State has "surrendered" its sovereign powers does not lie either on the commercial or the contractual nature of the dispute, nor on the international nature of the arbitral venue. In the view of the Ecuadorian Constitution's wording and the scope of the BITs at issue, the solution would reside on determining whether an international treaty making power had been actually exercised, with the effect of granting an international authority the power to rule over issues involving the exercise of sovereign powers. If the commercial and contractual relationships are normally governed by their own stipulations, it is difficult to perceive the usefulness of a State signing an international treaty in order to entitle undetermined foreign private parties to bring international arbitral disputes not foreseen in such mutual obligations. Evidently the scope of investment protection might cover commercial and contractual relationships, but these disputes will be always treaty based; consequentially these controversies will rest in the core of Public International Law. Looking at the Ecuadorian regulatory actions to impose obstacles to the deployment of international arbitration rules in view of the constitutional proscription analyzed (Art.422), it can be affirmed that attaching the distinction between commercial and non-commercial disputes to the signature of treaties would be somewhat futile. Moreover, the Constitution does not prohibit the offer of consent to arbitrate disputes derived from the breach of international treaties through national legislation or contracts, which is also a common and effective way of assuring binding commitments with foreign investors.

\subsubsection{Scope of the Constitutional Exception Allowing for Treaty Based Arbitration Involving the State and Individuals}

Taking a step forward, the provision prohibiting yielding sovereignty jurisdiction over international arbitral tribunals in disputes involving the State and foreign private and natural persons, allows for the settlement of disputes before international tribunals on the following terms (Art. 422, paragraph 2):

\footnotetext{
The emergence of the modern sovereign state, with its dominant national legal system, helped to bind commerce to territory. Newly emerging states offered traders enhanced security and enforceability of agreements but preferred their own law of contracts and their own courts (Stone Sweet 2006: 630-631). By the late $19^{\text {th }}$ century, international commercial disputes were increasingly adjudicated by the techniques of private international law ('conflicts of law'), in which municipal judges determine which set of domestic laws apply to a particular contractual dispute.
}

See, Dorsett (Shaunagh) and McVeigh (Shaun), Jurisdiction, Routledge-Cavendish, 2012, 43 p. 
The treaties and international instruments that provide for the settlement of disputes between States and citizens in Latin America by regional arbitration entities or by jurisdictional organizations designated by signatory countries are exempted from this prohibition. Judges of the States that, as such, or their nationals are part of the dispute cannot intervene in the above. ${ }^{804}$

Fach Gómez has already tackled this cryptic draft, underscoring its inconvenience and the drafters' lack of familiarity with this branch of International Law. ${ }^{805}$ First, as it was noted above, the drafters of the Constitution made clear their intention of regulating separately treaty and contract-based obligations. Then, it is hard to understand the simultaneous mention to "treaties" and "international instruments". It is illustrative to refer to the UN Charter, which as pointed out by Fitzmaurice and Elias, "appears to uphold a distinction between "treaty" and "international agreement".806 Although there has been an attempt to distinguish the former as one category emanating from the "highest authority in the State and the other from subordinate executive authority", such scholars warn that "this distinction has not been maintained in practice, case law, nor in the literature" 807 . Consequentially "nomenclature cannot be relied on in order to characterize the substance of an international agreement" $" 808$ and the essential element as prescribed by

804 See, Fach Gómez (Katia), "Ecuador's Attainment of the Sumak Kawsay and the Role Assigned to International Arbitration", Yearbook on International Investment Law and Policy, 2010-2011, 455 p.

${ }^{805}$ Fach Gómez highlights the threatened effectiveness of the constitutional proscription due to the evident disregard of international law concepts:

"It seems that this dissonance between the intention and the legislative reality was not foreseen at the time by the drafters of the Ecuadorian Constitution. This is understandable, given the complexity and technicality characterizing the international investment law and international arbitration."

See, Fach Gómez (Katia), "Ecuador's Attainment of the Sumak Kawsay and the Role Assigned to International Arbitration", Yearbook on International Investment Law and Policy, 2010-2011, 455 p.

${ }^{806}$ United Nations Charter:

Art, 102, 1. "[e]very treaty and every international agreement entered into by any Member of the United Nations after the present Charter comes into force shall as soon as possible be registered with the Secretariat and published by it. 2. No party to any such treaty or international agreement which has not been registered in accordance with the provisions of paragraph 1 of this Article may invoke that treaty or agreement before any organ of the United Nations".

See, Fitzmaurice (Malgosia) and Elias (Olufemi), Contemporary Issues in the Law of Treaties, Eleven International Publishing, Utrecht, 2005, 9 p.

${ }^{807}$ Fitzmaurice (Malgosia) and (Olufemi) Elias, Contemporary Issues in the Law of Treaties, Eleven International Publishing, Utrecht, 2005, 9 p.

${ }^{808}$ Fitzmaurice (Malgosia) and (Olufemi) Elias, Contemporary Issues in the Law of Treaties, Eleven International Publishing, Utrecht, 2005, 9 p. 
the VCLT, is underlined by its international nature and its submission to international law (“international agreement governed by international law"):

(...) This term is meant to imply that in order to constitute a treaty, an agreement must be legally binding in international law and create legally binding rights and obligations: it is not enough that it falls within the ambit of international law or that international law is applicable to it. In other words, for an agreement to constitute a treaty, not only must international law (as opposed to any other legal system) be applicable to it, but international law must also designate the agreement as one that is legally binding on the parties (as opposed to an agreement which is merely morally binding or merely political in nature). ${ }^{809}$

In addition, the agreements between States and non-state entities and individuals or corporations do not belong to the category of international treaties or agreements, as it was rendered in the Anglo-Iranian oil case ${ }^{810}$. Moreover, the element "governed by international law" 811 does not suffice to turn an agreement into an international one. This is particularly clear with respect to investment contracts, which may contain a submission

\footnotetext{
809 Fitzmaurice (Malgosia) and (Olufemi) Elias, Contemporary Issues in the Law of Treaties, Eleven International Publishing, Utrecht, 2005, 8 p.

${ }^{810}$ Anglo-Iranian Oil Company (United Kingdom v. Iran), Preliminary Objections, Judgement of 22 July 1952, 1952 ICJ Rep. 20, at 93:
}

\begin{abstract}
"The Court cannot accept the view that the contract signed by the Iranian Government and the Anglo-Persian Oil Company has a double character. It is nothing more than a concessionary contract between a Government and a foreign corporation. The United Kingdom is not a party of the contract; there is no privity of the contract between the Government of Iran and the Government of the United Kingdom. Under the contract the Iranian Government cannot claim from the United Kingdom Government any rights which it may claim from the company, nor can it be called upon to perform towards the United Kingdom Government any obligations which it is bound to perform towards the Company. The document bearing the signatures of the representatives of the Iranian Government and the Company has a single purpose: the purpose of regulating the relations between that Government and the company in regard to the concession. It does not regulate in any way the relations between the two governments."
\end{abstract}

See, Fitzmaurice (Malgosia) and (Olufemi) Elias, Contemporary Issues in the Law of Treaties, Eleven International Publishing, Utrecht, 2005, 18-20 pp.

811 The authors hold that subordinating an agreement between a State and private person to international law, does not convert it into "international":

First, it is aimed at excluding from the definition those agreements, even if international-and, indeed, even if made between States- which are governed by some other legal system in the sense that the applicable law is not international law. Second, the term "governed by international law" implies not just that international law is the law applicable to the agreement in question, but also that, under international law, that agreement is binding.

See, (Malgosia) Fizmaurice and (Olufemi) Elias, Contemporary Issues in the Law of Treaties, Eleven International Publishing, Utrecht, 2005, 20 p. 
to international law. In any case, with a contract of such a nature the subjective element would be lacking in order to constitute a treaty. It has also to be recalled that domestic law governs contracts even though they may regulate matters of an international character. ${ }^{812}$

Second, the reference to "citizens" seems to exclude legal persons thereby upsetting the reality of international investment law, wherein corporations usually bring their claims as autonomous entities in their own rights. In this line, the Constitution of Ecuador develops in a single chapter the rules of citizenship and leaves no doubt as to the fact that such a category is exclusively reserved to natural persons ${ }^{813}$. By choosing the term "citizen" instead of "person", the aim may be perceived for circumscribing treatybased disputes to injuries directly affecting stakeholders as individual persons. This attempt drastically narrows the scope in which investment agreements normally operate and would practically confine the supposed disputes to direct violations inflicted on the shareholders as individuals. This system is more like a human rights protection regime, and it would be very challenging to preserve the application of standards intimately linked with rule of law features embodied by investment agreements, like fair and equitable treatment and most favoured nation. ${ }^{814}$ For instance, it is difficult to foresee how a claim based on the impairment of legitimate expectations would be assessed individually taking into consideration the damage inflicted on particular right-holders, either as individuals or as a group, within usually complex corporate schemes. ${ }^{815}$

\footnotetext{
${ }^{812}$ See, (Malgosia) Fizmaurice and (Olufemi) Elias, Contemporary Issues in the Law of Treaties, Eleven International Publishing, Utrecht, 2005, 7 p.

${ }^{813}$ Constitución 2008:

"Art. 6.- Todas las ecuatorianas y los ecuatorianos son ciudadanos y gozarán de los derechos establecidos en la Constitución. La nacionalidad ecuatoriana es el vínculo jurídico político de las personas con el Estado, sin perjuicio de su pertenencia a alguna de las nacionalidades indígenas que coexisten en el Ecuador plurinacional. La nacionalidad ecuatoriana se obtendrá por nacimiento o por naturalización y no se perderá por el matrimonio o su disolución, ni por la adquisición de otra nacionalidad."
}

814 The American Convention on Human Rights limits the definition of person to "human being":

"Article 1.The States Parties to this Convention undertake to respect the rights and freedoms recognized herein and to ensure to all persons subject to their jurisdiction the free and full exercise of those rights and freedoms, without any discrimination for reasons of race, color, sex, language, religion, political or other opinion, national or social origin, economic status, birth, or any other social condition.

2.For the purposes of this Convention, "person" means every human being."

${ }^{815}$ Van Harten highlights the uniqueness of investment treaty arbitration as a regime of state liability. He explains that in fields of humanitarian and environmental law, the access to damage claims is exclusively restricted to individuals. Moreover, he points out that damage claims filled by individuals is the exception even under international human rights law, where standards as "just satisfaction" of rights do not 
Third, the reference to "Latin America" as the place where the disputes may take place disregards the ethnical-geographical complexity of listing the countries that this region embodies ${ }^{816}$. Fourth, the concept of "regional arbitration entities" rather than denoting a particular category of the venues apt to arbitrate defined by their legal nature, for instance, intergovernmental, alludes to the coverage that any institution regardless of its legal nature may achieve. In any case, the fervent integrationist orientation of the Constitution, in conjunction with the distrust of private arbitration bodies, sustained four rulings of the Constitutional Court ${ }^{817}$, that interpreted that the exception to the prohibition set forth in the constitutional provision analyzed, covers treaties that promote LatinAmerican integration ${ }^{818}$. The aim would consist in establishing these venues in regional intergovernmental organizations, like UNASUR.

necessarily entail the award of monetary damages. Additionally, it has to take into account further procedural limitations like the exhaustion of local remedies, the mediation of bodies within the relevant systems to bring the disputes on behalf of individuals, the impossibility to chose the rules governing the disputes, appointing adjudicators and enforcing the award against the State. In sum, restricting the personal jurisdiction to the access of the system of arbitration has important consequences.

See, Van Harten (Gus), Investment Treaty Arbitration and Public Law, Oxford University Press, 2007, 1011 pp.104 p.

816 The list of countries conforming the Economic Commission for Latin America, which also include Caribbean countries, several of them non-independent, portrays the inconvenience of circumscribing a legal category to a political notion.

${ }^{817}$ See, Dictamen No. 041-10-DTI-CC, Caso No.0011-10-TI, de 9 de diciembre de 2010.

${ }^{818}$ When the Constitutional Court confronted the text of the Investor-State arbitration clause contained in the Bilateral Investment Treaty signed between Ecuador and Germany with the Ecuadorian Constitution, it interpreted it to mean that the exception provided for in Art. 422 that allowed the submission of disputes to regional arbitration entitites, was viable only in treaties aimed at promoting regional integration. The Court held the same argument in the rulings concerning the BITs signed between Ecuador and France, Sweden and the United States:

The exception to the constitutional provision contained in Article 422 is given by the following paragraph: treaties and international instruments that provide for the settlement of disputes between States and citizens in Latin America by regional arbitration entities or by jurisdictional organizations designated by signatory countries are exempted from this prohibition. Judges of the States that, as such, or their nationals are part of the dispute cannot intervene in the above"; that is consistent with article 423 that proclaims the integration of Ecuador and Latin America, in its parragraphs 1 and 7 that tend to promote economic integration and regional trade; as well as favoring the consolidation of supranational organizations tending to regional integration. This is determined by the commitment of Ecuador to maintain an integration process and permanent regional integration, as well as for the purpose of achieving a process of deep integration with its Latin American counterparts. The analysis of article 9 of this international treaty shows that it does not tend towards a process of regional integration, but rather an instrument that commits the states, individuals and societies of Ecuador and Germany in a specific topic, which are investments; therefore, it is not classified within the exception provided by the constitutional text. Therefore, Article 9 of the international treaty, object of analysis, is clearly contrary to the Constitution of the Republic of Ecuador." 
And fifth, the allusion to "jurisdictional organizations designated by signatory countries" seems to cover entities vested with adjudicative jurisdiction, either legally or conventionally established:

Adjudicative jurisdiction relates both to the courts' competence to adjudicate international disputes according to its municipal rules, and to its discretion to decline to adjudicate proceedings over which it has jurisdiction. Conventionally, international litigation is divided into problems of jurisdiction, choice of law, and recognition of foreign judgments. ${ }^{819}$

It has to be taken into consideration that the reference to "signatory countries" would restrict the designation of such jurisdictional entities by the parties of the particular treaty. Since the signatory countries establish the jurisdiction of the relevant bodies, it seems not to be a determinant factor whether they hold neither a particular legal category nor a specific nationality, enabling as consequence, the selection of international and domestic adjudication entities, either public or private. Furthermore, from the allusion to treaties and "international instruments", it may be inferred that such designation could be made either concurrently or later, by a unilateral international act of the signatory State.

Notably this paragraph, which operates, as an exception to the general prohibition of concluding treaties having as effect the "surrender of jurisdiction" in the kind of disputes involving the subjects analyzed, seems to open the possibility that "citizens" covered by the new category of treaties, may bring controversies of any nature against the relevant States. Hence, this possibility would not bar submitting regulatory, "commercial", "contractual" or any other kind of disputes confined to this forum, insofar as individual persons (Latin-American citizens) can bring a claim against the State. In the paragraph referred to, the access to a particular forum is not given by the nature or the scope of the disputes but by the specific personal attribute of the claimants seeking the treaty based protection.

It must be recalled that the Constitutional Court has stated that the main flaw derived from investment treaties consists of the mechanism of investor - state arbitration, because it puts on an equal footing investors and States, making possible something "unthinkable in other times", namely, that a "legal entity", in this case, "transnational corporations may

See, Dictamen No. 023-10-DTI-CC, CASO No. 0006-10-TI, Registro Oficial Suplemento 249 de 3 de agosto de 2010.

${ }^{819}$ Keyes (Mary), Jurisdiction in International Litigation, The Federation Press, Sydney, 2005, 1 p. 
sue the National State" ${ }^{820}$ Thus, the exception to the general prohibition analyzed, would result in claims arising out of commercial or contractual disputes with the State may only be brought by individual persons before the relevant jurisdictional bodies in order to enjoy treaty based protection. Contrary to contractual disputes, defining the scope of commercial controversies would be somewhat challenging. In absence of a contractual link, it would have to be established whether the State, acting in its commercial capacity (iure gestioni) could have actually provoked a dispute of this nature with an individual. For instance, this possibility could cover the activities of State owned enterprises, which interact in the market with private actors. This expanded protection would resemble the coverage afforded by umbrella clauses, with the restriction that only individuals may resort them to.

Finally the paragraph at hand refers exclusively to "judges". As Fach Gómez asserts:

(...) the constitutional requirement that "judges of the States that, as such or their nationals, are part of the dispute and cannot intervene in the above" can pose terminological difficulties, as the reference to arbitrators is missing. ${ }^{821}$

This reference read in conjunction with the mention of "regional arbitration entities" and "jurisdictional entities" might suggest the foreclosure of ad hoc arbitration. This is particularly problematic taking as examples two of the most authoritative world

\footnotetext{
${ }^{820}$ The critics to the investment arbitration regime made by the Spaniard activist, Decio Machado, strongly persuaded several constitutional justices. They endorsed, for instance, the activist' assertions that categorized ICSID and UNCITRAL forums as "private courts" and the denunciation of ICSID as the State's withdrawal from international arbitration:
}

\begin{abstract}
"El tratadista Decio Machado sostiene que los TBI forman parte de un complejo sistema diseñado en varios niveles, que van desde lo nacional a lo multilateral, que constituye el marco jurídico para el reconocimiento de los intereses y prerrogativas de los inversionistas; que el hecho más relevante, subyacente en los TBI, se refiere al procedimiento de solución de controversias InversionistaEstado, en el cual se adopta la modalidad de "arbitraje" en cortes extranjeras. Esta cláusula pone en el mismo nivel a estos dos actores y posibilita algo impensable en otros tiempos: que una "persona jurídica", en este caso las corporaciones transnacionales, puedan demandar a un Estado Nacional. Hay distintos tipos de cortes de arbitraje. Talvez una de las más importantes es el CIADI, adscrita al Banco Mundial; UNCITRAL, adscrita a la ONU; y los mecanismos "ad-hoc" por acuerdo entre las partes. Estas cortes son de carácter privado y por tanto no responden a un interés colectivo (14). Debiendo aclarar que para el caso del Ecuador mediante Decreto Ejecutivo No. 1823, publicado en el Registro Oficial No. 632 de 13 de julio de 2009, se retiró del arbitraje internacional."
\end{abstract}

See, Machado (Decio), "Ecuador y la denuncia de los Tratados Bilaterales de Inversión", recogido de www.quiendebeaquien.org in Dictamen No.020-10-DTI-CC, "Convenio entre el Gobierno del Reino Unido de Gran Bretaña e Irlanda del Norte y el Gobierno de la República del Ecuador para la Promoción y Protección de Inversiones", Caso No. 008-10-TI, Registro Oficial Suplemento, 24 de junio de 2010.

${ }^{821}$ Fach Gómez (Katia), "Ecuador's Attainment of the Sumak Kawsay and the Role Assigned to International Arbitration", Yearbook on International Investment Law and Policy, 2010-2011, 455 p. 
arbitration venues, namely the Permanent Court of Arbitration, an intergovernmental organization and the International Court of the International Chamber of Commerce, a non-governmental organization. As it is known, none of them resolve disputes themselves, but they do administer the resolution of disputes by arbitral tribunals. Thus the wording of the paragraph analyzed seems to indicate that the treaties endured by the Constitution would have to comprise an investment court system, enabled to entertain the relevant claims either at the national or supranational levels ${ }^{822}$. Apparently, this terminology is influenced by the criticism of the legitimacy of the international investment regime has worsened drastically during the last decade and that has mainly targeted arbitrators' conduct. ${ }^{823}$ As observed, the technical deficiency of the cryptic constitutional rulings impedes the singling out of the main censure made by the justices to the dispute settlement mechanisms provided for by BITs. Pursuant to the Constitution, the Constitutional Court has acknowledged arbitration as an institution duly recognized by Public International Law for the settlement of inter-State disputes in the ruling regarding the BIT with China:

Arbitration is an institution recognized by Public International Law for the settlement of disputes arising between two or more States. Hence, in the event of any dispute between Ecuador and China concerning the interpretation and/or

\footnotetext{
822 This interpretation is in harmony with well-grounded critics to the system of international arbitration, revealed as "a unique form of public law adjudication" that "uses rules and structures of international law and private arbitration to make governmental choices regarding the regulatory relationship between individuals and the state" (Van Harten: p. 10). Van Harten categorically tackles the flaws of investment arbitration:
}

(...) Rather, the target of criticism is the particular way in which states have used a private method of international adjudication to resolve claims that should be finally determined by courts, whether domestic of international. Consensual arbitration is broadly suitable as a means to settle disputes between companies or between states, but it is fundamentally inadequate as a substitute for the public courts in the regulatory domain. As I shall argue, the courts and only the courts should have the final authority to interpret the law that binds sovereign power and to stipulate the appropriate remedies for sovereign wrongs that lead to business loss.

Van Harten (Gus), Investment Treaty Arbitration and Public Law, Oxford University Press, 2007, 10-11 pp.

${ }^{823}$ For instance, Rutledge points out the nomination process of arbitrators as one of the main problems derived from their adjudication attributions:

\footnotetext{
“As I have explained elsewhere, arbitrators, unlike bureaucrats or judges, often are nominated by parties to resolve a dispute, and critically their compensation is tied to their service. In theory, this nomination process gives the arbitrators a financial incentive to decide a case in favour of the player most likely to give the arbitrator repeated business, thereby skewing the result in favour of the more powerful party."
}

Rutledge (Peter B.), Arbitration and the Constitution, Cambridge University Press, United States of America, 40-41 pp. 
application of the Treaty, the recourse to arbitration is completely valid. It doesn't mean that national sovereignty will be affected or jurisdiction transferred, since under Article 419.9 of the Constitution, Ecuador recognizes international law as a standard of conduct. ${ }^{824}$

Inexplicably and with exception to this BIT and the BIT with Finland, the Court has also declared as unconstitutional the provisions regulating inter-State arbitration in the rest of BITs.

Anyway and assuming that treaty based arbitration in itself does not entail a transgression of the Constitution but the unlimited access afforded to corporations to such mechanism does so, it is not yet clear to what extent a "contractual" or "commercial" dispute would entitle individuals to stand as plaintiffs before a "regional arbitration body" or a "jurisdictional entity". Under a literal interpretation of the constitutional provision, it would not be prohibited for legal persons to access to a mechanism of treaty based dispute settlement provided that the disputes are neither contractual nor commercial. As the constitutional proscription is built upon the limits of subject matter jurisdiction, namely "contractual" and "commercial" disputes, it would seem fair to say that treaties embodying the settlement of controversies different to those referred to are not bound by the conditions analyzed.

While it is clear that the relationship between the State parties established through an international instrument is governed by international law, it is rather bold to anticipate which type of law the Constitutional Court would authorize to govern the disputes between individuals and the States. This scepticism is well established on the arguments found on the constitutional rulings at issue, which militate in favour of a restrictive notion of sovereignty. For instance, this Court by comparing the adjudicative tasks carried out by international tribunals with the administration of justice undertaken by State courts has deemed it as contrary to national interests to submit the Ecuadorian State to international jurisdiction, allegedly for diminishing its own jurisdiction. ${ }^{825}$ In tune with

\footnotetext{
${ }^{824}$ See, Fach Gómez (Katia), "Ecuador's Attainment of the Sumak Kawsay and the Role Assigned to International Arbitration”, Yearbook on International Investment Law and Policy, 2010-2011.

825 The Constitutional Court has alleged that the BITs have served as instruments to diminish the national courts' jurisdiction and also the domestic judiciary reputation:
}

"En lo fundamental, a través de estos instrumentos, el Estado ecuatoriano ha cedido el fuero o jurisdicción de los jueces nacionales para tratar desavenencias o conflictos, a instancias internacionales. Se ha aducido que nuestro sistema jurídico no es confiable ni idóneo, que es lento e inmoral, y se ha sostenido que el arbitraje externo es el mecanismo idóneo para solucionar los 
this parochial standing, it is hard to see the attraction of an international treaty regulating State-investor (individual person) disputes giving a large room of deference to the application of domestic law and the deployment of national jurisdiction. Anyway, this position is not alien to international investment law, taking as an example ICSID arbitrations, where tribunals may apply the law of the host countries, unless the parties have agreed otherwise. ${ }^{826}$

Probably, few answers to these queries will be delivered when the State enters into new agreements involving investment and trade. However and given that inter-State dispute settlement mechanisms, as embodied in the treaties currently negotiated by Ecuador, would not fall within the constitutional prohibition analyzed, the apparent radical opposition to submit the State to international jurisdiction should be moderated. Simply, the insular standing of the Constitutional Court concerning the establishment of international jurisdiction is opposed to international reality and should be progressively nuanced.

The evolution of the mechanisms of constitutional control show the different constitutional arrangements which impact upon the conformity review of international obligations with the municipal law. The relatively novel introduction of a judicial mechanism of prior constitutional review of treaties indicates on the one hand, the reluctance of the Legislature to yield influence over the exclusive interpretation of the Constitution and, on the other, the understanding of treaties as a matter of foreign relations. Despite the overhauled constitutional control of treaties by the incorporation of prior and ex post facto mechanisms of review, preserving a dual mechanism of treaty approval contingent upon the President's own judgment does not ensure the coherence of the legal framework, when it assimilates treaties as part of the domestic law. In any case,

conflictos o diferencias. La Constitución de la República establece actualmente parámetros bien definidos respecto a esta temática."

See, Dictamen No.020-10-DTI-CC, “Convenio entre el Gobierno del Reino Unido de Gran Bretaña e Irlanda del Norte y el Gobierno de la República del Ecuador para la Promoción y Protección de Inversiones", Caso No. 008-10-TI, Registro Oficial Suplemento, 24 de junio de 2010.

${ }^{826}$ Article 42 (1), Convention on the Settlement of Investment Disputes Between States and Nationals of Other States:

"Article 42:

(1) The Tribunal shall decide a dispute in accordance with such rules of law as may be agreed by the parties. In the absence of such agreement, the Tribunal shall apply the law of the Contracting State party to the dispute (including its rules on the conflict of laws) and such rules of international law as may be applicable." 
none of the constitutional filters introduced during the 1990s meant that the BITs were subject to a higher degree of scrutiny capable of detecting the far-reaching obligations such treaties entailed. Even the defective characterization of such treaties by the Constitutional Court as a result of the ex post facto review they were subject to, overlooks the profound domestic impact their application involves. Underscoring the domestic effects of the constitutional rulings, the alleged change of State model and especially, the transformation of the constitutional procedural and substantive mechanisms for signing and ratifying international treaties could be deemed as sufficient grounds to trigger an integral review of treaties. In any case, the Court should be mindful of the international State commitments and of the burdens attached to the review of treaty obligations, privileging a pattern of interpretation prone to harmonize international and domestic law. A parochial standing towards international relations in conjunction with an inaccurate determination of the scope of IIAs would require that the diverse efforts undertaken mainly at the domestic level with the purpose of resisting the regime, far from reducing would increase the State's exposure to investment conflicts, thereby also upsetting other levels of influence, like diplomacy and country risk classifications. Without disregarding the importance of legitimately and promptly resuming the room of regulatory space curtailed by treaties which were poorly bargained, there has to be a warning that the technical complexity of the rules not uniformly applied in the intermingled web of protection of investor's rights, obliges the decisions undertaken with the aim of ameliorating the State's stance in the system to be taken looking beyond the constitutional text.

\subsection{Drawing the Boundaries between the Constitutional Space and the International Legal Framework}

\subsubsection{The Termination of Treaties under Changed Circumstances}

In the opinion of the Ecuadorian constitutional justices, the "new challenges" in the political, economic and legal spheres "assumed by the Ecuadorian juridical structure" as embodied by the new brand constitutional framework made indispensable to "analyze and harmonize" the international commitments "in the light of the contemporary juridical reality and the Constitution". ${ }^{82}$ It is notable that this strong positivistic

827 See, Dictamen No. 022-13-DTI-CC, Caso No. 0022-13-DTI-CC, “Convenio entre el Gobierno de la República del Ecuador y el Gobierno de la República de Italia sobre la promoción y protección de inversión", Registro Oficial Suplemento 64 de 22 de agosto de 2013. 
approach places the constitutional transformation as the main outcome derived from the allegedly renewed economic and political trends. Looking at the prolific constitutional making powers abused along the chaotic Ecuadorian history, it does not seem persuasive to invoke the promulgation of the twentieth Constitution as a credible ground for resisting the application of an international commitment.

As to the 30 BITS Ecuador has signed to date, 27 were signed after 1992, meaning that four constitutional codifications $(1984,1993,1996,1997)$ and one Constitution (1998) applied during this period. The Constitutional Codification of 1993 framed the most aggressive period of signature of BITs (fifteen), followed by the Constitution of 1998 (nine). Importantly none of the BITs ratified after the Constitution of 1998, were subject to legislative approval, which implies that the respective Presidents judged that they did not fall within any of the categories of treaties imposed to follow such procedure. Again, the similarity of the list of treaties provided for, both by the Constitutions of 1998 and 2008, does not allow identifying a reasonable basis that justifies why the subsequent authorities reached such divergent conclusions out of very similar if not identical precepts. Unfortunately, the Constitutional Court did not notice such an irregular procedure of BITs approval, which should have left without grounds its assertion that these treaties did entry into force pursuant to the constitutional rules. As noted, even President Correa omitted the legislative approval to denounce 9 BITs in accordance to the Constitution of 1998, by assuming that the same did not fall with any of the categories provided therein. 828

With relation to the allocation of treaty making powers and the respective procedure of approval and entry into force of international treaties, the most salient constitutional innovation from the Constitution of 1998 , concerns the prior review of constitutionality in treaties required to pass through the Congress' approval. The possibility to review ex

${ }^{828}$ Constitución Política de 1998:

“Art. 161.- El Congreso Nacional aprobará o improbará los siguientes tratados y convenios internacionales:

1. Los que se refieran a materia territorial o de límites.

2. Los que establezcan alianzas políticas o militares.

3. Los que comprometan al país en acuerdos de integración.

4. Los que atribuyan a un organismo internacional o supranacional el ejercicio de competencias derivadas de la Constitución o la ley.

5. Los que se refieran a los derechos y deberes fundamentales de las personas y a los derechos colectivos.

6. Los que contengan el compromiso de expedir, modificar o derogar alguna ley." 
post facto the constitutionality of pre-existing international treaties was incorporated by the Constitution of 2008 and although this could be portrayed as a significant improvement, it is clear that treaties can be terminated on grounds different from their alleged contradiction to the Constitution. As it was highlighted, former President Correa did not need the Constitution of 2008 to denounce the first batch of BITs. By the same token, suppressing the direct effects of international treaties different from those concerning human rights by the Constitution of 2008 could not be deemed as an essential transformation with an impact on the international arena. The dense web of international investment agreements operating indistinctively from centrally planned to free market economies makes it difficult to find a conceivable example of constitutional change that may be strongly qualified as fundamental pursuant to International Law. Moreover and given that all BITs include a termination provision, it is difficult to ascertain the usefulness of alleging a fundamental change of circumstances, unless there was the intention to suspend immediately their application, especially as regard to the survival clauses.

Having said this, the VCLT defines a treaty as: "an international agreement concluded between States in written form and governed by international law, whether embodied in a single instrument or in two or more related instruments and whatever its particular designation”. (Art. 2 (1) (a)

In view of this definition, Aust remarks that a treaty is concluded between " $a$ state and another subject of international law" $" 829$, being outside of such category, other kinds of agreement reached with a party not considered a subject of international law, such as international or multinational companies. The fact that these latter agreements might be interpreted by reference to rules of international law does not afford them the category of treaties. $^{830}$

With regard to the termination of treaties and the terminology referred to bringing to an end international obligations derived from such instruments, Aust suggests:

Denunciation denotes a unilateral act by which a party terminates its participation in a treaty; lawful denunciation of a bilateral treaty terminates it. Although denunciation is also used in relation to a multilateral treaty, the better term is withdrawal, since withdrawal from a multilateral treaty will not, normally, result

\footnotetext{
${ }^{829}$ Aust (Anthony), Modern Treaty Law and Practice, Third Edition, Cambridge University Press, 2013, $15 \mathrm{p}$.

${ }^{830}$ See, Aust (Anthony), Modern Treaty Law and Practice, Third Edition, Cambridge University Press, 2013, 15-16 pp.
} 
in its termination. While 'denunciation' is used in relation to treaties as a technical term, non-lawyers may see it as carrying undertones of its ordinary, condemnatory meaning. For this reason it should be avoided, if at all possible, 'termination' being a much better word. ${ }^{831}$

Out of the 30 BITs signed by Ecuador, 27 effectively entered into force ${ }^{832}$. From these treaties, all contain fixed periods with the possibility of extension, as well as survival clauses, with the exception of the BIT with Egypt and Uruguay. ${ }^{833}$ Therefore and in light of the clear procedural mechanisms to terminate the treaties at issue, it is hard to elucidate the adjudicators' intention when they claimed a fundamental change of circumstances. At the international level it is difficult to envisage the convenience of invoking a fundamental change of circumstances, in view of the existence of specific duration and termination clauses. As noticed, the main practical effect that could reasonably be sought for raising such a fundamental change would be derogating the application of the survival clauses. At the domestic level, the binding precedent given to the constitutional rulings would entail that current and future treaty making authorities might be barred from signing treaties comprising international arbitration involving State and private persons in the sense interpreted by the Court ${ }^{834}$.

\subsubsection{Mechanisms for Termination of Treaties as Interpreted by the Constitutional Court}

Binder highlights the pacta sunt servanda principle as one of the cardinal rules of the international law of treaties, meaning that the duty to perform treaties in good faith

\footnotetext{
831 Aust (Anthony), Modern Treaty Law and Practice, Third Edition, Cambridge University Press, 2013, $245 \mathrm{p}$.

${ }^{832}$ The BITs signed with Costa Rica, Panama and the Russian Federation were not ratified.

${ }^{833}$ The BIT with Egypt had a fixed duration, which was not renewed by the Parties. The BIT with Uruguay was properly an exchange of notes during the service of the controversial Foreign Minister, Edgar Terán Terán, which did not have a survival clause. In any case it was considered a treaty for its termination.

834 The Organic Act on Jurisdictional Guarantees and Constitutional Control establishes as one of the principles of constitutional justice, the binding precedent of the Court's rulings:
}

\footnotetext{
“Art. 2.- Principios de la justicia constitucional.- Además de los principios establecidos en la Constitución, se tendrán en cuenta los siguientes principios generales para resolver las causas que se sometan a su conocimiento:

(...) 3. Obligatoriedad del precedente constitucional.- Los parámetros interpretativos de la Constitución fijados por la Corte Constitucional en los casos sometidos a su conocimiento tienen fuerza vinculante. La Corte podrá alejarse de sus precedentes de forma explícita y argumentada garantizando la progresividad de los derechos y la vigencia del estado constitucional de derechos y justicia. (...)"
} 
constitutes one of the pillars of international relations stability. Anyway, acknowledging such a principle would not diminish the likelihood that subsequent changes may make it unacceptable for one party to continue to be bound by a treaty:

(...) Imminent threats to essential interests such as ecological concerns or economic interests may also require States to derogate from treaty obligations. In short, there is an inherent tension between the principle of pact sunt servanda and the necessary dynamic of the law, which is bound to remain open to reality and societal change." $" 835$

In this context, the non-performance of a treaty due to subsequent changes is both dealt with in the Law of Treaties and the Law of State Responsibility. Whereas the former codification embodies the supervening impossibility of performance and the "clausula rebus sic stantibus", the latter comprises force majeure and necessity. Binder illustrates the main distinction between the referred codifications:

"While both mechanisms allow for non-performance of treaty obligations in cases of subsequent changes, they function differently.

The law of treaties provides for treaty termination or suspension, the law of State responsibility for the preclusion of wrongfulness in cases of non-performance." $" 836$

Binder illustrates that the main structural difference between the Laws of the Treaties and State Responsibility consists in their character of primary and secondary rules respectively, meaning that the latter will apply once the breach of the former had been verified $^{837}$. Bearing in mind that the VCLT and the BITs would be in the province of

\footnotetext{
${ }^{835}$ Binder (Christina), "Does the Difference Make a Difference? A Comparison between the Mechanisms of the Law of Treaties and of State Responsibility of Means to Derogate from Treaty Obligations in Cases of Subsequent? in State Responsibility and the Law of Treaties, Edited by Marcel Szabó, International Publishing, 2010, 1 p.

${ }^{836}$ Binder (Christina), "Does the Difference Make a Difference? A Comparison between the Mechanisms of the Law of Treaties and of State Responsibility of Means to Derogate from Treaty Obligations in Cases of Subsequent? in State Responsibility and the Law of Treaties, Edited by Marcel Szabó, International Publishing, 2010, 2 p.

${ }^{837}$ Binder further illustrates this core difference:
}

"This is most lucidly observed by Reuter, who argues that the theory of treaties and the theory of responsibility are separated by a basic difference: the rules of the law of treaties are primary, both chronologically and logically, whereas the rules of responsibility are secondary, applying only once a primary rule is breached."

See, Binder (Christina), "Does the Difference Make a Difference? A Comparison between the Mechanisms of the Law of Treaties and of State Responsibility of Means to Derogate from Treaty Obligations in Cases of Subsequent? in State Responsibility and the Law of Treaties, Edited by Marcel Szabó, International Publishing, 2010, $16 \mathrm{p}$. 
primary obligations, pursuant to the lex specialis principle, the mechanism for the termination of the treaty would have to be found on the provisions of the BIT:

"If the treaty provides for specific termination clauses, there will, in application of the lex specialis principle, consequently be no room for an application of the termination grounds under general international law (here: Articles 61 y 62 VCLT). A State will generally have to rely on the respective-more specific-treaty provision." 838

In the case of Ecuador, the constitutional rulings all tackle different crucial concepts of International Law, like the scope of treaties and their termination, the performance of obligations in good faith, the peaceful settlement of disputes and the nature of international arbitration. The authoritative scholarly sources used by the justices to sustain their decisions in the light of Public International Law are scarce. For instance, assertions that define treaties as "contracts between the States" blog of a Spanish sociologist well known in the country or the references to Wikipedia ${ }^{840}$ to justify the mechanism the State should use for denouncing treaties, explain partially the technical misperceptions found in the rulings. As regard to the interpretation for terminating treaties, the constitutional rulings did not apply the technique normally endorsed by the international case law and scholarship, which is lex specialis. Instead of first resorting to the specific provisions of termination provided for in the BITs, the

\footnotetext{
${ }^{838}$ Binder (Christina), "Does the Difference Make a Difference? A Comparison between the Mechanisms of the Law of Treaties and of State Responsibility of Means to Derogate from Treaty Obligations in Cases of Subsequent? in State Responsibility and the Law of Treaties, Edited by Marcel Szabó, International Publishing, 2010, $19 \mathrm{p}$.
}

839 By borrowing Decio Machado's definition of BITs, the Constitutional Court, reiterated its animadversion to the same underlining the inherent inequality favoring the investors' countries through the application of the same:

\begin{abstract}
"Disposiciones del Convenio suscrito hace 16 años, que instituyen el arbitraje como un mecanismo para someter las diferencias o conflictos al "Centro Internacional de Arreglo de Diferencias", instancia a la que se someten los denominados "Tratados Bilaterales de Inversión" (TBI) que el Ecuador ha suscrito también con otros Estados, los cuales constituyen un tipo especial de contrato suscrito entre dos Estados para asegurar una efectiva protección al inversionista extranjero por parte del Estado receptor, y de esta forma promover las inversiones en dicho país dentro de un marco legal estable, y que en la práctica ha significado que los beneficios vayan en gran medida a los países inversionistas o de origen de los capitales."
\end{abstract}

See, (Decio Machado), "Ecuador y la denuncia de los Tratados Bilaterales de Inversión", recogido de www.quiendebeaquien.org in Dictamen No.020-10-DTI-CC,"Convenio entre el Gobierno del Reino Unido de Gran Bretaña e Irlanda del Norte y el Gobierno de la República del Ecuador para la Promoción y Protección de Inversiones", Caso No. 008-10-TI, Registro Oficial Suplemento, 24 de junio de 2010.

${ }^{840}$ See, http://es.wikipedia.org/wiki/ Denuncia-(derecho-internacional) in Dictamen No. 027-10-DTI-CC, Caso No. 004-10-TI, Suplemento Registro Oficial 258, 17 de agosto de 2010. 
constitutional rulings referred predominantly to the VCLT. In lieu of applying general international law for complementing the treaty-specific termination clauses, the Constitutional Court did the contrary. And curiously, by invoking such specific clauses, the Court validated the further application of the survival clauses ${ }^{841}$. Again, this somewhat hybrid way of interpretation that borrows provisions from general international law and specific treaties does little to clarify the adjudicators intention behind invoking a fundamental change of circumstances. Moreover, and bearing in mind that the President has exclusive authority over international relations, it is not clear to what extent the grounds of the termination of the BITs drew by the Constitutional Court, would bind his decisions. As warned, the fact that 17 constitutional rulings had been delivered by different justices has made it difficult to identify the circumstances amounting to a fundamental change in the light of Public International Law. Although the different rulings reach the same conclusion and effect, the particular grounds elicited when the material and formal control were undertaken differ technically. Either because the BITs are categorized differently according to the list of treaties subject to control provided by the Constitution, or due to the dissimilar constitutional precepts and values allegedly disrupted due to the preservation of such instruments, it is very difficult to foresee the boundaries within which further investment agreements could be tolerated. In any case, two major arguments that purport to sustain a fundamental change of circumstances can be identified: 1) the promulgation of a new Constitution and a new State model, and; 2) the renewed mechanism of constitutional control of treaties.

Bearing in mind the distinction between primary and secondary rules, which draws a line between the Law of treaties and the Law on State responsibility, the procedure to determine whether a treaty has been properly terminated would rest in the former category of rules. As noted, the BITs subject to constitutional review embody without exception

\footnotetext{
841 In the constitutional ruling involving the Ecuador-Italy BIT, although it made a reference to a fundamental change of circumstances and a predominant application of the VCLT over the specific provision of the treaties, it was also clarified that the specific provision enables an immediate and unconditional termination. However, the Court failed to tackle the further application of the survival clauses:

“(...) Es decir, bastaría con la simple notificación de terminación por parte del Estado ecuatoriano, para que termine el compromiso asumido en el Convenio en mención; evidentemente, los compromisos e inversiones adquiridos antes de la fecha de terminación quedarían en vigor durante un período adicional de cinco años (...)."
}

See, Dictamen No. 022-13-DTI-CC, Caso No. 0022-13-DTI-CC, "Convenio entre el Gobierno de la República del Ecuador y el Gobierno de la República de Italia sobre la promoción y protección de inversión", Registro Oficial Suplemento 64 de 22 de agosto de 2013. 
specific termination clauses. By applying such specific clauses, there would no need either to invoke termination grounds or the procedural provisions regulating the termination of treaties prescribed by general international law. Again, and although having addressed very similar situations, the Constitutional Court invoked indistinctly different mechanisms for termination of the VCLT, whose application differ both at the substantive and procedural levels. In several cases it referred to the rule that enables the termination of a treaty as the result of the application of its own provisions ${ }^{842}$ (VCLT, Art. 42), whereas in others, it resorted to the clause that regulates the corresponding procedure in the absence of explicit rules of termination (Art. 56, VCLT) ${ }^{843}$. Whilst seeking the application of the specific provisions of BITs constitute a right of any of the Contracting parties, resorting to the rule based on the premise that the treaty lacks a termination provision, implies the reliance on an exception to general customary law that in principle, prohibits the withdrawal or unilateral termination of treaties. In the first case, the exercise of such a right is roughly based on termination periods and the extension of

${ }^{842}$ The ruling at issue clarifies that the sole notification of the treaty termination would bring the BIT to an end, without prejudice of the "undeniable incompatibility" of the dispute settlement provisions with the Constitution:

"Es decir, bastaría con la simple notificación de terminación por parte del Estado ecuatoriano, para que termine el compromiso asumido en el Acuerdo en mención; evidentemente, los compromisos e inversiones adquiridas antes de la fecha de terminación quedarían en vigor durante un período de diez años. Sin embargo, del análisis efectuado, se advierte que más allá de la legítima voluntad del Estado ecuatoriano de denunciar el compromiso internacional adquirido con el Reino de España, que por si sería suficiente para tal efecto por así determinarlo el artículo XII, se puede advertir adicionalmente que del texto del Acuerdo se deriva una innegable incompatibilidad con la Constitución de la República, que regula tanto los términos en el que se establecerían las relaciones internacionales, al igual que el modelo del Estado y los principios dentro de los cuales debe operar este, razón jurídica que justifica dicha necesidad."

See, Dictamen No. 010-13-DTI-CC, Caso No. 0010-11-TI, “Acuerdo para la Promoción y Protección Recíproca de Inversiones entre el Reino de España y la República del Ecuador”, Registro Oficial Suplemento 956 de 17 de mayo de 2013.

${ }^{843}$ The ruling concerning Ecuador-China BIT although making reference to the specific treaty provision to terminate the treaty resorted to Art. 56 of the VCLT that contemplates the termination of a treaty, in absence of a termination provision:

"Habrá que tener presente que la denuncia es uno de los modos de terminación de los tratados, y la naturaleza jurídica que garantiza la extinción de éstos, al contrario de los casos de nulidad, no se encuentra condicionada por ningún vicio del consentimiento o por resultar incompatible con las normas esenciales del Derecho Internacional, sino por el efecto de situaciones sobrevenidas en el marco de un tratado que hasta ese momento ha mantenido su validez, o por decisión de las partes, posterior a su entrada en vigor. Claro está que el propio Convenio de Viena sobre el Derecho de los Tratados reconoce a la denuncia (artículo 56) entre las circunstancias contempladas como causas de terminación, siempre que conste la intención de las partes en autorizarla o se deduzca de la naturaleza del tratado (2).

See, Dictamen No. 027-10-DTI-CC, Caso No. 0004-10-TI, “Convenio entre el Gobierno de la República del Ecuador y el Gobierno de la República Popular de China para el Fomento y Protección Recíproca de Invesrsiones", Registro Oficial Suplemento 258 de 17 de agosto de 2 
protected investments, whereas in the second, the incumbent party has to justify the grounds for terminating the treaty. In view of the wording of Article 56 (1) of VCLT, Aust explains that a party is forbidden from denouncing or withdrawing a treaty unless:

(a) it is established that the parties intended to admit the possibility of denunciation or withdrawal; or

(b) a right of denunciation or withdrawal may be implied by the nature of the treaty. ${ }^{844}$

In this line, the same scholar illustrates the substantial and procedural constraints imposed on the party wishing to terminate the treaty under this frame:

(...) It must also give the other party or parties at least twelve months' notice of its intention (Article 56 (2)). Since the grounds for justifying withdrawal are expressed as an exception, the onus of establishing that the exception applies lies with the party wishing to withdraw.

Since it is now very common to include provisions on withdrawal, when a treaty is silent about the matter, it may be that much harder for a party to establish the grounds for the exception $(\ldots) .{ }^{845}$

Since this not the case of the BITs, it is difficult to assimilate the logic of resorting to such a provision. As noted below, the Court's interpretation regarding the clause setting forth the rules of separability of treaty provisions (Art. 44, VCLT) is also problematic.

\subsubsection{Termination of Treaties and Severance of the Relevant Provisions}

Incongruously, the Constitutional Court has endorsed both the separability and non-separability of treaty provisions even though the termination had been grounded on specific BIT provisions, VCLT denunciation provisions, or even when it had omitted to mention any of the former mechanisms of termination. Given that BITs embody specific termination clauses, certain recommendations of the Court given to the legislative branch not to denounce the whole treaty but only the provisions in contradiction with the Constitution seems to be impractical:

If the treaty does provide for such a right of denunciation, withdrawal or suspension two further situations must be distinguished: If, despite such a right,

\footnotetext{
${ }^{844}$ Aust (Anthony), Modern Treaty Law and Practice, Third Edition, Cambridge University Press, 2013, $256 \mathrm{p}$.

${ }^{845}$ Aust (Anthony), Modern Treaty Law and Practice, Third Edition, Cambridge University Press, 2013, $256 \mathrm{p}$.
} 
the treaty does not specify the separability of provisions, the presumption is that the right may be exercised only with respect to the whole treaty $(. . .)^{846}$

Additionally, the BITs at hand set forth the termination of the whole treaty disregarding logically, the separability of the treaty provisions, unless the parties later agree to do so:

(...) Further it seems to be a defensible position to maintain that the principle of severance of the clauses of a treaty constitutes a general principle of law in the sense of Article 38 (1) (c) of the ICJ Statute, where these clauses are separable from the rest of the treaty from the point of view of their execution, and where it is established that their acceptance did not constitute the essential basis for the consent of the other party to be bound by the whole treaty. ${ }^{847}$

In short, severance of the provisions of treaties operates as an exception to the principle of indivisibility. As summarized by Sir Humphrey Waldock: "the primary rule that must be stated was the integrity of treaties, for it was not to be easily assumed that consent was divisible" 848 . Taking into consideration that one of the main if not the most important feature of the BITs consists of binding arbitration it is not feasible to dispute that the derogation of this clause would not affect an essential element of the other party's consent. In the absence of express statements in the BITs permitting the severance of the provisions, the only possible though remote way for perfecting such an alternative would be resorting to the principle of consensualism, whereby the parties may later agree to preserve several provisions. As to the principle of obligatory severance, it has to be recalled that its obligatory character can only take place provided that the conditions of Article 44, paragraph 3, are cumulatively met:

3. If the ground (for invalidity, termination, withdrawal or suspension that are recognized by the Vienna Convention) relates solely to particular clauses, it may be invoked only with respect to those clauses where:

(a) The said clauses are separable from the remainder of the treaty with regard to their application;

\footnotetext{
846 (Mark E.) Villiger, Commentary on the 1969 Vienna Convention on the Law of Treaties, Martninus Nijhoff Publishers, Leiden-Boston, 2009, 564-565 pp.

${ }^{847}$ Falkowska (Martina), Bedjaoui (Mohammed) and Leidgens (Tamara), “Article 44 Convention of 1969 Separability of treaty provisions " in The Vienna Convention on the Law of Treaties: A Commnentary, Volume II, Edited by Corten (Olivier) and Klein (Pierre), Oxford University Press, 2011, 1053 p.

${ }^{848}$ Falkowska (Martina), Bedjaoui (Mohammed) and Leidgens (Tamara), “Article 44 Convention of 1969 Separability of treaty provisions " in The Vienna Convention on the Law of Treaties: A Commentary, Volume II, Edited by Corten (Olivier) and Klein (Pierre), Oxford University Press, 2011, 1054 p.
} 
(b) It appears from the treaty or it is otherwise established that acceptance of those clauses was not a an essential basis of the consent of the other party or parties to be bound by the treaty as a whole; and

(c) Continued performance of the remainder of the treaty would not be unjust.

Given that the dispute settlement provisions constitute the only way provided by the BITs for enforcing the substantive clauses, it is implausible that this particular clause could meet none of the conditions set forth above. On this premise, the purported suppression of the dispute settlement clauses could compromise the whole operation of the treaty, thereby removing its "raison d'être". In the cases where the Constitutional Court did not consider it necessary to denounce the whole BIT, it reminded the Ecuadorian legislative branch of the importance of establishing mechanisms for settling disputes, "which must be subject to mutual agreement with the contracting party and respect the constitutional provisions". ${ }^{849}$ Such a reminder is eloquent because it both addresses the branch not entitled to modulating the scope of international treaties and it corroborates the adjudicators' comfort with the substantive standards of protection, as opposed to arbitration as the binding mechanism of dispute settlement. In any case, the mechanisms for the termination of treaties demarcated by the Court, either when it has recommended the whole or the partial denunciation of the BITs would not be in conformity with the relevant practice and rules of Public International Law. Pursuant to the specific provisions of the BITs, the denunciation affects the totality of their provisions, meaning that a purported severance of the same may be not resorted to. It has to be recalled that since the President activated the procedure of constitutional review of the BITs with the clear purpose of denouncing them, the Court did not consider other alternatives to bring the corresponding provisions into conformity with the Constitution, such as triggering renegotiation procedures or amending the constitutional provisions allegedly in contradiction with the treaties. In this line, the paragraph of the Act establishing the effects of declaring unconstitutional a ratified treaty sheds little light concerning the room of manoeuvre deferred to the corresponding State's branches in order to determine which alternative to choose for harmonizing the treaty provisions with the Constitution:

When a ratified treaty is declared unconstitutional, the State shall denounce the treaty before the relevant body, the order to trigger the renegotiation of the treaty, or activate the constitutional amend, reform or change. ${ }^{850}$

\footnotetext{
849 See, Fach Gómez (Katia), “Ecuador's Attainment of the Sumak Kawsay and the Role Assigned to International Arbitration”, Yearbook on International Investment Law and Policy, 2010-2011.

${ }^{850}$ Organic Act on Jurisdictional Guarantees and Constitutional Control:
} 
Although this provision has defective wording, it can be assumed that the duty of the Constitutional Court finishes when it undertakes the constitutional review of the treaty, resting the decision of triggering any of the alternatives statutorily provided for in the realm of others State's branches. This assumption is supported by the paragraph's reference to "State", which encompasses the different branches that may be involved in the different mechanisms to conciliate the Constitution with the treaty set forth above. On the premise that the mechanisms different to the denunciation should be initiated, the Constitutional Court still has the competence to rule about the procedures to be followed and the scope of the provisions, either constitutional or international, aimed to be put into motion in order to guarantee the Constitutional supremacy. In the light of the arguments raised above, denouncing partially the BITs would not be feasible under Public International Law. Therefore within the relevant BITs, the President would have to decide whether it is convenient underpinning the renegotiation of the provisions found in contradiction with the Constitution. Should this be the case, the procedure of constitutional review with respect to the terms agreed upon as a result of a hypothetical renegotiation would be completely different to that analyzed before. Additionally and on the premise, that it could be possible to successfully renegotiate the dispute settlement provisions (i.e, mediation, State to State arbitration), leaving unaffected the standards of protection of the BITs partially found in contradiction with the Constitution, there is the risk that investors covered by treaties concluded in the future and entitled to a more restricted scope of protection, might invoke the Most Favoured Nation clause. Hence, from a perspective of convenience and coherence, the effects of the Constitutional Court's assessment could also harm a consistent legal standpoint of the State with respect to the further application of investment protection rules. In the light of the aforementioned, the internal procedure for the denunciation of treaties initiated by the President would have to conclude with the notification of the termination of the whole BIT.

\footnotetext{
“Art. 112.- Efectos de las sentencias y dictámenes.- Las sentencias y dictámenes correspondientes tendrán los mismos efectos de las de constitucionalidad abstracta en general, y en particular, los siguientes:

4. Cuando se declara la inconstitucionalidad de un tratado ya ratificado, el Estado deberá denunciar el tratado ante el órgano correspondiente, la orden de promover la renegociación del tratado, o promover la enmienda, reforma o cambio constitucional."
} 


\subsubsection{The Doctrine Rebus Sic Stantibus as Ground for Terminating Treaties}

As noted, terminating a treaty in conformity with its own provisions constitutes an expression of the principle pacta sunt servanda. In consequence, the application of a particular provision set forth in a specific regime for the termination of treaties would pre-empt the deployment of General International Law. In the opinion of Binder, this position strengthens legal certainty since the exit of a treaty is not linked "to compliance with necessarily vague and general substantive criteria" ${ }^{251}$. Following this line of reasoning, invoking a fundamental change of circumstances would imply the exclusion of other grounds of termination of a treaty by law:

It is important to draw a distinction between cases of fundamental changes of circumstances as such and other instances of termination of treaties by operation of law which may also imply a change, but which are nonetheless independently founded. This differentiation has important practical consequences due to the fact that the rebus sic stantibus principle cannot be invoked where the termination or suspension by operation of law, even if certain circumstances are involved. ${ }^{852}$

Pursuant to this standing, Article 70 of VCLT sets forth the consequences of termination of a treaty, which in line with its Article 42 defers primacy to the effects foreseen by the parties as stated in the particular treaty:

As in the case of many other provisions in the Convention, rules relating to the consequences of the termination are supplementary; an application of the lex specialis principle is evident here. It is common for treaties to include denunciation clauses, notably for setting out time limits for giving notification. Certain treaties furthermore foresee the extension of certain effects of the treaty beyond the date at which it ends for the denouncing party. ${ }^{853}$

This precept has been upheld by the International Court of Justice:

\footnotetext{
851 See, Binder (Christina), "Does the Difference Make a Difference? A Comparison between the Mechanisms of the Law of Treaties and of State Responsibility of Means to Derogate from Treaty Obligations in Cases of Subsequent? in State Responsibility and the Law of Treaties, Edited by Marcel Szabó, International Publishing, 2010.

${ }^{852}$ Shaw (Malcolm N.) and Fournet (Caroline), "1969 Vienna Convention, Article 62, Fundamental change of circumstances" in The Vienna Convention on the Law of Treaties: A Commentary, Edited by Corten (Olivier) and Klein (Pierre), Oxford University Press Inc., New York, 2011, 1413 p.

${ }^{853}$ Ascensio (Hervé), "1969 Vienna Convention, Article 70, Consequences of the termination of a treaty" in The Vienna Convention on the Law of Treaties: A Commentary, Edited by (Olivier) Corten and (Pierre) Klein, Oxford University Press Inc., New York, 2011, 1589 p.
} 
The 1977 Treaty [between Czechoslovakia and Hungary] does not contain any provision regarding its termination...Consequentially, the parties not having agreed otherwise, the Treaty could be terminated only on the limited grounds enumerated in the Vienna Convention. ${ }^{854}$

In sum, this logical proposition is aligned with the procedure set forth in Article 56 of VCLT, confined to treaties lacking a provision regarding termination, denunciation or withdrawal. As Ciampi illustrates "the exercise of a power of denunciation is itself an independent cause of termination" and therefore, the Constitutional Court's construction consisting of intermingling different causes of derogation like the supervening impossibility of performance and fundamental change of circumstances in order to justify such attribution would not be in conformity with such an assertion. ${ }^{855}$

The mutually exclusive nature of the grounds to terminate treaties may become unfeasible at the international level to invoke jointly the right to terminate a treaty and the claim of fundamental change of circumstances. Logically, this difference also touches upon the procedural stage, whereby resorting either to the provision specified in the particular treaty or to the exhaustive clauses provided in the VCLT, entail different types of restrictions to the State's conduct, which may be substantially and formally conditioned. In the former case, the State may be released from explaining the reasons of disengagement and in the latter, it should be subject to different timeframes for providing notice. More important, resorting to the particular termination provision would involve the application and interpretation of the treaty itself, whereas claiming a fundamental change of circumstances would necessarily involve assessing the factual circumstances related to the treaty and its application, as well as the intention of the parties, which constitutes an element external to the treaty. ${ }^{856}$ As Shaw and Fournet explain, whilst the

\footnotetext{
${ }^{854}$ Gabcikovo-Nagymoros Project, International Court of Justice, 27 September 1997, ICJ Reports 1997, pp 62-3, para.100 in 1018.

855 Ciampi (Annalisa), "Invalidity and Termination of Treaties and Rules of Procedure" in The Law of Treaties beyond the Vienna Convention, Edited by (Enzo) Cannizaro, Oxford University Press, 2011, 363 p.

${ }^{856}$ Chapaux transcribes the commentary to the draft Article in which it is confirmed that terminating a treaty is normally a matter of its own application:
}

The majority of modern treaties contain clauses fixing their duration or the date of their termination or a condition or event which is to bring about their termination, or providing for a right to denounce or withdraw from the treaty. In these cases the termination of the treaty is brought about by the provisions of the treaty itself, and how and when this is to happen is essentially a question of interpreting and applying the treaty. 
requirement of objectivity refers to external elements independent of the will of the parties, the intention of the parties, although it is a subjective component, has been considered an essential element in the application of the theory ${ }^{857}$ Controversially, Helfer argues that the extreme and narrow form rebus sic stantibus has been codified has meant that it has never been successfully invoked in a court case, falling as result, into desuetude ${ }^{858}$ :

Commentators have largely ignored the doctrine's decline or have attributed it to a renewed faith in the competing legal norm that treaty commitments must be obeyed. However, the option to exit from a treaty provides a more plausible explanation for why the rebus sic stantibus doctrine has all but evaporated from the discourse of compliance with international commitments. Because states may unilaterally denounce or withdraw from most treaties without justifying their conduct to other treaty parties, they need not rely upon the narrower and more controversial doctrine. Exit provides a far simpler, and legally incontestable, alternative for states seeking to remove themselves from treaties whose circumstances have altered. ${ }^{859}$

Again, the incipient competence of the Constitutional Court to confront the constitutional framework with treaty obligations might have prejudiced the technical quality of its rulings. When it interpreted the doctrine rebus sic stantibus as the main ground of derogation of the principle pacta sunt servanda, it disregarded the fact that the application of the latter would lawfully bring a treaty into an end, due to the invocation of the specific termination provision. Moreover, affirming that the said doctrine constitutes the predominant basis for States to lean on for disengaging from treaty

Commentary on Art. 51 (future Art. 54), supra n 1 in Chapaux (Vincent), "1969 Vienna Convention Article 54 Termination of or withdrawal from a treaty under its provisions or by consent of the parties" in The Vienna Convention on the Law of Treaties: A Commentary, Edited by (Olivier) Corten and (Pierre) Klein, Oxford University Press Inc., New York, 2011, 1243 p.

857 As noted in the Third Restatement of the Foreign Relations Law of the US:

[r] ebus sic stantibus is not a principle of interpretation, as an implied clause (clausula) in every agreement, but rather a substantive principle permitting escape from obligations without regard to intentions of the Parties. The intention and understandings of the Parties are nonetheless critical in determining the circumstances that were deemed basic to the original agreement and which changes in circumstances bring the doctrine into play.

See, Shaw (Malcolm N.) and Fournet (Caroline), “1969 Vienna Convention, Article 62, Fundamental change of circumstances" in The Vienna Convention on the Law of Treaties: A Commentary, Edited by Corten (Olivier) and Klein (Pierre), Oxford University Press Inc., New York, 2011, 1415 p.

${ }^{858}$ See, Helfer (Laurence R.), “Exiting Treaties”, Virginia Law Review, [Vol. 91: 1579], 2005, 1643 p.

${ }^{859}$ See, Helfer (Laurence R.), “Exiting Treaties”, Virginia Law Review, [Vol. 91: 1579], 2005, 1644 p. 
obligations goes against the empirical evidence. In addition, asserting that the International Court of Justice case law "has accepted the possibility of terminating the treaty when there is a fundamental change of circumstances, that turns the fulfillment of the obligations or varies radically their scope" in "at least two cases" is wrong both factually and substantially ${ }^{860}$. In the first case, Helfer points out that: "there has never been a successful assertion of [the doctrine] in a court case and . . no clear example of its successful use in diplomatic exchanges" 861 . In the second case, it has to be recalled that although the International Court of Justice has not applied the doctrine, it has acknowledged its existence by stating that the changes rather than "onerous" must be vital, being capable of endangering "the existence or vital development of one of the parties" $" 862$.

In view of all this, Ecuador's intention of terminating the treaties rests in the realm of primary obligations and as such it would be confined to the Law of Treaties. In the same line and pursuant to the Constitutional Court's interpretation, should the President decide to terminate the treaty by invoking the principle of fundamental change of circumstances, this would apparently entail resorting to the VCLT instead of to the rules provided for by the BIT, thereby requesting the application of lex generali in order to set aside lex specialis. Assuming that International Investment Law has been developed as a self-

860 The academic sources resorted to by the justices to ground their rulings reflect the scarcity of domestic scholarship concerning specialized international law issues:

"El principio, pacta sunt servanda, de la intangibilidad de los tratados, deja de ser aplicable y surge el principio rebus sic stantibus o de revisión de los tratados, si el cambio de las circunstancias es de tal intensidad o naturaleza debe terminar el tratado.

Sustentándose en este principio, los Estados, en muchas ocasiones, se han visto obligados a desligarse de las obligaciones contractuales contraídas en los tratados. Lo que sí deja en firme la Convención es que no podrá alegarse variación de las circunstancias cuando el tratado establece fronteras, o si del cambio fundamental resulta una violación del tratado.

La jurisprudencia de la Corte Internacional de Justicia, al menos en dos de sus fallos, acepta la posibilidad de terminación del tratado cuando existe un cambio fundamental en las circunstancias, que vuelve más oneroso el cumplimiento de las obligaciones o varía radicalmente el alcance de las mismas (10)."

See, Endara Moncayo, (Jorge), Derecho Internacional Público, T. I. Editorial Universitaria, Quito, 2002, Pág. 126 in Dictamen No.020-10-DTI-CC, Caso No. 008-10-TI, Registro Oficial Suplemento, 24 de junio de 2010 (BIT between Ecuador and The United Kingdom).

${ }^{861}$ Helfer (Laurence R.), “Exiting Treaties”, Virginia Law Review, [Vol. 91: 1579], 2005, 1643 p.

${ }^{862}$ See, International Court of Justice, Fisheries Jurisdiction Case (United Kingdom v. Iceland), Jurisdiction of the Court, Judgment, February $2^{\text {nd }}, 1973$. 
contained regime, it is clear that the rules for the termination of treaties as well as agreeing upon a period of protection after their termination, seek to pre-empt the application of the specific rules set forth in VCLT. Since Ecuador was apparently willing to bring the BITs to an immediate end, the underlying controversy could not be categorized as State-toState dispute as prescribed in the same treaties, considering that the challenge does pertain either to the application or to the interpretation of these treaties.

Although the reasons elicited by the Constitutional Court do not seem to be appealing to discuss prima facie a fundamental change of circumstances at the international level, it is clear that the effects derived from the application of the international investment regime in Ecuador are indeed burdensome. The total sum of claims approximately amounting to 18 billion dollars is equivalent to $62 \%$ of the national budget of 2016 . Before July 2016, the State paid \$1,300 million as the losing party in investment arbitrations, as well as incurring legal fees and tribunal expenses for around \$200 million. These exorbitant numbers contrast with the low Foreign Direct Investment landing in Ecuador between 2000 and 2013, which represented 1.1\% of GDP. ${ }^{863}$ This data read in conformity with the representations of the Parties at the time the BITs were approved and the practical one-sided protection that the economic circumstances in force have developed would show an imbalanced burden on the side of Ecuador that could seriously threaten the fulfillment of the State's duties like sustaining public investment. Acknowledging that multiple economic interpretations may contradict the aforementioned findings, it is clear that the solution for bringing unilaterally the BITs to an immediate ending must be found in General International law. Taking into account the systemic nature of international law, General International law should complement the grounds for the termination of treaties, which are not exhaustively listed in the BITs. In this way, the absence of the grounds of fundamental change of circumstances in the BITs would not mean that the Parties are deprived from invoking such a principle. In any case, the dispute stems from a claim of such a nature which would relate to the permanence of the treaty relationship and not to its performance. Therefore the Law of the Treaties and not the Law of State responsibility would be applicable. However, this integrative notion asking for the complementary intervention of General International Law would be in

${ }^{863}$ See, Mancero (Piedad), "Results of an audit to treaties mutual investment protection and arbitration system on investment" in Investment chapters in Trade Agreements, Submitted at the World Social Forum by Invitation of Friedrich-Ebert-Stiftung, Berlin, September 13, 2016.

See, http://www.cadtm.org/Investment-chapters-in-Trade 
contradiction with the straightforward application of lex specialis (principle also embodied in the VCLT). In this regard it would be challenging to ascertain whether the exclusion of the grounds for termination of treaties as provided for by VCLT, would be interpreted as a specific choice of the Parties or as a gap that may be fulfilled by General International Law. Considering that the VCLT comprises general principles of law, thereby providing minimum regulation "in the world of regime-building and regimeadministration" 864 , it could be affirmed that their provisions could collide with, rather than integrate with the special regime. Since it is out of the question that it is the right of the parties to terminate BITs at any time without providing the reasons to do so, it should elucidate to what extent the principle of fundamental change of circumstances could neutralize the effects agreed upon by the parties after the decision to terminate the treaty has been notified. Considering that this principle has been recognized as customary international law, it may be affirmed that every treaty contains a clausula rebus sic stantibus. Taking due regard of Ecuador's stance, it could be assumed to be its unwillingness to resort to the specific provisions of treaty termination. Hence, it will be rather inclined to circumvent the specific BIT provisions, by unilaterally terminating them pursuant to the VCLT, in order to be released from any further obligation of performance (Art. 70 VCLT). Undoubtedly, the limited application of such a doctrine posits challenges that seem to be insurmountable, but it is also true that the same system has been proven to be ineffective in airing State to State controversies that may contribute to the better understanding of the scope of the agreements, as it can be seen in the issue that unsuccessfully Ecuador attempted to bring in the context of the US-Ecuador BIT. ${ }^{865}$

\footnotetext{
${ }^{864}$ See, International Law Commission, "Fragmentation on International Law: Difficulties arising from the Diversification and Expansion of International Law", Report of the Study Group of the International Law Commission, Finalized by Koskenniemi (Martti), Fifty Eight Session, Geneva, 1 May-9 June and 3 July11 August 2006, $100-101 \mathrm{pp}$.

${ }^{865}$ In the ILC report addressing the issue of the fragmentation of International Law, it has been stated, that "every special regime links up with general international la in three ways": 1) Providing for the conditions of validity of a special regime; 2) Providing for the conditions not foreseen by a special regime; 3) Providing for the consequences of the failure of the special regime, like in the cases "when a special dispute settlement ceases to function".

See, International Law Commission, "Fragmentation on International Law: Difficulties arising from the Diversification and Expansion of International Law", Report of the Study Group of the International Law Commission, Finalized by Koskenniemi (Martti), Fifty Eight Session, Geneva, 1 May-9 June and 3 July11 August 2006, $101 \mathrm{p}$.
} 
By the application of the VCLT, the unilateral termination would become effective immediately, rendering the periods for termination as well as the survival clauses also inapplicable. Should a State decide to unilaterally terminate the treaty in the fashion furnished by Article 62 of VCLT provoking the reaction of the State counterparties, it will face the case-by case- challenge of demonstrating factually that its consent was built upon crucial factors that have been radically altered by the tainted deployment of the regime. These elements could include but not be limited to the absence of greater flows of FDI, the possibility to control and in consequence to carve out entities, sectors and actions from the disputes expansively interpreted by the arbitrators thereby modifying $d e$ facto the scope of the provisions and finally, the emergence of further international obligations that, in the way in which BITs are being applied, could expose the State to further breaches of International Law. Thus, the analysis should be oriented to discern whether this kind of circumstances are objective and if so to what extent they shaped the common intention of the Parties at the time of the conclusion of the treaty, to the point that their radical transformation amounted to destroying the consensual basis of the obligations agreed upon. ${ }^{866}$ In this context, solely claiming a constitutional change would not constitute a fundamental change of circumstances.

In the light of the aforementioned and bearing in mind the difficulties of resorting to the doctrine at issue, should a State be willing to advance a claim of fundamental change of circumstances seeking as effect the immediate termination and suspension of the treaty, it would have to invoke directly the relevant provisions of VCLT, setting aside those prescribed in the BITs. However, it is relevant to note that the State party contesting such a termination could claim the material breach of the treaty due to the circumvention of the agreed procedure of termination and the application of the survival clause, which could weaken Ecuador's stance when invoking Article 62 of VCLT. Finally, it remains to be seen to what extent terminating unilaterally a BIT would foreclose an investment arbitration tribunal to rule negatively over its own jurisdiction, in the light of the derivative rights of the investors.

\footnotetext{
${ }^{866}$ Concerning the fundamental character of the change, Shaw and Fournet explain:

The consequences of the change must thus be to destroy or modify totally the basis of the obligation based on the factual and decisive situation in existence at the time the treaty was concluded as well as to make the actual or future realization of the objectives and goals of the treaty of the obligation impossible.
}

Shaw (Malcolm N.) and Fournet (Caroline), "1969 Vienna Convention, Article 62, Fundamental change of circumstances" in The Vienna Convention on the Law of Treaties: A Commentary, Edited by Corten (Olivier) and Klein (Pierre), Oxford University Press Inc., New York, 2011, 1426 p. 


\subsubsection{Application of Survival Clauses}

As noted above, one of the main problems that a State willing to terminate IIAs faces is dealing with the application of the survival clauses for a period, which in several cases exceeds the duration originally agreed upon by the Contracting Parties. In this sense, the predominant concern of the States and investors involved consists in determining to what extent the rights prescribed in the treaties will be enforced. In this sense, Gaillard firmly upholds the effect that the survival clauses preserve the state's consent to arbitrate, being applicable the whole provisions of the BIT denounced for such an extended period. And this effect would take place even when the State had for instance, denounced the ICSID Convention. This author asserts that in those cases where ICSID remains as the sole international dispute, the investor may also successfully resort to the dispute resolution options set forth in a third party treaty (most favoured nation clause) ${ }^{867}$ In this context, he underlines the importance of the wording of the arbitration clause in each international investment agreement, which should not leave any doubt, that it actually constitutes an effective agreement to consent, as opposed to an unqualified consent where a further agreement would be required. ${ }^{868}$ Given that the survival clauses would not bring into question the existence of the primary obligations as prescribed in the BITs, a State willing to challenge the application of such provisions after terminating the treaty in accordance to its own rules, could resort to the relevant provisions in the Articles of State Responsibility in order to claim the preclusion of wrongfulness in cases of nonperformance. In this context, it should be also elucidated whether the investor's acceptance of the State's consent to arbitrate after it had notified the treaty's termination, affords it full access to arbitration and whether the appraisal of the standards of protection may vary after such a period.

\footnotetext{
${ }^{867}$ See, Gaillard (Emmanuel), "The Denunciation of the ICSID Convention", International Arbitration Law-New York Law Journal, June 26, 2007.

${ }^{868}$ Gaillard (Emmanuel), "The Denunciation of the ICSID Convention", International Arbitration LawNew York Law Journal, June 26, 2007.
} 


\subsubsection{The Interplay of State and Investors Interests in the Dispute Settlement Arena}

When the Constitutional Court impeached the BITs, it devoted special attention to the dispute settlement provisions, censuring the investors' direct access to jurisdiction (individual procedural rights). It is not the access to arbitration, but the absence of procedural constraints to resort to its protection in view of a unilateral irrevocable consent provided in the BITs, which distinguishes this particular dispute settlement mechanism ("arbitration without privity") 869 . As De Brabandere recalls, the procedures granting nonState actors direct access to international adjudication to challenge a State's actions is not limited to human rights and investment law. By reference to the UN Compensation Commission, the Iran-US Claims Tribunal and the Seaber Chamber of the ITLOS, the author observes that:

[n]on-state entities have been given the right to bring claims directly against a state for claims related to a specifically delineated dispute or a factual situation. ${ }^{870}$

It is noteworthy that the bitterly criticized direct access to arbitration does not necessarily imply the grant of direct rights to private parties as De Brabandere explains:

Generally, in international law the grant of certain individual rights does not automatically entail the capacity to bring a claim for a violation of that right before an international tribunal or court, traditionally reserved to the state of the nationality of the individual through its right to exercise diplomatic protection and after the exhaustion by the foreign investor of the available local remedies. The direct access of foreign investors to arbitration in international investment disputes is simply put, the mere removal of these procedural requirements to enhance the effectiveness of remedies. ${ }^{871}$

As explained by the same author, the obligations set forth in the treaty create inter-state obligations regardless of whether they may also embody rights to be exercised by the investors. ${ }^{872}$ It is important to refer to the "direct rights" and the "derivate rights" theories, whereby the former holds the right to the foreign investor as independent of the right of the state to invoke diplomatic protection and the latter stands for the investor's right to

\footnotetext{
${ }^{869}$ Paullsson (Jan), “Arbitration Without Privity”, ICSID Review (1995) 10 (2): 232-257, 232 p.

${ }^{870}$ De Brabandere (Eric), Investment Treaty Arbitration as Public International Law, Cambridge University Press, United Kingdom, 2014, 18 p.

${ }^{871}$ De Brabandere (Eric), Investment Treaty Arbitration as Public International Law, Cambridge University Press, United Kingdom, 2014, 19 p.

${ }^{872}$ De Brabandere (Eric), Investment Treaty Arbitration as Public International Law, Cambridge University Press, United Kingdom, 2014, 63 p.
} 
seek the enforcement of interstate obligations on behalf of the state. These theories do not diminish the requirement that the content and extent of the obligations enshrined in the treaties are governed by the Law of Treaties, in view of the nature of such obligations regarded as primary. As noticed above, the application of the Articles of State responsibility requires as a pre-condition the breach of a primary obligation. ${ }^{873}$

Deepening the analysis about the structural design of IIAs' dispute settlement provisions, Roberts explains that this kind of treaties "concern horizontal relations between states as equals and vertical relations between those states and investors as nonstate actors $" 874$ :

In terms of what existing treaty parties have done, the standard modern investment treaties contain two dispute resolution clauses: one permits investor-state arbitration over investment disputes; and the other permits state-to-state arbitration over disputes about the interpretation and application of the treaty. Most of these treaties contain no mechanism for prioritizing between these forms of dispute resolution, such as a hierarchical ordering that privileges investor to state claims or sequential ordering that privileges the first claim filed. Some treaty regimes, such as the ICSID Convention, impose limits on the ability of home states to engage in diplomatic protection once an investor has consented to investor-state arbitration. ${ }^{875}$

Interestingly, Roberts categorizes the disputes that may revolve around the mentioned horizontal relations (State to State): 1) diplomatic protection claims; 2) pure interpretive disputes, and; 3) requests of declaratory relief. ${ }^{876}$ Overall, the BITs, the case law and the state to the art literature shed little light as to how the two mechanisms of dispute

${ }^{873}$ In this line, Binder explains:

"This is most lucidly observed by Reuter, who argues that the theory of treaties and the theory of responsibility are separated by a basic difference: the rules of the law of treaties are primary, both chronologically and logically, whereas the rules of responsibility are secondary, applying only once a primary rule is breached."

Binder (Christina), "Does the Difference Make a Difference? A Comparison between the Mechanisms of the Law of Treaties and of State Responsibility of Means to Derogate from Treaty Obligations in Cases of Subsequent? in State Responsibility and the Law of Treaties, Edited by Marcel Szabó, International Publishing, 2010, 16 p.

874 Roberts (Anthea), "Triangular treaties: the nature and limits to investment treaty rights", Harvard International Law Journal, 56 (2), ISSN 0017-8063, 374 p.

875 Roberts (Anthea), “Triangular treaties: the nature and limits to investment treaty rights", Harvard International Law Journal, 56 (2), ISSN 0017-8063, 392 p.

${ }^{876}$ Roberts (Anthea), "State- to- State Investment Treaty Arbitration: A Hybrid Theory of Interdependent Rights and Share Interpretive Authority”, Volume 55, Number 1, Winter 2014, 7 p. 
settlement should interact. ${ }^{877}$ Roberts has tackled this insufficiency and has pointed out the main legal challenges that could arise with relation to unilateral actions by home states and consensual decisions agreed upon by the treaty parties (i.e, joint interpretations of treaty provisions). This analysis is relevant in the Ecuadorian context, taking into consideration that the decisions followed by the constitutional rulings analyzed, will seek to minimize the investors' influence, by affording legitimacy only to decisions taken at the State to State level. As to the main questions underlying the potential emerging controversies within this scope, Roberts stresses the significant challenge to elucidate: a) whether a home state can bring and settle a class action on behalf of its investors against the host state without the knowledge or consent of its investors; b) whether the treaty parties may agree to jointly terminate or amend an investment treaty with immediate effect rendering inapplicable the survival clause; 3) whether the host State may invoke as defense of a treaty breach within an investor-State arbitration that his conduct derived from a lawful counter-measure against a previous violation by the investor's home State. ${ }^{878}$

Highlighting the truism that the States are the masters of the treaties, Roberts reconceptualizes investment treaties as triangular treaties, whereby the same being "agreements between sovereign states, create enforceable rights for investors as nonsovereign, third party beneficiaries " ${ }^{879}$ :

The balance struck between protection and sovereignty may differ depending on whether the relationship analysed is between the investor and the host state, the home state, or the treaty parties acting collectively. The purpose of depolicitization is primarily about protecting home states and secondarily about protecting host states. Thus, the introduction of investor-state arbitration, without more, enables investors to bring claims or immunize investors' claims from the underlying treaty-party relationship. ${ }^{880}$

On this assumption, the depolicitization of investment disputes, apparently favouring home states, comes with a cost: the immunization of investor's claims. Such a technical

\footnotetext{
877 See, Roberts (Anthea), "Triangular treaties: the nature and limits to investment treaty rights", Harvard International Law Journal, 56 (2), ISSN 0017-8063, 355 p.

878 See Roberts (Anthea), "Triangular treaties: the nature and limits to investment treaty rights", Harvard International Law Journal, 56 (2), ISSN 0017-8063, 355 p.

${ }^{879}$ See, Roberts (Anthea), "Triangular treaties: the nature and limits to investment treaty rights", Harvard International Law Journal, 56 (2), ISSN 0017-8063, 416 p.

${ }^{880}$ See, Roberts (Anthea), "Triangular treaties: the nature and limits to investment treaty rights", Harvard International Law Journal, 56 (2), ISSN 0017-8063, 417 p.
} 
approach to the structure of the treaties would actually fall foul the Constitutional Court's interpretation that assumes these treaties put the States and investors on equal footing at the expense of the latter. Through this prism, IIAs actually would serve as tools for avoiding diplomatic protection, thereby neutralizing the possibility that State-investors disputes escalate towards State-to-State conflicts. Interestingly, this interpretation would better harmonize with the Ecuadorian constitutional provisions advocating equality among States, non-intervention, the application of the Calvo Doctrine and the legal settlement of international disputes. Within this context, the future State actions need to carefully assess the type of relationships (horizontal-vertical) they are touching upon in order to prevent exposure to diplomatic conflicts, by differentiating the legal forums it is entitled to resort to with the aim to duly minimize the effects of investors' claims (without activating diplomatic protection).

\subsubsection{The Interpretation of International Treaties by the Constitutional Court}

The over-arching effect of international law and the complex assimilation of its rules by national courts, are notable in the Ecuadorian case, as shown in the revisited Constitutional Court's practice. By invoking Article 27 of VCLT to interpret the scope of the State's international obligations, the Court corroborates the State's obligation to observe its international commitments. With respect to the horizontal relationship laid down by the treaties, the Ecuadorian Constitution infers that treaties are predominantly a source of power for the government, which is exclusively entrusted to lead international relations and to exercise the competences resulting from the application of treaties. The hierarchical rank of treaties and the monist orientation of the Ecuadorian legal framework require that such obligations bind the whole State, namely, the government, the parliament and courts within the horizontal level and the local governments at the vertical level. ${ }^{881}$ Notably, the over-arching scope of International Investment Law means that any deed or omission attributable to any organ of the State connected to a right or interest of an investor might bind the State internationally. The cornerstone of International Law -

881 The Ecuadorian Constitution sets forth that the hierarchal rank of treaties is supra legal, with the exception of human right treaties, which enjoy a supra-constitutional category.

See, Nollkaemper (André), "The effects of treaties in domestic law" in Research Handbook on the Law of Treaties, Edited by Tams (Christian J.), Tzanakopoulos (Antonio) and Zimmermann (Andreas), EdwarElgar. 
"pacta sunt servanda"- relies on the obligation of the States to take all the necessary measures of internal law in order to ensure that treaties are duly fulfilled. In contrast, the Constitutional Court has interpreted such an obligation as the attribution of the State to decide for itself which method to employ to bring its internal provisions into conformity with the treaty obligations, by "updating, analyzing and harmonizing" the preconstitutional international commitments with the current domestic legal framework. ${ }^{882}$ As it is known, the Constitutional Court authorized the President to denounce the majority of the BITs precisely because their application would diminish the domestic legal framework, the system of justice, the popular sovereignty and the national interest. As a result of this ex post facto judicial review, the Constitutional Court did not limit its assessment to examine the conformity of the constitutional framework with the treaty provisions, but further elaborated the President's argument that the arbitral awards have mainly favoured the protection of investments to the detriment of allegedly lawful domestic measures. Properly, this would be an impact assessment of the international investment arbitration regime that apparently would undermine the principle of separation of powers, denoting the tension between foreign affairs and judicial review. ${ }^{883}$

882 The Constitutional Court stressed the radical change of the national legal framework, thus, being necessary to harmonize the international commitments to this new reality:

En el caso del "Convenio sobre la promoción y protección de inversión", fue suscrito contando con la voluntad soberana de los Estados firmantes en Roma, el 25 de octubre de 2001, es decir, hace doce años aproximadamente; sin embargo, la estructura jurídica ecuatoriana ha asumido nuevos retos en el ámbito jurídico, político y económico, en razón de que ha adoptado un nuevo modelo constitucional e institucional, lo que exige de manera inmediata la actualización de sus compromisos internacionales de naturaleza preconstitucional, analizarlos y armonizarlos a la luz de la realidad jurídica contemporánea y la normativa constitucional, a fin de integrar las normas jurídicas nacidas de los convenios internacionales con aquellas que forman parte del ordenamiento jurídico interno, en virtud del principio referido a que la regulación interna es competencia exclusiva de cada uno de los Estados.

See, Dictamen No. 022-13-DTI-CC, Caso No. 0022-13-DTI-CC, "Convenio entre el Gobierno de la República del Ecuador y el Gobierno de la República de Italia sobre la promoción y protección de inversión", Registro Oficial Suplemento 64 de 22 de agosto de 2013.

${ }^{883}$ In this sense, the Constitutional Court critically appraised the alleged pro-investor interpretations of the arbitral tribunals that disregard the State's legislative powers, like the attribution to impose taxes, although the BITs carve out tax measures from arbitration:

En efecto, revisado el texto del Convenio se establece que el mismo contiene cláusulas contrarias a la Constitución y consecuentemente lesivas para el interés nacional, como es el caso de la prevista en el artículo 9 del Convenio, que somete al Estado ecuatoriano al tribunal de arbitraje para la solución de controversias, en desmedro de lo estipulado en el artículo 422 de la Constitución de la República, que establece: "No se podrá celebrar tratados o instrumentos internacionales en los que el Estado ecuatoriano ceda jurisdicción soberana a instancias de arbitraje internacional, en controversias contractuales o de índole comercial, entre el Estado y personas naturales o jurídicas privadas"(2). Al someter jurisdiccionalmente al Ecuador al arbitraje 
The very straightforward standing of the Constitutional Court advocating that pursuant to the "constitutional trend, nothing is exempted from constitutional control" "884, would leave no room for instance, for the application of "the political questions doctrine", by which this court would be precluded from assessing whether the executive acted in conformity to international law. ${ }^{885}$

Understandably, the Constitutional Court did not refer to the direct effect of the treaties, because the Constitution grants such an effect exclusively to human rights treaties. In consequence, it devoted her analysis to the hierarchical standing of treaties in the light of constitutional supremacy, since the effects of such interpretations are merely domestic. It is noteworthy that the Court's power to review treaties ex post facto was not granted constitutionally but statutorily through the Organic Law of Jurisdictional

\begin{abstract}
internacional, no sería raro que se presenten experiencias como las que ha descrito el señor presidente de la República, en el sentido de que al resolver controversias entre compañías extranjeras y el Estado ecuatoriano se priorice el concepto de la "inversión", en menoscabo del ordenamiento interno, al considerar que las medidas legislativas tomadas por la República del Ecuador han sido "arbitrarias" o "discriminatorias", o a pesar de que en la mayoría de los convenios se ha respetado la soberanía tributaria de los países receptores de inversión, los tribunales arbitrales eventualmente las desconocen, al estimar que una medida tributaria es "confiscatoria", lo que evidentemente habría lesionado el interés nacional, justificándose, de esta manera, la intención de denunciar por parte de la Presidencia de la República al Convenio en mención.
\end{abstract}

See, Dictamen No. 010-13-DTI-CC, Caso No. 0010-11-TI, “Acuerdo para la Promoción y Protección Recíproca de Inversiones entre el Reino de España y la República del Ecuador", Registro Oficial Suplemento 956 de 17 de mayo de 2013.

884 Pursuant to this overarching constitutional control, the Court condemned the "creation of ad hoc tribunals for the settlement of disputes", whose arbitral awards entail "compulsory effects". This, would be in contradiction with Art. 422 and the "popular sovereignty":

Vale enfatizar que el artículo 422 de la Constitución de la República es concluyente al determinar expresamente la prohibición de que el Estado ecuatoriano ceda jurisdicción soberana a instancias de arbitraje internacional, que inclusive vulneraría el principio de supremacía constitucional respecto a que podrían generarse controversias en cuanto a la aparente aplicación de normas más favorables a las inversiones, pero en contradicción con la Constitución de la República, más aún respecto al efecto obligatorio que otorga este Acuerdo Internacional a cualquier laudo arbitral. Es preciso anotar que conforme a los criterios de la corriente constitucionalista nada está exento del control de constitucionalidad de allí que no se puede permitir la creación de tribunales ad hoc para la solución de controversias que se suscitaren del presente Acuerdo, aquello iría en contra no solo de disposición constitucional expresa, sino que sería un atentado a la soberanía popular expresada a través de la Constitución de la República y a su norma establecida en el artículo 424 constitucional.

See, Dictamen No. 029-10-DTI-CC, Caso No. 002-10-TI, "Acuerdo entre el Gobierno del Reino de Suecia y el Gobierno de la República del Ecuador para la Promoción y Protección Recíproca de Inversiones", Registro Oficial Suplemento 294 de 6 de octubre de 2010.

${ }^{885}$ See, Nollkaemper (André), "The effects of treaties in domestic law" in Research Handbook on the Law of Treaties, Edited by Tams (Christian J.), Tzanakopoulos (Antonio) and Zimmermann (Andreas), EdwarElgar, $138 \mathrm{p}$. 
Guarantees and Constitutional Control and the Organic Law of the Legislative Branch. As observed, the abstract control of the constitutionality of the treaties resulted in the declaration of unconstitutionality of their dispute settlement provisions rendering them ineffective within the national legal framework. Both the clearance to denounce the treaties and the unconstitutionality of the relevant provisions derive from the enforcement of the principle of constitutional supremacy. As explained by Nollkaemper neither the declaration of constitutional supremacy has effects on international law, nor does the claim to supremacy of international law bear legal consequences domestically. ${ }^{886}$ In this line, the reductionist method of interpretation of the Constitutional Court did not consider any of the usual techniques usually employed at the national level with the aim to moderate the effects of treaties, which according to the same author consist of but are not limited to: 1) applicability; 2) supremacy; 3) direct effect; 4) consistent interpretation; 5) non-justiciability and 6) the political question doctrine. ${ }^{887}$ This Court was categorical in upholding the supremacy of the Constitution- still domestic laws- without exploring

${ }^{886}$ Nollkaemper points out that it is not strange that States declare the supremacy of their constitutions and the applicability of international law as long as it is conformity with the national framework:

Most States have declared their constitutions to be supreme. Such States do not accept the supremacy of treaties as a formal principle, but make the effect of international law contingent on substantive conformity with fundamental values enshrined in national law. In this respect it is relevant that many States restricts the precedence of international law in the domestic legal order to international human rights treaties.

(...)In principle, the claim to supremacy of international law has no necessary legal consequences domestically. State practice shows no general acceptance of the supremacy of international law in the national legal order. What is wrong in the international law sphere may be right in the national sphere, and what is unlawful in the national legal order may be perfectly legal in international law.

See, Nollkaemper (André), "The effects of treaties in domestic law" in Research Handbook on the Law of Treaties, Edited by Tams (Christian J.), Tzanakopoulos (Antonio) and Zimmermann (Andreas), EdwarElgar, 142-144

887 The brief characteristics of each method would be the following:

1) Applicability: The domestic law automatically assimilates international law as part of domestic law (automatic incorporation).

2) Supremacy: International law prevails over national law (this precedence could be confined to human rights treaties).

3) Direct effect: The courts give direct effect to a treaty obligation.

4) Consistent interpretation: Courts attempt to achieve interpretations aligned with international law in order to secure the accomplishment of treaty obligations.

5) Non -justiciability: The application of international treaties by courts is limited giving deference to the executive.

6) Political question doctrine: Courts are precluded to assess whether the Executive has acted in conformity with International Law.

See, Nollkaemper (André), "The effects of treaties in domestic law" in Research Handbook on the Law of Treaties, Edited by Tams (Christian J.), Tzanakopoulos (Antonio) and Zimmermann (Andreas), EdwarElgar, 138 p.138- 146 pp. 
alternatives to reconcile the constitutional provisions with treaty obligations. According to Frishman and Benvenisti this position would fit with a "particularistic viewpoint", as opposed to a more cosmopolitan approach. In one hand, it is argued that this "solipsistic outlook" could be detrimental to inter-court co-ordination and co-operation, but in the other, he also contends that this position could revive the domestic democratic processes, consolidate autonomy and strengthen the government's bargaining position. ${ }^{888}$ Interestingly, the judicial resistance of the Constitutional Court came into play as a result of the impeachment of pre-constitutional treaties deemed as injurious to core public interests arguably incapable of being construed in harmony with the new constitutional framework. Regardless of the shortcomings that might be found to the Constitutional Court's assertions with respect to the scope of the rules of Public International Law and International Investment Law, it is undeniable that her position expresses a wide-spread discontent with respect to the premises under which the decision making processes and application of international obligations have been built up. In the Ecuadorian case, treaties were mostly exempted from judicial review, although the "constitutional like commitments" adopted in a context of bargaining inequality permeated the authority of national institutions and people's rights and opportunities.

\subsubsection{Judicial Interpretation and Resistance to International Law}

The Ecuadorian reality shows that the judicial and constitutional policy of deference both to the processes of decision-making and enforcement of international commitments, has been founded on the assumption that domestic politics and world politics are disconnected. This standpoint in light of the unrestrained forces of globalization is clearly outdated $^{889}$. Benvenisti illustrates that the traditional deference given to the governments'

${ }^{888}$ Frishman (Olga) and (Benvenisti) Eyal, National Courts and Interpretative Approaches to International Law: The Case Against Convergene Global Trust Working Paper 8/2014, ISSN 2309-7248, ISSN 23097248

889 Among the contemporary difficulties that the traditional deferential approach faces, Benvenisti underscores the aggressive penetration of foreign regulatory forces within the domestic legal framework:

The first underlying premise of the judicial policy of deference was the disconnection between domestic politics and world politics. National courts were happy to allow their government complete leeway in international politics on the assumption that this sphere is essentially unrelated to the domestic legal system, at least directly. This assumption has lost its force over the years, in conjunction with the increasing permeability of the domestic legal system to external regulatory efforts.

Benvenisti (Eyal), "Reclaiming Democracy: The Strategic Uses of Foreign and International Law by National Courts”, 102 Am. J. Int'l L. 241 2008, 245 p. 
ability to conduct negotiations, practically free from the radar of the courts has been affected by the growing complexity of global regulation and the interplay of global actors in the context of enforceable rules. ${ }^{890}$ The increasing exposure of governments to multiple transnational pressures at the expense of their capability to defend the public interest comes with the encroachment of the regulatory space assigned to domestic institutions. ${ }^{891}$

This consequence has apparently fuelled judicial resistance:

Given the economic and political dynamics described above, national courts have come to realize that, in conditions of increased external pressures, allowing the government carte blanche to act freely in world politics actually impoverishes the domestic democratic and judicial processes and reduces the opportunity of most citizens to use these processes to shape outcomes.

Domestic courts, better insulated from external pressures, may have concluded that, by aggressively restricting their government, they can actually revive the domestic democratic processes and secure their own autonomy. ${ }^{892}$

\footnotetext{
890 Benvenisti elaborates the three contemporary difficulties surrounding the traditional deferential approach: 1) permeability of the domestic legal system to external regulatory efforts, 2) vulnerability of the domestic legal system to external influence (normally of economic groups), 3) the replacement of diplomacy by law.
}

Benvenisti (Eyal), "Reclaiming Democracy: The Strategic Uses of Foreign and International Law by National Courts", 102 Am. J. Int'l L. 241 2008, 268 p.

${ }^{891}$ Benvenisti illustrates about the obsolescence of the traditional approach of deference to international relationships, due to the overhauled used of diplomacy as tool for shaping domestic institutions, without it being subject to any filter of accountability:

It was assumed first that the murky world of diplomacy is detached from the domestic one, where the rule of law should prevail; second, that the government adequately represents the interests of its domestic constituency in its foreign diplomacy; and third, that the government can better conduct diplomatic affairs without the intervention of the judiciary. None of these assumptions can be claimed to be valid today. The spheres of global regulation increasingly affect the lives of potentially all citizens; governments are more than ever the captives of narrow domestic interests, hence unable to represent broad constituencies; and the contemporary world of diplomacy exposes governments to increasing pressure, so that quite a few would actually benefit from domestic legal constraints that would tie their hands in the international bargaining process.

National courts are left with only limited opportunities to restrain or at least slow down the drain of power from domestic institutions. Even more threatening to the courts are measures taken by governments, foreign governments as well as their own,,that sap the courts of those opportunities and limit their independence. The newly evolving judicial approach may be interpreted, therefore, as aimed at facing up to globalization and revitalizing the authority of the national institutions.

Benvenisti (Eyal), "Reclaiming Democracy: The Strategic Uses of Foreign and International Law by National Courts”, 102 Am. J. Int'l L. 241 2008, 244-245 pp.

${ }^{892}$ Benvenisti (Eyal), "Reclaiming Democracy: The Strategic Uses of Foreign and International Law by National Courts", 102 Am. J. Int'l L. 241 2008, 247 p. 
The same author highlights the complexity in the way courts employ foreign and international law, as a tool to fostering inter-judicial co-ordination with the attempt either "to protect the independence of domestic political branches from external pressures or to protect their own independence (from encroachment by their governments) " 893 . This perspective would suggest the use of international law for parochial ends, with the aim of preserving the courts' influence as gatekeepers of national interest by testing not only the conformity of international commitments to the national framework but also assessing the cost and benefits of the same. ${ }^{894}$ By doing so, the courts bear the risk of being criticized for "overstepping their authority by pre-empting their respective political branches" at the domestic level, and for being "troublemakers" at the international plane $^{895}$. In this line, the consistent application of international law may foster international judicial dialogue and may moderate both international and domestic pressures. ${ }^{896}$. As explained by Benvenisti, the risk of assertive national courts applying international law could be that their decisions remain isolated as a result of the indifference or reluctance of other courts to embrace common grounds of interpretation. This is particularly evident in the Latin-American region, crossed by clashing approaches towards International Law, which have impeded the development of effective mechanisms to achieve "collective empowerment". ${ }^{897}$ In this context, the regional history

\footnotetext{
${ }^{893}$ Benvenisti (Eyal), "Reclaiming Democracy: The Strategic Uses of Foreign and International Law by National Courts", 102 Am. J. Int'l L. 241 2008, 268 p.

${ }^{894}$ Benvenisti (Eyal), "Reclaiming Democracy: The Strategic Uses of Foreign and International Law by National Courts", 102 Am. J. Int'l L. 241 2008, 268 p.

${ }^{895}$ The author underlines in one hand, the strong signal that may be sent by national courts applying consistently international law to the international community and tribunals, which in turn depend of domestic courts to enforce their decisions:

\begin{abstract}
A national court that seriously applies international law sends a strong signal to international courts that the national court regards itself as an equal participant in the transnational lawmaking process and will not accept just any decision rendered by an international tribunal. Since the effectiveness of international tribunals depends on compliance with their decisions, they must anticipate the reaction of the national courts to those decisions and come to terms with the national courts' jurisprudence. In this sense, assertive national courts invoking international law can effectively limit the autonomy of international tribunals.
\end{abstract}

Benvenisti (Eyal), "Reclaiming Democracy: The Strategic Uses of Foreign and International Law by National Courts", 102 Am. J. Int'l L. 241 2008, 249 p.

\footnotetext{
${ }^{897}$ Benvenisti warns that an "assertive strategy" entails a high reputational risk in the case that a common interjudicial-stance may not be achieved:
}

This strategy, however, lacks one crucial element for it to have effective impact: a united, coordinated judicial front. If only one national court adopted assertive policies, it would face the danger of being singled out as an individual troublemaker whose jurisprudence does not reflect 
has shown strong tendencies to race to the bottom both at the regulatory and adjudicative levels with the aim of attracting foreign direct investment. In the case of Ecuador, the Executive's unwillingness to swiftly conclude the process of denunciation of treaties shows its vulnerability to external and domestic pressures, which furthermore erodes the Constitutional Court's credibility and the future consistency of its rulings related to the application of International Law. In the light of the aforementioned, the long-standing disconnection between the national and international spheres is undeniable, especially when it comes to a coherent interpretation of international obligations that enable a common understanding of specific concepts. Within the current political situation, it is also notable that the judicial and constitutional branches have not been able to develop independent stances before the executive, tainting the legal propriety of their decisions. In the Ecuadorian case, the recognition of the hierarchy between international and national law, has not yet been developed as a mechanism to strengthen the notion of the international rule of law as advocated by Nollkaemper ${ }^{898}$.

Confronting the notions drawn in the Constitutional Court's rulings with identical concepts applied and developed by the international courts and foreign authoritative resources, allows a perception of the resistance embedded in national courts to afford full effects to international obligations impacting on the State's economic interests. The reluctance to resort to mechanisms of consistent interpretation facilitating the State compliance with its international obligations, demonstrates on the one hand, a strong and to some extent, explicable animadversion towards the rules of international investment protection, and in the other a prominent political alignment of the Constitutional Court with the Government's goals. The mere assertion of a fundamental change of circumstances, together with an inaccurate analysis of the mechanisms for the termination of treaties under a direct attack on the disputed settlement provisions, suggests the inclination of the court towards a solipsistic approach, reclaiming the pre-dominance of domestic law. It remains to be seen for how long such a radical approach could be

general state practice. Its government could therefore be side-stepped when global forces seek out other governments, those unconstrained by their courts, hence more vulnerable to external pressure. Thus, courts seeking to enhance domestic institutions and processes must try to ensure the adoption of a common interjudicial stance.

Benvenisti (Eyal), "Reclaiming Democracy: The Strategic Uses of Foreign and International Law by National Courts", 102 Am. J. Int'l L. 241 2008, 249 p.

${ }^{898}$ Nollkaemper (André), National Courts and the International Rule of Law, Oxford University Press, 2011, 66-67 pp. 
sustained. In any case, this stance suggests an understandable resistance towards the effects derived from the operationalization of the system of investment protection, perceived as undemocratically built and arbitrarily applied. In this sense, should the State be willing to challenge the system claiming a fundamental change of circumstances with potential effects in the international sphere, it should undertake a case by case factual analysis and resort to the application of the rules provided for in the VCLT, thereby disregarding the specific provisions of the BITs. It has been shown that successfully invoking such a principle is very unlikely, even more, when the termination of the BITs on the basis of their own provisions was unreasonably delayed, due to external pressures. From a theoretical point of view the State has to assess the deployment of primary and secondary obligations in order to neutralize to a maximum extent the application of treaty based protection. Logically, this resolution does not deprive the investors of diplomatic protection and does not shield the State from external influences, asserted either by State or non-State actors.

\subsection{Reconciling Further Investment Obligations with the New Constitutional Framework}

Salacuse claims that academia has been traditionally focused on the subject of international investment law, paying little attention to the two other crucial legal frameworks that enable the deployment of international investment protection rules, namely, national laws and investment contracts. According to this author, if such academic works show only "one third" of the story ${ }^{899}$, the complexity of the operation of the system might be undervalued.

The second chapter observed the aggressive way Ecuador operationalized the application of international investment protection with a set of abundant and intertwined, international obligations, regulatory measures and public declarations underpinned since the President, Sixto Durán Ballén, took office in 1992. Such a set of measures, as claimed by the investors, showed international campaigns to promote the country as institutionally and legally friendly for the protection of international investment, a consistent practice of signing bilateral investment treaties, commitments to liberalize strategic sectors through legal reforms and further signals praised by international business media and influential

899 Salacuse (Jeswald W.), The Three Laws of International Investment: National Contractual and International Frameworks for Foreign Capital, Oxford University Press, 2013, viii p. 
non state actors, which altogether would have induced the positive response of the investors to allocate their resources in Ecuador. As shown, the aggressive liberalization trend undergone by Ecuador during the 1990's was possible through the implementation of a dense web of treaties, regulatory measures and contractual commitments, which transcended the scope of treaty provisions designed to promote and protect foreign direct investment. The reforms undertaken to strategic sectors, the incorporation of model contracts and specific clauses through laws and regulations combined with the outspoken policy to privilege the attraction of foreign investors, meant that the government conditioned the exercise of regulatory powers to serve the aim of building up a liberal business climate. In this context, the State did act as sovereign in so far as this capacity would enable the implementation of such commitments. While the deployment of regulatory measures and the adoption of international obligations were orientated to encroach upon the State's own attributions, its role as facilitator of the articulation of the system was enlarged. While at the normative level the State had to undertake all the necessary measures for protecting foreign investments, at the contractual stage, it did have to back up the fulfillment of the specific commitments in its sovereign capacity either by issuing sovereign guarantees or by acting as sovereign counterparty in the case of contracts. As noticed, the pinnacle of such a conception was sacred to the Constitution of 1998, devoted to guaranteeing the model of "social market economy" unconditionally opening the doors to foreign direct investment. The constitutional provision enabling the State to provide for special "guarantees and assurances" with the aim of shielding investment contracts from the effects of laws or further rules of "any class", afforded these commitments supra-constitutional status by insulating them from public deliberation. This unlimited constitutional commitment pursued the effect of immobilizing the State's authority ad infinitum and contractualizing the exercise of sovereign powers, to the detriment of the principles of separation of powers, democratic representation and legitimacy, equality before the law and the stake of future generations in exercising their right of self-determination. Although the contractualization of sovereign powers would reflect a strong sign to subordinate any public notion to the values of the market, it does not equate to the impact of the "constitutional alike" commitments provided for by investment rules. These rules transcend any contractual commitment, even though the latter may embody the self-restraint of the State's authority. Schneiderman portrays this scope in a claimed consolidation of "the neo-liberal rule of law": 
Likened to a new form of constitutionalism, the regime inhibits the possibilities to for political action by enacting binding constraints, in the form of general legal principles, on the ability of states to intervene in the market. These rules operate both outside of states, as independent legal regimes that discipline state action, and within, through the agency of constitutional and statutory reform and oftentimes judicial review. ${ }^{900}$

Although, this system of meta-rules would frame the other seminal legal frameworks as explained by Salacuse, the specific deployment of the corresponding rules of each of them would trigger different layers of accountability and as such, distinct actors would come into play for their enforcement.

\subsubsection{The Interplay between Domestic Regulations and International Investors' rights}

The variety of regulatory initiatives in the frame of the all-embracing scope of investment rules renders useless the exercise of singularizing the types of regulations that may trigger the international rules of investment protection ${ }^{901}$. Furthermore, the minimal role of the State in the economy coined by the Constitution of 1998, as opposed to the predominant attributions conferred by the Constitution of 2008 in a context of mistrust and challenge of the current state of foreign relations, implies that the ability of political authorities and courts to enforce international commitments would have to be assessed taking into account the reformed framework. As Salacuse explains:

The degree to which a national framework will encourage or restrict foreign direct investment (FDI) may change over time depending on a country's economic and political circumstances.

(...) As important as the restrictions and incentives set down in national laws and regulations, are the extent to which national legal frameworks recognize and enforce the two fundamental building blocks of the investment process, property rights and contractual rights. Both of these rights are the creation of some national legal system; both are legal constructs. How the national legal framework

900 Schneiderman (David), Constitutionalizing Economic Globalization: Investment Rules and Democracy's Promise, Cambridge University Press, United Kingdom, 2008, 208 p.

901 Schneiderman's characterization of the regime of investment rules as a form of supra-constitution is very appealing:

A constitutional lens is helpful analytically as the regime of investment rules can be understood as an emerging form of supraconstitution that can supersede domestic constitutional norms. From this external perspective, investment rules can be viewed as a set of binding constraints designed to insulate economic policy from majoritarian politics.

Schneiderman (David), Constitutionalizing Economic Globalization: Investment Rules and Democracy's Promise, Cambridge University Press, United Kingdom, 2008, 3 p. 
conceives of, defines and enforces these two rights is fundamental to the process of undertaking and operating an investment project. ${ }^{902}$

The two fundamental blocks elicited by Salacuse, namely property rights and contractual rights remained practically unaltered when compared to the constitutional framework of 1998 and 2008. For instance, the Constitution of 2008 preserves a private language in the regulation of strategic sectors and non-renewable resources, both of them, the main sources of international litigation involving the Ecuadorian State.

By making out that all the rights and duties orbit around the right of property, regardless of whether the latter is attributed to the State or the investor, both actors are enabled to apprehend and resign certain rights and obligations they would not be normally entitled to. Moreover, when this wording circumscribes such resources and sectors to State's ownership, it disdains the well-rooted domestic notion that strategic sectors and non-renewable resources are out the reach of the right to private property. Therefore, espousing the concept of public resources like non-renewable resources to the notion of ownership confuses the fact that the management, regulation and control of such resources are on the one hand governed by specific Public Law's rules, and on the other, they are inalienable, imprescriptible and non-seizable. It has also to be recalled that the Constitution of 2008 entrusted the management of strategic sectors, non-renewable resources, subsoil products, mineral and hydrocarbon reserves, radio-electric spectrum, biodiversity and genetic assets to public enterprises. Notably, the Constitution also mandates that the State's profits share must be no lower than that earned by the companies exceptionally delegated to managing or exploiting such sectors and resources. As warned in the previous chapters, this would establish a straitjacket to the fiscal models that the future governments may design for maximizing the generation of revenue (Art. 408, CRE).$^{903}$ In any case, it has to be highlighted that the expansion of the State's role in the

902 Salacuse (Jeswald W.), The Three Laws of International Investment: National Contractual and International Frameworks for Foreign Capital, Oxford University Press, 2013, 36-37 pp.

903 The implementation of this constitutional mandate has proven difficult, especially in view of the volatility of the commodity prices and the particularities of the structure of costs of each resource. Taking as example the mining sector, the Mining Act, was modified in order that the profits calculation meets the sectorial reality. After 4 years of its enactment, the straightforward statutory percentages of royalties distribution had to be moderated and in relevant cases even suppressed to be determined by further regulations and contracts. In addition, the percentage of taxes levied and the share of the right holders (communities, regional governments) was a factor to differentiate both the duties and the rights derived from such distribution. Additionally, certain governmental goals were earmarked to a percentage of royalties in the case of regional governments, with a close monitoring of the central government. Finally, it has to be considered that the calculation of such profits' participation has to deduct further taxes applicable depending on the mineral and which comprise among others: the corporate profit tax, windfall 
economy, coupled with the reinforcement of the communities' rights over the exploitation of non-renewable resources, just to mention the most salient limitations, do undeniably affect the circumstances, rules and actors that come into play within strategic sectors and resources frameworks.

It is understandable that the all-embracing definition of investment as provided for by the BITs comprises all kinds of rights, goods and public resolutions, within the realm of investor's ownership, disregarding the aforementioned distinctions. By the same token, the principle that the State acts as the representative of the people in the management and exploitation of these resources implies the recognition of concomitant rights and obligations beyond the state's scope and organs. As observed, enclosing the management of non-renewable resources with the right of property is a clear expression of the privatistic logic of investment protection rules. However and as noticed in the previous chapters, the variety of investment disputes based on the ambiguity of investment protection rules allows investors to impeach any action or omission attributable to the State, regardless of whether they interfere with property or contractual rights.

\subsubsection{Regulatory Change and Investors' Interests}

As described by Salacuse, there are as many national legal frameworks as sovereign states. ${ }^{904}$ This fact, in conjunction with the truism that human and government conduct is inherently unpredictable creates the need to find mechanisms to equally distribute the

profits tax, labor participation rate, minimum sales tax, value added tax. Notably the reform to the Mining Act suppressed the rate of $70 \%$ to windfall profits originally established.

See Article 93, Ley Orgánica de Minería, Suplemento de R.O 517, 29 de enero de 2009 and Article 18 of Ley s/n, R.O. 0372S, 16 de Julio de 2013, which reformed this provision.

${ }^{904}$ Salacuse thoroughly demonstrates the diversity of sources, instruments and actors that interact within the boundaries of International Investment Law:

The national legal framework consists of the legislation, regulations, administrative acts, and judicial decisions of governmental authorities of countries and their subdivisions having jurisdiction over the investment or the investor. National legal frameworks are exceptionally diverse. Since there were more than 200 sovereign states in the world in 2012, there were at the time more than 200 national frameworks for foreign investment, without counting subnational systems of law. No two national frameworks are exactly alike, although as will be seen they have many common characteristics.

National legal frameworks express and concretize the policies of states toward foreign capital. In general, national frameworks seek to do two things in varying degrees: to encourage foreign investment and to control foreign investment.

Salacuse (Jeswald W.), The Three Laws of International Investment: National Contractual and International Frameworks for Foreign Capital, Oxford University Press, 2013, 35-36 pp. 
burden of future events. When the government actions are at stake, the "calculability of transactions" is dependent upon the clarity and preservation of the regulations and the consistency of their application. ${ }^{905}$ The latter condition is normally the drawback of countries with under-developed institutional capacity and unstable political regimes. Furthermore and considering that the public undertakings are governed by the law of the host government, there is the risk that the government is tempted to unilaterally modify or terminate them. ${ }^{906}$ In this line, Salacuse warns that a host government's obligations to foreign investors normally fall within the concept of "obsolescing bargains", whose main factors are: 1) changed circumstances and 2) decline in the investor's bargaining power after making the investment. ${ }^{907}$ By the first factor, the State would honour their obligations as long as the perceived benefits of performance exceed those of nonperformance. By the second factor, the investor's bargaining power diminishes once it has allocated the capital under the sovereignty of the host state. ${ }^{908}$ In this line, Bonnitcha and Aisbett undertake the economic analysis of substantive protection provided for in international investment treaties, highlighting the particularities revolving around the motivations of the investors to tackle regulatory change when they enjoy expansive legal protection, as illustrated below.

\subsubsection{Controlling Regulatory Change Through Iinternational Investment Agreements (IIAs)}

As explained by Bonnitcha and Aisbett, from an economic perspective the main commitment arising out of the adoption of international investment treaties consists of the agreement to compensate the investors for losses inflicted by government measures that breach such protection. Relying on the concept of efficiency linked to the economic analysis of public policy, these scholars explain that a policy improves efficiency if its economic benefits exceed its economic costs. This perspective is particularly suitable to the context of IITs on the basis that "economic objectives provide the most plausible

\footnotetext{
${ }^{905}$ Salacuse (Jeswald W.), The Three Laws of International Investment: National Contractual and International Frameworks for Foreign Capital, Oxford University Press, 2013, 26 -27 pp.

906 Salacuse (Jeswald W.), The Three Laws of International Investment: National Contractual and International Frameworks for Foreign Capital, Oxford University Press, 2013, 27 p.

907 Salacuse (Jeswald W.), The Three Laws of International Investment: National Contractual and International Frameworks for Foreign Capital, Oxford University Press, 2013, 27 p.

${ }^{908}$ Salacuse (Jeswald W.), The Three Laws of International Investment: National Contractual and International Frameworks for Foreign Capital, Oxford University Press, 2013, 27-28 pp.
} 
justification for the protection for foreign investors". ${ }^{909}$ The little understanding of the breadth of commitments embodied in the BITs, coupled with the absence of a cost-benefit analysis of the distributional effects of the treaty protections prevent the determination of the rationality supporting over-arching substantive protection, when strong regulatory and contractual guarantees were already provided in the Ecuadorian context. Under robust pro-investor regulatory and contractual frameworks, it is controversial to ascertain whether the investments made during the period when the BITs gained momentum, would not have been done in the absence of such protection. Bonnitcha and Aisbet portray two interesting scenarios that may take place when the impacts of international investment treaties on investment or regulatory decisions may fit well with the Ecuadorian reality:

(...) The first is a situation in which an investor contemplates a highly profitable prospective investment in the host country, which the investor would have undertaken even in absence of IIT protections. In this situation, the availability of IIT protection does not affect the investment decision. Increasingly expansive post-establishment protections in an ITT only serve to shift the risk of the project from the investor to the host country, thereby benefiting the investor at expense of the host country. (This situation is an example of the ex post facto effect described above). The second is a situation in which the investment protections are sufficiently broad to encourage investors to proceed with projects that are not globally efficient, or to choose production techniques and project structures for potentially efficient investments that are not globally efficient. This second scenario is likely to occur when IIT provisions are sufficiently protective to induce moral hazard on the part of investors. This situation clearly creates net benefits for the investors, as the inefficient project becomes profitable under the protection in question. In this scenario, the social cost of the investor proceeding with the welfare-decreasing project is borne by the host country ${ }^{910}$.

The moral hazard surrounding the investors' performance due to the concession of unlimited treaty based protection is particularly evident within investment sectors involving negative externalities like extractive industries:

In addition, foreign investments are extremely diverse. Some, such as high-tech manufacturing investments, may be associated with significant net positive externalities. Other, such as natural resource extraction, are likely to be associated with significant net negative externalities. The problem is that the substantive protections of IITs are available to all investments of a particular nationality, regardless of whether they are associated with positive or negative externalities.

\footnotetext{
909 Bonnitcha (Jonathan) and Aisbett (Emma), "An Economic Analysis of the Substantive Protections Provided by Investment Treaties" in Yearbook On International Law and Investment Policy, 2011-2012, Edited by Sauvant (Karl P.), Oxford University Press, 2013, 683 p.

910 Bonnitcha (Jonathan) and Aisbett (Emma), “An Economic Analysis of the Substantive Protections Provided by Investment Treaties" in Yearbook On International Law and Investment Policy, 2011-2012, Edited by Sauvant (Karl P.), Oxford University Press, 2013, 702 p.
} 
Perversely, IIT protections may be most effective in encouraging investment industries likely to be associated with negative externalities, notably investments in extractive industries. The reason for this is that governments are more likely to regulate investments found to entail negative externalities. Thus, the protections of IITs are more valuable to firms that are more likely to cause negative externalities. $^{911}$

As found in the Ecuadorian international investment litigation docket, the majority of the investors' claims were not related to direct expropriation, which would be the most basic breach of substantive protection. The variety of controversies was focused on the violation of the standard of fair and equitable treatment (FET):

The FET provisions of IITs are problematic, insofar they encourage the tribunal to consider the treatment of an investor in isolation from over-arching determinations of whether that treatment was justified on account of being efficient or of whether the investor suffered from discrimination. As such, FET provisions raise problems of over-protection of foreign investors relative to other investors and are likely to induce moral hazard on the part of foreign investors. Doctrines that protect the "legitimate expectations" of investors are particularly problematic. This doctrine encourages a tribunal to focus its inquiry on the extent to which a measure interferes with the interests of an investor, rather that the extent to which a measure interferes with the interests of a measure exceed its costs (including all costs that are borne by the investor) overall. ${ }^{912}$

As Bonnitcha and Aisbett illustrate, the institutional complexity within host states may mean that extensive substantive protection causes little impact on government behaviour and that in certain circumstances they have proved to be greatly inefficient, especially when they have already provided strong legal enforcement tools. The authors highlights that governments have normally overvalued the externalities of FDI justifying ITT protection. This has been particularly detrimental to net capital importers in the context of global efficiency analysis ${ }^{913}$. They assert that if the welfare maximizing policy response consists of rewarding all firms irrespective of their nationality for the provision

\footnotetext{
911 Bonnitcha (Jonathan) and Aisbett (Emma), "An Economic Analysis of the Substantive Protections Provided by Investment Treaties" in Yearbook On International Law and Investment Policy, 2011-2012, Edited by Sauvant (Karl P.), Oxford University Press, 2013, 700 p.

912 Bonnitcha (Jonathan) and Aisbett (Emma), “An Economic Analysis of the Substantive Protections Provided by Investment Treaties" in Yearbook On International Law and Investment Policy, 2011-2012, Edited by Sauvant (Karl P.), Oxford University Press, 2013, 704 p.

${ }^{913}$ Bonnitcha (Jonathan) and Aisbett (Emma), "An Economic Analysis of the Substantive Protections Provided by Investment Treaties" in Yearbook On International Law and Investment Policy, 2011-2012, Edited by Sauvant (Karl P.), Oxford University Press, 2013, 701 p.
} 
of positive externalities in proportion to their contributions, this could be achieved through targeted tax breaks or subsidies. ${ }^{914}$

In this context, it is remarkable that developed countries were quite aware that BITs alone are not capable of increasing investment, since the economic analysis practically neglected when such instruments were concluded. This is evident from the hearings which took place at the U.S. Senate, whereby the U.S. Department of State's delegates acknowledged that while BITs are an important part of the economic reforms required to attract private capital, further factors are normally prioritized by the private sector when it undertakes investment decisions. ${ }^{915}$ More eloquently, the representatives of the U.S Council for International Business praised the importance that the business community attaches to BITs, among other reasons because "they guarantee that investors will not be burdened by host governments restrictions and requirements" and "they reduce risk and uncertainty". ${ }^{916}$ On the top of these advantages, they underlined that "what makes all of

\footnotetext{
914 Bonnitcha (Jonathan) and Aisbett (Emma), "An Economic Analysis of the Substantive Protections Provided by Investment Treaties" in Yearbook On International Law and Investment Policy, 2011-2012, Edited by Sauvant (Karl P.), Oxford University Press, 2013, 700 p.
}

915 With respect to the question as to whether the adoption of BITs would increase investment, the U.S. State Department replied:

\begin{abstract}
"Question. Is there any new evidence to suggest that increased investment, as a result of protections provided through these treaties, will or could result in a reduction in direct U.S. foreign assistance over a period of time with respect to the countries involved?

Answer. In negotiating BITs, the U.S. is careful to point out that the existence of a BIT alone will not guarantee increased investment. Private sector investment decisions are made in response to a variety of factors in a free market; the BITs address only elements of how the investment is treated by the government. Other factors affecting investment decisions include the political stability of the host country the economic, industrial and administrative framework, particularly whether the; country has adopted sound, market-oriented policies; intellectual property protection and tax regimes; and, most important, the probable profitability of the investment. Thus, while a BIT offers U.S. investors increased security, it may not be sufficient to cause an investment to take place.

Since a BIT in and of itself may not result in increased investment, it is not possible to claim that a BIT will lead to a reduced need for U.S. assistance. However, at a time of increased demand and competition for foreign assistance worldwide, it is vitally important for developing countries to attract foreign direct investment, which has been the single largest component in international resource flows to developing countries over the last five years. A BIT is an important part of the economic reform needed to attract private capital."
\end{abstract}

See, Responses of the U.S Department of State to Questions Asked by Senator Pell, "Bilateral Investment Treaties with: Argentina, Treaty Doc. 103-2; Armenia, Treaty Doc. 103-11, Bulgaria, Treaty Doc. 103-3, Ecuador, Treaty Doc. 103-15; Kazakhstan, Treaty Doc 103-12; Kyrgyzstan, Treaty Doc 103-13; Moldova, Treaty Doc. 103-14; and Romania, Treaty Doc. 102-36.

Hearing before the Committee of Foreign Relations United States Senate, One Hundred Third Congress, First Session, September 10, 1993, 22 p.

916 See, Hearing before the Committee of Foreign Relations United States Senate, One Hundred Third Congress, First Session, September 10, 1993. 
these commitments meaningful is the availability of a binding dispute settlement mechanism, permitting the investor to redress the event of a breach of agreement". 917 They concluded that in the business community's view, the possibility to allow individual investors to bring claims against host governments through binding third party arbitration, is "the most valuable of the BIT provisions for promoting investor confidence as well as for imposing discipline on host governments". 918

The enforcement of regulatory discipline through the direct access of investors to binding international arbitration meant the Calvo Doctrine's ${ }^{919}$ formal burial. It is noteworthy that the U.S. Department of State's delegates confirmed its consistent position that deems

917 See, Hearing before the Committee of Foreign Relations United States Senate, One Hundred Third Congress, First Session, September 10, 1993.

918 Statement of Daniel Price, U.S. Council for International Business, New York, NY; Accompanied by Stephen J. Canner, Vice President for Investment Policy, U.S. Council for International Business, 28 p in "Bilateral Treaties Concerning the Encouragement and Reciprocal Protection of Investment: Treaty Doc. 104-19-Albania; Treaty Doc. 103-36-Belarus; Treaty Doc. 103-38-Estonia; Treaty Doc. 104-13-Georgia; Treaty Doc. 103-35-Jamaica; Treaty Doc. 104-12-Latvia; Treaty Doc. 104-10-Mongolia; Treaty Doc. 10414-Trinidad/Tobago. 103-37-Ukraine".

See, Hearing before the Committee of Foreign Relations United States Senate, One Hundred Fourth Congress, First Session, November 30, 1995, 28 p.

919 With regard to the definition of the Calvo Doctrine, the U.S. Department's delegate provided a very detailed explanation that stressed the national treatment obligation nuanced with the possibility of foreigners to resort to international arbitration in order to redress any harm in accordance to the rules of International Law:

"Question. Please supply a complete legal definition and explanation of the "Calvo Doctrine" and the "Calvo Clause." Include the position of the United States on the validity thereof.

Answer. The Calvo Doctrine, named after a nineteenth century Argentine jurist and diplomat, states that foreigners are not entitled to rights not accorded to nationals, and that a government's liability can be no greater for foreigners than that which it has for its own nationals. Thus, although the Doctrine provides for national treatment, it excludes the possibility that disputes between a foreign investor and a host government can be decided other than in the host country legal system. A Calvo Clause is a clause, usually contractual, in which a foreigner agrees to waive any right that the foreigner may have to the diplomatic protection of his or her government in connection with matters arising under the contract.

The United States has consistently taken the position that the Calvo Doctrine is invalid and that the rights and obligations of the United States with respect to the protection of the interests of its nationals in foreign countries cannot legally be affected by the Calvo Doctrine or a Calvo Clause."

See, Responses of the U.S Department of State to Questions Asked by Senator Pell, "Bilateral Investment Treaties with: Argentina, Treaty Doc. 103-2; Armenia, Treaty Doc. 103-11, Bulgaria, Treaty Doc. 103-3, Ecuador, Treaty Doc. 103-15; Kazakhstan, Treaty Doc 103-12; Kyrgyzstan, Treaty Doc 103-13; Moldova, Treaty Doc. 103-14; and Romania, Treaty Doc. 102-36.

Hearing before the Committee of Foreign Relations United States Senate, One Hundred Third Congress, First Session, September 10, 1993, 31 p. 
such a doctrine invalid since any contractual waiver to diplomatic protection or to any sacrifice of a further remedy provided for by international law, is ineffective with respect to the protection of the interests of their nationals ${ }^{920}$. In any event, this consistent and long-standing position was upheld through BITs, removing any obstacle that might oblige U.S. investors to submit disputes exclusively to local courts ${ }^{921}$.

Remarkably, the hearings held at the U.S. Senate unfold the aggressive strategy of multiplying the signature of BITs in order to extend the protections achieved therein to a possible multilateral framework. ${ }^{922}$ Furthermore, the incorporation of intellectual

${ }^{920}$ The U.S. State Department's delegate confirmed its long-standing position denying the validity of Calvo Doctrine:

Question. Is it possible to argue that by asserting a treaty provision negates a doctrine then there "is an implied recognition of that doctrine?

Answer. No. For example, the United States has maintained a firm and consistent position that the Calvo Doctrine is invalid. Argentina, in entering into the BIT, has removed U.S. investors in Argentina from the obligation to submit disputes only to local courts. Our noting this cannot be read to imply any recognition of the Calvo Doctrine by the United States."

Hearing before the Committee of Foreign Relations United States Senate, One Hundred Third Congress, First Session, September 10, 1993.

921 The U.S. State Department's delegate left no doubt with relation to the absolute right arising from the BITs enabling the investors to submit disputes to arbitration, meaning the inexorable abolishment of Calvo Doctrine in the region:

"The BIT signed with Argentina is an important milestone in our relations with South America. Like many South American countries, Argentina has long subscribed to the Calvo Doctrine (named after a 19th century Argentine jurist). The U.S. Argentina BIT, which provides investors the absolute right to international arbitration for the resolution of investment disputes, removes U.S. investors in Argentina from the Calvo Doctrine requirement to submit disputes arising there only to local courts. This treaty should help pave the way for similar agreements with other states in the region."

See, Responses of the U.S Department of State to Questions Asked by Senator Pell, "Bilateral Investment Treaties with: Argentina, Treaty Doc. 103-2; Armenia, Treaty Doc. 103-11, Bulgaria, Treaty Doc. 103-3, Ecuador, Treaty Doc. 103-15; Kazakhstan, Treaty Doc 103-12; Kyrgyzstan, Treaty Doc 103-13; Moldova, Treaty Doc. 103-14; and Romania, Treaty Doc. 102-36.

Hearing before the Committee of Foreign Relations United States Senate, One Hundred Third Congress, First Session, September 10, 1993, 8 p.

922 At the time, negotiations were taking place within the Organization for Economic Co-operation and Development to establish a multilateral agreement on investment. Mr, Tarullo and Mr. Abelson, representatives of the U.S. State Department, clarified that the protections negotiated through BITs could serve as a floor for the protections sought to be included at the multilateral level:

"Senator THOMPSON. Currently, within the Organization for Economic Co-operation and Development, negotiations are taking place to establish a multilateral agreement on investment. Under the auspices of the World Trade Organization, services negotiations are taking place.

What effect would these agreements have on BIT obligations? What would be the legal effect if legal standards in the OECD agreements? 
property rights as protected investments within these treaties appears to be a backup strategy, while more specific intellectual property agreements were sought for conclusion. ${ }^{923}$

Mr. TARULLO. First off, Mr. Chairman, the negotiations in Paris on the MAI are in an early stage. So we, of course, don't know exactly what the outcome will be.

(...) If a party to a BIT wanted to accede to the OECD agreement, for example, and become a member of that agreement, which is something we anticipate may be possible a few years from now, then we would have to address the question of whether we should set aside our BIT agreement with that country. But that, again, that's not a question that's been addressed to date, and it's a little bit premature right now I think one thing we can say is unless we have the kinds of protections

that we think are necessary in the MAI, we would not be in favour of giving up the kind of protections that we've negotiated through the BIT s. Our aim, however, is to get those very kinds of protections into the MAI.

Senator THOMPSON. Mr. Abelson, do you have any comments on that? Mr. ABELSON. Yes. This is an extremely important point and I agree 100 percent with Mr. Tarullo. Our goal in these discussions in Paris is to bring the kind of standards that we have in our bilateral investment treaties to a multilateral framework. We're starting with the countries who think like us, the members of the OECD."

"Bilateral Treaties Concerning the Encouragement and Reciprocal Protection of Investment: Treaty Doc. 104-19-Albania; Treaty Doc. 103-36-Belarus; Treaty Doc. 103-38-Estonia; Treaty Doc. 104-13-Georgia; Treaty Doc. 103-35-Jamaica; Treaty Doc. 104-12-Latvia; Treaty Doc. 104-10-Mongolia; Treaty Doc. 10414-Trinidad/Tobago. 103-37-Ukraine".

Hearing before the Committee of Foreign Relations United States Senate, One Hundred Fourth Congress, First Session, November 30, 1995, 16-17 pp.

${ }^{923} \mathrm{Mr}$. Abelson, Assistant of United States Trade Representative for Investment, addressed the enquiry concerning the level of protection provided to intellectual property rights through BITs. Interestingly, in the case of Ecuador, it may be observed that the BIT and a specific Intellectual Property Agreement were bundled as a sole package of negotiation:

"Senator THOMPSON. On the issue of intellectual property rights, they are protected as an investment in the bilateral investment agreements. Yet, the U.S. has held up the exchange of instruments of ratification of the BIT with Ecuador until that country concludes an intellectual property agreement with the United States. Is this an indication that the BIT does not effectively protect intellectual property and what efforts has the USTR and State Department made to increase the protections for intellectual property in the countries under consideration in these treaties?

Mr. ABELSON. We have an extensive program to improve the intellectual property protection provided to U.S. companies overseas.

It includes both negotiating separate, what we call intellectual property agreements, which are much more specific than the investment treaty itself with regard to intellectual property."

(...) With regard to Ecuador, we actually have concluded an intellectual property agreement with Ecuador. The problem is they have not approved it in their congress. And, as we concluded both of these agreements at the same time, that is, an intellectual property and investment agreement, we expect that both of them will be implemented at the same time.

They're having a bit of problem in their congress and we're waiting for them to complete their work."

"Bilateral Treaties Concerning the Encouragement and Reciprocal Protection of Investment: Treaty Doc. 104-19-Albania; Treaty Doc. 103-36-Belarus; Treaty Doc. 103-38-Estonia; Treaty Doc. 104-13-Georgia; 


\subsubsection{Boundaries of Regulatory Deference Provided for BITs: Expectation vs. Reality}

The precipitated mechanism of BITs approval in Ecuador behind closed doors relied solely on the laconic and repetitive references of the Commission of Foreign Affairs of National Congress praising the goal of promoting foreign direct investment through BITs. The succinct reports discussed before the Plenary of the National Congress primarily acknowledged, without criticism, the one sided mechanism of protection provided for by the BITs to foreign capital and secondly, neglected the direct and binding access to international arbitration though an open consent set forth in the BITs. In response to the concerns of a few congressmen to the unrestricted submission of disputes to international jurisdiction, the Commission, manifested for instance, that the ICSID Convention "already in force to the State since 1986", constituted an "intermediate level" for settling disputes through conciliation, since the national jurisdiction was entitled to rule over the "goods and investments landing in Ecuador". ${ }^{924}$ In any event, the important factors missing in the analysis were the scope of the standards of substantive protection set forth in the treaties, together with the definitions of investment and investor.

Treaty Doc. 103-35-Jamaica; Treaty Doc. 104-12-Latvia; Treaty Doc. 104-10-Mongolia; Treaty Doc. 10414-Trinidad/Tobago. 103-37-Ukraine".

Hearing before the Committee of Foreign Relations United States Senate, One Hundred Fourth Congress, First Session, November 30, 1995, 15-16 pp.

924 The President of the Permanent Special Commission for International Affairs, Congressman Pío Oswaldo Cueva Puertas presented before the Plenary of the National Congress, the report recommending the approval of the BIT with the United Kingdom based on the following grounds:

(...) Para los países en desarrollo como el Ecuador estos objetivos son importantes porque la captación del capital extranjero o tecnología resultan ser ingredientes de su desarrollo. El Convenio se refiere a buscar garantías para la presencia del capital inglés en el Ecuador, sin afectar lo dispuesto en la Constitución y en las leyes Nacionales.- Para la solución de Controversias en cuanto al proceso de inversión, las partes aceptan llevar sus diferencias a un organismo internacional denominado "El Centro", para resolverlas por conciliación o arbitraje, medios reconocidos por el Derecho Internacional. El organismo fue creado por el Convenio sobre Arreglo de diferencias relativas a inversiones, abierto para la firma de Washington desde el dieciocho de marzo de mil novecientos sesenta y cinco, del cual Ecuador e Inglaterra son parte. Para nuestro país, desde el tres de marzo de mil novecientos ochenta y seis, por publicación en el Registro Oficial número trescientos ochenta y seis de ese año. Es decir, se ha establecido internacionalmente una instancia intermedia de conciliación y arbitraje que no excluye o lesiona la jurisdicción contenciosa nacional. Si los bienes o inversiones vienen al Ecuador, corresponde conocer y fallar a los tribunales ecuatorianos. La presencia de este tipo de instancia intermedia ofrece garantías al capital extranjero en el sentido de confiar en que una conciliación puede coadyuvar en el arreglo de diferencias en el campo de inversiones. La Comisión a mi cargo por estas razones expone su criterio favorable a la aprobación de este Convenio.

Congreso Nacional del Ecuador, Acta No. Veinticinco, Sesión- Congreso Extraordinario (Vespertina), 28 de Junio de 1995, 5 p. 
Albeit basic, it can be identified that the Ecuadorian rule makers' understanding that the treaties embody specific guarantees applicable to certain foreigners and enforceable through international dispute settlement mechanisms. Apparently, granting such guarantees would be assumed as a fair trade-off for the sake of attracting foreign direct investment, understood as an "ingredient of national development"925. The lack of analysis concerning the definitions of investment and standards of protection was tolerated by strong ideological assumptions founded on the capability of these treaties of attracting foreign investment through the protection of the assets. However the expansionary definition of investment, in conjunction with vague standards of protection, paved the way for the deployment of investors' protection mechanisms as tools for adjusting the exercise of regulatory powers to the canons of the rule of law as further developed within the international investment regime. As explained by Bonnitcha, the scope of investment as enshrined in International Investment Agreements goes beyond the usual definition of foreign direct investment:

The legal situation under investment treaties is more straightforward. Almost all investment treaties cover 'investments' that fall outside the standard definition of FDI. Investment treaties commonly define the term 'investment' to include 'any type of asset' and go on to enumerate loans, minority shareholdings and contractual rights as examples of assets that fall within this definition. Consistently with such definitions, the tribunal in Deutsche Bank v Sri Lanka held that an oil hedging contract between a German bank and a Sri Lankan state-owned corporation was an 'investment' protected by the Germany-Sri Lanka BIT. ${ }^{926}$

In this way, Lise Johnson criticizes the standing usually undertaken by the tribunals that rely solely on the text of treaties, leaving to a secondary plane their context and purpose, which contributes to unlimited protection:

These broad interpretations of the term "investment" largely derive from tribunals' decisions to apply strict textualist interpretations of the treaties, declining to read in limitations to the scope of the term unless those limitations are expressly stated. An effect of this interpretive approach is that treaties are

925 See, Congreso Nacional del Ecuador, Acta No. Veinticinco, Sesión- Congreso Extraordinario (Vespertina), 28 de Junio de 1995, 5 p.

${ }^{926}$ Bonnitcha (Jonathan), "Foreign Investment, Development and Governance: What international investment law can learn from the empirical literature on investment", Journal of International Dispute Settlement, Volume 7, Issue 1, 1 March 2016, Pages 31-54 
increasingly growing longer, with drafters adding new language to clearly carve out some types of assets from the agreements' protection. ${ }^{927}$

In view of the Ecuadorian case, it is clear that the rule-makers entrusted to review the scope of protection provided for by International Law and particularly, International Investment Law, were not aware that the effects further enforced by such treaties would touch upon the way of framing and exercising regulatory powers. Remarkably, at the time the U.S. - Ecuador BIT was addressed before the U.S. Senate the delegates of the U.S. Department of State praised the strength of the Ecuadorian democratic institutions, as well as the long co-operative ties within between both countries. Openly, such representatives highlighted the Ecuadorian's government positive commitment to resolve to American satisfaction, the investment dispute involving EMELEC ${ }^{928}$. Finally, it was revealed that the commitment of Ecuadorian' negotiators to streamline the application of the BIT at the expense of internal regulations, meant that its sole ratification would prevail over any domestic requirement to carry out any business activity in the country. ${ }^{929}$ This

\footnotetext{
${ }^{927}$ Johnson (Lise), "The Impact of Investment Treaties on Governance of Private Investment in Infrastructure", European University Institute, Robert Schuman Centre for Advanced Studies Global Governance Programme, EUI Working Paper RSCAS 2014/32, Italy, March 2014, 10 p.

928 This statement shows the strong interference asserted by the American diplomacy in issues related to companies of its nationality:
}

"Ecuador has a long history of co-operative relations with the United States. It has strong democratic institutions and participates actively in inter-American organizations. Ecuador has eliminated almost all coca production and has developed a vigorous program of combating money laundering and drug trafficking. The current government also resolved to our satisfaction an investment dispute involving the $\mathbf{S}$. owner of the EMELEC power company".

See, Annex: Status of US Relations with the Proposed BIT Partners, "Bilateral Investment Treaties with: Argentina, Treaty Doc. 103-2; Armenia, Treaty Doc. 103-11, Bulgaria, Treaty Doc. 103-3, Ecuador, Treaty Doc. 103-15; Kazakhstan, Treaty Doc 103-12; Kyrgyzstan, Treaty Doc 103-13; Moldova, Treaty Doc. $103-$ 14; and Romania, Treaty Doc. 102-36, 10 p.

Hearing before the Committee of Foreign Relations United States Senate, One Hundred Third Congress, First Session, September 10, 1993, 10 p.

929 This statement reveals the unparalleled commitment of Ecuador to disregard the application of its domestic legal framework in favour of the direct effect of the BIT. It suffices to say, that it is rare giving direct effects to BITs:

"Question. What is the legal status of treaties in Ecuador? Why is it necessary to have pronouncements in the side letter that the treaty satisfies specific administrative or other authorizations found in the laws of Ecuador?

Answer. In accordance with international law, upon entry into force Ecuador must comply in good faith with the obligations of the Treaty. Thus, Ecuador has to take those steps necessary under its domestic law in order to be able to fulfill its international obligations.

The side letter was made an integral part of the Treaty at the request of Ecuador in order to simplify and hasten the granting of administrative and other authorizations under Ecuadorian law to U.S. 
confirms the substitution of domestic legislation and jurisdiction ${ }^{930}$ to a broad international public law framework suitable for economic exchange. ${ }^{931}$ And this framework includes the development of transnational mechanisms of adjudication, both at the multilateral and the domestic level, where especially, policy decisions taken in developing countries would have to be reviewed. ${ }^{932}$

Having said this, the drastic change of the regulatory framework impacting on the interests of investors protected by BITs in force shifts the "facts" that would be considered by an international adjudicator when it determines whether a violation of International Law has taken place and as such they are confined to limited timeframes within which the protection and the dispute evolved. In this regard, the claim of fundamental change of circumstances by the highest venue of judicial review would have merely domestic effects. As a consequence, the constraints drawn by the Constitutional Court, limited to the treaty based submission of the State to international venues in commercial or contractual disputes involving non-Latin American foreign investors, would operate

\begin{abstract}
investors. By explicitly confirming that the treaty constitutes the necessary approval under these laws, the Ecuadorian government sought to reduce or eliminate certain bureaucratic practices identified as impediments to investment there. The U.S. government believes that these provisions will make it easier for U.S. investors to operate in Ecuador.as U.S. investors. By explicitly confirming that the treaty constitutes the necessary approval under these laws, the Ecuadorian government sought to reduce or eliminate certain bureaucratic practices identified as impediments to investment there."
\end{abstract}

See, Responses of the U.S Department of State to Questions Asked by Senator Pell, "Bilateral Investment Treaties with: Argentina, Treaty Doc. 103-2; Armenia, Treaty Doc. 103-11, Bulgaria, Treaty Doc. 103-3, Ecuador, Treaty Doc. 103-15; Kazakhstan, Treaty Doc 103-12; Kyrgyzstan, Treaty Doc 103-13; Moldova, Treaty Doc. 103-14; and Romania, Treaty Doc. 102-36.

Hearing before the Committee of Foreign Relations United States Senate, One Hundred Third Congress, First Session, September 10, 1993, 37 p.

930 Salacuse illustrates about the emergency function of the international investment regime legitimized by undermining the trustworthiness of domestic legislation:

By substituting for domestic legislation and jurisdiction because of their real or perceived lack of efficiency, trustworthiness or transparency, the international investment regime is designed to offer guarantees that are equivalent to those the investor would find in his home country.

See, Salacuse (Jeswald W.), The Three Laws of International Investment: National Contractual and International Frameworks for Foreign Capital, Oxford University Press, 2013.

${ }^{931}$ See, Kennedy (David), "The "Rule of Law", Political Choices, and Development Common Sense" in The New Law and Economic Development: A Critical Appraisal, Edited by (David M.) Trubek and (Alvaro) Santos, Cambridge University Press, 2006, 103 p.

${ }^{932}$ See, Kennedy (David), "The Rule of Law", Political Choices, and Development Common Sense" in The New Law and Economic Development: A Critical Appraisal, Edited by (David M.) Trubek and (Alvaro) Santos, Cambridge University Press, 2006, 123 p. 
prospectively in the scope of the treaties falling within the referred subject and material matters. Hence, the argued fundamental change of circumstances in the sense interpreted by the Constitutional Court sets a precedent, although not binding to it, with relation to the scope of clauses of a similar nature subject to the prior or ex post facto reviews undertaken by this court. Moreover, these constitutional rulings will limit the scope of the treaties entailing the aforementioned characteristics that may be further signed by the Executive Branch. Concerning the expulsion of the BITs from the domestic legal framework as a result of the automatic control of constitutionality, the provisions deemed as unconstitutional would no longer be admitted as "law of the Republic". ${ }^{933}$ Oddly, the Executive's omission to formally denounce the BITs implies that at the domestic level, the provisions not declared unconstitutional were still part of the national framework. Although it has not been possible to identify records concerning the application of BITs provisions as a result of a hierarchical conflict of norms, there are specific treaty provisions that would straightforwardly conflict with post-constitutional regulations, like direct remittance of dividends and national treatment. Since it was the President's primary obligation complying with and enforcing the Constitution, the laws, international treaties and further regulations within its scope of attributions, the fact of delaying to denounce the BITs not only places the whole State at risk of incurring in international responsibility but also puts in a difficult position rule makers and adjudicators facing direct normative conflicts with treaty provisions presumed constitutional..$^{934}$

933 The Organic Act on Constitutional Control and Jurisdictional Guarantees set forths that the rulings derived from the abstract control of constitutionality will have future effect:

\begin{abstract}
"Art. 95.- Efectos de la sentencia en el tiempo.- Las sentencias que se dicten en ejercicio del control abstracto de constitucionalidad surten efectos de cosa juzgada y producen efectos generales hacia el futuro. De manera excepcional se podrán diferir o retrotraer los efectos de las sentencias, cuando sea indispensable para preservar la fuerza normativa y superioridad jerárquica de las normas constitucionales, la plena vigencia de los derechos constitucionales, y cuando no afecte la seguridad jurídica y el interés general.

Cuando la declaratoria de inconstitucionalidad de una disposición jurídica produzca un vacío normativo que sea fuente potencial de vulneración de los derechos constitucionales o produzca graves daños, se podrá postergar los efectos de la declaratoria de inconstitucionalidad."
\end{abstract}

934 Constitution of Ecuador, 2008:

“Art. 147.- Son atribuciones y deberes de la Presidenta o Presidente de la República, además de los que determine la ley:

1. Cumplir y hacer cumplir la Constitución, las leyes, los tratados internacionales y las demás normas jurídicas dentro del ámbito de su competencia." 


\subsection{Contractual Repercussions of the BITs' Constitutional Review}

Lissitz underscores that the main problem derived from the effect of a change of circumstances on treaty relationships consists in one of interpretation aimed to establish the shared intentions and expectations of the parties. Eloquently the author argues that a treaty is not breached if it is not applied in circumstances in which the parties did not intend it. Such interpretation would not only be protective of the principle of good faith but also of the principle of stability. ${ }^{935}$ Contrasting this scholarly opinion with the innovative proposal of Anthea Roberts that explains the hybrid nature of investment treaties as triangular frameworks bestowing non-state entities with enforceable rights, determining to what extent the change of the Contracting States' expectations would affect such third party benefits, is a very complex task. ${ }^{936}$ Apparently, in the absence of contractual commitments with the State, it seems that the expectations of further investors qualified personally, materially and temporarily for the protection of a BIT, would be circumscribed to be treated on a non-discriminatory basis. It is clear that the specificity of the contractual commitments, usually covered by the definition of investments, would entitle the investor located in such a position to resort to different mechanisms of redress depending on the type of breach. According to the domestic interpretation analyzed, declaring unconstitutional the submission of the State to international arbitral tribunals as provided for by the BITs, would seem to encompass the obligation to renegotiate the contractual stipulations expressing the State's consent to treaty based arbitration. Within this frame, the assimilation of contractual breaches to treaty violations in the sense protected by "umbrella clauses" would have to be foreclosed. In short, any consent given by the State or a State entity through contract to settle disputes on the basis of a particular BIT or the ICSID Convention would have to be rescinded.

The regulatory actions underpinned by the government and hallmarked by the Legislative Branch and the Constitutional Court indicate an improved understanding about the necessity of limiting the substantive standards of investment protection, rather than exclusively antagonizing international arbitration venues. The progressive change of narrative as compared to that predominant in the constitutional rulings analyzed, suggests an implicit acceptance of international arbitral tribunals' intervention in matters that,

935 Lissitzyn (Oliver J.), “Treaties and Changes Circumstances (Rebus Sic Stantibus)”, 61 Am. J. Int'1 L. $8951967,896 \mathrm{p}$.

936 See, Roberts (Anthea), "Triangular treaties: the nature and limits to investment treaty rights", Harvard International Law Journal, 56 (2), ISSN 0017-8063, 353 p. 
although labelled as contractual matters, touch upon the exercise of sovereign powers, like taxation and sectorial regulation as enshrined in the Code of Production Trade and Investment and the Act for Public Private Partnership.

The intended "contractualization" of investor protection as an attempt to neutralize the effects of treaty based protection, would seem to be a coherent measure in order to minimize the contingencies that may arise with investors that operate in areas subject to the management and control of the State, especially those related to extractive industries and infrastructure. Although this solution could provide an immediate sense of relief, it does not present any obstacle to the full deployment of the effects of the BITs still in force. This apparent obstruction would not prevent the same contractors from resorting to the protection of the BIT provided that the basis of the claim is founded on the violation of International Law. Therefore any contractual amendment oriented to curtail the consent of the State to submit a particular dispute to BIT arbitration would only be confined to contractual commitments that may fall within the boundaries of a legal dispute. By the same reason, investors not linked contractually to the State will preserve the prerogative to impeach any regulatory action in conflict with the substantive standards provided for by the BITs in force.

As noticed, the Constitutional Court omitted a detailed analysis of the conformity of the BITs substantive standards to the constitutional framework. Although speculative, one of the fundamental questions that the Constitutional Court would have had to answer was to which extent the State was obliged to provide fair and equitable treatment instead of the international minimum standard in international law. Neither did the court consider the definition of protected investments and national treatment in the light of the rights of indigenous peoples, rights of nature, preference of national industry and the overhauled obligations of attributions of the State in the profits share from the exploitation of extractive industries, just to mention a few. At the contractual level, updating the relevant stipulations in harmony with such constitutional innovations would have to be done on a case-by-case basis, since the State entity was compelled to act on its contractual rather than in its regulatory capacity. In theory, in the former capacity the State entity triggering the renegotiation would be equally affected by the regulatory changes as the private party is. Therefore, it would be to the interest of both parties to renegotiate the contract in good faith. Of course such hypothesis operates provided that the actions of the State as regulator and the State entity as contractor can be deemed functionally independent. In the Ecuadorian context, the over-arching scope of the BITs would focus the attention on 
the Executive's regulatory actions in view of the strong presidential model, which affords the President legislative initiative, with exclusive prerogatives in specific matters like taxation and public expenditure, the regulation and control of strategic sectors, as well as their management through public enterprises. However, it should not be disregarded that although the current State's structure undeniably leans on the exorbitant powers attributed to the Executive, the subnational levels of government like provinces and municipalities could also play a role, not only because of the powers which they are vested to regulate and control the exercise of specific activities, but also because of their autonomy to make long term contracts for the construction of infrastructure and provision of public services. Without referring to the significant structural and substantive changes enshrined by the Constitution of 2008 that touch upon the relationships with private investors that have been referred to in these chapters, it raises the question as to whether the fundamental change of circumstances to the extension claimed by the Constitutional Court, would impose also an obligation on further public authorities to bring contractual obligations into conformity with the rulings referred to. Furthermore, there should be an assessment of the extent to which triggering a renegotiation aimed to limit the scope of the arbitral clauses in the terms prescribed by the Constitutional Court would be a useful task in terms of time and strategy.

Among the numerous cases of individual conflicts that mainly contribute to contractual instability, Salacuse singles out changing circumstances after the signature of the agreement as one of the main factors driving renegotiation contracts. ${ }^{937}$ This author underscores that long-term arrangements are inherently imperfect due to the impossibility of the parties to foresee the future contingencies of the underlying relationship. The impossibility of predicting the transactions of the future, the transaction costs of making contracts, especially those related to long-term transactions, and finally the divergence of the parties' cultures, business practices, political systems, regulatory and enforcement factors, are according to Salacuse, obstacles that could inhibit the development of a lasting working relationship. ${ }^{938}$ Out of the three renegotiation categories listed by this

\footnotetext{
937 See, Salacuse (Jeswald W.), The Three Laws of International Investment: National Contractual and International Frameworks for Foreign Capital, Oxford University Press, 2013, 274. p.

938 See, Salacuse (Jeswald W.), The Three Laws of International Investment: National Contractual and International Frameworks for Foreign Capital, Oxford University Press, 2013, 274-275 pp.
} 
author ${ }^{939}$, the most suitable to the practice undergone by the Ecuadorian State could be found within the boundaries of "extra-contract renegotiation".

The most difficult, stressful and emotional renegotiations are those undertaken in apparent violation of the contract or at least in the absence of a specific clause authorizing a renegotiation. ${ }^{940}$

In fact renegotiation of the entirety of the State contracts with incidence in International Investment Law was influenced by sovereign acts. The interplay between such sovereign acts and the contractual stipulations purportedly allowing for a review have to be carefully assessed to minimize as much as possible first, the breach of International Law and secondly, the contractual obligations. This purpose could bring greater difficulty considering that investment contracts often include stabilization clauses and as such are signed by the State in its sovereign capacity. As remarked, and leaving aside the substantial modification in the share conditions in the profits derived from the exploitation of non-renewable resources, it is complex to ascertain whether the underlying prohibition to submit the State to treaty based arbitration could affect the financial equilibrium of the contract, which is usually the seminal cause of renegotiation.

In any event, the primary examination would consist in ascertaining whether the central action fuelling a contractual change or renegotiation rests in the State's realm either as sovereign or as contractor. In spite of the novelty of the application of international investment rules, the distinction of a State's acts assessing its capacity either as sovereign or contractor is deep-rooted or spread both in common and civil law systems. In the 1920s the U.S. Supreme Court on the basis of rulings of the XIX century, corroborated the doctrine that acts of government do not amount to a contractual breach:

The doctrine enunciated in this decision has certainly met with the approval of the Supreme Court, since in Horowitz v. United States, 267 U. S. 458, 45 Sup. Ct. 344, 69 L. Ed. 736 (1925), the court in its decision quotes from the opinion in the Jones case as follows: "The two characters which the government possesses as a contractor and as a sovereign cannot be thus fused; nor can the United States while sued in the one character be made liable in damages for their acts done in the other. Whatever acts the government may do, be they legislative or executive, so long as

\footnotetext{
939 Salacuse enlists three different situations revolving around contractual renegotiation: 1) post-contract renegotiations; 2) intra-contract renegotiations; 3) extra-contract renegotiation.

See, Salacuse (Jeswald W.), The Three Laws of International Investment: National Contractual and International Frameworks for Foreign Capital, Oxford University Press, 2013, 276-277 pp.

940 See, Salacuse (Jeswald W.), The Three Laws of International Investment: National Contractual and International Frameworks for Foreign Capital, Oxford University Press, 2013, 277 p.
} 
they be public and general, cannot be deemed specially to alter, modify, obstruct or violate the particular contracts into which it enters with private persons ... In this court the United States appear simply as contractors; and they are to be held liable only within the same limits that any other defendant would be in any other court. Though their sovereign acts performed for the general good may work injury to some private contractors, such parties gain nothing by having the United States as their defendants." 941

Pursuant to such standing, Preston summarized that "a contract between the government and an individual cannot be affected specially by a general law of Congress affecting all citizens alike". ${ }^{942}$ First this position is compatible with the principle of the separation of powers under which the State's power is distributed among three noticeable branches entrusted to make, apply and enforce the law ${ }^{943}$, being the signature and fulfillment of contracts disregarded as a manifestation of sovereign power. This reasoning is also aligned with the interpretation normally adopted by investment arbitral tribunals that differentiate between treaty and contract based disputes in the light of the rules of attribution of State responsibility.

This straightforward distinction becomes blurred in the Ecuadorian context. Particularly, when it comes to the exploitation of natural resources, the State predominantly performs sovereign functions in the preparation, development and execution of the terms set out in multiple instruments that indistinctly may be categorized as regulatory and contractual. Hence, distinguishing the exercise of sovereign

\footnotetext{
${ }^{941}$ Shealey (R. Preston), The Law of Government Contracts, Second Edition, Washington D.C., John Byrne \& Company, 1927, 171-172 pp.

${ }^{942}$ Shealey (R. Preston), The Law of Government Contracts, Second Edition, Washington D.C., John Byrne \& Company, 1927, 171p.

${ }^{943}$ Haljan underscores the principle of separation of powers as one of the cornerstones of modern constitutionalism:
}

The separation of powers represents one of the cornerstones to modern constitutionalism and
political thought. At its most basic and simple, the separation of powers doctrine holds that in each
state whose purpose is liberty and the well-being of its subjects, the government exercises three
discernible categories of power, which, in turn, are ascribed to three different, and separate, public
organs. The categories of power divide into law-making, law-enforcing and law-applying.
Hence the classic "trias politica", of the legislative branch, the executive branch and the judicial
branch. It has been the task of commentators, courts and constitutionalists following Montesquieu,
the doctrine's modern progenitor, to flesh out in workable detail which officials belong to which
branch of government, and what specific, actual functions fall into which category-in whole or
in part. Haljan (David), Separating Powers: International Law Before National Courts, Springer, The Hague, 2013, $31 \mathrm{p}$. 
prerogatives from contractual rights in the course of a long-term relationship may determine the nature of the controversy involving the State and the investor. ${ }^{944}$ As seen in Chapter II, although the existence of a contractual relationship may shed light concerning the categorization of the investor's claim and as such it may be supposed as a procedural relief to the State, it does not reduce its exposure to the application of International Law. Indeed, the fact that further investors lacking such contractual link are enabled to impeach the State's actions shows the futility of attempting to hinder the access to investment arbitration either through regulatory proscriptions or contractual waivers. In contract law, the application of the contractual stipulations by a governmental officer does not make such actions sovereign. In this line a regulatory action does not necessarily amount to a contractual breach. In the event that the regulatory may not be distinguished from the contractual standing as the actions of the State as sovereign and as the Contractor might be lacking independence, autonomy and singularity, it would seem that the regulatory conduct could actually interfere in the performance of contractual obligations. In this case, it would seem more likely that the investor would seek to have the breach of treaty obligations declared. Although the Ecuadorian State became an active signatory of contracts for the exploitation of oil from the 1960s, there may be observed a fairer distinction between the standing of the State as sovereign and as contractor back then as compared to the 1990s. During this decade, the tendency to contractualize the exercise of sovereign prerogatives gained momentum through the development of Participation Contracts and the incorporation of investment contracts, providing for over-arching stabilization clauses and the consent to ICSID arbitration. Notably the Constitution of 1998 enshrined a hybrid formula authorizing the State to establish special guarantees within contracts signed with investors with the aim of avoiding that the corresponding stipulations may not be modified or even affected by laws and any further decisions of any class (Art. 271). Within the contracts referred to, the State used the double hat of

\footnotetext{
${ }^{944}$ Greiman links investment treaty arbitration with the novel concept of global administrative law:
}

\footnotetext{
"Because investment treaty arbitration falls between the two extremes of a purely public international dispute between states and a purely private international dispute between private parties, it results in a unique form of public law adjudication that is understood by some scholars as a comprehensive form of global administrative law."
}

Greiman (Virginia A.) "The Public/Private Conundrum In International Investment Disputes: Advancing Investor Community Partnerships”, 32 Whittier L. Rev. 395 2010-2011, 405 p. 
sovereign and contractor subordinating the exercise of extra-contractual prerogatives to the terms actually stipulated in the contract.

In theory a constituent process arguably bolstered and validated by mechanisms of direct democracy outside the State's scope, may not be attributed to the State either as sovereign or as Contractor. Where a BIT may be applicable, the constitutional changes in the matter of international investment arbitration as interpreted by the Constitutional Court would attempt to curtail the access to international arbitration to the extension provided in the dispute settlement clauses contained in the treaties, which were declared unconstitutional. In view of the principle of non-retroactivity of law ${ }^{945}$ and given that the constitutional restriction attains to treaties, the existing contracts should in theory not be affected by the rulings analyzed. However, the consent given in such contracts to submit the disputes to international arbitration should be exclusively circumscribed to the breach of contractual obligations, setting aside any further obligation that may trigger the application of a BITs standard of protection, like the umbrella clause. Scrutinizing the constitutional compatibility of the substantial protection agreed upon in such contracts is a matter of public policy choice and in the case of oil exploitation contracts, the renegotiation process launched in 2008 changed the participation contracts to service contracts, incorporating a new share formula and reviewed dispute settlement provisions. In any case, any action aimed at renegotiating such contracts for any reason, should be in good faith and in theory, on an equal footing.

\subsubsection{Constitutional Review of Contracts}

It has to be recalled that in the Ecuadorian context, Public and Administrative Law governs State contracts without exception, since with the administrative contentious jurisdiction is the specialized forum to air any dispute derived from an allegedly contractual or legal breach. Obviously, the categorization of the claim will determine first, the quantification of the damages and second, it will condition the access to further forums like the constitutional. For instance, the mere breach of a contractual obligation would in principle preclude resorting to a constitutional writ. Accordingly, the Constitutional Court has ruled that the contracts either civil or administrative bind the

\footnotetext{
945 The Constitution of 2008 embodies a final derogation clause that derogates the Constitution of 1998 and any norm contrary to the Constitution. It upholds any inferior norm insofar it does not contradict the Constitution.

Considering that contracts are not norms they would be outside this derogation clause.
} 
Contracting Parties, since they are the primary source to govern their relationships. ${ }^{946}$ Properly, it may not be affirmed that the State organ exercises private autonomy when it signs contracts. It rather constitutes an expression of the principle of legality, which enables such an organ to undertake several administrative attributions, among which may be identified the prerogative to assume contractual obligations according to the procedural and substantive limitations prescribed by the Law. ${ }^{947}$ It also may be asserted

${ }^{946}$ The Constitutional Court found itself incompetent to rule over merely contractual matters:

"SEXTO. Los convenios en principio jurídicos son ley para las partes suscriptoras. Este principio no solo es aplicable a los contratos civiles, sino también a los contratos administrativos. Su origen y naturaleza jurídica evidencia que se debe reclamar en los términos clásicos del Derecho Civil o Administrativo, según el caso. Las obligaciones y controversias tienen que sujetarse a dicho convenio. De allí que, no es la garantía de los derechos denominada acción de amparo constitucional la llamada a remediar las consecuencias del convenio, sino y sin mayor esfuerzo le corresponde conocer y resolver esta materia a la justicia ordinaria; por lo que habiendo el accionante equivocado la vía para reclamar sus derechos, deviene en improcedente la acción de amparo constitucional, pues, así establecía el Art. 50 del Reglamento de Trámites de Expedientes en el TC, que regía al momento de iniciar esta acción, manifestando: 'No procede la acción de amparo:... '6. Respecto de actos de naturaleza contractual o bilateral'. En tal sentido, corresponde negar la acción propuesta, y dejar a salvo las acciones que el demandante considere emprender en las vías pertinentes.

SÉPTIMO.- Este asunto cuestionado por su naturaleza merece que sea tratado en un proceso de conocimiento en el que definitivamente se consagren legítimos derechos de propiedad. Es importante resaltar que esta acción constitucional se encuentra instituida para proteger los derechos de las personas consagrados en la Constitución; y, de ninguna manera se trata de una acción declarativa que resuelva los intereses patrimoniales en que se disputa la pertenencia de divisas. Por tanto, no es competencia de la Corte Constitucional declarar o pronunciarse sobre derechos monetarios; sino, de los órganos jurisdiccionales que el ordenamiento jurídico ecuatoriano ha previsto para el efecto. Además cabe señalar que las cuestiones vertidas en esta acción son asunto de mera legalidad que escapa al control constitucional."

See, Resolución No. 01992007RA, Tercera Sala de la Corte Constitucional, R.O. 226S, July 1st, 2010.

${ }^{947}$ Prior to the promulgation of the Constitution 2008, the Constitutional Tribunal developed a restrictive approach towards the overarching delegation of public prerogatives. The following dissenting opinion distinguished between administrative acts and privatecontracts, underscoring the bilateral character of the latter. As indicated in the next footnote, the Plenary categorized a concession, whose terms were perfected through a contract as an unilateral declaration manifested in an administrative act and hence, subject to constitutional scrutiny:

"Que, el contrato administrativo implica el acuerdo de voluntades, por lo que no existe declaración de voluntad unilateral por parte de la administración, si bien esa voluntad se somete a un régimen jurídico distinto al de la contratación privada, fundamentalmente limitando su autonomía por parte de la autoridad pública contratante, la que debe someterse estrictamente a los principios de legalidad y juridicidad a partir de su propia facultad de suscribirlo (Art. $119 \mathrm{CE}$ ). Además, el contrato administrativo no reúne las características de la ejecutividad del acto administrativo, esto es, que el acto esté dotado de la fuerza de cosa decidida, y de la ejecutoriedad, es decir, que no se requiera de previa declaración judicial para que la decisión concreta contenida en el acto se cumpla. Así, esta Magistratura ha señalado que 'no puede pronunciarse sobre la validez contractual pues tal cuestión no está dentro de sus competencias, establecidas expresamente por el artículo 276 de la Constitución de la República' (Resolución No. 054-2000-TP, adoptada por el Pleno en el caso No. 374-99-RA). El contrato administrativo, sustantivamente, es un contrato sinalagmático común y similar al que se emplea en el derecho privado, aunque con una serie de variantes relativas 
that historically, the national adjudicators have been inclined to decide that even within a contractual obligation, the public entities exercise administrative attributions. For example, the Constitutional Tribunal has ruled that a concession conferred on a corporation to provide services of forestry management and supervision albeit perfected through a contract in the reality constituted an administrative act of delegation related to non-delegable public prerogatives and as such it was subject to its authority. ${ }^{948}$

\begin{abstract}
a la libertad de las partes en cuanto a su ejecución y extinción y al hecho de que la administración no goza de la libertad de elegir con quien contratar, sino que tal decisión se determina en la ley, por lo que, mientras el acto administrativo es unilateral y no volitivo, el contrato administrativo refleja una voluntad bilateral, aunque con ciertas limitaciones, tal como lo señaló el Pleno de este Tribunal en la Resolución No. 201-2000-TP, tomada en el caso No. 172-2000-RA;"
\end{abstract}

See, Resolución No. 008-2003-AA, R.O. 206, 7-XI-2003.

${ }^{948}$ Nevertheless that the Constitution of 1998 has been accused of being extremely open to privatization and delegation of public prerogatives, the Constitutional Tribunal applying this framework took restrictive decisions as to the operationalization of such model:

“(...)Así las cosas, es indiscutible que la delegación de servicios públicos a la iniciativa privada es un acto administrativo, que se expresa en la formalidad de un contrato, pero la esencia misma de la delegación es un acto administrativo incuestionable. En consecuencia, que se impugne la inconstitucionalidad del acto administrativo consistente en la formalidad del contrato de Delegación a la Iniciativa Privada de la Prestación de Servicios Técnicos de Administración y Supervisión Forestales, celebrado entre la Ministra del Ambiente, en representación del Estado ecuatoriano, y la Compañía SGS del Ecuador S.A. es de plena competencia del Tribunal Constitucional, sin necesidad de entrar a las citas doctrinarias del principio 'iura novit curia', pues la resolución que se expida debe referirse, exclusivamente, a los actos impugnados expresamente por el accionante, en la especie, el acto administrativo de delegación a la Compañía SGS de la prestación de servicios técnicos de administración y supervisión forestales y al pago de una tarifa a favor de la compañía contratista por parte de los usuarios;

(...)Que, el artículo 249 de la Constitución de la República dispone que 'Será responsabilidad del Estado la provisión de servicios públicos de agua potable y de riego, saneamiento, fuerza eléctrica, telecomunicaciones, vialidad, facilidades portuarias y otros de naturaleza similar. Podrá prestarlos directamente o por delegación a empresas mixtas o privadas, mediante concesión, asociación, capitalización, traspaso de la propiedad accionaria o cualquier otra forma contractual, de acuerdo con la ley'. La enumeración que hace esta disposición constitucional, si bien no es taxativa en atención a la expresión 'otros de naturaleza similar', tampoco significa que cualquier actividad de la Administración pueda ser considerada como servicio público, en los términos de la norma, y que esté permitida la delegación de cualquier tipo de atribución de la Administración. Una enumeración ejemplificativa siempre tiene presente un concepto común amplio y unos caracteres en los cuales comulgan los elementos ejemplificados, aunque en las circunstancias o los accidentes difieran. Esto a diferencia de la enumeración taxativa en la cual aparecen elementos que demuestran la exclusividad de la indicación. En la enumeración ejemplificativa, el intérprete a través de la hermenéutica, puede analizar los elementos del caso particular y determinar si se encuentran reunidos en él los conceptos y caracteres comunes a los cuales se refiere el legislador, pero está vedado separarse, precisamente, de aquellos conceptos y caracteres en que comulgan los elementos de la enumeración, que constituyen un aspecto reglado; ..."

See, Resolución No. 008-2003-AA, R.O. 206, 7-XI-2003. 
Although the direct constitutional scrutiny of contracts would appear to be in principle foreclosed, the administrative or judicial decisions issued as a result of the application of contractual provisions could be impeached, provided there was violation of constitutional rights. For instance, the Constitutional Court has declared that a judicial ruling disregarding the parties' agreement to submit a contractual dispute to a particular judicial forum constitutes a violation of the due process. ${ }^{949}$

As explained alongside the previous chapters, the State's intervention in fields and transactions traditionally regarded as falling within the realm of private autonomy, has expanded the monitoring powers of administrative agencies and the use of mechanisms of constitutional redress enshrined by the Constitution of 2008. Curiously the main users of the extraordinary writ of protection have been state organs due to the statutory enlargement of the plain meaning of the relevant constitutional provision, by virtue of which, State entities are also deemed as "persons" and as such bearers of constitutional rights. Since this novel constitutional redress can be invoked against judgments and judicial decisions with the effect of "res judicata", State organs have argued the violation of their constitutional rights, especially those related to due process in order to overturn adverse final judgments. The unconstrained resort of such a constitutional writ by State entities has opened very controversial mechanisms of judicial interpretation. In a remarkable case, the Constitutional Court reversed a Supreme Court's judgment where a State organ (previously a State owned corporation governed by private law), was the losing party in a civil proceeding derived from a contractual breach. The parties signed an Exclusive Lease Agreement for the use of the lightning network under the management

\footnotetext{
949 Identically to the American Convention of Human Rights (Art.8), the Constitution enlists several guarantees of the right to due process. According to the Constitutional Court the Act of Consumer Protection provided for a civil redress to the conflicts arisen out from the relations between traders and consumers. This legal provision in conjunction with a contractual agreement renders incompetent any distinct judicial authority entertaining such conflict. As a consequence, the judicial process aired before a different court to that statutorily and contractually determined, violated the right to a fair trial before a competent tribunal:
}

(...) Por lo expuesto, esta Corte Constitucional concluye que en el presente caso se distrajo del juez competente el conocimiento de un tema que, por la materia y por acuerdo expreso de las partes, correspondía ventilarse ante un Juzgado Civil y no ante el intendente general de Policía, deviniendo en la vulneración del derecho constitucional al debido proceso en relación a la garantía que dispone que solo se podrá juzgar a una persona ante un juez o autoridad competente y con observancia del trámite propio de cada procedimiento, no pudiendo desconocerse entonces el orden jurídico establecido y la competencia que cada juez tiene en cuanto a cada asunto litigioso.

Extraordinary writ of constitutional protection, Sentencia No. 055-14-SEP-CC, Pleno de la Corte Constitucional, R.O. 237-S, 02-V-2014. 
of the referred State owned enterprise. Shortly after the entry into force of this contract (January 2005), the State owned enterprise notified the Contractor that the exclusivity clause was against the Constitution of 1998 and in consequence it decided to unilaterally suppress it from the contract. By doing so, the Provincial Court and the Supreme Court concluded that the State owned enterprise breached the contract. When it filed the extraordinary writ of protection, the State organ claimed the violation of the constitutional principles of legal certainty and free competition due to the judgments upholding a contractual clause against the legal framework. Additionally, it requested the Constitutional Court to set a precedent in favour of consumer rights allegedly affected by anti-competitive behaviour. Given that the Constitution of 2008 was not in force when the contract was signed and the corresponding proceedings were initiated, the Constitutional Court stepped into the shoes of the judicial authorities that decided the case, determining what constitutional provisions in force during such a period they should have had to apply in order not to violate the principle of legal certainty. By acknowledging that no violation of the Constitution of 2008 could have been inflicted prior to its promulgation, it asserted that a constitution does not embody "provisions but values and principles". 950 As a consequence, the Court construed that the principles of legal certainty and free competition had been enshrined by both Constitutions (1998-2008). According to the Court, the fact that the extraordinary writ of protection was not comprised by the Constitution of 1998, was negligible since the principles referred to remained violated by the judicial decisions examined. Given "the primary end of the new Ecuadorian State consisting of guaranteeing the constitutional rights" and the direct

950 The Constitutional Court justified the retroactive application of the extraordinary writ of constitutional protection on the basis of the rights of legal certainty and free competition:

\footnotetext{
En este sentido, la Corte estima que si bien es cierto que la sentencia impugnada se emitió bajo la vigencia de la anterior Constitución y por consiguiente no se pudieron haber vulnerado disposiciones de la actual, es menester señalar que una Constitución, antes que normas, contiene valores y principios, los que son comunes tanto en la anterior como en la actual Carta Constitucional, como son: el derecho a la libre competencia y el derecho a la seguridad jurídica, los que son acusados de infringirse en la sentencia. Por tanto, puestas en marcha las garantías jurisdiccionales que no contemplaba la Constitución de 1998, pero sí la actual, la acción extraordinaria de protección procede, a fin de adoptar el control de constitucionalidad de las decisiones judiciales, puesto que la finalidad primordial del nuevo Estado ecuatoriano es ser garante de los derechos constitucionales, los cuales, de conformidad con los numerales 3 y 5 del artículo 11 de la Constitución, son de directa e inmediata aplicación y plenamente justiciable, por y ante cualquier servidor público, jueza o juez, sin que puedan establecerse o exigir requisitos adicionales. Por tanto, si se presume que los derechos y principios constitucionales están siendo vulnerados hay que dar paso a esta acción a fin de adoptar el control de constitucionalidad de las disposiciones judiciales.
}

See, Sentencia No. 005-13-SEP-CC, Corte Constitucional, R.O. 933-S, 15-IV-2013. 
application of the same by any authority, the extraordinary writ was deemed admissible. Consequentially the Court found that the exclusivity contractual clause violated the provisions setting out the principles of free competition in both Constitutions. By disregarding such a principle explicitly embodied in the Constitution of 1998, the Court found that the judicial authorities violated the principle of legal certainty and due process. ${ }^{951}$ As noted, the economic model of the Constitution of 1998 ("social market economy") differed considerably from that established by the Constitution of 2008 ("social and solidarity economy"). This is clear with the wording of the provisions regulating the scope of the State's attributions within the economy. Whereas in the former Constitution, the State's prerogatives were oriented to facilitate and promote competitive markets, in the current constitutional framework there may be identified unlimited intervention powers in any type of economic transaction. In fact, the Constitution of 2008 does not explicitly acknowledge the principle of free competition, as the Constitution of 1998 did. Moreover the Constitution of 1998 subordinated the sanction of anticompetitive behaviour to the terms prescribed by law, as the constitutional guidelines to tackle such conduct are not self-executing. The Constitutional Court hypothetical solution suggests that the judicial authorities should have dismissed the application of a contractual clause lacking a legal basis mandating to do so thereby contravening the same constitutional provision requiring legislative action to impose such burdensome effects. By doing so the judicial authorities would have incurred in the violation of one of the

951 The Constitutional Court declared violated the principle of legal certainty because the courts that entertained the case were not mindful of the principle of free competition:

En el presente caso, los legitimados pasivos no tomaron en consideración todos los antecedentes necesarios para tomar una decisión adecuada en el caso, por lo que se vulneró además el derecho a la seguridad jurídica, previsto en el artículo 82 de la Carta Magna, que dispone: 'El derecho a la seguridad jurídica se fundamenta en el respeto a la Constitución y en la existencia de normas jurídicas previas, claras, públicas y aplicadas por las autoridades competentes', ya que los jueces integrantes de la Sala de lo Civil, Mercantil y Familia de la Corte Nacional de Justicia inobservaron la disposición constitucional vigente a la fecha de suscripción del contrato de arrendamiento de postes, comprendida en el artículo 244 numeral 3 de la Constitución de 1998, que disponía: '...Promover el desarrollo de actividades y mercados competitivos. Impulsar la libre competencia y sancionar, conforme a la ley, las prácticas monopólicas y otras que la impidan y distorsionen', fias negrillas son nuestras). Como se observa, existía una disposición constitucional explícita contraria a las prácticas monopólicas de mercado, y que en este caso debieron observarse desde el momento mismo de la suscripción del contrato, cuestión que, como se analizó anteriormente, se enmendó con la suscripción del adendum, dejando sin efecto el inconstitucional segundo inciso de la cláusula quinta del contrato referente a la duración del mismo y a la improcedente y posteriormente extinta exclusividad, la cual vulneraba derechos fundamentales consagrados en la Norma Suprema.

See, Sentencia No. 005-13-SEP-CC, Corte Constitucional, R.O. 933-S, 15-IV-2013. 
fundamentals of the right to liberty also enshrined by both Constitutions, whereby no one is obliged to do something forbidden by law or refrain from doing something not forbidden by law. ${ }^{952}$ Taking into consideration that the Act for the Regulation and Control of the Power Market was promulgated on 2011, there are no records showing that any judicial or administrative authority had directly applied a sanction tantamount to the dismissal of a contractual clause by solely relying on the Constitution.

\subsubsection{Constitutional Control and Investors' Contractual Rights}

Despite the fact that in the cases stated above, the Contractors were not international investors protected by an International Investment Agreement, this interpretation shows the exorbitant powers asserted by the Constitutional Court, which under the label of "normative harmonization", has indiscriminately cherry picked provisions either in force or derogated in order to adjust any legal transaction according to the terms it believes would conform to the "new constitutional paradigm". As underscored in the second Chapter, the dispute stems from the investment contract for the construction and operation of the new airport of Quito, that escalated to a notice of ICSID arbitration and later its discontinuation due to the renegotiation of the contract, revealed the exorbitant powers of the Constitutional Court to overturn any sort of decision, either public or private, with retroactive effects. When the Constitutional Court impeached the constitutionality of the General's Attorney decision that deemed airport charges as private resources, it notably declared as unconstitutional creating, modifying, increasing or extinguishing taxes or regulatory fees through contract. Given that the airport charges were one of the principal factors of the project's financing structure, the Constitutional Court's decision prompted a contractual renegotiation. Additionally and because the Attorney General's ruling was issued under the Constitution of 1998, the Constitutional Court had to interpret whether the decisions constituting res judicata issued under the former constitution were binding to it. In answering this enquiry, the Court drew a line between both constitutions, asserting that the principles embodied by the same were "irreconcilable" and as such incapable of

952 Constitution of 2008 :

“Art. 66.- Se reconoce y garantizará a las personas:

29. Los derechos de libertad también incluyen:

d) Que ninguna persona pueda ser obligada a hacer algo prohibido o a dejar de hacer algo no prohibido por la ley." 
harmonization even by resorting to the "most sophisticated methods of constitutional interpretation":

(...) the philosophical foundations that inspired the rulings referred to, compared to those supporting the current constitutional engineering, have such opposite genesis, that the former stands for the minimum role of the State and of the structural dimension of the world's life and in the contrary, magnifies the social dynamic subject to the market forces of supply and demand and to the man's desires as an individual agency that overlays the collective dimension of development. To this respect, both the evolution of the doctrinaire-scientific thought and of the legal-political thought of a nation as the Ecuadorian, progresses towards the advent of a new paradigm that change substantially the reality and the nuclear characteristics of the facts and situations upon which the rulings examined were issued. ${ }^{953}$

This statement reveals the supreme value given to the Constitution not only as the main source of legal obligations and limitations to the exercise of public authority but also as a set values aiming to model individual conducts. Clearly as of the Constitution of 2008 promulgation, individual freedom has been subordinated to collective welfare as defined by the State. By the same token, asserting that a later normative change modifies prior factual situations would be equal to say that a mere normative reform substitutes the reality and its facts developed under a previous context. In the ruling examined the Constitutional Court concluded:

The resolutions of the former Constitutional Tribunal that acquired the res judicata dimension, although they could be in conformity with the Constitution of 1998 and with the economic thesis that dominated the 1990s, could become incongruent under the current constitutional principles. In that sense, deeming as non-binding precedents the former Constitutional Tribunal's resolutions vested with res

953 Categorically, the Constitutional Court declared that the principles sustaining the Constitution of 1998 and the Constitution of 2008 are irreconcilable:

En ese sentido, la Corte estima que los principios que sustentan las Constituciones de 1998 y 2008 son irreconciliables, no pueden mantenerse, ni aun poniendo en práctica los métodos más sofisticados de interpretación constitucional, pues los fundamentos filosóficos que inspiraron a las sentencias mencionadas y aquellos fundamentos que sostienen la ingeniería constitucional vigente, tienen un génesis tan opuesto, que el primero pregona el rol mínimo del Estado y de la dimensión estructural de la dinámica del mundo de la vida y por el contrario, magnifica la dinámica social sometida a las fuerzas del mercado y de la libre oferta y demanda y a los designios del hombre como agencia individual que se superpone a la dimensión colectiva del desarrollo.

Al respecto, la evolución del pensamiento científico doctrinario, así como del pensamiento jurídico político de una nación como la ecuatoriana, transita hacia la emergencia de un nuevo paradigma que cambia sustancialmente la realidad y las características nucleares de los hechos y situaciones en las que en un momento se basaron las sentencias, sujetas a crítica.

See, Sentencia No. 003-09-SIN-CC, Suplemento-Registro Oficial 644, 29 de julio de 2009. Own translation. 
judicata effects is by no means an arbitrary decision of this Court, because, on the contrary, this is aimed to sustain the current Constitution supremacy and eventually correcting the error of law and the injustice of the result. ${ }^{954}$

Perhaps due to the fact that the concessionaire of Quiport was not a party within this constitutional proceeding nothing was said concerning the stability of the investment contract and its protection under Canada-Ecuador BIT. In any event, this standing shows the parochial and absolute interpretative approach of the Court advocating the unrestricted supremacy of the Constitution.

In a later constitutional action ("acción de incumplimiento"955) brought by a citizen demanding the compliance of the decisions commanded by the Constitutional Court within the ruling declaring the unconstitutionality of the "privatizing" of the airport charges previously examined, the concessionaire acting as Respondent, acknowledged that the promulgation of the Constitution of 2008 entailed the obligation of bringing into conformity the signed agreements with the new constitutional framework. According to the Respondent such fulfilment of obligations began with the transformation of the State owned entity, formerly governed by private law, to a public enterprise. It further recognized that the public powers should adapt their "acts and contracts, either public or private to the current constitutional framework, otherwise they could be declared null and void, pursuant to Article 424 of the Constitution". When the Constitutional Court

\footnotetext{
954 The Constitutional Court justified the deprivation of res judicata effects to the constitutional rulings declared by the former Constitutional Tribunal on her obligation to bring any public decision into conformity with the economic values of the Constitution of 2008:

\begin{abstract}
Las resoluciones del ex Tribunal Constitucional, que adquirieron la dimensión de ius iudicata, si bien podrían estar de acuerdo con la Constitución Política de 1998 y con las tesis económicas que dominaron en la década de los noventa, podrían devenir en incongruentes bajo los principios jurídicos constitucionales actuales. En ese sentido, la no obligatoriedad de precedente respecto de las resoluciones del ex Tribunal Constitucional pasadas en autoridad de cosa juzgada, de ningún modo es una resolución arbitraria de esta Corte, pues por el contrario, se trata de sustentarse sobre la base de sostener la supremacía de la constitución vigente y corregir eventualmente el error de
\end{abstract} derecho y la injusticia del resultado.
}

See, Sentencia No. 003-09-SIN-CC, Suplemento-Registro Oficial 644, 29 de julio de 2009. Own translation.

${ }^{955}$ Constitution of 2008:

“Art. 93.- La acción por incumplimiento tendrá por objeto garantizar la aplicación de las normas que integran el sistema jurídico, así como el cumplimiento de sentencias o informes de organismos internacionales de derechos humanos, cuando la norma o decisión cuyo cumplimiento se persigue contenga una obligación de hacer o no hacer clara, expresa y exigible. La acción se interpondrá ante la Corte Constitucional. “

See, Sentencia No. 001-14-SIS-CC, Pleno de la Corte Constitucional, Suplemento Registro Oficial 184, 14 de febrero de 2014. 
analyzed whether the alleged non-compliance had actually taken place, it referred to the Strategic Alliance Agreement signed between the Municipality of Quito and the concessionaire whereby the Parties declared their interest to "align the contractual documents and the concession contract to the current constitutional framework, in the light of the ruling No. 003-09-SIN-CC (...)”. The Court also referred to the judicial decision that it adopted pursuant to the ruling aforementioned and the consultation made by the General Comptroller of the State regarding the timeframe and legal mechanisms allowed for the renegotiation demanded:

"...during the transition and until the complete alignment of the pre-existing legal situations to the new constitutional and legal framework, the Municipality of Quito is the holder of the public funds collected from airport charges; and the obligation of bringing into conformity the acts and the contracts, either public or private, to the current constitutional framework must be subject to the process and timetable set by the competent authorities, legal representatives and contractual parties, as appropriate (...) Concerning the legal mechanisms to carry out such adjustment (...) the managers of such public funds may apply all the financiallegal tools comprised by the Ecuadorian legal system, in order to ensure the efficient, effective and adequate compliance with the judgment, it being understood that the proper execution of the activities of collecting and administering such funds involves a process in which different stakeholders interact (concessionaires, public and private financial institutions, municipalities and the Comptroller General of the State) in the corresponding stages of collection, custody, delivery, administration, disposition and control".956

The Constitutional Court dismissed such constitutional action taking into consideration that the Municipality of Quito through its public enterprise assuming the management of the new airport of Quito, signed a Strategic Alliance Agreement with the concessionaire. Thereby it was stipulated that the airport charges declared as public funds by the constitutional ruling examined, should be managed and collected by the municipality and its relevant public enterprise. Within this alliance, an agreement for the collection of airport charges was signed, whereby the Municipality of Quito designated "unconditionally and irrevocably" the concessionaire as the collector of such charges, as it was obliged to transfer such resources to a trust constituted by the Municipality and its public enterprise. By doing so, the Constitutional Court concluded that the Municipality

\footnotetext{
956 The General Comptroller of the State consulted the Constitutional Court concerning the timeframe imposed to the Municipality of Quito to adjust its acts and contracts to a the new constitutional framework. He also consulted whether the Municipality and its public enterprise were entitled to use the tools comprised in the national framework, like management or guarantees trusts, in order to carry out the renegotiation process.
}

As result, the Constitutional Court took the aforementioned decision on September 29, 2009. 
and the concessionaire acted in harmony with the new constitutional framework and the Act on Public Enterprises.

In this context, it can be observed the solipsistic approach adopted by the Constitutional Court when it comes to the formal control of constitutionality. Although a fundamental change of circumstances was not claimed within this review, it is clear that the constitutional transformation was understood as a sufficient basis with which to trigger a contractual renegotiation. And the private or public nature of the legal relationship seems not to be a limitation that could bar the Constitutional Court's intervention. In this line, Jenny Small harshly criticizes the formalistic standing adopted by the Court in its original ruling that was corroborated in its later judicial decision, wherein it did not observe that the airport charges were managed and collected by the concessionaire provided they were transferred to a trust in the light of the Strategic Alliance ${ }^{957}$ :

The Constitutional Court attempted to legitimize its decision, not through reason, but through enumerating procedural constitutional provisions. A large portion of the opinion was a justification of the court's authority to find Quiport in violation of the Constitution. The procedural provisions cited by the Court created a gloss of authority for what was otherwise a retroactive attempt to extort money, estimated to be at least USD \$ 200 million, out of the project. ${ }^{958}$

It has been categorically affirmed by the legal counsellors involved in the complex process of the renegotiation of this contract, that the investment protection agreement signed with the Republic of Ecuador in 2003 was the leverage that allowed the investors to reach a successful renegotiation settlement ${ }^{959}$. The Ecuadorian government had no choice but to accept that the "affirmed investment protection and access to ICSID

957 The US Embassy cable (09QUITO899) of October 23rd, 2009, filtered by Wikileaks, shows the position of Augusto Barrera, former Mayor of Quito, whereby the practical effects of the contractual changes purported, remained the same as to the management and collection of the airport charges:

"He emphasized that since the municipal government had kept airport fees in the hands of Quiport and the lenders, he expected the lenders to maintain funding for new airport construction. At the end of the meeting Barrera admitted that the airport access roads were likely "two and a half" years from completion (although he estimated two years during a subsequent radio interview) but added that the new airport was now 8 months behind schedule. He blamed Quiport rather than the renegotiation process for the delay."

See, https://wikileaks.org/plusd/cables/09QUITO899 a.html, Website visited on August 2016.

958 Small (Jenny), "Project Finance Investors: Solution to Populismo", 10 BYU Int'l L. \& Mgmt. R. 71 (2014), 86-87 pp.

${ }^{959}$ See, Hamilton (Jonathan C.), "Solving Complex Problems: Crisis Management, Complex Negotiations and the New Quito International Airport", Latin Arbitration Law,

http://www.latinarbitrationlaw.com/solving-complex-problems-crisis-management-complex-negotiationsand-the-new-quito-international-airport/, Website visited on August 2016. 
international arbitration" were part of the renegotiation package. As Jenny Small affirms:

Ecuador's populist trend poses a significant risk to all investors in the region, but project financiers are in a position to minimize the risk by negotiating for strong contracts that include a stabilization clause like one in Quiport's agreement. Stabilization clauses protect investors the clause allow investors "to control the future". Stabilization clauses do this by shielding investors through international and domestic enforcement as well as by providing a basis for insurance recovery. Quiport's stabilization clause was a significant reason why the settlement and renegotiation of the airport was so successful.

(...) Ecuador's opting out of ICSID and BITs has limited the traditional enforcement of stabilization clauses; however these limitations do not entirely negate stabilization clauses as a significant protection. Stabilization clauses can also be effective if the concession agreement somehow "internationalize [s]" itself. For example, investors may still conceivably enforce their contracts under international law through a United Commission on International Trade Law (UNCITRAL) arbitration or through the Arbitration Institute of the Stockholm Chamber of Commerce." 960

In fact those who criticised the decisions prompted by the Ecuadorian government assert that "populism" is a political risk that has to be taken into account when investing in the country. In this sense, alternatives like stabilization clauses, policies of political risk insurance and distribution of risk through project finance may minimize the effects of political driven decisions. The interpretative line of the Constitutional Court shows a strong political connection with the Executive's goals. Although it could be conceded that the "airport fees were a public resource because they were the type of funds that only a public institution can administer" 961 deeming in consequence, the concession agreement as unconstitutional, it is surprising that such alleged violation that threated such a complex long-term project, could have been overcome solely by constituting a trust whereby the management and collection of the fees, whatever their nature, always remained in control of the concessionaire. Contrasting roughly with the main flaws attributed to BITs with the contractual tools that actually pushed the State to renegotiate, namely the stabilization and ICSID arbitration clauses, it can be assumed that both delocalize the disputes from local influence, hence undermining local administration of justice, a "key manifestation of territorial sovereignty", ${ }^{962}$ What criterion the Court normally employs to prioritize its

\footnotetext{
960 Small (Jenny), "Project Finance Investors: Solution to Populismo", 10 BYU Int'l L. \& Mgmt. R. 71 (2014), 87-88 pp.

961 Small (Jenny), "Project Finance Investors: Solution to Populismo", 10 BYU Int'1 L. \& Mgmt. R. 71 (2014), 86 p.

${ }^{962}$ See, Dictamen No. 032-13-DTI-CC, Caso No. 0016-13-DTI-CC, 26 de noviembre de 2013.
} 
attention in one particular violation to the Constitution over another within the same case is highly speculative. However, it can be seen that it normally makes prevail the form over the substance depending on the political priorities at the moment of entertaining and resolving a constitutional conflict.

This concern is significant in the case of the apparent absolute prohibition on submitting the State to international arbitration through "international instruments" within contractual or commercial disputes involving foreign persons. Regardless of the technicalities surrounding the treaty and contract based arbitration the main allegation against BITs was their use as a tool to circumvent the national adjudicative jurisdiction on regulatory issues (non-arbitrable). Such "surrender" pursuant to the insular notion embraced by the Court would take place insofar as an adjudicator different to a local court entertains a dispute. Hence, the legal mechanism used to perfect such a"waiver" would be negligible (treaty, regulation or contract). The dispute previously examined confirms that the Constitutional Court uses different standards for similar issues doing little to contribute to the coherent and uniform interpretation of the Constitution. Moreover, the posterior clauses inserted into the Organic Code of Planning and Public Finances, the statutory authorization to submit disputes to international arbitration within investment contracts embodied by the Organic Code of Production Trade and Investment as well as within the Act of Public-Private Partnerships, together with the Attorney General's consistent practice of issuing enabling rulings to international dispute settlement either judicial or arbitral, indicates the comfort of the domestic rule makers and administrators with the submission of controversies with foreign persons to international venues. Thus, it is unclear whether contractually consenting the submission of the State to international arbitral tribunals would actually disturb the fundamental balance between the obligations of the parties.

\subsubsection{Consent To Arbitration Under Changed Circumstances}

Taking as an example the French administrative framework, upon which most LatinAmerican countries have designed their Public Law regime, it is interesting that whereas the civil courts have applied restrictively the principle of sanctity of contracts (pacta sunt servanda), in the case of public contracts, the administrative courts have been more prone to adapt public contracts to changed circumstances (rebus sic stantibus): 
By means of the judicially developed théorie de l' imprevision (doctrine of the unforeseen events), the French administrative courts are prepared to "adapt public contracts,"i.e., contracts performed in the public interest and subject to the public administrative law (as opposed to the general commercial law), to change circumstances. The seminal case is Gaz de Bordeaux, which was the subject of a famous decision by the Conseil' d Etat (State Council) of March 30, 1916.

In Gaz de Bordeuax, the Conseil d'Etat directly contradicted the Cour de Cassation. It held that the public interest in the performance of public contracts is more important than in purely private agreements in order to assure the continued supply of public services to the community. Contract adaptation thus is intended to avoid an excessive economic loss suffered by a party supplying such services endangering the orderly and timely performance to the "public contract". This objective generally is reached through a price revision agreed upon by the parties or, failing such agreement, determined by the courts. The extra-costs are assumed by the French government. ${ }^{963}$

Pursuant to this interpretation, it may be observed that the public interest is balanced between the guarantee of the continued provision of public services and the assumption of the economic loss by the government. Accordingly, the protection of the public interest goes beyond mere legal assessment by incorporating criteria of convenience both in favour of the community and the contractor, assumed as a collaborator for the achievement of public goals. In contrast and as noted in the criticisms referred to above, the Constitutional Court has privileged a literal and radical enforcement of constitutional provisions individually considered, disregarding an integral interpretation able to preserve the contractual relationship and to allocate equitably the burdens derived from a normative change. According to Dretta, the notions of pacta sunt servanda and rebus sic stantibus as understood within lex mercatoria have predominantly evolved within the realm of public international law, and two theories stand out with relation to the latter principle: 1) the contractualistic approach, and;2) the objective approach. According to the author, the former consists of elucidating the intention of the parties arguably construed upon an essential modified factual situation and the latter, concerned with the determination as to whether the purpose of the agreement can still be achieved in view of the changed circumstances. In this context, it has be to ascertained whether a supervening prohibition of treaty based protection could undermine the will and purpose of the parties as expressed in the contractual relationship at issue. ${ }^{964}$ Acknowledging that the

\footnotetext{
${ }^{963}$ Draetta (Ugo), Lake (Ralph B.) and Nanda (Ved P.), Breach and Adaptation of International Contracts: An Introduction to Lex Mercatoria, Butterworth Legal Publishers, 1992, 184 p.

${ }^{964}$ The authors explain the two main theories developed within Public International Law modulating this doctrine:
} 
attributions exercised by the State and its entities stem from the law, it could be in principle affirmed that a supervening constitutional proscription of a particular prerogative could undermine both the intention and the purpose undertaken by the State when it signed the contract. However, this interpretation would clash with a seminal principle of law, namely, non-retroactivity. Moreover, and in the light of the fact that the declaration of unconstitutionality exerts its effects over the BITs and the legal acts directly founded thereon, it is unclear whether a contractual clause with identical effects to the treaties dispute provisions could also be found as being in contradiction with the Constitution on similar grounds. In this way, it has to be recalled that the offer to arbitrate contained in a treaty differs from those embodied in domestic legislation and in contracts:

In that sense, the 'offer to arbitrate' made according to national investment codes is broader than the offer to arbitrate made by virtue of BITs or investment contracts. Consent to arbitration through BITs is an offer limited to foreign investors whose states of nationality have concluded a BIT with the host state against which they intend to initiate arbitration proceedings. In the same vein, consent to arbitration through investment contracts is an offer strictly limited to foreign investors that are parties to those contracts. By contrast, consent to arbitration through national investment legislations constitutes an offer made to the foreign investment community as a whole with no real possibility of individualizing the scope of the offer. This is a particular feature of foreign investment legislation, which should be taken into account by states when deciding to draft such pieces of legislation. ${ }^{965}$

\footnotetext{
There are two notions of rebus sic stantibus, which reflect two different theories under public international law. According to the first notion, rebus sic stantibus has a contractual nature, similar to the corresponding notions of frustration, hardship imprevision, etc., with respect to contracts between private parties. Acknowledging that for the interpretation of the treaties it is also necessary to search for the real intention of the parties, rebus sic stantibus is seen in this context as evidencing the parties' intention to consider the continuation of a given factual situation existing at the time of the treaty stipulation as essential for the continued existence of their obligations. Hence a fundamental change of a factual situation would justify the termination or revision of a treaty.
}

Some of the supporters of this contractualistic approach to rebus sic stantibus shift the emphasis to the doctrine's objective elements, as opposed to the search for the subjective intention of parties. According to them, the doctrine would operate in the sense of allowing the termination or revision of a treaty when its purpose can no longer objectively be achieved because of the change of the surrounding circumstances existing at the time of its stipulation

Draetta (Ugo), Lake (Ralph B.) and Nanda (Ved P.), Breach and Adaptation of International Contracts: An Introduction to Lex Mercatoria, Butterworth Legal Publishers, 1992, 187-188 pp.

965 Mbengue Makane (Moïse), "Consent to Arbitration Through National Investment Legislation, Investment Treaty News", International Institute for Sustainable Development, https://www.iisd.org/itn/2012/07/19/consent-to-arbitration-through-national-investment-legislation/

Website visited on August 2016. 
As clearly explained by Mbengue, the scope of the offer to arbitrate differs depending on the instrument upon which this is made. Hence, the offers to arbitrate included in the BITs as interpreted by the Constitutional Court would be barred prospectively, remaining unaffected while the corresponding treaties are not denounced. By the same token any consent to investment arbitration agreed upon long-term contracts would be enforceable as long as the parties do not rescind or modify it according to the contractual stipulations. This understanding is aligned with the Attorney General's standing that distinguishes between treaty based and contract -based commitments. In any event, it is inaccurate to affirm that whenever the State offers its consent to arbitrate through contract it does so exclusively exercising non-sovereign powers (acta jura gestionis). Given that international and domestic courts have fairly applied the long-lasting distinction between acta jura imperii and acta jura gestionis, it can be asserted that the dichotomy stems from this private-public distinction and constitutes a relatively common legal notion. Therefore it is shortsighted of the Attorney General to reasoning that implies that the sovereign or commercial nature of the State's action is given solely by the instrument through which the same manifests its will.

\subsection{Reaction to Changed Circumstances}

\subsubsection{Constitutional Control of Legislative Measures Changing the Economic Terms of Oil Exploitation}

The avalanche of investment disputes triggered by Law 2006-42 ${ }^{966}$ that raised the State's share over the extraordinary prices of oil allegedly in breach of the stipulations of

\footnotetext{
966 The Ecuadorian Congress passed the Law No. 2006-42 amending the Hydrocarbons Law on 29 March 2006, This law took effect on April 25, 2006. According to the Murphy Tribunal, the main changes purported by this amending Law were the inclusion of the entitlement of the State to participate in the surplus of oil sale prices and the incorporation of the minimum rate of $50 \%$ as the State's participation in such difference:
}

82. On 29 March 2006, the Ecuadorian Congress passed Law 42. It took effect on 25 April 2006. Law 42 applied to all investors holding participation contracts. It amended Article 44 of the Hydrocarbons Law so as to entitle the State to receive from oil companies with participation contracts what was described as "participation in the surplus of oil sale prices".

83. Law 42 also amended Article 55 of the Hydrocarbons Law, thereby granting the State a participation of at least $50 \%$ of the "extraordinary income" arising from the price difference between the then prevailing oil price and the oil price prevailing at the date the participation contracts were concluded, multiplied by the number of oil barrels:

The State's participation in the surplus of oil sale prices, which have not been agreed upon or foreseen.-.Contractor companies that have current participation contracts with the State 
the Share Contracts concluded on the second half of the 1990s, shows the risk which arises from using sovereign mechanisms to modify contractual terms in which the State has made commitments through its different instrumentalities. In May 2006, two challenges were filed against the constitutionality of the law referred to, which were dismissed by the Constitutional Tribunal applying the Constitution of $1998 .{ }^{967}$ In its decision, the Constitutional Tribunal mainly contrasted two provisions, which in one side, prohibited the unilateral modification of the public service contracts enlisted therein (Art. 249), and in the other, provided for the State's attribution to grant special guarantees and securities to further contracts with the object that their clauses be shielded from legal or regulatory modifications (Art. 271). The Tribunal concluded that not being the Contracts for Hydrocarbon Exploration and Crude Oil Exploitation within the category of public service contracts as set out by the aforementioned constitutional provision (Art.249), they did not automatically enjoy the guarantee of not being affected by further regulatory modifications. ${ }^{968}$ Hence, in the absence of a particular State's commitment to restraining

\begin{abstract}
for hydrocarbon exploration and exploitation, notwithstanding their crude oil participation volumes, when the monthly average FOB Ecuadorian crude oil sale price exceeds the monthly average FOB sale Price prevailing as of the date of execution of their contracts, stated at constant prices as of the month of payment, shall grant the Ecuadorian State a participation of at least $50 \%$ of the extraordinary income arising from the price difference. For purposes of this Article, extraordinary income shall be understood to mean the above described price difference multiplied by the number of oil barrels. The Price of crude oil as of the date of the contract used as a reference for the calculation of the difference shall be adjusted based on the United States Consumer Price Index published by the Central Bank of Ecuador.
\end{abstract}

See, Murphy Exploration \& Production Company - International v. The Republic of Ecuador In The Matter Of An Arbitration Under The Treaty Between The United States Of America And The Republic Of Ecuador Concerning The Encouragement And Reciprocal Protection of Investment Signed On 27 August 1993, Partial Final Award, 6 May 2016.

967 See, Tribunal Constitutional, Resoluciones 0005-06 TC y 0010-06-TC, Suplemento-Registro Oficial 350,6 de septiembre de 2006 .

968 The Constitutional Tribunal limited the State's attribution to unilaterally modify administrative contracts from public services contracts and contracts specifically stipulating regulatory stabilization as provided for by Art. 271 of the Constitution 1998:

Consecuentemente, la ejecución de la potestad de modificación o reforma de los contratos administrativos de que goza el Estado, está vedada, por expreso mandato constitucional, cuando estos tienen por objeto la prestación de servicios públicos; no así en tratándose de los demás casos, en los que la renuncia al ejercicio de tal potestad debe realizarse de forma expresa en el correspondiente contrato administrativo, conforme lo sugiere el artículo 271 de la Carta Política. En definitiva, siendo ese el sentido del artículo 271, no se puede alegar que las normas impugnadas de la Ley Reformatoria a la Ley de Hidrocarburos vulneran el principio de seguridad jurídica, toda vez que el legislador, para aprobar esas disposiciones, tomo en cuenta dicho precepto constitucional. 
itself from further regulatory modifications within specific administrative contracts as established by Art. 271, the adjustment in the State's share profits as mandated by the law challenged did not violate any constitutional right. According to the Tribunal, the fact that the Claimants did not prove that the contracts at issue embodied such a type of commitment, together with the nature of the hydrocarbons categorized as goods of public property and as such out of the right to private property, confirms the State's authority to alter their terms of exploitation and profitability in view of the national interest:

The contemporary theory of public domain has pointed out that the national goods of public use ("bienes demaniales)" are not State property, because the goods of public domain are inalienable, imprescriptible and non susceptible of seizure, in contrast with those upon which rests the right to property. In this sense, Article 1 of Hydrocarbons Law establishes that hydrocarbon deposits and accompanying substances "belong to the inalienable patrimony of the State".

There is no right to property concerning these goods ("bienes demaniales"), because they belong to the whole Nation, upon which the State exercises administrative powers and hydrocarbon deposits are part of such goods. The State exercises such powers directly or indirectly, as in the case of the concession whereby royal administrative rights are created. Ultimately, the State's relationship with such goods ("bienes demaniales"), despite the patrimonyoriented trends ("corrientes patroimonialistas") expressed in the Hydrocarbons Law and the Civil Code, is not of an owner as in the Civil Law but of an administrator who exercises public powers in respect of such goods.

(...) This being said, it is not pertinent to the argument that the rights derived from the petroleum contracts imply the right to property violation, because they may vary, except in the contracts wherein guarantees or assurances had been accorded as provided for in Article 271 of the Constitution. In this case, what the Reformatory Law to the Hydrocarbons Law solely does (Law 2006-42) is establishing the State's share in the oil windfall profits derived from oil sale prices, as a non-renewable resource that have to be exploited in view of the national interest, as mandated by Article 247 of the Constitution." 969

The Tribunal's reasoning advocating the lawful exercise of State's exorbitant powers when it comes to administrative contracts would allow the same to self-judge a change of conditions and in consequence adjust the contractual stipulations, especially those of an economic nature, to the new reality:

Now, beyond the constitutional and legal provisions and notwithstanding that the matter of exploitation of non-renewable natural resources comes closer to the granting of concessions than to the closing of contracts, it has to be borne in mind

See, Tribunal Constitucional, Resoluciones 0005-06 TC y 0010-06-TC, Suplemento-Registro Oficial 350, 6 de septiembre de 2006.

969 See, Tribunal Constitucional, Resoluciones 0005-06 TC y 0010-06-TC, Suplemento-Registro Oficial 350, 6 de septiembre de 2006. Own translation. 
that there are differences between administrative and civil contracts, not only because in the former, one of the participants is the Public Administration, but, essentially, because it acts in the public interest, thereby being allowed the exercise of extraordinary powers emanating from the legal framework which has no equivalent in Civil Law. Thus, the Public Administration is placed in a privileged position before the individual being enabled to exercise prerogatives, which would not have basis within a civil contract. This privileged position allows the Public Administration, as counterpart within an administrative contract, exercising its power to alter or modify the contract. Without prejudice of the principle that a contract validly entered into is binding upon the parties (pacta sunt servanda), the same could be fractured due to the emergence of causes that substantially alter those that were part of the reality or the state of things upon which the signature of the contract were based. ${ }^{970}$

This way, the Tribunal upheld the principle of fundamental change of circumstances as an element that can be independently assessed and consequentially applied by the Public Administration to adapt public contracts in the light of the privileged position it enjoys within public administrative law. As noted, in the absence of a specific contractual commitment of stability as constitutionally allowed, the power to alter directly or indirectly contractual stipulations by any means would remain unaffected. Interestingly, the Tribunal dismissed the allegation that the Reformatory Law at issue was in contradiction with the provisions enshrined in the BITs, thus violating the principles of legal certainty and the supra-legal hierarchy of treaties, because in its opinion such normative antinomy was a legal and not a constitutional conflict, being as such, out of the reach provided for by the constitutional action. It added that even in the case that such a review were likely, should the State be committed to refraining from exercising the power to unilaterally modify the investment contracts as set forth by the Constitution (Art. 271), it should have made such a particular commitment within the treaties at issue. ${ }^{971}$ It also

${ }^{970}$ See, Tribunal Constitucional, Resoluciones 0005-06 TC y 0010-06-TC, Suplemento-Registro Oficial 350,6 de septiembre de 2006. Own translation.

${ }^{971}$ The Constitutional Tribunal refused to examine the alleged violation to BITs because in her opinion, such conflict did not fall within the constitutional action at issue and because these treaties did not contain the State commitment to refrain itself from unilaterally modifying investment contracts :

De conformidad con lo señalado en el considerando precedente, la alegación efectuada en la demanda de que la aplicación de la Ley Reformatoria a la Ley de Hidrocarburos o Ley No. 200642 afectaría instrumentos internacionales, plantea, a la vez, un tema de legalidad, al tratarse de la determinación del valor jurídico de las normas con rango de Ley con normas internacionales que no puede ser dilucidado en una acción de inconstitucionalidad, ya que la misma, como queda analizado, se orienta a proteger el principio de supremacía constitucional. Aún si fuera del caso esta revisión, sería necesario que en todos los convenios bilaterales de protección de inversiones conste una estipulación en virtud de la cual el Ecuador se hubiere comprometido a no hacer uso del poder de modificar unilateralmente los contratos de inversión para la producción destinada al consumo interno y a la exportación, compromiso que el Estado hubiera podido adquirir en virtud del artículo 271 de la Constitución, situación que no han demostrado los accionantes. 
clarified that only human rights treaties can be directly invoked within a constitutional action. In any case, both the grounds of the claimants' allegation and of the Tribunal's decision to dismiss it show the little understanding of both parties as to the nature and scope of BITs. The attempt of the claimants seeking the direct application of BITs as a way to challenge the validity of a domestic law that prima facie do not target specific investors on the basis of nationality appears to be a very bold strategy to stretch the boundaries of protection embodied by such treaties to any kind of companies engaged in the oil exploitation industry through participation contracts. By the same token, what is puzzling is the Tribunal's assertion that it was necessary to have a treaty provision encompassing the State's commitment not to modify unilaterally the investment contracts as identically provided for by the Constitution (Art. 271) in order that the Reformatory Law at issue may be found in violation with the principle of normative hierarchy. On the hypothesis that the Ecuadorian State could have bargained the insertion of such clause in the BITs, the Reformatory Law exerts general effects over the oil companies engaged with the State through a participation contract, regardless of whether they may be qualified as foreign investors covered by a BIT. Accepting such an interpretation would mean that the State would have to extend the application of the commitments agreed upon in the BITs to companies that would not fulfill the requirements ratione materiae and ratione personae established for their coverage. This would be translated into the virtual freezing of the regulatory powers of the State so long they may potentially conflict with the nationals supposedly covered by the BITs, even when such measures were not taken on a discriminatory measure. Such a result would denature not only the action of unconstitutionality but also the BITs' scope of protection. Moreover, assessing a breach of obligations within international investment law is a much more complex process than mechanically confronting normative provisions promulgated at different levels. This assertion is corroborated by investment arbitration awards involving Ecuador, wherein it has been ruled for instance, that not all the agreements signed by a state-owned entity amount to an agreement made by the host state and as such being capable of falling within the definition of investment agreement, whose meaning has to be analyzed in the light of each BIT. As Dolzer and Schreuer illustrate:

Occasionally, tribunals have had to define the term 'investment agreement'. In Duke Energy $v$ Ecuador the Tribunal very narrowly held that such an agreement

See, Tribunal Constitutional, Resoluciones 0005-06 TC y 0010-06-TC, Suplemento-Registro Oficial 350, 6 de septiembre de 2006. Own translation. 
must be entered into by the host state and the foreign investor, and not by a stateowned entity or a local company established by the investor. In Burlington $v$ Ecuador, the Tribunal had to answer the question whether an agreement between the host state and a subsidiary of the claimant incorporated in a third state amounted to an 'investment agreement' between the host State and a national of the other party. In a split decision, following earlier jurisprudence, the Tribunal found that such an agreement was not an 'investment agreement' within the meaning of the US-Ecuador BIT. ${ }^{972}$

Likewise, these interpretations are aligned with the assessment that has to be done to elucidate whether the State when concluding a particular agreement has exercised its sovereign or private capacity. In this line the Tribunal, in the case El Paso Energy International Company v. The Argentine Republic concluded:

"In view of the necessity to distinguish the State as a merchant, especially when it acts through instrumentalities, from the States as a sovereign, the Tribunal considers that the 'umbrella clause' in the Argentine-US BIT [...] can be interpreted in the light of Article VII(1) which clearly includes among the investment disputes under the Treaty all disputes resulting from a violation of a commitment given by the State as a sovereign State, either through an agreement, an authorization, or the BIT [...] Interpreted this way, the umbrella clause read in conjunction with Article VII, will not extend the Treaty protection to breaches of an ordinary commercial contract entered into by the State or a State-owned entity, but will cover additional investment protections contractually agreed by the State as a sovereign, such as a stabilisation clause, inserted in an investment agreement." 973

In the case of the domestic ruling analyzed, it is worth noting the reference to the term "Administration" or "Public Administration" instead of "State" when it comes to the exercise of exorbitant prerogatives to adapt public contracts to supervening changed circumstances. This reference would narrow down the conduct of state organs or instrumentalities as a counterpart within an administrative contract regardless of the branch they belong to (executive, legislative or judiciary). According to the Constitutional Tribunal, the "Public Administration" is entitled to unilaterally alter contractual stipulations provided the public interest so allows. Although this decision may be subject to judicial review, the resolution as such is deemed to be legal and executable until a

\footnotetext{
972 Dolzer (Rudolph) and Schreuer (Rudolph), Principles of International Investment Law, Second Edition. Oxford University Press, United Kingdom, 2014,80-81 pp.

${ }^{973}$ Decision on Jurisdiction, El Paso Energy International Company v. The Argentine Republic, ICSID Case No. ARB/03/15, Decision on Jurisdiction, 27 April 2006, para. 70.

See, "Interpretation of the Umbrella Clause in Investment Agreements", Chapter II, International Investment Law: Understanding Concepts and Tracking Innovations, OECD, 2008, 119 p.
} 
judicial decision overturns its validity. This notion differs with the French case law aforementioned, which sets the courts as the forum to determine such adjustment. Therefore it becomes difficult to categorize whether the Public Administration's prerogative to apply such adjustments as interpreted by the Constitutional Tribunal derives from the contractual relationship being able to be categorized as a manifestation of acta jure gestionis, or on the contrary, such power constitutes the expression of a sovereign act (acta jura imperii). By resorting to mechanisms provided for by the contract for airing any dispute derived therefrom, it could be affirmed that the State-entities would exercise their powers as contractors, which would be acta jure gestionis performed in an official capacity. Again, such appraisal has to be made on a case-by-case basis and most likely the arbitral tribunal's interpretations will differ.

\subsubsection{Assessing the Possibility of Reacting to Changed Circumstances Within the oil Investment Disputes Faced by Ecuador}

Taking as an example the disputes which stem from the application of Law 200642, it has to be underlined that the contractual counterpart was the state owned company, Petroecuador. In this context, the investment disputes revolving around the modification of oil contracts pertained to a bulk of legislative and regulatory measures starting with the promulgation of Law 2006-42. As noted, such sovereign measures had the effect of changing the conditions of the State's participation share, whose variables allegedly did not originally include the fluctuation of oil price. ${ }^{974}$ The fact that the Participation Contracts embody the conditions for the exploitation of a non-renewable resource to which the State acts in its sovereign capacity does not allow the latter to circumvent the corresponding clauses that provide for the relevant mechanisms for their modification or termination. In this context, the application of the contractual stipulations would fall

974 The Tribunal noted the exclusion of the variable price in the calculation formula:

67. According to Claimant, the price of oil was not a variable included in the calculation formula; rather, its participation share was to be based only on the number of barrels produced per day.52 Claimant submits that one of the main goals of the conversion to the Participation Contract was to allocate to the Consortium the risk of fluctuations in the global price of oil: if the price of oil was excessively low, the Consortium had no right to claim that it was not able to recoup its investment. By the same logic, if the price of oil was high, the Government had no right to claim that the Consortium's share of the profits was too high.

See, Murphy Exploration \& Production Company - International v. The Republic of Ecuador In The Matter Of An Arbitration Under The Treaty Between The United States Of America And The Republic Of Ecuador Concerning The Encouragement And Reciprocal Protection of Investment Signed On 27 August 1993, Partial Final Award, 6 May 2016. 
within the category of acta jure gestionis exercised in an official capacity as indicated above. Anyway, such assessment should be done on a case-by-case basis. In the legislative and regulatory measures at issue, was the Executive under whose control fell the state owned companies and in this case Petroecuador, who presented to the Congress the bill to amend the Hydrocarbons Law (President, Alfredo Palacio, March 2006). On July 2006 President Palacio issued the Decree No. 1672, which established the State's participation at a minimum 50\%. ${ }^{975}$ On 18 October 2007, the new President, Rafael Correa, issued Decree No. 662 under Law 42, which increased the "additional participation" to a minimum of $99 \% .{ }^{976}$ Later and exercising its exclusive power to present legislative bills on the matter of taxation, President Rafael Correa submitted to the National Constituent Assembly the bill denominated "Ley Reformatoria para la Equidad Tributaria", which created a 70\% tax on "extraordinary income" from the sale of crude oil to the participation contracts, new or modified entered into from January 1 , 2008 onwards. ${ }^{977}$

This complex context undeniably embedded by a strong presidential influence in the decision making of the further branches shows a long-standing assumption that places the Government as the ultimate representative of the interests attached to the exploitation of non-renewable resources. It was thus extremely difficult to draw a line between the actions exercised either in sovereign capacity or commercial capacity. Thus, the chain of

${ }^{975}$ The Tribunal transcribed the relevant Decree's provision that operationalized the additional participation of the State at a $50 \%$ :

84. On 13 July 2006, President González issued Decree No. 1672, which set the "additional participation" at a minimum of $50 \%$. Section 2 of Decree No. 1672 stated:

The State right to the surplus resulting from oil sale prices not agreed upon or established in the participation Contracts for Hydrocarbon Exploration and Crude Oil Exploitation entered into with the State of Ecuador through PETROECUADOR shall amount to a minimum of $50 \%$ of extraordinary income resulting from the difference between the monthly weighted average effective [FOB] sale price of Ecuadorian oil by the contractor and the weighted average monthly sale price on the date following execution of the abovementioned Participation Contracts, times the number of barrels produced by each contractor, pursuant to the provisions set out in section 4 of these Replacing Regulations.

See, Murphy Exploration \& Production Company - International v. The Republic of Ecuador In The Matter Of An Arbitration Under The Treaty Between The United States Of America And The Republic Of Ecuador Concerning The Encouragement And Reciprocal Protection of Investment Signed On 27 August 1993, Partial Final Award, 6 May 2016.

${ }^{976}$ Decree 662 was issued under Law42-2006 in October 18, 2007.

977 The "Ley Reformatoria para la Equidad Tributaria”, was approved by the Constituent Assembly on December 28, 2007. 
measures that escalated towards the different international arbitral disputes and that were weighed by the different tribunals has little to do with the conduct of Petroecuador, as counterparty of the oil contracts. As noted below, the promulgation of Law 2006-42 shows a turbulent coexistence between sovereign and contractual tools along the life of long-term agreements, exacerbated when the bargaining power is not balanced by objective factors. In view of the initial failed attempts to bring the companies to the negotiation table, the subsequent deployment of sovereign actions attempted to stir the renegotiation of contracts, in such a manner that they incorporate the new economic terms of profit distribution. ${ }^{978}$ Recalling that Law 2006-42 was promulgated prior to the Constitution of 2008, one should note in particular the process of approval it followed, as well as Ecuador's claim of the principle "rebus sic stantibus" as applicable to the hydrocarbon contractual relations, as illustrated in the Perenco award:

89. The cover letter of the Bill stated that it "should be processed as economically urgent" and that its rationale may be summed up "as the recovery of economic equity to the benefit of the State in hydrocarbons exploration and exploitation contracts entered into by the Republic of Ecuador." The significant increase in prices, the explanatory memorandum stated further, "obligates the National Government to submit reforms to the Hydrocarbons Law to the National Congress."

Remarkably, the President explained the grounds that would make applicable the principle rebus sic stantibus, denying that the re-establishment of the equilibrium sought would affect the current contractual obligations:

978 The Murphy Tribunal took note of the negotiations attempted by instruction of the Executive President of Petroecuador in order to modify the existing participation contracts:

91. In December 2007, the Executive President of Petroecuador gave instructions for the commencement of negotiations to modify all existing participation contracts.92 Petroecuador constituted and assigned groups to carry out negotiations with the Consortium as well as the other contractors in the country.

(...) 277. In late 2005, Petroecuador invited the Consortium to negotiate the Participation Contract towards an increase in the State's share and appointed a renegotiation committee for this purpose. However, the Consortium rejected the invitation. According to Respondent, it was in the face of the unwillingness of investors to renegotiate their contracts that it decided to enact Law 42.

See, Murphy Exploration \& Production Company - International v. The Republic of Ecuador In The Matter Of An Arbitration Under The Treaty Between The United States Of America And The Republic Of Ecuador Concerning The Encouragement And Reciprocal Protection of Investment Signed On 27 August 1993, Partial Final Award, 6 May 2016. 
90. The memorandum stated further that "[t]he contracts for oil and gas exploration and exploitation in Ecuador were entered into considering the rebus sic stantibus ['things standing thus'] clause, which means that the contracts are understood to have been reached under the tacit condition that the original conditions contracted will subsist, and that when this is not so and a change in those circumstances occurs, equilibrium in the contractual obligations needs to be re-established to the extent that something extraordinary and unforeseeable has an impact on what the parties had foreseen, on which economic basis they assumed their obligations." It concluded that "[a]t all times, the equilibrium of the contracts is being maintained, since all the technical, economic and legal parameters considered by the companies in their analysis are being respected, and what is being legislated upon are those events that never formed a part of the will of the parties, such as the extraordinary increase in crude oil prices at the international level." 979

There are notable dual arguments stated by the President in such a memorandum, on one hand, because it heavily relies in a contractual doctrine which is far from being applied uniformly in the Latin-American jurisdictions, and on the other, because it asserts that the proposed measures do not affect the equilibrium and structure of the contracts, as the oil prices did not constitute a factor expressly bargained. It seems that in the first case the President stepped into the shoes of the contractor and in the second, it justifies its sovereign proposal as being a measure wielding extra-contractual effects. Anyhow, is neither for the President nor the Congress to judge whether a modification of the tax regime is framed within any particular contractual stipulation. This chaotic approach that mixes regulatory and contractual actions within a same relationship has resulted ultimately that contractual and treaty breaches may be very difficult to distinguish, as noted below in the Perenco award, where the State and Petroecuador, were deemed practically as a single entity.

Notably, the tribunals in Murphy, Perenco and Burlington did not dismiss the occurrence of a change of circumstances but roughly censured the proportionality of the mechanisms adopted by the Ecuadorian government in order to materialize its legitimate access to a higher share of the windfall profits. Resorting to the approach adopted by the French Administrative Courts as previously mentioned within the Gaz de Bordeaux case, Momberg Uribe illustrates that the imprévision doctrine is only applicable to administrative contracts, understood as instruments laying down the terms on which the state agency exercises its legal task of performing a contractual relationship before the

\footnotetext{
979 See, Perenco Ecuador Limited vs. The Republic of Ecuador, ICSID Case No. Arb/08/6, Decision On Remaining Issues Of Jurisdiction And Liability, September 12, 2014.
} 
private parties. Thus, within the contracts where the public agency performs a plain commercial activity, not attributable to its special position before a particular sector or resource, the theory at issue would not be applicable. ${ }^{980}$ Since it is undeniable that the exploitation of non-renewable resources involves the public interest, especially in countries highly dependent on the resulting revenues for sustaining public expenditure, it is remarkable that the approach undertaken by the Conseil d'Etat, with regard to the application of the theory at issue, prioritizes the assurance of the continuation of the public activity and the right of the private party to a certain degree of economic equilibrium. ${ }^{981}$ The Ecuadorian case shows exactly the opposite situation, since the economic equilibrium of the contract was allegedly breached to the detriment of the State, in the terms originally agreed upon by Petroecuador.

Putting the oil disputes in context, the Murphy Tribunal evaluated the international and domestic legal framework that shaped investor's legitimate expectations during the

980 The scholar illustrates about the different standings emerging from administrative and private law issues implicating the imprévision doctrine:

(...) However, the conditions for the application of the imprévision doctrine are very strict: it is only applicable to administrative contracts, i.e. whose object is the execution or operation of a public service (e.g. concessions, procurement contracts for supplies, services or transport). 'Private contracts', i.e. contracts concluded between the authority and private parties with an objective which is different from the ones mentioned above, are therefore excluded. In addition, the supervening events have to be unforeseen, external to the parties and resulting in a far-reaching alteration to the economic balance of the contract which exceeds the reasonable expectations of the parties at the time of contracting. The doctrine is imperative for the parties (d'ordre public) and therefore cannot be excluded from the contractual relationship.

Momberg Uribe (Rodrigo), The effect of a change of circumstances on the binding forcé of contracts,: Comparative Perspectives, Intersentia, 2011, 51 p.

${ }^{981}$ Momberg Uribe addresses the element of public interest attached to administrative contracts and its evolution, leaving a straightforward public/private distinction somewhat outdated:

The different approach between administrative law and private law has been explained because in private contracts there is no public interest involved while in the performance of administrative contracts the interest of the community requires the continuity of the public service through, if necessary a revision of the terms originally agreed upon. However, such an explanation has been criticized because both in private and administrative contracts the public and the private interest are mostly mixed, as it is evident in public economic policies (e.g. protective rules or particularly the specific intervention of the French legislator in some cases allowing the revision of contracts), and because some private contracts are also necessary for the correct operation of public services. As a result of such criticism, the Conseil d' Etat has stated that the revision of administrative contracts in cases of imprévision is not founded exclusively on the necessities or continuity of the public service but also on the right of the private party to a certain degree of economic equilibrium. In conclusion, it can be stated that the different approach of French administrative and private law has no valid justification nowadays and in this sense it is regarded by modern legal doctrines as being somewhat incoherent.

Momberg Uribe (Rodrigo), The effect of a change of circumstances on the binding forcé of contracts,: Comparative Perspectives, Intersentia, 2011, 51-52 pp. 
1990s, when the Ecuadorian government promoted the amendment of the hydrocarbons legal regime in order to convert service contracts into participation contracts ${ }^{982}$. Among other measures, it underscored that part of the overhaul of the hydrocarbons industry was linked to the signature of " 27 bilateral investment treaties, 19 of which were concluded in the 1990s". ${ }^{983}$ The Tribunal recalled that "was within the context of this positive legal reform that the Consortium and Petroecuador entered into negotiations in mid-1996, with a view to transforming the Block 16 Service Contract into a participation contract". ${ }^{984}$ In the course of these "lengthy and detailed negotiations", the Tribunal noted the participation of "highly-qualified executives", who fully comprehended the exclusion of the oil price from the calculation formula agreed upon, as a means to balance the risks entailing such type of contract by granting the investor direct participation in oil production. Contrasting similar contracts wherein the price oil was expressly factored in the share calculation formula and resorting to the conclusions of further tribunals dealing with analogous disputes, namely Burlington and Occidental II, the Tribunal found that the bargain reflected in the Participation Contract left no doubts as to the exclusion of the

\footnotetext{
982 The Tribunal referred to the statement of President Durán Ballén when he introduced the bill to amend the Hydrocarbons Law (November 1993), wherein he roughly pointed out as the grounds of the reform, namely: the limited financial resources of the country, the complexity in the management and control attached to the Services Contract "due to the relationship of dependency created among the various State agencies" and the inability of such type of contract to allow the company "to have a production flow on its own". It further alluded to the implementing Decree of the law abovementioned where by this type of contract was introduced highlighting the provisions designed to attract foreign investment, like the contractors' entitlement to participation in oil production in accordance to the formula established in the contracts, the exemption from royalties and the economic stability clause ensuring the readjustment of the participation production should the applicable tax regime be modified. In addition, it was remarked the promulgation of the Law on the Modernization of the State (December 1993). Concerning the "significant positive legal reforms" undertaken after the investor agreed to the Participation Contract, the Tribunal draw attention to the Investment Promotion and Guarantee law (December 1997), in which the State "made important undertakings" such as legal stability. Finally it noted the provision inserted in Constitution 1998, that authorized the State to include stabilization clauses in contracts in order to shield them from any future regulatory changes.
}

See, Murphy Exploration \& Production Company - International v. The Republic of Ecuador In The Matter Of An Arbitration Under The Treaty Between The United States Of America And The Republic Of Ecuador Concerning The Encouragement And Reciprocal Protection of Investment Signed On 27 August 1993, Partial Final Award, 6 May 2016.

983 See, Murphy Exploration \& Production Company - International v. The Republic of Ecuador In The Matter Of An Arbitration Under The Treaty Between The United States Of America And The Republic Of Ecuador Concerning The Encouragement And Reciprocal Protection of Investment Signed On 27 August 1993, Partial Final Award, 6 May 2016, 79 p.

${ }^{984}$ See, Murphy Exploration \& Production Company - International v. The Republic of Ecuador In The Matter Of An Arbitration Under The Treaty Between The United States Of America And The Republic Of Ecuador Concerning The Encouragement And Reciprocal Protection of Investment Signed On 27 August 1993, Partial Final Award, 6 May 2016, 79 p. 
price of oil as a factor of calculation of the investor's production share ${ }^{985}$ Finally, the Tribunal alluded to the contractual stipulation that allegedly barred the unilateral modification of the Contract's terms ${ }^{986}$. As previously noted, Ecuador claimed that precisely the unwillingness of the investors to renegotiate the Participation Contract in

985 The Tribunal looking at other Participation Contracts, were the price was included, dismissed the Respondent's claim that the omission of such factor in the contract framing the dispute did mean its express exclusion in the negotiation of the economic terms:

268. The parties to the Tarapoa Contract expressly factored in the price of oil. Had the parties to the Participation Contract truly agreed on such a significant term, that term would have been reflected clearly in the contractual documents as it was in the Tarapoa Contract. Given that the negotiation teams for both sides were sophisticated and experienced actors in the oil industry, the Tribunal does not accept that the reference to USD 15.26 as a "basic parameter" in Annex V indicates that the parties had agreed that the price of oil would be a factor for the calculation of the Contractor's production share.

269. The Tribunal further notes that the Burlington and Occidental II tribunals reached the same conclusion with respect to the formula for the calculation of the contractor's production share (which is the same formula as in this case) and the reference to a price of oil in an annex $\mathrm{V}$ to the underlying contracts (where those annexes also comprised reports of the renegotiating committee): Annex V was not intended to set out the terms of the prospective [Participation Contract], but merely to establish whether it would be in Ecuador's interest to enter into a [Participation Contract] in lieu of a service contract from an economic standpoint.

'It is clear to the Tribunal that, in the Participation Contract, the Claimants knowingly accepted the risk of losses on its investment in case of a low Price scenario and the Respondent knowingly forewent the opportunity to increase its participation in case of a high price scenario. This was the bargain which was struck by the parties and which was reflected in the Participation Contract.

270. Under clause 10 of the Participation Contract, Claimant had the right to "freely dispose of the Crude Oil that corresponds to it," subject to domestic supply needs.434 Clause 10.2 guaranteed Claimant the right to market its production share on the domestic or international markets, and Article 10.3 of the Contract guaranteed Claimant the full value of its share of production.

See, Murphy Exploration \& Production Company - International v. The Republic of Ecuador In The Matter Of An Arbitration Under The Treaty Between The United States Of America And The Republic Of Ecuador Concerning The Encouragement And Reciprocal Protection of Investment Signed On 27 August 1993, Partial Final Award, 6 May 2016.

986 The Tribunal upheld the sanctity of the contract as the main source the Parties relied upon to set the economic terms of exploitation:

271. In addition, clause 15.2 of the Participation Contract provided that it would be possible to modify the contracts upon the prior agreement of the parties. The contracts could not be modified unilaterally.

When the Tribunal found that the Law 42 at $99 \%$ did breach investor's legitimate expectations, it noted that this clause (15.2) also referred to Law. 44 which additionally referred to the Constitution, whereby the terms defining the prerogative to explore and exploit hydrocarbons would have to be set by contractual stipulations.

See, Murphy Exploration \& Production Company - International v. The Republic of Ecuador In The Matter Of An Arbitration Under The Treaty Between The United States Of America And The Republic Of Ecuador Concerning The Encouragement And Reciprocal Protection of Investment Signed On 27 August 1993, Partial Final Award, 6 May 2016. 
response to the invitation of Petroecuador to increase the State's share made in late 2005 pursuant to the abovementioned contractual stipulation, prompted Law 42-2006's enactment. Although the Tribunal rejected that the Participation Contract did contain a stabilization clause amounting to the State's commitment to refraining itself from making legislative or regulatory adjustments in exceptional circumstances, it considered that such a contract included several clauses purporting to "maintain the status quo of the contract notwithstanding changes in the law (clauses 8.6 and 11.11) "'987, thereby upholding the mutual understanding that future regulatory changes capable of affecting the contractual stipulations were likely to occur.

278. Following the enactment of Law 42 and Decree No. 1672, the Consortium was then entitled to only $50 \%$ of the "extraordinary" revenue generated from sales of its production share. The Tribunal does not consider that this fundamentally changed the operation of the Participation Contract for the Consortium. The latter continued to receive a share of production calculated under the Participation Contract. It was still able to earn more revenue with Law 42 at $50 \%$ than it did before the oil price rise, notwithstanding that it was not receiving the full potential revenue from those sales. What is important is that the basic structure of the agreement remained in place.

(...) 280. In light of the foregoing considerations, the Tribunal does not accept that Claimant could have reasonably expected that there would be no governmental response to the significant rise in oil prices. The Tribunal does not consider that the enactment of Law 42 and Decree No. 1672 changed the operation of the Participation Contract in such a fundamental way that Claimant's legitimate expectations of not having its contractual agreement disturbed, or unilaterally changed without agreement, were breached. In sum, the Tribunal does not consider that the enactment of Law 42 at 50\% breached Claimant's legitimate expectations and thus finds that it did not breach the FET standard of the Treaty.

Conversely, the Tribunal found that the Law in the terms implemented by Decree No.662

(18 October 2007) that raised the State's participation in the extraordinary income from $50 \%$ to $99 \%$ did change fundamentally the nature of the Participation Contract. Furthermore, it condemned the environment of hostility and pressure fuelled by President Correa with the alleged purpose of pushing the Contractors towards the conversion of the Participation Contract into a service contract. It concluded that "the application of the 99\% participation of the State effectively transformed the Participation Contract into a

987 See, Murphy Exploration \& Production Company - International v. The Republic of Ecuador In The Matter Of An Arbitration Under The Treaty Between The United States Of America And The Republic Of Ecuador Concerning The Encouragement And Reciprocal Protection of Investment Signed On 27 August 1993, Partial Final Award, 6 May 2016, 87 p. 
service contract." 988 It is unclear why the difference of the percentages in the levy imposed would ultimately determine the breach of the investor's legitimate expectations, considering that the State's commitments enshrined in the relevant regulations and in the contractual stipulations would have been breached irrespective of the levy's rate. As reported by Murray and Northcott:

The breach of the BIT the Tribunal did identify was in respect of the $99 \%$ levy this was considered to be a violation of a legitimate expectation that the terms of the PSCs would not change except within the confines of the law, and pursuant to a negotiated, mutual agreement between the parties. The Tribunal was reluctant to determine (despite being asked) exactly where the cut-off of permissible taxation/governmental levies lay between $50 \%$ and $99 \%$, as each case will ultimately turn on its facts. ${ }^{989}$

These practitioners recalled that the Tribunal's recognition of Ecuador's prerogative to take advantage of the oil market's prices fluctuation resulted in 93\% of Murphy's damages claim being rejected. Assuming that the Tribunal's reasoning was founded on proportionality criteria, it is remarkable its sympathetic approach towards the adaptation of changed circumstances through the exercise of sovereign attributions:

276. The sharp increase in global oil prices that began several years into the Participation Contract was not foreseen by the Consortium or Ecuador. It dramatically changed the dynamics of the oil industry in Ecuador and oil industries around the world. It is well recognised in investment treaty arbitration that States retain flexibility to respond to changing circumstances unless they have stabilised their relationship with an investor. Ecuador was within its sovereign right to react to the significant change in oil prices, as many States did. Indeed, it would not have been reasonable for the contractors to expect that the contractual terms or Ecuadorian law would not change at all in the face of such exceptional prices rises. This is all the more so given that the Consortium knew that the "interests of the State" had been a key factor in the overhaul of the hydrocarbons industry in the 1990s and a key qualifier to certain State guarantees. As expressed by the Perenco tribunal:

It would be unsurprising to an experienced oil company that given its access to the State's exhaustible natural resources, with the substantial increase in world oil prices, there was a chance that the State would wish

\footnotetext{
988 See, Murphy Exploration \& Production Company - International v. The Republic of Ecuador In The Matter Of An Arbitration Under The Treaty Between The United States Of America And The Republic Of Ecuador Concerning The Encouragement And Reciprocal Protection of Investment Signed On 27 August 1993, Partial Final Award, 6 May 2016, 87-88 pp.

989 Murray (Dorothy) and Northcott (Edmund), "Case Report: Murphy Exploration \& Production Company-International v The Republic of Ecuador, May 2016”, Lexology, September 15, 2016. See, http://www.lexology.com/library/detail.aspx?g=e121916e-b975-457a-b16c-3468966af903 Website visted in September 2016.
} 
to revisit the economic bargain underlying the contracts. ${ }^{990}$

Pursuant to this paragraph it is notable, that the tribunals in Murphy and Perenco have interpreted the "sophistication" in the negotiation of the contractual terms as a threshold operating for both parties. This means that, whereas in the case of the State, the exclusion of the price in the calculation formula was deemed as an express and fundamental choice that structured the Participation Contract, on the investor's side, it was presumed that his capability to foresee that a significant fluctuation in the oil price could have triggered the State's response to adapt the economic conditions to the underlying circumstances.

\subsubsection{The Effectiveness of Contractual Remedies to Adapt Changed Circumstances}

In view of the awards examined, worthy of note is the practical obsolescence of the contractual clause stipulating the terms for the Contract's review, requiring a negotiated mutual agreement, whose achievement was very unlikely to occur, in view of the fact that that such an option relied solely on the will of the parties. As it may be observed in the Murphy award, it sufficed that one party be reluctant to negotiate, in order that such clause loses its effectiveness. Salacuse recalls that long term-agreements bring the challenge of balancing contractual stability and flexibility, in the context of the parties' presumption that during such a period many unforeseen circumstances of any type may arise. ${ }^{991}$ This scholar points out that one of the approaches suitable to balance the imperatives of stability and flexibility in investment agreements is "for the contract itself to authorize the parties to renegotiate key elements of their relationship upon the happening of specific events or circumstances", ${ }^{992} \mathrm{He}$ also warns of the little use and application of such clauses, on one hand, because the western practice has resorted to stabilization clauses or in their absence, it has contractually enlisted all possible future contingencies, and on the other, due to the weak enforceability of renegotiation clauses

\footnotetext{
990 See, Murphy Exploration \& Production Company - International v. The Republic of Ecuador In The Matter Of An Arbitration Under The Treaty Between The United States Of America And The Republic Of Ecuador Concerning The Encouragement And Reciprocal Protection of Investment Signed On 27 August 1993, Partial Final Award, 6 May 2016.

991 Salacuse (Jeswald W.), The Three Laws of International Investment: National Contractual and International Frameworks for Foreign Capital, Oxford University Press, 2013, 281 p.

${ }^{992}$ Salacuse (Jeswald W.), The Three Laws of International Investment: National Contractual and International Frameworks for Foreign Capital, Oxford University Press, 2013, 281 p.
} 
("agreement to agree"). ${ }^{993}$ In spite of the absence of consistent case law concerning the enforceability of the agreements to negotiate, this scholar indicates that insofar as the contractual renegotiation clause embodies specific terms as to how the parties have to conduct the renegotiation process, measuring the compliance of both parties in the light of the applicable provisions would permit an acceptable degree of enforceability:

(...) The required certainty would be further satisfied by specifying the precise events that give rise to the obligation to renegotiate and by specifically providing for the timing, locale, and conditions of the renegotiation process among others.

Practical considerations have led western lawyers and executives to view renegotiation clauses with suspicion on the grounds that they increase uncertainty and risk in business transactions and offend western concepts of the sanctity of the contract. Their presence in a contract also creates a risk that one of the parties will use a renegotiation clause as a lever to force changes in provisions that, strictly speaking, are not open to revision. Moreover, the challenges of drafting these provisions and the heightened risks to contractual stability by renegotiation provisions that have yet to be tested in the courts are additional factors that have deterred lawyers from using them in long-term business contracts. ${ }^{994}$

Although it is the pitfall of an intra-renegotiation clause, Salacuse holds that a renegotiation clause can fairly represent "such middle ground between total contractual rigidity in one hand and complete relational flexibility on the other" 995 . As noted, putting successfully into motion the renegotiation clause should not have to depend solely on the parties' good will, but on laying down the events and framework within which such a process will be conducted:

Despite these potential pitfalls, the inclusion of a renegotiation clause may actually contribute to transactional stability in certain situations. First, in cases in which significant changes in circumstances may result in severe unexpected financial hardship, a renegotiation clause may permit the parties to avoid default, with the attendant risk of litigation and extra-contractual renegotiations. At the outset, the parties should recognize the risk of changed circumstances and create within the contract a process to deal with them, rather than to try to predict all eventualities and leave the matter up to the courts or arbitrators when those predictions prove to be flawed. ${ }^{996}$

\footnotetext{
993 Salacuse (Jeswald W.), The Three Laws of International Investment: National Contractual and International Frameworks for Foreign Capital, Oxford University Press, 2013, 281-282 pp.

994 Salacuse (Jeswald W.), The Three Laws of International Investment: National Contractual and International Frameworks for Foreign Capital, Oxford University Press, 2013, 282 p.

995 Salacuse (Jeswald W.), The Three Laws of International Investment: National Contractual and International Frameworks for Foreign Capital, Oxford University Press, 2013, 283 p.

996 Salacuse (Jeswald W.), The Three Laws of International Investment: National Contractual and International Frameworks for Foreign Capital, Oxford University Press, 2013, 282 p.
} 
Looking at the oil contracts signed by Ecuador during the 1990s in the midst of a liberalizing trend, it may be observed that the relevant contractual clauses stipulating a possible modification of the terms upon mutual agreement of the parties, set forth the causes triggering their renegotiation and consequent amendment, but not the rules to conduct such a process. Considering that both the renegotiation and the stabilization clauses would have the effect of compelling the parties to enter into negotiations, ${ }^{997}$ such a commitment would entail the obligation of the parties "only to negotiate, not to agree,. 998

As observed in the Murphy case, the inflexibility of the relevant clause, barring on one side, the unilateral modification of contractual stipulations and on the other, conditioning a renegotiation process to endogenous factors, would partially explain the decision of the government to resort to extra-contract mechanisms to prompt the redistribution of the oil windfall profits. In the view that the scope of the appraisal of the arbitral Tribunals depends on the nature of the claims submitted by the investor, the weight allocated to the efforts exhausted with the aim of achieving a negotiated solution as contractually stipulated will depend on whether the alleged breach is based on the treaty or on the contract. The Murphy and the Perenco awards constitute a good example of such an assertion. Since the Murphy case was focused on the breach of the EcuadorUS BIT, the agreements included in the Participation Contract were examined in the light of the Claimant's legitimate expectations. ${ }^{999}$ In the Perenco case, the award was

\footnotetext{
997 Salacuse indicates:
}

"In addition, as Kolo and Walde point out, renegotiation clauses in investment contracts often accompany stabilization clauses, by which a host country promises that any changes in laws or regulations will not adversely affect the foreign investment project. The effect of the two clauses is to obligate the host government and the project company to enter into negotiations to restore the financial equilibrium that such new laws and regulations may have destroyed."

Salacuse (Jeswald W.), The Three Laws of International Investment: National Contractual and International Frameworks for Foreign Capital, Oxford University Press, 2013, 285 p.

998 Salacuse comes to this conclusion on the basis of the case Wintershall, A G, et al v. Government of Qatar (1989)

Wintershall, A G, et al v. Government of Qatar, (1989) 28 ILM. 795, 814 (Ad Hoc Arbitral Tribunal 1989); J Carver and H Hossain, “An Arbitration Case Study: The Dispute That Never Was,” 5 ICSID Rev (1990) 311, in Salacuse (Jeswald W.), The Three Laws of International Investment: National Contractual and International Frameworks for Foreign Capital, Oxford University Press, 2013, 285.

999 The Tribunal considered that while the implementation of Law 42 at $50 \%$ did not breach the FET standard, the rate at $99 \%$ did: 
predominantly devoted to the examination of the contractual breaches, although the standard of fair and equitable treatment was also deemed to have been violated in the terms enshrined in the Ecuador France-BIT ${ }^{1000}$.

\title{
4.9.4. Appraising the Futility of Contractual Stipulations of Renegotiation
}

The Perenco Tribunal assessed the investor's claim regarding the futility of the renegotiation remedy provided by the Contract, once a taxation modification such as that embodied by Law 42 at 50\% took place, acknowledging that the contract stipulated a negotiating process that could eventually have led to adjust the Parties' respective entitlements. ${ }^{1001}$ It underscored that irrespective of the complexity of the negotiations and

\begin{abstract}
261. The Tribunal turns next to an examination of the contractual arrangements agreed by the Parties under the Participation Contract. The Tribunal confines its examination to those terms that it considers pertinent to its analysis of Claimant's legitimate expectations.

(...)273. Considering both the terms of the Participation Contract and the legal framework that was in place in Ecuador at the time that Claimant signed up to the Participation Contract, the Tribunal finds that the Consortium members held legitimate expectations that the terms of the Participation Contract would not change except within the confines of the law and pursuant to a negotiated mutual agreement between the contractual partners. The State had committed to maintaining a contractual business relationship with the Consortium according to the terms of the Participation Contract set within a stable and predictable legal and business framework. What those guarantees meant in practical terms for the Contractor was that the price of crude oil would not be factored into the calculation of its participation share in the contract. As such, Claimant would assume the risk of any decrease in the price of crude oil as well as the benefit of any increase, in exchange for assuming the risk of its exploration activities. Claimant would then enjoy the principal benefit obtained by its decision to convert the Block 16 Service Contract into the Participation Contract, which was entitlement to full ownership of a percentage of its production through participation.
\end{abstract}

See, Murphy Exploration \& Production Company - International v. The Republic of Ecuador In The Matter Of An Arbitration Under The Treaty Between The United States Of America And The Republic Of Ecuador Concerning The Encouragement And Reciprocal Protection of Investment Signed On 27 August 1993, Partial Final Award, 6 May 2016.

${ }^{1000}$ See, Perenco Ecuador Limited vs. The Republic of Ecuador, ICSID Case No. Arb/08/6, Decision On Remaining Issues Of Jurisdiction And Liability, September 12, 2014.

1001 The Tribunal assessed to what extent the taxation modification process was followed in accordance with the contractual stipulations:

384. The existence of a taxation modification process is of pivotal importance in considering Perenco's claim that Law 42 at $50 \%$ breached the two Contracts. Clause 11 of both Contracts provided the parties, in this case Perenco, with a means to subject new or modified taxes to a negotiating process that could lead to an adjustment of their respective entitlements. Given the fact that the process' initiation was requested but nothing happened thereafter, the Tribunal must decide who bears responsibility for this state of affairs and what legal consequences follow. Put simply, did Perenco do enough?

See, Perenco Ecuador Limited vs. The Republic of Ecuador, ICSID Case No. Arb/08/6, Decision On Remaining Issues Of Jurisdiction And Liability, September 12, 2014. 
that Petroecuador would have maintained the Government's view that Law 42 did not have any impact on the economy of the contract, the debate about the pertinence of the information produced by the Company as being the party resorting to this contractual avenue, could have been expected to be discussed. With this evidence, the pricing and the profitability expectations of the original contracting parties at the time the contracts were signed could also have been elucidated. ${ }^{1002}$

Indeed the Tribunal qualified the modifications enshrined in Law 42 as a fiscal measure capable of triggering the mechanism to seek the modification of the contract. ${ }^{1003}$ In this

1002 The Tribunal concluded that it was upon Perenco to produce the documentation necessary to negotiate with Petroecuador the economic burden contractually acceptable after the enactment of Law 42-2006:

393. The Tribunal has no illusions that any such negotiations would have been challenging. Petroecuador could have been expected to have advanced the Government's view (expressed by the former President) that Law 42 did not have any impact on the economy of the contracts and the parties would likely have debated the meaning of 'economy of the contract' as they have in this proceeding. Had Perenco submitted its study, Petroecuador would no doubt have scrutinised the company's financial performance, both prior to and after Law 42's enactment, and if Perenco had performed as well as the limited evidence before the present Tribunal suggests, it can be anticipated that Petroecuador would have pressed it on 'how much profit is enough?' Much of the evidence that has been led by both Parties in the current arbitration as to whether or not Law 42 had an impact on the Contracts' economy, including the evidence of the pricing and profitability expectations of the original contracting parties at the time of the Contracts' making, general industry expectations of returns on investment, and so on, could be expected to have been discussed. But the challenges of negotiating a modification cannot be accepted as a basis for deciding not to press the contractual avenue and cannot support a finding of futility.

394. In the end, if Perenco wished to rely on clauses $11.12 / 11.7$, respectively, it was incumbent upon it to make its case with appropriate documentation at that time and its failure to have done so is fatal to this part of its claim.

See, Perenco Ecuador Limited vs. The Republic of Ecuador, ICSID Case No. Arb/08/6, Decision On Remaining Issues Of Jurisdiction And Liability, September 12, 2014.

1003 The Tribunal transcribed the contractual stipulation that may resort to the process as provided for by the Regulations for Application of the Law Amending the Hydrocarbons Law:

361. The parties also addressed the relationship between taxation measures and their respective shares of production. Clause 11, paragraphs 1 to 11 in the Block 7 Contract (and clause 11, paragraphs 1 to 6 of the Block 21 Contract) contained a comprehensive list of fiscal measures and was clearly designed to operate such that if a new tax was implemented, or an existing tax was changed, the right to seek a modification of the Contract would be triggered. This is made clear by the final provision of clause 11.12 of the Block 7 Contract (clause 11.7 of the Block 21 Contract) which provides:

11.12 Modification to the tax regime. In the event of a modification to the tax regime or the creation or elimination of new taxes not foreseen in this Contract... on the signature date of this Contract and as described in this Clause, or their interpretation, which have consequences for the economy of this Contract, a correction factor shall be included in the participation percentages, which absorbs the increase or decrease in the tax burden...This correction factor shall be calculated between the Parties and following the procedure set forth in Article thirty-one (31) of the Regulations for Application of the Law Amending the Hydrocarbons Law.

See, Perenco Ecuador Limited vs. The Republic of Ecuador, ICSID Case No. Arb/08/6, Decision On Remaining Issues Of Jurisdiction And Liability, September 12, 2014. 
regard, the relevant contractual provision stipulated that the process to be followed once this right may have been resorted to was that enshrined in Art. 31 of the Regulations for Application of the Law Amending the Hydrocarbons Law. ${ }^{1004}$ Although this so called "process" does not entail a clear set of rules organizing the way negotiations should have to be carried out, it is assumed that the Parties' have an obligation to conduct the negotiations in good faith. Again, the prerequisite that the parties reach a mutual agreement in order to advance the process, renders very challenging the possibility to facilitate an outcome, which in principle, does not have to depend solely on the parties' will. Remarkably, the fact that an agreement may not be reached once negotiations in good faith have been concluded would entail the exemption from liability of the party allegedly affected by the imbalance in the original economic terms agreed upon. ${ }^{1005}$ The investment disputes in the Ecuadorian hydrocarbons sector show that mutual attempts for bringing into action the different clauses for contractual amendments were fruitless, on

1004 Article 31 was translated by the Tribunal as follows:

Competition from other bodies: No CEL require approval of contract modifications derived from tax changes applicable to the contract, so as to not affect the essence of the contract, classified as such by the CEL, after consultation with the agency by Executive President of Petroecuador, the same that will be approved by the Board of Directors of Petroecuador and modificaborios implemented through contracts. Those cases where the Act expressly provides for the competence of other organs are excepted.") Article 32 follows on to provide in part (Claimant's translation): "Article 32 Procedure [for amending the contracts]: "The modifications which are subject to the Special Bidding Commission (CEL), shall comply the following procedure:" (...) b) Provided that the parties have reached mutual agreement over the proposed modification, Petroecuador's Executive President shall submit the modifications agreed to with the contractor to the Administrative Counsel for consideration and report; (...) d) Should the corresponding Minister agree with the negotiated modifications, it shall issue a favourable report and request reports from the Attorney General's Office and from the Joint Chiefs of Staff respectively.

See, Perenco Ecuador Limited vs. The Republic of Ecuador, ICSID Case No. Arb/08/6, Decision On Remaining Issues Of Jurisdiction And Liability, September 12, 2014.

1005 Salacuse refers to an award based on a contract of exploration of petroleum concluded between the government of Qatar and oil company, upon which it was agreed that should gas be found in the contract area, the parties would negotiate future agreements for its exploitation. When the company found comercial quantities of natural gas an entered into negotiations with the government, no agreement could be reached:

When the two parties failed to reach agreement, the oil company brought an arbitral proceeding against the government. The oil company claimed that, by failing to agree to a renegotiation of their agreement with respect to natural gas, the Qatar government had breached its contract with the oil company. The arbitral tribunal rejected the argument on the grounds that the duty to negotiate in good faith does not include an obligation to accept proposals made by the other side and the Qatar government's refusal to accept the proposal was based on reasonable commercial judgments."

Salacuse (Jeswald W.), The Three Laws of International Investment: National Contractual and International Frameworks for Foreign Capital, Oxford University Press, 2013, 286 p. 
one hand, because it was the government and not Petroecuador, which exerted the mechanisms for perfecting the revisited economic terms and on the other, because the companies were entitled to refuse to participate in possible negotiations without breaching the letter of the contract. In the absence of an enforceable obligation to renegotiate and in view of the oil price exclusion from the calculation formula, should Petroecuador decide to repudiate the contract, the counterparty would have had the remedy to resort to arbitration in order to enforce it or claiming damages for nonperformance.

As noted by the Perenco and Murphy Tribunals, it is hard to hold that experienced oil companies, familiar with diverse legal frameworks and significantly active in operations within Latin America, where the exploitation of non-renewable resources entails profound social and economic sensitivities could have reasonably expected that the State wouldn't react to a significant change of economic circumstances. A disproportionate impetus towards the liberalization of the oil sector in a regulatory framework promptly built for attracting foreign investment at any means had an impact on the contractual commitments agreed upon in this context. While, the contractual stipulations embodying the limited grounds for force majeure and termination would show a strong compromise towards the stagnation of the allocation of duties originally established, the awards at issue did not conclude that the relevant contracts contained a stabilization clause. Irrespective of this finding, neither the stabilization clauses, nor the prohibition of unilateral changes, entail the commitment not to react to an alleged significant disturbance of the economic equilibrium of the contract. The extent to which such equilibrium was breached in view of the parties' representation at the time of concluding the contract, was not conclusively elucidated in the awards at issue, namely Murphy and Perenco, precisely because the Parties were not capable of putting fully into motion the contractual stipulations contemplating the contract's economy review. ${ }^{1006}$ The

1006 The Tribunal set out the factors that could have been assessed in case the parties would follow the renegotiation process:

396. The Tribunal's additional reasons for declining to divine what might have happened in a negotiation are threefold. First, the taxation modification clauses required the parties to determine the predicate for making a change to their respective entitlements, i.e. an agreement that the new or modified tax had an impact on the contract's economy. They would do so on the basis of the data submitted by the private contractor in its capacity as the party moving for a change to the contract. The parties would then determine the tax's impact on the contract's economy and calculate an adjustment to absorb that impact. In the Tribunal's view, the clauses dictated the objective, but not the precise means of correction and this could only be determined through negotiations that arrived at a mutually agreeable outcome (or, if such negotiations foundered, thereafter by a tribunal armed with all of the relevant documentation produced by both parties 
Perenco award acknowledges that the determination of the tax's impact on the contract's economy and the calculation of the adjustment in order to absorb it was matter of commercial affairs to be settled by both parties on the basis of "critical contemporary data". The Tribunal's finding that it was incumbent on Perenco to pursue the renegotiation remedy as stipulated in the contract, because it had not demonstrated Petroecuador's unwillingness to engage in good faith negotiations was confined to the application of Law 42 at a rate of $50 \% .{ }^{1007}$ According to the Tribunal, moving from $50 \%$ to $99 \%$, with a parallel pressure to sign a new model of contract was no longer an acceptable attempt of the State to adjust a contractual relationship. Thus, the futility of the renegotiation could not have been proven in the context of a good faith renegotiation where Law 42 at a rate of $50 \%$ would have been applied.

\subsubsection{The Application of Domestic Law within International Investment Contracts}

It is noteworthy that contrary to the Murphy and the Burlington cases, in which

during the negotiations).

397. This leads to the second point. While, as discussed above at paragraph 393, the Tribunal can conceive of the kinds of considerations that would have motivated the parties in the negotiations, with the passage of time and the absence of critical contemporaneous data, it would be wholly speculative for the Tribunal to try to estimate what the parties would have done. Based upon the pleadings and expert reports filed in this arbitration, the Tribunal can make a guess as to the kinds of arguments that both sides would have advanced, but in the end it is only a guess.

398. Finally, the single most important piece of evidence that would necessarily have to be submitted during the negotiations - the analysis that Perenco prepared in order to demonstrate Law 42 's impact on the Contracts - has not been produced to the Tribunal.This is the seminal piece of evidence in the whole evaluative exercise.

See, Perenco Ecuador Limited vs. The Republic of Ecuador, ICSID Case No. Arb/08/6, Decision On Remaining Issues Of Jurisdiction And Liability, September 12, 2014.

1007 Regarding the futility of resorting to the renegotiation process when law 42 was applied at $50 \%$, the Tribunal concluded:

"401. The Tribunal recognises that in requiring Perenco to demonstrate futility in order to succeed on this point it might be regarded as applying too exacting a requirement; but issues such as that which faced Perenco in late 2006, early 2007 frequently arise in commercial affairs and they require difficult decisions to be taken. In the end, Perenco chose not to press its rights, considering instead that it "would be prudent to wait a little bit to see whether things would settle down so [that it] could arrange a talk." It was of course entitled to do so, but it cannot then argue that insisting on its clause 11 rights, which had been so recently shown to be effective, was futile. At the end of the day, the clauses were not tested and found wanting. This part of Perenco's claim is therefore dismissed."

See, Perenco Ecuador Limited vs. The Republic of Ecuador, ICSID Case No. Arb/08/6, Decision On Remaining Issues Of Jurisdiction And Liability, September 12, 2014. 
the tribunals asserted jurisdiction only over treaty disputes the Perenco case did assess the breach of the Participation Contracts (Blocks 7 and 21). It asserted jurisdiction over Block 21 by interpreting that the "declaration of caducidad", allegedly non- arbitrable, had economic consequences and as such fell under the category of "technical and/or economic dispute", as provided by the arbitration clause ${ }^{1008}$. Since the applicable law to the contract is Ecuadorian law, the Tribunal deferred not only to the applicable legal framework, but also to the relevant case law like the ruling issued by the Constitutional Court with relation to Law 42-2006 and doctrinaire interpretations submitted by the parties' experts. Given that the contract stipulated that it had to be interpreted in accordance with the provisions of the Ecuadorian Civil Code, the Tribunal quoted as the most relevant provision therein, Article 1561, which establishes: "All contracts legally entered into are law for the parties, and can only be invalidated by mutual consent or on legal grounds". This provision read in conjunction with those relevant to the Hydrocarbons Law and the applicable clauses of the Participation Contract sustained the Tribunal's conclusion that oil contracts could be amended provided this had the mutual consent of the parties. As noted above, the contracts included clauses contemplating the

${ }^{1008}$ By concluding that the caducity proceeding was subject to arbitration provided that it had been activated on technical or economic grounds, the Tribunal transcribed the ICSID arbitration clause:

314. The situation is different under the terms of the Block 21 Contract, which does not provide that "[i]n cases of termination for reasons other than caducity, the procedures agreed to by the Parties in [the Arbitration section]" shall apply. Instead, it states that if a caducity proceeding has been initiated, and the cause is related to technical or economic aspects, and the parties "have differing views", either party may submit the matter to arbitration. In such event, the process of caducity should be suspended for the duration of the arbitration. As the Tribunal discussed in its Decision on Jurisdiction, the parties also added provisions regarding the procedure of the arbitration through Annex XVI to the Block 21 Contract. Annex XVI provides that:

Once the Convention on the Settlement of Investment Disputes, ICSID, has been approved by the National Congress of the Republic of Ecuador and, therefore, is fully in force, the Parties agree that any technical and/or economic dispute arising out of the application of the Participation Contract for the Exploration and Exploitation of Hydrocarbons in Block 21 of the Amazon Region, which is the object of the present Contract, shall be resolved according to the provisions of the aforementioned Convention, leaving, accordingly, without effect the Arbitration procedure provided in clause twenty of the Contract.

For the application of the Convention on the Settlement of Investment Disputes, ICSID, the following procedural rules shall also apply:

1. The Parties agree to submit to the INTERNATIONAL CENTRE FOR THE SETTLEMENT OF INVESTMENT DISPUTES any technical and/or economic dispute relating to this Participation Contract for the Exploration and Exploitation of Hydrocarbons for resolution through the Arbitration mechanism, which for all effects is hereafter referred to as "THE CENTRE"...

See, Perenco Ecuador Limited vs. The Republic of Ecuador, ICSID Case No. Arb/08/6, Decision On Remaining Issues Of Jurisdiction And Liability, September 12, 2014. 
event of economic changes due to acts attributable to the Ecuadorian government or Petroecuador or due to specific events exhaustively listed, like the modification of the tax regime that triggered the obligation of negotiating a correction factor that could absorb the increase or the decrease of the tax burden ${ }^{1009}$. Stipulating a correction factor not only for the increase but also for the decrease of the tax burden, would suggest that the Parties, acknowledged the particular position of Petroecuador in the Contract as an independent entity acting for its own benefit, in contrast to the conclusion of the Tribunal. For instance, in an opposite context, whereby the tax measure had the effect of diminishing the effective participation rates of Petroecuador, it could have been also entitled to trigger the renegotiation process. The ancillary importance given by the Perenco Tribunal to Petroecuador in the course of the dispute, as having concluded that it was the State and not this entity which was party to the Participation Contracts, implied that the breach of the contractual stipulations through the application of sovereign measures had been attributed to the State. ${ }^{1010}$ Moreover it is explicable that the Tribunal had disregarded the argument that the measures at issue covered revenues and not participation shares falling outside the Contracts, as the futility of distinguishing between the actions executed in a sovereign capacity from those undertaken according to the letter of the contract was early professed at the jurisdictional stage, when Petroecuador was dismissed as a party to the

1009 The Tribunal interpreted such obligation as follows:

362. By their own terms, clauses 11.7 and 11.12 of the two Contracts did not preclude the State from introducing new taxes or modifying existing ones, but in the event that such measures were introduced that had "consequences for the economy of" the Contract, the obligation arose to negotiate a "correction factor" that would absorb the increase or decrease in the tax burden.

See, Perenco Ecuador Limited vs. The Republic of Ecuador, ICSID Case No. Arb/08/6, Decision On Remaining Issues Of Jurisdiction And Liability, September 12, 2014.

1010 Interestingly, the Tribunal grounded its interpretation in the Constitutional Court's stance advocating for the State's attribution to alter the pacta sunt servanda rule (parragraph 372):

371. That however is not the end of the matter. The fact that Petroecuador, as the nominal counterparty to Perenco, did not itself purport to amend the Contracts does not mean that the State did not modify their operation by other means. Law 42 required the contractor to pay to the State a newly declared "participation in windfalls from oil prices not negotiated or anticipated." In doing so, it effectively modified the operation of clauses 5.3.2 (the right to receive the Contractor's share of the production at the Fiscalization and Delivery Center and to "freely dispose of" that share), 8.2.1 (the Contractor's right to opt to receive its share in cash), and 10.2 (the Contractor's right to market the production that belongs to it on the domestic or foreign market) of the Block 7 Participation Contract (and the corresponding clauses of the Block 21 Participation Contract).

See, Perenco Ecuador Limited vs. The Republic of Ecuador, ICSID Case No. Arb/08/6, Decision On Remaining Issues Of Jurisdiction And Liability, September 12, 2014. 
Participation Contracts. ${ }^{1011}$ Approaching the writings of civil law theorists, concerning the State's power to modify an administrative contract, the Tribunal addressed the limits that Ecuadorian law sets on the exercise of the jus variandi on the basis on the expert report submitted by the Claimants, incorporating a four pronged test grounded on LatinAmerican doctrine:

"(i) the changes must have a reasonable justification ("in other words, they must not respond to a 'deviation of power')

(ii) the changes cannot distort the contract's very objective;

(iii) the contracting entity must respect constitutional guarantees that could be affected by its decision to amend the contract; and

(iv) if the exercise of jus variandi negatively affects the economic rights of the contractor, the entity must compensate the contractor, in such a way that the stipulated price does not change. ${ }^{1012}$

Relying on the Constitutional Court ruling related to Law 42-2006, the Tribunal conceded that the Court has just addressed parts (iii) and (iv) of this four-part test. It

1011 The Tribunal concluded that Petroecuador's distinct juridical personality, legal autonomy and own rights and obligations in the contracts did not suffice to deem this entity as a party to the participation contracts. By the same token, it disregarded Petroecuador's involvement as party in other ICSID proceedings to reach the conclusion at issue:

207. The only inference, that the Tribunal can draw from the circumstances is that Ecuador intended to provide Petroecuador with some considerable assets and powers to manage Ecuador's oil affairs. However, this does not demonstrate an intention that Petroecuador act as an independent entity for its own benefit when performing the Contracts.

(...) The Tribunal notes that Petroecuador's obedience to Ecuador's instructions is reflected by Petroecuador's implementation of Law 42. If, as Claimant contends, Petroecuador enjoyed so much autonomy that it made Petroecuador a party to the Contracts, Petroecuador did not have to comply with Law 42, which allegedly modified the Contracts. In the Tribunal's view, Petroecuador's compliance with Ecuador's instruction to implement Law 42 is evidence that Petroecuador never reached the level of autonomy that would make it an independent party to the Contracts.

(...) 219. Therefore, the Tribunal finds that Petroecuador undertook some rights and obligations, not in its own interest, but rather as representative of the Ecuadorian State and in furtherance of the State's interests. In this respect, Petroecuador cannot be considered as a party to the Participation Contracts

(...) 223. In other words, whatever position Petroecuador may have taken in other proceedings, this cannot possibly confer jurisdiction on the Tribunal. Therefore, the Tribunal finds that Petroecuador's prior conduct is irrelevant and, in any event, does not indicate assumption by Petroecuador of obligations as principal which would make it an independent party to the Participation Contracts.

See, Perenco Ecuador Limited vs. The Republic of Ecuador, ICSID Case No. Arb/08/6, Decision On Jurisdiction, June 30, 2011.

1012 See, Perenco Ecuador Limited vs. The Republic of Ecuador, ICSID Case No. Arb/08/6, Decision On Remaining Issues Of Jurisdiction And Liability, September 12, 2014. 
recalled that the Court's assessment affirmed that Law 42-2006 was "fully subject to the rules of Constitution 2008", although this finding could not be extrapolated to Decree 662 since its promulgation was prior to the ruling at issue. This fact did not stop the Tribunal from considering that part (iii) also satisfied such a Decree. By the same reason, it also upheld part (iv), as the Constitutional Court confirmed that the Participation Contract's financial equilibrium could be modified. However, it considered that limbs (i) and (ii) were not contemplated by the Constitutional Court and hence, it tested their compliance. Within this context, the Tribunal concluded that Law 42 at $99 \%$ as applied by Decree 662 constituted a breach of contract. As to part (i), mandating a reasonable justification to the changes effected through jus variandi, the Tribunal found that while the adjustment of a contractual relationship disrupted by an unforeseen raise of oil prices was acceptable, imposing the rate of $99 \%$ in a context of pressure and hostility with the aim of converting de facto such contracts into service contracts, was not. ${ }^{1013}$ With relation to part (ii), prohibiting changes from distorting the contract's very objective, the Tribunal found that the application of Decree 662, "completely modified the Contract's objective as it was understood by Ecuadorian law", rendering the exercise of the jus variandi unlawful ${ }^{1014}$. In the light of these findings, the Tribunal did not challenge the lawfulness

1013 When the Tribunal found that Law 42 at $899 \%$ did breach the Contract, it determined that the Decree implementing such decision in view of the context of the Parties' contractual relation could be categorized as deviation of power:

407. The Tribunal is of the view that Law 42 at $99 \%$ constituted a breach of contract. Having regard to part (i), in the Tribunal's view, there was no possible reasonable justification for the State to claim $99 \%$ of "extraordinary revenues" above the reference price. While the nature of a "deviation of power" is not precisely defined, the writings of the civil law theorists cited by Dr. Pérez Loose indicate that it concerns the misuse of power. In the Tribunal's view, Decree 662 constituted an act of coercion when viewed within the context of the parties' contractual relations and therefore it can be regarded to be a deviation of power.

(...) 409. In the Tribunal's view, the application of Decree 662 and the statements of senior officials in relation thereto signaled a new phase in the State's relationship with Perenco (and the other oil companies in similar circumstances). This was no longer a question of the State seeking an adjustment of an otherwise acceptable contractual relationship which, in its view, had been disrupted by price increases of an unanticipated magnitude. Rather, Law 42 at $99 \%$ unilaterally converted the Participation Contracts into de facto service contracts while the State developed a new model of such contracts which it demanded the contractor to sign.

See, Perenco Ecuador Limited vs. The Republic of Ecuador, ICSID Case No. Arb/08/6, Decision On Remaining Issues Of Jurisdiction And Liability, September 12, 2014.

1014 The Tribunal concluded that the exercise of jus variandi as perfected through Decree 662 was unlawful under the frame of Ecuadorian Law:

410. part (ii) was also violated. In the Tribunal's view, as of 4 October 2007, Perenco's Contracts were participation contracts in name only; Decree 662 completely modified the Contracts' objective as it was understood under Ecuadorian law. It follows that Decree 662 cannot be justified as a lawful exercise of the jus variandi power under Ecuadorian law. 
of the measure seeking a balance and alleged imbalance in the economy of the Contract but it censured the proportionality of the rates further applied, in conjunction with the assumed pressures exerted by governmental officials which put under discussion the real goal of such modifications. ${ }^{1015}$

As it may be observed, the richness of the Perenco case, rests on the Tribunal's challenging task of integrating aspects of international and domestic law within a regulatory dispute triggered by contractual breach claims governed by Ecuadorian Law. The fact that the Tribunal has declared that the State and not Petroecuador was the party of the investment transaction annuls the role of the Contract as a way of controlling the type of relationships and disputes that the former as sovereign is willing to face in the light of the public interest attached to specific sectors or resources. This approach renders useless the mechanisms of governance internally designed to normalize the rights and obligations which stem from the complex interactions taking place in the course of the extractive activities, where the State and not only the government, performs its duties through different branches and instrumentalities. Thus, in the case of exploitation of nonrenewable resources, the allocation of attributions and duties made at different levels and through regulatory and contractual mechanisms, does not only pertain to the implementation of the terms corresponding to the cycle exploitation of these commodities, but also such distribution mirrors the participation of different stakeholders constitutionally and statutorily compelled to take part in the decision making associated to such activities within their competences. Disregarding the distinctions canvassed by the parties as prescribed in the administrative acts and contractual commitments agreed upon, implies the disdain of the primary normative framework within which the scope of compromises was configured and as such the Ecuadorian law chosen as the applicable

See, Perenco Ecuador Limited vs. The Republic of Ecuador, ICSID Case No. Arb/08/6, Decision On Remaining Issues Of Jurisdiction And Liability, September 12, 2014.

1015 The application of a rate of $99 \%$ to the extraordinary profits rendered useless to determine whether the activation of the contractual renegotiation would have been succesful:

411. Thus, in the Tribunal's view, in moving beyond 50\% up to $99 \%$ the Respondent breached the Participation Contracts. Whatever might have transpired in clause 11 negotiations on the impact of Law 42 at $50 \%$ on the Contracts' economy (had they occurred), moving from $50 \%$ to $99 \%$, in the Tribunal's view, was no longer an attempt to claim an equitable distribution of the windfall revenues generated by an unexpected and significant increase in oil prices, and could not be justified under the applicable Ecuadorian legal standards for the exercise of the jus variandi power.

See, Perenco Ecuador Limited vs. The Republic of Ecuador, ICSID Case No. Arb/08/6, Decision On Remaining Issues Of Jurisdiction And Liability, September 12, 2014. 
law for the settlement of disputes. This implies that key legal limitations domestically developed like the non-arbitrability of certain disputes or the decision to manage certain sectors and resources through state enterprises become inapplicable, thereby distorting the foundations on which the ambit of the consent and expectations of the parties were built upon. Such expansionary interpretation puts on an equal footing interests and rights, converting any dispute into a legal one and the State as a single entity, thus, rendering unlimited and undistinguishable the nature of the actions that may be deemed as a breach regardless their source. Logically, this criticism does not advocate the subordination of international law to national law, but rather observes the necessity to weigh integrally the latter in order not to counterfeit the goals and limits of the former:

(...)In short, the application of international law to investment transactions is always a comparative process, comparing whether the government's treatment through its laws and regulations of an actual or proposed investment does or does not meet the standards required by international law.

In order to engage in that evaluation and comparison, one must thoroughly analyze and understand the relevant national law upon which such actual or proposed measure is based. 1016

The chain of events surrounding the measures to restore the allegedly economic balance underpinned by the unexpected raise of oil prices, together with the marginalization of Petroecuador as party of the Contract, do not allow a thorough analysis of what would have happened in the event that the remedies of adaptation and termination of the contract would have been resorted to ${ }^{1017}$. In the latter remedy, the Participation Contracts provided for specific grounds of termination of the contract, being in theory, those most suitable,

1016 Salacuse (Jeswald W.), The Three Laws of International Investment: National Contractual and International Frameworks for Foreign Capital, Oxford University Press, 2013, 407 p.

1017 The Tribunal heavily relied on the report produced by the Claimant's expert and interpreted the principle pacta sunt servanda in light of the Civil Code, as stipulated in the Participation Contract:

420. Dr. Pérez Loose asserted that a corollary of the proposition that the principle of pacta sunt servanda fully applied to administrative contracts is that a contractor faced with a situation of nonperformance by the public contracting entity may pursuant to Article 1505 of Ecuador's Civil Code "go before a judge or arbitrator, as applicable, to request either: (a) that he declare the contract terminated, or (b) that he order the other party to stop violating the contract and comply as was agreed."661 Under either option, the contractor has the right to claim damages.6 In any event, faced with a material breach, the private contracting entity is entitled to withhold performance of its own contractual obligations, recognised in Ecuadorian law under Article 1568 of its Civil Code and known as the "defense of the unfulfilled contract" or by its Roman law expression, "exceptio non adimpleti contractus."

See, Perenco Ecuador Limited vs. The Republic of Ecuador, ICSID Case No. Arb/08/6, Decision On Remaining Issues Of Jurisdiction And Liability, September 12, 2014. 
so that providing for such a declaration by a "res judicata" judgment declaring the termination of the one and the other, the termination by the parties' mutual agreement ${ }^{1018}$. This presupposes bringing an action before a domestic court founded on a specific clause action, being the most salient claim of material breach. However and contrary to LatinAmerican jurisdictions like the Argentinian, the Ecuadorian Civil Code does not embody a specific provision on imprevisión. ${ }^{1019}$ This hurdle read in conjunction with the submission to ICSID arbitration of "economic and technical disputes" that at the end was expansively interpreted as including certain legal conflicts, would have rendered the implementation of such a basis for termination practically ineffective. However in the event that the companies would have refused to renegotiate the terms of the contract in

1018 The contractual provision established in the Participation Contract sets the grounds for termination and caducity as follows:

Vigésimo Primera: De la terminación y Caducidad de este Contrato:

Veintiuno. Uno (21.1).- Terminación: Este Contrato terminará:

Veintiuno. Uno. Uno (21.1.1).- Por declaratoria de caducidad emitida por el Ministerio del Ramo por las causales y bajo y el procedimiento establecido en los artículos setenta y cuatro (74), setenta y cinco (75) y setenta y seis (76) de la Ley de Hidrocarburos, en lo que le sean aplicables.

Veintiuno. Uno. Dos (21.1.2).- Por transferir derechos y obligaciones de este Contrato, sin autorización del Ministerio del Ramo.

Veintiuno. Uno. Tres (21.1.3).- Por sentencia judicial ejecutoriada de quiebra de la Contratista.

Veintiuno. Uno. Cuatro (21.1.4).- Por modificación de la personalidad jurídica de la Contratista, sin autorización del Ministerio del Ramo.

Veintiuno. Uno. Cinco (21.1.5).- Por extinción de la personalidad jurídica de la Contratista.

Veintiuno. Uno. Seis (21.1.6).-Por acuerdo de las partes.

Veintiuno. Uno. Siete (21.1.7).- Por sentencia judicial ejecutoriada que declare la terminación de este Contrato.

Veintiuno. Uno. Ocho (21.1.8).- En cualquier tiempo y durante la vigencia de este Contrato, a opción de la Contratista, una vez que hubiere cumplido con sus obligaciones contractuales y legales exigibles a la fecha, previa autorización del Ministerio del Ramo.

Veintiuno. Uno. Seis (21.1.9).- Por el vencimiento del plazo de este Contrato.

Veintiuno. Dos. Seis (21.2).-Caducidad: Para los casos de incumplimiento que puedan constituir causa de caducidad, de acuerdo con lo dispuesto en la Ley de Hidrocarburos, se seguirá el procedimiento descrito a continuación:--(...)"

1019 Momberg Uribe addresses thoroughly the reception of imprevisión doctrine by Latin-American jurisdictions, remarking its complete lack of uniformity. However, in the case of Argentina such a doctrine has developed consistently, to the point to expressly include this corresponding on provision of the Civil Code. The author embraces the convenience of such statutory recognition:

(...) Argentinian legal theory and case law have developed a consistent doctrine with regard to the subject of unexpected circumstances. Thus, the conditions and effects of imprevision have been widely analyzed in theory and tested in practice, especially in periods of economic crisis which have affected Argentina since 1975. However, the right of the affected party to rely on the imprevision doctrine has not led to the instability of the socio-economic system through the destruction of the principle of the sanctity of contracts or reliance on their enforcement but, on the contrary, they have become a tool to correct unjust and undesired effects of such a system for contractual parties $(\ldots)$

Momberg Uribe (Rodrigo), The effect of a change of circumstances on the binding forcé of contracts,: Comparative Perspectives, Intersentia, 2011, 136 p. 
good faith making impossible the review of the economic terms of the contract, such a judicial avenue could have also been activated on the grounds of abus do droit, doctrine stated in the Ecuadorian Civil Code and that may moderate the principle of pacta sunt servanda. The described spaghetti bowl of statutorily and contractually applicable sources and forums both at the international and domestic levels surrounding long investment agreements makes it difficult to draw the boundaries between acta jure gestioni and acta jure imperii, as well as of the type of disputes amenable to being initiated before the diverse venues contemplated in the relevant contracts. In any case, the Tribunal warned that when it examined the contractual breaches Ecuadorian law bound its interpretation by an express choice of the Parties, whereas in the case of assessing treaty breaches, its mandate was confined to assuring the prevalence of International Law. ${ }^{1020}$

\subsubsection{The Introduction of Legal and Contractual Waivers to Resort to the Protection of International Investment Treaties}

The Perenco tribunal took note of the attempts of the Ecuadorian officials expressed through letters and public statements to induce the companies to agree to convert all participation contracts into service contracts. Such a contractual modification included carving out certain disputes from arbitration, as well as replacing ICSID arbitration with regional arbitration. ${ }^{1021}$ These attempts were consistent with the measures taken by the

1020 In this regard, the Tribunal clarified:

581. Listing these measures, taken over a period of some four years, illustrates the deepening and intensification of the State's demands and actions. When evaluating the international lawfulness of Law 42 at 50\%, however, the Tribunal will consider this measure separately from the measures which ensued. In the course of this analysis, it will be evident that certain of the Tribunal's determinations with regard to the alleged breaches of contract assume importance in the Treaty claim. To some extent, the Treaty analysis mirrors the contract analysis. However, in contrast to its contractual jurisdictional mandate, in exercising its jurisdiction to apply the Treaty, the Tribunal is not bound by Ecuadorian law or by the courts' interpretation of that law, although it will defer to an authoritative interpretation of the domestic law.

See, Perenco Ecuador Limited vs. The Republic of Ecuador, ICSID Case No. Arb/08/6, Decision On Remaining Issues Of Jurisdiction And Liability, September 12, 2014.

1021 The Tribunal referred to the letter submitted by the Minister of Energy enlisting the amendments the State wanted to materialize through the new model of contracts:

618. The Tribunal can understand why Burlington arrived at this conclusion. In his letter to Perenco dated 18 August 2008, Minister Chiriboga commented: 
State to disengage from the regime of international investment protection, like the notice of withdrawal of consent submitted to ICSID concerning disputes involving nonrenewables resources, the insertion of constitutional provisions limiting expansive assurances to foreign companies and the subsequent denunciation of the ICSID Convention. Since at the time when these measures were implemented, Ecuador was facing an avalanche of investment disputes, reacting to any type of instrument embodying the possibility of resorting to investment arbitration was understandable. Although the oil contracts were primarily targeted ${ }^{1022}$, further contracts involving foreign investments embodied the State's attempt to neutralize the effects of international investment protection. Andrade Cadena quotes the relevant stipulation of a contract signed with a Spanish investor:

The arbitration made in conformity with this Clause shall be the only and exclusive competent forum for the settlement of disputes. Hence, the Parties waive the ordinary jurisdiction and shall not allege lack of jurisdiction of the Arbitral Tribunal, sovereign immunity or resorting to different jurisdictions set forth in any agreement for the reciprocal protection of investments or other instruments signed by the Republic of Ecuador or any similar exception that challenges the exclusive and exclusionary jurisdiction of the Tribunal, within any settlement procedure, with the exceptions enlisted in this Contract.

(...)

The Parties waive the mechanisms of dispute settlement set forth in the

$[\mathrm{T}]$ he Ecuadorian State maintains its position of converting all participation contracts to services contracts, which, among other matters, include changing from ICSID arbitration to regional arbitration...fiscal sovereignty, so that tax issues will not be subject to arbitration but to the country's courts; fulfillment of the contractual obligations of the company and of Law 42; and the withdrawal of your claims before the ICSID.

See, Perenco Ecuador Limited vs. The Republic of Ecuador, ICSID Case No. Arb/08/6, Decision On Remaining Issues Of Jurisdiction And Liability, September 12, 2014.

1022 Andrade Cadena also refers to the arbitration clause inserted in the model of Service Contacts proposed by governmental officials, which designated as forum the Permanent Court of Arbitration:

Choice and waiver: The arbitration under this Clause shall be considered the forum for the disputes arising out of this Contract or in connection therewith in accordance with the provisions set forth in any Agreement on the Promotion or Protection of Investments that could be invoked by the Contractor.

The Parties expressly waive to right to settle the disputes arising out of the Contractor in connection therewith through arbitration as established by the Convention on the Settlement of Investment Disputes between States and Nationals of Other States (ICSID).

See, Andrade Cadena (Xavier), "Renuncia al arbitraje previsto en un tratado: el caso ecuatoriano", http://www.latinarbitrationlaw.com/renuncia-al-arbitraje-previsto-en-un-tratado-el-caso-ecuatoriano/ Website visited in October 2016. Own translation. 
agreements signed by the Government of the Republic of Ecuador related to the Promotion and Reciprocal Protection of Investments with respect to any matter related, originated or linked to the execution, termination or effects of this Contract. ${ }^{1023}$

Recalling Roberts' characterization of investment treaties as triangular frameworks bestowing autonomous rights to investors, it would seem in principle, that a contractual waiver to a right stemming from a treaty would be inconvenient. Remarkably, Ecuador has not been alone in the attempt to impose waivers to investment arbitration in contracts, as Strong shows in the Colombian case. Although this country has been praised for its keenness to afford incentives and enhanced protection to foreign investment, one can note the waiver of international investment arbitration included in the model concession agreement ${ }^{1024}$, that was further amended due to the outcry of potential investors and interested parties:

The Parties agree not to resort to investment arbitration contemplated in any Bilateral Investment Treaty or other international treaty that may contain the aforementioned protection and that may come to be applicable, when a controversy has arisen between the Parties relating to the initiation, execution or termination of the present Contract, in which case the parties should resort to the dispute resolution mechanisms referred to in the present Contract to resolve such controversies. ${ }^{1025}$

As Strong underscores, the resistance towards the expansionary coverage developed by investment arbitration has stimulated governmental actions towards the return to commercial arbitration. Undoubtedly, this attempt entails a series of substantive

\footnotetext{
1023 See, Andrade Cadena (Xavier), "Renuncia al arbitraje previsto en un tratado: el caso ecuatoriano", http://www.latinarbitrationlaw.com/renuncia-al-arbitraje-previsto-en-un-tratado-el-caso-ecuatoriano/ Website visited in October 2016.

${ }^{1024}$ Concerning the Colombian case, Strong illustrates:
}

The contract was expected to generate approximately 10 to 20 concessions over several months, with each contract lasting between 25 and 30 years (ibid). Bids were anticipated to come from a number of countries, including Brazil, China, France, Italy, Portugal and Spain (ibid).

See, República de Colombia, Ministerio de Transporte, Agencia Nacional de Infraestructura, 'Contrato de Concesión Bajo el Esquema de APP No [*] de [*] Global Arbitration Review $<$ http://www.globalarbitrationreview.com/ cdn/files/gar/articles/PPP_Model_Contract.pdf $>$ accessed 12 May 2014 ('Model Agreement'); see also Perry (n 12) in S.I Strong, "Note: Contractual Waivers of Investment Arbitration: Wa (i) ve of the Future?” 692, ICSID Review, Vol. 29, No. 3 (2014), pp. 690-700 doi:10.1093/icsidreview/siu011 Published Advance Access June 18, 2014.

1025 Strong (S.I), "Note: Contractual Waivers of Investment Arbitration: Wa (i) ve of the Future?" 692, ICSID Review, Vol. 29, No. 3 (2014), pp. 690-700 doi:10.1093/icsidreview/siu011 Published Advance Access June 18, 2014, 692 p. 
and procedural complexities that go beyond the control of the State willing to restrain the boundaries of international investment protection. In the first place, the fact that commercial arbitration primarily relies on the host State's law as the law applicable for the formation and execution of the arbitration agreement implies that fundamental issues like the arbitrability of disputes and the validity of the agreement will be governed by domestic rules. Since the internationalization of commercial agreements bring to the table more than one system of legal rules, the interaction of laws governing procedural and substantive issues as well as those governing the recognition and enforcement of awards is completely different to that developing within investment disputes. The clash between party autonomy and mandatory rules arising out of treaties raises the question as to what extent the Parties may effectively agree upon the contractual waiver of treaty based protection. Strong indicates that the question surrounding this conflict is "whether contractual waivers of investment arbitration give rise to an inconsistency between national and international law"1026. It is also worth noting the legislative attempt to curtail the effects of treaty based protection in the financial sector by obliging foreign entities establishing branches in Ecuador to recognize their subordination to the domestic framework and national courts as well as the State's authority to exercise regulatory powers not limited by the provisions of any investment or trade agreement. However, the wording of such provisions does not contain an explicit and unambiguous obligation to waive international investment arbitration. In the case of contractual waivers and notwithstanding the lack of binding precedents in a context where it is not rare Tribunals reach opposite conclusions regarding very similar issues, the pattern of decisions scholarly analyzed suggests that the primary perspective consists of distinguishing contract from treaty claims. Concerning the imposition of statutory waivers, it would seem that the predominance of international law over domestic law as provided for by Article 27 of the VCLT would settle any underlying inconsistency. However this regulatory innovation could be deemed as a factor to construe the scope of the investors' legitimate expectations as well as any possible finding of the host State's bad faith. Contrasting the awards Toto Construzioni Generali SpA v Republic of Lebanon, SGS and Aguas del Tunari and the Annuling Decision in Compañia de Aguas del Aconquija SA and Vivendi Universal $v$ Argentine Republic, Strong concludes that claims "based in

${ }^{1026}$ Strong (S.I), "Note: Contractual Waivers of Investment Arbitration: Wa (i) ve of the Future?" 692, ICSID Review, Vol. 29, No. 3 (2014), pp. 690-700 doi:10.1093/icsidreview/siu011 Published Advance Access June 18, 2014, 695 p. 
whole or in part on a contract that includes a waiver of investment arbitration could properly be excluded from an investment proceeding" ${ }^{1027}$. In this line, renouncing the right to arbitrate contract claims in a treaty forum will also be admissible.

By the same token, such a waiver does not affect the tribunal's ability to entertain claims arising out of a treaty. This conclusion would be in line with the interpretation reached by the SGS Tribunal that holds "the right to international arbitration in situations involving treaty claims due to concerns about the presumed involvement of some public interest on the part of the home state". ${ }^{1028}$ Thereby, the right to treaty based investment arbitration would be considered to rest in the realm of international public policy being the high threshold to enforce such a waiver. ${ }^{1029}$ In any event and admitting that contractual waivers to contract based disputes may be in principle allowed ${ }^{1030}$, it is clear that the wording of the specific contractual waiver as well as of the treaty at issue will play a seminal role. Particularly challenging are the inquiries as to whether a waiver should be considered a matter of admissibility or jurisdiction, especially when an umbrella clause may come into play. In view of the domestic effects of the constitutional rulings in the Ecuadorian case, it would follow that the public authorities would be barred from giving consent to contractual disputes in the treaty forums as set forth in the dispute settlement provisions of the BITs examined. In this regard, it could be affirmed that the logic behind these measures would be reducing the exposure of the State to be held liable for the breach of international law due to a breach of contractual obligations. In any case

1027 Strong (S.I), "Note: Contractual Waivers of Investment Arbitration: Wa (i) ve of the Future?" 692, ICSID Review, Vol. 29, No. 3 (2014), pp. 690-700 doi:10.1093/icsidreview/siu011 Published Advance Access June 18, 2014, 697 p.

1028 Strong (S.I), "Note: Contractual Waivers of Investment Arbitration: Wa (i) ve of the Future?" 692, ICSID Review, Vol. 29, No. 3 (2014), pp. 690-700 doi:10.1093/icsidreview/siu011 Published Advance Access June 18, 2014, 697 p.

1029 Strong, (S.I) "Note: Contractual Waivers of Investment Arbitration: Wa (i) ve of the Future?" 692, ICSID Review, Vol. 29, No. 3 (2014), pp. 690-700 doi:10.1093/icsidreview/siu011 Published Advance Access June 18, 2014, 699 p..

${ }^{1030}$ Notably Perenco acknowledged the possibility to waive the right to submit treaty claims, provided such a waiver were explicit:

Perenco submitted that "only an explicit, clear and unambiguous waiver by the investor of its right to submit treaty claims to an ICSID Tribunal [could] bar such claims in ICSID arbitration" 4 , and that none of the provisions in the Contracts could be said to constitute a clear and unambiguous waiver of ICSID jurisdiction over caducidad-related Treaty claims.

See, Perenco Ecuador Limited vs. The Republic of Ecuador, ICSID Case No. Arb/08/6, Decision On Remaining Issues Of Jurisdiction And Liability, September 12, 2014. 
and following principles of customary international law, the repudiation of a contract not based on commercial reasons by the exercise of sovereign authority would potentially trigger the State's international liability, as the principle pacta sunt servanda would also apply to contracts of an international character. ${ }^{1031}$ However it is undeniable that breaching the standards of protection in accordance with the principle of customary international law imposes a higher threshold of appreciation as to the standards of protection normally established by BITs.

Undeniably, the drastic change of paradigm between the Constitution of 1998 and the Constitution of 2008 concerning the State's role in the economy, the over-arching exercise of constitutional control and the revisited participation in the benefits of the exploitation of non-renewable resources have underpinned regulatory measures with an impact in contractual relationships touching upon investors' interests. Contrasting the regulatory measures impacting such relationships, it is clear that resorting to a particular constitutional framework has not been crucial to operationalize the State's interests over particular sectors. Indeed, the regulatory measures adopted for increasing the State's participation after the alleged surplus of oil prices have been adopted under the Constitution of 1998. Although the Constitutional Court has been reluctant to rule directly over the constitutionality of contracts, it has controlled the administrative acts upon which seminal contractual commitments have been built. In any case, it is clear that neither the treaties nor the contracts have barred the possibility to react to changing circumstances. What the Tribunals ultimately have ruled about concerns the lawfulness of the means and the proportionality of the measures undertaken in order to modify contractual commitments. Clearly, the expansionary interpretation of the disputes that may be subject to arbitration has rendered useless the internal mechanisms of governance and management of strategic sectors and resources, making it difficult to distinguish between contractual and regulatory disputes. This is properly a manifestation of the contractualization of regulatory powers, which was aggressively implemented during the 1990s. The blurred private/public distinction also expressed in the dichotomy of commercial/regulatory, has meant that the mechanisms foreseen in the contracts for negotiating changed circumstances had become ineffective. In this context, a careful assessment of the position under which a measure is adopted is crucial for minimizing

1031 Salacuse (Jeswald W.), The Three Laws of International Investment: National Contractual and International Frameworks for Foreign Capital, Oxford University Press, 2013, 319 p. 
the deployment of investment protection rules (i.e, sovereign or contractor). The same reflection applies for the intended waivers as set forth in the municipal legislation and contracts, which in principle may not override treaty-based protections. In sum, what the tribunals have assessed is not whether reacting to changed circumstances is allowed, but the lawfulness and proportionality of the means used to adapt to such transformations. The manifold sources integrated to settle a dispute demonstrates the technical complexity surrounding the relationships between the State and investors.

\subsection{Conclusions}

The interplay between international law and national law within a new constitutional context unfolds the interaction of multiple actors and interests nuanced by overlapping layers of regulation within a framework based on domestic rules, strongly permeated by international obligations. The permeation of international law in the national legal order disrupts the notion that the latter lies outside the municipal legal framework. The vigorous reclaiming of sovereignty by attempting to enforce the principle of constitutional supremacy through a renewed control mechanism of international obligations shows the resistance of domestic organs to the perceived encroachment of their influence areas.

Contrasting the way the Constitutional Court interprets and applies International Law with the meaning given to the same concepts by international courts, as well as the Court's arguments to challenge the international status quo is noteworthy. The reluctance to employ mechanisms of consistent interpretation grounded on a firm criticism of legal constraints - allegedly founded on neo-liberal values - portrays the significant political weight involving the assessment of international legal obligations.

The attempt to invoke the "rebus sic stantibus" principle as the key legal doctrine for challenging the allegedly detrimental deployment of IIAs implies an individual examination of the resulting effects, depending on the viewpoint and forum whereupon the applicability of such a principle has been claimed. In this regard, the Constitutional Court's finding that a fundamental change of circumstances took place with the promulgation of the 2008 Constitution-rendering the BITs incompatible with the new constitutional framework - implies that these treaties are no longer considered part of the domestic legal system and, as such, a source of rights and obligations binding to the domestic organs. 
In view of the scope of competencies of the Constitutional Court and the domestic effects of its rulings, confronting the wording of the treaties to specific constitutional provisions - as this Court did-involves an exercise of literal interpretation of legal sources integrated into the domestic framework. Therefore, the Court's allegation of fundamental change of circumstances - rather than sustaining a unilateral termination of the BITs - constitutes an internal justification of the overhauled mechanism of control as exercised by it.

The situation is different at an international level, where the State acts as a Contracting Party of the BITs and is subject to the Law of Treaties and the Articles of State responsibility. As noticed, the narrative developed by the Constitutional Court differs drastically from the cautious approach of the States to the rebús sic stantibus doctrine corroborated by its rare applicability in international courts. Regardless of the abundant substantive and procedural hurdles surrounding the potential application of this principle, it is clear that - in the event Ecuador decides to take this path - the strength of its argument will rest upon presenting the factual elements external to its will, which ultimately might have diluted the basis of its consent.

Logically, the internal legal and political conditions will be disregarded as there are strong grounds militating in favor of such an argument. Moreover, defining the boundaries between primary and secondary obligations is essential for achieving a coherent disengagement of the system, while minimizing the responsibility for wrongfulness. In the case of contracts, the State has to avoid targeting contractual obligations through sovereign actions allowing the designed Contract Party to resort to the relevant contractual stipulations in order to prompt possible re-negotiations.

The aforementioned conclusions suggest that neither International Law nor the municipal legal systems are reluctant to react to changed circumstances. In the case of International Investment Law, the complex interaction of State and non-State actors, along with the operation of treaty provisions, national laws and investment contracts, makes it difficult to create a thoughtful legal choice capable of adapting changes to new realities without incurring in significant contingencies. The expanding arbitral interpretations have overshadowed the ability of many of these stakeholders to react to changed circumstances, thereby resorting to mechanisms of political resistance rather than to remedies theoretically available within International Investment Law. Under these circumstances - and assuming that solutions to such failure may not be found exclusively 
within the international investment law regime — general international law should play a more prominent role in order to restore the international rule of law.

\section{Recent Developments}

From International Investment Law's lens, it is notable a political shift welcoming the return of concepts which may re-edit the neo-liberal script of the 1990s that run afoul the global mainstream that challenges the rationality of the system like the ECJ's ruling related to the Achmea case. ${ }^{1032}$ There have been important announcements aimed at overcoming the declaration of Bilateral Investment Treaties as unconstitutional, like 1) the launch of a new model of bilateral investment agreement which does not yet contemplate a definitive mechanism for the settlement of disputes ${ }^{1033}$; 2) the attempt to approve a legislative request to the Constitutional Court to re-interpret Art. 422 of the Constitution $^{1034}, 3$ ) the last minute introduction of a provision in an urgent economic bill that attempted to declare the legality of international investment agreements ${ }^{1035}$, later

1032 Case 284/16 Slovak Republic v. Achmea EU:C:2018:158.

1033 On March 2018, the Minister of Foreign Affairs presented the draft of the agreement for foreign investment protection to the ambassadors of the countries, which formerly maintained bilateral investment treaties with Ecuador. It has been affirmed, that this new draft develops standards of protection in conformity with the Constitution of 2008 and includes features of the new generation of investment treaties attaining a balance between the rights of the investors and the exercise of regulatory powers by the State. Although, it was announced procedural novelties, like the State`s standing to sue investors and an appeal stage, it is still unresolved whether ad hoc arbitration is contemplated in this proposal.

See, Ministerio de Relaciones Exteriores y Movilidad Humana, "Cancillería presenta los nuevos convenios bilaterales de inversion"; https:/www.cancilleria.gob.ec/cancilleria-presenta-los-nuevos-conveniosbilaterales-de-inversion/. Last visited, May 2018.

${ }^{1034}$ Congress-woman, Mrs. Karina Arteaga made public her proposal to submit for approval of the Plenary of the National Assembly, the request to ask the Constitutional Court for the interpretation of the provision that allegedely prohibit State the signature of treaties providing for investment arbitration (Constitution of Ecuador; Art.422). Although the Constitutional Court has delivered 18 rulings related to this provision, this shows a progressive pressure towards a new interpretation that paves the way for the adoption of treaties restablishing adhoc arbitration. The attempt is that the Constitutional Court confirms that the prohibition set forth at the provision at issue is circumscribed to "contractual and commercial disputes", which are different to treaty based disputes. The consequence of such interpretation would entitle the Government to sign international investment agreements.

See, Asamblea Nacional del Ecuador, "Propuesta para brindar seguridad jurídica a inversión recibió resplado de amplios sectores del país", June 12, 2018, https://www.asambleanacional.gob.ec/es/noticia/56079-propuesta-para-brindar-seguridad-juridicainversion. Last visited, June 2018.

1035 The National Assembly included in the urgent economic bill submitted by the President on May 24, 2018, a provision that declares the legality of treaties of investment protection as well as of the dispute settlement mechanisms provide therein. It included the offer to arbitrate before UNCITRAL and ICC venues. 
modified by a presidential veto providing for an unlimited and open statutory offer to submit all kind of disputes ("umbrella clause") with investors (foreign or national) to arbitration according to ICC, IACAC or UNCITRAL Rules, among others; in addition it did derogate the provisions of the Organic General Code of Processes for the recognition and enforcement of foreign arbitral awards and judgements ${ }^{1036}$; and 4 ) the beginning of

In the urgent economic bill approved by the National Assembly, there were introduced two reforms to Organic Code of Production, Trade and Investment that aimed to overcome the apparent prohibition to submit disputes involving the State and foreign investors to international arbitration:

\begin{abstract}
"Art (...) Investment contracts.- The State guarantees to foreign or national investors or contractors the application of technical, reliable and independent foreign or regional mechanisms of dispute settlement. The State`s organs have the obligation to offer to the investors and / or contractors the corresponding national or international regional arbitration clause, as well as the standards of public international law.

"Art. (...) Regional Arbitration.- For investments and / or contracts exceeding ten million US dollars, the State will offer in favor of investors and / or contractors, regional arbitration in law. The investor may express his written consent to the State's organ, without requiring any approval, in accordance with one of the following clauses:

1. UNCITRAL.- Any controversy resulting from the investment or the contract, its noncompliance, termination or nullity, will be resolved through arbitration in accordance with the Arbitration Rules of the UNCITRAL in force.

2. ICC.- All disputes arising or related to the investment or the contract, will be resolved definitively in accordance with the Arbitration Rules of the International Chamber of Commerce by three arbitrators appointed in accordance with the Regulation. "
\end{abstract}

See, Proyecto de Ley Orgánica para el Fomento Productivo Atracción de Inversiones, Generación de Empleo, y Estabilidad y Equilibrio Fiscal. Free translation. This approved provision in the referred bill, was modified by the President when exercised his veto as provided in the following footnote.

${ }^{1036}$ Besides stating an open offer to international arbitration in all kind of disputes with investors, it also derogated the provisions of the General Organic Code of Processes providing for the requirements to the recognition of foreign arbitral awards. By this fashion, foreign arbitral awards have the same status as a national judgement:

Art. (...) Arbitration.- For investment contracts exceeding ten million dollars of the United States of America, the State must accord national or international arbitration in law, in accordance with the law.

In the case in which the State accords international arbitration in law, the investment contract will make reference to the fact that any controversy resulting from the investment or the contract, its non-compliance, rescission or nullity, will be resolved, at the claimant's choice, through arbitration, among others, in accordance to the following rules in force at the time of the promulgation of this Law: (i) UNCITRAL - United Nations Arbitration Rules administered by the Permanent Court of Arbitration of The Hague (CPA); (ii) Arbitration Rules of the International Court of Arbitration of the International Chamber of Commerce based in Paris (CCI); or, (iii) Inter-American Commercial Arbitration Commission (IACAC). The rules of emergency arbitration will not apply in any case.

The recently enacted "Act on Productive Promotion, Investment Attraction, Employment Creation and Fiscal Balance and Stability" derogated the internal process for recognition of foreign judgements and arbitration awards, by giving foreign arbitration awards the same effect as domestic arbitration awards. This means that foreign arbitration awards like judgements of national courts bear res judicata effect.

See, Ley Orgánica para el Fomento Productivo, Atracción de Inversiones, Generación de Empleo, y Estabilidad y Equilibrio Fiscal, Ley 0, Official Gazette Suplement 309, August 21 ${ }^{\text {st }}, 2018$. 
negotiations with the intention to set up a branch of the Permanent Court of Arbitration in Ecuador ${ }^{1037}$. These maneuvers contradict the prior systematic State's stance disposed to redefine its longstanding exposure to international investment disputes.

The desperate budgetary needs along to the unexpected governmental's lenience towards international investment agreements have disdained the multiple political and diplomatic costs derived from the BITs' denunciation concluded on May 2017. The negative outcome of Chevron III award rather than converging the concerns towards the flaws of the system of investment protection, prompted the advocacy of the policy-makers for the consolidation of legal certainty through the re-adoption of international investment agreements, by acknowledging the scarce capacities and spread corruption in the Public Administration and specifically, the Judicial Branch ${ }^{1038}$.

The measures aimed to implement a fast track renegotiation of new treaties for investment protection may attempt to counterbalance the obstacles emerging by the strong precedent of seventeen constitutional rulings deeming the BITs unconstitutional, as well as the complex domestic procedure for materializing the denunciation. This situation, although weakened, remains, thereby suggesting that the acceptance of a new treaty model for investment protection could be extremely challenging both at the political and legal levels.

As noted, the assorted attempts to reedit a similar regime of investment protection as the one established in the 1990s have taken the form of reforms to statutes, regulations and contracts. This situation confirms that the battle for designing the revisited rules of investment protection takes place in different levels. This demonstrates the diverse normative tools through which the State may be exposed to international responsibility in the absence of institutional checks and balances capable to deal in a comprehensive way

\footnotetext{
1037 Apparently the intergovernmental nature of the Permanent Court of Arbitration may fall within the positive exception provided for in Art. 422 that consents treaty based investment arbitration before regional venues designated by the signatory parties.

1038 As soon as the Chevron III award was released the Secretary General to the President of Ecuador, requested the Attorney General to initiate the legal proceedings against the former President Rafael Correa and other former governmental authorities placing on them the responsibility of the negative outcome to the State. The Secretary General asserted that one of the main factors that the Arbitral Tribunal assessed to deem the State responsible was the active campaign of the Executive Branch, both domestically and internationally, to advocate against Chevron, specifically through the campaign "The Dirty Hand of Chevron".
}

See, Diario Expreso, "Ecuador solicitará derecho de repetición contra Correa si pierde fallo contra Chevron", September 6th, 2018, https://www.expreso.ec/actualidad/gobiernoecuador-rafaelcorreacorrupcion-chevron-juicios-HD2360900. 
with the extent of commitments a State may engage to both from a policy and legal perspective. Of course this task goes far beyond that merely assessing the fulfillment of putative constitutional or statutory prohibitions to sign any kind of treaties.

The fragile institutionalism cemented in the country would not make it impossible for adjudicators and rulers to depart from their prior opinions, provided that the public fiscal needs put the government in a weak bargaining position towards its counterparties, who do demand the signature of new bilateral investment treaties as a condition to materialize strategic concessions or investments; or even worse, that the revived narrative that links the concepts of liberty and democracy with the reedition of pro-bussiness rules, annihilates the massive evidence against the failed recipes already tried out by the country during the 1990s, making possible the fast track adoption of new bilateral investment treaties, with cosmetic changes.

This reality shows, on one side, the unbeatable capacity of the neo-liberal legal principles to renew and readapt themselves in circumstances of crisis, as well as the incapability of countries affected by the deployment of International Investment Law to prompt coordinated structural reforms to the system. Inter-governmental proposals like the establishment of the UNASUR Court for the Settlement of Investment Disputes have been received with skepticism and have lost pace due to the change of the political forces in the region, obliged to moderate their nationalist impetus. It is noteworthy that even the subsistence of UNASUR is in peril. ${ }^{1039}$ In light of the aforementioned, defining a solid domestic stance is essential to protect the public interest, taking into account that the uncertainties surrounding investment treaty arbitration, would incentivize multinational corporations to go back to the system of arranging their protection through contract, at the expense of transparency and accountability ${ }^{1040}$. In conclusion, both the boundaries of

1039 For instance, the recently elected President of Colombia, Iván Duque, announced his country's withdrawal from UNASUR. Also, the President of Ecuador did request the Members of UNASUR to return the headquarters building donated by the Ecuadorian government.

See: Telesur; "Colombia's Duque Reaffirms Intention to Withdraw From UNASUR”, July 9, 2018; https://www.telesurtv.net/english/news/Duque-Reaffirms-Intention-to-Withdraw-Colombia-FromUnasur-20180709-0019.html. Last visited, July 2018.

See, Diario "El Comercio", Ecuador solicitará a Unasur la devolucion del edificio que funciona como su sede en Quito; July 5, 2018; http://www.elcomercio.com/actualidad/ecuador-unasur-devolucion-edificioleninmoreno.html. Last visited, July 2018

1040 Sornarajah, M. (2015). Resistance and change in international investment law. In Resistance and Change in the International Law on Foreign Investment (pp. 389-420). Cambridge: Cambridge University Press. doi:10.1017/CBO9781316156339.009 
comfort given by a chauvinist notion of sovereignty and a blind faith towards unlimited concessions to investors should be redefined taking into consideration the inextricable engagement of domestic actions with international law. ${ }^{1041}$

${ }^{1041}$ Crawford explains the inextricable relationship between International and Domestic Law:

International law acts in such cases not as a first order definer of rights and duties but as a second order criterion of appropriatness or lawfulness-a critical standard. It operates in many respects in relation to national law; and that might be tought to cast into question its status as a system.

Moreover, Crawford points out that agencies perform both their designated functions in the internal constitutional order and also act as agents for the international legal system.

Crawford (James), Chance, Order, Change: The Course of International Law: General Course on Public International Law, Hague Academy of International Law, Ail-Pocket, 2014, 216 p. 


\section{CONCLUSIONS}

Examining whether international investment arbitration is constitutional reveals an unsettled - albeit indissoluble - relationship between International and Domestic Law. Conceptualizing International Investment Law as a framework drawing the exercise of sovereign powers implies the reconsideration of the position given to Domestic Law to enable, substantiate and enforce international obligations derived therefrom. Within this logic, International Investment Law and Domestic Law develop identical constitutionallike principles under different standards mutually influenced, evident at the rule-making and adjudicatory levels.

It has been claimed that this relationship - and specifically the deference to interpretations well settled at the domestic level-have been underestimated by international arbitral tribunals in detriment of the scope of obligations that the States sovereignly agreed upon, thereby harming the sustainability of the whole system. Looking at International Investment Law from the prism of Domestic Law, Chapter I addressed the evolution of the regulatory space in light of the protection afforded to the right to property and the development of the standards of treatment to foreigners, as well as the scope of recognition of International Law.

Notwithstanding that the discussion over the scope of the State's role within the economy and the extension of its influence over natural resources has been recurrent, its exclusive authority to regulate these areas has never been questioned. However, the significance of developments arisen from international and regional agreements concerning, for instance, the construction of a new international economic order and the strengthen of the principle of permanent sovereignty over natural resources on the constitutional design is noteworthy.

In contrast to the irradiation of the principle of permanent sovereignty over natural resources in the subsequent development of the domestic legal framework, the boundaries of Calvo Doctrine - as drafted by the different constitutions-have been stretched, shortened or even ignored according to the circumstances. Internally, the presence of a "minimal, yet enabling State" 1042 has been essential to materializing the instauration, deployment and enforcement of transnational rules of investment protection. Notably, the construction of concepts such as legitimate expectations and the strong reliance over

1042 See footnote 393. 
investors' representations lean on an aspiration of a subsidiary State's role devoted to facilitating private interests.

Nonetheless, given the utilitarian value attributed to the manifold Ecuadorian constitutions as a stamp for sanctifying circumstantial political and institutional arrangements, the exercise of overhauled mechanisms of constitutional control to recalibrate treaty-based obligations to suit to domestic standards is remarkable. This stance abolishes the well-established assumption that foreign affairs are confined to the exclusive authority of the diplomacy and it also questions the stance that treaties once ratified are exempted from domestic legal constraints and further constituencies' interests.

In that sense, the constitutional design shows that, until 2008, the State's regulatory space has been detached from foreign affairs both at the normative and decision-making levels. This outdated approach contrasts with the emergence of nonState actors as well as obligations and values that transcend the State's sphere as set forth in the Constitution. Hence, the frontiers within which international obligations have to be reviewed, negotiated and applied also become affected.

The way of delimitating the boundaries between Domestic and International Law has rested upon the assumption that the former is not permeated by the latter, as both would operate in different levels disregarding that such interaction affects the ultimate addressees of such rules: the citizens. Under the command of diplomacy, international arbitration and, specifically, investor-State, arbitration developed silently along the construction of allegedly universal concepts of good governance that featured the multilateral institutional system. Accordingly, the international system of dispute settlement in the context of International Investment Law borrowed the conceptual milestones underpinned at the multilateral level, as well as its most effective procedural features, blurring - at the same time - the distinction between regulatory and private relationships.

As highlighted in Chapter II, while the development of International Investment Law was underpinned by multilateral efforts, the definition of the scope of commitments was confined to bilateral and mostly uneven relationships, becoming —in practice - accession agreements. Albeit the presence of a clear-cut distinction between regulatory and the private space's contours - especially when multilateral instruments have been concluded - such understanding has vanished when it has involved bilateral treaties. Moreover, policy-makers misunderstood and assumed that the main source of conflict 
involving the State and investors derived from contractual or commercial relationships influenced by the constitutional design. Likewise, they overlooked the fact that its core lies upon the exercise of regulatory powers provided for by international investment agreements.

As the Ecuadorian experience shows, when the State departs from this minimal role and later pushes to regain regulatory space, legally complex and highly politicized disputes may arise. In this context, the contrast between the Constitutions of 1998 and 2008 is remarkable, being the former a paradigmatic example of a normative text that subordinated any action - public or private - to any type of commitment reached with foreign investors. In this context, the BITs operated just as gatekeepers for regulatory stagnation, as the subsequent treaty-based disputes evidence.

Indeed, several standards of protection provided for in BITs remained in tension with the different Constitutions and reforms that followed one another and all the internal check and balances failed for the purpose of limiting further State international responsibility. As noted, most of the substantive provisions of BITs adopted by Ecuador from 1965 to 2001 could have been in conflict with the constitutions in which they were concluded due to the extension of the standards of protection they enshrined, especially through umbrella clauses.

The reluctance of domestic adjudicators to apply mechanisms of consistent interpretation in the assessment of Bilateral Investment Treaties' constitutionality inspired by an open opposition to neoliberal values is also noteworthy, which evidences the significant political weight involving the assessment of international legal obligations. Bearing in mind the scope of competencies of the Constitutional Court and the domestic effects of its rulings, confronting the wording of the treaties with specific constitutional provisions - as this Court did-involves an exercise of literal interpretation of legal sources recognized by the domestic framework.

This means that the Constitutional Court's allegation of fundamental change of circumstances as neutralizer of the application of BITs constitutes an internal justification of a brand new mechanism of control to international obligations. In the international sphere, the State acts as a Contracting Party of the BITs and, thus, it is subject to the Law of Treaties and the Articles of State responsibility. Indeed, the domestic narrative developed by the Constitutional Court differs drastically with the cautious approach of the States to this principle corroborated by its rare applicability in international courts.

Regardless of the multiple substantive and procedural hurdles surrounding the 
potential application of the rebus sic stantibus principle, it is clear that in the event that Ecuador would have decided to advocate for the application of this principle at the international level, the strength of its argument would have rested on presenting the factual elements external to its will and ultimately might have diluted the basis of its consent.

In this regard, a lesson that should be learned consists on thoroughly assessing the importance of defining the boundaries between primary and secondary obligations for achieving a coherent disengagement of the system, while minimizing the responsibility for wrongfulness. In the case of contracts - as the investment disputes involving the Ecuadorian State show-it should avoid targeting contractual disputes through sovereign actions, thereby allowing the corresponding Contract Party to resort to the relevant contractual stipulations in order to prompt possible renegotiations.

Notwithstanding the allegedly expanding arbitral decisions limiting the ability of stakeholders to react to changed circumstances, it is clear that neither International Law nor the municipal legal systems are reluctant to react to the them in view of the complex interaction of treaty provisions, national laws and investment contracts. The far-reaching effects of first generation treaty-based standards of protection for foreign investors bind inextricably the domestic regulatory activity to their scrutiny, meaning that there is no domestic action exempted from the control of treaty-based obligations. This protection extends to any action emerging either from private or public activities and its breadth overrides further obligations of General International Law.

In this context, the importance of the overhauled legal awareness of decision-makers and the systemic influence of multi-sectorial measures aimed to resist the effects of the regime by incorporating constitutional, regulatory and contractual-based hurdles as indicated in Chapter III, should not be underestimated. These unilateral and integral responses do attempt to bring under closer scrutiny the effects of International Law in Domestic Law. In any case, there is little doubt regarding the fact that the impact of investment awards on the regulatory space triggered the redefinition of the relationship between Domestic and International Law by the national rule makers and adjudicators, as the constitutional provision aiming to annihilate international investment arbitration indicates.

Apart from the unquestionable disparities of the international investment protection system and its unforeseen expansionism, the Ecuadorian experience shows the inextricable relationship of domestic regulatory conducts with international standards. 
Therefore, the solution is neither returning to international investment agreements as adhesion instruments nor to confining Calvo Doctrine to the domestic boundaries. In countries with deficient governance, the pattern that intends to channel all investment disputes through domestic adjudication - in addition to being unrealistic and inwardlooking-does not favor the balanced protection of common interests from the international community and inconveniently shields domestic decision-makers from stronger standards of accountability.

While it may be asserted that —in a significant amount of cases-International Investment Law might have been used or even abused to serve causes it was not created for, it might also have been stated that International Law might have been unfairly beaten by this legitimacy crisis, being blamed for deficiencies for which it is not responsible. This stance might relegate one of the main features of International Law, namely cooperation, which is a more suitable approach to give voice to those who do not enjoy dominant positions.

An objective assessment should reduce nationalistic impetus willing to reassert sovereignty through re-foundational projects, which constantly claim for fundamental changes of circumstances within the domestic context. At the same time, such assessment should not disregard the anachronism of several International Law's rules deployed to serve a particular set of protected values and actors. Consequentially, the resistance of those who portray themselves as losers of an allegedly unidirectional system of protection should not be overlooked, since this discontent—rather than contributing to the cause of looking for multilateral and balanced responses that properly consider the voice of the unheard-could speed up the return to bilateral arrangements, where the bargaining power of the countries would certainly depend on their geopolitical influence.

Clearly, this could also be seen as sign of the incapability of International Law's institutions and actors to opportunely tackle the malfunction of a system. By the same token, the plausible efforts to push for the emergence of balanced treaties, by adding a never-ending variety of substantive and procedural standards, may turn them inapplicable. Thereby, the uncertainties linked to investment treaty arbitration may foster the aggressive return of contract-based arbitration, to the detriment of transparency and equality. Again, this consequence-rather than enhancing the position of resisting States - could probably contractualize investment treaty standards carefully drafted to limit the exercise of regulatory powers. Moreover, the usual confidentiality of contractbased arbitration could aggravate the democratic deficit of the adjudication system, 
whereby issues of public interest - such as disputes related to natural resources or strategic sectors-will remain in the shadows, although their outcome would impact taxpayers' pockets directly.

As emphasized, the main shortcoming of the domestic decision-makers entrusted to face and react to the burdensome effects of the system has mainly consisted on disregarding the complex web of links that construct the relations of foreign investors. On the contrary, it may be also claimed that the little deference given by international adjudicators to well-settled domestic rules and interpretations-by taking in due consideration the inextricable links between International and Domestic Law in the context of International Investment Law - could have also prompted the system's crisis from the Ecuadorian perspective.

In consequence, placing recognition of the State's right to regulate as one of the main drivers of Investment Law reform - although it restates one of the main tenets of statehood - implies a recalibration of the weight of Domestic Law standards and a major deference to its contents and local interpretation. In that context, re-editing one of the essential elements of Calvo Doctrine, stating that aliens should be afforded the same protection as locals in addition to the recognition of international forums to settle disputes could achieve greater coherence and coordination between International and Domestic Law.

This approach could respond better to the States' concerns attempting to address the interaction of multiple actors and interests nuanced by the overlapping layers of regulation within a framework grounded by domestic rules, strongly permeated by international obligations. This stance must be carefully developed in a manner that considers the exercise of regulatory attributions as a power rather than a right of the State; thereby enabling an upstream interaction between Domestic and International Investment Law.

Aside from solipsistic approaches willing to remove a State's conduct from the scrutiny of International Law, one should highlight the overhauled - albeit chaoticawareness of countries like Ecuador concerning the far-reaching effects and the multilevel dimensions of the system. This way, the incorporation of constitutional, statutory, regulatory and contract-based hurdles, in conjunction with costly decisions at the diplomatic level—like denouncing treaties while multilateral solutions are sought—show a state of alertness that may quickly be exhausted and may be of little efficacy if a systematic and organized set of measures is not taken. 
These measures should be aimed at reducing the State's exposure to international conflicts and also at attracting sustainable investment. No credible reform would be possible if the close interaction between Domestic and International Law is not taken into account. Hence, the State should look more closely inwards rather than outwards and, consequentially, focus its efforts on the measures it can immediately implement to better delineate the boundaries within which its conduct will be tested according to International Law standards.

Particularly, a legitimate attitude of resistance would be strengthened when a set of integral reforms encompassing treaties, statutes, regulations and contracts, involves correlatively an integral assessment of the internal structure of governance, including the build of technical capacities among the main domestic actors of the system and the identification of the regulatory actions that often trigger investment disputes; whichdomestically deployed-substantiate International Investment Law considering the principle that International Law regulates the conduct among States.

This challenge is colossal since it demands the democratization of International Law along all State branches and State agents, whose deeds and omissions could trigger a potential international dispute. For this reason, agents should be aware of such responsibility, which entails a fair understanding of the sources foreign investors' interests could stem from, in order to lawfully react to changed circumstances as remarked in Chapter IV.

In light of the aforementioned, no sustainable reform would be achievable if actors of this complex system remain unaware of the multi-dimensional interaction of a set of different regimes and sources of rights and obligations. To this end, it is indispensableon one hand - that Latin American countries in a legitimate resistance position reassess the scope of Calvo Doctrine and - on the other hand - that the global community shaping International Law asserts its unavoidable responsibility of protecting —in a decentralized manner-global societal values by strengthening transnational justice rather than transnational legality. 


\section{VALORIZATION ADDENDUM}

\section{RELEVANCE}

The small relevance of a developing country such as Ecuador in the geopolitical arena contrasts with its high exposure to investment disputes and its bold proposals to react to the regime of foreign investment protection.

From the perspective of International Investment Law, the overview of the Ecuadorian experience regarding the process of construction, deployment and resistance to the system allows to understand the whole picture of how the regime functions both at the international and domestic levels. Paying due attention to the complex web of links that constructs the relations of foreign investors through treaty, statutory and contract-based obligations, improves the dispute prevention process and also decision-making quality.

While the focus of the legitimacy concerns have been mainly devoted to the system of dispute settlement, the interplay between Domestic and International Law in order to set this regime into motion has been overlooked. In this regard, the integral legal assessment undertaken in this research attempts to bridge Domestic Law standards with International Law standards by grasping the way they interact and are interpreted. Such understanding contributes for better tailoring mechanisms of facilitation, regulation and protection of the investment that properly fits to the common interest and intention of a State, either as treaty signatory, regulator or contractor.

From an economic perspective, the legal categorization of international investment agreements - as instruments aimed to enforce regulatory standards of good governance instead of vehicles of attraction of investment flows-allows to look for further mechanisms of investment facilitation, regulation and protection capable of better distributing the risks among stakeholders.

In sum, a thorough legal confrontation of the intermingled narratives, concepts, rules and standards - as applied in the Ecuadorian context - contributes to current discussions surrounding reform of the system and development of new relationship mechanisms between the State, foreign investors and further stakeholders. 


\section{TARGET GROUPS}

Academics. Scholars from different legal disciplines such as International Investment Law, Public International Law, International Economic Law, International Dispute Settlement, Constitutional Law and Administrative Law may benefit from this research. In the same way, political scientists and public administration scholars may deem the complex chain of policy choices - undertaken to set the architecture of the international investment regime in a particular country —of interest.

Adjudicators. National judges increasingly engaged with the interpretation of International Law.

Policy makers. The integral legal assessment undertaken-which covers all the stages of the system's articulation and performance - draws lessons regarding the kind of issues and considerations that should be taken into consideration when dealing with key aspects like the negotiation of treaties, the emergence of disputes and the reaction to changed circumstances. They may also benefit from the analysis concerning the distinction and interplay between treaty, statutory and contract-based obligations in order to make thoughtful policy choices, either to participate, reform or pull out from the system.

Students and citizens- This research addresses the evolution of the State's regulatory space and its shaping through the interaction between Domestic and International Law, as well as the historical influence of different actors to define a particular model of State.

\section{ACTIVITIES/PRODUCTS}

This research may guide countries, agencies and other organizations devoted to recalibrating their investment instruments. It provides policy recommendations covering the entire system of foreign investment engagement.

Due to the focus of this thesis on the Ecuadorian context, this book may become an scholarly source that may: 1) clarify the scope of international treaties within the domestic framework; 2) shed light concerning the conditions under which arbitration Stateinvestors may be permitted and; 3) elucidate the scope of investment agreements and further instruments capable to suit the national framework. 


\section{INNOVATION}

This research provides a detailed account of legal history from the perspective of the evolution of protection mechanisms for foreign investors in light of regulatory space. This issue was most likely not discussed earlier in English.

It also addresses the articulation and deployment of International Investment Law standards from the prism of Domestic Law. Evaluating the role of Domestic Law on enabling and substantiating International Investment Law standards-from a historical examination that blends legal and policy assessment-departs from the common focus from researches undertaken in this area.

\section{DISSEMINATION}

Being Ecuador a paradigmatic country on the field of investment policy and arbitration, it would be easy to present the main findings of this research in any academic forum worldwide dealing with matters of investment. Additionally, the mechanisms used to articulate and set the system in motion, as well as the kind of disputes arisen, do not differ drastically among developing countries. Multilateral forums like UNCTAD and UNCITRAL and international non-governmental organizations-such as the International Institute of Sustainable Investment—-may be interested in using the entire or part of the assessment as working material.

It may also contribute to the policy and judicial debates that may arise in the immediate future in Ecuador, regarding the possibility of adopting new investment treaties and the proposal for new tools of investment facilitation and regulation, including the prevention of disputes through mechanisms like mediation. During the course of the research, several findings were presented in forums such as the meeting of the Latin-American Society of International Economic Law (2017) and the 12 $2^{\text {th }}$ Forum of Country Investment Negotiators convened by UNCTAD (2019). 
Agencies from developing countries embarked on the renegotiation of their investment agreements may be approached, stressing the necessity to look beyond treaties by fostering, in parallel, comprehensive reforms from inwards. 


\section{BIBLIOGRAPHY}

\section{Articles, Books and Reports}

- Acosta (Alberto), Breve Historia Económica del Ecuador, Corporación Editora Nacional, Quito, 2012.

- Alvarez (José), The Public International Law Regime Governing International Investment, Hague Academy of International Law, 2011.

- Andrade Cadena (Xavier), "Renuncia al arbitraje previsto en un tratado: el caso ecuatoriano", http://www.latinarbitrationlaw.com/renuncia-al-arbitraje-previstoen-un-tratado-el-caso-ecuatoriano/ Website visited in October 2016.

- Andrade Quevedo (Karla), "La acción de protección desde la jurisprudencia constitucional" in Manual de justicia constitucional ecuatoriana, Coord. Benavides Ordóñez (Jorge) and Escudero Solíz (Jhoel), Corte Constitucional, Quito, 2013.

- Andrade (Santiago), Grivalva (Agustín) y Storini (Claudia), La nueva Constitución del Ecuador: Estado, derecho e instituciones, Universidad Andina Simón Bolívar, Quito, 2009.

- Ascensio (Hervé), “1969 Vienna Convention, Article 70, Consequences of the termination of a treaty" in The Vienna Convention on the Law of Treaties: A Commentary, Edited by (Olivier) Corten and (Pierre) Klein, Oxford University Press Inc., New York, 2011.

- Aust (Anthony), Modern Treaty Law and Practice, Third Edition, Cambridge University Press, 2013.

- Aust (Helmut Philipp), "Investment and Sustainable Development: What Role for the Law of State Responsibility?" in Shifting Paradigms in International Investment Law: More Balanced, Less Isolated, Increasingly Diversified, Editors, (Hindelang) Steffen and (Krajewski (Markus), Oxford Scholarship Online, April, 2016. 
- Ávila Santamaría (Ramiro), "El constitucionalismo ecuatoriano. Breve caracterización de la Constitución de 2008”, en Tendencias del constitucionalismo en Iberoamérica, UNAM-IIJ, México DF, 2009; Carbonell (Miguel), Carpizo (Jorge) y Zovato (Daniel) (Coordinadores).

- Ayala Mora (Enrique), Historia Constitucional: Estudios comparativos, Biblioteca de Historia. Vol. 36, Universidad Andina Simón Bolívar, 2014.

- Bandelj (Nina) and Matthew C (Mahutga), "Structures of globalization: Evidence from worldwide network of bilateral investment treaties (1959-2009)", International Journal of Comparative Sociology 54 (2).

- Basset Moore (John), “The Monroe Doctrine”, Annals of the American Academy of Political and Social Science, Vol. 96, The Place of the United States in a World Organization for the Maintenance of Peace, 1921.

- Beale (Joseph H.), “The Jurisdiction of a Sovereign State”, Harvard Law Review, Vol. XXXVI, No.3, 1923.

- Beatson, Matthews and Elliot's, Administrative Law: Text and Materials, Third Edition, Oxford University Press, 1999.

- Binder (Christina), "Does the Difference Make a Difference? A Comparison between the Mechanisms of the Law of Treaties and of State Responsibility of Means to Derogate from Treaty Obligations in Cases of Subsequent?" in State Responsibility and the Law of Treaties, Edited by Marcel Szabó, International Publishing, 2010

- Benalcázar Guerrón (Juan Carlos), Derecho Procesal Administrativo Ecuatoriano: Jurisprudencia, dogmática y doctrina, Quito, 2007.

- Behn (Daniel), "Legitimacy, Evolution, and Growth in Investment Treaty Arbitration: Empirically Evaluating the State-of-the-Art”. Geo. J. Int'1 L., 2014, vol. 46.

- Benvenisti (Eyal), The Law of Global Governance, Hague Academy of International Law, 2014.

- Benvenisti (Eyal), "Reclaiming Democracy: The Strategic Uses of Foreign and International Law by National Courts", 102 Am. J. Int'1 L. 2412008.

- Blackaby (Nigel), "Investment Arbitration and Commercial Arbitration (Or the tale of the Dolphin and the Shark)" in Pervasive Problems in International Arbitration, Ed. Mistelis (Loukas A.) and Lew (Julian D.M), Kluwer law International, The Netherlands, 2006. 
- Bogach (Susan V.) and Zolezzi (Eduardo), "Electricity Sector" in Revisiting Ecuador's Economic and Social Agenda in an Evolving Landscape, 202, FretesCibils (Vicente), Giugale (Marcelo), Somensato (Eduardo), Editors, The World Bank, Washington DC, 2008.

- Blanksten (George I.), Ecuador: Constitutions and Caudillos, University of California Press, Berkeley and Los Angeles, 1951.

- Bonnitcha (Jonathan) and Aisbett (Emma), "An Economic Analysis of the Substantive Protections Provided by Investment Treaties" in Yearbook On International Law and Investment Policy, 2011-2012, Edited by Sauvant (Karl P.), Oxford University Press, 2013

- Brownlie (Ian), Principles of International Public Law (Oxford: Oxford University Press, 2008, 7th edn), 31 in (Boas) Gideon, Public International Law: Contemporary Principles and Perspectives, Edwar Elgar Publishing Limited, 2012

- Bustamante (Teodoro) and Zapata Ríos (Oscar), "Características de los contratos petroleros" in Detrás de la cortina de humo: dinámicas sociales y petróleo en el Ecuador, Ed. Bustamante (Teodoro), FLACSO, 2007.

- Camp Keith (Linda), Political Repression: Courts and the Law, University of Penssylvania Press, 2012.

- Carver (J) and Hossain (H), “An Arbitration Case Study: The Dispute That Never Was," 5 ICSID Rev (1990) 311, in Salacuse (Jeswald W.), The Three Laws of International Investment: National Contractual and International Frameworks for Foreign Capital, Oxford University Press, 2013.

- Chapaux (Vincent), "1969 Vienna Convention Article 54 Termination of or withdrawal from a treaty under its provisions or by consent of the parties" in The Vienna Convention on the Law of Treaties: A Commentary, Edited by (Olivier) Corten and (Pierre) Klein, Oxford University Press Inc., 2011.

- Chinchilla (Laura) and Schodt (David), The Administration of Justice in Ecuador, Center for the Administration of Justice, Florida International University, 1987.

- Chimni, "Co-option", in Miles (Kate), The Origins of International Investment Law: Empire, Environment and the Safeguarding of Capital, Cambridge University Press, 2013.

- Ciampi (Annalisa), "Invalidity and Termination of Treaties and Rules of Procedure" in The Law of Treaties beyond the Vienna Convention, Edited by (Enzo) Cannizaro, Oxford University Press, 2011. 
- Comisión para la Auditoría Integral Ciudadana de los Tratados de Protección Recíproca de Inversiones y del Sistema de Arbitraje en Materia de Inversiones, "Auditoría integral ciudadana de los tratados de protección recíproca de inversiones y del sistema de arbitraje en materia de inversiones en Ecuador: Informe ejecutivo", May 2017.

- Correa (Rafael), Ecuador: de Banana Republica a la No República, Debolsillo, 2012.

- Coolidge (Calvin), President of the United States, 1923-1929, "Address Before the Pan-American Conference on Arbitration and Conciliation”, Washington, D.C., December 10th, 1928; http://www.presidency.ucsb.edu/ws/?pid=471

- Crawford (Gordon), “The World Bank and good governance: Rethinking the state or consolidating neo-liberalism?", in The IMF, World Bank and Policy Reform, Ed. Paloni (Alberto) and Zanardi (Maurizio), Routledge, 2006.

- Crawford (James), Peel (Jacqueline), Olleson (Simon), “The ILC's Articles on Responsibility of States for Internationally Wrongful Acts: Completion of the Second Reading”, EJIL 2001, vol. 12, no 5, p. 963-991.

- Crawford (James), "Similarity of Issues in Disputes Arising under the Same or Similarly Drafted Investment Treaties", in Precedent in International Arbitration, General Editor: Emmanuel Gaillard, Edited by Yas Banifatemi, International Arbitration Institute, IAI Seminar, Paris-December 14, 2007.

- Dajani (Omar. M), “Contractualism in the Law of Treaties”, 34 Mich. J. Int'l L. 2012, vol. 34 .

- D’Aspremont (Jean) and Brölmann (Catherine), "Challenging International Criminal Tribunals Before Domestic Courts" in Challenging Acts of International Organizations Before National Courts, Edited by Reinisch (August), Oxford University Press, 2010.

- De Brabandere (Eric), Investment Treaty Arbitration as Public International Law, Cambridge University Press, United Kingdom, 2014.

- De Vey Mestdagh (K), "Supervision within the UN Conference for Trade and Development" in Supervisory Mechanisms in International Economic Organisations: In the Perspective of a Restructuring of International Economic Order, Van Dijk (P), General Editor, Kluwer Law and Taxation Publishers, 1984.

- Dolzer (Rudolph) and Schreuer (Rudolph), Principles of International Investment Law, Second Edition, Oxford University Press, 2014 
- Domke (Martin), “The United Nations Conference on International Commercial Arbitration", The American Journal of International Law, Vol.53, No.2, (Apr. 1959).

- Dorr (Oliver) and Schmalenbach (Kirsten), Editors, "Interpretation of Treaties" in Vienna Convention on the Law of Treaties: A Commentary, Springer, 2012.

- Dorsen (Norman), Rosenfeld (Michel), Sajó (András), Baer (Susanne), Comparative Constitutionalism: Cases and Materials, Second Edition, West, 2010.

- Dorsett (Shaunagh) and McVeigh (Shaun), Jurisdiction, Routledge-Cavendish, 2012.

- Draetta (Ugo), Lake (Ralph B.) and Nanda (Ved P.), Breach and Adaptation of International Contracts: An Introduction to Lex Mercatoria, Butterworth Legal Publishers, 1992.

- Duggan (Stephen P.), "Latin America, The League, and the United States", Foreign Affairs, Vol. 12, No. 2 (Jan., 1934).

- Embajada del Ecuador en Estados Unidos, 2 "Informe relativo a los trabajos del Comité Especial sobre la Ejecución de Sentencias Arbitrales Internacionales", Nueva York, Abril 4, 1955.

- Endara Moncayo (Jorge), Derecho Internacional Público, T. I. Editorial Universitaria, Quito, 2002.

- Espinosa (Sebastian), "State Sovereignty in International Investment Law: the case of Ecuador", Maastricht University, 2011.

- Fach Gómez (Katia), “Ecuador's Attainment of the Sumak Kawsay and the Role Assigned to International Arbitration", Yearbook on International Investment Law and Policy, 2012.

- Falkowska (Martina), Bedjaoui (Mohammed) and Leidgens (Tamara), “Article 44 Convention of 1969 Separability of treaty provisions " in The Vienna Convention on the Law of Treaties: A Commnentary, Volume II, Edited by Corten (Olivier) and Klein (Pierre), Oxford University Press, 2011.

- Federal Research Division, Ecuador a country study, Edited by M. Hanratty (Dennis), Research completed December 1989.

- Fitzmaurice (G.), “The General Principles of International Law Considered from the Standpoint of the Rule of Law" (1957-II) 92 Hague Recueil. 
- Fitzmaurice (Malgosia) and Elias (Olufemi), Contemporary Issues in the Law of Treaties, Eleven International Publishing, 2005.

- Franck (Susan D.) and Wylie (Lindsey E.), "Predicting Outcomes in Investment Treaty Arbitration”, 473, 474, 482 pp, http://scholarship.law.duke.edu/dlj/.

- Frishman (Olga) and (Benvenisti) Eyal, National Courts and Interpretative Approaches to International Law: The Case Against Convergence, Global Trust Working Paper 8/2014, ISSN 2309-7248, ISSN 2309-7248

- Gaillard (Emmanuel), “The Denunciation of the ICSID Convention”, International Arbitration Law-New York Law Journal, June 26, 2007.

- Garro (Alejandro M.), "Unification and Harmonization of Private Law in Latin America", The American Journal of Comparative Law, Vol. 40, No.3 (Summer, 1992).

- Garcia (Frank J.), "Investment treaties are about justice", Columbia FDI Perspectives, 2016, no. 185.

- García de Enterría (Eduardo) and Fernández (Tomás Ramón), Op. Cit., pp. 187 y 554 in Benalcázar Guerrón (Juan Carlos), Derecho Procesal Administrativo Ecuatoriano: Jurisprudencia, dogmática y doctrina, Quito, 2007.

- Gerlach (Allen), Indians, Oil and Politics: A recent History of Ecuador, Scholarly Resources Inc., Wilmington, 2003.

- Godin (Robert E.), Pettit (Philip) and Poge (Thomas), A Companion to Contemporary Political Philosophy, 2nd Edition, Volume 1, Blackweel Publishing, 2007.

- Gómez Fernández (Itzíar), “Los tratados internacionales en el ordenamiento jurídico ecuatoriano: su función como objeto y parámetro de control de constitucionalidad" en Derecho Procesal Constitucional, Pérez Tremps (Pablo) coord., Quito, Corporación Editora Nacional.

- Greiman (Virginia A.) "The Public/Private Conundrum In International Investment Disputes: Advancing Investor Community Partnerships", 32 Whittier L. Rev. 2010, vol. 32.

- Guerra Bello (Gustavo), "La negociación de acuerdos internacionales de inversión como instrumento para la promoción de inversiones en el Ecuador", MS thesis. Universidad Andina Simón Bolívar, Sede Ecuador, 2008.

- Haljan (David), Separating Powers: International Law Before National Courts, Springer, 2013. 
- Haupt (AJ), Paizee (D), Paizee (K), Saner (JS), Wasserfal (I), Introduction to Law, Person Education South Africa (Pty) Ltd 2009

- Helfer (Laurence R.), "Exiting Treaties”, Virginia Law Review, 2005 Vol. 91.

- Howse (Rob), "Bilateral or Multilateral Courts, Arbitration, or State-to-State Dispute Settlement: thinking about an optimal system for international investment disputes", Forthcoming, Helene Ruiz-Fabri, ed. International Law and Litigation, Nomos Press, 2017.

- Hurd (Douglas), The Search for Peace (London: Warner Books, 1997), p. 6 in International Law, Lowe (Vaughan), Oxford Press, 2007.

- Internal Auditing Commission for Public Credit of Ecuador, Final ReportExecutive Summary, November 2008.

- Johnson (Lise), "The Impact of Investment Treaties on Governance of Private Investment in Infrastructure", European University Institute, Robert Schuman Centre for Advanced Studies Global Governance Programme, EUI Working Paper RSCAS 2014/32, March 2014.

- Julliard (Patrick), "Calvo Doctrine/ Calvo Clause”, Max Planck Encyclopedia of Public International Law (MPEPIL), January 2007, http://opil.ouplaw.com/view/10.1093/law:epil/9780199231690/law9780199231690-e689.

- Karras (Bill J.), "José Martí and the Pan- American Conference”, 1889-1891, Revista de Historia Americana, vol. 77 (1974).

- Kahale (G.) III, “Is Investor State Arbitration Broken?”, Transnational Dispute Management (TDM), 2012, vol. 9, no 7.

- Kennedy (Duncan), "Three Globalizations of the Law and Legal Thought: 18502000", in The New Law and Economic Development, Edited by David M. Trubek and Alvaro Santos, Cambridge University Press, 2006.

- Kennedy (David), "The "Rule of Law", Political Choices, and Development Common Sense" in The New Law and Economic Development: A Critical Appraisal, Edited by (David M.) Trubek and (Alvaro) Santos, Cambridge University Press, 2006.

- Keyes (Mary), Jurisdiction in International Litigation, The Federation Press, Sydney, 2005.

- Kingsbury (Benedict) y Stewart (Richard B.), El Nuevo Derecho Administrativo Global en América Latina, Ediciones Rap S.A, 2009. 
- Kujiper (Peter Jan), "Study on Investment Protection Agreements as Instruments of International Economic Law", on Directorate-General for External PoliciesPolicy Department, Investor-State Dispute Settlement (ISDS) Provisions in the EU's International Investment Agreements, Volume 2-Studies, European Union, 2014.

- Lissitzyn (Oliver J.), "Treaties and Changes Circumstances (Rebus Sic Stantibus)", Am. J. Int'l L, 1967, vol. 61, no 4.

- Llanes (Henry), "Correa radicalizaría las concesiones petroleras”, June 30, 2010; https://redciecuador.wordpress.com/2010/06/30/correa-radicalizaria-las$\underline{\text { concesiones-petroleras/ }}$

- Lucy (William), "Equality under and before the Law", The University of Toronto Law Journal, 2011, vol. 61, no 3.

- Luque Macías (María José), "Reliance on Alternative Methods for Investment Protection trhough National Laws, Investment Contracts and Regional Institutions in Latin America", in Shifting Paradigms in International Investment Law: More Balanced, Less Isolated, Increasingly Diversified, Hindelang (Steffen) and Krajewsky (Markus), Editors, Oxford University Press, 2016.

- Lynn Karl (Terry), "Ensuring Fairness: The Case for a Transparent Fiscal Social Contract" in Escaping the Resource Curse, Humpfreys (Macartan), Sachs (Jeffrey D.) and Stiglitz (Joseph E.), Initiative for Policy Dialogue at Columbia, Columbia University Press, 2007.

- McPherson (Alan) Editor, Encyclopedia of U.S Military Interventions in Latin America First International American Conference, ABC-CLIO, LLC, Washington, 2013.

- Mancero (Piedad), "El Debilitamiento Institucional en la Década de los 90: Investigación y análisis del préstamo BIRF-3822-EC/Proyecto de Modernización del Estado", Quito, Diciembre de 2006, Versión revisada en septiembre de 2008.

- Mancero (Piedad), "Results of an audit to treaties mutual investment protection and arbitration system on investment" in Investment chapters in Trade Agreements, Submitted at the World Social Forum by Invitation of FriedrichEbert-Stiftung, Berlin, September 13, 2016.

- Manzetti (Luigi), "The Politics of Privatization and Deregulation in Latin America", The Quarterly Review of Economics and Finance, 1994. 
- Miles (Kate), The Origins of International Investment Law: Empire, Environment and the Safeguard of Capital, Cambridge University Press, Cambridge, 2013.

- Molano Cruz (Giovanni), "La integración andina: origen, transformaciones y estructuras", Instituto para la Integración de América Latina y el Caribe (BIDINTAL), N.33, Año 15, Julio-Diciembre 2011.

- Momberg Uribe (Rodrigo), The effect of a change of circumstances on the binding force of contracts, 2011. Doctoral Dissertation, . University Utrecht.

- Montt (Santiago), State Liability in Investment Treaty Arbitration: Global Constitutional and Administrative Law in the BIT Generation, Bloomsbury Publishing, 2009.

- Moscoso Álvarez (Raúl), Apología del Tribunal de Garantías Constitucionales, Fundación Ecuatoriana de Estudios Sociales, 1993.

- Nolte (Georg), "Constitutional Implications of German Participation in Treaty Regimes" in Delegating State Powers: The Effect of Treaty Regimes on Democracy and Sovereignty, Edited by Thomas M. Franck, Transnational Publishers, United States of America.

- Nowrot (Karsten), International Investment Law and the Republic of Ecuador: From Arbitral Multilateralism to Judicial Regionalism, Institute of Economic Law Transnational Economic Law Research Center (TELC) School of Law Martin Luther University Halle-Wittenberg, Heft 96, May 2010.

- Nollkaemper (André), National Courts and the International Rule of Law, Oxford University Press, Great Britain, 2011.

- Nollkaemper (André), “Conversations among Courts: Domestic and International Adjudicators", in The Oxford Handbook of International Adjudication, Ed. Romano (Cesare Pr), Alter (Karen J) and Shany (Yuval), Oxford University Press, 2015.

- Nollkaemper (André), "The effects of treaties in domestic law" in Research Handbook on the Law of Treaties, Edited by Tams (Christian J.), Tzanakopoulos (Antonio) and Zimmermann (Andreas), Edward Elgar Publishing, 2014.

- O'keefe (Thomas Andrew), "How the Andean Pact Transformed Itself into a Friend of Foreign Enterprise", The International Lawyer, 1996, Vol. 30, No. 4.

- Oliver (Dawn), Prosser (Tony) and Rawlings (Richard), The Regulatory State: Constitutional Implications, Oxford University Press, 2010. 
- Organization of American States, Department of International Law, "Development of International Law: The History of the Cidip Process" (Specialized Conferences on Private International Law”); http://www.oas.org/dil/PrivateIntLawHistDevPriLaw-Eng.htm

- Organization of the American States (OAS), "Our origins"; http://www.oas.org/en/about/our_history.asp

- Oyarte Martínez (Rafael), Derecho Constitucional: ecuatoriano y comparado, Corporación de Estudios y Publicaciones, 2014.

- Pareja Diezcanseco (Alfredo), Historia de la República, Tomo I, Colección Bicentenaria, Campaña de Lectura Eugenio Espejo, 2009.

- Paullsson (Jan), “Arbitration Without Privity”, ICSID Review, 1995, Vol. 10 No. 2.

- Pellet, (Allain) “A French Constitutional Perspective on Treaty Implementation” in Delegating State Powers: The Effect of Treaty Regimes on Democracy and Sovereignty.

- Pereira (Ricardo) and Gough (Orla), "Permanent Sovereignty over Natural Resources in the 21st Century: Natural Resource Governance and the Right to SelfDetermination of Indigenous Peoples under International Law", Melbourne Journal of International Law, 2014, vol. 14, no 2.

- Pérez Loose (Hernán), "International arbitration in public-private partnership", International Law Office, January 21, 2016.

- Polanco Lazo (Rodrigo), "Systems of Legal Defence Used by Latin American Countries in Investment Disputes", Journal of World Investment \& Trade 2016, vol. 17 , no 4.

- Polanco Lazo (Rodrigo), "Beyond ICSID Arbitration: The Center for Settlement of Investment Disputes of UNASUR" in Yearbook on International Law and Policy, 2014-2015.

- Poulsen (Lauge N. Skovgaard), "Bounded Rationality and the Diffusion of Modern Investment Treaties”, International Studies Quarterly 2014, vol. 58, no 1.

- Prieto Muñoz (José Gustavo), “The Rise of Common Principles for Investment in Latin America: Proposing a Methodological Shift for Investor-State Dispute Settlement", Journal of World Investment \& Trade, 2016, vol. 17, no 4. 
- Procuraduría General del Estado, "A Critical View of Investment Arbitration Based On Ecuadorian Experience”, Management 2008-2016, García Carrión (Diego), Gómez de la Torre (Blanca) and Gaybor, Quito (Christel), August 2016.

- Robalino Orellana (Javier) and Jijón Letort (Rodrigo), "National and International Arbitration in Ecuador", The Arbitration Review of the Americas, 2014.

- Roberts (Anthea), "Triangular treaties: the nature and limits to investment treaty rights", Harvard International Law Journal, 2015, vol. 56, no2.

- Ruiz-Fabri (Helene), "Bilateral or Multilateral Courts, Arbitration, or State-toState Dispute Settlement: thinking about an optimal system for international investment disputes" (Forthcoming_, ed. International Law and Litigation, Nomos Press, 2017.

- Romano (Carlo), “Advanced Tax Rulings and Principles of Law: Towards a European Tax Ruling System?”, IBFD Publications BV, Amsterdam 2002

- Rutledge (Peter B.), Arbitration and the Constitution, Cambridge University Press, 2013.

- Ryan (Alana), "Liberalism", on Godin (Robert E), Pettit (Philip) and Poge (Thomas) Editors, A Companion to Contemporary Political Philosophy, Chapter 14, 2nd Edition, Volume 1, Blackweel Publishing, 2007

- Salacuse (Jeswald W.), The Three Laws of International Investment: National Contractual and International Frameworks for Foreign Capital, Oxford University Press, 2013.

- Salgado Levy (Claudia), "La legalidad de las inversiones como un requisito para la protección de los tratados internacionales de inversiones", Foro Revista de Derecho, 2017, no 18.

- Santa Cruz (Hernán) "The creation of the United Nations and ECLAC", CEPAL Review 57, December, 1995.

- Santos (Álvaro), "The World Bank's Uses of the "Rule of Law" Promise in Economic Development" in The New Law and Development: A Critical Appraisal, Cambridge University Press, 2006

- Sartori (Giovanni), “Constitutionalism: A Preliminary Discussion”, 56. AMER. POL. SCI. REV. 853, 853-857, 861-862 (1962) on Dorsen (Norman), Rosenfeld (Michel), Sajó (András), Baer (Susanne), Comparative Constitutionalism: Cases and Materials, Second Edition, West, 2010. 
- Santa Cruz (Hernán) "The creation of the United Nations and ECLAC", CEPAL Review, 1995

- Schneiderman (David), Constitutionalizing Economic Globalization: Investment Rules and Democracy's Promise, Cambridge University Press, 2008.

- Schiffler (Andrei), "State versus Private Ownership", National Bureau of Economic Research, Working Paper 6665, 1998.

- Schreuer (Christopher), "The Relevance of Public International Law in International Commercial Arbitration: Investment Disputes", unpublished paper)< www. univie. ac. at/intlaw/wordpress/pdf/81_csunpublpaper_, 2006, vol. 1.

- Schutze Robert, "The Treaty Power and Parliamentary democracy: comparative perspective" in Foreign Affairs and the EU Constitution, Cambridge University Press, 2014.

- Shaw (Malcolm N.) and Fournet (Caroline), “1969 Vienna Convention, Article 62, Fundamental change of circumstances" in The Vienna Convention on the Law of Treaties: A Commentary, Edited by Corten (Olivier) and Klein (Pierre), Oxford University Press Inc., New York, 2011.

- Shealey (R. Preston), The Law of Government Contracts, Second Edition, John Byrne \& Company, 1927.

- Simma (Bruno), Erasmus Khan (Daniel), Nolte (Georg), Paulus (Andreas) Editors, The Charter of the United Nations, Oxford Commentaries on International Law, Oxford University Press, Third edition, 2012.

- Small (Jenny), "Project Finance Investors: Solution to Populismo" Int'l L. \& Mgmt. Rev., 2014, vol. 10.

- Sornarajah (M), The International Law on Foreign Investment, Cambridge, Cambridge University Press, 2010.

- Sornarajah, M. Resistance and Change in the International Law on Foreign Investment, Cambridge: Cambridge University Press, 2015 doi:10.1017/CBO9781316156339.009

- Strong (S.I.), "Note: Contractual Waivers of Investment Arbitration: Wa (i) ve of the Future?” ICSID Review-Foreign Investment Law Journal, 2014, vol. 29, no 3.

- Stiglitz (Joseph E.), "What is the Role of the State?" in Escaping the Resource Curse, (Ed.) Humpreys (Macartan), Sachs (Jeffrey D.) and Stiglitz (Joseph E.), Initiative for Policy Dialogue at Columbia, Columbia University Press, 2007. 
- Skovgaard Poulsen, (L.N.), Bounded Rationality and Economic Diplomacy: The Politics of Investment Treaties in Developing Countries, Cambridge University Press, 2015.

- Tinajero Villamar (Francisco), "Incidencia de las reformas constitucionales en el contencioso-administrativo”, p. 81 in Benalcázar Guerrón (Juan Carlos), Derecho Procesal Administrativo Ecuatoriano: Jurisprudencia, dogmática y doctrina, Quito, 2007.

- Tobias-Stoll (Peter) and Holterhus (Till Patrik), "The 'Generalization' of International Investment Law in Constitutional Perspective", Shifting Paradigms in International Investment Law, More Balanced, Less Isolated, Increasingly Diversified, Edited by Steefen Hidenlang and Markus Krawjewsky, Oxford University Press, 2016.

- Trackman (Leon E.) and Rainieri (Nicola W.), Regionalism in International Investment Law, Oxford University Press, 2013.

- Tribunal de Garantías funciona sin Ley, Impreso en los Talleres de la Editora Nacional, Quito-Ecuador, 1987

- Trubek (David M.) and Santos (Alvaro) Ed., The New Law and Economic Development: A critical appraisal, Cambridge University Press, 2006.

- Trujillo (Julio César), Constitucionalismo contemporáneo: teorías, procesos, procedimientos y retos, Universidad Andina Simón Bolívar, 2013.

- Tobey (Edward S.), Miner (A.A), Howard (R.B), The American Peace Society, Communication addressed to Hon. T. Jefferson Collidge and others, members of the International Conference of American Nations, 1890.

- United Nations, Report submitted pursuant to resolution 2102 (XX), adopted by the General Assembly on 20 December 1965. Report of the Secretary-General, Document A/6396, September 23 ${ }^{\text {rd }}, 1966$.

Organization of the American States (OAS), "Our origins", Official website; http://www.oas.org/en/about/our history.asp

- United States Senate, U.S Department of the State - "Hearing before the Committee of Foreign Relations United States Senate", One Hundred Third Congress, First Session, September 10, 1993.

- United States Senate, Responses of the U.S Department of State to Questions Asked by Senator Pell, "Bilateral Investment Treaties with: Argentina, Treaty Doc. 103-2; Armenia, Treaty Doc. 103-11, Bulgaria, Treaty Doc. 103-3, Ecuador, 
Treaty Doc. 103-15; Kazakhstan, Treaty Doc 103-12; Kyrgyzstan, Treaty Doc 103-13; Moldova, Treaty Doc. 103-14; and Romania, Treaty Doc. 102-36.

- Van den Berg (Albert Jan), Convention on the Recognition and Enforcement of Foreign Arbitral Awards, http://legal.un.org/avl/ha/crefaa/crefaa.html.

- Van Harten (Gus), "The Public-Private Distinction in the International Arbitration of Individual Claims against the State", International and Comparative Law Quarterly, 2007, vol. 56, no 2.

- Van Harten (Gus), "Five Justification for Investment Treaties: A critical discussion”, Trade L. \& Dev., 2010, Vol. 2.

- Van Harten (Gus) and Loughin (Martin), "Investment Treaty Arbitration as a Species of Global Administrative Law", The European Journal of International Law, 2006, Vol. 17 No. 1.

- Van Harten (Gus), Investment Treaty Arbitration and Public Law, Oxford University Press, 2007.

- Viteri Torres (Cristina), "ICSID withdrawal: A thorn in one's side", Original version of the thesis for the Master of Law at the Graduate Institute at the Geneva University, Geneva 2009, under the supervision of Prof. Gabrielle KaufmannKohler.

- Villiger (Mark E.), Commentary on the 1969 Vienna Convention on the Law of Treaties, Martninus Nijhoff Publishers, Leiden-Boston, 2009.

- Weisbrot (Mark), Johnston (Jake) and Lefebvre (Stephan), “Ecuador's New Deal: Reforming and Regulating the Financial Sector", Center for Economic and Policy Research. February, 2013.

- Weiler (Joseph H.H.), "The Geology of International Law-Governance, Democracy and Legitimacy", Zeitschrift für ausländisches öffentliches Recht und Völkerrecht, 2004, vol. 64, no 3.

- World Bank, Report No.15419-EC, "Memorandum of the President of the International Bank for Reconstruction and Development to the Executive Director on a Country Assistance Strategy of the World Bank Group for Ecuador", March 13, 1996.

- Williams (Marc), International Economic Organisations and the Third World, Harvester Wheatshead, 1994.

- Wray (Alberto), "La soberanía del Estado frente al arbitraje internacional", 8/12/2008, www.cywlegal.com. 
- Yalkin (Tolga), “The International Minimum Standard and Investment Law: The Proof is in the Pudding", EJIL:Talk!, August 3, 2009.

- Zetterquist (Ola), “ A European Social Contract?”, Scandinavian Studies in Law, 1999-2012, p. 333. http://www.scandinavianlaw.se/pdf/52-18.pdf

- U.S Department of State, "Office of the Historian"; https://history.state.gov/milestones/1801-1829/monroe

- World Bank, Implementation Completion Report, Ecuador, Debt and Debt Service Reduction Loan (Loan 3820-EC), Report 16187, December 18, 1996.

- World Bank, "Report and Recommendation of the President of the International Bank for Reconstruction and Development and the International Finance Corporation to the Executive Director on a Country Assistance Strategy for the Republic of Ecuador", Bolivia-Ecuador-Peru-Venezuela Country Management Unit, Report No. 25817 EC, April 29, 2003.

\section{International Cases}

- Alasdair Ross Anderson Et Al. v. Costa Rica, ICSID Case NO. ARB(AF)/07/3 , Award, May 19, 2010.

- Anglo-Iranian Oil Company (United Kingdom v. Iran), Preliminary Objections, Judgement of 22 July 1952, 1952 ICJ Rep. 20

- Case 284/16 Slovak Republic v. Achmea, European Court of Justice, EU:C:2018:158.

- Chevron Corporation (USA) and Texaco Petroleum Company (USA) v. The Republic of Ecuador, PCA Case No. 34877, Final Award, in an Arbitration Under the Treaty Between the United States of America and The Republic of Ecuador Concerning the Encouragement and Reciprocal Protection of Investment and The UNCITRAL Arbitration Rules, August 31, 2011.

- Chevron Corporation (USA) and Texaco Petroleum Company (USA) v. The Republic of Ecuador, in an Arbitration Under the Treaty Between the United States of America and The Republic of Ecuador Concerning the Encouragement and Reciprocal Protection of Investment and The UNCITRAL Arbitration Rules, PCA Case No. 2009- 23. 
- Continental Casualty Company v. Argentine Republic, ICSID Case No. ARB/03/09, Award, 5 September (2008).

- Compañía del Desarrollo de Santa Elena S.A and the Republic of Costa Rica (No. $\mathrm{ARB} / 96 / 1)$.

- Corporación QUIPORT S.A. and others v. Republic of Ecuador, ICSID Case No. $\operatorname{Arb} / 09 / 23$, Order of Discontinuance (november 11, 2011.

- Duke Energy Electroquil Partners \& Electroquil S.A. v Republic of Ecuador, International Centre for Settlement of Investment Disputes (ICSID), ICSID Case No. ARB/04/19, 18 August 2008, Award.

- Empresa Eléctrica del Ecuador, Inc (EMELEC) V. Republic of Ecuador (ICSID Case No. ARB/05/9).

- El Paso Energy International Company v. The Argentine Republic, Decision on ICSID Case No. ARB/03/15, Decision on Jurisdiction, 27 April 2006

- Eli Lilly and Company v. Canada, ICSID Case No. UNCT/14/2.

- Fisheries Jurisdiction Case (United Kingdom v. Iceland), International Court of Justice, Jurisdiction of the Court, Judgment, February $2^{\text {nd }}, 1973$.

- Gabcikovo-Nagymoros Project, International Court of Justice, 27 September 1997, ICJ Reports 1997.

- IBM World Trade Corporation c. República del Ecuador, Centro Internacional de Arreglo de Diferencias Relativas a Inversiones, Caso CIADI N. ARB/02/10.

- Inceysa Vallisoletana, S.L (Claimant) v. Republic of Salvador (Respondent), International Centre for Settlement of Investment Disputes Washington, D.C., ICSID Case No. ARB/03/26, August 2, 2006.

- Ioan Micula, Viorel Micula, S.C. European Food S.A., S.C.Starmill S.R.L. and S.C. Multipack S.R.L. V. Romania, ICSID Case No. ARB/05/20.

- Metalclad v. Mexico, Award, 30 August 2000, 5 ICSID Reports 212; 16 ICSID Review-FILJ (2001).

- M.C.I. Power Group L.C. and New Turbine, Inc. V. Republic of Ecuador, ICSID Case No. ARB/03/06.

- Methanex Corporation v. United States of America, NAFTA case, under UNCITRAL rules, Decision on Amicus Curiae, 15 January 2001.

- Murphy Exploration \& Production Company - International v. The Republic of Ecuador, ICSID Case No. ARB/08/4, Award on Jurisdiction. 
- Murphy Exploration \& Production Company - International v. The Republic of Ecuador In The Matter Of An Arbitration Under The Treaty Between The United States Of America And The Republic Of Ecuador Concerning The Encouragement And Reciprocal Protection of Investment Signed On 27 August 1993 and the UNCITRAL Arbitration Rules 1976, Permanent Court of Arbitration, Partial Final Award, 6 May 2016.

- Noble Energy Inc. And Machala Power Cía. Ltd v. Republic of Ecuador anf Consejo Nacional de Electricidad, ICSID Case No. ARB/05/12.

- Notice of Arbitration filed by Carlos Nicolás Pérez Lapentti, October 3, 2011

- Occidental Petroleum Corporation and Occidental Exploration and Production Company v. The Republic of Ecuador, ICSID Case No. ARB/06/11

- Occidental Exploration and Production Company v. The Republic of Ecuador. Final Award in the matter of UNCITRAL Arbitration, London Court of International Arbitration Administered Case No. UN 3467

- Perenco Ecuador Limited v Republic of Ecuador, ICSID Case No. ARB/08/6, Interim Decision on the Environmental Counterclaim (Interim Decision), August 11, 2015.

- Perenco Ecuador Limited vs. The Republic of Ecuador, ICSID Case No. Arb/08/6, Decision On Remaining Issues Of Jurisdiction And Liability, September 12, 2014.

- Polish Upper Silesia, Judgment of 25 August 1925 (series A, no. 6), P.C.I.J., (ser.A) No. 7

- Proceeding 158-IP-2006, Tribunal of Justice of the Andean Community.

- Proceeding 01-AI-200,Judgment of June 27, 2002, Tribunal of Justice of the Andean Community, published in the Official Gazette of the Cartagena Agreement $\mathrm{N}^{\circ} 818$, of July 23,2002

- Salvador Chiriboga v. Ecuador, Inter- American Court of Human Rights, Judgment of May 6, 2008Wintershall, A G, et al v. Government of Qatar, (1989) 28 ILM. 795, 814 (Ad Hoc Arbitral Tribunal 1989)

- Singarasa (Nallaratnam) v Attorney General of Sri Lanka, Application for judicial review, SC Spl (LA) No 182/99, ILDC 518 (LK 2006), 15th September 2006, Supreme Court.

- $\quad$ S.S Wimbledon Case, Judgment of 17 August 1923, P.C.I.J., (ser. A) No. 1.

- Técnicas Reunidas S.A. and Eurocontrol S.A. v Republic of Ecuador, (ICSID Case No. ARB/06/17). 
- The Mayagna (Sumo) Awas Tingni Community v. Nicaragua, Interamerican Court of Human Rights, Judgment of August 31, 2001, Inter-Am. Ct. H.R., (Ser. C) No. 79 (2001).

- Ulysseas, Inc. V. The Republic of Ecuador, In The Matter Of An Arbitration Under The Treaty Between The United States Of America And The Republic Of Ecuador Concerning The Encouragement And Reciprocal Protection of Investment Signed On 27 August 1993 and the UNCITRAL Arbitration Rules 1976, Permanent Court of Arbitration.

- Únete Telecomunicaciones, S.A. y Clay Pacific, S.R.L c. República del Ecuador, Arbitraje conforme al Reglamento de Arbitraje de la Comisión de las Naciones Unidas para el Derecho Mercantil Internacional, 2013.

- Urbaser S.A. and Consorcio de Aguas Bilbao Bizkaia, Bilbao Biskaia Ur Partzuergoa v The Argentine Republic, ICSID Case No. ARB/07/26.

- Vattenfall AB and others v. Federal Republic of Germany, ICSID Case No. $\mathrm{ARB} / 12 / 12$ (Vattenfall II).

\section{Domestic Cases}

- Acción extraordinaria de protección 141, Suplemento Registro Oficial, 23 de enero de 2015.

- Casos acumulados Nos. 032-2000-TC, 035-2000-TC y 051-2000-TC, Registro Oficial 260-S, Corte Constitucional del Ecuador, 6 de febrero de 2001.

- Corte Nacional de Justicia, Sala de lo Civil, Mercantil y Familia, Gaceta Judicial. Año CXI. Serie XVIII, No. 10. Página 3524.

- Dictamen No. 003-09-SIN-CC, Corte Constitucional del Ecuador, R.O. 644-S, 29-VI-2009.

- Dictamen No.020-10-DTI-CC, Caso No. 008-10-TI, Corte Constitucional del Ecuador, Registro Oficial Suplemento, 24 de junio de 2010.

- Dictamen No. 027-10-DTI-CC, Caso No. 0004-10-TI, "Convenio entre el Gobierno de la República del Ecuador y el Gobierno de la República Popular de China para el Fomento y Protección Recíproca de Inversiones”, Registro Oficial Suplemento 258 de 17 de agosto de 2010. 
- Dictamen No. 022-13-DTI-CC, Caso No. 0022-13-DTI-CC, "Convenio entre el Gobierno de la República del Ecuador y la República Italiana sobre la Promoción y Protección de Inversiones”, Corte Constitucional del Ecuador, Registro Oficial Suplemento 64 de 22 de agosto de 2013.

- Dictamen No. 029-10-DTI-CC, Caso No.002-10-TI, Corte Constitucional del Ecuador, Registro Oficial Suplemento 294, 6 de octubre de 2010.

- Dictamen No. 040-10-DTI-CC, Caso No. 0012-10-TI, "Acuerdo entre la República del Ecuador y la Confederación Suiza Relativo a la Protección y al Fomento de las Inversiones", Corte Constitucional del Ecuador, Registro Oficial 331,30 de noviembre de 2010

- Dictamen No. 041-10-DTI-CC, Caso No. 041-10-DTI-CC, Corte Constitucional del Ecuador, Suplemento Registro Oficial 342, 6 de diciembre de 2010.

- Dictamen No. 005-13-SEP-CC, Corte Constitucional del Ecuador, R.O. 933-S, 15-IV-2013.

- Dictamen No. 010-13-DTI-CC, Caso No. 0010-11-TI, “Acuerdo para la Promoción y Protección Recíproca de Inversiones entre el Reino de España y la República del Ecuador", Corte Constitucional del Ecuador, Registro Oficial Suplemento 956 de 17 de mayo de 2013.

- Dictamen No. 022-13-DTI-CC, Caso No. 0022-13-DTI-CC, “Convenio entre el Gobierno de la República del Ecuador y el Gobierno de la República de Italia sobre la promoción y protección de inversión”, Registro Oficial Suplemento 64 de 22 de agosto de 2013.

- Dictamen No. 032-13-DTI-CC, Caso No. 0016-13-DTI-CC, Suplemento Registro Oficial, 26 de noviembre de 2013

- Dictamen No. 001-14-SIS-CC, Corte Constitucional del Ecuador, R.O. 184-5, 14II-2014

- Dictamen No. 055-14-SEP-CC, Corte Constitucional del Ecuador, R.O. 237-S, $02-\mathrm{V}-2014$.

- "Recurso Extraordinario de Protección 141", Corte Constitucional del Ecuador, Tercer Suplemento del Registro Oficial 423, 23 de enero de 2015

- Recurso Extraordinario de Protección, Corte Constitucional del Ecuador, Sentencia No. 055-14-SEP-CC, Pleno de la Corte Constitucional, R.O. 237-S, 02V-2014. 
- Recurso Extraordinario de Protección 146, Corte Constitucional del Ecuador, Suplemento Registro Oficial 362, 27 de octubre de 2014

- Resolución Nro. 171-2000-TP, Tribunal Constitucional, 26 de septiembre de 2000.

- Resolución del Tribunal Constitucional 193, Registro Oficial Suplemento 231, 26 de diciembre de 2000

- Resolución No. 008-2003-AA, Corte Constitucional del Ecuador, R.O. 206, 7XI-2003.

- Resolución 0005-06 TC, Tribunal Constitucional del Ecuador, Suplemento Registro Oficial 350, 6 de septiembre de 2006

- Resoluciones 0005-06 TC y 0010-06-TC, Tribunal Constitucional, SuplementoRegistro Oficial 350, 6 de septiembre de 2006.

- Resolución 0010-06-TC, Tribunal Constitucional del Ecuador, Suplemento Registro Oficial 350, 6 de septiembre de 2006.

- Resolución del Tribunal Constitucional mediante el cual sus magistrados asumen la calidad de jueces de la Corte Constitucional, Tribunal Constitucional del Ecuador, Suplemento Registro Oficial, 22 de octubre de 2008.

- Resolución de la Corte Constitucional "Inconstitucionalidad por la Forma de la Ley de Minería”, Corte Constitucional del Ecuador, Registro Oficial Suplemento, 21 de abril de 2010.

- Resolución No. 01992007RA, Tercera Sala de la Corte Constitucional, Corte Constitucional del Ecuador, R.O. 226S, 1 de julio de 2010

- Resolución de la Corte Constitucional 1, Constitutional Court of Ecuador, Registro Oficial Suplemento 670, 27 de marzo de 2012.

- Sentencia Interpretativa del Art. 422 de la Constitución (N.0001-09-SIC-CC), Caso 0005-09-IC, Suplemento de Registro Oficial 549, 16 de marzo de 2009

- Sentencia No. 003-09-SIN-CC, Corte Constitucional del Ecuador, Registro Oficial Suplemento 644, 29 de julio de 2009.

- Sentencia N. 0 001-10-SIN-CC, Corte Constitucional del Ecuador, R.O., 18-III2010

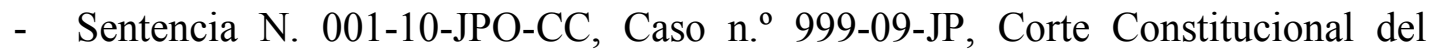
Ecuador para el Periodo de Transición, 22 de diciembre de 2010

- Sentencia No. 005-13-SEP-CC, 1, Corte Constitucional del Ecuador, R.O. 933-S, 15-IV-2013 
- Sentencia N. 016-13-SEP-CC, Caso N. 1000-12-EP, Corte Constitucional del Ecuador, 16 de mayo de 2013 .

- Sentencia N. 014-13-SEP-CC, Caso N. 2004-12-EP, Corte Constitucional del Ecuador, Registro Oficial, 21 de junio 2013.

- Sentencia No. 001-14-SIS-CC, Pleno de la Corte Constitucional, Corte Constitucional del Ecuador, Suplemento Registro Oficial 184, 14 de febrero de 2014.

\section{Legal Instruments}

- Acuerdo de Integración Subregional Andino (Acuerdo de Cartagena), 26 de mayo de 1969.

- American Declaration of the Rights and Duties of Man -Pact of San Jose, Costa Rica.

- $\quad$ American Treaty of Pacific Settlement (Pact of Bogotá), 30 de abril de 1948.

- Charter of the Organization of American States, Adopted by the Ninth International Conference of American States, Bogotá, 1948.

- China-Australia Free Trade Agreement, http://dfat.gov.au/trade/agreements/chafta/officialdocuments/Documents/chafta-agreement-text.pdf. Last visited, March 2017.

- Código Civil del Ecuador (1970), Registro Oficial 104, 20 de noviembre de 1970.

- Código Civil del Ecuador, Registro Oficial Suplemento 46, 24 de junio de 2005

- Código de Derecho Internacional Privado "Sánchez de Bustamante", Codificación 1220, Registro Oficial Suplemento 153 de 25 de noviembre de 2005.

- Código Orgánico Monetario y Financiero, Ley 0, Registro Oficial Suplemento 332 de 12 de septiembre de 2014.

- Código Orgánico Administrativo, Ley 0, Registro Oficial Suplemento 31 de 7 de julio de 2017.

- Código Orgánico de Organización Territorial (COOTAD), Ley 0, Registro Oficial Suplemento 303 de 19 de octubre de 2010.

- Código Orgánico de Producción, Comercio e Inversiones ; Official translation, Organic Code of Production, Commerce and Investment, National Assembly, December $22^{\text {nd }}, 2010$, www. mcpec.gob.ec. 
- Código Orgánico General de Procesos, Registro Oficial Suplemento 506, 22 de mayo de 2015.

- Commission draft text TTIP-investment, “Transatlantic Trade and Investment Partnership: Trade in Services, Investment and E-Commerce, http://trade.ec.europa.eu/doclib/docs/2015/september/tradoc_153807.pdf Last visited, March 2017.

- Communication No. 00-550-DAJ.T.332 of June 5, 2000 whereby the President Rafael Correa requested the Constitutional Tribunal to issue the prior ruling with regards Washington Convention's approval.

- Communication No. 4543-SCN of May 24, 2000, whereby the Secretary of the National Congress requested the President to consul the Constitutional Tribunal about his ruling with relation to the Washington Convention, before its legislative approval in accordance to Art. 162 of the Constitution of 1998.

- Communication sent by the Minister of Foreign Affairs, Rafael García Velasco to Dr. Bruno Toepfer, President of the German Delegation (28.06.1965)

- Congreso Nacional del Ecuador, Acta No. Veinticinco, Sesión- Congreso Extraordinario (Vespertina), 28 de Junio de 1995.

- Congreso Nacional del Ecuador, Acta No. Cincuenta y Uno, February 7, 2001.

- Constitución Política Grancolombiana de 1821, Decreto Legislativo 0, Registro Auténtico de 1 de enero de 1821.

- Constitución Política Grancolombiana de 1830, Decreto Legislativo 0, Diario de la Convención Nacional 1830, 1 de enero de 1830.

- Constitución Política de 1830, Decreto Legislativo 0, Diario de la Convención Nacional 1830, 14 de junio de 1830.

- Constitución Política de 1835, Decreto Legislativo 0, Diario de la Convención Nacional 1835, 13 de agosto de 1835.

- Constitución Política de 1843, Diario de la Convención Nacional 1843, 1 de abril de 1843.

- Constitución Política de 1845, Decreto Legislativo 0, Diario de la Convención Nacional 1845, 3 de diciembre de 1845.

- Constitución Política de 1851, Decreto Legislativo 0, Diario de la Convención Nacional 1851, 25 de febrero de 1851.

- Constitución Política de 1852, Decreto Legislativo 0, Diario de la Convención Nacional 1852, 6 de septiembre de 1852. 
- Constitución Política de 1861, Decreto Legislativo 0, Diario de la Convención Nacional 1861, 2 de mayo de 1861.

- Constitución Política de 1869, Decreto Legislativo 0, Diario de la Convención Nacional 1869, 28 de julio de 1869.

- Constitución Política de 1878, Decreto Legislativo 0, Diario de la Convención Nacional 1878, 31 de marzo de 1878.

- Constitución Política de 1884, Decreto Legislativo 0, Diario de la Convención Nacional 1884, 4 de febrero de 1884.

- Constitución Política de 1897, Decreto Legislativo 0, Registro Oficial Suplemento 272 de 14 de enero de 1897.

- Constitución Política de 1906, Decreto Legislativo 0, Registro Oficial 262 de 24 de diciembre de 1906.

- Constitución Política de 1929, Ley 0, Registro Oficial 138 de 26 de marzo de 1929.

- Constitución Política de 1945, Decreto Legislativo 0, Registro Oficial 228 de 6 de marzo de 1945.

- Constitución Política de 1946, Decreto Legislativo 0, Registro Oficial 773 de 31 de diciembre de 1946.

- Constitución Política de 1967, Decreto Legislativo 0, Registro Oficial 133 de 25 de mayo de 1967.

- Constitución Política de 1979, Decreto Supremo 0, Registro Oficial 800 de 27 de marzo de 1979.

- Constitución Política de la República del Ecuador 1984- Codificación, Ley 0, Registro Oficial 763 de 12 de junio de 1984.

- Constitución Política de la República del Ecuador 1993-Codificación, Ley 0, 1993, Registro Oficial 183 de 5 de mayo de 1993.

- Constitución Política de la República del Ecuador 1996 Codificación, Registro Oficial 969 se 18 de junio de 1996.

- Constitución Política de la República del Ecuador de 1998, Decreto Legislativo 0, Registro Oficial 1 de 11 de agosto de 1998.

- Constitución de la República del Ecuador 2008, Decreto Legislativo 0, Registro Oficial 449 de 20 de octubre de 2008.

- Constitución Política del Estado Plurinacional de Bolivia; 7 de febrero de 2009. 
- Contrato de Inversión para el Proyecto Minero "Mirador" suscrito entre el Ministerio Coordinador de la Producción, Empleo y Competitividad, en representación del Estado Ecuatoriano y Ecuacorriente S.A.

- Contrato de Inversión entre el Estado ecuatoriano, representado por el Ministerio de Comercio, Industrialización y Pesca con las Compañías Oleoducto de Crudos Pesados (OCP) Ltd. y Oleoducto de Crudos Pesados (OCP) Ecuador S.A.”, February 15, 2001.

- Contrato de Inversión entre el Estado ecuatoriano representado por el Ministerio de Comercio Exterior, Industrialización, Pesca y Competitividad; Samedan Oil Corporation y la Compañía MACHALAPOWER Cía. Ltda, 15 de octubre de 2001

- Contrato de Inversión suscrito entre el Estado Ecuatoriano y el Ministerio de Comercio Exterior, Industrialización, Pesca y Competitividad y las compañías AECON Construction Group Inc., ADC Management LTD., y Corpotación Quiport S.A. 24 de junio de 2003.

- Contrato de Participación para la Exploración y Explotación de Hidrocarburos (Petróleo C) entre el Estado Ecuatoriano-PETROECUADOR y las compañías City Oriente Ltd, y Consolidated Ramrod Gold Corporation”, March 29, 1995.

- Contrato modelo para la exploración y expotación de hidrocarburos (1973), Decreto Supremo, Registro Oficial 283, 10 de abril de 1973.

- Convention Establishing the Multilateral Investment Guarantee Agency (MIGA).

- Convention for the Recognition and Enforcement of Arbitral Awards, New York, June $10^{\text {th }}, 1958$.

- Convention on the Settlement of Investment Disputes Between States and Nationals of Other States (ICSID Convention), Washington, March 18, 1965.

- Decisión 24, Comisión del Acuerdo de Cartagena de 31 de diciembre de 1971.

- Decisión 220, Comisión del Acuerdo de Cartagena, 11 de mayo de 1987.

- Decisión N²91 que establece el Régimen Común de Tratamiento a los Capitales Extranjeros y sobre Marcas, Patentes, Licencias y Regalías, Comisión del Acuerdo de Cartagena, 21 de marzo de 1991.

- Decisión 324-Arancel Interno Común, Comisión del Acuerdo de Cartagena, Programa de Liberación de Incentivos a las Exportaciones intra-subregionales, Lima, 25 de agosto de 1992. 
- Decisión 370-Arancel Externo Común, Comisión del Acuerdo de Cartagena, Sexagésimo-tercer período ordinario de sesiones de la Comisión, 25-26 de noviembre de 1994

- Decision 598, Andean Council of Foreign Affairs Ministers, Quito, July 11, 2004.

- Decisiones 37, 37a, 47, 48, 70, 103, 109, 110, 118, 124, 125, 144 y 189 de la Comisión del Acuerdo de Cartagena.

- Decreto Ejecutivo 1417-B, Registro Oficial 309, 19 de abril de 2001.

- Dictamen N. 154-ATJ, Ministerio de Relaciones Exteriores del Ecuador, Quito, 13 de Octubre de 1958.

- Differential and More Favourable Treatment, Reciprocity and Fuller Participation of Developing Countries, Decision of 28 of November 1979, GATT, L/4904 (December 3, 1979).

- Diplomatic note submitted by Dr.Edgar Terán Terán, Minister of Foreign Affairs of Ecuador to Enrique Iglesias, Minister of Foreign Affairs of the Republic of Uruguay, containing the compromises for reciprocal protection of foreign investment, Note No. 14/85 CN, Quito, July 31 ${ }^{\text {st }}, 1985$.

- Draft Articles on Responsibility of States for Internationally Wrongful Acts, with commentaries, 2001, International Law Commission, http://legal.un.org/ilc/texts/instruments/english/commentaries/9 6 2001.pdf

- Ecuador Constitutional Codification of 1997

- Formato Básico Común del Contrato de Inversión, Official Gazette 255, January $30,2001$.

- Free Trade Agreement Between the Government of Australia and the Government of the People's Republic of China.

- Gaceta Judicial. Año XCV. Serie XVI. Nro. 2. Pág. 524, 7 de febrero de 1994.

- Hearing before the Committee of Foreign Relations United States Senate, One Hundred Third Congress, First Session, September 10, 1993. Ley 99-24, Registro Oficial 181-S, 30 de abril de 1999.

- Hearing before the Committee of Foreign Relations United States Senate, One Hundred Third Congress, First Session, September 10, 1993.

- Hearing before the Committee of Foreign Relations United States Senate, One Hundred Fourth Congress, First Session, November 30, 1995. 
- House of Representatives- Committee of Foreign Affairs, Special Study Mission to Latin America: Peru, Ecuador, Colombia, Panama, Costa Rica, $88^{\text {th }}$ Congress, $1^{\text {st }}$ Session, Washington, 1963.

- Inter-American Treaty of Reciprocal Assistance (Rio de Janeiro, 1947).

- Investment Contracts signed with: 1) Oleoducto de Crudos Pesados; 2) Machala Power Cia. Ltda.; 3) Termoriente Cia.Ltda.; 4) Termoriente, Modificación de Contrato; 5) Quiport S.A.; 6) Grunenthal Ecuatoriana Cia. Ltda.; 7) General Motors S.A.; 8) IPAC S.A.; 9) Hidroabanico S.A.; 10) San Carlos S.A.

- Japan-Australia Economic Partnership Agreement.

- $\quad$ Ley de Mercado de Valores, Registro Oficial 367 de 23 de julio de 1998.

- $\quad$ Ley 99-24, Registro Oficial 181-S, 30 de abril de 1999.

- Ley de Arbitraje y Mediación de 1997, Registro Oficial 145 de 04 de septiembre de 1997.

- $\quad$ Ley del Ministerio Público, Registro Oficial 871 de 10 de Julio de 1979.

- Ley de Comercio Exterior e Inversiones, Registro Oficial Suplemento 82, 9 de junio 1997.

- Ley de Contratación Pública, Registro Oficial 501, 16 de agosto de 1990).

- Ley Especial de Telecomunicaciones, Ley 184, Registro oficial 996 de 10 de agosto de 1992.

- Ley General de Instuticiones del Sistema Financiero, Ley 52, Registro Oficial Suplemento 439 de 12 de mayo de 1994

- Ley Orgánica de Aduanas (1994), Decreto Ley de Emergencia 4, Registro Oficial 396 de 10 de marzo de 1994 .

- Ley Orgánica de Empresas Públicas, Registro Oficial Suplemento 48, 16 de octubre de 2009.

- Ley Orgánica de Garantías Jurisdiccionales y Control Jurisdiccional, Registro Oficial Suplemento 52, 10 de septiembre de 2009.

- Ley Orgánica de Incentivos para Asociaciones Público Privadas, Suplemento Registro Oficial 652, 18 de diciembre de 2015.

- Ley Orgánica del Sistema Nacional de Contratación Pública, Suplemento de Registro Oficial 395, 4 de agosto de 2008.

- Ley Orgánica de Minería, Suplemento de R.O 517, 29 de enero de 2009 and Article 18 of Ley s/n, R.O. 0372S, 16 de Julio de 2013. 
- Ley de Régimen Monetario y Banco del Estado, Decreto Ley de Emergencia 2, Registro Oficial Suplemento 930, 7 de mayo de 1992.

- Ley de la Modernización del Estado, Registro Oficial 349, 31 de diciembre de 1993.

- Ley Orgánica para el Fomento Productivo, Atracción de Inversiones, Generación de Empleo, y Estabilidad y Equilibrio Fiscal, Ley 0, Official Gazette Suplement 309, August 21 ${ }^{\text {st }}, 2018$.

- Ley para la Promoción de la Inversión y de la Participación Ciudadana, Suplemento del Registro Oficial 144, 18 de agosto de 2000.

- Memorandum N/032-88 DCT submitted by the General Direction of Treaties to Politics Undersecretariat; reference: Agreement between Ecuador and Switzerland Related to Protection and Promotion of Investments.

- Memorandum No.426 SG/DGT, 2 de enero de 2001, Ministry of Foreign Affairs of Ecuador.

- Memorandum of the President of the National Bank for Reconstruction and Development to the Executive Directors on a Country Assistance Strategy of the World Bank Group for Ecuador, Report 15419-EC, March 13, 1996

- Memorandum sent by Serena H. Clarke, Deputy Secretary of the World Bank, depositary of the Washington Convention, sent the following letter to Edgar Terán Terán, Minister of Foreign Affairs of Ecuador on February 19, 1986.

- Mera Giler (Alexis), National Secretary of Legal Affairs, "Presidencia de la República del Ecuador”, Oficio No. T.1.-C.1-SMJ-12-1134, October 5th, 2012.

- National Constituent Assembly, Acta 068, León Roldós, 174 p.

- National Constituent Assembly, Acta 85, María Augusta Calle.

- National Plan for Good Living (2013-2017), Objective 8, "Strengthen the solidarity, and social economic system in a sustainable manner", Secretaría Nacional de Planificación y Desarrollo, 2013

- Nota N. 5084/GVM/DGPEI/DGT08, by which the Ecuadorian State notified the Republic of Paraguay with the decision to terminate the BIT, Quito 30 de enero de 2008.

- National Plan for Good Living (2013-2017), Objective 8, "Strengthen the solidarity, and social economic system in a sustainable manner", Secretaría Nacional de Planificación y Desarrollo, 2013. 
- Notice of ICSID Arbitration, Corporación Quiport S.A. and Others against Ecuador, 18 December 2009

- Plan Nacional de Desarrollo (2007-2010)-Planificación para la Revolución Ciudadana",

- Note submitted by the Extraordinary and Plenipotentiary Ambassador of Ecuador in Switzerland to the Director of the Commerce Division of the Federal Department of Public Economy of Switzerland, Ambassador, Peter Jolle, berne, 1968.

- "Normas reglamentarias sobre inversión extranjera y sobre contratos de transferencia de tecnología, marcas patentes, licencias y regalías”, Official Gazette, January 13, 1993.

- Oficio PGE 0436, 11 de septiembre de 2007, resolución de la Procuraduría General del Estado, Registro Oficial 257, 22 de enero de 2008.

- Organic Act of Public Enterprises, Official Gazette, Supplement 48, October 16, 2009.

- Organic Act of Incentives for Public-Private Partnerships Official Gazette, Supplement 652, December 18, 2015.

- Organic Law on Constitutional Guarantees and Constitutional Control, Official Gazette, Supplement 52, October 22, 2009.

- General Regulation for the Aplication of the Organic Law of Incentives for Public-Private Partnerships, Official Gazette 786, June 29,2016

- Proyecto de Ley Orgánica para el Fomento Productivo Atracción de Inversiones, Generación de Empleo, y Estabilidad y Equilibrio Fiscal. Free translation.

- Reforma a Ley de Hidrocarburos (1993), Registro Oficial 326 de 29 de noviembre de 1993.

- Reglamento General de Aplicación de la Ley Orgánica de Incentivos Para Asociaciones Público-Privadas y la Inversión Extranjera, Decreto Ejecutivo 1040, Registro Oficial 786 de 29 de junio de 2016.

- Report of the Secretary-General, Inter-American Commercial Arbitration Commission, Document A/6396, September 23 $3^{\text {rd }}, 1966$.

- Request for arbitration Burlington Resources Inc, April, 21, 2008

- Resolución No. 290 del COMEXI, published in the Official Gazette No. 487, December 22, 2004. 
- Resolution 2205 (XXI), United Nations General Assembly, 1497 ${ }^{\text {th }}$ plenary meeting, December $17^{\text {th }}, 1966$.

- Responses of the U.S Department of State to Questions Asked by Senator Pell, "Bilateral Investment Treaties with: Argentina, Treaty Doc. 103-2; Armenia, Treaty Doc. 103-11, Bulgaria, Treaty Doc. 103-3, Ecuador, Treaty Doc. 103-15; Kazakhstan, Treaty Doc 103-12; Kyrgyzstan, Treaty Doc 103-13; Moldova, Treaty Doc. 103-14; and Romania, Treaty Doc. 102-36.

- Resolution of the Constitutional Court, "Protocolo para la elaboración de Precedentes Constitucionales Obligatorios“, August 5th, 2010.

- Resolution N. 171-2000-TP, September 28, 2000, Constitutional Tribunal.

- Supreme Decree No. 797 B Official Gazette 193, Supreme Decree No. 797 B, October 15, 1976.

- Resolution 2205 (XXI), United Nations General Assembly, 1497 ${ }^{\text {th }}$ plenary meeting, December $17^{\text {th }}, 1966$.

- Treaty of Creation of the Tribunal of Justice of the Andean Community, May 28, 1979.

- The United Nations Convention on Transparency in Treaty-based Investor-State Arbitration

- Treaty of Peace, Friendship, Navigation and Commerce between the United States of America and the Republic of Ecuador, Quito, June 13th, 1839

- Tratado de Amistad Comercio y Navegación celebrado con Colombia, Decreto Legislativo 1, Registro Oficial 26, 6 de octubre de 1905

- Vienna Convention on the Law of Treaties, resolution 2102 (XX), adopted by the General Assembly on 20 December 1965. Report of the Secretary-General, Document A/6396, September 23 ${ }^{\text {rd }}$, 1966; Decreto Ejecutivo No.619, publicado en el Registro Oficial 134 de 28 de Julio de 2003

\section{Reports, Press Resources and Speeches}

- Asamblea Nacional del Ecuador, "Propuesta para brindar seguridad jurídica a inversión recibió resplado de amplios sectores del país”, June 12, 2018, https://www.asambleanacional.gob.ec/es/noticia/56079-propuestapara-brindar-seguridad-juridica-inversion. Last visited, June 2018. 
- Alvarez (José), "The Use and Misuse of European Human Rights Law in Investor State Arbitration", Max Planck Institute Luxembourg for Procedural Law, Max Planck Lecture Series, May 3, 2017, https://www.youtube.com/watch?v=LUSzYFquVx0\&app=desktop. $\quad$ Last Visited, June 2017,.

- Azevêdo (Roberto), Book Launch: "Regional Trade Agreements and the Multilateral Trading System", Speeches-DG Roberto Azevêdo, September 29 ,

https://www.wto.org/english/news_e/spra_e/spra138_e.htm?utm_source= dlvr.it\&utm_medium=twitter.

- Cable 235229, 11/17/2009, Reference to November 12 meeting with Embassy representatives of the affected countries, http://www.eluniverso.com/2011/04/26/1/1355/cable-235229.html. Last visited, January 2017.

- Chaisse (Julien) and Marisi (Flavia), "Another Conflict of Norms: How BEPS and International Taxation Relate to Investment Treaties", June $12^{\text {th }}$, 2017, http://www.iisd.org/itn/2017/06/12/another-conflict-norms-howbeps-international-taxation-relate-investment-treaties-julien-chaisseflavia-marisi/?utm_source $=$ newsletter-

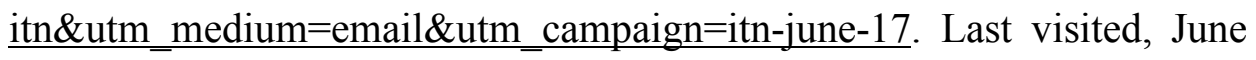
2017.

- Commission for the Integral Citizens' Audit of the Treaties of Reciprocal Protection of Investments and of the International Arbitral System on the Subject of Investments, official release of CAITISA's report, May 8, 2017. See the official presidential ceremony, https://www.youtube.com/watch?v=JxjbTdm19Rc. Last visited, May 2017.

- Diario "El Comercio", Ecuador solicitará a Unasur la devolucion del edificio que funciona como su sede en Quito; July 5, 2018; http://www.elcomercio.com/actualidad/ecuador-unasur-devolucionedificio-leninmoreno.html. Last visited, July 2018.

- Diario « El Mundo », “El 'Brexit' y la guerra de Apple complican un pacto sobre el TTIP”, Diario El Mundo, 
http://www.elmundo.es/economia/2016/09/29/57e3f2a5468aeb9b028b46

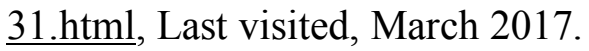

- Diario "El Telégrafo", "Gobierno firma concesión para modernizar Puerto Bolívar", El Telégrafo, 8 de Agosto de 2016. See, http://www.eltelegrafo.com.ec/noticias/economia/8/gobierno-firmaconcesion-para-modernizacion-de-puerto-bolivar

- Diario "E1 Tiempo" "La Constituyente acelera el paso", June 2 2008. http://www.eltiempo.com/archivo/documento/MAM-2959018.

- _ Diario "El Universo", "Ecuador renunció ayer al CIADI por decision de la Comisión Legislativa”, 13 de junio de 2009.

- Website: http://www.eluniverso.com/2009/06/13/1/1355/0A1B8191EE3E40D5A2 337486894A24F7.html Visited on August 2016.

- Diario "El Universo", "Solo con Finlandia se ha llegado a finalizar el tratado de inversiones", Ecuador, April 16, 2011.

- Diario Hoy, “Apertura total al capital extranjero”, 28 de octubre de 1992 ; http://www.explored.com.ec/noticias-ecuador/apertura-total-al-capitalextranjero-55813.html

- Diario Hoy, "Noboa culpa de fracaso de privatización a opositores", February $2^{\text {nd }}, 2003$; http://www.explored.com.ec/noticias-ecuador/noboaculpa-de-fracaso-de-privatizacion-a-opositores-124947.html

- Ecuadorinmediato, "Ecuador evita denuncia de tratados de inversión y alista Código de la Producción”, September 16th, 2010; http://www.ecuadorinmediato.com/Noticias/news_user_view/ecuador_evi ta denuncia de tratados de inversion y alista codigo de produccion-134048.

- El Diario, "Gobierno ofrece rescatar los correos postales, August 23 ${ }^{\text {rd }}$, 2007. http://www.eldiario.ec/noticias-manabi-ecuador/49966-gobiernoofrece-rescatar-los-correos-postales/.

- Embajada del Ecuador en Estados Unidos, Informe relativo a los trabajos del Comité Especial sobre la Ejecución de Sentencias Arbitrales Internacionales, Nueva York, Abril 4, 1955. 
- Entrevista al Presidente Rafael Correa by Andrés Carrión, Teleamazonas, October 17, 2016; https://www.youtube.com/watch?v=fK4Dh-djCnE. Last visited in November 2016.

- European Commission-DG Trade, "UN agrees to start to work on multilateral reform of investment dispute settlement”, Brussels, July 10, 2017, http://trade.ec.europa.eu/doclib/docs/2017/july/tradoc 155744.pdf. Last visited July 2017.

- Global Arbitration Review, "Nobel and Ecuador settle as port dispute looms", January 12, 2009

- Gouiffes (Laurent), Imad Khan (M.) and Smith (Jennifer), "CETA paves the way for Investment Court System", http://www.lexology.com/library/detail.aspx?g=cddc2b70-9425-418fbcf1-512cb8483100. Last visited, March 2017.

- Graceffo (Antonio), “Trump's New Protectionism: Economic and Strategic Impact", Foreign Policy Journal, Feb 1, 2017, https://www.foreignpolicyjournal.com/2017/02/01/trumps-newprotectionism-economic-and-strategic-impact/. Last visited, March 2017.

- Hamilton (Jonathan C.), "Solving Complex Problems: Crisis Management, Complex Negotiations and the New Quito International Airport", Latin Arbitration Law, http://www.latinarbitrationlaw.com/solving-complexproblems-crisis-management-complex-negotiations-and-the-new-quitointernational-airport/, Website visited on August 2016.

- Herbert Smith Freehills: Dispute Resolution-Arbitration Notes, "Brexit-the future of state, investor-state and domestic dispute resolution", http://hsfnotes.com/arbitration/2017/03/02/brexit-the-future-of-state-tostate-investor-state-and-domestic-dispute-resolution/

- Herbert Smith Freehills, "English Court Stays Enforcement of Micula Award Against Romania”, Arbitration Notes, July 7, 2017, http://hsfnotes.com/arbitration/2017/07/07/english-court-staysenforcement-of-micula-icsid-award-against-romania/. Last visited, July 2017.

- Herbert Smith Freehills Arbitration Notes, "Urbaser v. Argentina and Burlington v. Ecuador: Investment arbitration is not over the counterclaims yet", March 14, 2017, http://hsfnotes.com/arbitration/2017/03/14/urbaser- 
v-argentina-and-burlington-v-ecuador-investment-arbitration-is-not-overthe-counterclaims-yet/. Last visited, March 2017.

- Hepburn (Jarrod) and Huber (Mark), An Assessment of Australia's Parliamentary Report on ISDS in the TPP, Kluwer Arbitration Blog, January 5, 2017, http://kluwerarbitrationblog.com/2017/01/05/reservedan-assessment-of-australias-parliamentary-report-on-isds-in-thetpp/?print=pdf, Last visited, March 2017.

- International Chamber of Commerce, ICC reveals record number of new Arbitration cases filed in 2016, https://iccwbo.org/media-wall/newsspeeches/icc-reveals-record-number-new-arbitration-cases-filed-2016/.

Last visited, June 2016.

- International Centre for Settlement of Investment Disputes, 'The ICSID Caseload-Statistics' (Issue 2016 )https://icsid.worldbank.org/apps/ICSIDWEB/resources/Documents /ICSID\%20Web\%20Stats\%202016-1\%20(English)\%20final.pdf. $\quad$ Last visited in November, 2016.

https://issuu.com/periodicodiagonal/docs/conclusiones_caitisa. http://investmentpolicyhub.unctad.org/ISDS.

- International Law Commission, "Fragmentation on International Law: Difficulties arising from the Diversification and Expansion of International Law”, Report of the Study Group of the International Law Commission, Finalized by Koskenniemi (Martti), Fifty Eight Session, Geneva, 1 May-9 June and 3 July-11 August 2006

- Investment Treaty News, 'Ecuador's audits on investment treaties: CAITISA reports leaked”, February 29, 2016, https://www.iisd.org/itn/2016/02/29/ecuadors-audit-on-investmenttreaties-caitisa-reports-leaked/. Last visited, November 2016.

- Katainen (Jyrki), Statement from the EU Commissioner for Jobs, Growth and Investment, "Katainen suggests dropping investment from trade deals", Euroactiv with AFP, July 10, 2017; http://www.euractiv.com/section/economy-jobs/news/katainen-suggestsdropping-investment-from-trade-deals/. Last visited, July 2017.

- Levine (Matthew), 'ICSID tribunal renders interim decision on Ecuador's environmental counterclaim in long-running dispute', Investment Treaty 
News, November 26, 2015, https://www.iisd.org/itn/2015/11/26/icsid$\underline{\text { tribunal-renders-interim-decision-on-ecuadors-environmental- }}$ counterclaim-in-long-running-dispute-perenco-ecuador-limited-vrepublic-of-ecuador-icsid-case-no-arb-08-6/. Last visited in November 2016.

- Machado (Decio), "Ecuador y la denuncia de los Tratados Bilaterales de Inversión”, recogido de www.quiendebeaquien.org

- Malmström (Cecilia), "Proposing an Investment Court System”, European Commissioners Blog, $\quad$ September 16, 2015, https://ec.europa.eu/commission/commissioners/2014-

2019/malmstrom/blog/proposing-investment-court-system_en Last visited, March 2017.

- Marchán (Juan Manuel), "Conclusiones de CAITISA según sus ejes de acción", Pérez Bustamante \& Ponce Estudio Juridico, See, http://www.ecamcham.com/site/cam/conferencias/2016/Hallazgo_de_la CAITISA_Juan_Manuel_Merchan.pdf. Last visited, January 2017.

- Ministerio de Relaciones Exteriores y Movilidad Humana, "Cancillería presenta los nuevos convenios bilaterales de inversion"; https://www.cancilleria.gob.ec/cancilleria-presenta-los-nuevosconvenios-bilaterales-de-inversion/.

- Mbengue Makane Moïse, "Consent to Arbitration Through National Investment Legislation, Investment Treaty News", International Institute for Sustainable Development, https://www.iisd.org/itn/2012/07/19/consent-to-arbitration-throughnational-investment-legislation/. Website visited on August 2016.

- Ministerio de Transporte, Agencia Nacional de Infraestructura, República de Colombia, 'Contrato de Concesión Bajo el Esquema de APP No [*] de [*] Global Arbitration Review <http://www.globalarbitrationreview.com/ cdn/files/gar/articles/PPP_Model_Contract.pdf> accessed 12 May 2014 ('Model Agreement'

- Minister of Foreign Affairs and Human Mobility, "Ecuador leads the proposed creation of an International Instrument on Human Rights and Transnational Corporations". See, http://www.cancilleria.gob.ec/ecuador- 
leads-the-proposed-creation-of-an-international-instrument-on-humanrights-and-transnational-corporations/. Last visited, January 2017.

- Minister of Foreign Affairs and Human Mobility, "Southern States Organize Observatory on Transnational Investment". See, http://www.telesurtv.net/english/news/Ecuadors-Correa-Proposes-WorldCourt-of-Environment-Justice-20151130-0007.html. Last visited, January 2017.

- Murray (Dorothy) and Northcott (Edmund), "Case Report: Murphy Exploration \& Production Company-International $\mathrm{v}$ The Republic of Ecuador, May 2016", Lexology, September 15, 2016.

- Nottage (Luke), Investor-State Arbitration: Not in the Australia-Japan Free Trade Agreement, and Not Ever for Australia, https://sydney.edu.au/law/anjel/documents/2014/ZJR_38_05_Nottage_8.p df, Last visited, March 2017.

- OECD, "Interpretation of the Umbrella Clause in Investment Agreements", Chapter II, International Investment Law: Understanding Concepts and Tracking Innovations, OECD, 2008

- Pérez Rocha (Manuel), "When Corporations Sue Governments", The New York Times, December $\quad 3^{\text {rd }}$ 2014, https://www.nytimes.com/2014/12/04/opinion/when-corporations-suegovernments.html

- Procuraduría General del Estado, "A Critical View of Investment Arbitration Based On Ecuadorian Experience", Management 2008-2016, García Carrión (Diego), Gómez de la Torre (Blanca) and Gaybor, Quito (Christel), August 2016.

- Procuraduría General del Estado, "Caso Burlington: Tribunal arbitral emite laudo final y acepta contrademanda ambiental de Ecuador, Boletín de Prensa, Quito, 08 de febrero de 2017, CS/03, http://www.pge.gob.ec/index.php/component/k2/item/887-casoburlington-tribunal-arbitral-emite-laudo-final-y-acepta-la-reconvencionambiental-del-ecuador. Last visited, March 2017.

- Procuraduría General del Estado, Dirección de Asuntos Internacionales, "Síntesis de Gestión (2015)". See, 
http://www.pge.gob.ec/?option=com_azurapagebuilder\&view=page\&id= 33. Last visited, November 2016.

- Roberts (Anthea), "A Turning of the Tide against ISDS?, EJIL: Talk!, Blog of the European Journal of International Law, May 19, 2017, https://www.ejiltalk.org/a-turning-of-the-tide-against-isds/. Last visited, June 2016.

- Roldós (León), "Rajá Perro" in Diario el Universo, October, 25th, 2010. http://www.eluniverso.com/2010/10/25/1/1363/rajaperro.html? $\mathrm{p}=1363 \& \mathrm{~m}=788$

- Speech of the President Rafael Correa in the release of the book "Caso Oxy: Defensa Jurídica de una Decisión Soberana y en Derecho del Estado Ecuatoriano", organized by the Attorney General's Office, October 17, 2014.

- Statement of the Attorney General of the State, Dr. Diego García Carrión. Diario Hoy", published on October $20^{\text {th }}, 2010$.

- Telesur; "Colombia's Duque Reaffirms Intention to Withdraw From UNASUR", July 9, 2018; https://www.telesurtv.net/english/news/DuqueReaffirms-Intention-to-Withdraw-Colombia-From-Unasur-201807090019.html. Last visited, July 2018

- Telesur TV, “Ecuador's Correa Proposes International Court of Environment Justice at COP21". See, http://www.telesurtv.net/english/news/Ecuadors-Correa-Proposes-WorldCourt-of-Environment-Justice-20151130-0007.html. Last visited, January 2017.

- Telesur, "La CIA en Ecuador", June 6, 2016. https://www.youtube.com/watch?v=mLbV1vy4Egk. Last visited November, 2016.

- UNCTAD's Investment Policy Hub, http://investmentpolicyhub.unctad.org/ISDS. Last visited November 2016.

- "The Dirty Hand of Chevron" was released by President Correa on September 17, 2013. See, http://www.thedirtyhand.com Last visited on November 2016. The film was released on October 12, 2016. See, http://www.eljuegosucio.com, Last visited on November 2016. 
- The Guardian, Knaus (Christopher), "Philip Morris cigarettes charged millions after losing plain packaging case against Australia", July 10, 2017; https://www.theguardian.com/business/2017/jul/10/philip-morriscigarettes-charged-millions-after-losing-plain-packaging-case-againstaustralia. Last visited, July 2017.

- The Hindu Business Line, Basu (Nayamina), "US junks Bilateral Investment Treaty talks", June 28, 2017; http://m.thehindubusinessline.com/economy/policy/us-junks-bilateralinvestment-treaty-talks/article9740501.ece. Last visited, July 2017.

- Tucker (Todd), Development matters: Emerging trends in investment treaty arbitration, Vale Columbia Center/Ecuadoran Embassy Conference on Investment, Washington, DC-April 8, 2014.

- UNCTAD's Investment Policy Hub, http://investmentpolicyhub.unctad.org/ISDS. Last visited November 2016.

- United Nations Conference on Trade and Development, "Fair and Equitable Treatment- UNCTAD Series on Issues in International Investment Agreements II", United Nations, New York and Geneva, 2012.

- United Nations Conference on Trade and Development, Official Website, “About us". See: http://unctad.org/en/Pages/Statistics.aspx

- United Nations Conference on Trade and Development, "Fair and Equitable Treatment- UNCTAD Series on Issues in International Investment Agreements II”, United Nations, New York and Geneva, 2012

- United Nations Information Service, "Cameroon signs the United Nations Convention on Transparency in Treaty-based Investor-State Arbitration", May 12, 2017. http://www.unis.unvienna.org/unis/en/pressrels/2017/unisl245.html. Last visited, June 2017.

- US Embassy cable (09QUITO899) of October 23rd, 2009, filtered by Wikileaks, $\quad$ https://wikileaks.org/plusd/cables/09QUITO899_a.html, Website visited on August 2016.

- World Maritime News, "Yildrim Holding Set on Investing USD 750 Min in Ecuador", World Maritime News, February 16, 2016. See, http://worldmaritimenews.com/archives/183136/yildirim-holding-set-oninvesting-usd-750-mln-in-ecuador/. 
- "Yildrim Holding Set on Investing USD 750 Min in Ecuador", World Maritime News, February 16, 2016. See, http://worldmaritimenews.com/archives/183136/yildirim-holding-set-oninvesting-usd-750-mln-in-ecuador/. 